ÆUSGS

science for a changing world
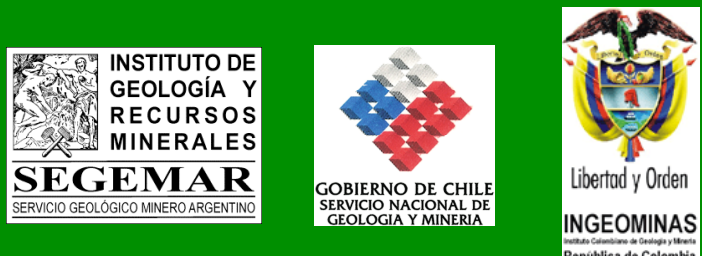

Kone EMMEI

Prepared and published jointly by the geological surveys of Argentina, Chile, Colombia,

Peru, and the United States

\title{
Quantitative Mineral Resource Assessment of Copper, Molybdenum, Gold, and Silver in Undiscovered Porphyry Copper Deposits in the Andes Mountains of South America
}
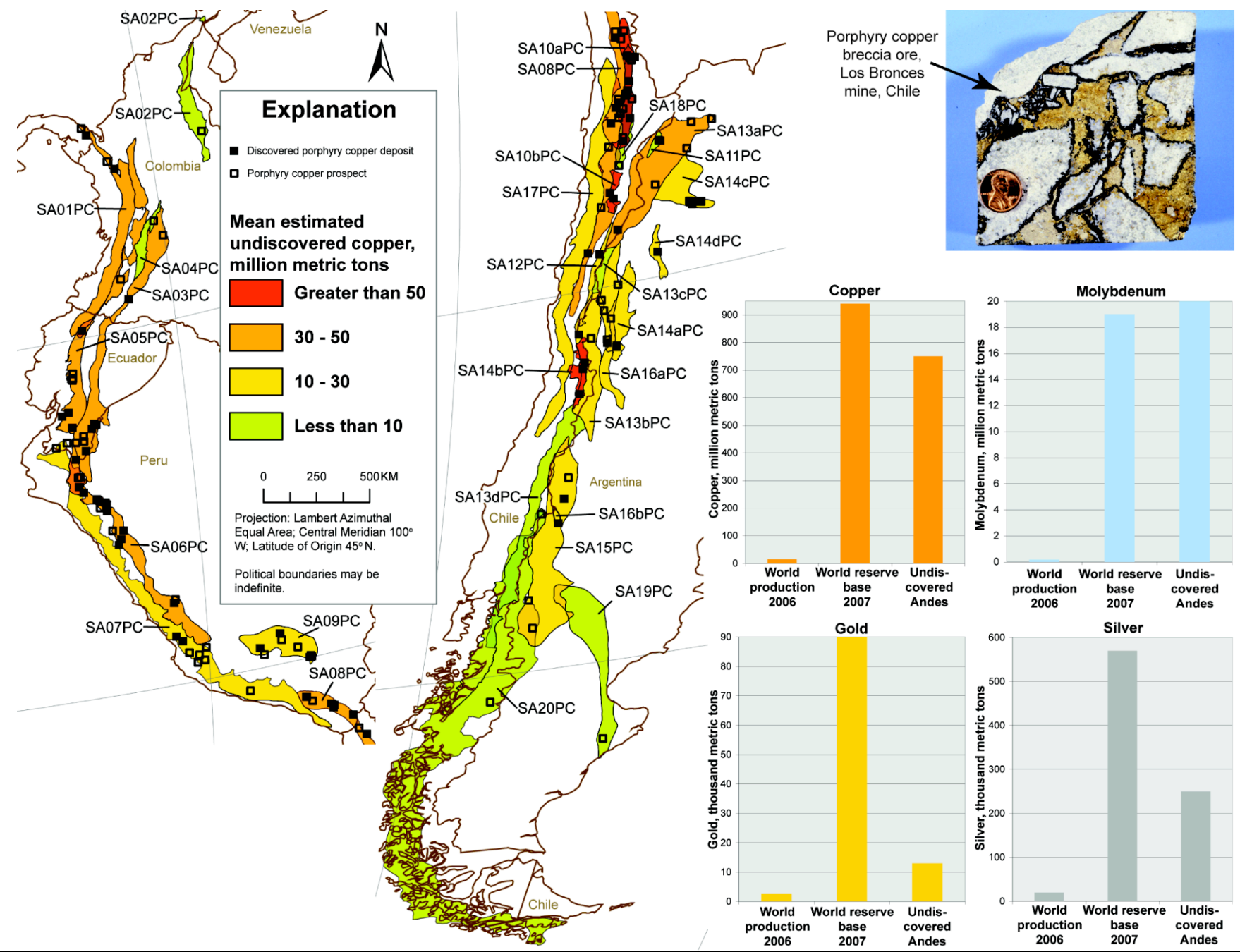

Open-File Report 2008-1253, version 1.0

U.S. Department of the Interior

U.S. Geological Survey 


\section{U.S. Department of the Interior DIRK KEMPTHORNE, Secretary}

\section{U.S. Geological Survey}

Mark D. Myers, Director

\section{U.S. Geological Survey, Reston, Virginia: 2008}

For product and ordering information:

World Wide Web: http://www.usgs.gov/pubprod

Telephone: 1-888-ASK-USGS

For more information on the USGS - the Federal source for science about the Earth, its natural and living resources, natural hazards, and the environment: World Wide Web: http://www.usgs.gov

Telephone: 1-888-ASK-USGS

Suggested citation:

Cunningham, C.G., Zappettini, E.O., Vivallo S., Waldo, Celada, C.M., Quispe, Jorge, Singer, D.A., Briskey, J.A, Sutphin, D.M., Gajardo M., Mariano, Diaz, Alejandro, Portigliati, Carlos, Berger, V.I., Carrasco, Rodrigo, and Schulz, K.J., 2008,

Quantitative mineral resource assessment of copper, molybdenum, gold, and silver in undiscovered porphyry copper deposits in the Andes Mountains of South America: U.S. Geological Survey Open-File Report 2008-1253, 282 p., available on CD-ROM and online.

Any use of trade, product, or firm names is for descriptive purposes only and does not imply endorsement by the U.S. Government.

Although this report is in the public domain, permission must be secured from the individual copyright owners to reproduce any copyrighted material contained within this report.

Photograph on front cover by Charles G. Cunningham (USGS). Maps are from figure 1 and graphs are from figure 23 . 


\section{Quantitative Mineral Resource Assessment of Copper, Molybdenum, Gold, and Silver in Undiscovered Porphyry Copper Deposits in the Andes Mountains of South America}

By

The Geological Surveys of:

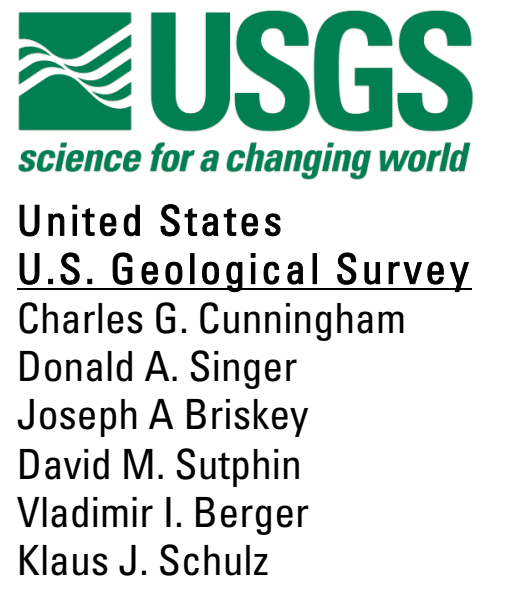

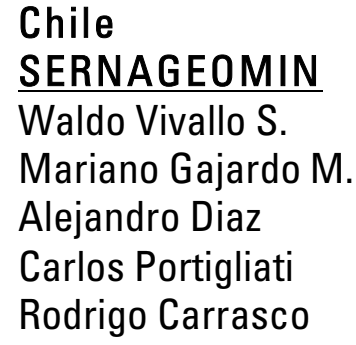

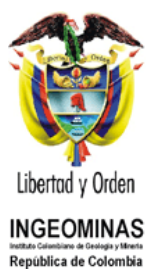

Colombia INGEOMINAS

Carlos Mario Celada

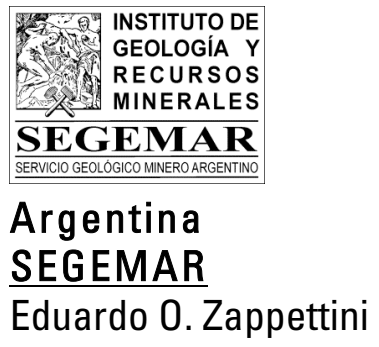

\section{Eduardo 0. Zappettini}

Jointly published by:

\begin{tabular}{ll} 
Country & Organization \\
\cline { 2 - 2 } Argentina & Instituto de Geología y Recursos Minerales (SEGEMAR) \\
Chile & Servicio Nacional de Geología y Minería (SERNAGEOMIN) \\
Colombia & Instituto Colombiano de Geología y Minería (INGEOMINAS) \\
Peru & Instituto Geológico Minero y Metalúrgico (INGEMMET) \\
United States & United States Geological Survey (USGS)
\end{tabular}




\section{Contents}

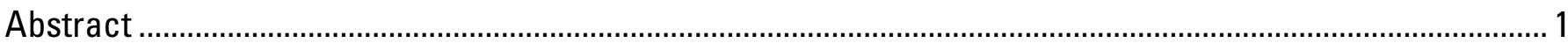

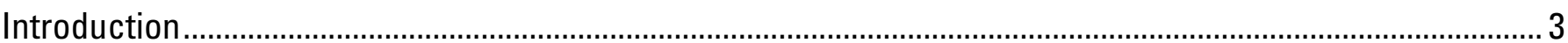

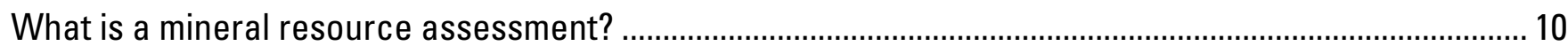

Need for mineral resource assessments............................................................................................... 10

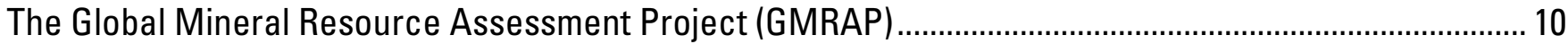

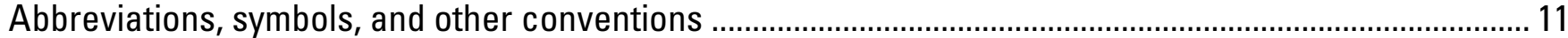

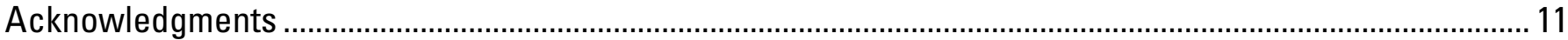

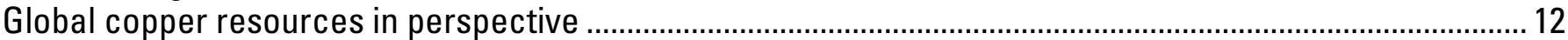

Regional geologic setting of porphyry copper deposits in South America ...................................................... 17

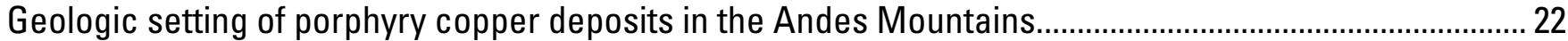

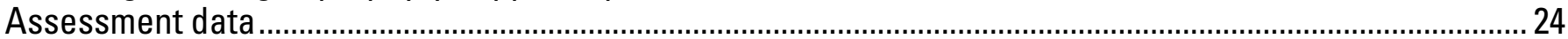

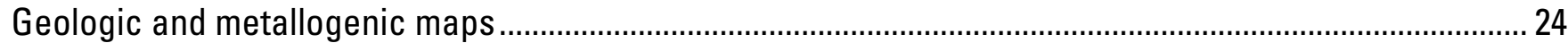

Discovered (known) deposits and prospects.............................................................................................. 25

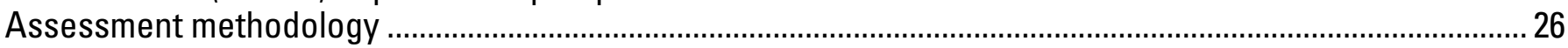

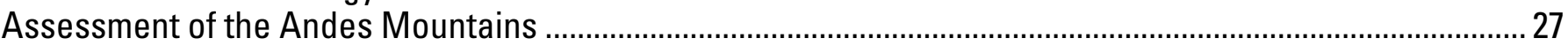

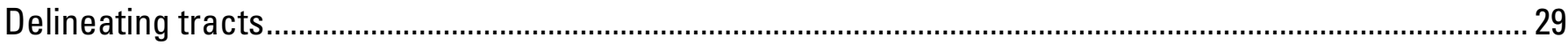

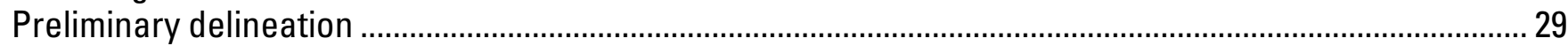

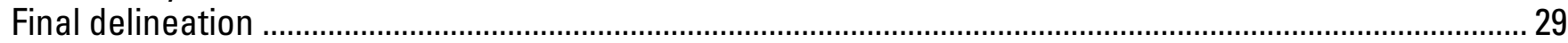

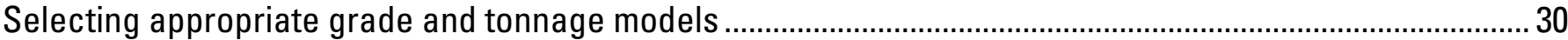

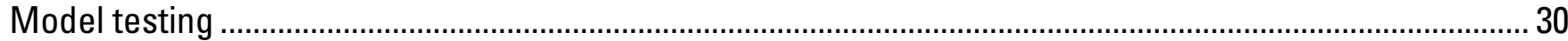

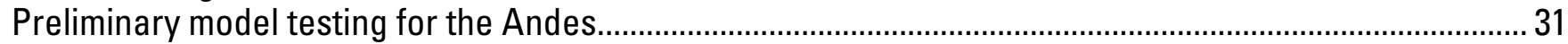

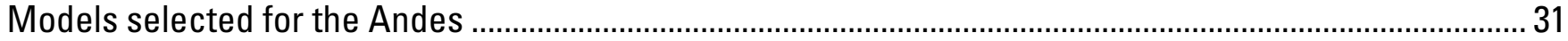

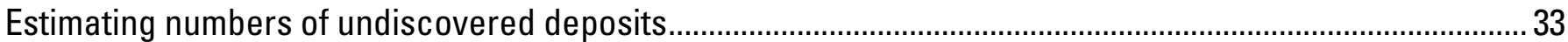

Counting discovered (known) deposits, undiscovered deposits, and prospects.......................................... 33

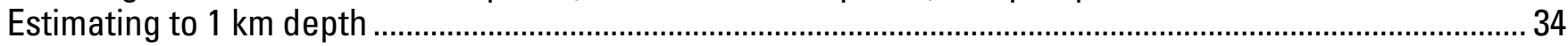

Preliminary estimates of numbers of undiscovered deposits in the Andes .................................................. 34

Final estimates of numbers of undiscovered deposits in the Andes ............................................................. 34

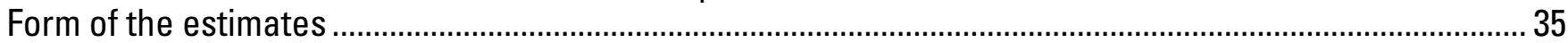

Estimating amounts of undiscovered metal .......................................................................................... 35

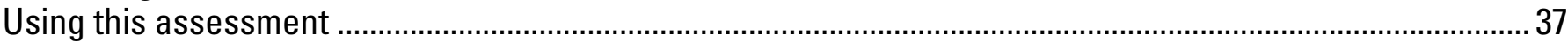

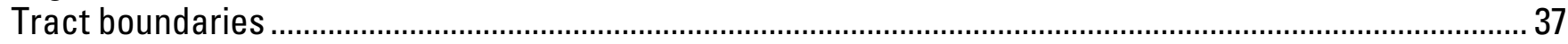

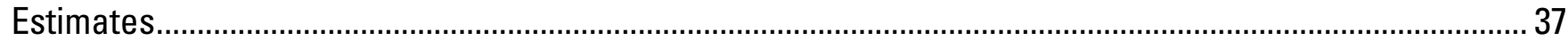

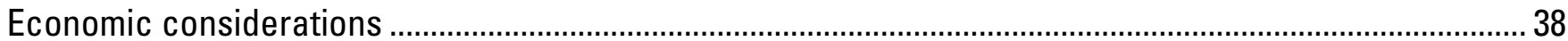

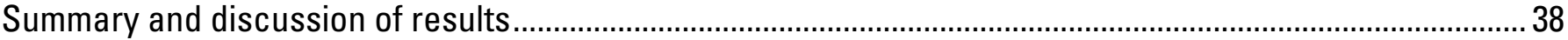

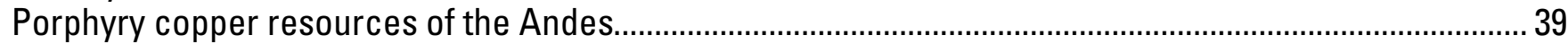

Distribution of porphyry copper resources in the Andes........................................................................... 41

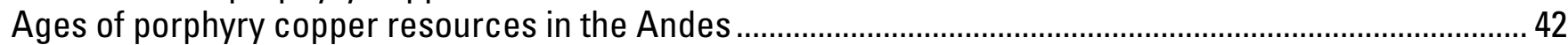

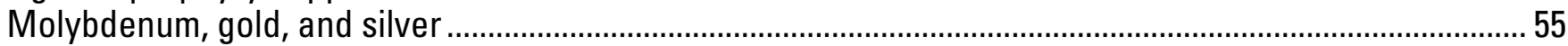

Potential for porphyry copper resources elsewhere in South America .........................................................5

References cited ............................................................................................................................... 57

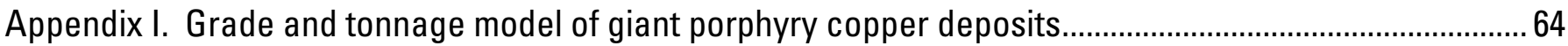

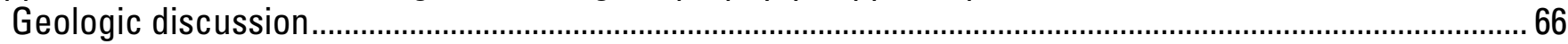

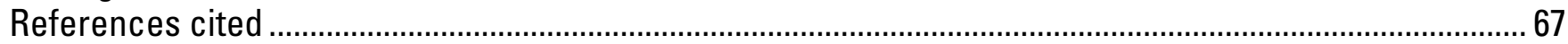

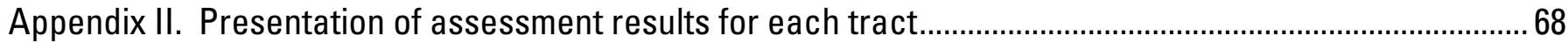

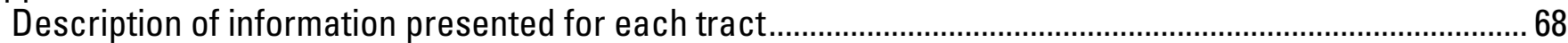

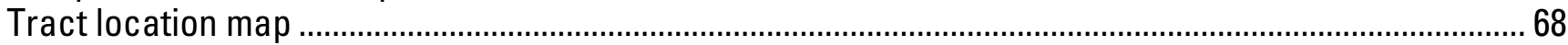

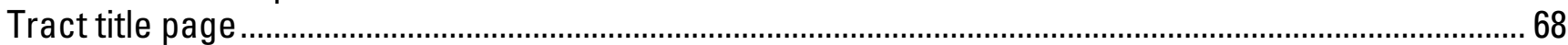

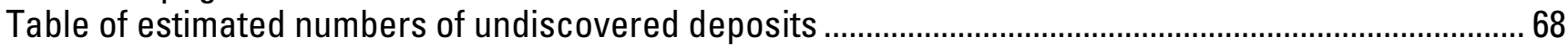

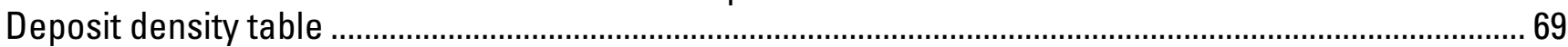


Probability distribution of numbers of undiscovered deposits ................................................................. 69

Histograms of metal and mineralized rock from the EMINERS Monte Carlo simulation ............................. 69

Cumulative probability distribution of metal and mineralized rock from the EMINERS Monte Carlo

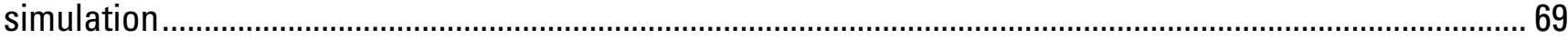

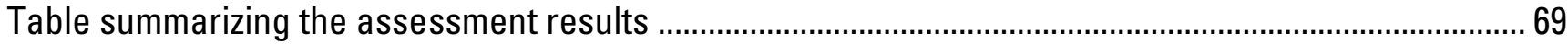

Rationale for tract delineation ........................................................................................................... 70

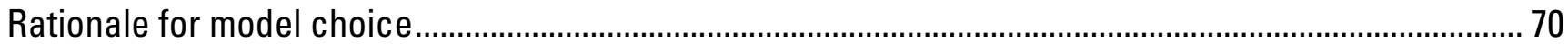

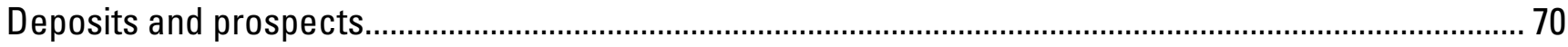

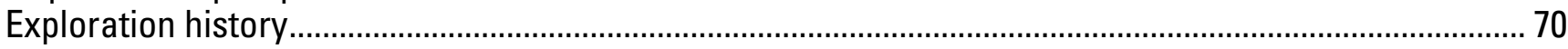

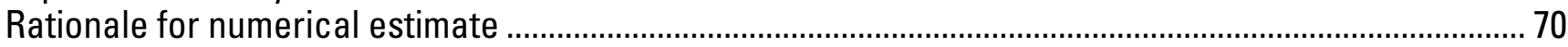

Expected distribution of undiscovered deposits ................................................................................... 70

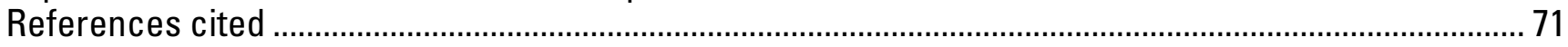

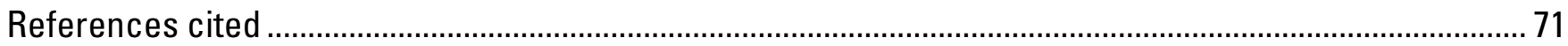

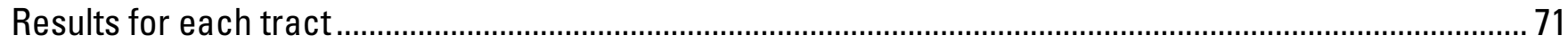

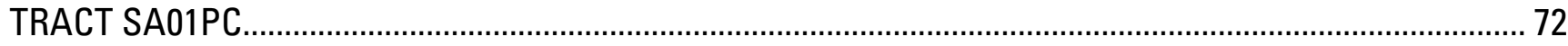

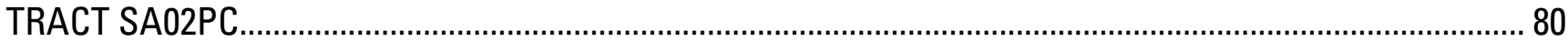

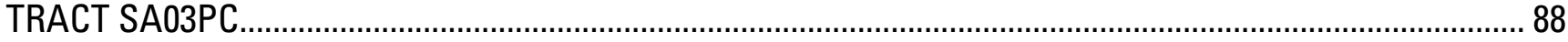

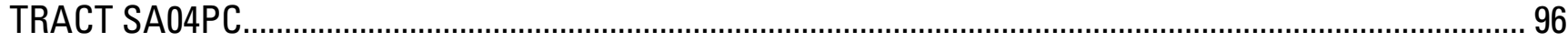

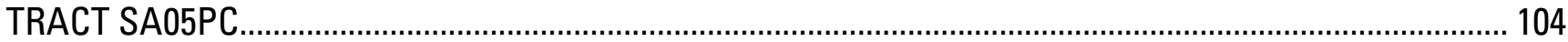

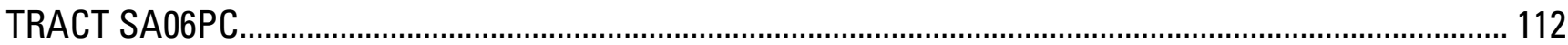

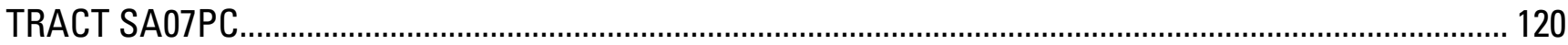

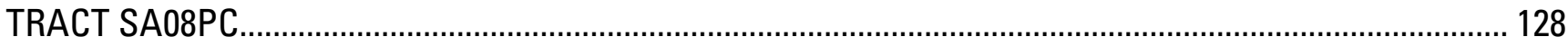

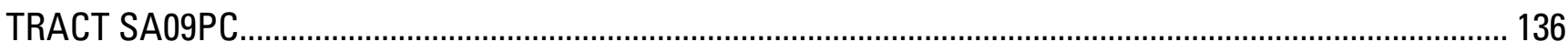

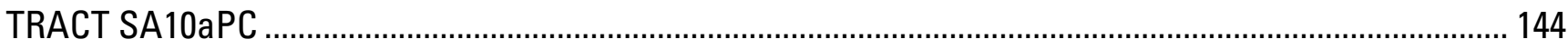

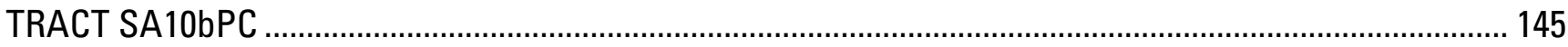

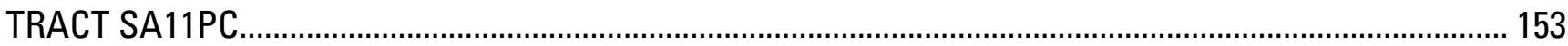

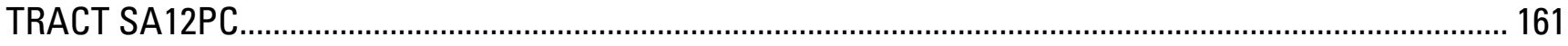

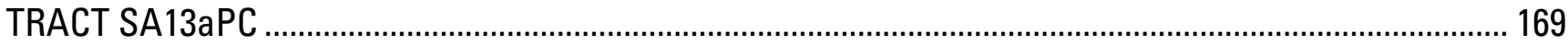

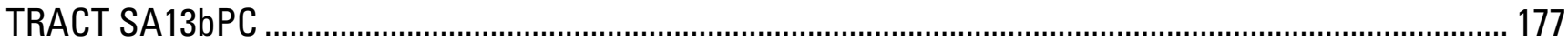

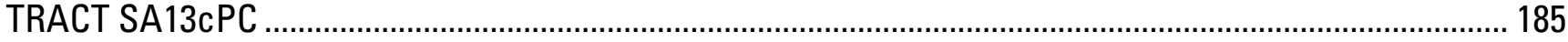

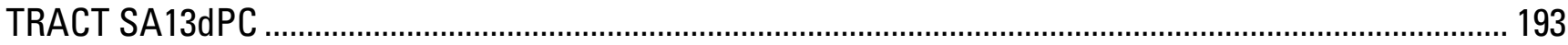

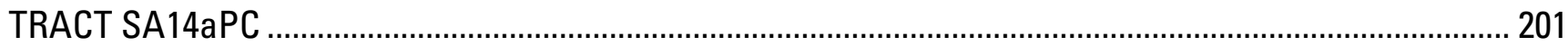

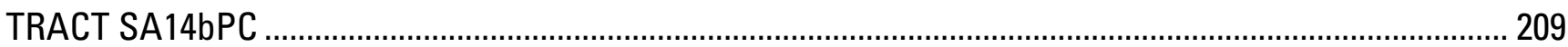

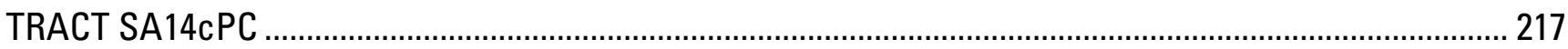

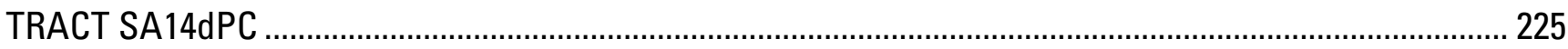

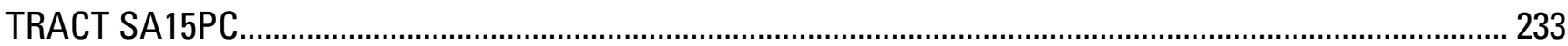

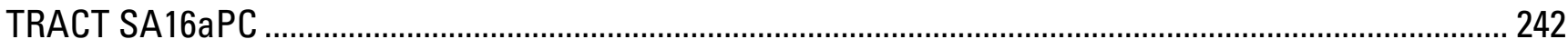

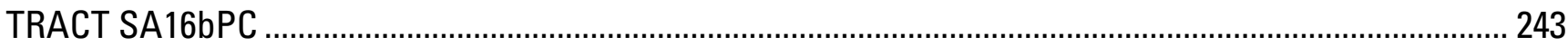

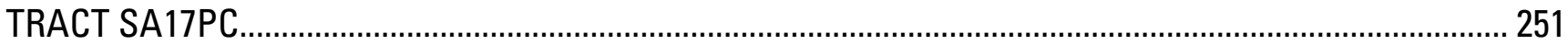

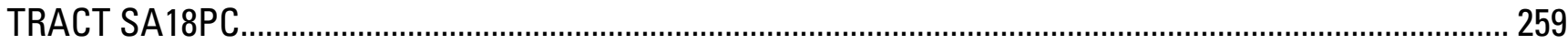

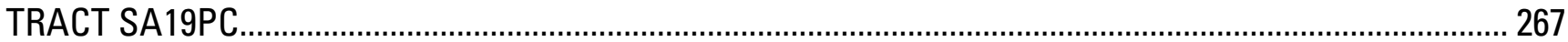

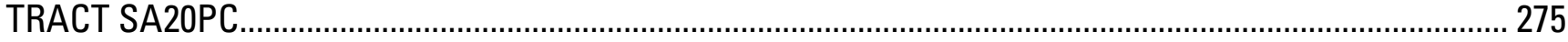




\section{Plates}

\section{[Plates are oversize]}

Plate 1. Map showing porphyry copper deposit tracts by age, discovered deposits, and prospects in the Andes Mountains of South America at scale 1:4,000,000. Separate PDF file.

Plate 2. Map showing porphyry copper deposit tracts by amount of mean estimated undiscovered copper in the Andes Mountains of South America at scale 1:4,000,000.Separate PDF file.

Plate 3. Map showing porphyry copper deposit tracts by density of mean estimated undiscovered copper in metric tons $/ \mathrm{km}^{2}$ in the Andes Mountains of South America at scale 1:4,000,000. Separate PDF file.

\section{Figures}

Figure 1. Map showing porphyry copper deposit tracts by age, discovered deposits, and prospects in the Andes Mountains of South America

Figure 2. Map showing porphyry copper deposit tracts by amount of mean estimated undiscovered copper in the Andes Mountains of South America

Figure 3. Map showing porphyry copper deposit tracts by density of mean estimated undiscovered copper in metric tons $/ \mathrm{km}^{2}$ in the Andes Mountains of South America

Figure 4. Column chart showing world copper production compared to copper resources of the Andes Mountains, United States, and world

Figure 5. Column chart comparing copper production in 2006 from the United States, South America, and the world

Figure 6. Photograph of high-grade porphyry copper ore from a breccia pipe in the uppermost part of the Los Bronces-Rio Blanco porphyry copper-molybdenum deposit, Chile

Figure 7. Diagram illustrating the plate tectonic setting in which porphyry copper deposits are formed

Figure 8. Simplified geologic map of South America showing the Nazca Plate being subducted beneath South America and showing the approximate locations of Precambrian copper porphyry prospects in Brazil.

Figure 9. Schematic tectonic map of South America and the Pacific oceanic plates showing porphyry copper deposits and modern volcanoes

Figure 10. Photograph of participants at the principal assessment workshop in Santiago, Chile, May 16-20, 2005.

Figure 11. Schematic illustration of Monte Carlo resource simulation of undiscovered copper by EMINERS

Figure 12. Column chart comparing discovered and mean estimated undiscovered porphyry copper resources in the giant and other tracts in the Andes

Figure 13. Column chart comparing discovered and mean estimated undiscovered copper by geologic age of host rocks and known mineralization.

Figure 14. Column chart comparing copper endowment by geologic age of host rocks 
Figure 15. Column chart comparing copper endowment by geologic age of host rocks without the effects of giant tracts SA10a,bPC and SA14bPC

Figure 16. Column chart comparing the ages of Cenozoic host rocks, known mineralization, and copper resources

Figure 17. Column chart comparing discovered and mean estimated undiscovered copper among Cenozoic mineralization events and with pre-Cenozoic copper..... 49

Figure 18. Column chart comparing mean estimated undiscovered copper in each tract by approximate age of known mineralization.

Figure 19. Column chart comparing discovered copper in each tract by approximate age of known mineralization

Figure 20. Column chart comparing copper endowment of each tract by approximate age of known mineralization

Figure 21. Column chart comparing density of mean estimated undiscovered copper in each tract by approximate age of known mineralization

Figure 22. Column chart comparing mean estimated undiscovered copper as a percentage of the copper endowment in each tract by approximate age of known mineralization....

Figure 23 a-d. Column charts comparing world production (2006) and reserve base (2007) for copper, molybdenum, gold, and silver to the mean resources of these metals estimated in undiscovered porphyry copper deposits in the Andes

Figure Al-1. Graph showing cumulative frequency of tonnages of giant porphyry copper deposits 65

Figure Al-2. Graph showing cumulative frequency of copper grade of giant porphyry copper deposits

Figure Al-3. Graph showing cumulative frequency of molybdenum grade of giant porphyry copper deposits.

Figure Al-4. Graph showing cumulative frequency of silver grade of giant porphyry copper deposits .....65

Figure Al-5. Graph showing cumulative frequency of gold grade of giant porphyry copper deposits .......66

\section{Tables}

Table 1. Permissive tracts, discovered deposits, and prospects 8

Table 2. Summary of principal assessment results. 15

Table 3. Probability from t-test that tonnages and grades of known deposits in each tract are from the general porphyry copper grade and tonnage model.

Table 4. Comparison of tonnages and grades of giant and general porphyry copper deposit models......33

Table Al-1. Tonnage and grade data from Singer, Berger, and Moring (2005) for the deposits in tracts SA10a,bPC and SA14bPC that comprise the giant model.

Table Al-2. Comparison of tonnages and grades of giant and general porphyry copper deposit models. 66

Table All-1. Measures of uncertainty in estimates of numbers of undiscovered deposits. 69 


\section{Conversion Factors}

\begin{tabular}{lcl}
\hline \multicolumn{1}{c}{ Multiply } & By & \multicolumn{1}{c}{ To obtain } \\
\hline kilometer $(\mathrm{km})$ & 0.6214 & mile $(\mathrm{mi})$ \\
meter $(\mathrm{m})$ & 1.094 & yard $(\mathrm{yd})$ \\
square kilometer $\left(\mathrm{km}^{2}\right)$ & 247.1 & acre \\
square kilometer $\left(\mathrm{km}^{2}\right)$ & 0.3861 & square mile $\left(\mathrm{mi}^{2}\right)$ \\
megagram $(\mathrm{Mg})($ metric ton $)$ & 1.102 & ton, short $(2,000 \mathrm{lb})$ \\
megagram $(\mathrm{Mg})($ metric ton $)$ & 0.9842 & ton, long $(2,240 \mathrm{lb})$ \\
\hline
\end{tabular}




\section{Quantitative Mineral Resource Assessment of Copper, Molybdenum, Silver, and Gold in Undiscovered Porphyry Copper Deposits in the Andes Mountains of South America}

By

Charles G. Cunningham, ${ }^{1}$ Eduardo 0. Zappettini, ${ }^{2}$ Waldo Vivallo S., ${ }^{3}$ Carlos Mario Celada, ${ }^{4}$ Jorge Quispe, ${ }^{5}$ Donald A. Singer, ${ }^{6}$ Joseph A Briskey, ${ }^{1}$ David M. Sutphin, ${ }^{1}$ Mariano Gajardo M., ${ }^{3}$ Alejandro Diaz, ${ }^{3}$ Carlos Portigliati, ${ }^{3}$ Vladimir I. Berger ${ }^{6}$ Rodrigo Carrasco, ${ }^{3}$ and Klaus J. Schulz ${ }^{1}$

'U.S. Geological Survey, Reston, VA, USA.

IInstituto de Geología y Recursos Minerales, Buenos Aires, Argentina.

${ }^{3}$ Servicio Nacional de Geología y Minería, Providencia, Santiago, Chile.

${ }^{4}$ Instituto Colombiano de Geología y Minería, Colombia.
${ }^{5}$ Instituto Geológico Minero y Metalúrgico, Peru.

Instituto Geológico Minero y Metalúrgico, Peru.
${ }^{6}$ U.S. Geological Survey, Menlo Park, CA, USA.

\section{Abstract}

Quantitative information on the general locations and amounts of undiscovered porphyry copper resources of the world is important to exploration managers, land-use and environmental planners, economists, and policymakers. This publication contains the results of probabilistic estimates of the amounts of copper $(\mathrm{Cu})$, molybdenum (Mo), silver $(\mathrm{Ag})$, and gold ( $\mathrm{Au}$ ) in undiscovered porphyry copper deposits in the Andes Mountains of South America. The methodology used to make these estimates is called the "Three-Part Form." It was developed to explicitly express estimates of undiscovered resources and associated uncertainty in a form that allows economic analysis and is useful to decisionmakers.

The three-part form of assessment includes: (1) delineation of tracts of land where the geology is permissive for porphyry copper deposits to form; (2) selection of grade and tonnage models appropriate for estimating grades and tonnages of the undiscovered porphyry copper deposits in each tract; and (3) estimation of the number of undiscovered porphyry copper deposits in each tract consistent with the grade and tonnage model. A Monte Carlo simulation computer program (EMINERS) was used to combine the probability distributions of the estimated number of undiscovered deposits, the grades, and the tonnages of the selected model to obtain the probability distributions for undiscovered metals in each tract. These distributions of grades and tonnages then can be used to conduct economic evaluations of undiscovered resources in a format usable by decisionmakers. Economic evaluations are not part of this report.

The results of this assessment are presented in two principal parts. The first part identifies 26 regional tracts of land where the geology is permissive for the occurrence of undiscovered porphyry copper deposits of Phanerozoic age to a depth of $1 \mathrm{~km}$ below the Earth's surface. These tracts are believed to contain most of South America's undiscovered resources of copper. The second part presents probabilistic estimates of the amounts of copper, molybdenum, gold, and silver in undiscovered porphyry copper deposits in each tract. The study also provides tables showing the location, tract number, and age (if available) of discovered deposits and prospects. For each of the 26 permissive tracts delineated in this study, summary information is provided on: (1) the rationale for delineating the tract; (2) the rational for choosing the mineral deposit model used to assess the tract; (3) discovered deposits and prospects; (4) 
exploration history; and (5) the distribution of undiscovered deposits in the tract. The scale used to evaluate geologic information and draw tracts is 1:1,000,000.

There are 69 known porphyry copper deposits in the Andes using criteria adopted herein to define a deposit. This assessment estimates that about 145 undiscovered deposits remain. In other words, about twice as many new deposits might be found as have already been found. Not only have large quantities of copper been discovered, but also even larger quantities of undiscovered copper remain. About 590 million metric tons of copper have been discovered. About 190 million tons of this amount are in 57 deposits of the general porphyry copper type whereas nearly 400 million metric tons are in an additional 12 giant deposits. This study estimates that there are approximately 750 million metric tons of copper in undiscovered deposits of these two types in the Andes. This undiscovered copper resource is the sum of the mean estimated copper in each of 26 tracts. About 470 million metric tons of this copper are estimated to occur in 137 undiscovered deposits in 24 tracts of the general porphyry copper type, plus another 280 million metric tons estimated in 8 undiscovered deposits in 2 tracts of the giant porphyry copper type. The total discovered, mined, and undiscovered copper amounts to an endowment, or grand total, of about 1.3 billion metric tons. The estimates suggest there may be almost 1.3 times as much copper to be found in porphyry copper deposits of the Andes as has already been found.

In addition to copper, the undiscovered deposits also contain large estimated amounts of molybdenum (20,000,000 metric tons), gold (13,000 tons), and silver (250,000 tons). The estimated undiscovered copper is equivalent to about 80 percent of the world reserve base; molybdenum, 105 percent; gold, 14 percent; and silver, 44 percent.

Not all of these undiscovered mineral resources are likely to be available for discovery and development. Commonly, a significant amount of land delineated as permissive or even favorable for the occurrence of undiscovered mineral deposits is not available for mineral exploration, discovery, and development because it consists of urban areas, transportation corridors, forest and wildlife preserves, sensitive ecosystems, protected biodiversity areas, sensitive and threatened surface and groundwater supplies, wilderness areas, national parks, private land where mining is not desired, and many other reasons. Global inventory and analysis are needed of such restrictions and their probable impact on future mineral supply and costs.

The porphyry copper resources reported herein are not evenly distributed throughout the Andes region. The Chuquicamata tract (SA10a,bPC) and the El Teniente tract (SA14bPC) are remarkable in containing exceptionally large deposits of discovered, mined, and estimated undiscovered copper that do not conform to grade and tonnage characteristics of the general porphyry copper model appropriate for other Andean tracts. The deposits in these two tracts being significantly larger in tonnage and higher in grade necessitated a new giant model that is more representative of their characteristics. The greatest premining endowment of copper is in Eocene-Oligocene tract SA10a,bPC with about 460 million metric tons, followed by late Miocene-early Pliocene tract SA14bPC with about 220 million metric tons. The next largest endowments are in tract SA8PC (a Paleocene-Eocene tract of Chile-southern Peru) containing an endowment of about 98 million metric tons and in tract SA6PC (the middle-late Miocene tract of PeruEcuador) with an endowment of about 96 million metric tons. The undiscovered copper remaining to be found in these four tracts is estimated to be: tract SA10a,bPC, 210 million metric tons; tract SA14bPC, 69 million; tract SA6PC, 49 million; and tract SA8PC, 43 million.

Density of estimated undiscovered metal in tracts was examined as mean metric tons of metal per $\mathrm{km}^{2}$ in undiscovered deposits. Giant tracts SA10a,bPC and SA14bPC have the highest copper densities with about 8,200 and 7,400 metric tons per $\mathrm{km}^{2}$, respectively. The next richest tracts, with just over 2,000 metric tons per $\mathrm{km}^{2}$, are tracts SA12PC and SA14dPC.

About 90 percent of the total discovered and estimated undiscovered copper resources in Andean porphyry copper deposits is of Cenozoic age; the remainder is Cretaceous (4\%), Jurassic (5\%), and Permian $(2 \%)$ in age. The Cenozoic resources are in tracts with host rock ages of Eocene-Oligocene 
(39\%), Miocene-Pliocene (29\%), Paleocene-Eocene (12\%), and Miocene (11\%). The Eocene-Oligocene and Miocene-Pliocene tracts are dominated by giant tracts SA10a,bPC (includes Chuquicamata deposit) and SA14bPC (includes El Teniente deposit).

There appear to have been three approximately 16-million-year-long episodes of porphyry copper deposit formation in the Andes during Cenozoic time: Paleocene-early Eocene, late Eocene-early Oligocene; and middle Miocene-early Pliocene. These three episodes appear to be separated by two intervening quiescent periods of 5 to 9 million years duration in the middle Eocene (44-49 Ma) and late Oligocene-early Miocene (20-29 Ma). These two periods correspond to times of change in Pacific plate boundaries, geometries, and directions and rates of spreading and convergence.

There are variations in the geographic trends of magmatic arcs in the southern Andes. Tract SA14cPC, for example, follows a transverse SE-trending band of late Miocene-early Pliocene volcanic rocks and associated upper Miocene porphyry copper deposits, prospects, and other areas of altered and mineralized rocks. The parent magmatic source is approximately perpendicular to the grain of the faultcontrolled outcrops of metamorphic basement rocks that reflect the surface geology and could be controlled by a tear fault in a subducted plate. Southeast-trending tract SA19PC, which extends from the Andes south southeasterly across the Patagonia of Argentina to the Atlantic Ocean, and contains the Bajo de la Leona prospect, also shows that Mesozoic porphyry copper ore-forming processes occurred outside of the present-day trend of the Andes.

The results of this assessment study are likely to spur research and exploration activities in the Andes and adjacent regions, which in turn will enable the evaluation and update of regional assessments of porphyry copper resources in the future.

\section{Introduction}

Quantitative information on the general locations and amounts of undiscovered porphyry copper resources of the world is important to exploration managers, land-use and environmental planners, economists, and policymakers. This publication describes the process and results of a mineral resource assessment that delineates the regional locations and probabilistically estimates the amounts of copper $(\mathrm{Cu})$, molybdenum $(\mathrm{Mo})$, gold $(\mathrm{Au})$, and silver $(\mathrm{Ag})$ in undiscovered porphyry copper deposits in the Andes Mountains of South America.

These assessment results are presented in two principal parts. The first part identifies 26 tracts of land where the geology is permissive for the occurrence of undiscovered porphyry copper deposits of Phanerozoic age to a depth of $1 \mathrm{~km}$ below the Earth's surface. The "Digital Map File" that is part of this publication contains digital shape files and linked attribute tables for each tract at a scale of 1,1000,000 for use in GIS applications. In addition, plates 1-3 are PDF maps showing in various ways all of the tracts delineated in the Andes together at a scale of 1:4,000,000. Page-size versions of these maps are shown as figures 1-3. Plate 1 and figure 1 show the ages, discovered deposits, and prospects of the tracts. Table 1 tabulates the geologic ages and locations of each tract, together with the ages and locations of discovered deposits and prospects known at the time of the assessment. These 26 tracts are believed to contain most of South America's undiscovered resources of copper.

The second part of the assessment results are presented in Appendix II and consist of tabular and graphical presentations of probabilistic estimates of the numbers of undiscovered deposits, tons of rock, and contained tons of copper, molybdenum, gold, and silver in each tract. Also included are location maps and supporting technical descriptions and rationales for tract delineation and deposit estimation. These results are illustrated in map form in plate 2 and figure 2, which show tracts by mean estimated undiscovered copper, and in plate 3 and figure 3, which show tracts by density of mean estimated undiscovered copper in metric tons $/ \mathrm{km}^{2}$. Tract labels (e.g., SA01PC) on the three plates are linked to the 
sections of this report describing the assessment results for each tract. Clicking on a tract label will open the PDF version of the report to the appropriate section. 


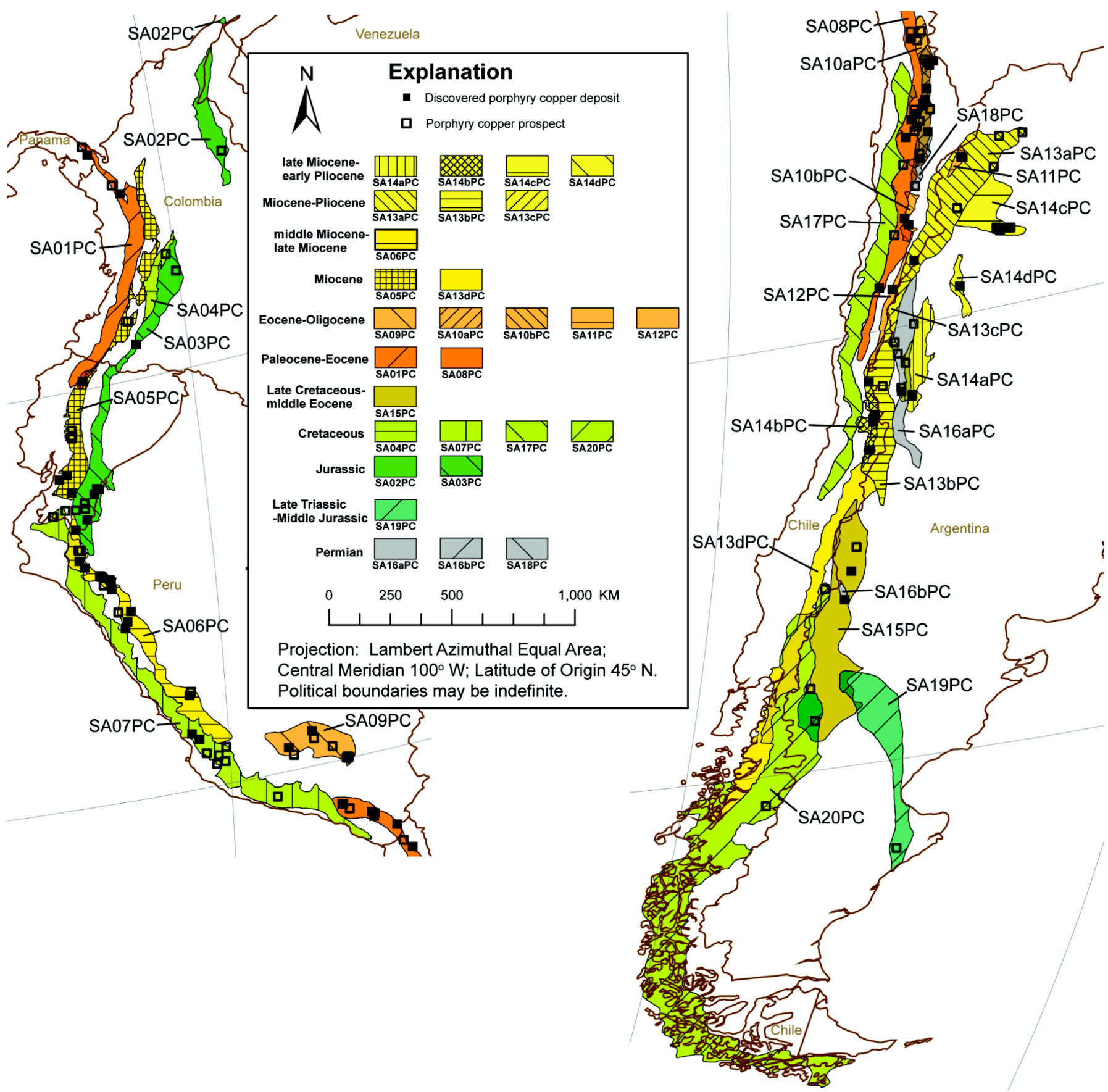

Figure 1. Map showing porphyry copper deposit tracts by age, discovered deposits, and prospects in the Andes Mountains of South America. This is a simplified version of plate 1. 


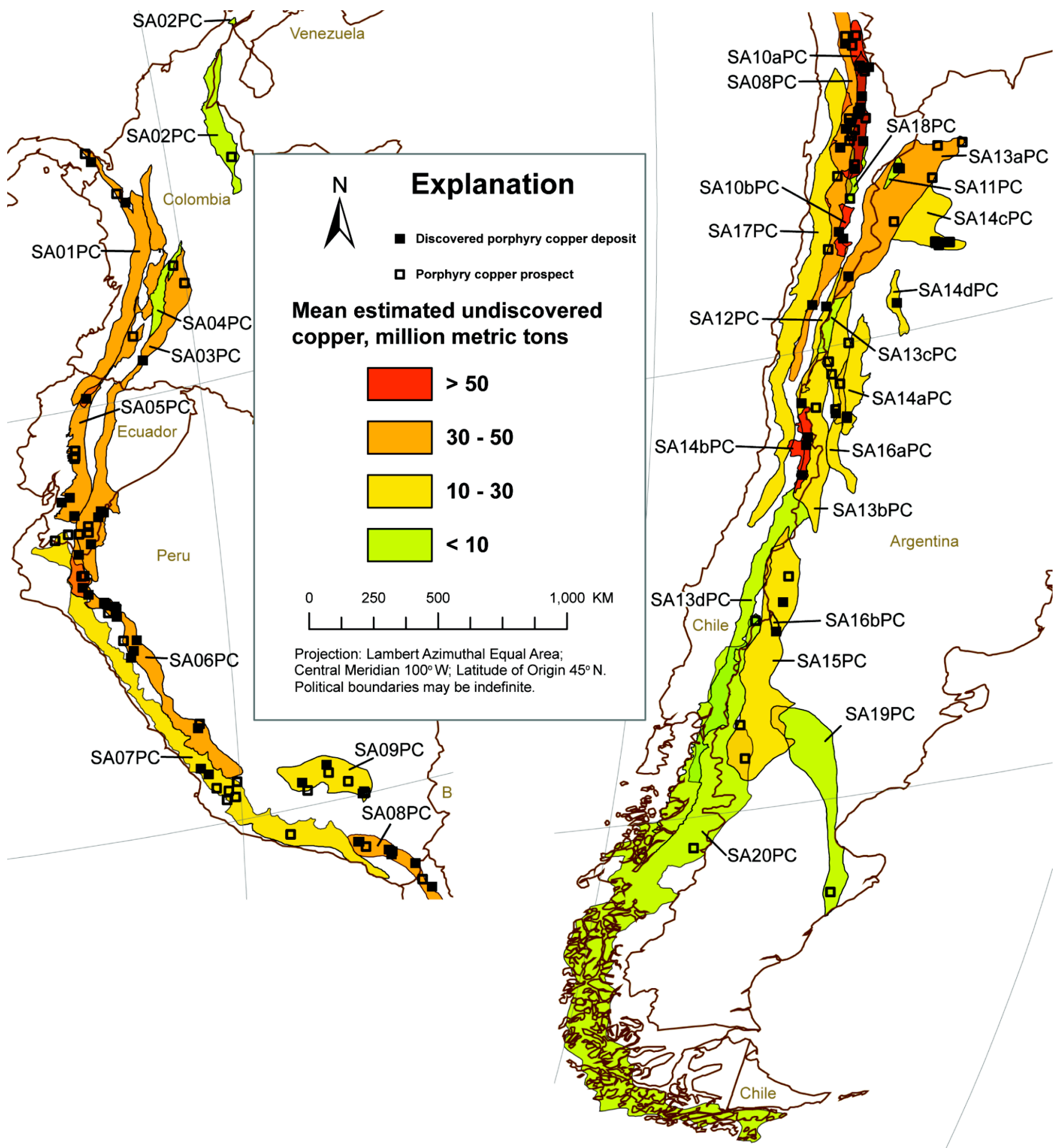

Figure 2. Map showing porphyry copper deposit tracts by amount of mean estimated undiscovered copper in the Andes Mountains of South America. This is a simplified version of plate 2. 
Prepared and published jointly by the geological surveys of Argentina (SEGEMAR), Chile (SERNAGEOMIN), Colombia,

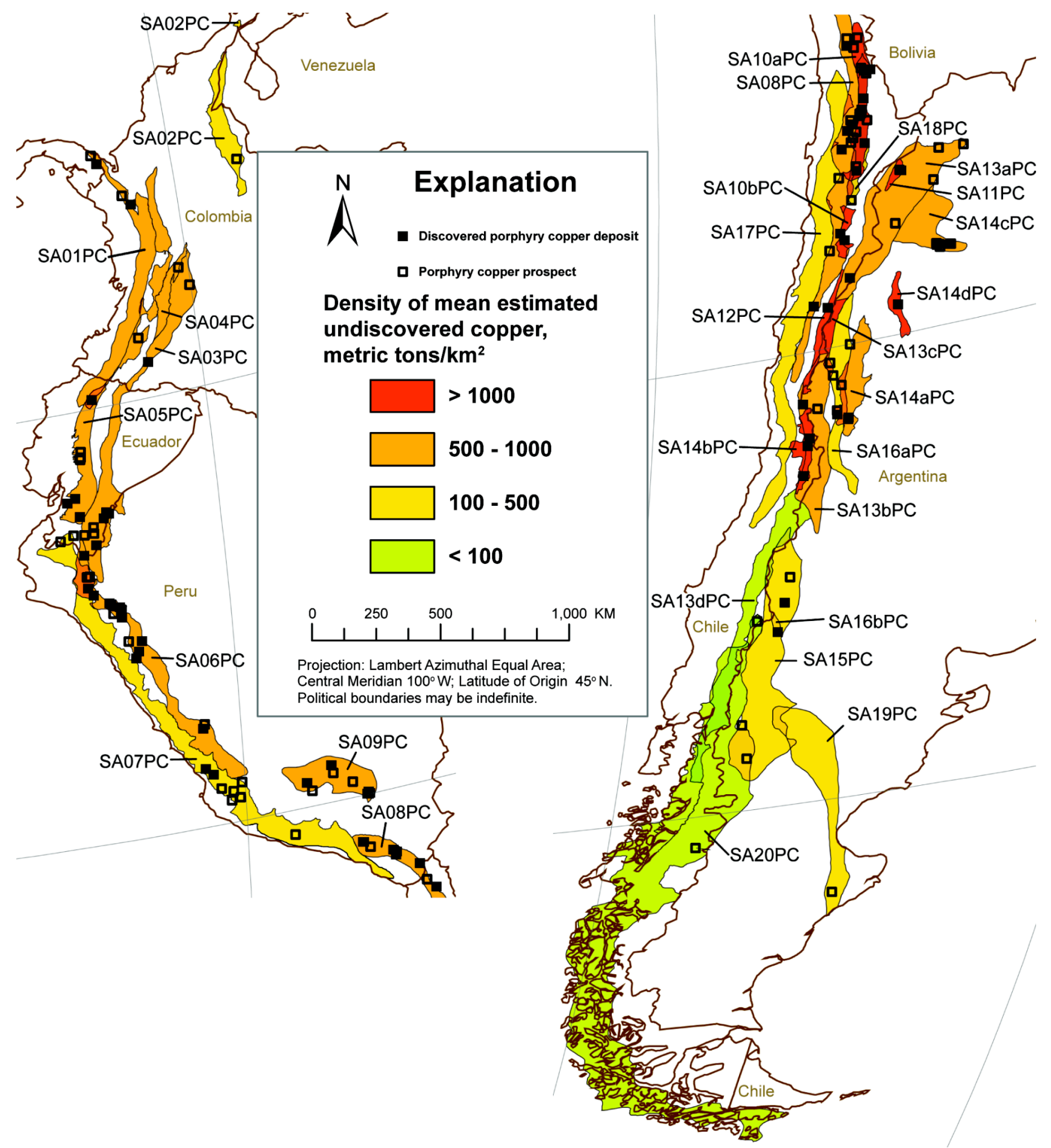

Figure 3. Map showing porphyry copper deposit tracts by density of mean estimated undiscovered copper in metric tons $/ \mathrm{km}^{2}$ in the Andes Mountains of South America. This is a simplified version of plate 3. 
Table 1. Permissive tracts, discovered deposits, and prospects.

\begin{tabular}{|c|c|c|c|c|c|c|c|c|c|c|c|}
\hline \multicolumn{3}{|c|}{ Tracts } & \multicolumn{9}{|c|}{ Porphyry copper deposits and prospects' } \\
\hline $\begin{array}{l}\text { Tract } \\
\text { No. }\end{array}$ & Host-rock age ${ }^{2}$ & Countries & Name & Other names & 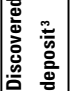 & $\begin{array}{l}\text { Mineralization } \\
\text { age, Ma }\end{array}$ & Country & Latitude & Longitude & $\begin{array}{l}\text { Lati- } \\
\text { tude } \\
\text { (dd) }\end{array}$ & $\begin{array}{c}\text { Longi- } \\
\text { tude } \\
\text { (dd) }\end{array}$ \\
\hline SA01PC & Paleocene-Eocene & Colombia-Eduador-Panama & Acandi & & Yes & 38 & Colombia & $\mathrm{B}^{\circ} 20^{\prime} 0^{\prime \prime} \mathrm{N}$ & $77^{\circ} 24^{\prime} 0^{\prime \prime} \mathrm{W}$ & & -77.40 \\
\hline SA01PC & Paleocene-Eocene & Colombia-Eduador-Panama & Murindo & & & 55 & Colombia & $7^{\circ} 03^{\prime} 00^{\prime \prime} \mathrm{N}$ & $76^{\circ} 45^{\prime} 0^{\prime \prime} \mathrm{W}$ & 7.05 & -76.75 \\
\hline SA01PC & Paleocene-Eocene & Colombia-Eduador-Panama & Pegadorcito-Pantanos & & Yes & 43 & Colombia & $6^{\circ} 42^{\prime} 0^{\prime \prime} \mathrm{N}$ & $76^{\circ} 30^{\prime} 0^{\prime \prime} \mathrm{W}$ & 6.70 & -76.50 \\
\hline SA01PC & Paleocene-Eocene & Colombia-Eduador-Panama & Rio Pito & & & 49 & Panama & $8^{\circ} 38^{\prime} 0^{\prime \prime} \mathrm{N}$ & $77^{\circ} 34^{\prime} 0 " \mathrm{~W}$ & 8.63 & \begin{tabular}{|c|}
-77.57 \\
\end{tabular} \\
\hline SA02PC & Jurassic & Colombia-Venezuela & California & & & 144 & Colombia & $7^{\circ} 19^{\prime} 0^{\prime \prime} \mathrm{N}$ & $72^{\circ} 52^{\prime} 0 " \mathrm{~W}$ & 7.32 & \begin{tabular}{|c|}
-72.87 \\
\end{tabular} \\
\hline SA03PC & Jurassic & Colombia-Ecuador-Peru & Cumay & & & 141 & Ecuador & $4^{\circ} 03^{\prime} 0^{\prime \prime S}$ & $78^{\circ} 57^{\prime} 0 " \mathrm{~W}$ & -4.05 & -78.95 \\
\hline SA03PC & Jurassic & Colombia-Ecuador-Peru & Dolores & & & 166 & Colombia & $3^{\circ} 31^{\prime} 0^{\prime \prime} \mathrm{N}$ & $75^{\circ} 02^{\prime} 0 " \mathrm{~W}$ & 3.52 & -75.03 \\
\hline SA03PC & Jurassic & Colombia-Ecuador-Peru & El Hito & & & 154 & Ecuador & $4^{\circ} 15^{\prime} 0^{\prime \prime} \mathrm{S}$ & $78^{\circ} 57^{\prime} 0 " \mathrm{~W}$ & -4.25 & -78.95 \\
\hline SA03PC & Jurassic & Colombia-Ecuador-Peru & Mirador & & Yes & 154 & Ecuador & $4^{\circ} 39^{\prime} 0^{\prime \prime} \mathrm{S}$ & $78^{\circ} 54^{\prime} 0^{\prime \prime} \mathrm{W}$ & -4.65 & -78.90 \\
\hline SA03PC & Jurassic & Colombia-Ecuador-Peru & Mocoa & & Yes & 166 & Colombia & $1^{\circ} 14^{\prime} 30^{\prime \prime} \mathrm{N}$ & $76^{\circ} 40^{\prime} 0^{\prime \prime} \mathrm{W}$ & 1.24 & -76.67 \\
\hline SA03PC & Jurassic & Colombia-Ecuador-Peru & Panantza & & Yes & 154 & Ecuador & $3^{\circ} 36^{\prime} 0^{\prime \prime} \mathrm{S}$ & $78^{\circ} 30^{\prime} 0 " \mathrm{~W}$ & -3.60 & -78.50 \\
\hline SA03PC & Jurassic & Colombia-Ecuador-Peru & San Carlos & & Yes & 154 & Ecuador & $3^{\circ} 39^{\prime} 0^{\prime \prime} \mathrm{S}$ & $78^{\circ} 25^{\prime} 0^{\prime \prime} \mathrm{W}$ & -3.65 & -78.42 \\
\hline SA03PC & Jurassic & Colombia-Ecuador-Peru & Tumi & & & 154 & Ecuador & $4^{\circ} 15^{\prime} 0^{\prime \prime S}$ & $79^{\circ} 15^{\prime} 0^{\prime \prime} \mathrm{W}$ & -4.25 & -79.25 \\
\hline SA03PC & Jurassic & Colombia-Ecuador-Peru & \begin{tabular}{|l|} 
Warintza \\
\end{tabular} & & Yes & 154 & Ecuador & $3^{\circ} 47^{\prime} 0^{\prime \prime} \mathrm{S}$ & $78^{\circ} 36^{\prime} 0^{\prime \prime} \mathrm{W}$ & -3.78 & -78.60 \\
\hline SA04PC & Cretaceous & Colombia & Infierno-Chilí & & & 131 & Colombia & $4^{\circ} 11^{\prime} 0^{\prime \prime} \mathrm{N}$ & $75^{\circ} 17^{\prime} 0 " \mathrm{~W}$ & 4.18 & -75.30 \\
\hline SA05PC & Miocene & Colombia-Ecuador & Balzapamba-Las Guardias & & & 20 & Ecuador & $1^{\circ} 39^{\prime} 0^{\prime \prime} \mathrm{S}$ & $79^{\circ} 09^{\prime} 0 " \mathrm{~W}$ & -1.65 & -79.15 \\
\hline SA05PC & Miocene & Colombia-Ecuador & Chaso Juan & & & 20 & Ecuador & $1^{\circ} 23^{\prime} 0^{\prime \prime} \mathrm{S}$ & $79^{\circ} 07^{\prime} 0 " \mathrm{~W}$ & -1.38 & -79.12 \\
\hline SA05PC & Miocene & Colombia-Ecuador & Chaucha & & Yes & 11 & Ecuador & $2^{\circ} 56^{\prime} 0^{\prime \prime} \mathrm{S}$ & $79^{\circ} 25^{\prime} 0^{\prime \prime} \mathrm{W}$ & -2.93 & -79.42 \\
\hline SA05PC & Miocene & Colombia-Ecuador & Fierro Urcu & & Yes & 10 & Ecuador & $3^{\circ} 35^{\prime} 0^{\prime \prime} \mathrm{S}$ & $79^{\circ} 20^{\prime} 0^{\prime \prime} \mathrm{W}$ & -3.58 & -79.33 \\
\hline SA05PC & Miocene & Colombia-Ecuador & Gaby-Papa Grande & & Yes & 19 & Ecuador & $3^{\circ} 3^{\prime} 0^{\prime \prime} \mathrm{S}$ & $79^{\circ} 41^{\prime} 0^{\prime \prime} \mathrm{W}$ & -3.05 & -79.68 \\
\hline SA05PC & Miocene & Colombia-Ecuador & Junin & & Yes & 7 & Ecuador & $10^{\circ} 20^{\prime} 0^{\prime \prime} \mathrm{N}$ & $78^{\circ} 35^{\prime} 0^{\prime \prime} \mathrm{W}$ & 0.33 & -78.58 \\
\hline SA05PC & Miocene & Colombia-Ecuador & Piedrasentada & & & 17 & Colombia & $2^{\circ} 06^{\prime} 0^{\prime \prime} \mathrm{N}$ & $76^{\circ} 53^{\prime} 0 " \mathrm{~W}$ & 2.10 & -76.88 \\
\hline SA05PC & Miocene & Colombia-Ecuador & Telimbela & & & 15 & Ecuador & $1^{\circ} 34^{\prime} 0^{\prime \prime} \mathrm{S}$ & $79^{\circ} 08^{\prime} 0 " \mathrm{~W}$ & -1.57 & -79.13 \\
\hline SA06PC & middle-late Miocene & Peru-Ecuador & Aguila & El Aguila & Yes & & Peru & $8^{\circ} 33^{\prime} 35^{\prime \prime} \mathrm{S}$ & $77^{\circ} 53^{\prime} 48^{\prime \prime} \mathrm{W}$ & -8.56 & -77.90 \\
\hline SA06PC & middle-late Miocene & Peru-Ecuador & Alto Dorado & & & & Peru & $8^{\circ} 10^{\prime} 0^{\prime \prime} \mathrm{S}$ & $78^{\circ} 11^{\prime} 0^{\prime \prime} \mathrm{W}$ & -8.17 & -78.18 \\
\hline SA06PC & middle-late Miocene & $\begin{array}{l}\text { Peru-Ecuador } \\
\end{array}$ & \begin{tabular}{|l|l} 
Cañariaco \\
\end{tabular} & & Yes & 15 & $\begin{array}{l}\text { Peru } \\
\end{array}$ & $6^{\circ} 5^{\prime} 0^{\prime \prime} \mathrm{S}$ & $79^{\circ} 17^{\prime} 0^{\prime \prime} \mathrm{W}$ & -6.08 & -79.28 \\
\hline SA06PC & middle-late Miocene & Peru-Ecuador & Cerro Corona & Hualgayoc District & Yes & 11 & Peru & $6^{\circ} 45^{\prime} 42^{\prime \prime} \mathrm{S}$ & $78^{\circ} 36^{\prime} 21^{\prime \prime} \mathrm{W}$ & -6.76 & -78.61 \\
\hline SA06PC & middle-late Miocene & Peru-Ecuador & El Galeno & & Yes & 14 & Peru & $7^{\circ} 1^{\prime} 0^{\prime \prime} \mathrm{S}$ & $78^{\circ} 19^{\prime} 0^{\prime \prime} \mathrm{W}$ & -7.02 & -78.32 \\
\hline SA06PC & middle-late Miocene & Peru-Ecuador & La Granja & & Yes & 12 & Peru & $6^{\circ} 21^{\prime} 30^{\prime \prime} \mathrm{S}$ & $79^{\circ} 7^{\prime} 10^{\prime \prime} \mathrm{W}$ & -6.36 & -79.12 \\
\hline SA06PC & middle-late Miocene & Peru-Ecuador & La Vega & & & & Peru & $5^{\circ} 42^{\prime} 17^{\prime \prime} \mathrm{S}$ & $79^{\circ} 16^{\prime} 51^{\prime \prime} \mathrm{W}$ & -5.70 & -79.28 \\
\hline SA06PC & middle-late Miocene & Peru-Ecuador & Laguna Chamis & & & & Peru & $7^{\circ} 07^{\prime} 05^{\prime \prime} \mathrm{S}$ & $78^{\circ} 34^{\prime} 32^{\prime \prime}$ & -7.12 & -78.58 \\
\hline SA06PC & middle-late Miocene & $\begin{array}{l}\text { Peru-Ecuador } \\
\end{array}$ & \begin{tabular}{|l|l} 
Magistral \\
\end{tabular} & & Yes & 15 & \begin{tabular}{|l|l|} 
Peru \\
\end{tabular} & $8^{\circ} 13^{\prime} 0^{\prime \prime} \mathrm{S}$ & $77^{\circ} 46^{\prime} 0^{\prime \prime} \mathrm{W}$ & -8.22 & \begin{tabular}{|c|}
-777.77 \\
\end{tabular} \\
\hline SA06PC & middle-late Miocene & Peru-Ecuador & Michiquillay & & Yes & 20 & Peru & $7^{\circ} 18^{\prime} 0^{\prime \prime} \mathrm{S}$ & $78^{\circ} 19^{\prime} 20^{\prime \prime} \mathrm{W}$ & -7.30 & -78.32 \\
\hline SA06PC & middle-late Miocene & Peru-Ecuador & Minas Conga & & Yes & 16 & Peru & $6^{\circ} 55^{\prime} 32^{\prime \prime} \mathrm{S}$ & $78^{\circ} 21^{\prime} 31^{\prime \prime} \mathrm{W}$ & \begin{tabular}{|c|}
-6.93 \\
\end{tabular} & \begin{tabular}{|c|}
-78.36 \\
\end{tabular} \\
\hline SA06PC & middle-late Miocene & Peru-Ecuador & Paramo & & & & Peru & $5^{\circ} 42^{\prime} 54^{\prime \prime} \mathrm{S}$ & $79^{\circ} 12^{\prime} 25^{\prime \prime} \mathrm{W}$ & -5.72 & -79.21 \\
\hline SA06PC & middle-late Miocene & Peru-Ecuador & Pashpap & & Yes & 15 & Peru & $8^{\circ} 46^{\prime} 30^{\prime \prime} \mathrm{S}$ & $77^{\circ} 59^{\prime} 30^{\prime \prime} \mathrm{W}$ & -8.78 & -77.99 \\
\hline SA06PC & middle-late Miocene & Peru-Ecuador & Puy-Puy & & & 7 & Peru & $11^{\circ} 28^{\prime} 47^{\prime \prime} \mathrm{S}$ & $76^{\circ} 5^{\prime} 40^{\prime \prime} \mathrm{W}$ & -11.48 & -76.08 \\
\hline SA06PC & middle-late Miocene & Peru-Ecuador & Rio Blanco & & Yes & 16 & Peru & $4^{\circ} 56^{\prime} 40^{\prime \prime} \mathrm{S}$ & $79^{\circ} 18^{\prime} 30^{\prime \prime} \mathrm{W}$ & -4.94 & -79.31 \\
\hline SA06PC & middle-late Miocene & Peru-Ecuador & Tantahuatay & & Yes & & Peru & $6^{\circ} 43^{\prime} 31^{\prime \prime} \mathrm{S}$ & $78^{\circ} 40^{\prime} 10^{\prime \prime} \mathrm{W}$ & -6.73 & \begin{tabular}{|l|l|}
-78.67 \\
\end{tabular} \\
\hline SA06PC & middle-late Miocene & Peru-Ecuador & Toromocho & Toro Mocho & Yes & 8 & Peru & $11^{\circ} 36^{\prime} 0^{\prime \prime} \mathrm{S}$ & $76^{\circ} 8^{\prime} 0^{\prime \prime} \mathrm{W}$ & -11.60 & -76.13 \\
\hline SA07PC & Cretaceous & Peru-Ecuador & Almacen & & Yes & & Peru & $13^{\circ} 14^{\prime} 5^{\prime \prime} \mathrm{S}$ & $75^{\circ} 55^{\prime} 0 " \mathrm{~W}$ & -13.23 & -75.92 \\
\hline SA07PC & Cretaceous & Peru-Ecuador & Alondra & & & & Peru & $15^{\circ} 49^{\prime} 0^{\prime \prime} \mathrm{S}$ & $73^{\circ} 35^{\prime} 0^{\prime \prime} \mathrm{W}$ & -15.82 & $\begin{array}{ll}-73.58 \\
\end{array}$ \\
\hline SA07PC & Cretaceous & Peru-Ecuador & Anita de Tibilos & & & & Peru & $14^{\circ} 11^{\prime} 00^{\prime \prime} \mathrm{S}$ & $75^{\circ} 08^{\prime} 54^{\prime \prime} \mathrm{W}$ & -14.18 & -75.15 \\
\hline SA07PC & Cretaceous & Peru-Ecuador & Chavez N2 & & & & Peru & $14^{\circ} 14^{\prime} 00^{\prime \prime S}$ & $75^{\circ} 25^{\prime} 15^{\prime \prime} \mathrm{W}$ & -14.23 & -75.42 \\
\hline SA07PC & Cretaceous & Peru-Ecuador & Eliana & & & & Peru & $13^{\circ} 46^{\prime} 0^{\prime \prime} \mathrm{S}$ & $75^{\circ} 43^{\prime} 0 " \mathrm{~W}$ & -13.77 & -75.72 \\
\hline SA07PC & Cretaceous & Peru-Ecuador & Los Linderos & & & & Ecuador & $4^{\circ} 20^{\prime} 0^{\prime \prime} \mathrm{S}$ & $80^{\circ} 00^{\prime} 0 " \mathrm{~W}$ & -4.33 & -80.00 \\
\hline SA07PC & Cretaceous & Peru-Ecuador & Los Pinos & & Yes & & Peru & $12^{\circ} 58^{\prime} 33^{\prime \prime S}$ & $76^{\circ} 8^{\prime} 22^{\prime \prime} \mathrm{W}$ & -12.98 & -76.14 \\
\hline SA07PC & Cretaceous & Peru-Ecuador & Puquio & & & & Peru & $13^{\circ} 55^{\prime} 45^{\prime \prime S}$ & $75^{\circ} 21^{\prime} 0^{\prime \prime} \mathrm{W}$ & -13.93 & -75.35 \\
\hline SA07PC & Cretaceous & Peru-Ecuador & Rio Playas & & & & Ecuador & $4^{\circ} 12^{\prime} 0^{\prime \prime} \mathrm{S}$ & $79^{\circ} 35^{\prime} 0 " \mathrm{~W}$ & -4.20 & -79.58 \\
\hline SA07PC & Cretaceous & Peru-Ecuador & Tingo & & & & Peru & $13^{\circ} 41^{\prime} 10^{\prime \prime} \mathrm{S}$ & $75^{\circ} 15^{\prime} 35^{\prime \prime} \mathrm{W}$ & -13.69 & -75.09 \\
\hline SA08PC & Paleocene-Eocene & Chile-Peru & Cerro Colorado (Chile) & & Yes & 58 & Chile & $20^{\circ} 2^{\prime} 36^{\prime \prime} \mathrm{S}$ & $69^{\circ} 15^{\prime} 30^{\prime \prime} \mathrm{W}$ & -20.05 & -69.29 \\
\hline SA08PC & Paleocene-Eocene & Chile-Peru & Cerro Colorado (Peru) & & Yes & 59 & Peru & $17^{\circ} 40^{\prime} 54^{\prime \prime} \mathrm{S}$ & $69^{\circ} 54^{\prime} 3 " \mathrm{~W}$ & -17.68 & \begin{tabular}{|l|}
-69.90 \\
\end{tabular} \\
\hline SA08PC & Paleocene-Eocene & Chile-Peru & Cerro Negro & & Yes & 57 & Peru & $16^{\circ} 32^{\prime} 45^{\prime \prime} \mathrm{S}$ & $71^{\circ} 33^{\prime} 10^{\prime \prime} \mathrm{W}$ & -16.55 & -71.55 \\
\hline SA08PC & Paleocene-Eocene & Chile-Peru & Cerro Verde & Santa Rosa & Yes & 62 & Peru & $16^{\circ} 33^{\prime} 0^{\prime \prime S} \mathrm{~S}$ & $71^{\circ} 34^{\prime} 0^{\prime \prime} \mathrm{W}$ & -16.55 & -71.57 \\
\hline SA08PC & Paleocene-Eocene & Chile-Peru & Chapi & & & & Peru & $16^{\circ} 46^{\prime} 25^{\prime \prime} \mathrm{S}$ & $71^{\circ} 21^{\prime} 28^{\prime \prime} \mathrm{W}$ & -16.77 & -71.36 \\
\hline SA08PC & Paleocene-Eocene & Chile-Peru & Cuaione & & Yes & 51 & Peru & $17^{\circ} 02^{\prime} 32^{\prime \prime S}$ & $70^{\circ} 40^{\prime} 16^{\prime \prime} \mathrm{W}$ & & -70.67 \\
\hline SA08PC & Paleocene-Eocene & Chile-Peru & Dos Hermanos & & & & Chile & $18^{\circ} 17^{\prime} 24^{\prime \prime S}$ & $69^{\circ} 43^{\prime} 18^{\prime \prime}$ & -18.29 & -69.72 \\
\hline SA08PC & Paleocene-Eocene & Chile-Peru & Inca de Oro & & & 63 & Chile & $26^{\circ} 45^{\prime} 58^{\prime \prime} \mathrm{S}$ & $6952^{\prime} 177^{\prime \prime} \mathrm{W}$ & -26.77 & \begin{tabular}{|l|}
-69.87 \\
\end{tabular} \\
\hline SA08PC & Paleocene-Eocene & Chile-Peru & Lomas Bayas & & Yes & 61 & Chile & $23^{\circ} 25^{\prime} 42^{\prime \prime} \mathrm{S}$ & $69^{\circ} 30^{\prime} 24^{\prime \prime} \mathrm{W}$ & -23.45 & -69.51 \\
\hline SA08PC & Paleocene-Eocene & Chile-Peru & Mani & & & 64 & Chile & $22^{\circ} 33^{\prime} 51^{\prime \prime} \mathrm{S}$ & $69^{\circ} 14^{\prime} 32^{\prime \prime} \mathrm{W}$ & -22.56 & -69.24 \\
\hline SA08PC & Paleocene-Eocene & Chile-Peru & Mocha & & & 58 & Chile & $19^{\circ} 48^{\prime} 35^{\prime \prime} \mathrm{S}$ & $69^{\circ} 16^{\prime} 50^{\prime \prime} \mathrm{W}$ & -19.81 & -69.28 \\
\hline SA08PC & Paleocene-Eocene & Chile-Peru & Quellaveco & & Yes & 54 & Peru & $17^{\circ} 6^{\prime} 29^{\prime \prime} \mathrm{S}$ & $70^{\circ} 35^{\prime} 2^{\prime \prime} \mathrm{W}$ & -17.11 & -70.58 \\
\hline SA08PC & Paleocene-Eocene & Chile-Peru & Relincho & Porvenir & Yes & 64 & Chile & $28^{\circ} 30^{\prime} 0^{\prime \prime} \mathrm{S}$ & $70^{\circ} 18^{\prime} 0^{\prime \prime \prime} \mathrm{W}$ & -28.50 & -70.30 \\
\hline SA08PC & Paleocene-Eocene & Chile-Peru & Sierra Gorda & & Yes & 64 & Chile & $22^{\circ} 50^{\prime} 18^{\prime \prime} \mathrm{S}$ & $69^{\circ} 20^{\prime} 48^{\prime \prime} \mathrm{W}$ & -22.87 & \begin{tabular}{|l|}
-69.34 \\
\end{tabular} \\
\hline SA08PC & Paleocene-Eocene & Chile-Peru & Spence & & Yes & 58 & Chile & $22^{\circ} 41^{\prime} 21^{\prime \prime S}$ & $69^{\circ} 10^{\prime} 53^{\prime \prime} \mathrm{W}$ & -22.69 & \begin{tabular}{|c|}
-69.18 \\
\end{tabular} \\
\hline SA08PC & Paleocene-Eocene & \begin{tabular}{|c|} 
Chile-Peru \\
\end{tabular} & Ticnámar & & Yes & & \begin{tabular}{|c|c|} 
Chile \\
s
\end{tabular} & $18^{\circ} 35^{1} 36^{\prime \prime S}$ & $69^{\circ} 27^{\prime} 0^{\prime \prime} \mathrm{W}$ & -18.59 & \begin{tabular}{|c|c|}
-69.45 \\
\end{tabular} \\
\hline SA08PC & Paleocene-Eocene & Chile-Peru & Toquepala & Pampa Negra & Yes & 57 & Peru & $17^{\circ} 13^{\prime} 0^{\prime \prime} \mathrm{S}$ & $70^{\circ} 36^{\prime} 0^{\prime \prime} \mathrm{W}$ & -17.22 & -70.60 \\
\hline $\begin{array}{l}\text { SA09PC } \\
\end{array}$ & Eocene-Oligocene & Peru & Antapaccay & & $\begin{array}{lll}\text { Yes } & \\
\end{array}$ & & Peru & $14^{\circ} 57^{\prime} 36^{\prime \prime S}$ & $71^{\circ} 20^{\prime} 48^{\prime \prime} \mathrm{W}$ & -14.96 & -71.35 \\
\hline SA09PC & Eocene-Oligocene & Peru & Ccalla & Cotabambas area & Yes & 36 & Peru & $13^{\circ} 44^{\prime} 24^{\prime \prime S}$ & $72^{\circ} 22^{\prime} 0^{\prime \prime} \mathrm{W}$ & -13.74 & \begin{tabular}{|l|l|}
-72.37 \\
\end{tabular} \\
\hline SA09PC & Eocene-Oligocene & Peru & Chalcobamba & & & 36 & Peru & $14^{\circ} 01^{\prime} 36^{\prime \prime} \mathrm{S}$ & $72^{\circ} 20^{\prime} 0 " \mathrm{~W}$ & -14.03 & -72.33 \\
\hline SA09PC & Eocene-Oligocene & Peru & Coroccohuayco & & \begin{tabular}{l|l} 
Yes \\
\end{tabular} & 31 & Peru & $14^{\circ} 57^{\prime} 12^{\prime \prime S}$ & $71^{\circ} 16^{\prime} 24^{\prime \prime} \mathrm{W}$ & -14.95 & -71.27 \\
\hline SA09PC & Eocene-Oligocene & Peru & Lahuani & & & 36 & Peru & $14^{\circ} 27^{\prime} 42^{\prime \prime} \mathrm{S}$ & $72^{\circ} 59^{\prime} 36^{\prime \prime} \mathrm{W}$ & -14.46 & -72.99 \\
\hline SA09PC & Eocene-Oligocene & Peru & Los Chancas & & Yes & 32 & Peru & $14^{\circ} 9^{\prime} 29^{\prime \prime} \mathrm{S}$ & $73^{\circ} 08^{\prime} 0 " \mathrm{~W}$ & -14.16 & -73.13 \\
\hline
\end{tabular}


Table 1. Permissive tracts, discovered deposits, and prospects (cont.).

\begin{tabular}{|c|c|c|c|c|c|c|c|c|c|c|c|}
\hline \multicolumn{3}{|c|}{ Tracts } & \multicolumn{9}{|c|}{ Porphyry copper deposits and prospects } \\
\hline $\begin{array}{l}\text { Tract } \\
\text { No. }\end{array}$ & Host-rock age $^{2}$ & Countries & Name & Other names & 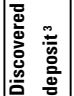 & $\begin{array}{l}\text { Mineralization } \\
\text { age, Ma }\end{array}$ & Country & Latitude & Longitude & $\begin{array}{l}\text { Lati- } \\
\text { tude } \\
\text { (dd) }\end{array}$ & $\begin{array}{c}\text { Longi- } \\
\text { tude } \\
\text { (dd) }\end{array}$ \\
\hline SA09PC & Eocene-Oligocene & Peru & Quechua & & Yes & 38 & Peru & $14^{\circ} 58^{\prime} 48^{\prime \prime} \mathrm{S}$ & $71^{\circ} 18^{\prime} 24^{\prime \prime} \mathrm{W}$ & -14.98 & \begin{tabular}{|l|}
-71.31 \\
\end{tabular} \\
\hline SA09PC & Eocene-Oligocene & Peru & San Jose & & & 33 & Peru & $14^{\circ} 27^{\prime} 42^{\prime \prime} \mathrm{S}$ & $71^{\circ} 46^{\prime} 0^{\prime \prime} \mathrm{W}$ & -14.46 & -71.77 \\
\hline SA09PC & Eocene-Oligocene & Peru & Tintaya & & Yes & 33 & Peru & $14^{\circ} 54^{\prime} 30^{\prime \prime} \mathrm{S}$ & $71^{\circ} 18^{\prime} 48^{\prime \prime} \mathrm{W}$ & -14.91 & \begin{tabular}{|l|}
-71.31 \\
\end{tabular} \\
\hline SA10aPC & Eocene-Oligocene & Chile & Centinela & & & 44 & Chile & $23^{\circ} 09^{\prime} 48^{\prime \prime} \mathrm{S}$ & $69^{\circ} 10^{\prime} 06^{\prime \prime} \mathrm{W}$ & -23.16 & -69.17 \\
\hline SA10aPC & \begin{tabular}{|l} 
Eocene-Oligocene \\
\end{tabular} & Chile & Chimborazo & & & 37 & Chile & $24^{\circ} 08^{\prime} 0^{\prime \prime} \mathrm{S}$ & $69^{\circ} 05^{\prime} 0^{\prime \prime} \mathrm{W}$ & -24.13 & -69.08 \\
\hline SA10aPC & Eocene-Oligocene & Chile & Chuquicamata & & Yes & 32 & Chile & $22^{\circ} 16^{\prime} 30^{\prime \prime} \mathrm{S}$ & $68^{\circ} 54^{\prime} 0^{\prime \prime} \mathrm{W}$ & -22.28 & -68.90 \\
\hline SA10aPC & Eocene-Oligocene & Chile & Collahuasi & Rosario & Yes & 32 & Chile & $20^{\circ} 58^{\prime} 30^{\prime \prime} \mathrm{S}$ & $68^{\circ} 41^{\prime} 5^{\prime \prime} \mathrm{W}$ & -20.98 & -68.69 \\
\hline SA10aPC & Eocene-Oligocene & Chile & Copaquire & & & 35 & Chile & $20^{\circ} 54^{\prime} 06^{\prime \prime S}$ & $68^{\circ} 53^{\prime} 07^{\prime \prime} \mathrm{W}$ & -20.90 & -68.89 \\
\hline SA10aPC & Eocene-Oligocene & Chile & El Abra & & Yes & 36 & Chile & $21^{\circ} 54^{\prime} 30^{\prime \prime} \mathrm{S}$ & $68^{\circ} 50^{\prime} 12^{\prime \prime} \mathrm{W}$ & -21.91 & \begin{tabular}{|l|}
-68.84 \\
\end{tabular} \\
\hline SA10aPC & Eocene-Oligocene & Chile & Esperanza & & & 40 & Chile & $22^{\circ} 59^{\prime} 16^{\prime \prime} \mathrm{S}$ & $69^{\circ} 04^{\prime} 35^{\prime \prime} \mathrm{W}$ & -22.99 & -69.08 \\
\hline SA10aPC & Eocene-Oligocene & Chile & Gaby & Gaby Sur & Yes & 42 & Chile & $23^{\circ} 24^{\prime} 39^{\prime \prime} \mathrm{S}$ & $68^{\circ} 49^{\prime} 8^{\prime \prime} \mathrm{W}$ & -23.41 & \begin{tabular}{|l|}
-68.82 \\
\end{tabular} \\
\hline SA10aPC & Eocene-Oligocene & Chile & La Escondida & Escondida & Yes & 37 & Chile & $24^{\circ} 15^{\prime} 54^{\prime \prime} \mathrm{S}$ & $69^{\circ} 04^{\prime} 18^{\prime \prime} \mathrm{W}$ & -24.27 & -69.07 \\
\hline SA10aPC & Eocene-Oligocene & Chile & La Planada & & & 31 & Chile & $20^{\circ} 10^{\prime} 30^{\prime \prime} \mathrm{S}$ & $69^{\circ} 05^{\prime} 0 " \mathrm{~W}$ & -20.18 & -69.08 \\
\hline SA10aPC & Eocene-Oligocene & Chile & Mansa Mina & MM & Yes & 34 & Chile & $22^{\circ} 22^{\prime} 50^{\prime \prime} \mathrm{S}$ & $68^{\circ} 54^{\prime} 45^{\prime \prime} \mathrm{W}$ & -22.38 & \begin{tabular}{|l|}
-68.91 \\
\end{tabular} \\
\hline SA10aPC & Eocene-Oligocene & Chile & Opache & & & 38 & Chile & $22^{\circ} 28^{\prime} 0 " \mathrm{~S}$ & $68^{\circ} 58^{\prime} 0^{\prime \prime} \mathrm{W}$ & -22.47 & -68.97 \\
\hline SA10aPC & Eocene-Oligocene & Chile & Polo Sur & & & & Chile & $23^{\circ} 18^{\prime} 0^{\prime \prime} \mathrm{S}$ & $69^{\circ} 14^{\prime} 0^{\prime \prime} \mathrm{W}$ & -23.30 & -69.23 \\
\hline SA10aPC & Eocene-Oligocene & Chile & Quebrada Blanca & & Yes & 36 & Chile & $21^{\circ} 0^{\prime} 0^{\prime \prime} \mathrm{S}$ & $68^{\circ} 48^{\prime} 0^{\prime \prime} \mathrm{W}$ & -21.00 & -68.80 \\
\hline SA10aPC & Eocene-Oligocene & Chile & Queen Elizabeth & & & 36 & Chile & $19^{\circ} 52^{\prime} 0 " \mathrm{~S}$ & $68^{\circ} 58^{\prime} 0^{\prime \prime} \mathrm{W}$ & -19.87 & -68.97 \\
\hline SA10aPC & Eocene-Oligocene & Chile & Toki & & & 36 & Chile & $22^{\circ} 25^{\prime} 0^{\prime \prime} \mathrm{S}$ & $68^{\circ} 57^{\prime} 0^{\prime \prime} \mathrm{W}$ & -22.42 & -68.95 \\
\hline SA10aPC & Eocene-Oligocene & Chile & Ujina & & Yes & 35 & Chile & $20^{\circ} 59^{\prime} 46^{\prime \prime} \mathrm{S}$ & $68^{\circ} 36^{\prime} 18^{\prime \prime} \mathrm{W}$ & -21.00 & $\mid-68.61$ \\
\hline SA10bPC & Eocene-Oligocene & Chile & El Salvador & & Yes & 42 & Chile & $26^{\circ} 15^{\prime} 15^{\prime \prime} \mathrm{S}$ & $69^{\circ} 33^{\prime} 2^{\prime \prime} \mathrm{W}$ & -26.25 & -69.55 \\
\hline SA10bPC & Eocene-Oligocene & Chile & Potrerillos & Andes & Yes & 37 & Chile & $26^{\circ} 29^{\prime} 15^{\prime \prime} \mathrm{S}$ & $69^{\circ} 25^{\prime} 26^{\prime \prime} \mathrm{W}$ & -26.49 & -69.42 \\
\hline SA11PC & Eocene-Oligocene & \begin{tabular}{|l} 
Argentina \\
\end{tabular} & Taca Taca Alto & & & 29 & Argentina & $24^{\circ} 34^{\prime} 0^{\prime \prime} \mathrm{S}$ & $67^{\circ} 47^{\prime} 0^{\prime \prime} \mathrm{W}$ & -24.57 & -67.78 \\
\hline SA11PC & Eocene-Oligocene & Argentina & Taca Taca Bajo & Taca Taca Lower & Yes & 31 & Argentina & $24^{\circ} 35^{\prime} 0^{\prime \prime} \mathrm{S}$ & $67^{\circ} 44^{\prime} 0^{\prime \prime} \mathrm{W}$ & -24.58 & \begin{tabular}{|l|}
-67.73 \\
\end{tabular} \\
\hline SA12PC & Eocene-Oligocene & Chile-Argentina & La Fortuna & El Morro & Yes & 34 & Chile & $28^{\circ} 38^{\prime} 0^{\prime \prime} \mathrm{S}$ & $69^{\circ} 53^{\prime} 0^{\prime \prime} \mathrm{W}$ & -28.63 & -69.88 \\
\hline SA13aPC & Miocene-Pliocene & Argentina-Chile & Betito & & & 14 & Argentina & $26^{\circ} 18^{\prime} 26^{\prime \prime} \mathrm{S}$ & $67^{\circ} 54^{\prime} 0^{\prime \prime} \mathrm{W}$ & -26.30 & -67.90 \\
\hline SA13aPC & Miocene-Pliocene & Argentina-Chile & Cerro Casale & \begin{tabular}{|l} 
Aldebaran \\
\end{tabular} & Yes & 14 & Chile & $27^{\circ} 47^{\prime} 39^{\prime \prime} \mathrm{S}$ & $69^{\circ} 16^{\prime} 46^{\prime \prime} \mathrm{W}$ & -27.78 & \begin{tabular}{|l|}
-69.23 \\
\end{tabular} \\
\hline SA13aPC & Miocene-Pliocene & Argentina-Chile & El Oculto & & & & Argentina & $24^{\circ} 08^{\prime} 0 " \mathrm{~S}$ & $66^{\circ} 36^{\prime} 0^{\prime \prime} \mathrm{W}$ & -24.13 & -66.60 \\
\hline SA13aPC & Miocene-Pliocene & Argentina-Chile & Inca Viejo & & & 15 & Argentina & $25^{\circ} 8^{\prime} 40^{\prime \prime} \mathrm{S}$ & $66^{\circ} 45^{\prime} 45^{\prime \prime} \mathrm{W}$ & -25.14 & -66.76 \\
\hline SA13aPC & Miocene-Pliocene & Argentina-Chile & Pancho Arias & & & 15 & Argentina & $24^{\circ} 12^{\prime} 0 " \mathrm{~S}$ & $65^{\circ} 52^{\prime} 0^{\prime \prime} \mathrm{W}$ & -24.20 & -65.87 \\
\hline SA13bPC & Miocene-Pliocene & Argentina-Chile & Arroyo Chita & & & 12 & Argentina & $30^{\circ} 30^{\prime} 0^{\prime \prime} \mathrm{S}$ & $69^{\circ} 45^{\prime} 0^{\prime \prime} \mathrm{W}$ & -30.50 & -69.75 \\
\hline SA13bPC & Miocene-Pliocene & Argentina-Chile & Cerro Mercedario & & & 13 & Argentina & $31^{\circ} 57^{\prime} 0 " \mathrm{~S}$ & $70^{\circ} 03^{\prime} 0^{\prime \prime} \mathrm{W}$ & -31.95 & -70.05 \\
\hline SA13bPC & Miocene-Pliocene & Argentina-Chile & Los Pelambres/El Pachon & & Yes & 10 & Chile & $31^{\circ} 42^{\prime} 30^{\prime \prime} \mathrm{S}$ & $70^{\circ} 30^{\prime} 0^{\prime \prime} \mathrm{W}$ & -31.71 & -70.50 \\
\hline SA13bPC & Miocene-Pliocene & Argentina-Chile & Vizcachitas & & Yes & 11 & Chile & $32^{\circ} 53^{\prime} 0^{\prime \prime} \mathrm{S}$ & $70^{\circ} 14^{\prime} 0^{\prime \prime} \mathrm{W}$ & -32.88 & -70.23 \\
\hline SA13cPC & Miocene-Pliocene & Argentina-Chile & None & & & & & & & & \\
\hline SA13dPC & Miocene & Chile-Argentina & None & & & & & & & & \\
\hline SA14aPC & late Miocene-early Pliocene & Argentina & Paramillos Norte & & Yes & 14 & Argentina & $32^{\circ} 25^{\prime} 0^{\prime \prime} \mathrm{S}$ & $69^{\circ} 05^{\prime} 0^{\prime \prime} \mathrm{W}$ & -32.42 & -69.08 \\
\hline SA14aPC & late Miocene-early Pliocene & Argentina & Paramillos Sur & & Yes & 14 & Argentina & $32^{\circ} 29^{\prime} 0^{\prime \prime} \mathrm{S}$ & $69^{\circ} 06^{\prime} 0^{\prime \prime} \mathrm{W}$ & -32.48 & -69.10 \\
\hline SA14bPC & late Miocene-early Pliocene & Chile & El Teniente & Braden & Yes & 5 & Chile & $34^{\circ} 5^{\prime} 30^{\prime \prime} \mathrm{S}$ & $70^{\circ} 20^{\prime} 18^{\prime \prime} \mathrm{W}$ & -34.09 & -70.34 \\
\hline SA14bPC & late Miocene-early Pliocene & Chile & Los Bronces/Rio Blanco & & Yes & 6 & Chile & $33^{\circ} 5^{\prime} 0^{\prime \prime} \mathrm{S}$ & $70^{\circ} 17^{\prime} 29^{\prime \prime} \mathrm{W}$ & -33.13 & -70.27 \\
\hline SA14cPC & late Miocene-early Pliocene & Argentina & Agua Rica & Mi Vida & Yes & 6 & Argentina & $27^{\circ} 22^{\prime} 15^{\prime \prime} \mathrm{S}$ & $66^{\circ} 16^{\prime} 48^{\prime \prime} \mathrm{W}$ & -27.37 & -66.28 \\
\hline SA14cPC & late Miocene-early Pliocene & Argentina & Bajo de Agua Tapado & & & 9 & Argentina & $27^{\circ} 16^{\prime} 0^{\prime \prime} \mathrm{S}$ & $66^{\circ} 39^{\prime} 0^{\prime \prime} \mathrm{W}$ & -27.27 & -66.65 \\
\hline $\mathrm{SA} 14 \mathrm{cPC}$ & late Miocene-early Pliocene & Argentina & Bajo de la Alumbrera & & Yes & 8 & Argentina & $27^{\circ} 19^{\prime} 0^{\prime \prime} \mathrm{S}$ & $66^{\circ} 37^{\prime} 0^{\prime \prime} \mathrm{W}$ & -27.32 & -66.62 \\
\hline SA14cPC & late Miocene-early Pliocene & Argentina & Bajo de San Lucas & & & 7 & Argentina & $27^{\circ} 24^{\prime} 0 " \mathrm{~S}$ & $66^{\circ} 33^{\prime} 0^{\prime \prime} \mathrm{W}$ & -27.40 & -66.55 \\
\hline SA14cPC & late Miocene-early Pliocene & Argentina & Bajo El Durazno & & Yes & 8 & Argentina & $27^{\circ} 17^{\prime} 0^{\prime \prime} \mathrm{S}$ & $66^{\circ} 34^{\prime} 0^{\prime \prime} \mathrm{W}$ & -27.28 & -66.57 \\
\hline SA14cPC & late Miocene-early Pliocene & Argentina & Filo Colorado & & & & Argentina & $27^{\circ} 23^{\prime} 0 " \mathrm{~S}$ & $66^{\circ} 13^{\prime} 0^{\prime \prime} \mathrm{W}$ & -27.38 & -66.22 \\
\hline SA14dPC & late Miocene-early Pliocene & Argentina & Nevados de Famatina & la Estrechura & Yes & 4 & Argentina & $29^{\circ} 0^{\prime} 0^{\prime \prime} \mathrm{S}$ & $67^{\circ} 45^{\prime} 0^{\prime \prime} \mathrm{W}$ & -29.00 & -67.75 \\
\hline SA15PC & Late Cretaceous-middle Eocene & Argentina-Chile & Arroyo Luque & & & Late Cretaceous & Argentina & $43^{\circ} 16^{\prime} \mathrm{S}$ & $71^{\circ} 01^{\prime} \mathrm{W}$ & -43.27 & -71.02 \\
\hline SA15PC & Late Cretaceous-middle Eocene & Argentina-Chile & Campana Mahuida & & Yes & 61 & Argentina & $38^{\circ} 13^{\prime} 0^{\prime \prime} \mathrm{S}$ & $70^{\circ} 32^{\prime} 0^{\prime \prime} \mathrm{W}$ & -38.22 & -70.53 \\
\hline SA15PC & Late Cretaceous-middle Eocene & Argentina-Chile & Cerro Coihue & & & \begin{tabular}{|l} 
Jurassic-Eocene \\
\end{tabular} & Argentina & $42^{\circ} 08^{\prime} \mathrm{S}$ & $71^{\circ} 19^{\prime} \mathrm{W}$ & -42.13 & -71.35 \\
\hline SA15PC & Late Cretaceous-middle Eocene & Argentina-Chile & Quebrada del Bronce & & & 45 & Argentina & $37^{\circ} 25^{\prime} 0 " \mathrm{~S}$ & $70^{\circ} 27^{\prime} 0^{\prime \prime} \mathrm{W}$ & -37.42 & -70.45 \\
\hline SA16aPC & Permian & Argentina & Alcaparrosa & & & 267 & Argentina & $31^{\circ} 18^{\prime} 0 " \mathrm{~S}$ & $69^{\circ} 22^{\prime} 0^{\prime \prime} \mathrm{W}$ & -31.30 & -69.37 \\
\hline SA16aPC & Permian & Argentina & Carrizal & & & 261 & Argentina & $30^{\circ} 00^{\prime} 0 " \mathrm{~S}$ & $69^{\circ} 10^{\prime} 0 " \mathrm{~W}$ & -30.00 & -69.17 \\
\hline SA16aPC & Permian & Argentina & El Salado & & & & Argentina & $30^{\circ} 56^{\prime} 0^{\prime \prime} \mathrm{S}$ & $69^{\circ} 38^{\prime} 0 " \mathrm{~W}$ & -30.93 & -69.63 \\
\hline SA16aPC & Permian & Argentina & San Jorge & & Yes & $257-270$ & Argentina & $32^{\circ} 15^{\prime} 0^{\prime \prime} \mathrm{S}$ & $69^{\circ} 26^{\prime} 0^{\prime \prime} \mathrm{W}$ & -32.25 & -69.43 \\
\hline SA16aPC & Permian & Argentina & Yalguaraz & & & 264 & Argentina & $32^{\circ} 08^{\prime} 0 " \mathrm{~S}$ & $69^{\circ} 27^{\prime} 0 " \mathrm{~W}$ & -32.13 & -69.45 \\
\hline SA16bPC & Permian & Argentina-Chile & La Voluntad & & Yes & 281 & Argentina & $39^{\circ} 11^{\prime} 0^{\prime \prime} \mathrm{S}$ & $70^{\circ} 38^{\prime} 0^{\prime \prime} \mathrm{W}$ & -39.18 & -70.63 \\
\hline SA17PC & Cretaceous & Chile & Angelina & & & & Chile & $24^{\circ} 23^{\prime} 54^{\prime \prime} \mathrm{S}$ & $69^{\circ} 36^{\prime} 27^{\prime \prime} \mathrm{W}$ & -24.40 & -69.61 \\
\hline SA18PC & Permian & Chile & El Loa & & & 252 & Chile & $21^{\circ} 07^{\prime} 0 " \mathrm{~S}$ & $68^{\circ} 44^{\prime} 0^{\prime \prime} \mathrm{W}$ & -21.12 & -68.73 \\
\hline SA18PC & Permian & Chile & Lilian & & & 275 & Chile & $22^{\circ} 40^{\prime} 0 " \mathrm{~S}$ & $68^{\circ} 45^{\prime} 0^{\prime \prime} \mathrm{W}$ & -22.67 & -68.75 \\
\hline SA18PC & Permian & Chile & Rio Frio & & & 292 & Chile & $25^{\circ} 13^{\prime} 0 " \mathrm{~S}$ & $69^{\circ} 13^{\prime} 0 " \mathrm{~W}$ & -25.22 & -69.23 \\
\hline SA19PC & Late Triassic-Middle Jurassic & Argentina & Bajo de la Leona & & & 200 & Argentina & $48^{\circ} 04^{\prime} 30^{\prime \prime} \mathrm{S}$ & $67^{\circ} 18^{\prime} 30^{\prime \prime} \mathrm{W}$ & -48.08 & -67.31 \\
\hline SA20PC & Cretaceous & Chile-Argentina & Gualletue & & & \begin{tabular}{|l} 
Late Cretaceous \\
\end{tabular} & Chile & $38^{\circ} 42^{\prime} 36^{\prime \prime}$ & $71^{\circ} 19^{\prime} 48^{\prime \prime} \mathrm{W}$ & -38.71 & -71.33 \\
\hline SA20PC & Cretaceous & Chile-Argentina & Turbio & & & & Chile & $46^{\circ} 02^{\prime} 0 " \mathrm{~S}$ & $72^{\circ} 09^{\prime} 0 " \mathrm{~W}$ & -46.03 & -72.15 \\
\hline
\end{tabular}

${ }^{1}$ These are the deposits and prospects known at the time of the assessment of each tract. Modified from Singer, Berger, and Moring (2005).

${ }^{2} \mathrm{Age}$ of the volcanic and (or) plutonic rocks formed during a period of approximately coeval arc magmatism judged capable of producing porphyry copper deposits and whose spatial distribution, projected to $1 \mathrm{~km}$ depth, defines a tract boundary. Periods and Epochs follow International Commission on Stratigraphy (2000).

${ }^{3}$ Porphyry copper deposits classified as discovered (known) at the time of the assessment are shown in pink font. Discovered deposits are those reported in the published literature to be well explored in three dimensions, unopen in any direction, and have published tonnages and grades. Explored metal occurrences not meeting these criteria are classified as prospects. Some of these prospects might represent some of the estimated undiscovered deposits. 


\section{What is a mineral resource assessment?}

The kind of assessment used here was founded in decision analysis in order to provide a framework for making decisions concerning undiscovered mineral resources under conditions of uncertainty. We provide probabilistic estimates of the number of undiscovered mineral deposits and their associated grades and tonnages that may be present to a specified depth within an identified tract of land. "A 'mineral deposit' is a mineral occurrence of sufficient size and grade that it might, under the most favorable of circumstances, be considered to have economic potential." (Cox, Barton, and Singer, 1986, p. 1) We can know with certainty the number of economically exploitable deposits in an area only if we choose to drill with a high density grid. But, generally, the cost of that knowledge is far greater than its value for planning and decisionmaking (Harris and Rieber, 1993). Only the results of future exploration can verify the probabilistic estimates made herein.

\section{Need for mineral resource assessments}

The demand for mineral resources continues to grow in response to the world's increasing population and rising standard of living (Matos and Wagner, 1998; Brown, Matos, and Sullivan, 2000; Menzie, DeYoung, and Steblez, 2003; and Menzie, Singer, and DeYoung, 2004). To satisfy this demand requires renewed and expanded geologic research on mineral deposits, and continuing exploration for and development of new mineral deposits (e.g., Kesler, 2007). However, the ability to find and develop new mineral resources is increasingly affected in all areas of the world by competing land uses and concerns about the environmental effects of mining (e.g., James, 1999; O’Neil, Kral, and Yernberg, 2000; Briskey and others, 2001 and 2007; Cunningham and others, 2007; and Langhammer, 2007). Effective land management planning for sustainable resource development requires informed decisions and a long-term global perspective with an integrated international approach to land-use, resource, economic, and environmental management, and to technological innovation and development (Doggett, 2007; Nooten, 2007; Walser, 2007; and Wellmer and Becker-Platen, 2007). To achieve this, we need to know more about the Earth's mineral resources: where they are located and why they occur where they do; what the subtle indications are that undiscovered deposits may be present beneath a cover of unmineralized rocks; and how development may affect other resources such as biological diversity, air, and water.

\section{The Global Mineral Resource Assessment Project (GMRAP)}

The U.S. Geological Survey (USGS) is coordinating a cooperative international project to estimate the regional locations and probable quantity and quality of the world's undiscovered nonfuel mineral resources. The Global Mineral Resource Assessment Project (GMRAP) is a research project that is developing, testing, and (or) applying a variety of methods to quantitatively assess undiscovered mineral resources to a depth of $1 \mathrm{~km}$ or more below the Earth's surface (Briskey and others, 2001, 2007; Schulz and Briskey, 2003). The primary objectives are to identify the principal areas in the world that have potential for selected undiscovered mineral resources using available compiled information about geology, geochemistry, geophysics, and previous exploration results in the context of modern quantitative statistical models.

Global assessment is being conducted on a regional-multinational basis and includes the cooperative participation of interested national geologic, mineral resource, and academic institutions. A global mineral resource assessment will provide: (1) a regional and global framework for understanding a nation's mineral resources, (2) information to attract international investment capital, (3) a foundation to help plan new mineral exploration in the context of sustainable development, and (4) assistance in landuse and environmental planning. The USGS is: (1) providing overall coordination for the assessment, (2) helping organize, conduct, and facilitate the international workshops wherein the assessments are done, (3) 
leading the quantitative estimation of undiscovered mineral deposits, and (4) promoting joint publication of the results to benefit all.

Regional assessment studies like this one are compiling and integrating existing information at a scale of 1:1,000,000 using GIS technology including: databases and maps of the location, size, and geologic type of known mineral deposits and occurrences; maps and explanations of regional geology, metallogeny, tectonics, geochemistry, and geophysics; and available information about regional mineral exploration history. The integrated information will be used to delineate tracts of land permissive for particular types of undiscovered nonfuel mineral deposits and to make and constrain probabilistic estimates of the quantity and quality of the undiscovered resources. The resulting quantitative mineral resource assessment then can be evaluated using economic filters and cash flow models for economic and policy analysis, and can be applied to mineral supply, economic, environmental, and land-use planning. Such evaluations are not part of this report.

GMRAP assessments in South America began with publication of a review (Cunningham and others, 2005) summarizing the current knowledge of nonfuel mineral resources in Latin America and Canada. The present report includes a very brief examination of the importance, supply, and production of copper in the world, the geologic setting of South America that determines where future copper supplies are likely to be discovered, and presents estimates of the quantity, quality, and regional locations of porphyry copper resources that have yet to be discovered in South America.

\section{Abbreviations, symbols, and other conventions}

Symbols for the chemical elements:

$\mathrm{Ag}$, silver

$\mathrm{Au}$, gold

$\mathrm{Cu}$, copper

Mo, molybdenum

Tract identification numbers; for example SA01PC:

SA, South America

01, Tract number

PC, porphyry copper deposit type

The SA prefixes and PC suffixes may in places be dropped to facilitate tabulation and plotting.

Geologic time:

Wherever possible, nomenclature and divisions for geologic time follow International Commission on Stratigraphy (2000).

Ma, the time of a geologic event in million of years before A.D. 1950.

Significant digits and rounding

Undiscovered resources are totaled to two significant digits. In some places in the report, rounding and adherence to significant digits may appear to result in slight discrepancies between totaled numbers, and in totals of 99 or 101 percent.

\section{Acknowledgments}

This resource assessment of porphyry copper in South America has been a group effort with many people contributing their knowledge and resources to help it achieve success. The assessment was organized by the U.S. Geological Survey but much of the technical knowledge was generously provided by members of the geological surveys of Argentina (SEGEMAR), Brazil (CPRM), Chile (SERNAGEOMIN), Colombia (INGEOMINAS), and Peru (INGEMMET). Francisco Camus and Alvaro Puig Godoy (CODELCO) contributed an industry perspective, Paula Cornejo (SERNAGEOMIN) 
presented the regional perspective, and John Horton, Walter Bawiec, Boris Barrios, and Connie Dicken (USGS) helped with GIS. Paul Schruben helped with GIS and was indispensible in numerous aspects of production. Elmer Boulanger assisted with early compilations. Juan Palo Lacassie of the University of Chile assisted with the assessment of tract SA14bPC. Byron R. Berger (USGS) provided invaluable geological and other assistance during the preassessment analysis. Expert reviewers included Joaquin Buenaventura Arango, W. David Menzie, Floyd Gray, and Robert G. Luedke. Dr. Menzie, one of the original developers of quantitative mineral resource assessment techniques and applications, generously provided invaluable insights on assessment geology and methodology.

\section{Global copper resources in perspective}

Copper is an important commodity in today's economy because of its ability to conduct electricity and heat, high ductility and malleability, resistance to corrosion, and its abundance as a natural resource. Edelstein (2007) recently summarized world copper production and reserves (see figs. 4 and 5). The world reserve base for 2006 was 940 million metric tons of copper (fig. 4). The world reserve base is that part of the identified resource that meets specified minimum physical and chemical criteria related to current mining and production practices, including those for grade, quality, thickness, and depth. World reserves were 480 million metric tons and are that part of the reserve base that could be economically produced at the time of determination (U.S. Geological Survey, 2007). 


\section{Copper Production, Reserves, and Resources of the Andes Mtns., United States, and World}

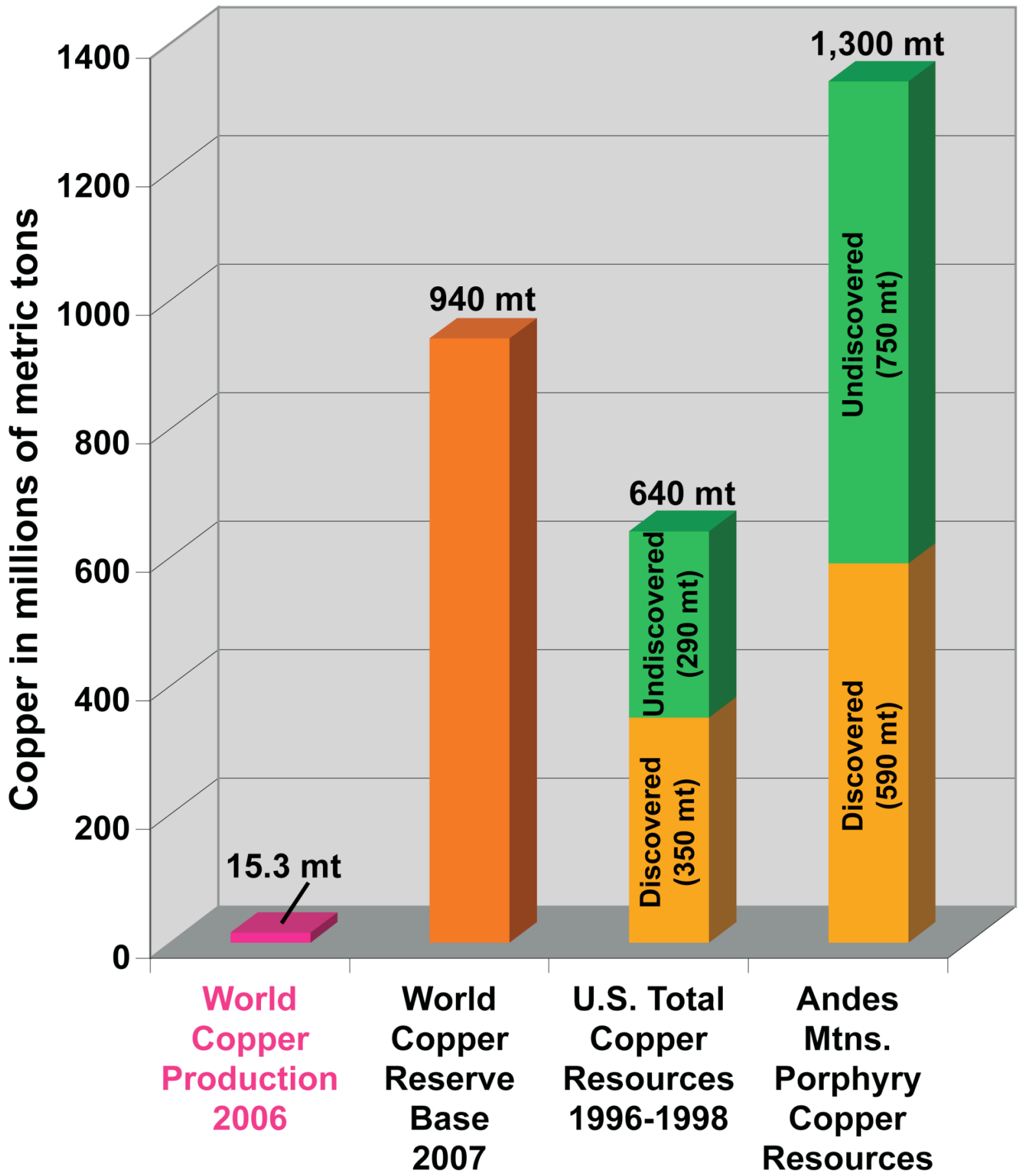

Figure 4. Column chart showing world copper production compared to copper resources of the Andes Mountains, United States, and world. World production and reserve base from Edelstein (2007); United States total resources (all copper deposit types) from Ludington, Cox, and McCammon (1996), U.S. Geological Survey National Mineral Resource Assessment Team (2000), and Schruben (2002); and Andes porphyry copper resources from this study. Total for Andes resources reported to two significant digits. $\mathrm{mt}$, million metric tons. 
In the year 2006, South America produced about 6.5 million metric tons of copper, of which most came from Chile and Peru (fig. 5). South America production represents about 43 percent of the world's total of 15.3 million metric tons of copper that year (Edelstein, 2007). The United States produced 1.2 million metric tons of copper in 2006. Results presented herein (table 2) indicate that about 590 million metric tons of copper are known in 69 porphyry copper deposits in the Andes. Another 750 million metric tons are estimated to occur in about 145 undiscovered porphyry copper deposits. By comparison, United States discovered copper resources in all copper deposit types were about 350 million metric tons, and undiscovered deposits were estimated to contain approximately 290 million metric tons of copper (Geological Survey National Mineral Resource Assessment Team, 2000; Schruben, 2002). 
Prepared and published jointly by the geological surveys of Argentina (SEGEMAR), Chile (SERNAGEOMIN), Colombia,

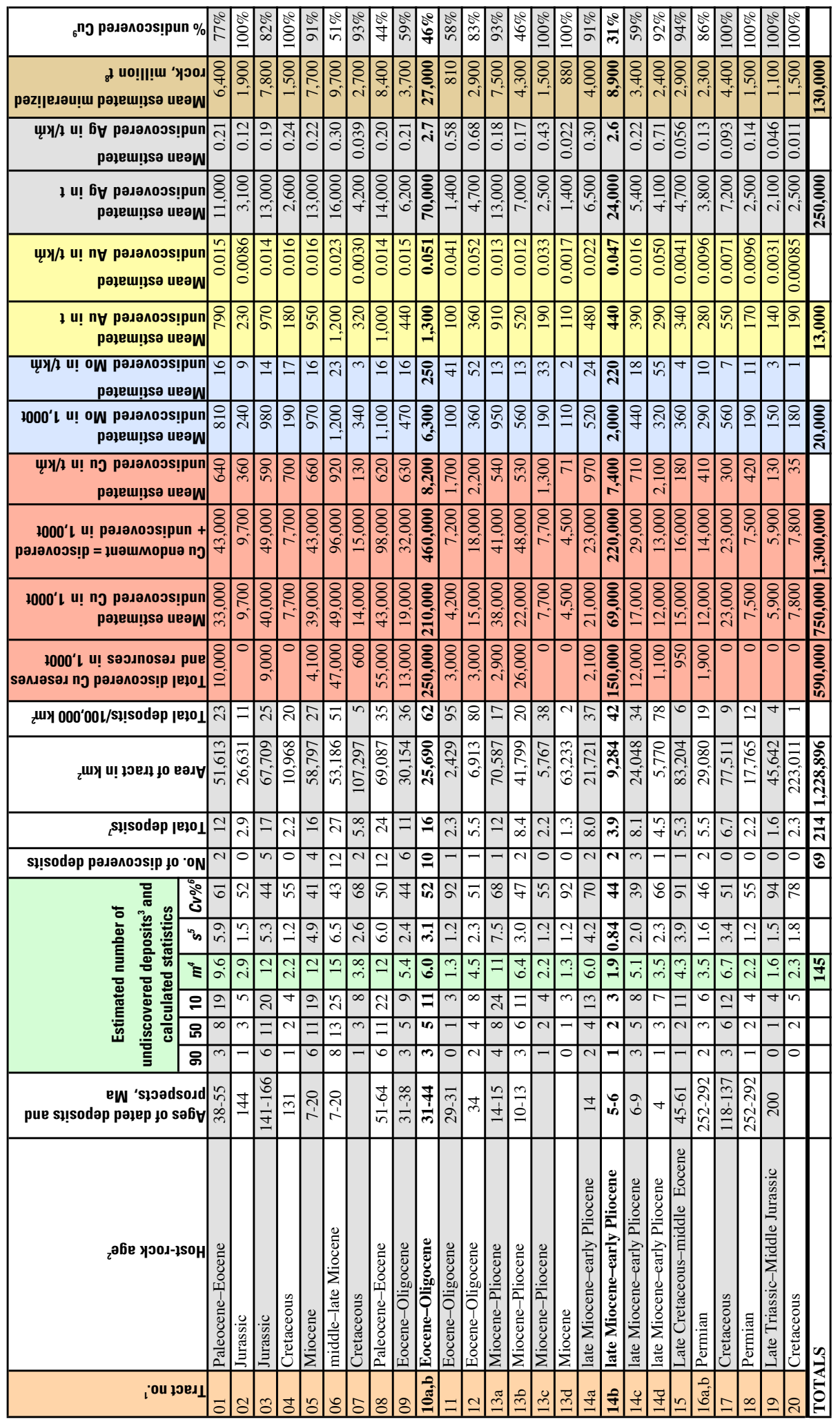

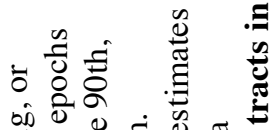

की

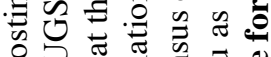

를

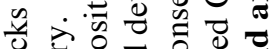

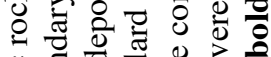

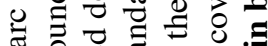

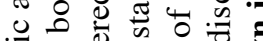

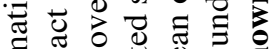

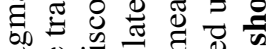

छั

छ

论苟

๑ च $\overrightarrow{0}$.

«

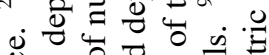

نू

की

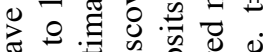

क वे के

원

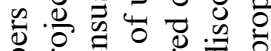

है एँ

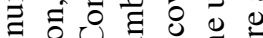

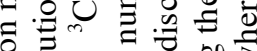

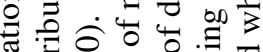

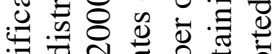

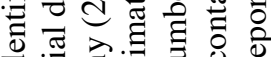

.를

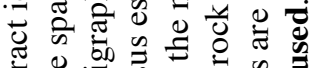

I 0.000

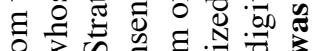

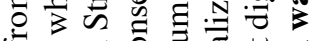

ช

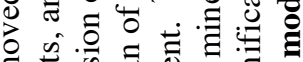

ज.

ए वे है छ ए

चี च 2 잉

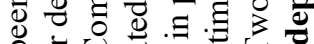

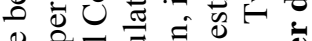

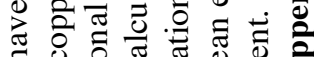

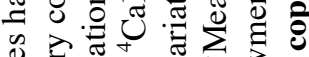

×

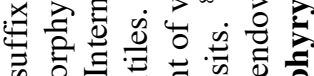

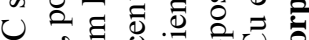

o oi o

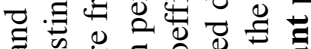

นิ

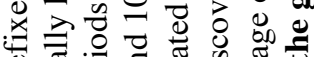

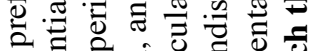

$\checkmark$ ब

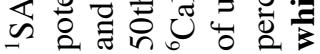




\section{Copper Production}

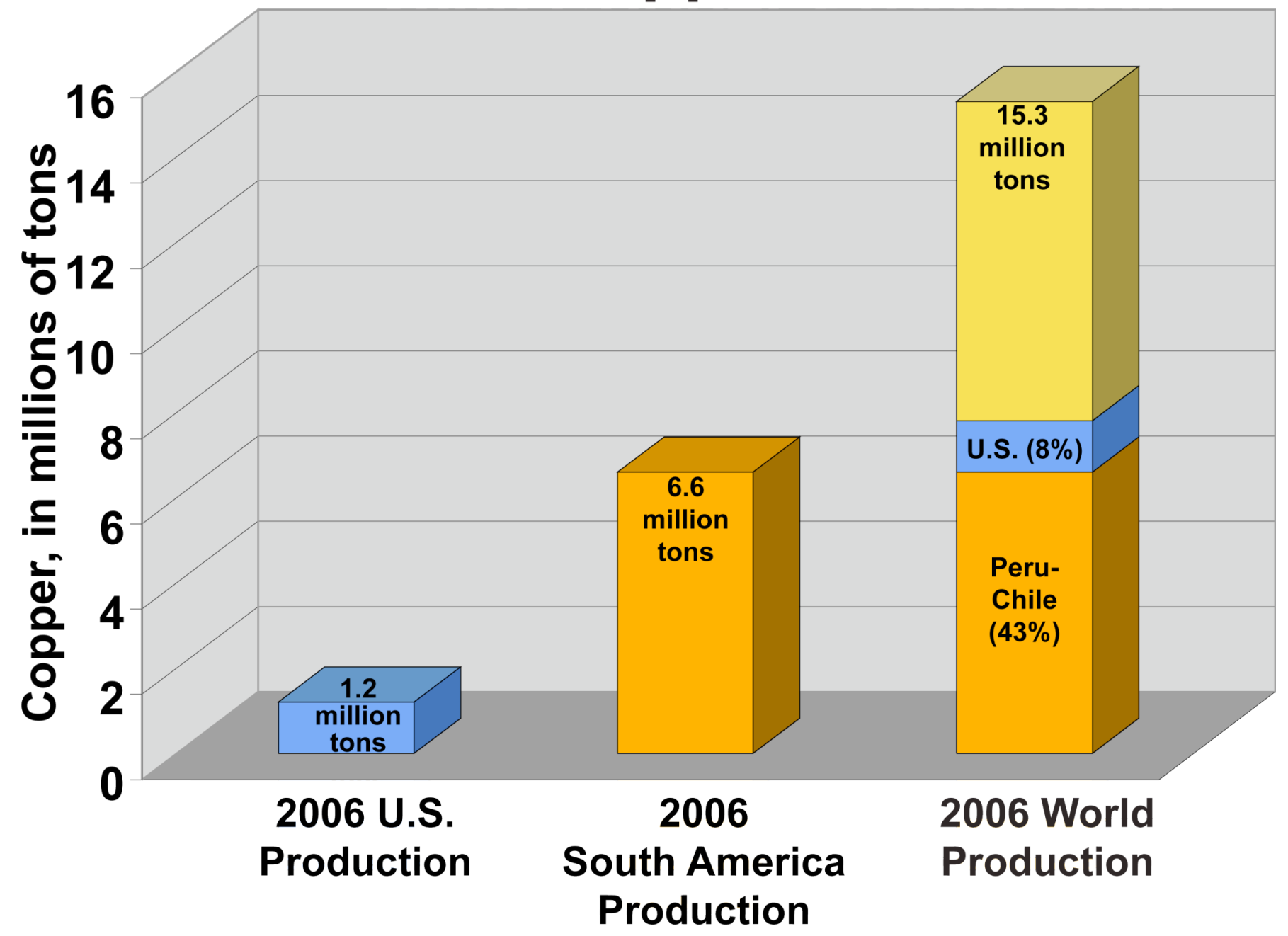

Figure 5. Column chart comparing copper production in 2006 from the United States, South America, and the world. Data from Edelstein (2007).

Although Andean and world copper resources potentially are very large, unknown but probably large amounts are unavailable or restricted in ways that discourage discovery and development and (or) increase cost. The cost of copper is of growing concern. Copper prices increased about 470 percent between 2002 and 2007. One reason copper resources are limited is because a large amount of land permissive or even favorable for the occurrence of undiscovered mineral deposits is unavailable or restricted for mineral exploration, discovery, and development because these lands include urban areas, transportation corridors, forest and wildlife preserves, scenic natural areas, sensitive ecosystems, protected biodiversity areas, sensitive and threatened surface and groundwater supplies, wilderness areas, national parks, and private land where mining is not desired. In the western United States, for example, Hyndman and others (1991) found that about 55 percent of the 2.1 million $\mathrm{km}^{2}$ of Federal mineral estate they studied was severely restricted or unavailable for mineral exploration and development; only 37 percent was available without restrictions. Our mineral resource assessment of the Andes herein delineates 1.2 million $\mathrm{km}^{2}$ of land permissive for the occurrence of undiscovered porphyry copper deposits. How much of this land is available for mineral exploration, discovery, and development? 


\section{Regional geologic setting of porphyry copper deposits in South America}

Copper is concentrated into minable ore deposits by geologic processes. About 80 percent of the world's copper comes from two types of copper deposits: porphyry copper deposits and sediment-hosted copper deposits. Porphyry copper deposits are accumulations containing, in part, copper minerals (fig. 6) in rocks and form from fluids associated with certain types of molten igneous rocks called magma. These deposits also are important sources of molybdenum, gold, silver, and other elements. Porphyry copper deposits and commonly associated volcanoes and mountain ranges form where large tectonic plates moving across the Earth's surface collide and are subducted along convergent zones into the hot interior Earth's mantle and are melted (fig. 7). Understanding these processes, gathering and using appropriate geological, geochemical, and geophysical data, and integrating all of this information into the best possible models permits quantitative predictions to be made about the numbers, sizes, and general locations of deposits not yet discovered. 


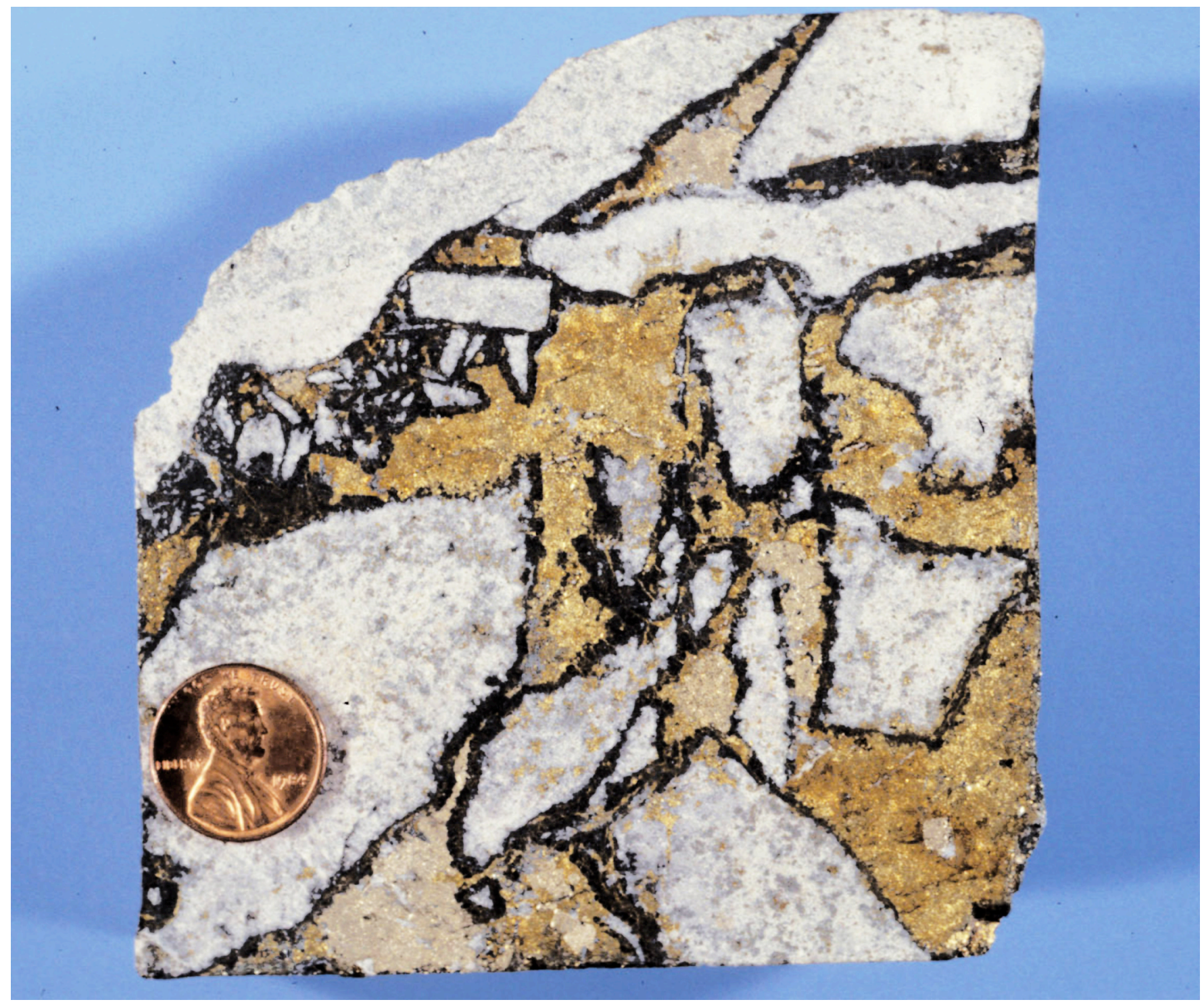

Figure 6. Photograph of high-grade porphyry copper ore from a breccia pipe in the uppermost part of the Los Bronces-Rio Blanco porphyry copper-molybdenum deposit, Chile. This is the Donoso orthomagmatic breccia with angular clasts of sericitized quartz monzonite. The breccia includes fine-grained, black crystals of tourmaline (boron mineral) that coat the breccia fragments. These crystals are oriented perpendicular to the breccia fragments and were probably deposited from a vapor phase that resulted from the pressure drop following the explosion that caused the breccia. Boron probably was partitioned into the vapor phase. The rest of the matrix is filled mostly with chalcopyrite and pyrite that was deposited from saline hydrothermal fluids that flooded the areas between the breccia fragments as the system cooled. Sample is about $8 \mathrm{~cm}$ in diameter. 


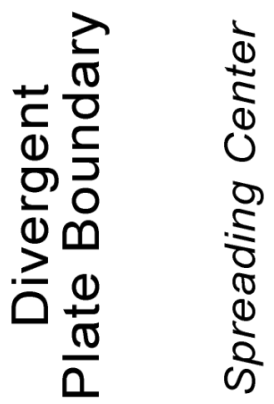

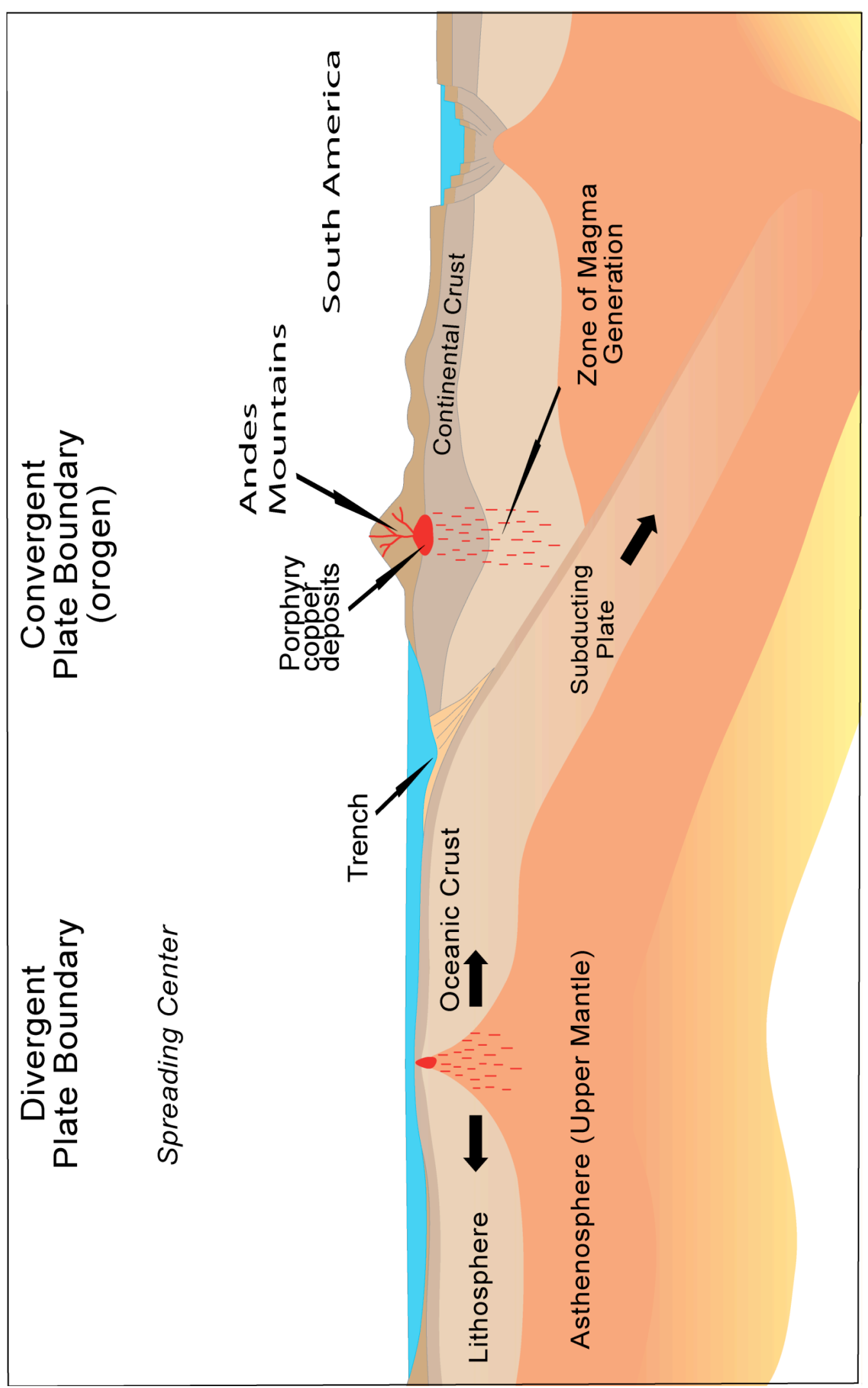

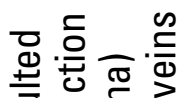
쥰긍 등 을 的点紊

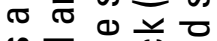

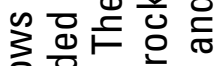
응은 엉 क् 응 E

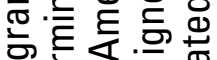
응 은 $\frac{5}{0} \cdot \frac{\pi}{0}$ Q $\Sigma \frac{\pi}{\infty} \mathscr{E}$

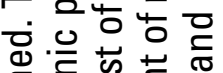

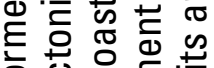

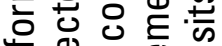
(1)

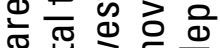
c 5 的

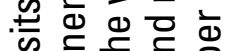
들 등 응 등 웅등ㅇㅇㅇ ब。 등 क के 응 등 든

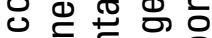
入す

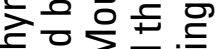
흥히응 넝 \& 증 응 \&..

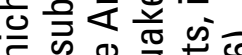
के

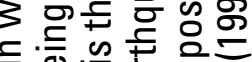
용 ब

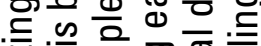

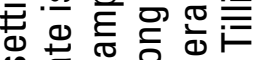
s $\frac{0}{2}$ 这

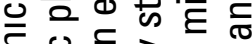

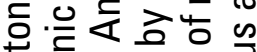

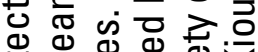
o ¿ 증 정을 즌 은

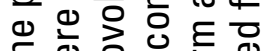

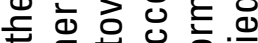

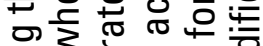

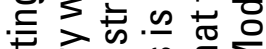
元工此 离

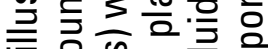

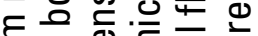
हते d。

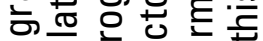

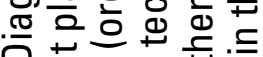

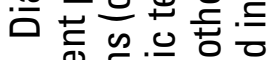

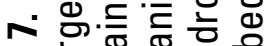

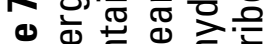
닌

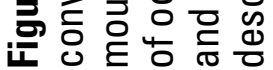


Porphyry copper deposits have an average of 630 million metric tons of mineralized rock with an average of 0.5 percent copper (Singer, Berger, and Moring, 2005). But because of the rareness of large deposits, only half of porphyry copper deposits are larger than 230 million tons and only half are richer than 0.44 percent copper. Chile contains unusually large examples of this deposit type. The world's largest porphyry copper deposit is Chuquicamata in Chile, which contains over 17 billion metric tons of ore averaging 0.65 percent copper. Other large deposits in Chile include El Teniente, La Escondida, and Los Bronces-Rio Blanco. Almost all of the known porphyry copper deposits of South America occur in the Andes Mountains, a range of high mountains along and near the western margin of the continent. The Andes mark the uplifted rocks above the collision zone where subduction and magma generation have been ongoing for millions of years as the Nazca oceanic plate has been subducted eastward beneath the South American plate (fig. 8). The western edge of the subduction zone is marked by a prominent trench on the ocean floor. If the magma that is produced by this process reaches the Earth's surface, it is likely to form volcanoes such as those along the crest of the Andes today. If conditions are such that the magma and associated fluids have the appropriate chemistry to concentrate metals, and cool and harden into rock before reaching the Earth's surface, a porphyry copper deposit may form. 


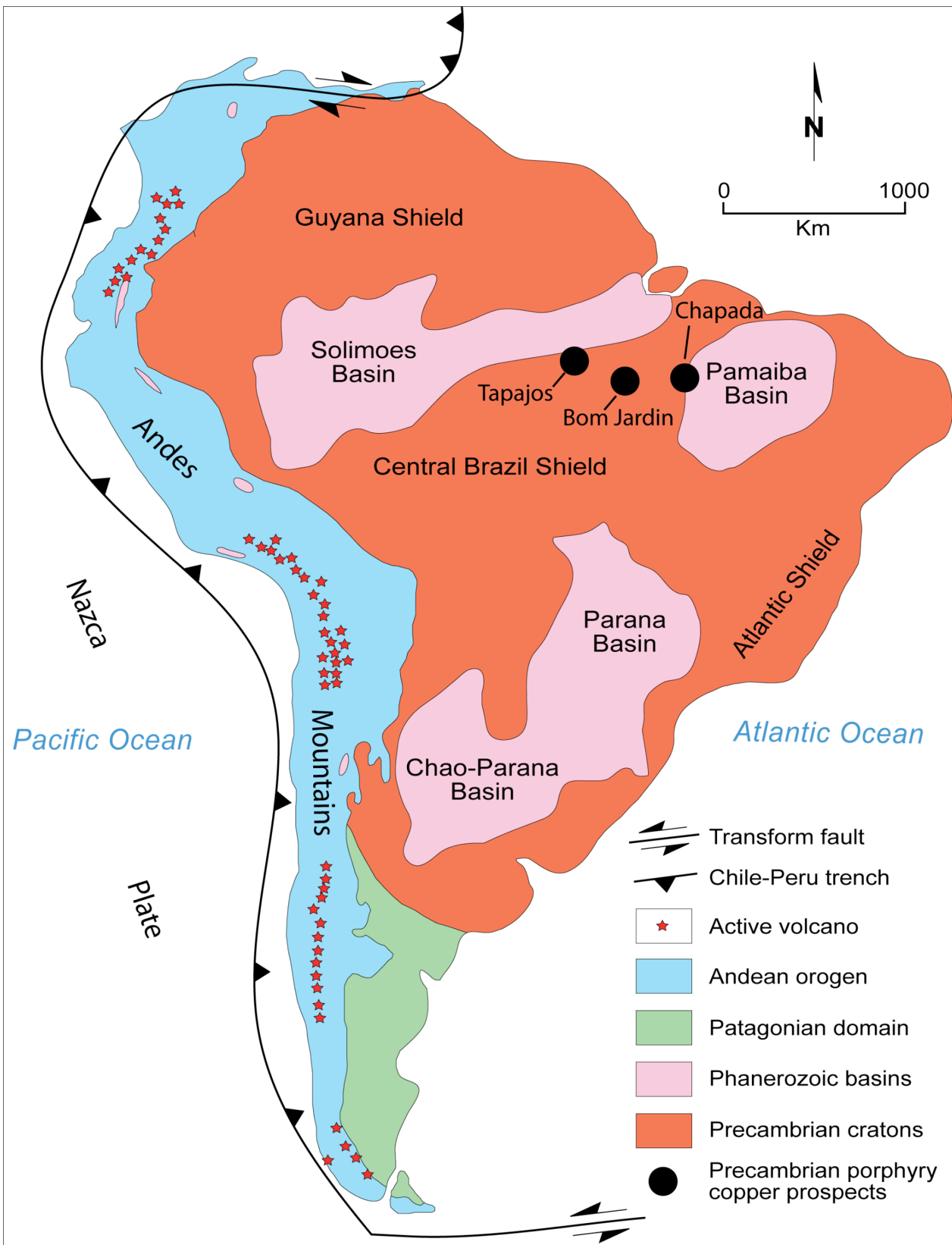

Figure 8. Simplified geologic map of South America showing the Nazca Plate being subducted beneath South America and showing the approximate locations of Precambrian copper porphyry prospects in Brazil. The westernmost surficial expression of the zone of subduction is marked by a prominent trench on the floor of the ocean. Volcanoes, shown as small red stars, form in four areas along the crest of the Andes. Modern earthquakes show that the sites of magma generation and movement are located along steeply dipping parts of the subduction zone. 
East of the Andes, in the interior of the continent, are old rocks that form stable areas called cratons or shields. These areas are overlain in part by younger rocks that accumulated in basins. The cratons record the geologic history of past mountains, subduction zones, and volcanoes, and contain hints of ancient porphyry copper deposits like the Precambrian porphyry copper prospects identified in figure 8 .

\section{Geologic setting of porphyry copper deposits in the Andes Mountains}

Knowledge of the porphyry copper geology of the Andes has changed significantly in the past few years as a result of increased detailed geologic mapping, use of spectral remote sensing, application of radiometric isotope systematics, and progress in understanding and integrating magmatic, hydrothermal, and tectonic systems. The plate tectonic separation of South America from Africa began during the earliest Jurassic and resulted in the opening of the Atlantic Ocean. Concomitant subduction-related magmatic activity along the west coast of South America in and beneath the Andes evolved through time as a result of variations in the subduction process. The spatial and temporal distribution of ore deposits throughout the Andes does not correspond with formation by a simple progressive subduction system. Instead, ore deposits are concentrated in distinct bands that experienced pulses of intense metallogenic activity apparently related to unique combinations of geologic factors (Stern, 2004; Rosenbaum and others, 2005).

The Andes are host to over 200 potentially active Quaternary volcanoes spaced unevenly along the front of the western margin of the continent (fig. 9). These volcanoes provide clues to the tectonic, magmatic, and ore-forming processes that have occurred in the Andes and give some unique insights to use in quantitative assessment of undiscovered porphyry copper deposits. The location of active volcanoes appears to be related to the feature that most strongly characterizes the subduction geometry beneath the Andean Cordillera - the along-strike variation in dip of the subducted Nazca plate from subhorizontal flatslab segments to normal subduction (fig. 9). Active volcanoes occur where the angle of subduction is relatively steep $\left(>25^{\circ}\right)$ (Stern, 2004). There presently are four distinct zones of active volcanoes that have persisted since late Miocene time. These zones of active volcanoes alternate with four flat-slab segments in which the subduction angle decreases to less than 10 degrees at depths greater than $100 \mathrm{~km}$. Buoyant topographic features on the ocean floor, such as aseismic ridges, seamount chains, and oceanic plateaus that are being subducted, or have been subducted, may have a spatial and genetic relationship to the flat slab segments (Rosenbaum and others, 2005; Stern, 2004; and Sillitoe and Perelló, 2005). Moreover, topographic and thermal anomalies on the down-going slab may act as tectonic triggers for the formation of porphyry copper deposits (Cooke, 2005). Associated crustal thickening and suppression of volcanism may lead to: (1) magma being trapped in large, shallow magma chambers; (2) accumulation of volatiles and metals; and (3) ultimately the formation of rich porphyry copper deposits (Rosenbaum and others, 2005; Sillitoe and Perelló, 2005). 


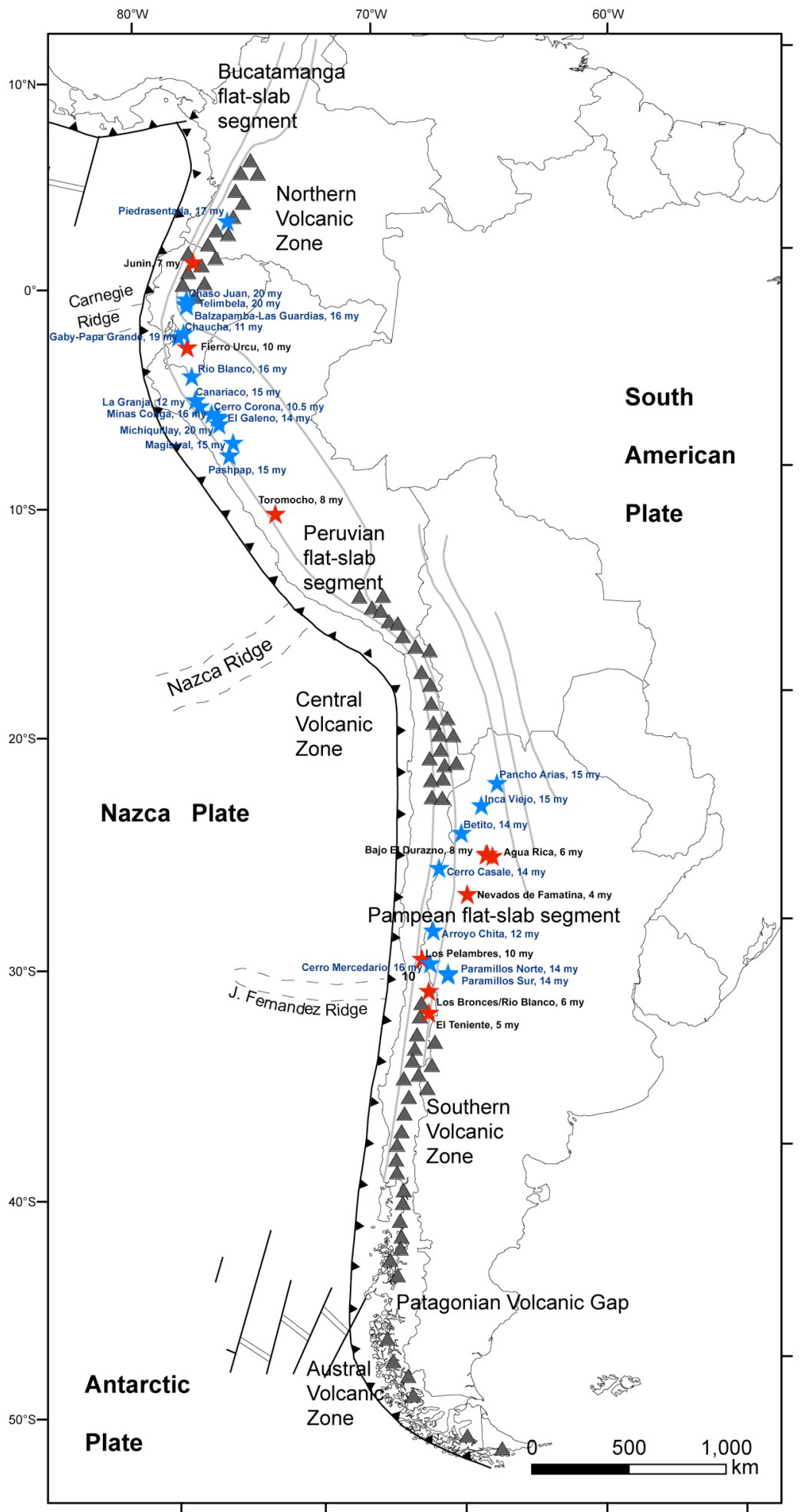

Figure 9. Schematic tectonic map of South America and the Pacific oceanic plates showing porphyry copper deposits and modern volcanoes. Modified in part from Ramos and Alemán (2000) and Stern (2004). Map shows four volcanically active segments in the Andes, subduction geometry of the Nazca Plate (Engdahl, van der Hilst, and Berrocal, 1995; Engdahl, van der Hilst, and Buland, 1998), oceanic ridges (Gutscher, 2002), the Perú-Chile trench (line with black triangles) (Norambuena and others, 1998; Angermann and others, 1999), and porphyry copper deposits distinguished by age (0-10 Ma in red stars and 11-20 Ma in blue stars). Black triangles show the location of modern volcanoes. 
In the last $20 \mathrm{Ma}$, the formation of many large porphyry copper deposits in the circum-Pacific region has been closely associated with the subduction of aseismic ridges, seamount chains, and oceanic plateaus beneath oceanic and continental arcs. Figure 9 shows the time-spatial relationships between the subducted Nazca Plate, active volcanoes, and porphyry copper deposits formed within the past 20 Ma. A transient compressive event began in the late Miocene and continued into the Pliocene as the result of subduction of the Juan Fernandez ridge. This collision caused slab shallowing, crustal thickening, rapid uplift, and exhumation, and has produced the highest mountains outside of the Himalayas (e.g., Mount Aconcagua at 6,962 $\mathrm{m}$ in westernmost Argentina).

Most large porphyry copper deposits of the Andes are related genetically to porphyritic calc-alkalic dacitic-granodioritic stocks emplaced as parts of a series of magmatic arcs. These arcs tend to become progressively younger to the east, at least in the central Andes, and this is thought to result from a series of subduction erosional events at the continental margin (Mpodozis and Ramos, 1990). Initial Sr isotope ratios of the porphyritic stocks are low and $\mathrm{Pb}$ isotope ratios have a narrow range. These isotopic data are thought to indicate an upper mantle source between the subducted oceanic plate and the continental crust (see fig. 7). It has been suggested that magmas responsible for the porphyritic systems ascended rapidly through the crust with little contamination. Kay and Mpodozis (2001) proposed that progressive slab flattening through the Miocene caused radical thickening of the sub-arc continental crust and a concomitant depression of the major locus of crustal anatexis. Rare-earth-element data were interpreted as evidence for a transition in residual mineralogy from clinopyroxene through amphibole to garnet. The onset of fertile hydrothermal activity was ascribed to large-scale breakdown of hornblende in the deep crust.

Many important porphyry copper deposits of the Andes lie in or close to large fault zones. The relative amount and importance of the strike-slip displacement along these faults versus that of normal reverse and inverted-extension faults is controversial (McClay, Skarmeta, and Beertens, 2002).

Nevertheless, as detailed by Sillitoe and Perelló (2005), pronounced crustal shortening and thickening accommodated by regional faults and followed by rapid surface uplift and erosion are important controls on the origin of porphyry copper deposits. These investigators deduce that such conditions can impede magma venting and foster development of large, shallow magma chambers that concentrate copper and magmatic fluids to form porphyry copper deposits. Relaxation of compressional stress favors the rise of buoyant, evolved magma and explains the common occurrence of porphyry copper deposits at the end of tectonomagmatic events (Richards, 2005).

\section{Assessment data}

Geologic maps, data about known deposits, and the experience of the assessment teams were the primary sources of information used in this assessment, but any and all available data resources were utilized, including those described and listed below.

\section{Geologic and metallogenic maps}

Geologic maps at a scale of 1:1,000,000 are the foundation of this assessment. Excellent geological base maps at a scale of 1:1,000,000 were available and more detailed maps were obtained from the SERNAGEOMIN and other local geological libraries as needed. The maps principally used were modern digital maps. Where digital maps were not available, paper maps were scanned and digitized for use. In some cases, maps with scales of 1:500,000 were consulted where more detail was needed to resolve questions. Metallogenic maps were examined in conjunction with the geologic maps. The new Metallogenic Map of South America (Zappettini, 2005) was especially helpful. The principal geologic maps used were: 
Argentina: Servicio Geológico Minero Argentino (SEGEMAR), Geologic map of Argentina, digital version. Zappettini, E.O., Editor., Metallogenic map of Argentina (preliminary version).

Brazil: Bizzi, L.A., Schobbenhaus, Carlos, Vidotti, R.M., and Goncalves, J.H., eds., 2003, Geología, tectonica, e recursos minerais do Brasil; texto, mapas \& SIG, Servico Geológico do Brasil (CPRM), DVD and CD versions. Compatible with a 1:1,000,000 scale.

Chile: Servicio Nacional de Geología y Minería (SERNAGEOMIN), 2003, Mapa Geológico de Chile: Version Digital: Publicacion Geologica digital No. 4, CD-ROM, version 1.0.

Colombia: Mapa Gelógico del Colombia: Instituto Nacional de Investigaciones Geológico - Mineras (INGEOMINAS): 1988, Escala 1:500,000.

Ecuador: 2001, Mapa Geológico del Ecuador: Ministerio Energía y Minas, pdf file.

Ecuador: 2003, Mapa Gelógico de la República del Ecuador: Escala 1:1,000,000, Ministerio Energía y Minas.

Mpodozis, C., and Ramos, V., 1990, The Andes of Chile and Argentina: Circum-Pacific Council for Energy and Mineral Resources Earth Science Series, v. 11, p. 59-90.

Perú: Instituto Geológico Minero Metalúrgico (INGEMMET), 1999, Mapa Geológico del Perú: Escala 1:1,000,000, preliminary edition.

South America: Servico Geológico do Brasil (CPRM): 2001, GIS - Geologic Map of South America, $1: 5,000,000$.

South America: Mapa Metalogenético de América del Sur, 2005, Coordinación General Zappettini, Eduardo O., Servicio Geológico Minero Argentino, Anales No. 44.

Uruguay: Bossi, Jorge, y Ferrando, Lorenzo, 2001, Carta Geológica del Uruguay a escala 1/500,000, versión 2.0.

Venezuela: U.S. Geological Survey and Corporación Venezolana de Guayana, Técnica Minera, C.A., 1993, Geology and Mineral Resource Assessment of the Venezuelan Guayana Shield: U.S. Geological Survey Bulletin 2062, scale 1:500,000.

\section{Discovered (known) deposits and prospects}

Deposits herein referred to as "discovered" or "known" are reported in the published literature to be well explored in three dimensions, unopen in any direction, and have published tonnages and grades. "Unopen" means that a deposit has been fully delimited by exploration. Explored metal occurrences not meeting these criteria are classified as prospects even if they are being mined and there is an indication that more resources are expected. Such a definition is necessary to avoid either double counting or missing some resources. Some of these prospects represent some of the undiscovered deposits estimated herein. The expressions "discovered deposits" and "known deposits" are used interchangeably in this report.

Data about the discovered porphyry copper deposits and prospects in South America used in this assessment came from a variety of sources. Much of the data concerning these productive ore-forming systems was obtained from the published literature that has been extensive in recent years.

An essential data source for the assessment was the database, map, and grade and tonnage models published by Singer, Berger, and Moring (2005). This publication contains information on porphyry copper deposits around the world and is especially useful for quantitative assessment because of the consistent manner of data gathering and reporting. An important consideration is what the sampling unit should be for such a compilation. Singer, Berger, and Moring (2005) assure consistency by using the following operational rules to define a deposit: (1) all mineralized rock or alteration within $2 \mathrm{~km}$ are combined as one deposit, and (2) grade and tonnage data reported for deposits include average grade of each metal and associated tonnage based on total production, reserves, and resources at the lowest possible cutoff grade for thoroughly delineated deposits. These operational rules are followed herein and are 
necessary for defining deposits to ensure that deposits in grade, tonnage, and deposit-density models correspond to both discovered and undiscovered deposits consistently. Rules such as the 2-km spatialcombination rule are essential to have an internally consistent assessment system where the estimates of the number of undiscovered deposits are consistent with the grade and tonnage models. In addition to deposits, Singer, Berger, and Moring (2005) also list available information about prospects.

Information about known deposits and prospects was supplemented by several recent compendiums that were especially helpful, including: Skinner (1999), Zappettini (1999a, b; and 2005), Zappettini and others (2001), Camus (2003), Kirkham and Dunne (2000), Sillitoe and others, (2004), Cooke, Hollings, and Walshe (2005), Porter (2005), Sillitoe and Perelló (2005), and references cited therein. More recent data are discussed in the text.

\section{Assessment methodology}

A general understanding of assessment methodology can be gained by examining the procedures, data, and assumptions involved in predicting the weather. Weather forecasters have gotten pretty good at predicting the weather. There has been a great increase in the amount and quality of weather data that are collected. Today, there are stations even in remote locations that measure precipitation, temperature, and wind speed and direction. There has been a large improvement in predictive weather models because weather-forming processes are becoming better understood: as we learn more about how tornados form we get better at predicting when the conditions are right to form a tornado and maybe we can say something about how big it will be and where it will be. There also has been great improvement in computing capabilities to effectively use more and better data and models. Consequently, weather forecasters can do a better job predicting the weather tomorrow or next week. Similarly, geologists can improve their predictions of the quantity, quality, and location of undiscovered mineral resources with more and better data and models, and better computer facilities. For mineral resource assessments, we do pretty much the same things exploration managers of major mining companies would do if they were starting a major exploration program.

The best available geological, geochemical, and geophysical data available were integrated with the best available mineral deposit models. These data and the ideas of the assessment team, based on their experience, were combined to make knowledgeable predictions as to where, and how large, the undiscovered mineral deposits may be. The result is a probabilistic quantitative assessment of copper, molybdenum, silver, and gold in undiscovered porphyry copper deposits of the Andes. The assessment was done in three parts and then the estimates were combined:

(1) Delineate tracts of land where the geology would permit porphyry copper deposits to form;

(2) Evaluate and select, or construct, grade and tonnage models appropriate for estimating grades and tonnages in the undiscovered porphyry copper deposits in each tract;

(3) Make a probabilistic estimate for each tract of the number of undiscovered deposits consistent with the grade and tonnage models.

A Monte Carlo simulation computer program (EMINERS) was used to combine the probability distributions of the estimated number of undiscovered deposits with the distributions of grades and the tonnages of the selected model to obtain the probability distributions of undiscovered metals in each tract.

The first three parts are known as the "Three-Part Form" of assessment (Singer, 1993), which, together with the Monte Carlo simulation, were developed by the USGS to express probabilistically the amounts and associated uncertainties of estimates of undiscovered mineral resources. These estimates then can be used to conduct quantitative economic evaluation of resources in a format usable by 
decisionmakers (e.g., Singer, 1975; Root, Menzie, and Scott, 1992; Singer, 1993a; and Singer and others, 2001). However, such economic evaluations are not part of this report.

\section{Assessment of the Andes Mountains}

After initial data collation, the assessment of the Andes began with preliminary tract delineation, analysis of known deposits and appropriate grade and tonnage models, and estimation of numbers of undiscovered deposits by Vladimir Berger and Donald Singer. Byron R. Berger (USGS) assisted with preliminary tract delineation. Although the boundaries of most of the preliminary tracts changed as the assessment progressed, having these tracts available as a starting place, together with appropriately tested, selected, or constructed grade and tonnage models, and preliminary estimates of numbers of undiscovered deposits using deposit density models, greatly increased the efficiency of the international assessment team.

Subsequently, the principal assessment workshop was conducted May 16-20, 2005, in Santiago, Chile, at the headquarters of SERNAGEOMIN (the Geological Survey of Chile), and included participants from Colombia, Peru, Argentina, Chile, and the United States (fig. 10). The workshop began with a series of formal talks providing overviews of the: geology and porphyry copper deposits of the Andes, process for delineating permissive tracts, construction and use of USGS porphyry copper deposit models, and process of estimating and reporting numbers of undiscovered mineral deposits in each tract. The work and products from the preliminary assessment greatly aided and accelerated production of the final assessment results. Following the general assessment workshop, several meetings in Argentina and Chile clarified geological data, further evaluated areas as more data became available, and discussed the implications of preliminary interpretations. 


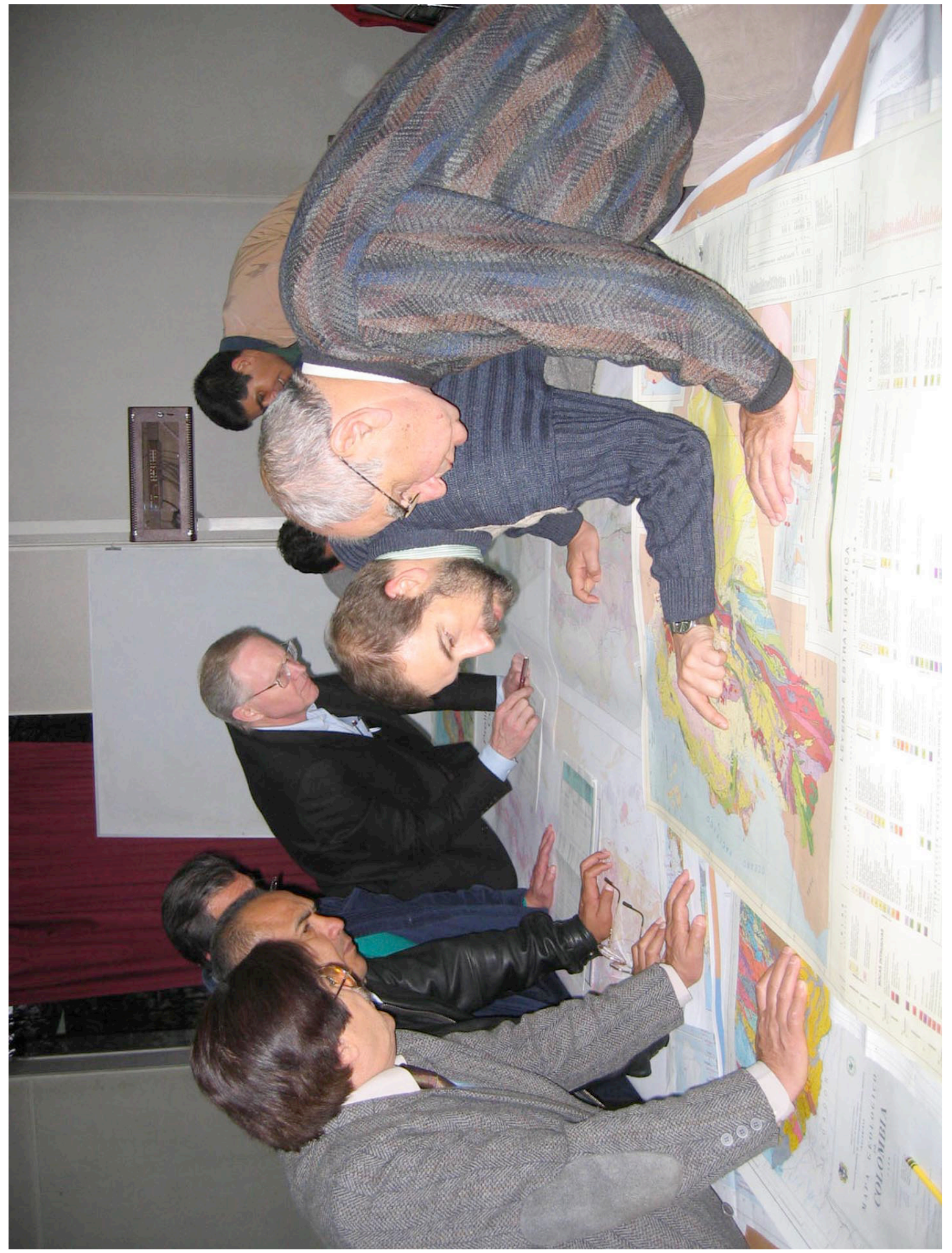




\section{Delineating tracts}

An important goal of quantitative mineral resource assessment is to delineate tracts of land permissive for the occurrence of undiscovered mineral deposits, and estimate numbers of undiscovered deposits, in ways that permit the estimates to be used for a variety of applications in land, resource, economic, and environmental planning and decisionmaking. To make it possible to disaggregate assessment results for some of these kinds of applications, tracts are delineated with the following rules:

(1) All tracts of land where the geology is permissive for the occurrence of the undiscovered mineral deposits are delineated such that the probability of a deposit being outside of a tract is negligible.

(2) The tracts are subdivided where reasons exist to suspect spatial differences in the density or probability of occurrence of undiscovered deposits within the tracts. Because probabilities of deposit occurrence are not commonly estimated within tracts, a more practical guide is that tracts should be divided whenever the expected number of deposits or the level of uncertainty varies within a tract.

The central integrating factor of a mineral resource assessment is the mineral deposit model, which relates deposit types to geologic environments. Porphyry copper deposits form in island and continental volcanic-arc subduction-boundary zones. Consequently, broad igneous arcs that formed at approximately the same time in such tectonic settings are the fundamental unit for the delineation of areas permissive for the occurrence of these deposits.

\section{Preliminary delineation}

To begin the tract delineation process, all known Andean porphyry copper deposits and prospects, with ages (Singer, Berger, and Moring, 2005), were plotted on geologic base maps. This global porphyry copper database was used because it is the only one that applies a consistent rule for defining a deposit. Moreover, the data are consistent with the grade and tonnage models and density models used herein to assess the Andes. The 2-km spatial-combination rule was applied so that deposits in grade and tonnage and spatial density models are consistently defined to avoid introducing biased estimates of the number of deposits and resources.

As the next step in the process, 12 preliminary tracts were drawn along the borders of magmatic arcs while taking into consideration deposit and prospect ages and the locations of major structures. Information about the extent and depth of cover also was considered as well as the extent and types of exploration that have taken place in the area. A simple point counting method using a transparent grid was employed to estimate the area of each tract covered by rocks younger than the tract's porphyry copper host rocks and any known mineralization event(s). These estimates were refined after the maps were digitized. Digital tract maps could not be constructed directly from the digital geologic maps. Geologic maps show rocks exposed at the Earth's surface, whereas permissive terranes extend beneath surficial deposits of younger rocks and sediments. Information about the subsurface geology was integrated into decisions made at the Santiago workshop to estimate tract boundaries beneath cover.

\section{Final delineation}

Working from the preliminary tract boundaries drawn during the preliminary assessment, the international assessment teams used the distribution of known deposits, appropriate prospects, similaraged intrusive and volcanic rocks of comparable magmatic arcs, fault and tectonic control, available geophysics and geochemistry, and regional and deposit-model experience, in an interactive, integrated procedure to refine the boundaries of the preliminary tracts and draw new ones the data suggested would be permissive for undiscovered porphyry copper deposits. Discovered deposits and prospects plotted on 
the geologic base for the preliminary assessment were reviewed and some were added, changed, or deleted. The amount, types, and availability of exploration information and knowledge also were reviewed and evaluated, as were the distribution and thickness of younger geologic cover such as stream sediments or volcanic ash. Estimates of undiscovered porphyry copper deposits were made to a depth of $1 \mathrm{~km}$ beneath the surface. If an area of permissive rock was covered by more than $1 \mathrm{~km}$ of rock or was known to be barren, then the area was excluded from the tract.

These permissive tracts then were subdivided wherever different degrees of uncertainty or different likelihoods of deposit occurrence could be identified within the tract. Tract subdivision was based primarily on differences in the types, amounts, availability, and reliability of information on the geology and mineral exploration in the tract. Differences in the extent and intensity of exploration commonly are related to availability of geologic information, including information about types and thickness of cover rocks. Exploration also may be limited by assorted political, economic, environmental, and other societal land-use restraints. In all, 26 tracts were finally delineated. Future studies of igneous rock suites in the Andes region may identify additional permissive tracts. Examples of such suites include Jurassic igneous rocks along the south coast of Peru, and Jurassic and late Paleozoic igneous rocks in southern Chile.

The tracts were drawn on a geological base but are presented here on a cultural base to avoid release of proprietary geologic information and to allow nontechnical users to locate the tracts more easily. A 1:4-million-scale summary map of all of the tracts by geologic age is plate 1 of this report.

\section{Selecting appropriate grade and tonnage models}

A mineral deposit model can be defined as the systematic arrangement of the essential characteristics of a group of similar mineral deposits. Descriptive models of the various types of porphyry copper deposits are based on worldwide occurrences and are listed in Cox and Singer (1986).

Frequency distributions of tonnages and average grades of well-explored deposits of a given type are employed as models for grades and tonnages of undiscovered deposits of the same type in geologically similar settings. Because the number of deposits and grade and tonnage models are typically combined through expected values or Monte Carlo simulation to estimate the undiscovered mineral resources of areas, it is important that estimated undiscovered deposits be compatible with the grade and tonnage models and that the grade and tonnage model be representative of the grades and tonnages of the undiscovered deposits (Singer, 1993b; Singer, 1994).

Three subtypes of porphyry copper deposits were defined in Cox and Singer (1992) and quantified by Singer, Berger, and Moring (2002). These subtypes were defined as: (1) porphyry $\mathrm{Cu}-\mathrm{Au}$ if the $\mathrm{Au} / \mathrm{Mo}$ ratio is greater than or equal to 30, (2) porphyry $\mathrm{Cu}-\mathrm{Mo}$ if the $\mathrm{Au} / \mathrm{Mo}$ ratio is less than or equal to 3, and (3) porphyry $\mathrm{Cu}$ for ratios between 3 and 30. Gold is in ppm and Mo is in percent.

A general porphyry copper deposit model (Singer, Berger, and Moring, 2005) incorporating all three subtypes was the one selected to represent the undiscovered deposits in most Andean tracts. Grade and tonnage characteristics of the discovered deposits in these tracts best fit the grades and tonnages of this general model that is based on 380 worldwide porphyry copper deposits. There are few tracts around the world that contain one subtype exclusively. For discovered deposits in the porphyry copper tracts reported here, grade and tonnage data from Singer, Berger, and Moring (2005) show that tract SA10aPC contains deposits of the porphyry $\mathrm{Cu}-\mathrm{Au}$ (La Escondida) and porphyry $\mathrm{Cu}-\mathrm{Mo}$ (Chuquicamata) subtypes. Tract SA10bPC contains both porphyry $\mathrm{Cu}$ (El Salvador) and $\mathrm{Cu}-\mathrm{Au}$ (Potrerillos) subtypes. Regional maps do not appear to contain information to clearly distinguish which subtype might occur.

\section{Model testing}

How can a mineral deposit grade and tonnage model be checked to see if it provides an unbiased representation of the grades and tonnages of undiscovered mineral deposits in a tract? Before estimating 
numbers of undiscovered deposits, the grades and tonnages of the well explored - that is, completely drilled (discovered) - deposits are tested to see if they are statistically different from the grades and tonnages of the general model. It is not enough to note that the grades and tonnages of the discovered deposits occur in the general grade and tonnage model because all of the discovered deposits might, for example, have tonnages that are on the low-tonnage part of the model. The appropriate test of the discovered deposits is a $t$-test of their tonnage and average grade(s) compared to the deposits in the model excluding the discovered deposits being tested. All of the data should be in logarithms.

The $t$-test gives the probability that the difference between the means of the two tested data sets occurred by chance. In our tests of the Andean tracts against the general model, if this probability is less than 0.01 , the difference is considered to be "significant," that is, the difference is not caused by chance and we reject the hypothesis that the discovered deposits in the tract are a random sample from the general model. If the discovered deposits were significantly different in size or grade from the general model, the discovered deposits were examined to see if they belong to a geologically homogeneous subset of the general grade and tonnage model.

In cases where no discovered deposits are known in a tract, the general model is assumed to be the best representative of the undiscovered deposits in the tract. This is done because there is no basis for selecting a more specific model for the tract.

\section{Preliminary model testing for the Andes}

For each of the 12 tracts outlined during the preliminary assessment, the discovered deposits from the general porphyry copper deposit model (Singer, Berger, and Moring, 2005) that are located in a tract were tested against all of the other deposits in the world in the general model. For example, $\log _{10}$ tonnages of the 12 well-explored deposits in the preliminary Miocene tract in northern Peru were tested to see if they were significantly different from the other 368 deposits in the general model. The $t$-test gave:

$$
t=(8.330-8.638) / 0.1849=-1.67
$$

with 378 degrees of freedom, mean tonnage of the Miocene deposits in northern Peru $=8.638$, mean tonnage of the remaining part of the world $=$ 8.330 , and the pooled standard error $=0.1849$.

The probability of getting a $t=1.67$ with 378 degrees of freedom is $0.10\{\mathrm{p}=0.10\}$. Differences as large as seen here between tonnages of porphyry copper deposits in this tract and those of the world-wide porphyry copper deposits happen by chance alone about 10 percent of the time. Therefore, the global model was accepted as appropriate for undiscovered porphyry copper deposits of the Miocene tract in northern Peru. Similar results were observed for $\mathrm{Cu}$ grades $\{\mathrm{p}=0.21\}$.

The general model was accepted for all of the preliminary tracts except for one Eocene and one Miocene-Pliocene tract in Chile. These two tracts required construction of a new giant porphyry copper deposit model discussed below. The general and giant models were used to guide the preliminary and final estimation of the number of undiscovered deposits in appropriate tracts.

\section{Models selected for the Andes}

Eighteen Andean tracts each contain at least one discovered deposit that was deemed well enough explored to be included by Singer, Berger, and Moring (2005) in the general porphyry copper deposit model. $T$-tests were used to compare the tonnages and grades of all of the well-explored deposits in each of these 18 tracts to the tonnages and grades of the other well-explored deposits in the general model (table 3). The results of the tests show that three of the Andean tracts contain deposits that have tonnages or copper grades significantly different from the general model. One of these tracts, Eocene-Oligocene tract SA09PC in southern Peru, contains deposits that have significantly higher copper grades than the 
other deposits in the general model. The deposits in this tract commonly contain skarn mineralization that has copper grades above the average grade of other porphyry copper deposits. The assessment team believes that the undiscovered porphyry copper deposits in this tract will not be associated with the limestones that help produce the skarns and therefore the general porphyry copper model is selected for this tract despite failing the $t$-test. Tracts SA10a,bPC and SA14bPC failed the $t$-tests for tonnage because they have known deposits with tonnages significantly higher than the general model. In addition, known deposits in tract SA10a,bPC have average copper grades significantly higher than the general model.

Consequently, a new grade and tonnage model had to be constructed and used for these two tracts and is referred to as the giant porphyry copper deposit model. This model is summarized in table 4 and presented formally in appendix I.

Table 3. Probability from t-test that tonnages and grades of known deposits in each tract are from the general porphyry copper grade and tonnage model.

\begin{tabular}{|c|c|c|c|c|c|c|}
\hline $\begin{array}{c}\text { Tract } \\
\text { no. }\end{array}$ & $\begin{array}{c}\text { No. } \\
\text { known } \\
\text { deposits }\end{array}$ & $\begin{array}{c}\text { Tons, } \\
\text { general } \\
\text { model }\end{array}$ & $\begin{array}{c}\text { Cu, } \\
\text { general } \\
\text { model }\end{array}$ & $\begin{array}{c}\text { Mo, } \\
\text { general } \\
\text { model }\end{array}$ & $\begin{array}{c}\text { Au, } \\
\text { general } \\
\text { model }\end{array}$ & $\begin{array}{c}\text { Ag, } \\
\text { general } \\
\text { model }\end{array}$ \\
\hline 01 & 2 & 0.281 & 0.127 & 0.656 & nd & nd \\
\hline 02 & 0 & nd & nd & nd & nd & nd \\
\hline 03 & 5 & 0.937 & 0.088 & 0.111 & nd & nd \\
\hline 04 & 0 & nd & nd & nd & nd & nd \\
\hline 05 & 4 & 0.626 & 0.379 & 0.181 & 0.181 & 0.852 \\
\hline 06 & 12 & 0.096 & 0.207 & 0.063 & 0.558 & 0.298 \\
\hline 07 & 2 & 0.299 & 0.457 & 0.489 & nd & 0.102 \\
\hline 08 & 12 & 0.055 & 0.083 & 0.173 & nd & 0.724 \\
\hline 09 & 6 & 0.918 & $0.000 * *$ & 0.061 & 0.579 & nd \\
\hline $10 a, b$ & 10 & $0.000 * *$ & $0.000 * *$ & 0.846 & 0.451 & 0.305 \\
\hline 11 & 1 & 0.524 & 0.696 & 0.809 & 0.980 & nd \\
\hline 12 & 1 & 0.534 & 0.668 & nd & 0.395 & nd \\
\hline $13 a$ & 1 & 0.261 & 0.264 & nd & 0.286 & nd \\
\hline $13 b$ & 2 & 0.033 & 0.681 & 0.804 & 0.142 & 0.975 \\
\hline $13 c$ & 0 & nd & nd & nd & nd & nd \\
\hline $13 d$ & 0 & nd & nd & nd & nd & nd \\
\hline $14 \mathrm{a}$ & 2 & 0.877 & 0.528 & 0.817 & nd & nd \\
\hline $14 \mathrm{~b}$ & 2 & $0.001 * *$ & 0.056 & 0.556 & 0.013 & 0.101 \\
\hline $14 c$ & 3 & 0.193 & 0.810 & 0.346 & 0.605 & 0.583 \\
\hline $14 d$ & 1 & 0.828 & 0.697 & 0.114 & 0.638 & 0.326 \\
\hline 15 & 1 & 0.935 & 0.849 & nd & 0.742 & nd \\
\hline 16 & 2 & 0.737 & 0.073 & nd & 0.980 & nd \\
\hline 17 & 0 & nd & nd & nd & nd & nd \\
\hline 18 & 0 & nd & nd & nd & nd & nd \\
\hline 19 & 0 & nd & nd & nd & nd & nd \\
\hline 20 & 0 & nd & nd & nd & nd & nd \\
\hline
\end{tabular}

Red font with $^{* *}=$ significantly different at $1 \%$ level. $\mathrm{nd}=$ no deposit to test. 
Table 4. Comparison of tonnages and grades of giant and general porphyry copper deposit models.

\begin{tabular}{|l|c|c|c|c|c|c|c|c|}
\hline & \multicolumn{2}{|c|}{$\begin{array}{c}\text { Number } \\
\text { of deposits }\end{array}$} & \multicolumn{2}{c|}{$\begin{array}{c}\mathbf{1 0}^{\text {th }} \text { percentile } \\
\text { of deposits }\end{array}$} & \multicolumn{2}{c|}{$\begin{array}{c}\mathbf{5 0}^{\text {th }} \text { percentile } \\
\text { of deposits }\end{array}$} & \multicolumn{2}{|c|}{$\begin{array}{c}\mathbf{9}^{\text {th }} \text { percentile } \\
\text { of deposits }\end{array}$} \\
\hline & Giant & General & Giant & General & Giant & General & Giant & General \\
\hline Tons & 12 & 380 & 16,000 & 1,400 & 1,500 & 230 & 880 & 32 \\
\hline Cu grade & 12 & 380 & 1.4 & 0.80 & 0.83 & 0.44 & 0.55 & 0.25 \\
\hline Mo grade & 12 & 380 & 0.04 & 0.03 & 0.008 & 0.008 & 0.0 & 0.002 \\
\hline Ag grade & 12 & 380 & 5 & 3.8 & 0.0 & 1.3 & 0.0 & 0.40 \\
\hline Au grade & 12 & 380 & 0.61 & 0.57 & 0.0 & 0.095 & 0.0 & 0.016 \\
\hline
\end{tabular}

The general model is reported in Singer, Berger, and Moring (2005). Tonnages are in millions of metric tons. Copper $(\mathrm{Cu})$ and molybdenum $(\mathrm{Mo})$ grades are reported as percent of the metals. Gold $\mathrm{Au})$ and silver $(\mathrm{Ag})$ grades are reported as grams/metric ton of the metal.

\section{Estimating numbers of undiscovered deposits}

A key part of estimating amounts of undiscovered mineral resources is making probabilistic estimates of numbers of undiscovered mineral deposits by appropriate methods (e.g. Menzie and Singer, 1990; Root, Menzie, and Scott, 1992; Singer, 1993a; Singer and Menzie, 2005; and Singer, 2007). Such estimates most commonly are based on some form of analogy whereby experience from similar areas, together with knowledge of the numbers of deposits in those areas, permits estimates for the new areas (Singer, 2007). A second approach that also was used relies on identifying potential exploration targets for the type of deposit being estimated. This requires detailed information. In this case, individual targets such as partially explored deposits can be compared to descriptive deposit models to evaluate the likelihood that they are deposits of the type being estimated. Mineral deposit spatial-density models from well-explored control areas worldwide have become important tools for guiding and making estimates by analogy (e.g., Bliss and Menzie, 1993; Singer and others, 2001; Singer and Menzie, 2005; Singer and others, 2005; Mosier and others, 2007; and Singer, 2008). Estimates herein of numbers of undiscovered porphyry copper deposits in the Andes also were made using various forms of analogy, including the deposit density models published by Singer and others (2005).

Estimates of numbers of undiscovered deposits must be consistent with and guided by the grade and tonnage models in that the undiscovered deposits estimated must, as a group, have grades and tonnages similar to those of the model. For example, on average, 50 percent of the estimated deposits should be larger than the median size, and 10 percent should be as large as the upper 10 percent of the deposits in the model (Singer, 1994, 2007). Individual and (or) consensus estimates consistent with the grade and tonnage models were made by the Andean assessment teams at the 90th, 50th, and 10th percentiles, defined as percent chance that at least the indicated number of deposits are present. Spatial combination rules were closely followed in defining what constitutes an individual deposit to help assure that the assessment methodology is internally consistent.

\section{Counting discovered (known) deposits, undiscovered deposits, and prospects}

Deposits that are thoroughly explored and have published grades and tonnages are counted as discovered deposits whereas, those that do not meet these criteria are counted as undiscovered prospects in order to avoid double counting. In some cases this results in deposits that are being mined with reserves being counted as prospects, albeit with a high probability of being an undiscovered deposit. When it is clear that exploration of the deposit is not complete, it should be counted as a prospect. 


\section{Estimating to 1 km depth}

Some porphyry copper deposits have vertical extents of well over a kilometer. Consequently, if any part of an estimated undiscovered porphyry copper deposit's mineralizing system is judged to occur anywhere in the upper kilometer of the Earth, it is included in the undiscovered deposit estimate. Although direct surface exploration is conducted to this depth only rarely today, this rationale is consistent with mining practice whereby deposits discovered at depths above $1 \mathrm{~km}$ may be explored and developed to depths of up to $3 \mathrm{~km}$. Continuing advances in exploration and mining technologies no doubt will extend these limits in the future.

\section{Preliminary estimates of numbers of undiscovered deposits in the Andes}

With the guidelines provided by appropriate grade and tonnage models, number of deposit estimates were made for each of the 12 preliminary tracts using deposit density models. Before deposit density estimates were made, the area permissive and the portion covered were estimated for each tract by point counting. The part covered is important to estimate because it typically is poorly explored and, in some cases such as the Eocene-Oligocene tract that contains Chuquicamata, perhaps the only place for undiscovered deposits. After each tract's area was estimated, the following two equations (Singer and others, 2005) were used to provide general guidelines for estimates for each tract:

$$
\begin{aligned}
& \mathrm{R}_{50}=-1.1167+0.4443 \log _{10}(\text { area }) \\
& \mathrm{L}_{90}, \mathrm{U}_{10}=\left(\mathrm{R}_{50} \pm t \mathrm{~s}_{\mathrm{ylx}} \sqrt{ }\left(1+(1 / \mathrm{n})+\left(\log _{10}(\text { area })-4.897\right)^{2} /(\mathrm{n}-1) \mathrm{s}_{\mathrm{x}}{ }^{2}\right)\right.
\end{aligned}
$$

Where, area is the area that is permissive in square kilometers, the mean area is $4.897, t$ (Student's $t$ at the $10 \%$ level with 17 degrees of freedom, $t_{10,17 \mathrm{df}}$ ) is $1.740, \mathrm{~s}_{\mathrm{ylx}}$ (standard deviation of number of deposits given area) is $0.2700, \mathrm{n}=19, \mathrm{~s}_{\mathrm{x}}{ }^{2}$ (variance of area) is 0.2916 , and the $\mathrm{R}_{50}, \mathrm{~L}_{90}$, and $\mathrm{U}_{10}$ estimates need to be used as exponents to the power of 10. For example (Singer and others, 2005), if the permissive area of a tract is $25,000 \mathrm{~km}^{2}$, then the $50^{\text {th }}$ percentile estimate would be 7 deposits (that is, $10^{0.8375}$ or $10^{(-}$ $1.1167+0.4443 \log 10(25,000))$. The $90^{\text {th }}$ percentile estimate would be 2 deposits (that is, $10^{(0.8375-1.740 \cdot 0.2700 \sqrt{ }(1+(1 / 19)+(4.398}$ $\left.-4.897)^{\wedge} 2 / 18 \cdot 0.2916\right)$, and the $10^{\text {th }}$ percentile estimate would be 21 deposits. These equations can be used in a spreadsheet. The expected number of deposits can be estimated (Singer and Menzie, 2005) as 10 to the power of:

$$
\log _{10}\left(\mathrm{~N}_{50}\right)+\left(\left(\left(\log _{10}\left(\mathrm{~N}_{10}\right)-\log _{10}\left(\mathrm{~N}_{50}\right)\right) / t\right)^{\wedge^{2}}\right) / 2
$$

The expected number of deposits was reduced by the number of discovered deposits in the tract. From the example above, the expected number of deposits is 8. If there were 3 known deposits, the expected number of undiscovered deposits would be 5. The other estimates are reduced to be consistent with this expected number. Porphyry copper prospects were recorded separately because, in the resource assessment, only well-explored deposits represented by the grade and tonnage models are counted as discovered deposits. In the assessment, these prospects may be counted as "undiscovered deposits."

\section{Final estimates of numbers of undiscovered deposits in the Andes}

The international assessment teams made estimates principally by using a combination of: (1) experience from many other similar areas, together with knowledge of the numbers of deposits in those areas, to make estimates for the tracts; (2) deposit density models, including extrapolation of known deposit densities in exposed, well-explored areas of the tract proportionally beneath areas of postmineralization cover rocks; and (3) identifying potential exploration targets including known prospects of 
the type of deposit being estimated. The deposit density estimates for the 12 preliminary tracts served as a useful crosscheck on the team's estimates.

Recurring discussions throughout the estimation process focused on a number of topics, including: (1) the presence or absence of mineral suites with modes of occurrence indicative of porphyry-style mineralization and (or) alteration near the surface or at depth; (2) presence or absence of types and styles of faulting commonly associated with porphyry copper formation, and (3) aspects of the origin of porphyry copper deposits.

Throughout the estimation process, estimates were informed and guided by team knowledge and estimates of the thickness and extent of cover rocks, and of the types, intensity, and extent of mineral exploration in each tract. Estimators' collective knowledge of the extent, intensity, vintage, and results of past mineral exploration in each tract were used by analogy with results from thoroughly explored areas elsewhere to help evaluate how well the Andean tracts have been explored and how many undiscovered deposits might remain.

\section{Form of the estimates}

During and (or) following the aforementioned discussions, estimators made independent estimates of the least number of undiscovered deposits in each tract at cumulative probabilities of $0.9,0.5$, and 0.1 $\left(90^{\text {th }}, 50^{\text {th }}\right.$, and $10^{\text {th }}$ percentiles $)$. Some details regarding this part of the deposit estimation procedure are found in Root, Menzie, and Scott (1992). For example, an estimate at 0.9 probability estimates "the greatest number of deposits present with probability 0.9 or more...; that is, the probability of at least that many deposits being present is 0.9 or greater, and the probability of more deposits is less than 0.9 " (Root, Menzie, and Scott, 1992, p. 130). Probabilities for the existence of undiscovered deposits are stated as inequalities because mineral deposits occur only as discrete numbers of deposits. The result is a cumulative probability distribution of numbers of undiscovered deposits presented for each tract. After the independent estimates were made, the estimates were discussed among the group and a group consensus of the best estimates at the three percentiles were agreed upon. In most cases, the group consensus estimates were close to the averages of their individual estimates.

The spread of the estimated numbers of deposits at the 90-50-10 percentiles explicitly expresses the uncertainty in the estimate. Equations from Singer and Menzie (2005) were used in a spreadsheet to estimate the mean number of deposits and standard deviation. The coefficient of variation in percent also was calculated and is equal to the standard deviation divided by the mean, times 100 . The standard deviation and coefficient of variation are standard measures of uncertainty - larger standard deviations and coefficients of variation indicate less certainty. The mean number of estimated undiscovered deposits in and among tracts can be considered a measure of favorability, as can comparisons of estimates made at the same probability level.

\section{Estimating amounts of undiscovered metal}

One of the primary purposes of this assessment is to estimate amounts of copper, molybdenum, gold, and silver yet to be discovered in each tract. These metal amounts are presented as probability distributions that are obtained by combining the probability distribution of estimated numbers of undiscovered deposits with the probability distributions for tonnages and grades from the mineral deposit models. However, the probability distributions used to describe numbers of deposits, tonnages, and grades are empirical (i.e., not mathematical) and cannot easily be combined mathematically without some simplifying assumptions that may not be acceptable. Consequently, a Monte Carlo simulation program, now called EMINERS (formerly called MARK3), is used for this purpose (Root, Menzie, and Scott, 1992). The simulator randomly selects from each distribution an estimated number of undiscovered deposits, a tonnage, and a grade. This is done repeatedly by the program many thousands of times and new 
probability distributions are derived of the distributions of contained undiscovered metal, number of deposits, and tonnage.

The workings of the simulator as described by Root, Menzie, and Scott (1992) are illustrated in a general way by the schematic diagram shown for copper in figure 11. There are an infinite number of distributions consistent with each set of 90-50-10 estimates of numbers of undiscovered deposits. The shaded (gray) area of the column chart in figure 11 indicates the region where all graphs of distributions are consistent with the 2-4-7 estimates shown in this example. Using the calculations described by Root, Menzie, and Scott (1992, p. 130-131), the simulator chooses "a default distribution approximately in the middle of all possible choices." The process of developing a distribution for all numbers of undiscovered deposits in the range of the estimates can produce somewhat different probabilities for the numbers of deposits the teams estimated at the 90-50-10 percentiles.

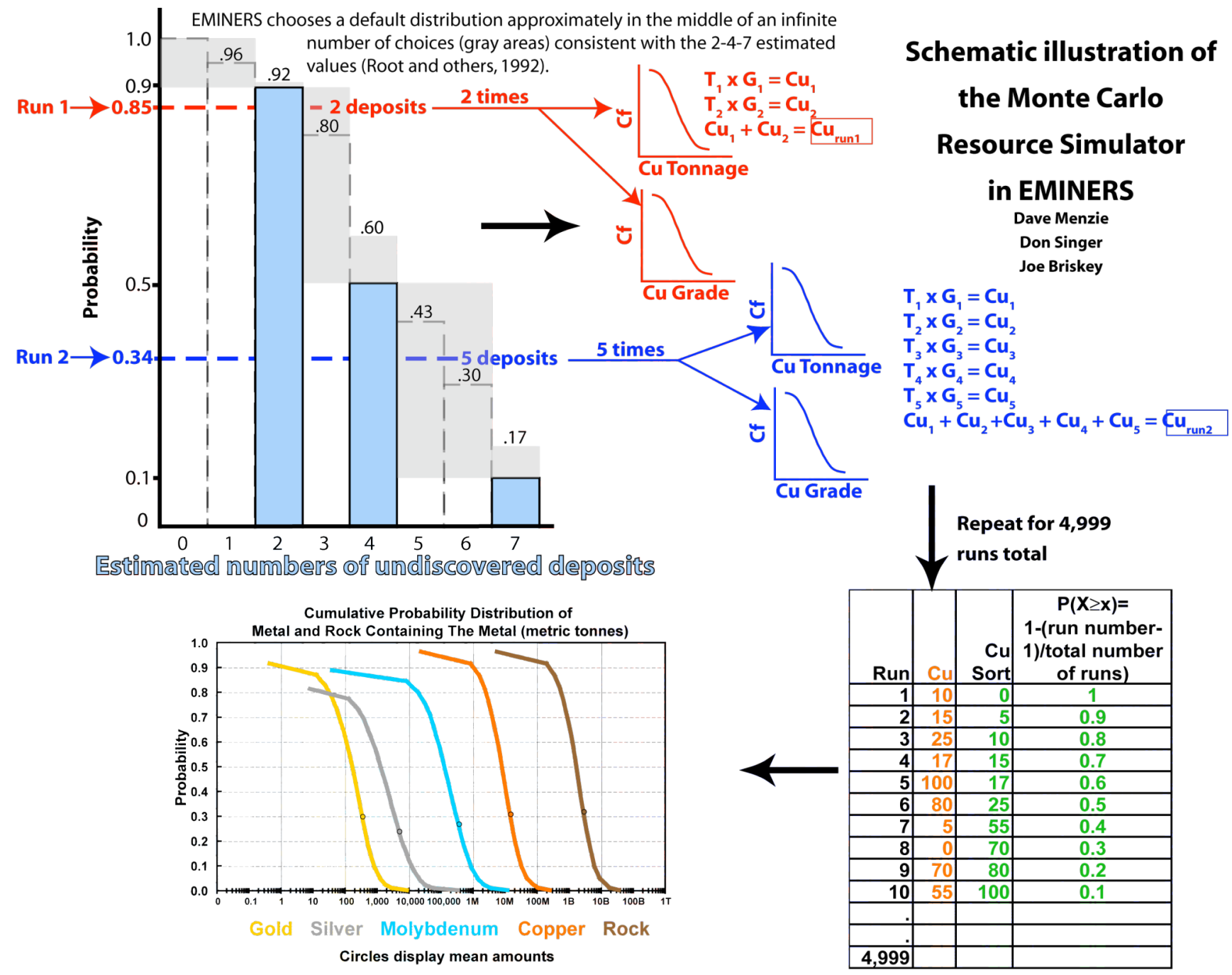

Figure 11. Schematic illustration of Monte Carlo resource simulation of undiscovered copper by EMINERS.

The simulator provides a distribution for number of deposits and user selected empirical or lognormal distributions for calculating the probability distributions for tonnages and grades (Root, Menzie, and Scott, 1992). The most common method, and the one used herein, is the empirical option designed to avoid unrealistically large values for grades and tonnages by approximating the data by 
bounded distributions. "The bounded approximation used in the simulation is a piecewise linear distribution calculated in stages" in the way described by Root, Menzie, and Scott (1992, p. 135-138).

After calculating the probability distribution of numbers of undiscovered deposits, the simulator begins the first of its runs (iterations) by choosing a probability level at random; for example, $\mathrm{p}=0.85$ for Run 1 shown in figure 11. At this probability level, the simulator reads two deposits from the deposit distribution. The simulator then selects a random grade $\left(G_{1}\right)$ and tonnage $\left(T_{1}\right)$ from those respective distributions. The selected grade and tonnage are multiplied together to get a quantity of copper for one deposit $\left(\mathrm{Cu}_{1}\right)$. Because the program found two deposits, it then selects another grade $\left(\mathrm{G}_{2}\right)$ and tonnage $\left(\mathrm{T}_{2}\right)$ and calculates an amount of copper $\left(\mathrm{Cu}_{2}\right)$ for a second deposit. The two amounts of copper are added together to get the total amount of copper for Run 1. Similarly, for Run 2, the simulator randomly selects a probability of 0.34 , reads five deposits, and calculates and adds together five amounts of copper to get the total copper for Run 2. A total of 4,999 runs are made.

The copper from each run is tabulated as shown in the lower right corner of figure 11 . The quantities of copper in the table are sorted and the probability that each quantity occurs is calculated using the formula shown at the top of the right hand column. Data in the table then are used to produce the tabular and graphical representations of undiscovered metal presented for each tract in this report and illustrated in figure 11 by the graph of the cumulative probability distribution of copper and other metals.

\section{Using this assessment}

Based on past experience, there are several subjects that should be clarified for the benefit of users, particularly those without technical or earth science backgrounds. These clarifications include limitations on using the tract maps and boundaries at varying scales; quoting and otherwise representing the estimates; disaggregating the estimates for planning and decisionmaking; and using the estimates to address issues involving economics.

\section{Tract boundaries}

Tract boundaries were defined and drawn at a scale of 1:1,000,000. The boundaries maintain this accuracy when reduced and used at smaller scales such as 1:1,500,000 or 1:2,000,000, but become progressively less accurate if enlarged and used at larger scales such as 1:750,000 or 1:500,000.

To the extent possible, tracts were drawn and subdivided so that the probability of occurrence of an undiscovered deposit is as uniform as possible throughout each tract. This was done in support of decisionmakers, planners, and other users who sometimes have a need to disaggregate the estimates and apportion a part or parts of the estimated undiscovered mineral resources to one or more land-management areas that intersect or occur within a permissive tract. Nonetheless, users are cautioned that there is uncertainty in the disaggregated results because of the tendency of porphyry copper deposits to appear clustered.

\section{Estimates}

Estimates of numbers of undiscovered deposits and amounts of metals are presented as a series of numerical, probabilistic representations of the expert judgment of the teams of geoscientists that made the estimates and can be shown in various ways. Estimated numbers of undiscovered deposits, and of metric tons of copper, molybdenum, gold, silver, and rock containing those metals, are shown for each tract as a function of various quantiles (including percentiles) that express uncertainties. Various quantiles and the means are best used for comparisons between and among estimates for different deposit types or different permissive tracts. For example, the mean number of estimated undiscovered deposits in and among tracts can be considered a measure of favorability as can comparisons of estimates at the same quantile level. 
Values of the mean are of particular use because they provide a statistical basis for comparison. For example, the mean values of multiple tracts can be added together while quantile values cannot. However, no single number can adequately represent the magnitude of an estimate, because no single number can represent the uncertainty that is inherent in the estimation process or the distribution of values that make up the grade and tonnage models.

At various places in this report, the tracts are characterized by mean values and by mean values $/ \mathrm{km}^{2}$ for copper. This is done so that the estimated amounts and richness, respectively, of resources in the tracts can be seen, compared, contrasted, and otherwise characterized and discussed. These estimates do not capture the large uncertainties commonly associated with such estimates; for example, the probability of the mean copper amounts or more occurring in the tracts ranges from 0.24 to 0.45 . Moreover, within each tract, the specific locations of the estimated undiscovered porphyry copper deposits and their contained resources are not known, and the deposits would occupy only a tiny fraction of the area of each tract.

\section{Economic considerations}

Care must be exercised when using the results of this assessment to address issues involving economics. Estimated undiscovered mineral resources are based on grade and tonnage models made up of deposits of varying economic viability. Projections about the economics of undiscovered porphyry copper deposits depend on a number of factors, including assumptions made about future commodity demand, supply, and prices; technological innovations and efficiencies; changes in land use; and on the length of the planning and (or) forecasting period. Porphyry copper deposits in the general porphyry copper model were perceived to have sufficient development potential to justify the relatively high cost of exploration sufficient to define their size and grade. Nonetheless, many of these deposits still have not been developed because they cannot yet be mined economically.

Many of the undiscovered deposits estimated herein are likely to occur beneath areas of younger cover rocks, thereby reducing their economic viability in comparison to past discoveries, most of which were exposed at the surface. Moreover, the estimates are for undiscovered deposits likely to exist, not necessarily those likely to be discovered. For example, some concealed deposits included in our assessment may be beyond the reach of present day exploration technology, or their discovery may require exploration expenditures so large they are unlikely to be discovered in the foreseeable future. Although technological advances act over time to lower mining costs and impacts (e.g., Doggett, 2007) thereby allowing formerly uneconomic deposits to become operating mines, some deposits in the general model might "never" be mined for one or more of a variety of reasons, including relatively low tonnages and grades, deep burial, and (or) occurrence in or near environmentally sensitive areas.

\section{Summary and discussion of results}

Working together, the geological surveys of Argentina, Chile, Colombia, Peru, and the United States have used the U. S. Geological Survey three-part form of mineral resource assessment to delineate the regional locations and estimate the amounts of undiscovered porphyry copper resources in the Andes. Quantitative information on the general locations, uncertainties about, and expected amounts of undiscovered mineral resources of the world is important to exploration managers, land-use and environmental planners, economists, and policymakers.

International assessment teams from these countries used the distribution of known deposits, appropriate prospects, similar-aged mainly calc-alkaline intrusive and volcanic rocks of similar magmatic arcs, similar-aged altered rocks, fault and tectonic control, available geophysics and geochemistry, and regional and deposit-model experience, in an interactive, integrated procedure to draw tracts that the data suggested would be permissive for occurrence of undiscovered porphyry copper deposits of a similar age 
grouping and geologic setting to a depth of $1 \mathrm{~km}$. Team members then used various forms of geologic analogy to make probabilistic estimates of numbers of undiscovered deposits consistent with appropriate tonnage and grade models. The deposit estimates were combined with the frequencies of deposit model tonnages and grades using Monte Carlo simulation to provide probabilistic estimates of numbers of deposits, tonnages, and amounts of metals contained in the estimated undiscovered deposits in each tract.

The results of the assessments of each permissive tract are in two principal parts: (1) digital boundaries of the tracts at a scale of 1:1,000,000, which are stored in the "Digital Map File" that is part of this report; and (2) the tract results and rationale forms in Appendix II, which present the estimates of numbers of undiscovered deposits and metals in tabular and graphical formats followed by supporting technical descriptions and rationales for tract delineation and deposit estimation. Digital tract maps of all of the Andes at scales of 1:4,000,000 also are included in the Digital Map File. Estimates for each tract are analyzed in a variety of ways, including spatial and temporal variations, mean metal content, metal density (mean metric tons of $\mathrm{Cu}, \mathrm{Mo}, \mathrm{Au}$, or $\mathrm{Ag}$ per $\mathrm{km}^{2}$ ), and as a measure of exploration success.

\section{Porphyry copper resources of the Andes}

There are 69 known porphyry copper deposits in the Andes (table 1) according to the rules set forth (Singer, Berger, and Moring, 2005) to define a porphyry copper deposit in contrast to a prospect. This assessment estimates that about 145 deposits remain undiscovered. In other words, about twice as many new deposits might be found as have already been found. Not only have large quantities of copper been discovered, but the results of this assessment estimate that even larger quantities remain to be discovered in the future.

There are about 590 million metric tons of copper in discovered porphyry copper deposits in the Andes (table 2). About 190 million metric tons are in 57 deposits in 16 tracts of the general porphyry copper type whereas about 400 million metric tons are in 12 deposits in 2 tracts characterized by a new giant deposit model (fig. 12). In addition, this study estimates that there are approximately 750 million metric tons of copper in undiscovered porphyry copper deposits in the Andes. This undiscovered copper resource is the sum of the mean estimated undiscovered copper in each of the 26 tracts. About 470 million metric tons of this undiscovered copper are estimated to occur in 137 undiscovered deposits in 24 tracts of the general porphyry copper type, plus another 280 million tons in 8 estimated undiscovered deposits in 2 tracts containing the giant porphyry copper type. Although much of the porphyry copper resources in the Andes is in the two giant tracts, this assessment estimates that nearly two-thirds of the undiscovered copper is in tracts of the general model type. 


\section{Discovered and undiscovered copper in giant and other tracts}

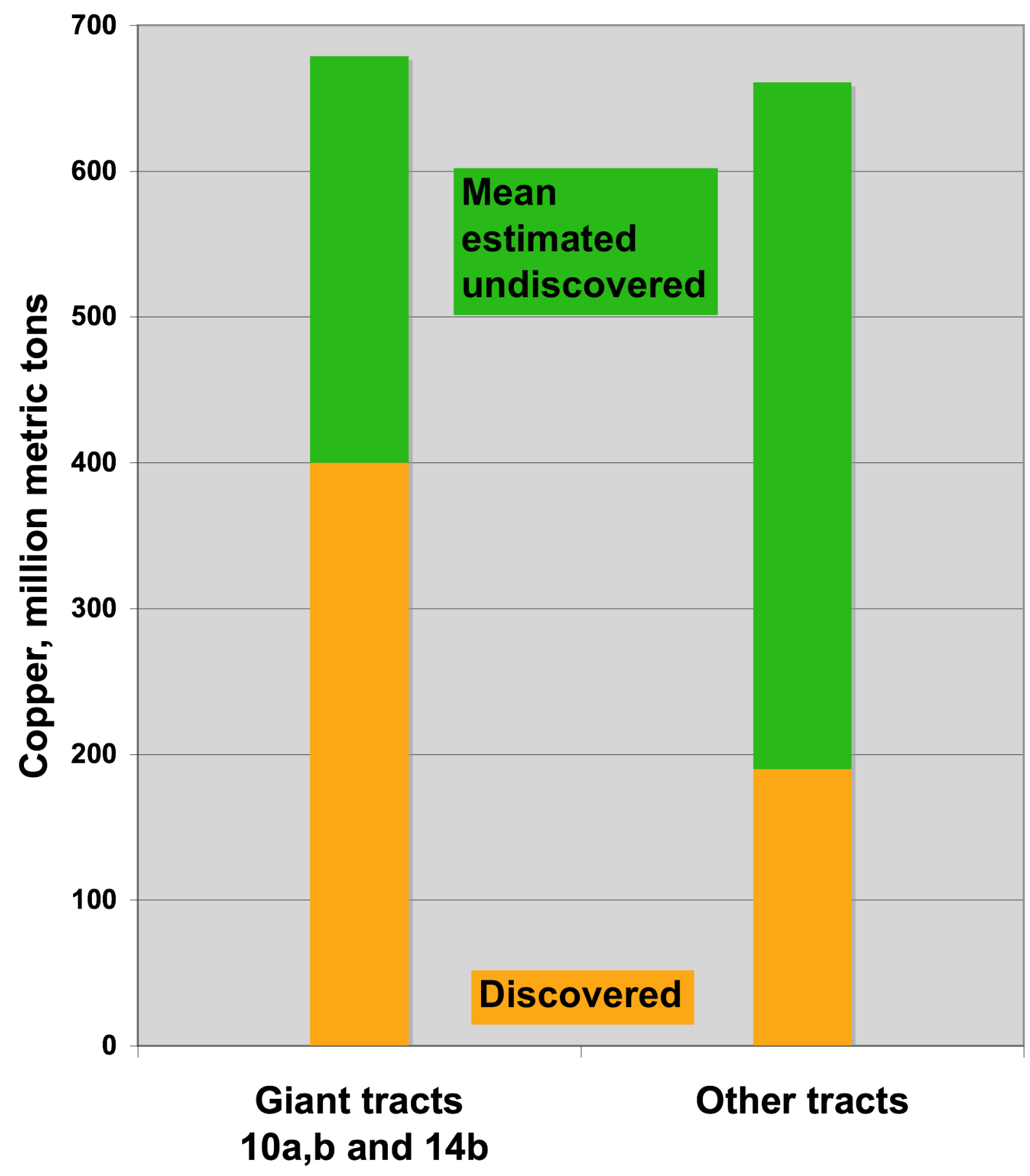

Figure 12. Column chart comparing discovered and mean estimated undiscovered porphyry copper resources in the giant and other tracts in the Andes. Data from table 2. 
The total discovered, mined, and estimated undiscovered copper in the Andes amounts to an endowment, or grand total, of about 1.3 billion metric tons (table 2). In other words, this study estimates there is about 1.3 times as much copper to be found in porphyry copper deposits in the Andes as has already been found. For comparison, the United States, in all types of copper deposits, has 350 million metric tons of discovered copper and an estimated 290 million metric tons of undiscovered resources (Schruben, 2002; fig. 4). The Andes, in porphyry copper deposits alone, have more that twice as much estimated undiscovered copper as the United States has in all deposit types.

\section{Distribution of porphyry copper resources in the Andes}

The porphyry copper resources of the Andes region are not evenly distributed in space or time (see figs. 2, 3, and 12-22, and plates 2 and 3). The Chuquicamata tract (SA10a,bPC) and the El Teniente tract (SA14bPC) stand out as containing exceptionally large deposits of discovered and estimated undiscovered copper (table 2). Statistical comparisons of grade and tonnage data for deposits in these two tracts show that the tracts are significantly different from the rest of the tracts and therefore are represented by a separate giant deposit model as opposed to the general model that is the best fit for the other tracts (see table 4 and appendix I). The greatest endowment of copper is in tract SA10a,bPC (the Chuquicamata tract) with about 460 million metric tons, followed by tract SA14bPC (the El Teniente tract) with about 220 million metric tons.

Tract SA10a,bPC also is the only tract where significantly younger permissive rock (EoceneOligocene tract SA10a,bPC) is superimposed on known older known permissive rock (Permian tract SA18PC) over a relatively large region. There has been speculation that pre-existing copper mineralization, or rocks otherwise enriched in copper, in the older tract (pre-enrichment) may have contributed to the unusually large average size and grade of the discovered porphyry copper deposits in tract SA10a,bPC. Multiple superimposed intrusions, separated by a span of only a few million years, also have been suspected as a cause of the high grades and tonnages of porphyry copper deposits in tract SA10a,bPC (Reynolds, Ravenhurst, and Lindsay, 1998; Ballard and others, 2001; and Harris and others, 2004). Sillitoe and Perelló (2005) point to pronounced crustal shortening and thickening, accommodated by regional faults and followed by rapid surface uplift and erosion, as important controls on the origin of giant porphyry copper deposits (see Appendix I).

The next largest copper endowments (table 2) are in tract SA08PC (the Paleocene-Eocene tract of northern Chile-Peru), which contains an endowment of about 98 million metric tons of copper, and in tract SA06PC (the middle-late Miocene tract of Peru and Ecuador) with an endowment of about 96 million metric tons. The estimated undiscovered copper remaining to be found in these four tracts is: tract SA10a,bPC, 210 million metric tons; tract SA14bPC, 69 million; tract SA06PC, 49 million, and tract SA08PC, 43 million.

The distribution of undiscovered resources among tracts also was examined using metal density expressed as mean metric tons of estimated undiscovered copper per $\mathrm{km}^{2}$. This measure shows tracts SA10a,bPC and SA14bPC leading with about 8,200 and 7,400 metric tons per $\mathrm{km}^{2}$, respectively (table 2). The next richest tracts, with just over 2,000 metric tons per $\mathrm{km}^{2}$, are tracts SA12PC and SA14dPC. Tract SA12PC is a small Eocene-Oligocene tract that forms the southern continuation of tract SA10a,bPC and is located at the same structural and stratigraphic horizon, between Paleocene-Eocene tract SA08PC and the Miocene-Pliocene tracts SA13aPC, SA13bPC, and SA13cPC (see fig. 1 and plate 1), but does not appear to involve precursor permissive rocks.

Another product of this study is a measure of the success of exploration in discovering all of the mineral deposits that comprise the copper endowment of each tract. This measure is shown in the last column in table 2 ( $\%$ undiscovered $\mathrm{Cu}$ ), and in figure 22 , where the estimated amount of undiscovered copper is shown as a percentage of the copper endowment. Tracts that contain estimated undiscovered 
deposits but no known deposits are listed as 100 percent undiscovered. Note that the five tracts containing less than 51 percent of porphyry copper deposits remaining undiscovered include some of the most highly endowed tracts. Explorationists appear to have recognized and focused on these tracts very successfully.

\section{Ages of porphyry copper resources in the Andes}

Some generalizations can be made about the probable ages of the estimated undiscovered porphyry copper deposits and resources relative to the ages of the host rocks, discovered deposits, and prospects in the tracts. The term "host rocks," as used in this report, refers to the volcanic and (or) plutonic rocks formed during a period of approximately coeval arc magmatism judged capable of producing porphyry copper deposits, and whose spatial distribution, projected to $1 \mathrm{~km}$ depth, defines a tract boundary.

Most of the world's discovered porphyry copper resources are of Cenozoic age (0-65 Ma) (Singer, Berger, and Moring, 2002). Similarly, in the Andes, about 90 percent of the total discovered and estimated undiscovered copper resources in porphyry copper deposits is of Cenozoic age (see fig. 13); the remainder is Cretaceous (4\%), Jurassic (5\%), and Permian (2\%) in age. The Cenozoic copper resources in the Andes are in tracts with host rock ages of Eocene-Oligocene (39\%), Miocene-Pliocene (29\%), PaleoceneEocene (12\%), and Miocene (11\%) (see fig. 14). The Eocene-Oligocene and Miocene-Pliocene tracts are dominated by giant tracts SA10a,bPC and SA14bPC (cf. figs. 14 and 15). 


\section{Discovered and undiscovered copper by age of host rocks and known mineralization}

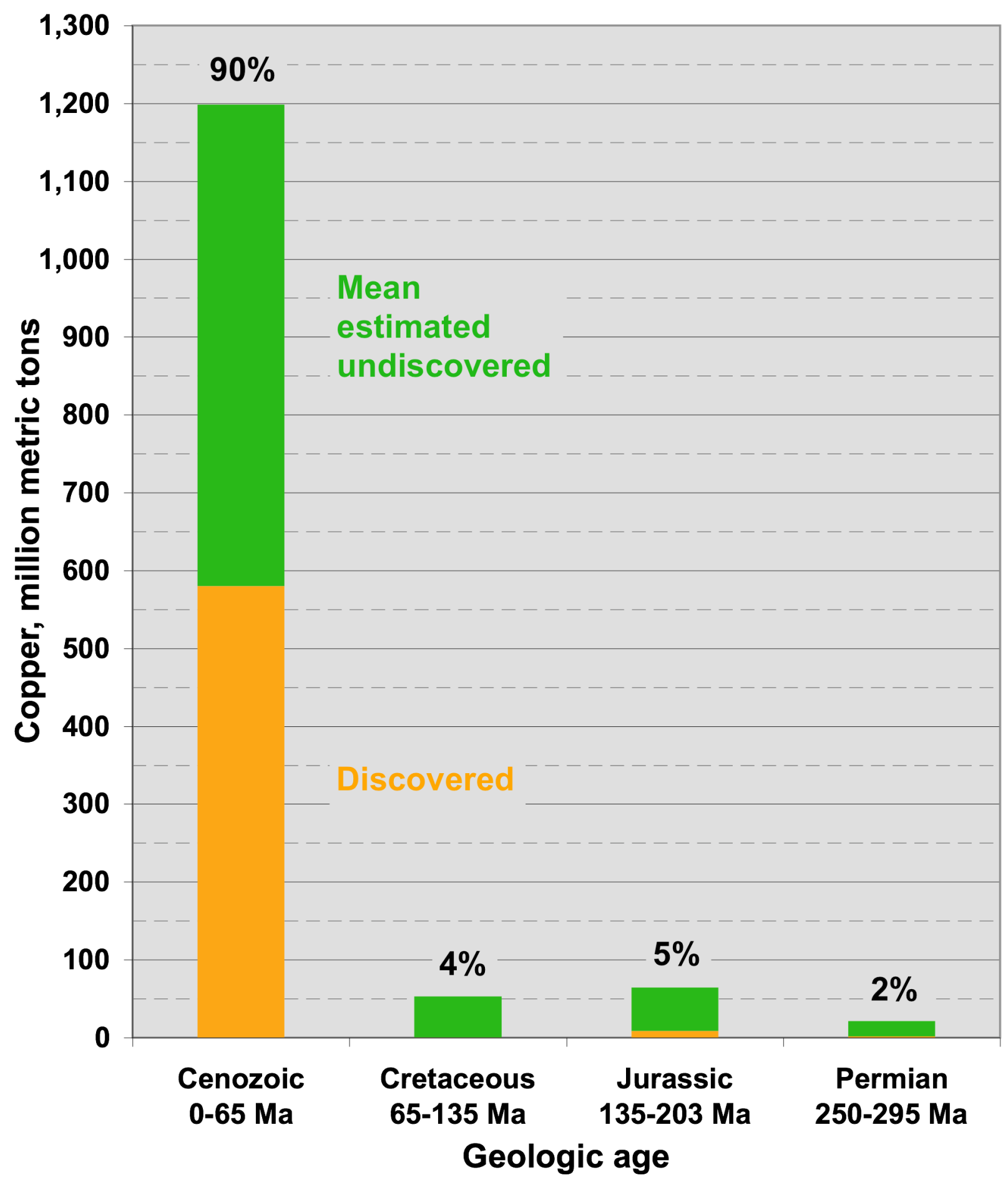

Figure 13. Column chart comparing discovered and mean estimated undiscovered copper by geologic age of host rocks and known mineralization. Cenozoic Era. Cretaceous, Jurassic, and Permian Periods. Data from table 2. 


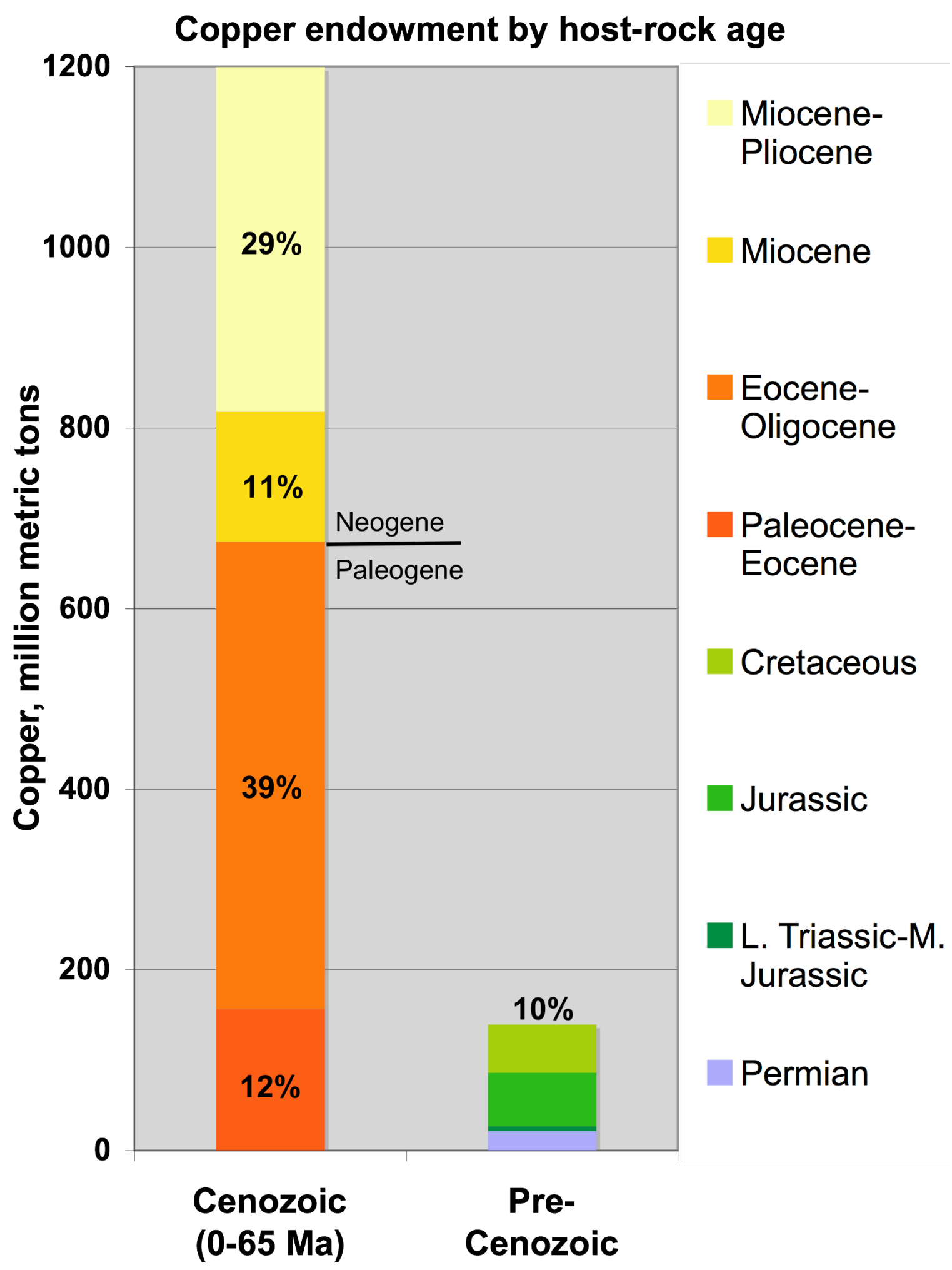

Figure 14. Column chart comparing copper endowment by geologic age of host rocks. Copper resources in Late Cretaceous-middle Eocene tract SA15PC are included here with the Paleocene-Eocene host rocks because the dated deposit and prospect in tract 15 are Paleocene and Eocene respectively. Data from table 2. 


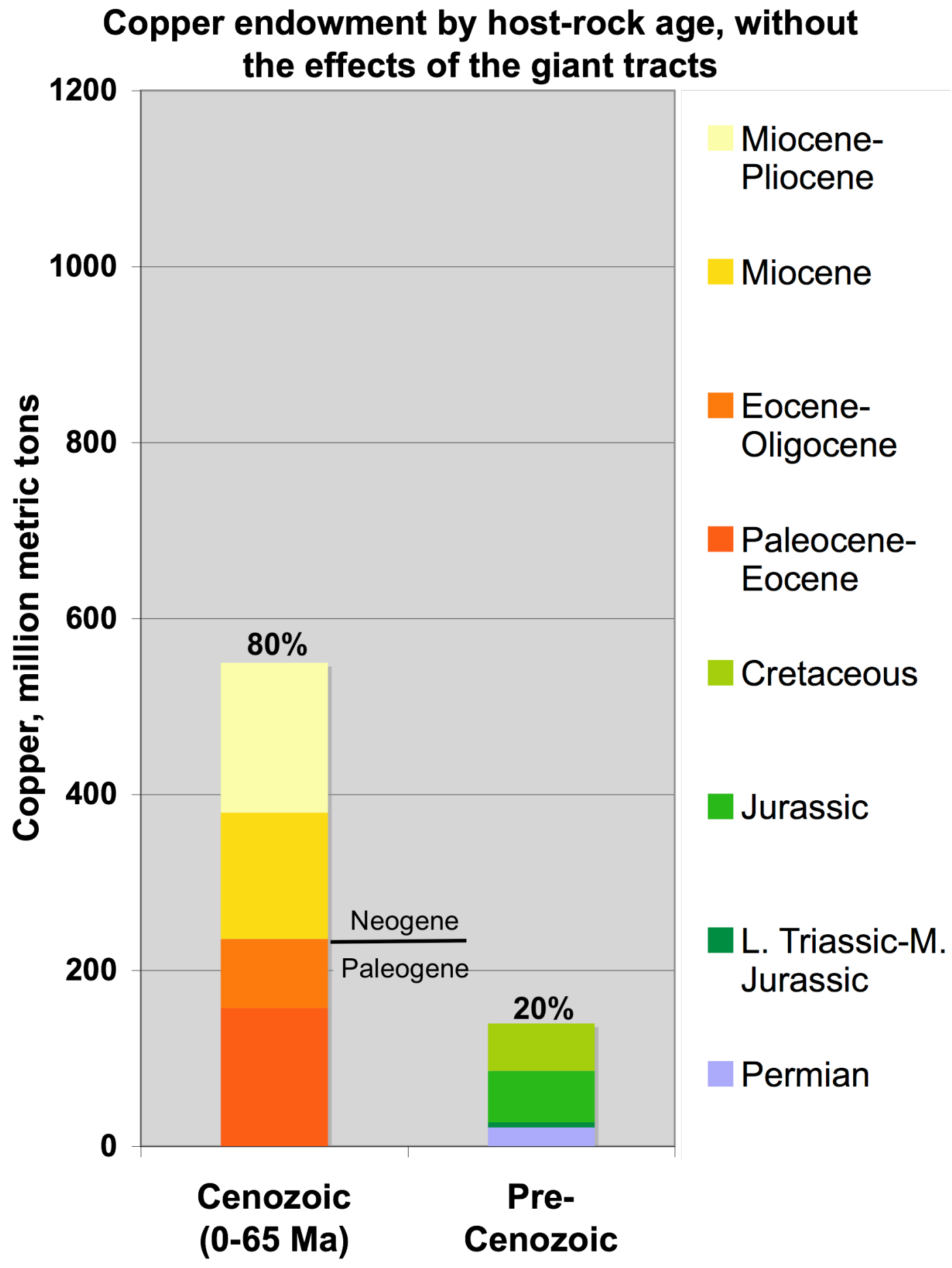

Figure 15. Column chart comparing copper endowment by geologic age of host rocks without the effects of giant tracts SA10a,bPC and SA14bPC. In this figure, the average copper endowment $/ \mathrm{km}^{2}$ of tracts of the same host rock age as the giant tracts have been assigned to the giant tracts in an effort to examine Cenozoic mineralization events without the extraordinary effects of the giant tracts. For tract 10a,b, the average endowments $/ \mathrm{km}^{2}$ of tracts 9,11 , and 12 were used. For tract $14 \mathrm{~b}$, the average endowments $/ \mathrm{km}^{2}$ of tracts $14 a, c, d$, and 13a, b, c were used. Data from table 2. 
There appear to have been three approximately 16-million-year-long episodes of porphyry copper deposit formation in the Andes during Cenozoic time (see fig. 16). Sillitoe's (1988) summary of 74 dates on igneous-related copper deposits and prospects in the Andes also suggested three epochs of copper mineralization in the central Andes: Paleocene-early Eocene (66-52 Ma), late Eocene-early Oligocene (42-31 Ma), and middle Miocene-early Pliocene (16-5 Ma); these three epochs apparently lasted 11-14 Ma and were separated by quiescent intervals of about the same duration. Three belts of Cenozoic porphyry copper deposits of comparable ages also have been summarized by Camus (2002 and 2003) and Maksaev and others (2007) in Chile. Comparison of Sillitoe's earlier summary with the 84 Cenozoic dates on porphyry copper deposits and prospects shown in figure 16 suggests that the apparent durations of the three mineralization events have expanded somewhat (15-16 million years) while the two intervening quiescent periods (5-9 million years) appear to have contracted as the number of dates have increased. 


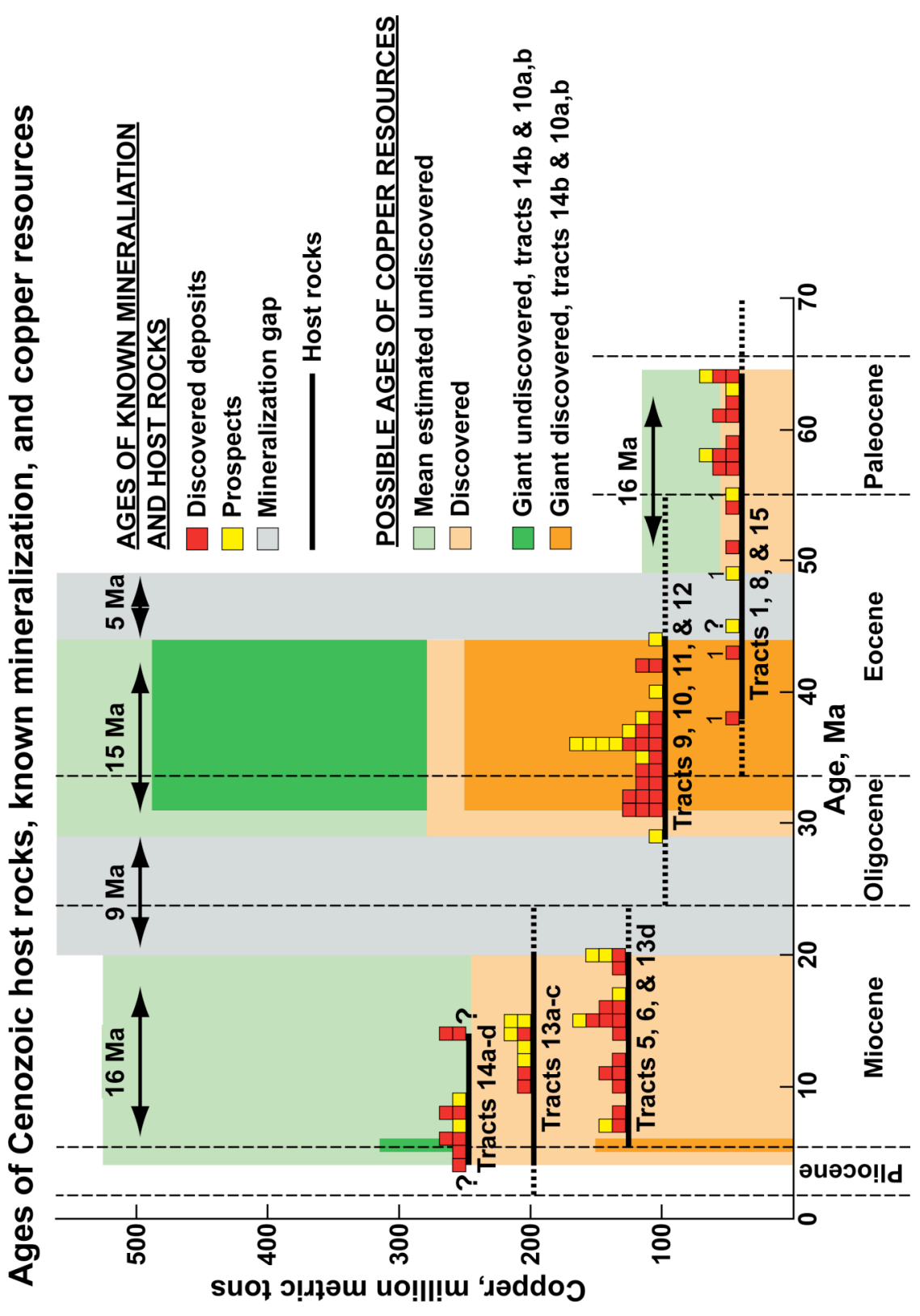


The mineralization gaps illustrated in figure 16 might imply a continental-scale interruption of generally continuous subduction processes that otherwise were forming porphyry copper deposits at one place or another in the Andes throughout the Cenozoic. Indeed, these gaps correspond to times of change in Pacific plate boundaries, geometries, and directions and rates of spreading and convergence. For example, the Oligocene-early Miocene gap (20-29 Ma) encompasses the time of break-up of the Farallon plate into the Cocos and Nazca plates at about 23-25 Ma (e.g., Ramos, 1999a; Meschede and Barckhausen, 2000; and Wilder, 2003), which apparently coincided with the initiation of higher, more orthogonal convergence rates in the central and southern Andes (Pardo Casas and Molnar, 1987) concomitant with the beginning of widespread Miocene magmatism (Ramos, 1999b). Two of the three major plate boundary reorganizations in the southeast Pacific documented by Tebbens and Cande (1997) occurred at 20 and $24 \mathrm{Ma}$. The Eocene mineralization gap (44-49 Ma) also was a time of major changes in plate motion and forces in the Pacific. These changes are reflected in the bend in the HawaiianEmperor seamount chain beginning about $50 \mathrm{Ma}$ and continuing for more than 8 million years, and also in the development of the Aleutian, Izu-Bonin-Marianas, and Tonga-Kermadec subduction zones between 55 and $45 \mathrm{Ma}$ (Stock, 2006).

Figures 16-21 compare and contrast the probable ages of the estimated undiscovered porphyry copper resources of the Andes relative to the ages of known mineralization in the tracts, or relative to hostrocks ages for those five tracts $(7,13 \mathrm{c}, 13 \mathrm{~d}, 17$, and 20) without dated mineralization. For the Cenozoic, figures 16 and 17 make the assumption that the undiscovered deposits will have the same age ranges as the discovered deposits. If this assumption proves correct, the estimated undiscovered copper attributed to the Miocene-Pliocene and Eocene-Oligocene mineralization events will continue to dominate in the Andes in amounts roughly equal to each other and to discovered copper. However, while the estimated undiscovered copper attributable to the Eocene-Oligocene event probably will occur largely in giant tract $10 \mathrm{a}, \mathrm{b}$, giant tract $14 \mathrm{~b}$ is expected to contain a much smaller proportion of undiscovered Miocene-Pliocene copper (fig. 16). A principal difference between the copper resources of these two mineralization events is that the Eocene-Oligocene endowment is concentrated in an area of only about $94,000 \mathrm{~km}^{2}$, where as that of the Miocene-Pliocene event is spread over about $354,000 \mathrm{~km}^{2}$ (fig. 17). 


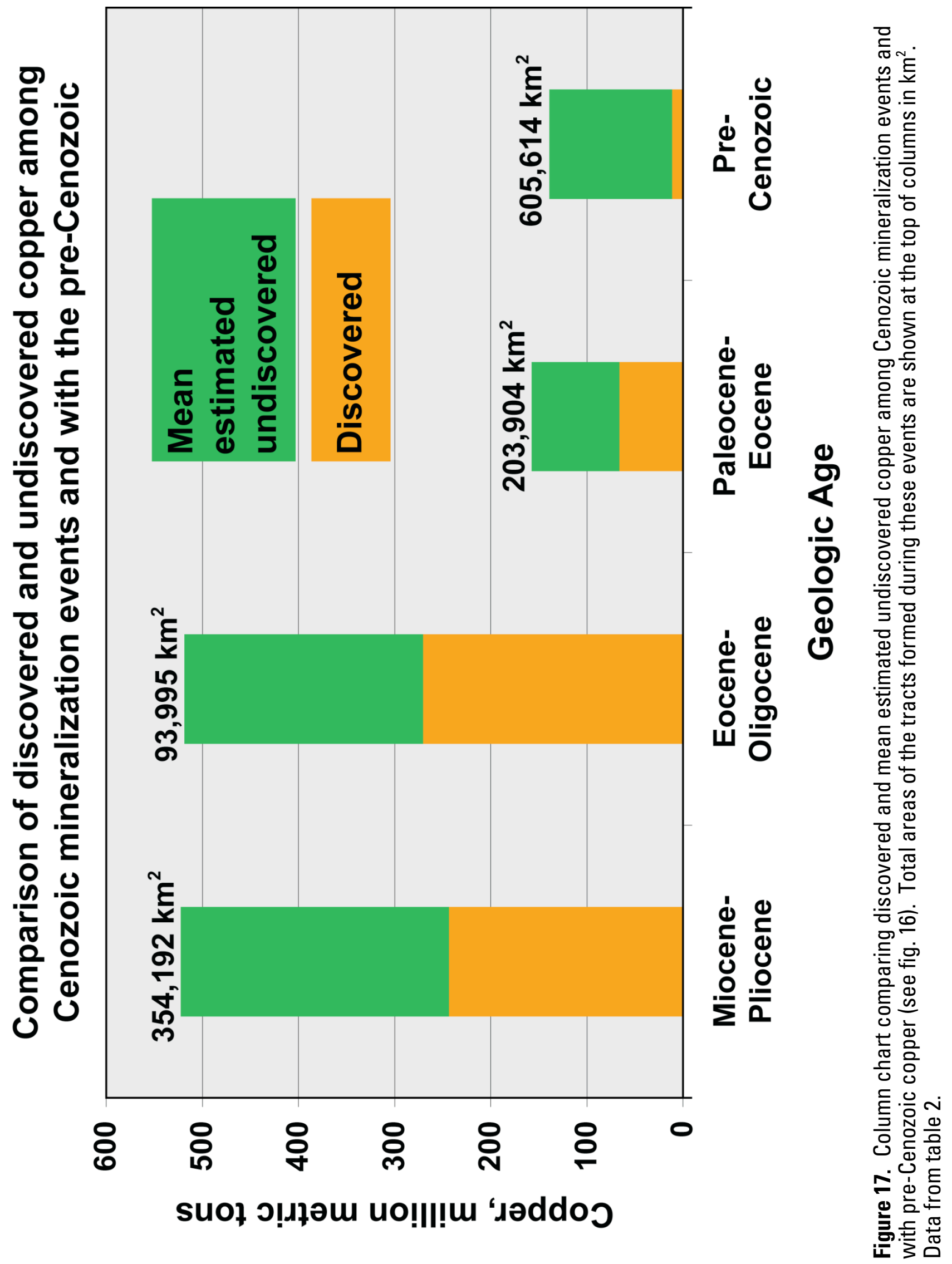


The relative approximate ages of discovered and estimated undiscovered copper in individual tracts is portrayed in figures 18-20 where the tracts are arranged from youngest (left) to oldest (right) using the midpoint age of dated deposits and prospects, or using the midpoint age of the tract's host rocks where there are no dated deposits or prospects (i.e., tracts $7,13 \mathrm{c}, 13 \mathrm{~d}, 17$, and 20). Three heavy black vertical lines delineate the three Cenozoic mineralization events defined in figure 16 . In the same fashion, figures 21-22 compare and contrast for each tract the density of mean estimated undiscovered copper and the mean estimated undiscovered copper as a percentage of the copper endowment. 


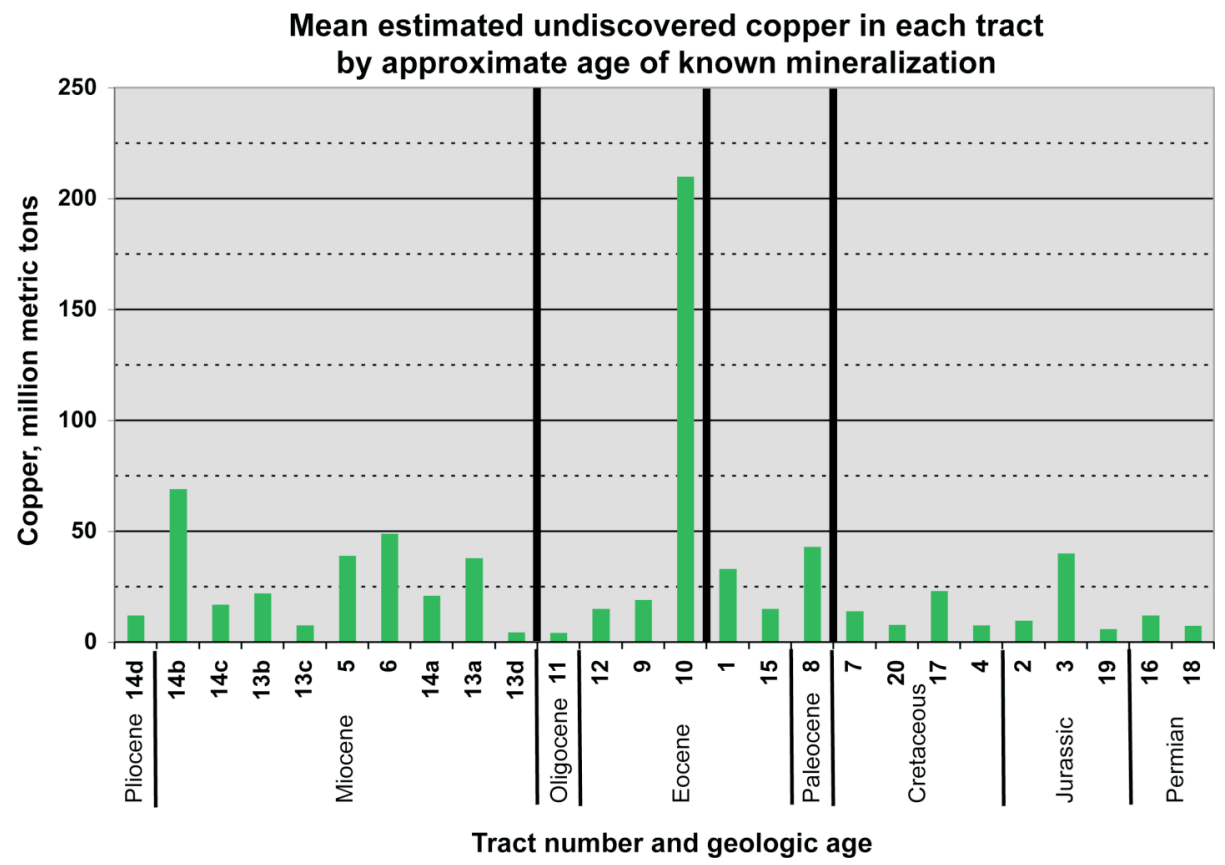

Figure 18. Column chart comparing mean estimated undiscovered copper in each tract by approximate age of known mineralization. See figure 19 for additional explanation.

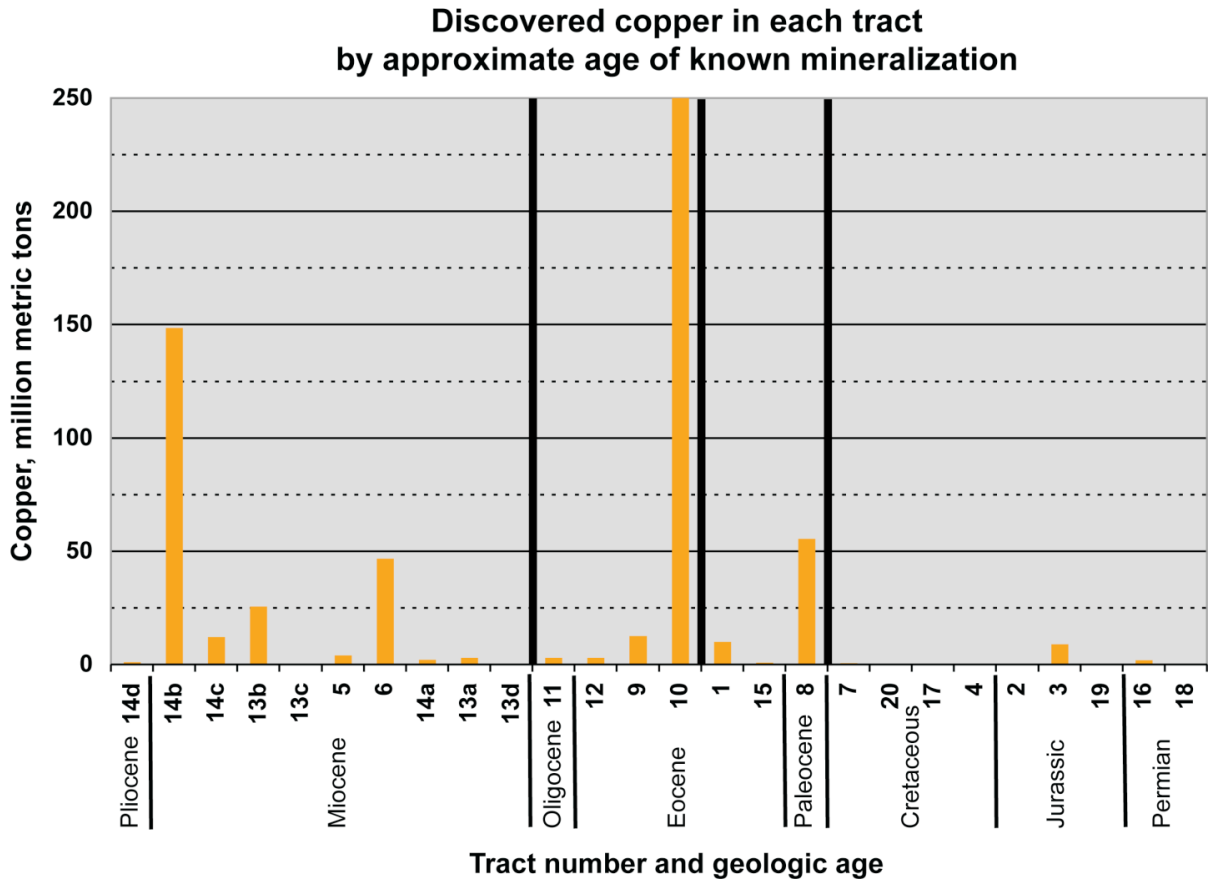

Figure 19. Column chart comparing discovered copper in each tract by approximate age of known mineralization. Tracts are arranged from youngest (left) to oldest (right) using the midpoint age of dated deposits and prospects, or using the midpoint age of the host rocks for tracts with no dated deposits or prospects (tracts 7, 13c, 13d, 17, and 20). Three heavy black vertical lines delineate the three Cenozoic mineralization events defined in figure 16. Horizontal axis is not linear. The SA prefixes and PC suffixes for the tract numbers have been dropped to facilitate plotting, as have the $a, b$ designations for tracts 10 and 16. Data from table 2. 


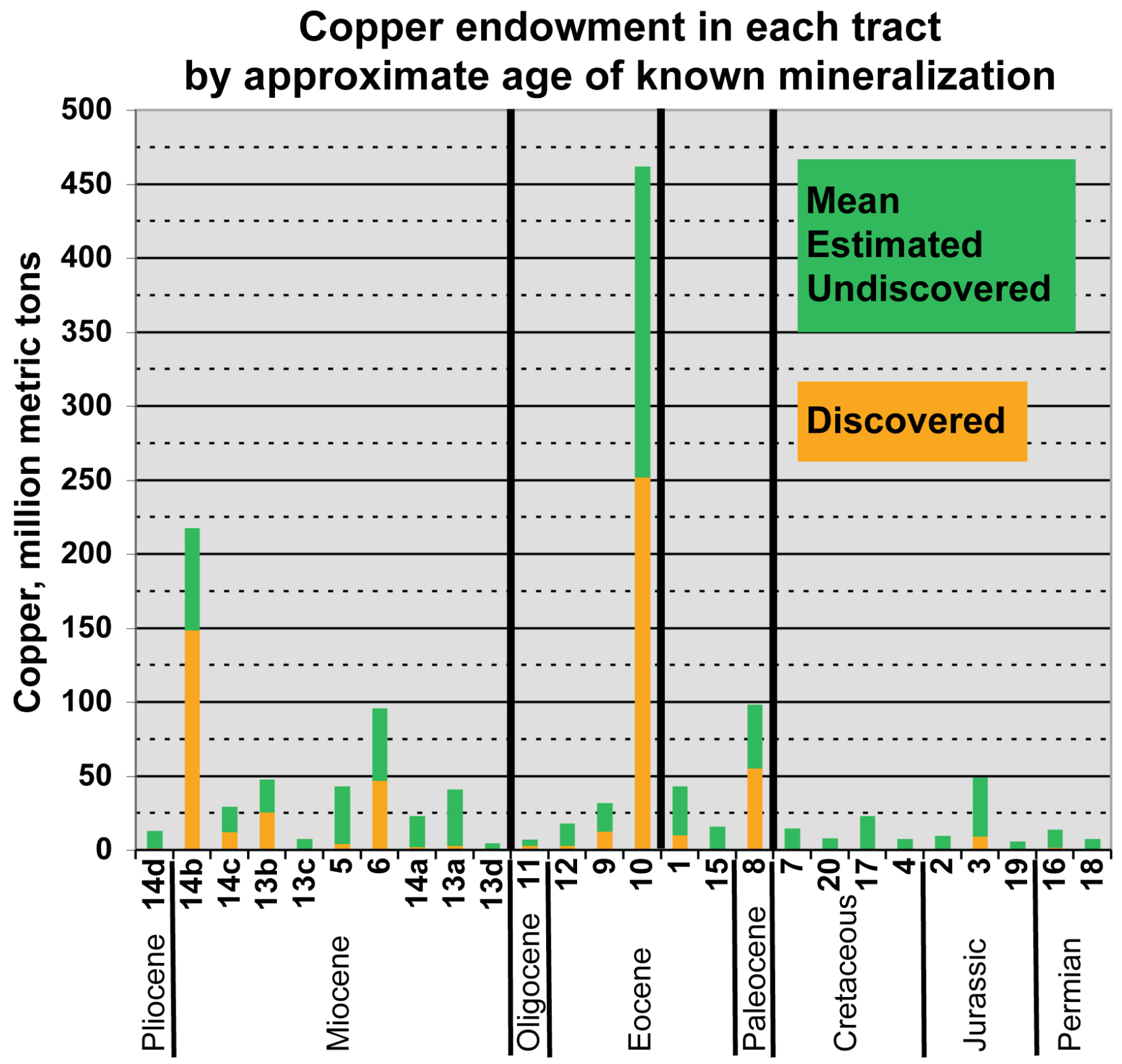

Tract number and geologic age

Figure 20. Column chart comparing copper endowment of each tract by approximate age of known mineralization. Tracts are arranged from youngest (left) to oldest (right) using the midpoint age of dated deposits and prospects, or using the midpoint age of the host rocks for tracts with no dated deposits or prospects (tracts 7, 13c, 13d, 17, and 20). Three heavy black vertical lines delineate the three Cenozoic mineralization events defined in figure 16. Horizontal axis is not linear. The SA prefixes and PC suffixes for the tract numbers have been dropped to facilitate plotting, as have the $a, b$ designations for tracts 10 and 16. Data from table 2. 


\section{Density of mean estimated undiscovered copper in each tract by approximate age of known mineralization}

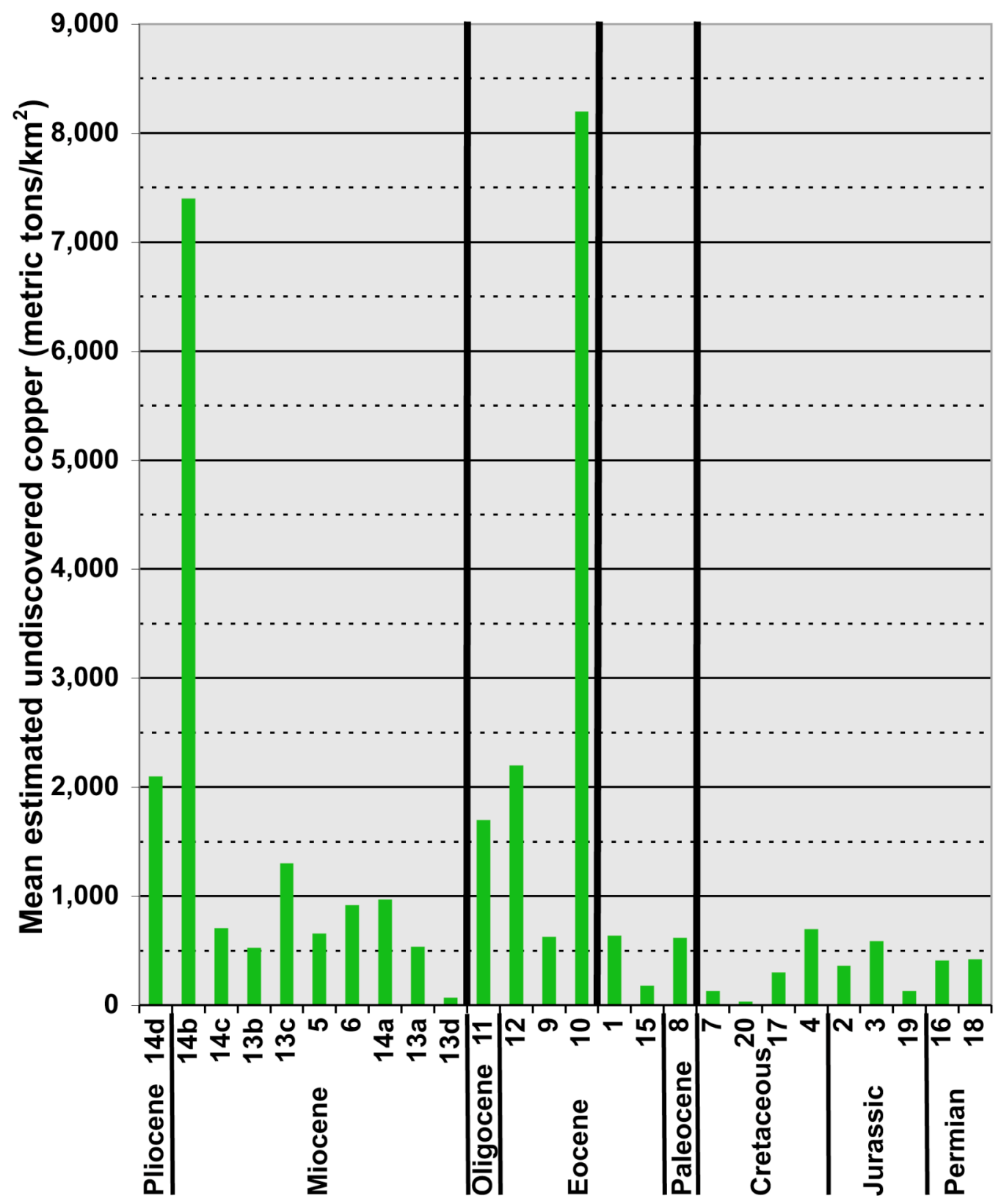

Tract number and geologic age

Figure 21. Column chart comparing density of mean estimated undiscovered copper in each tract by approximate age of known mineralization. Tracts are arranged from youngest (left) to oldest (right) using the midpoint age of dated deposits and prospects, or using the midpoint age of the host rocks for tracts with no dated deposits or prospects (tracts 7, 13c, 13d, 17, and 20). Three heavy black vertical lines delineate the three Cenozoic mineralization events defined in figure 16. Horizontal axis is not linear. The SA prefixes and PC suffixes for the tract numbers have been dropped to facilitate plotting, as have the $a, b$ designations for tracts 10 and 16. Data from table 2. 


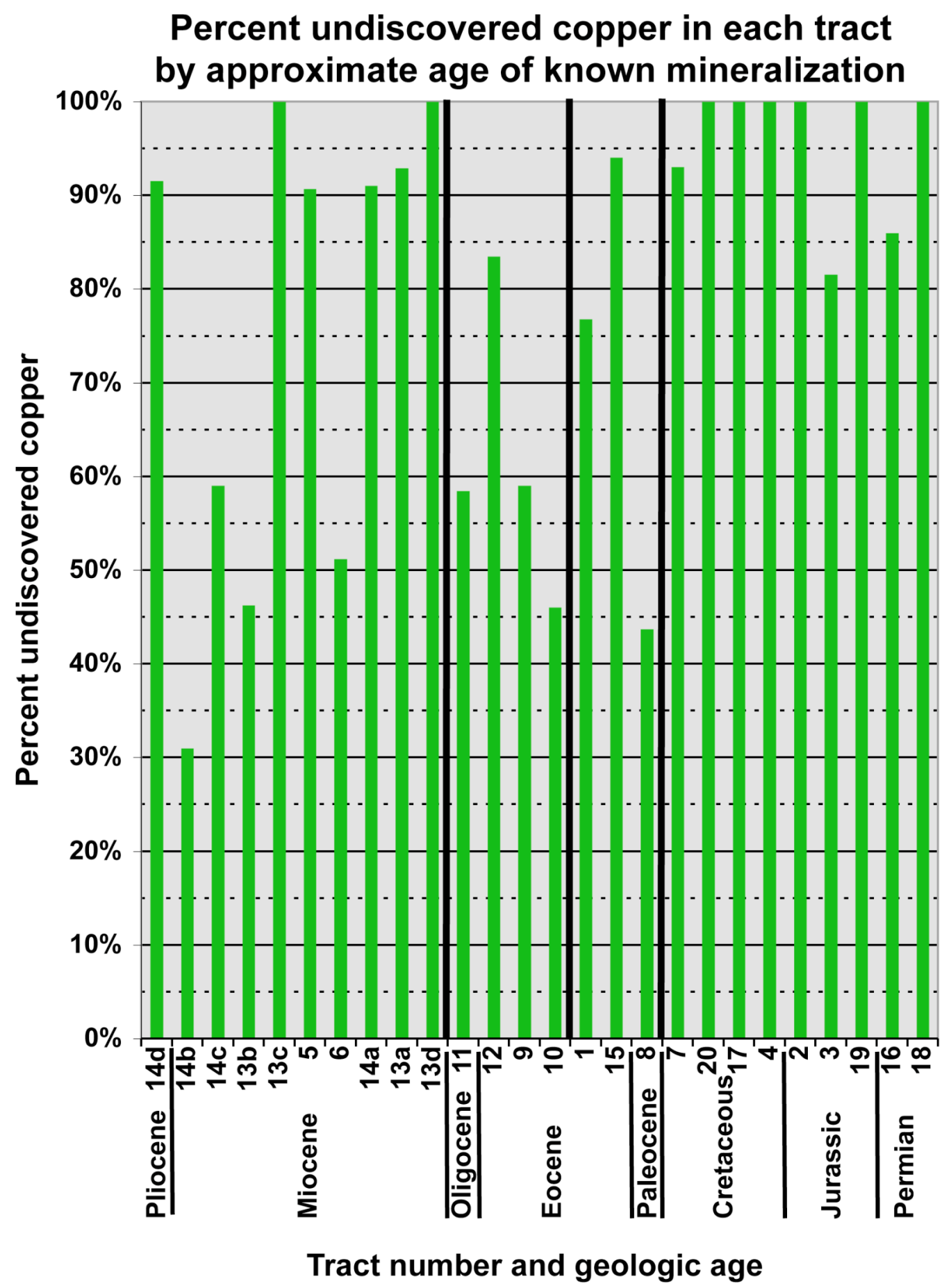

Figure 22. Column chart comparing mean estimated undiscovered copper as a percentage of the copper endowment in each tract by approximate age of known mineralization. Tracts are arranged from youngest (left) to oldest (right) using the midpoint age of dated deposits and prospects, or using the midpoint age of the host rocks for tracts with no dated deposits or prospects (tracts 7, 13c, 13d, 17, and 20). Tracts that contain estimated undiscovered deposits but no known deposits indicate 100 percent undiscovered. Three heavy black vertical lines delineate the three Cenozoic mineralization events defined in figure 16. Horizontal axis is not linear. The SA prefixes and PC suffixes for the tract numbers have been dropped to facilitate plotting, as have the a,b designations for tracts 10 and 16 . Data from table 2. 


\section{Molybdenum, gold, and silver}

Production of by-product metals is an important part of the value of porphyry copper deposits. Table 2 shows that undiscovered porphyry copper deposits in the Andes are estimated to contain large amounts of molybdenum (20,000,000 metric tones), gold (13,000 tons) and silver (250,000 tons). Figures 23a-d compare world production and reserve base of these three metals and copper, in all deposit types, to their estimated resources in undiscovered Andean porphyry copper deposits: undiscovered Andean porphyry copper is equivalent to about 80 percent of the world reserve base; molybdenum, 105 percent; gold, 14 percent; and silver, 44 percent. 
(a) Copper

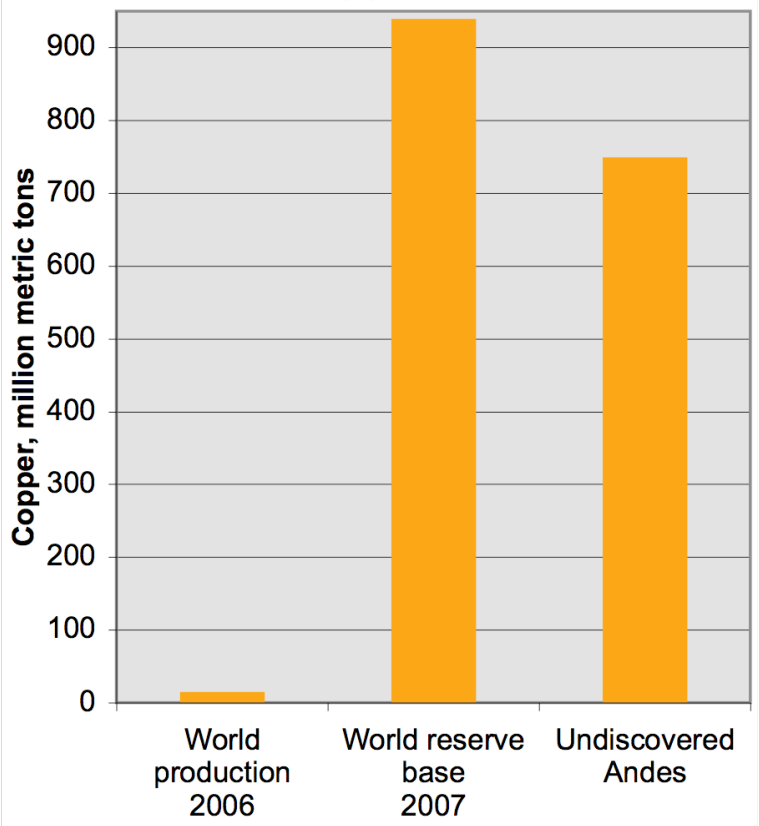

(c) Gold

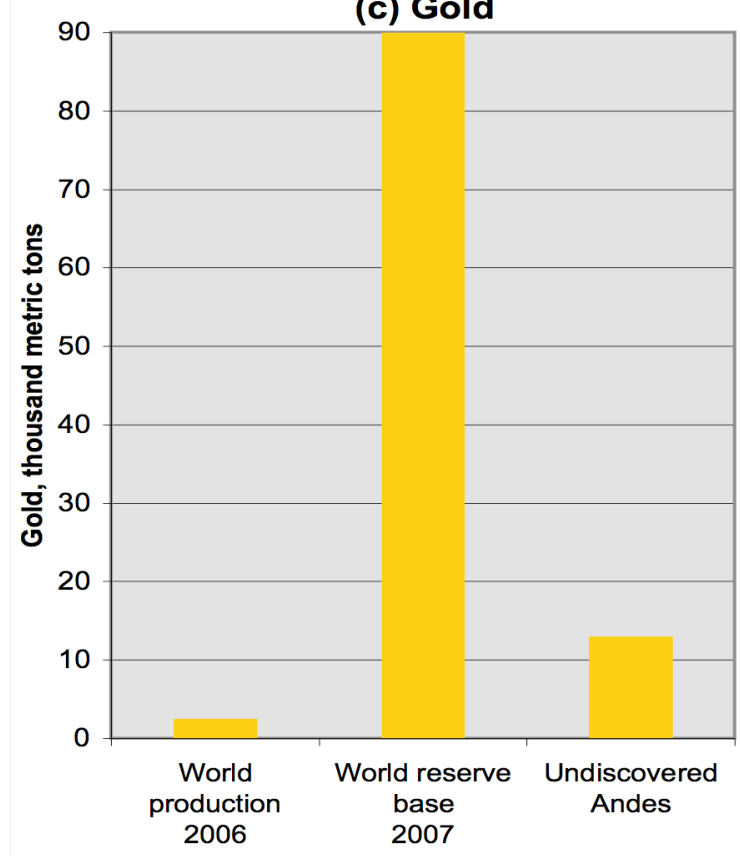

(b) Molybdenum

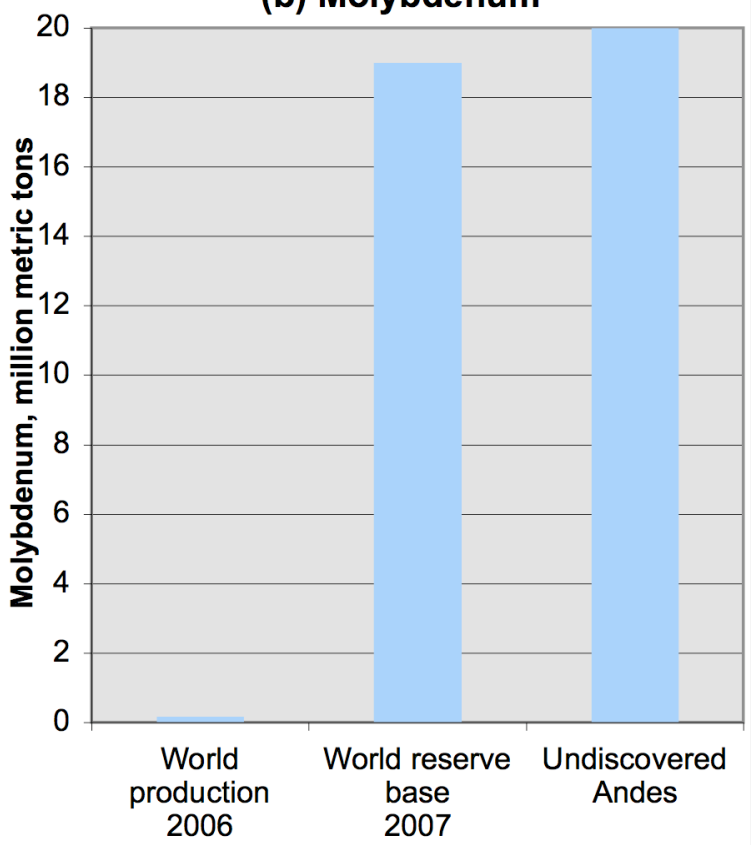

(d) Silver

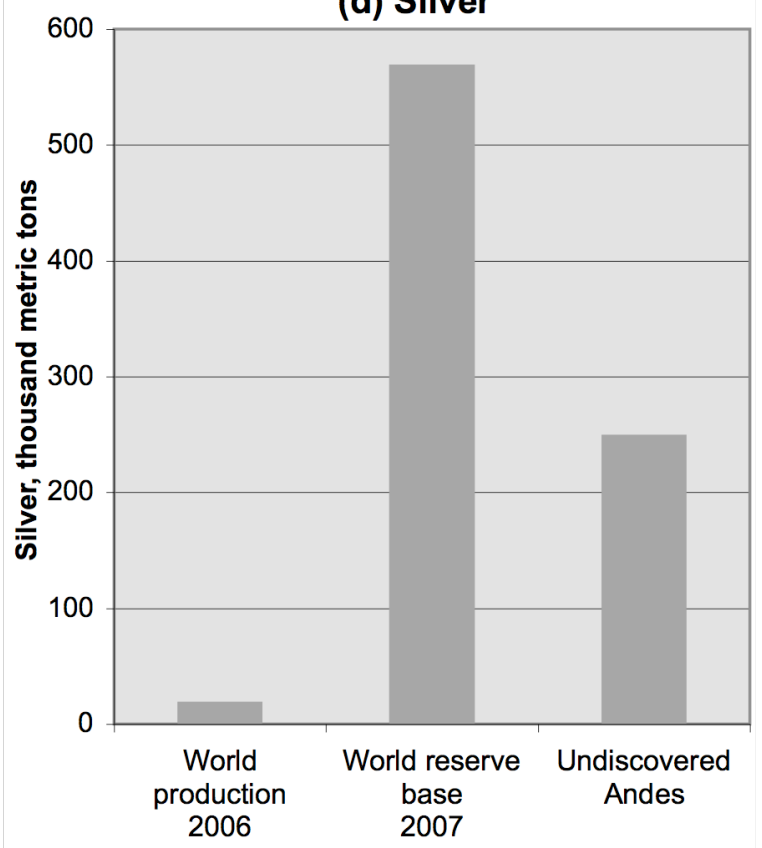

Figure 23 a-d. Column charts comparing world production (2006) and reserve base (2007) for copper, molybdenum, gold, and silver to the mean resources of these metals estimated in undiscovered porphyry copper deposits in the Andes. Production and reserve-base numbers are from Edelstein (2007), Magyar (2007), George (2007), and Brooks (2007), respectively. 


\section{Potential for porphyry copper resources elsewhere in South America}

This study affirms the belief of most, if not all, economic geologists that the Andes, particularly in their central and northern parts, have the greatest known reserves and potential for undiscovered porphyry copper deposits in South America. Nevertheless, there also is the possibility of undiscovered deposits elsewhere on the continent. One example is tract SA19PC, which extends from the Andes southsoutheasterly following the Late Triassic to early Middle Jurassic Subcordilleran and Central Patagonian batholiths across the Patagonia of Argentina to the Atlantic Ocean. The existence of this tract and the Bajo de la Leona prospect demonstrates that processes forming porphyry copper deposits in southern South America occurred outside of the present-day trend of the Andes.

Recent discoveries in the Precambrian shields of Brazil indicate possible undiscovered porphyry copper deposits in these regions also (see fig. 8). Several such deposits have been suggested in the Amazon though there are differing opinions about their deposit type. The Tapajos gold province of Brazil looks particularly promising. The host rocks are ash-flow tuffs and silicic volcanic domes associated with large-scale circular features suggestive of nested calderas. Recently, veins of magmatic-steam alunite indicative of near-surface, high-sulfidation conditions typical of the upper parts of porphyry systems have been investigated by Juliani and others (2005). The host rocks have been U-Th dated at about 1.85 billion years, and recent Ar-Ar dating of the alunite gives the same age as well as a remarkably flat plateau age spectrum. This means the correct rocks and mineralization to form porphyry copper deposits have been bobbing like a cork in the Amazon for almost 2 billion years. Other deposits and prospects look promising, and current exploration activities may significantly improve our understanding of the origin and preservation of Precambrian deposits.

Current research and exploration activities will significantly improve our understanding of the origin and preservation of the porphyry copper deposits in the Andes, as well as in other parts of South America. The results of this assessment study is likely to spur research and exploration activities in these regions, which in turn will enable the evaluation and update of regional assessments of porphyry copper resources in the future.

\section{References cited}

Angermann, D., Klotz, J., and Reigber, C., 1999, Space-geodetic estimation of the Nazca-South America Euler vector: Earth and Planetary Science Letters, v. 171, p. 329-334.

Amey, E.B., 2002, Gold: U.S. Geological Survey Mineral Commodity Summaries 2002, p. $72-73$ (Also available online at http://minerals.usgs.gov/minerals/pubs/mcs/.)

Amey, E.B., 2003, Gold: U.S. Geological Survey Mineral Commodity Summaries 2003, p. $74-75$ (Also available online at http://minerals.usgs.gov/minerals/pubs/mcs/.)

Ballard, J.R., Palin, J.M., Williams, I.S., Campbell, I.H., and Faunes, A., 2001, Two ages of porphyry intrusion resolved for the supergiant Chuquicamata copper deposit of northern Chile by ELA-ICP-MS and SHRIMP: Geology, v. 29, p. 383-386.

Bliss, J.D., and Menzie, W.D., 1993, Spatial mineral deposit models and the prediction of undiscovered mineral deposits, in Kirkham, R.V., Sinclair, W.D., Thorpe, R.I., and Duke, J.M., eds., Mineral deposit modeling: Geological Association of Canada Special Paper 40, p. 693-706.

Blossom, J.W., 2002, Molybdenum: U.S. Geological Survey Mineral Commodity Summaries 2002, p. 112-113 (Also available online at http://minerals.usgs.gov/minerals/pubs/mcs/.)

Brown, W.M., Matos, G.R., and Sullivan, D.E., 2000, Materials and energy flows in the earth science century - A summary of a workshop held by the USGS in November 1998: U.S. Geological Survey Circular 1194, $71 \mathrm{p}$. 
Briskey, J.A., Schulz, K.J., Mosesso, J.P., Horwitz, L.R., Cunningham, C. G., 2001, It's time to know the planet's mineral resources: Geotimes, v. 46, no. 3 (March), p. 14-19. Available online at http://www.geotimes.org/mar01/feature1.html

Briskey, J.A., Schulz, K.J., Mosesso, J.P., Horwitz, L.R., and Cunningham C.G., 2007, Environmental planning issues and a conceptual global assessment of undiscovered nonfuel mineral resources, in Briskey, J.A., and Schulz, K.J., eds., Proceedings for a Workshop on Deposit Modeling, Mineral Resources Assessment, and Their Role in Sustainable Development, $31^{\text {st }}$ International Geological Congress, Rio de Janeiro, Brazil, August 18-19, 2000: U.S. Geological Survey Circular 1294, p. 19-28 (Also available online at http://pubs.usgs.gov/circ/2007/1294/.)

Brooks, W.E., 2007, Silver: U.S. Geological Survey Mineral Commodity Summaries 2007, p. 148-149 (Also available online at http://minerals.usgs.gov/minerals/pubs/mcs/.)

Camus, Francisco, 2002, The Andean porphyry systems, in Cooke, D.R., and Pongratz, J., eds., Giant ore deposits-Characteristics, genesis, and exploration: Australia, CODES Special Publication, v. 4, p. 521.

Camus, Francisco, 2003, Geología de los sistemas porfíricos en los Andes de Chile: Servicio Nacional de Geología y Minería, Santiago, Chile, 267 p.

Cooke, D.R., 2005, Cenozoic and Mesozoic porphyry copper deposits of the Chilean and Peruvian Andes [abs.]: Geological Society of America Abstracts with Programs, Vol. 37, No. 7, p. 239.

Cooke, D.R., Hollings, Peter, and Walshe, J.L., (Guest Editors), 2005, A special issue devoted to giant porphyry-related mineral deposits: Economic Geology, v. 100, no. 5, p. 801-1066.

Cox, D.P., Barton, P.B., and Singer, D.A., 1986, Introduction, in Cox, D.P., and Singer, D.A., eds., 1986, Mineral deposit models: U.S. Geological Survey Bulletin 1693, p. 1-10.

Cox, D.P., and Singer, D.A., eds., 1986, Mineral deposit models: U.S. Geological Survey Bulletin 1693, $379 \mathrm{p}$.

Cox, D.P., and Singer, D.A., 1992, Distribution of Gold in Porphyry Copper Deposits, in DeYoung, J.H., and Hammerstrom, J.M., eds., Contributions to Commodity Research, U.S. Geological Survey Bulletin 1877, p. C1-C14.

Cunningham, C.G., Bawiec, W.J., Schulz, K.J., Briskey, J.A., Carlin, Jr., J.F., and Sutphin, D.M., 2007, Minerals, biodiversity, and choices, in Briskey, J.A., and Schulz, K.J., eds., Proceedings for a Workshop on Deposit Modeling, Mineral Resources Assessment, and Their Role in Sustainable Development, $31^{\text {st }}$ International Geological Congress, Rio de Janeiro, Brazil, August 18-19, 2000: U.S. Geological Survey Circular 1294, p. 31-34 (Also available online at http://pubs.usgs.gov/circ/2007/1294/.)

Cunningham, C.G., Zientek, M.L., Bawiec, W.J., and Orris, G.J., 2005, Geology and nonfuel mineral deposits of Latin America and Canada: U.S. Geological Survey Open-File Report 2005-1294B, 60 p. (Also available online at http://pubs.usgs.gov/of/2005/1294.

Doggett, M.D., 2007, Global mineral exploration and production - The impact of technology, in Briskey, J.A., and Schulz, K.J., eds., Proceedings for a Workshop on Deposit Modeling, Mineral Resources Assessment, and Their Role in Sustainable Development, $31^{\text {st }}$ International Geological Congress, Rio de Janeiro, Brazil, August 18-19, 2000: U.S. Geological Survey Circular 1294, p. 63-68. (Also available online at http://pubs.usgs.gov/circ/2007/1294/.)

Edelstein, D.L., 2002, Copper: U.S. Geological Survey Mineral Commodity Summaries 2002, p. 54-55 (Also available online at http://minerals.usgs.gov/minerals/pubs/mcs/.)

Edelstein, D.L., 2003, Copper: U.S. Geological Survey Mineral Commodity Summaries 2003, p. 56-57 (Also available online at http://minerals.usgs.gov/minerals/pubs/mcs/.)

Edelstein, D.L., 2007, Copper: U.S. Geological Survey Mineral Commodity Summaries 2007, p. 52-53 (Also available online at http://minerals.usgs.gov/minerals/pubs/mcs/.)

Edelstein, D.L., 2008, Copper: U.S. Geological Survey Mineral Commodity Summaries 2008, p. 54-55 (Also available online at http://minerals.usgs.gov/minerals/pubs/mcs/.) 
Engdahl, E.R., van der Hilst, R.D., and Berrocal, J., 1995, Imaging of subducted lithosphere beneath South America: Geophysical Research Letters, v. 22, p. 2317-2320.

Engdahl, E.R., van der Hilst, R.D., and Buland, R., 1998, Global teleseismic earthquake relocation with improved travel times and procedures for depth relocation: Bulletin of the Seismological Society of America, v. 88, p. 722-743.

George, M.W., 2007, Gold: U.S. Geological Survey Mineral Commodity Summaries 2007, p. 70-71 (Also available online at http://minerals.usgs.gov/minerals/pubs/mcs/.)

Gutscher, M.A. 2002, Andean subduction styles and their effect on thermal structure and interplate coupling: Journal of South American Earth Sciences, v.15, p. 3-10.

Harris, A.C., Allen, C.M., Bryan, S.E., Campbell, I.H., Holcombe, R.J., and Pailn, J.M., 2004, ELA-ICP$\mathrm{MS} \mathrm{U}-\mathrm{Pb}$ zircon geochronology of regional volcanism hosting the Bajo de la Alumbrera $\mathrm{Cu}-\mathrm{Au}$ deposit : Implications for porphyry-related mineralization: Mineralium Deposita, v. 39, p. 46-67.

Harris, DeVerle, and Rieber, Michael, 1993, Evaluation of the United States Geological Survey's threestep assessment methodology: U.S. Geological Survey Open-File Report 93-258-A, 491 numbered pages.

Hilliard, H.E., 2002, Silver: U.S. Geological Survey Mineral Commodity Summaries 2002, p. 150-151 (Also available online at http://minerals.usgs.gov/minerals/pubs/mcs/.)

Hilliard, H.E., 2003, Silver: U.S. Geological Survey Mineral Commodity Summaries 2003, p. 152-153 (Also available online at http://minerals.usgs.gov/minerals/pubs/mcs/.)

Hyndman, P.C., Roberts, C.A., Bottge, R.G., and Barnes, D.J., 1991, The availability of federal mineral estate in Alaska, Arizona, Colorado, Idaho, Nevada, New Mexico, Oregon, Utah, and Washington, in Lootens, D.J., Greenslade, W.M., and Barker, J.M., eds., Environmental management for the 1990'sProceedings of the Symposium on Environmental Management for the 1990's: Society for Mining, Metallurgy, and Exploration, Inc., Littleton, Colorado, p. 263-269.

International Commission on Stratigraphy, 2000, International Stratigraphic Chart: International Union of Geological Sciences, 1 p., downloaded from: http://www.iugs.org/iugs/pubs/intstratchart.htm, on November 14, 2003.

James, P.M., 1999, The miner and sustainable development: Mining Engineering, v. 51, no. 6 (June), p. 89-92.

Juliani, C., Rye, R.O., Nunes, C.M.D., Snee, L.W., Corrệa, Silva, Monteiro, L.V.S., Bettencourt, J.S., Neumann, R., and Neto, A.A., 2005, Paleoproterozoic high-sulfidation mineralization in the Tapajós gold province, Amazonian Craton, Brazil: geology, mineralogy, alunite argon age, and stable-isotope constraints: Chemical Geology, v. 215, issues 1-4, p. 95-126.

Kay, S.M., and Mpodozis, Constantino, 2002, Magmatism as a probe to the Neogene shallowing of the Nazca plate beneath the modern Chilean flatslab: Journal of South American Earth Sciences, v. 15, p. 39-58.

Kesler, S.E., 2007, Mineral supply and demand into the $21^{\text {st }}$ century, in Briskey, J.A., and Schulz, K.J., eds., Proceedings for a Workshop on Deposit Modeling, Mineral Resources Assessment, and Their Role in Sustainable Development, $31^{\text {st }}$ International Geological Congress, Rio de Janeiro, Brazil, August 1819, 2000: U.S. Geological Survey Circular 1294, p. 55-62. (Also available online at http://pubs.usgs.gov/circ/2007/1294/.)

Kious, W.J and Tilling, R.I., 1996, This dynamic Earth: The story of plate tectonics. ONLINE version 1.0. Available: http://pubs.usgs.gov/publications/text/dynamic.html\#anchor19309449 [January 30, 2004] Kirkham, R.V, and Dunne, K.P.E., compilers, 2000, World distribution of porphyry, porphyry-associated skarn, and bulk-tonnage epithermal deposits and occurrences: Geological Survey of Canada Open-File 3792a, 26p. (1 map, 1 diskette). Online updates available at: http://gdr.nrcan.gc.ca/minres/metadata_e.php?id=6 
Langhammer, Penny Flick, 2007, Who will use a global mineral resource assessment, in Briskey, J.A., and Schulz, K.J., eds., Proceedings for a Workshop on Deposit Modeling, Mineral Resources Assessment, and Their Role in Sustainable Development, $31^{\text {st }}$ International Geological Congress, Rio de Janeiro, Brazil, August 18-19, 2000: U.S. Geological Survey Circular 1294, p. 29-30. (Also available online at http://pubs.usgs.gov/circ/2007/1294/.)

Ludington, Steve, Cox, Dennis, and McCammon, Richard, eds., 1996, Data base for a national mineralresource assessment of undiscovered deposits of gold, silver, copper, lead, and zinc in the conterminous United States: U.S. Geological Survey Open-File Report 96-96, one CD-ROM. (Also available online at http://pubs.usgs.gov/of/1996/of96-096/.)

Magyar, M.J., 2003, Molybdenum: U.S. Geological Survey Mineral Commodity Summaries 2003, p. 114115 (Also available online at http://minerals.usgs.gov/minerals/pubs/mcs/.)

Magyar, M.J., 2007, Molybdenum: U.S. Geological Survey Mineral Commodity Summaries 2007, p. 110111 (Also available online at http://minerals.usgs.gov/minerals/pubs/mcs/.)

Maksaev, Victor (coordinator), Townley, Brian, Palacios, Carlos, and Camus, Francisco, 2007, Metallic ore deposits, in Moreno, Teresa, and Gibbons, Wes, eds., The Geology of Chile: London, The Geological Society, p. 179-199.

Matos, Grecia, and Wagner, Lorie, 1998, Consumption of materials in the United States, 1900-1995: Annual Review of Energy and the Environment, v. 23, p. 107-122.

McClay, Ken, Skarmeta, Jorge, and Beertens, Alfredo, 2002, Chile: new models and implications for CuMo mineralization in subduction orogens \{abs.\}: Applied structural geology for Mineral Exploration and Mining, International Symposium, September 23-25, 2002, Kalgoorlie, Western Australia, Abstract volume, p. 127.

Menzie, W.D., DeYoung, J.H., Jr., and Steblez, W.G., 2003, Some implications of changing patterns of mineral consumption: U.S. Geological Survey Open-File Report 03-382, 35 p.

Menzie, W.D., and Singer, D.A., 1990, A course on mineral resource assessment, in Proceedings of ISME-AI'90 - International Symposium on Mineral Exploration, The Use of Artificial Intelligence, 1990, Tokyo and Tsukuba, Japan, p. 177-188.

Menzie, W.D., Singer, D.A., and DeYoung, J.H., Jr., 2004, Chapter 2 Mineral resources and consumption in the 21st century, in Ayres, R.U., Simpson, R.D., and Toman, M.A., eds., Scarcity and growth in the new millennium -Summary of an interdisciplinary workshop: Washington, D.C., Resources for the Future.

Meschede, Martin, and Barckhausen, Udo, 2000, 7. Plate tectonic evolution of the Cocos-Nazca spreading center, in Silver, E.A., Kimura, G., and Shipley, T.H., eds., Proceedings of the Ocean Drilling Program, Scientific Results, v. 170, 10 p. Available online at: <http://wwwodp.tamu.edu/publications/170_SR/VOLUME/CHAPTERS/SR170_07.PDF>. [Cited February 29, 2008]

Mpodozis, C., and Ramos, V., 1990, The Andes of Chile and Argentina: Circum-Pacific Council for Energy and Mineral Resources Earth Science Series, v. 11, p. 59-90.

Mosier, D.L., Singer, D.A., and Berger, V.I., 2007, Volcanogenic massive sulfide deposit density: U.S. Geological Survey, Scientific Investigations Report 2007-5082, 15p.

Nooten, G.A., 2007, Sustainable development and nonrenewable resources-A multilateral perspective, in Briskey, J.A., and Schulz, K.J., eds., Proceedings for a Workshop on Deposit Modeling, Mineral Resources Assessment, and Their Role in Sustainable Development, $31^{\text {st }}$ International Geological Congress, Rio de Janeiro, Brazil, August 18-19, 2000: U.S. Geological Survey Circular 1294, p. 35-40. (Also available online at http://pubs.usgs.gov/circ/2007/1294/.)

Norambuena, E., Leffer-Griffin, L., Mao, A., Dixon, T., Stein, S., Sacks, S., Ocola, L., and Ellis, M., 1998, Space geodetic observations of Nazca-South America convergence across the Central Andes: Science, v. 279, p. 358-362. 
O’Neil, Tim, Kral, Steve, and Yernberg, W.R., 2000, New frontiers in mining-Meeting 21st century challenges: Mining Engineering, v. 52, no. 6 (June), p. 70-78.

Pardo-Casas, F., and Molnar, P., 1987, Relative motion of the Nazca (Farallon) and South American plates since Late Cretaceous time: Tectonics, v. 6, p. 233-248.

Porter, T.M., ed.., 2005, Super porphyry copper and gold deposits, a global perspective: v. 1, PGE Publishing, Australia, 280 p.

Ramos, V.A., 1999a, Plate tectonic setting of the Andean Cordillera: Episodes, v. 22, no. 3, p. 183-190 Ramos, V.A., 1999b, Los depósitos sinorogónicos de la región andina, in Caminos, R., ed., Geología Argentina: Instituto de Geología y Recursos Naturales Anales, v. 29, p. 651-682.

Ramos, V.A., and Alemán, A., 2000, Tectonic Evolution of the Andes, in Tectonic evolution of South America: Cordani, U.G., Milani, E.J., Thomaz Filho, A., and Campos, D.A., eds., International Geological Congress, No. 31, p. 635-685. Río de Janeiro.

Reynolds, P., Ravenhurst, C., Zentilli, M., and Lindsay, D., 1998, High precision 40Ar/39Ar dating of two consecutive hydrothermal events in the Chuquicamata porphyry copper system, Chile: Chemical Geology, v. 148p. 45-60.

Richards, J.P., 2005, Cumulative factors in the generation of giant calc-alkaline porphyry copper deposits, in Porter, T.M. (ed.), Super porphyry copper \& gold deposits - A global perspective: PGC Publishing, Linden Park, Australia, p. 7-25.

Root, D.H., Menzie, W.D., III, and Scott, W.A., 1992, Computer Monte Carlo simulation in quantitative resource assessment: Nonrenewable Resources, v. 1, no. 2, p. 125-138.

Rosenbaum, Gideon, Giles, David, Saxon, Mark, Betts, P.G., Weinberg, R.F., and Duboz, Cecile, 2005 , Subduction of the Nazca Ridge and the Inca Plateau: Insights into the formation of ore deposits in Peru: Earth and Planetary Science Letters, v. 239, p. 18-32.

Schruben, Paul, (recompiler), 2002, Assessment of undiscovered deposits of gold, silver, copper, lead, and zinc in the United States-A portable document format (pdf) recompilation of USGS OFR 96-96 and Circular 1178, by the National Mineral Resource Assessment Team: U.S. Geological Survey Open-File Report 02-198, one CD-ROM. (Also available online at http://pubs.usgs.gov/of/2002/of02-198/.)

Schulz, K.J., and Briskey, J.A., 2003, The Global Mineral Resource Assessment Project: U.S. Geological Survey Facts Sheet FS-053-03, 4 p. (Also available online at http://pubs.usgs.gov/fs/fs053-03/).

Sillitoe, R.H., 1988, Epochs of intrusion-related copper mineralization in the Andes: Journal of South American Earth Sciences, v. 1, no. 1, p. 89-108.

Sillitoe, R.H., and Perelló, Jose, 2005, Andean copper province-Tectonomagmatic settings, deposit types, metallogeny, exploration, and discovery, in Hedenquist, J.W., Thompson, J.F.H., Goldfarb, R.J., and Richards, J.P., eds., Economic Geology One Hundredth Anniversary Volume, 1905-2005, Littleton, Colorado, Society of Economic Geologists, p. 845-890.

Sillitoe, R.H., Perelló, José, and Vidal, C.E., eds., 2004, Andean metallogeny: new discoveries, concepts, and updates: Society of Economic Geologists, Special Publication Number 11, 357 p.

Singer, D.A., 1975, Mineral resource models and the Alaska Mineral Resource Assessment Program, in Vogely, W.A., ed., Mineral materials modeling-A state-of-the-art review: Baltimore, Johns Hopkins University Press, p. 370-382.

Singer, D.A., 1993a, Basic concepts in three-part quantitative assessments of undiscovered mineral resources: Nonrenewable Resources, v. 2, no. 2, p. 69-81.

Singer, D.A., 1993b, Development of grade and tonnage models for different deposit types, in Kirkham, R.V., Sinclair, W.D., Thorpe, R.I., and Duke, J.M., eds., Mineral deposit modeling: Geological Association Canada Special Paper 40, p. 21-30. 
Singer, D.A., 1994, The relationship of estimated number of undiscovered deposits to grade and tonnage models in three-part mineral resource assessments: 1994 International Assoc. Mathematical Geology Annual Conference, Papers and Extended Abstracts, Oct. 3-5, 1994, Mount Tremblant, Quebec, Canada, p. 325-326.

Singer, D.A., 2007, Estimating amounts of undiscovered mineral resources, in Briskey, J.A., and Schulz, K.J., eds., Proceedings for a Workshop on Deposit Modeling, Mineral Resource Assessment, and Their Role in Sustainable Development, 31st International Geological Congress, Rio de Janeiro, Brazil, August 18-19, 2000: U.S. Geological Survey Circular 1294, p. 79-84 (Also available online at http://pubs.usgs.gov/circ/2007/1294/).

Singer, D.A., 2008, Mineral deposit densities for estimating mineral resources: Mathematical Geosciences, v. 40, no. 1, p. 33-46.

Singer, D.A., and Berger, V.I., 2007, Deposit models and their application in mineral resource assessments, Briskey, J.A., and Schulz, K.J., eds., Proceedings for a Workshop on Deposit Modeling, Mineral Resources Assessment, and Their Role in Sustainable Development, $31^{\text {st }}$ International Geological Congress, Rio de Janeiro, Brazil, August 18-19, 2000: U.S. Geological Survey Circular 1294, p. 71-78 (Also available online at http://pubs.usgs.gov/circ/2007/1294/).

Singer, D.A., Berger, V.I., Menzie, W.D., and Berger, B.R., 2005, Porphyry copper density: Economic Geology, v. 100, no. 3, p. 491-514.

Singer, D.A., Berger, V.I., and Moring, B.C., 2002, Porphyry copper deposits of the world-Database, maps, and preliminary analysis: U.S. Geological Survey Open File Report, 02-268, 61 p., 6 over-size sheets, http://pubs.er.usgs.gov/pubs/ofr/ofr02268

Singer, D.A., Berger, V.I., and Moring, B.C., 2005, Porphyry copper deposits of the world-Database, map, and grade and tonnage models: U.S. Geological Survey Open-file Report 2005-1060, http://pubs.usgs.gov/of/2005/1060/)

Singer, D.A., and Menzie, W.D., 2005, Statistical guides to estimating the number of undiscovered mineral deposits: an example with porphyry copper deposits, in Cheng, Qiuming and Bonham-Carter, Graeme, eds., Proceedings of IAMG - The annual conference of the International Association for Mathematical Geology: Geomatics Research Laboratory, York University, Toronto, Canada, p. 10281033.

Singer, D.A., Menzie, W.D., Sutphin, David, Mosier, D.L., and Bliss, J.D., 2001, Mineral deposit density - an update, in Schulz, K.J., ed., Contributions to global mineral resource assessment research: U.S. Geological Survey Professional Paper 1640-A, p. A1-A13. (Available online at: http://pubs.usgs.gov/prof/p1640a/.)

Skinner, B.J., ed., 1999, Geology and ore deposits of the central Andes: Society of Economic Geologists, Special Publication Number 7, $351 \mathrm{p}$.

Stern, C.R., 2004, Active Andean volcanism: its geologic and tectonic setting: Revista Geológia de Chile, v. 31, p. 161-206.

Stock, J.M., 2006, The Hawaiian-Emperor Bend-Older than expected: Science, v. 313, no. 5791, p. 1250-1251.

Tebbens, S.F., and Cande, S.C., 1997, Southeast Pacific tectonic evolution from early Oligocene to Present: Journal of Geophysical Research, v. 102, B6, p. 12,061-12,084.

U.S. Bureau of Mines, and U.S. Geological Survey, 1980. Principles of a resource/reserve classification for minerals: U.S. Geological Survey Circular 831, 5 p.

U.S. Geological Survey, 2007, Appendix C: Mineral Commodity Summaries 2007, p. 191-193. 
U.S. Geological Survey National Mineral Resource Assessment Team, 2000, 1998 assessment of undiscovered deposits of gold, silver, copper, lead, and zinc in the United States: U.S. Geological Survey Circular 1178, 21 p., one CD-ROM in pocket. (Also available online http://pubs.usgs.gov/circ/c1178/.) (Because of software limitations and several errors and numbering inconsistencies, Circular 1178 was superceded by Schruben, 2002.)

Walser, Gotthard, 2007, Mineral resources information and socioeconomic development, in Briskey, J.A., and Schulz, K.J., eds., Proceedings for a Workshop on Deposit Modeling, Mineral Resources Assessment, and Their Role in Sustainable Development, $31^{\text {st }}$ International Geological Congress, Rio de Janeiro, Brazil, August 18-19, 2000: U.S. Geological Survey Circular 1294, p. 41. (Also available online at http://pubs.usgs.gov/circ/2007/1294/.)

Welmer, Friedrich-Wilhelm, and Becker-Platen, J.D., 2007, Global nonfuel mineral resources and sustainability, in Briskey, J.A., and Schulz, K.J., eds., Proceedings for a Workshop on Deposit Modeling, Mineral Resources Assessment, and Their Role in Sustainable Development, $31^{\text {st }}$ International Geological Congress, Rio de Janeiro, Brazil, August 18-19, 2000: U.S. Geological Survey Circular 1294, p. 1-16. (Also available online at http://pubs.usgs.gov/circ/2007/1294/.)

Wilder, D.T., 2003, Relative motion history of the Pacific-Nazca (Farallon) plates since 30 million years ago: St. Petersburg, Florida, College of Marine Science, University of South Florida, Master of Science thesis, 105 p. Available online at: http://etd.fcla.edu/SF/SFE0000069/WILDERTHESIS.PDF. [Cited February 29, 2008].

Zappettini, Eduardo, ed., 1999a, Recursos Minerales de la República Argentina, v.1: Servicio Geológico Minero Argentino, Buenos Aires.

Zappettini, Eduardo, ed., 1999b, Recursos Minerales de la República Argentina, v.2: Servicio Geológico Minero Argentino, Buenos Aires.

Zappettini, Eduardo, coordinación general, 2005, Mapa metalogenético de América del sur, 1:5,000,000: Servicio Geológico Minero Argentino, Buenos Aires, 275 p.

Zappettini, Eduardo, Miranda-Angles, Vitaliano, Rodriguez S., Carolina, Palacios, Oscar, Cocking, Robert, Godeas, Marta, Uribe-Zeballos, Hernán, Vivallo S., Waldo, Paz, Manuel Maidana, Seggiaro, Raúl., Heuschmidt, Bertand, Gardeweg P., Moyra, Boulangger Rondoy, Elmere, Korzeniewski, Lidia I., Mpodozis M., Constantino, Carpio R., Mario, and Rubiolo, Daniel, 2001, Mapa metalogénico de la región fronteriza entre Argentina, Bolivia, Chile y Perú $\left(14^{\circ} \mathrm{S}-28^{\circ} \mathrm{S}\right)$ : Servicio Nacional de Geología y Minería, Publicacion Geológica Multinacional No. 2, Santiago, Chile, escala 1:1,000,000, 222 p., 1 map. 


\section{Appendix I. Grade and tonnage model of giant porphyry copper deposits}

By

Donald A. Singer, Joseph A Briskey, and Charles G. Cunningham

\section{U.S. Geological Survey}

Tonnages and (or) copper grades of known (discovered) porphyry copper deposits in tracts SA10a,bPC and SA14bPC (table AI-1) are significantly higher in than the general model of Singer, Berger, and Moring (2005) at the one percent level (table 3) ( $t$-test; $\alpha=0.01$ ). The tonnages and grades of these deposits are used to construct a grade and tonnage model for "giant" porphyry copper deposits (figs. AI 1-5). Data for the giant model are listed in Singer, Berger, and Moring (2005) along with appropriate references. Given the small number of deposits in the giant model, in addition to the even smaller number of values reported for Mo, $\mathrm{Ag}$, and $\mathrm{Au}$, the differences in these three metals between the giant and general models (table AI-2) probably are not meaningful.

Table Al-1. Tonnage and grade data from Singer, Berger, and Moring (2005) for the deposits in tracts SA10a,bPC and SA14bPC that comprise the giant model.

\begin{tabular}{|c|c|c|c|c|c|c|}
\hline Deposit name & $\begin{array}{c}\text { Country } \\
\text { code }\end{array}$ & Metric tons & $\begin{array}{c}\text { Cu grade, } \\
\%\end{array}$ & $\begin{array}{c}\text { Mo grade, } \\
\%\end{array}$ & $\begin{array}{c}\mathbf{A g} \\
\text { grade, } \\
\text { grams } \\
\text { /metric } \\
\text { ton }\end{array}$ & $\begin{array}{c}\text { Au } \\
\text { grade, } \\
\text { grams } \\
\text { /metric } \\
\text { ton }\end{array}$ \\
\hline Chuquicamata & CILE & $17,100,000,000$ & 0.65 & 0.04 & 5 & 0.013 \\
\hline Collahuasi & CILE & $3,100,000,000$ & 0.86 & 0.04 & 5 & 0 \\
\hline El Abra & CILE & $1,620,000,000$ & 0.62 & 0.0058 & 0 & 0 \\
\hline El Salvador & CILE & $866,000,000$ & 1.41 & 0.01 & 1.5 & 0.12 \\
\hline El Teniente & CILE & $11,800,000,000$ & 0.92 & 0.019 & 0.52 & 0.005 \\
\hline Gaby & CILE & $900,000,000$ & 0.52 & 0 & 0 & 0 \\
\hline La Escondida & CILE & $4,860,000,000$ & 0.97 & 0.0062 & 5 & 0.25 \\
\hline Los Bronces-Rio Blanco & CILE & $5,000,000,000$ & 0.8 & 0.019 & 0 & 0 \\
\hline Mansa Mina & CILE & $1,000,000,000$ & 1.3 & 0 & 0 & 0 \\
\hline Potrerillos & CILE & $1,030,000,000$ & 0.976 & 0.011 & 0 & 0.77 \\
\hline Quebrada Blanca & CILE & $1,090,000,000$ & 0.72 & 0 & 0 & 0 \\
\hline Ujina & CILE & $1,298,000,000$ & 0.71 & 0 & 0 & 0 \\
\hline
\end{tabular}




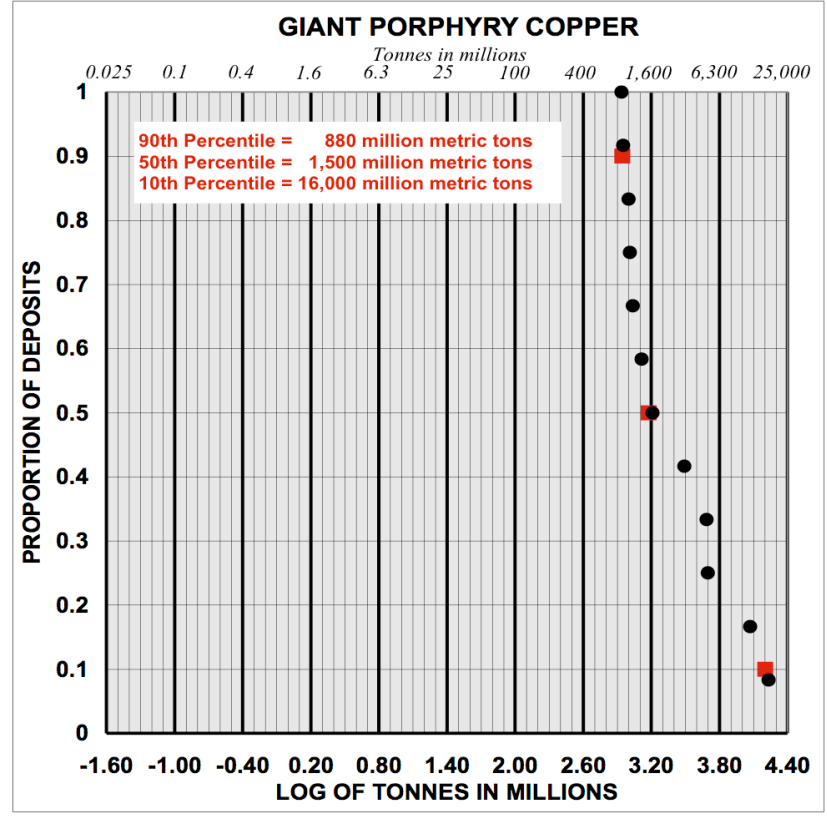

Figure AI-1. Graph showing cumulative frequency of tonnages of giant porphyry copper deposits. Each black dot represents an individual deposit. Red squares are the intercepts for the 90th, 50th, and 10th percentiles.

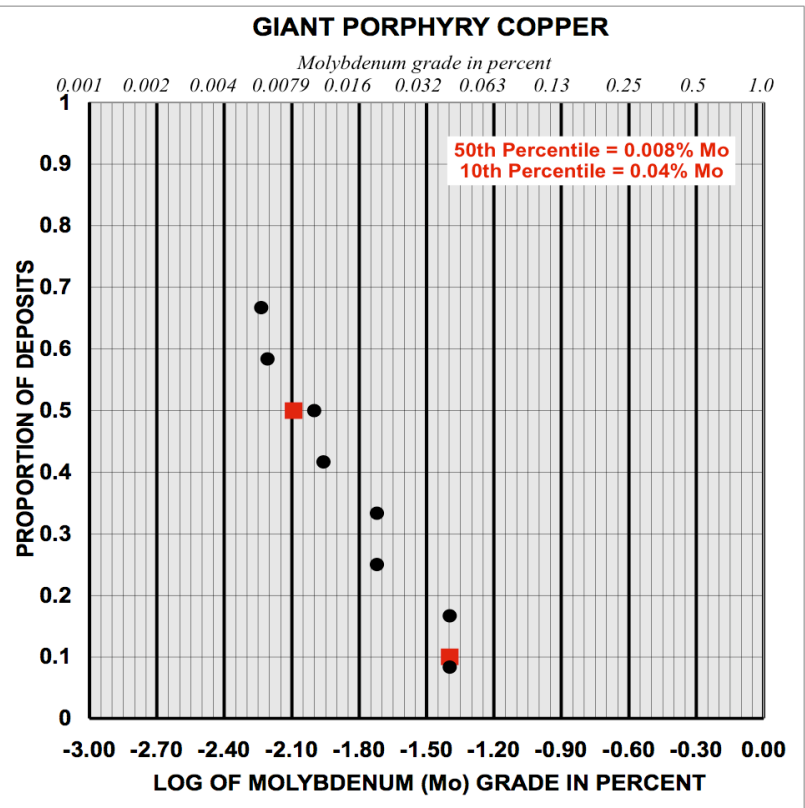

Figure AI-3. Graph showing cumulative frequency of molybdenum grade of giant porphyry copper deposits. Each black dot represents an individual deposit. Red squares are the intercepts for the 50th and 10th percentiles.

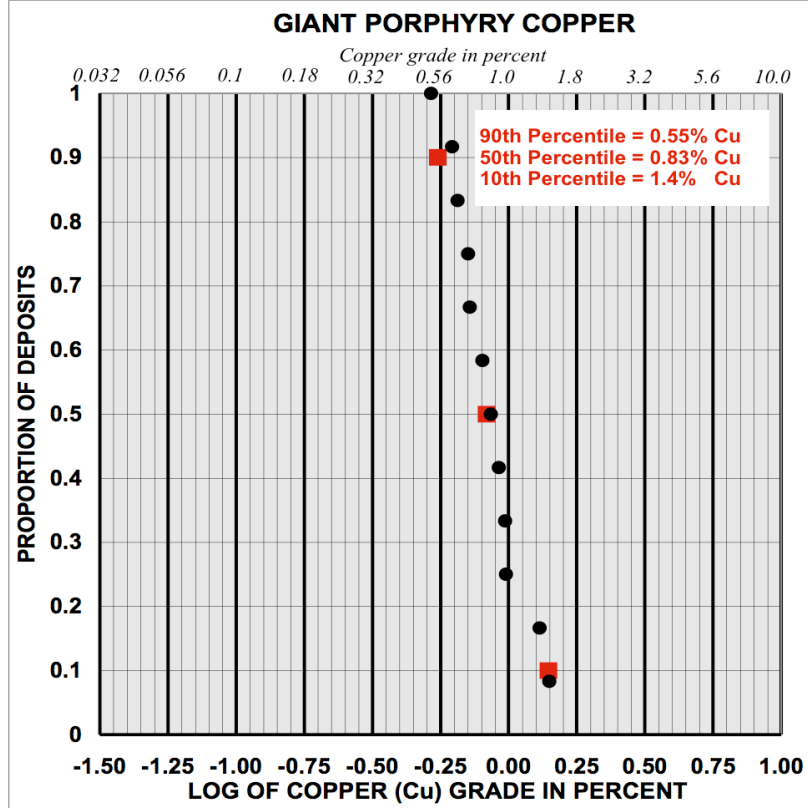

Figure Al-2. Graph showing cumulative frequency of copper grade of giant porphyry copper deposits. Each black dot represents an individual deposit. Red squares are the intercepts for the 90th, 50th, and 10 th percentiles.

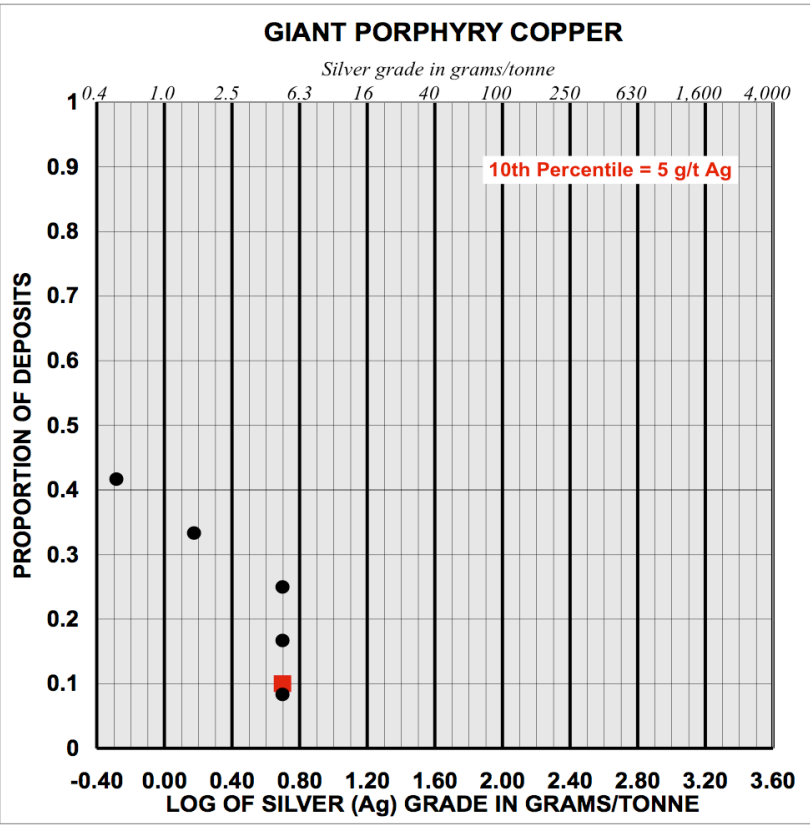

Figure Al-4. Graph showing cumulative frequency of silver grade of giant porphyry copper deposits. Each black dot represents an individual deposit. The red square is the intercept for the 10th percentile. 


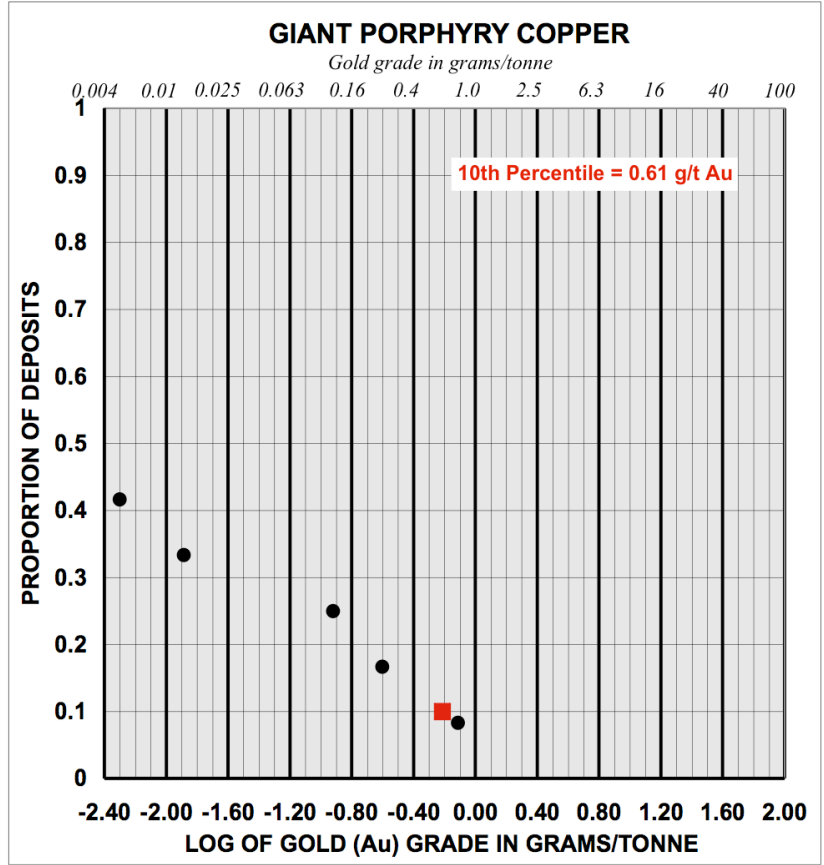

Figure Al-5. Graph showing cumulative frequency of gold grade of giant porphyry copper deposits. Each black dot represents an individual deposit. The red square is the intercept for the 10th percentile.

Table Al-2. Comparison of tonnages and grades of giant and general porphyry copper deposit models.

\begin{tabular}{|l|c|c|c|c|c|c|c|c|}
\hline & \multicolumn{2}{|c|}{$\begin{array}{c}\text { Number } \\
\text { of deposits }\end{array}$} & \multicolumn{2}{c|}{$\begin{array}{c}\mathbf{1 0}^{\text {th }} \text { percentile } \\
\text { of deposits }\end{array}$} & \multicolumn{2}{c|}{$\begin{array}{c}\mathbf{5 0}^{\text {th }} \text { percentile } \\
\text { of deposits }\end{array}$} & \multicolumn{2}{c|}{$\begin{array}{c}\mathbf{9 0}^{\text {th }} \text { percentile } \\
\text { of deposits }\end{array}$} \\
\hline & Giant & General & Giant & General & Giant & General & Giant & General \\
\hline Tons & 12 & 380 & 16,000 & 1,400 & 1,500 & 230 & 880 & 32 \\
\hline Cu grade & 12 & 380 & 1.4 & 0.80 & 0.83 & 0.44 & 0.55 & 0.25 \\
\hline Mo grade & 12 & 380 & 0.04 & 0.03 & 0.008 & 0.008 & 0.0 & 0.002 \\
\hline Ag grade & 12 & 380 & 5 & 3.8 & 0.0 & 1.3 & 0.0 & 0.40 \\
\hline Au grade & 12 & 380 & 0.61 & 0.57 & 0.0 & 0.095 & 0.0 & 0.016 \\
\hline
\end{tabular}

The general model is reported in Singer, Berger, and Moring (2005). Tonnages are in millions of metric tons. Copper $(\mathrm{Cu})$ and molybdenum (Mo) grades are reported as percent of the metals. Gold $\mathrm{Au})$ and silver $(\mathrm{Ag})$ grades are reported as grams/metric ton of the metal.

\section{Geologic discussion}

The formation of giant porphyry copper deposits in parts of the Andes over the last $20 \mathrm{Ma}$ has been the subject of much speculation. For example, multiple superimposed intrusions separated by a span of only a few million years have been suspected as the cause of the high grades and tonnages of porphyry copper deposits in tract SA10a,bPC of this report (Reynolds and others, 1998; Ballard and others, 2001; and Harris and others, 2004). This tract also is the only one where significantly younger mineralization (Eocene-Oligocene of tract SA10aPC) is superimposed on known older mineralization (Permian of tract 18) over a relatively large region leading to speculation that pre-existing rock permissive for copper mineralization or copper-enriched host rocks (pre-enrichment) in one or both of the older tracts may have contributed to the unusually large average size and grade of the discovered porphyry copper deposits in tract SA10a,bPC. 
Sillitoe and Perelló (2005) point to pronounced crustal shortening and thickening, accommodated by regional faults and followed by rapid surface uplift and erosion, as important controls on the origin of giant porphyry copper deposits. These investigators deduce that such conditions can impede magma venting and foster development of large, shallow magma chambers that concentrate copper and magmatic fluids resulting in the formation of large porphyry copper deposits. There is geologic evidence suggesting that such conditions may have occurred during regional contractional events possibly related to flattening of the underthrust slab containing buoyant oceanic features such as aseismic ridges, seamount chains, and oceanic plateaus (Sillitoe and Perelló, 2005). Resultant crustal thickening, suppression of volcanism, and surface uplift appear to favor conditions to supply fluids from large, shallow magma chambers leading to the formation of the deposits (Sillitoe and Perelló, 2005). However, these explanations apply to a wider region than the tracts demonstrated to contain giant deposits.

\section{References cited}

Ballard, J.R., Palin, J.M., Williams, I.S., Campbell, I.H., and Faunes, A., 2001, Two ages of porphyry intrusion resolved for the supergiant Chuquicamata copper deposit of northern Chile by ELA-ICP-MS and SHRIMP: Geology, v. 29, p. 383-386.

Harris, A.C., Allen, C.M., Bryan, S.E., Campbell, I.H., Holcombe, R.J., and Pailn, J.M., 2004, ELA-ICPMS U-Pb zircon geochronology of regional volcanism hosting the Bajo de la Alumbrera $\mathrm{Cu}-\mathrm{Au}$ deposit : Implications for porphyry-related mineralization: Mineralium Deposita, v. 39, p. 46-67.

Reynolds, P., Ravenhurst, C., Zentilli, M., and Lindsay, D., 1998, High precision 40Ar/39Ar dating of two consecutive hydrothermal events in the Chuquicamata porphyry copper system, Chile: Chemical Geology, v. 148p. 45-60.

Sillitoe, R.H., Perelló, José, and Vidal, C.E., eds., 2005, Andean metallogeny: new discoveries, concepts, and updates: Society of Economic Geologists, Special Publication Number 11, 357 p.

Sillitoe, R.H., and Perelló, Jose, 2005, Andean copper province-Tectonomagmatic settings, deposit types, metallogeny, exploration, and discovery, in Hedenquist, J.W., Thompson, J.F.H., Goldfarb, R.J., and Richards, J.P., eds., Economic Geology One Hundredth Anniversary Volume, 1905-2005, Littleton, Colorado, Society of Economic Geologists, p. 845-890.

Singer, D.A., Berger, V.I., and Moring, B.C., 2005, Porphyry copper deposits of the world-Database, map, and grade and tonnage models: U.S. Geological Survey Open-file Report 2005-1060, http://pubs.usgs.gov/of/2005/1060/) 


\section{Appendix II. Presentation of assessment results for each tract}

The assessment results from this study are presented in two principal parts. The first part identifies 26 tracts of land where the geology is permissive for the occurrence of undiscovered porphyry copper deposits of Phanerozoic age to a depth of $1 \mathrm{~km}$ below the Earth's surface. The "Digital Map File" that is part of this publication contains digital shape files and linked attribute tables for each tract at a scale of $1,1000,000$ for use in GIS applications. In addition, plates 1-3 are PDF maps showing in various ways all of the tracts delineated in the Andes together at a scale of 1:4,000,000. Plate 1 shows the ages, discovered deposits, and prospects of the tracts. Plate 2 shows each tract by mean estimated undiscovered copper. Plate 3 shows each tract by density of mean estimated undiscovered copper in metric tons $/ \mathrm{km}^{2}$.

The second part of the assessment results are presented here in appendix II, which consists of tabular and graphical presentations of probabilistic estimates of the numbers of undiscovered deposits, tons of rock, and contained tons of copper, molybdenum, gold, and silver in each tract. Also included are location maps and supporting technical descriptions and rationales for tract delineation and deposit estimation. Results for each tract are presented as independent, separately authored sections in a consistent order and format intended to facilitate use by planners and decisionmakers. Tract labels (e.g., SA01PC) on plates 1-3 are linked to the sections below that describe the assessment results for each tract. Clicking on a tract label will open the PDF version of the report to the corresponding section. Following are brief summaries, in order of appearance, of the types of information presented for each tract:

\section{Description of information presented for each tract}

\section{Tract location map}

The first page is a map showing the tract location and shape together with any discovered deposits and (or) prospects on a cultural base that includes cities, political boundaries, and streams.

\section{Tract title page}

The upper half of the second page serves as a title page and lists: title and authorship; deposit type and model used for the assessment; informal tract name, country location(s), and tract identification (ID) number; region of the world; date of the principal assessment workshop and (or) date of last revision; assessment depth; names of the assessment team leader and regional coordinator, and the members of the team that estimated numbers of undiscovered deposits in the tract. The order in which the names of these estimators are listed does not correspond with that of the estimates in the subsequent table showing estimated numbers of undiscovered deposits in the tract by quantile. This was done intentionally to help encourage objective estimates.

\section{Table of estimated numbers of undiscovered deposits}

Estimated numbers of undiscovered deposits are shown by percentile and are sorted by mean $(m)$. The standard deviation $(s)$ and the coefficient of variation in percent $(C v \%=s / m \times 100)$ also are shown. The standard deviation and coefficient of variation are standard statistical measures of uncertainty and were estimated using equations from Singer and Menzie (2005). There may be slight variations $( \pm 0.1)$ between the means estimated by these equations and by the EMINERS Monte Carlo simulator. Large spreads in the 90-50-10 estimates, and large standard deviations and coefficients of variation, all indicate more uncertainty in the estimates (see table AII-1). 
The estimated numbers of undiscovered deposits for most tracts are the consensus of individual estimates. However, seven tracts in the Andes have consensus estimates only. Estimates for these seven tracts were made by smaller groups of estimators who met after the principal Santiago assessment workshop to clarify geological data, further evaluate areas as more data became available, and discuss the implications of earlier preliminary interpretations. These groups decided that the most acceptable way to begin discussions leading to numerical estimates for each tract was by initially applying the porphyry copper deposit density model of Singer and others (2005). Numbers of undiscovered deposits suggested by this model at the $90^{\text {th }}, 50^{\text {th }}$, and $10^{\text {th }}$ percentiles were evaluated, discussed, modified, and remodified iteratively by the group in relation to the group's collective knowledge of the mineral deposit type and of the mineral resource geology and exploration history for each of the seven tracts. This process continued until consensus estimates were achieved for each tract that were satisfactory to all members of the group.

\section{Deposit density table}

The deposit density table shows the number of discovered deposits, mean of the consensus estimates of the number of undiscovered deposits, total number of deposits, area of the tract, and the deposit density expressed as the total number of deposits per $100,000 \mathrm{~km}^{2}$.

\section{Probability distribution of numbers of undiscovered deposits}

The estimated probability distribution of numbers of undiscovered deposits shown in this graph is calculated by EMINERS' Monte Carlo resource simulator from the team consensus estimates of numbers of undiscovered deposits using the method reported by Root, Menzie, and Scott (1992). Increasing probability means increasing certainty in the estimates.

\section{Histograms of metal and mineralized rock from the EMINERS Monte Carlo simulation}

This is a class-interval histogram showing amounts of metals, and rock containing the metals, in metric tons, for each tract. Each of the 4,999 simulations (iterations) from the Monte Carlo simulator is placed in a bin. The total number of simulations in each bin is shown on the histogram as a proportion of all simulations and emphasizes those amounts of metal and rock.

Cumulative probability distribution of metal and mineralized rock from the EMINERS Monte Carlo simulation

This is a graph of the cumulative probability distribution of metals, and rock containing the metals, in metric tons. It is especially useful because all the information generated by the simulation can be read from this single plot.

\section{Table summarizing the assessment results}

This is a tabular summary showing the estimated amounts of metals and rock containing the metals, in metric tons, at several levels of probability. The table also shows the mean (expected value), the probability of the mean amount or more occurring, and the probability of zero metal. A quantile is a 
number that partitions the values of a frequency distribution into a number of classes, $\mathrm{n}$, each containing the same number of data. A percentile is the value that divides the area of a frequency distribution into specific percentages. The quantiles shown in this table, multiplied by 100 , are equivalent to percentiles (i.e., the 0.90 quantile equals the $90^{\text {th }}$ percentile). These percentiles are defined as the percent chance that at least the indicated amounts of metal are present.

\section{Rationale for tract delineation}

This section explains why the tract boundaries are located where they are and summarizes the tract's geology and why it is permissive. The term "host rocks" as used in this report refers to the volcanic and (or) plutonic rocks formed during a period of approximately coeval arc magmatism judged capable of producing porphyry copper deposits and whose spatial distribution, projected to $1 \mathrm{~km}$ depth, defines a tract boundary. Users are reminded that tract boundaries were defined and drawn at a scale of 1:1 million. Therefore, the boundaries are accurate at this and smaller scales such as 1:1,500,000 or 1:2,000,000, but are not accurate if used at larger scales such as 1:750,000; 1:500,000; or larger.

\section{Rationale for model choice}

This discussion explains why the identified mineral deposit model was chosen to represent the undiscovered deposits in the tract. Typically, this choice is determined by the results of the $t$-tests listed in table 3 and may be supported by general information about the geology, mineralogy, geochemistry, and structure of discovered deposits and prospects in the tract.

\section{Deposits and prospects}

This section lists discovered deposits and prospects known in the tract at the time of the assessment. Relevant features of deposits and prospects that may have influenced the assessment are described as appropriate. Discovered (known) deposits are those reported in the published literature to be well explored in three dimensions, unopen in any direction, and have published tonnages and grades. "Unopen" means that a deposit has been fully delimited by exploration. Explored metal occurrences not meeting these criteria are classified as prospects. Some of these prospects might represent some of the estimated undiscovered deposits.

\section{Exploration history}

This section provides a brief qualitative statement or summary of the assessment team's knowledge of the intensity and extent of coverage of past mineral exploration.

\section{Rationale for numerical estimate}

This section provides a brief summary of the basis and (or) reasoning for the team's estimate of numbers of undiscovered deposits.

\section{Expected distribution of undiscovered deposits}

The information provided in this section is intended to inform users whether or not the assessment team had reason to suspect that the density and (or) probability of occurrence of undiscovered deposits in the tract might vary, and how. This is critical information for decisionmakers and other users when attempting to apportion part(s) of the estimated undiscovered mineral resources to one or more landmanagement areas that intersect or occur within the permissive tract. 


\section{References cited}

This section lists the publications and other sources of data and information used and cited in the tract results and rationale form.

\section{References cited}

Singer, D.A., Berger, V.I., Menzie, W.D., and Berger, B.R., 2005, Porphyry copper density: Economic Geology, v. 100, no. 3, p. 491-514.

Singer, D.A., and Menzie, W.D., 2005, Statistical guides to estimating the number of undiscovered mineral deposits: an example with porphyry copper deposits, in Cheng, Qiuming and Bonham-Carter, Graeme, eds., Proceedings of IAMG - The annual conference of the International Assoc. for Mathematical Geology: Geomatics Research Laboratory, York University, Toronto, Canada, p. 10281033.

\section{Results for each tract}


TRACT SA01PC

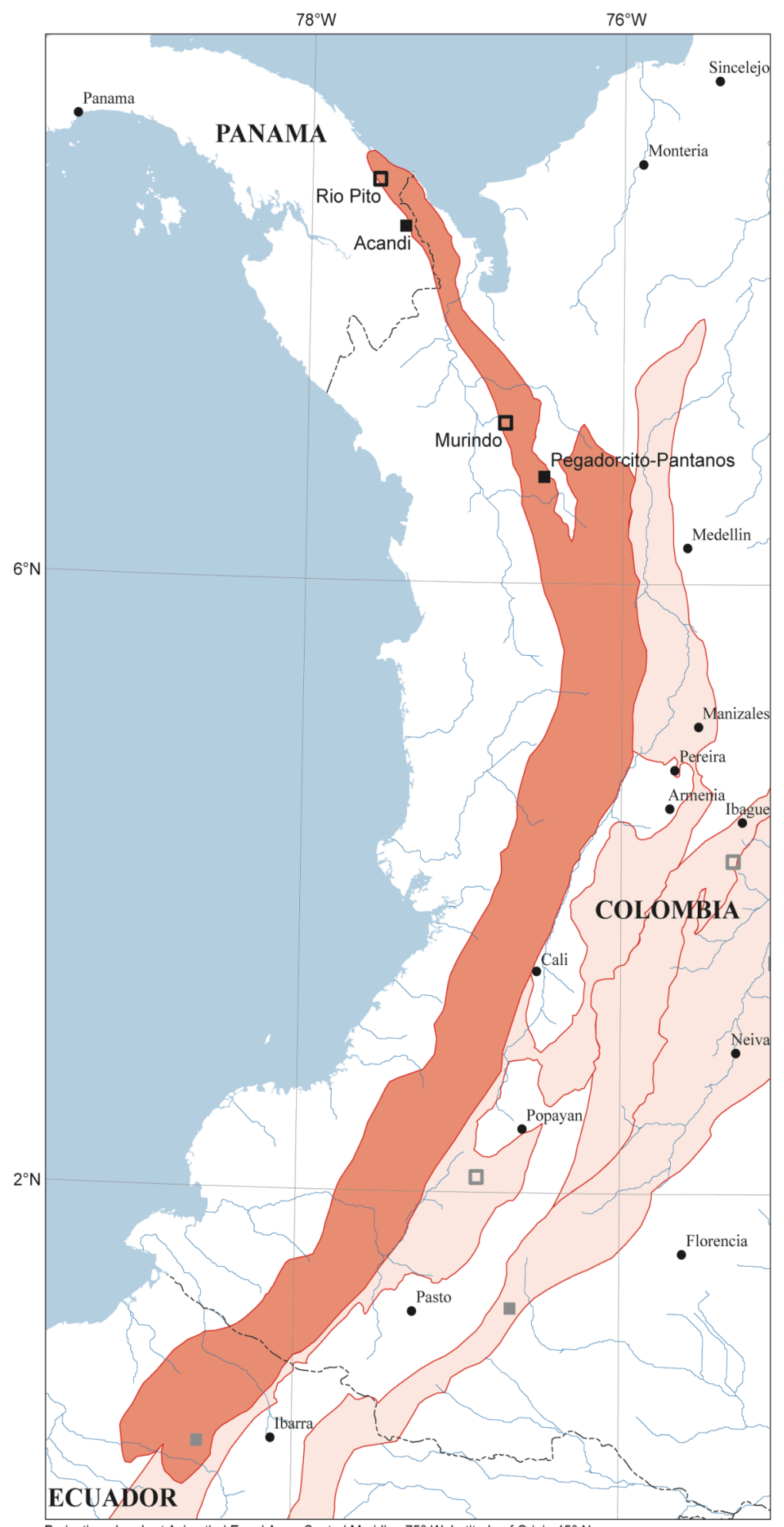

Projection: Lambert Azimuthal Equal Area; Central Meridian $75^{\circ} \mathrm{W}$; Latitude of Origin $45^{\circ} \mathrm{N}$

$0 \quad 50 \quad 100 \quad 150 \quad 200$ KILOMETERS

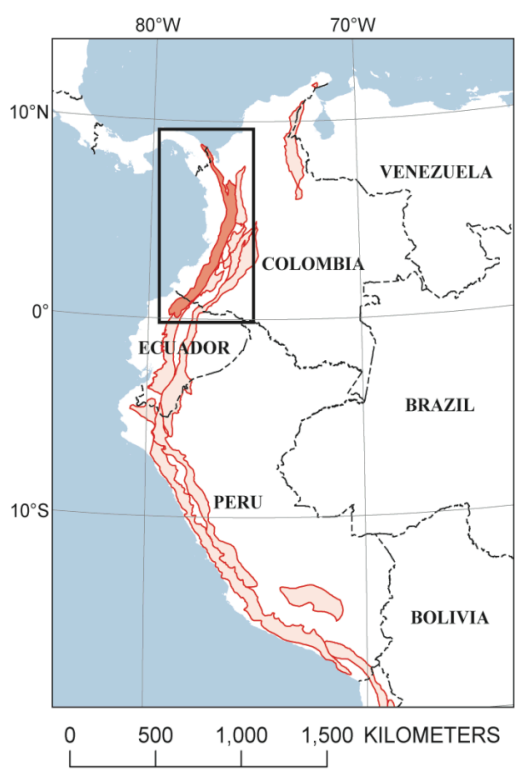

\section{EXPLANATION}

Porphyry copper

Assessed porphyry copper tract

Other porphyry copper tracts

Deposit

- Name of deposit Prospect

口 Name of prospect Deposits and prospects in other tracts are shown in gray

Political boundary (may be indefinite) Stream

- $\quad$ City 


\section{Estimated Undiscovered Porphyry Copper Resources in Tract SA01PC Colombia, Ecuador, and Panama}

Charles G. Cunningham, ${ }^{1}$ Eduardo 0. Zappettini, ${ }^{2}$ Waldo Vivallo S., ${ }^{3}$ Carlos Mario Celada, ${ }^{4}$ Jorge Quispe ${ }^{5}$ Donald A. Singer, ${ }^{1}$ Joseph A Briskey, ${ }^{1}$ David M. Sutphin, ${ }^{1}$ Mariano Gajardo M., ${ }^{3}$ Alejandro Diaz, ${ }^{3}$ Carlos Portigliati, ${ }^{3}$ Vladimir I. Berger, ${ }^{1}$ Rodrigo Carrasco, ${ }^{3}$ and Klaus J. Schulz ${ }^{1}$

'USA-U.S. Geological Survey (USGS)

${ }^{2}$ Argentina - Instituto de Geología y Recursos Minerales (SEGEMAR)

${ }^{3}$ Chile-Servicio Nacional de Geología y Minería (SERNAGEOMIN)
${ }^{4}$ Colombia-Instituto Colombiano de Geología y Minería (INGEOMINAS)

${ }^{5}$ Peru-Instituto Geológico Minero y Metalúrgico (INGEMMET)

\begin{tabular}{|l|l|}
\hline Deposit type assessed: Porphyry copper & $\begin{array}{l}\text { Model: General porphyry copper deposit model } \\
\text { (Singer, Berger, and Moring, 2005) }\end{array}$ \\
\hline $\begin{array}{l}\text { Tract name: Colombia Paleocene-Eocene } \\
\text { Acandi }\end{array}$ & Countries: Colombia, Ecuador, and Panama \\
\hline Tract ID: SA01PC & Region: South America \\
\hline Date of assessment: May 16-18, 2005 & Date of last revision: \\
\hline Assessment depth: $1 \mathrm{~km}$ & \\
\hline Assessment team leader: Donald A. Singer & Regional coordinator: Charles G. Cunningham \\
\hline $\begin{array}{l}\text { Estimators: Carlos Mario Celada, Vladimir I. Berger, Joseph A Briskey, Charles G. Cunningham, } \\
\text { Donald A. Singer, David M. Sutphin, Waldo Vivallo S., and Eduardo O. Zappettini. }\end{array}$ \\
\hline
\end{tabular}

Table of estimated numbers of undiscovered deposits by quantile. Also showing calculated mean $(m)$, standard deviation $(s)$, and coefficient of variation in percent $(C v \%)$. Sorted by mean.

\begin{tabular}{|l|r|r|r|r|c|c|}
\hline \multicolumn{1}{|c|}{ Estimators } & $\mathbf{9 0}$ & $\mathbf{5 0}$ & $\mathbf{1 0}$ & $\boldsymbol{m}$ & $\boldsymbol{s}$ & $\mathbf{C v} \%$ \\
\hline Estimator & 2 & 5 & 10 & 5.5 & 3.0 & 55 \\
\hline Estimator & 3 & 5 & 12 & 6.3 & 3.5 & 56 \\
\hline Estimator & 3 & 8 & 18 & 9.3 & 5.5 & 59 \\
\hline Consensus of estimators & $\mathbf{3}$ & $\mathbf{8}$ & $\mathbf{1 9}$ & $\mathbf{9 . 6}$ & $\mathbf{5 . 9}$ & $\mathbf{6 1}$ \\
\hline Estimator & 5 & 10 & 20 & 11 & 5.6 & 51 \\
\hline Estimator & 4 & 7 & 25 & 11 & 8.0 & 73 \\
\hline Estimator & 4 & 12 & 20 & 12 & 5.6 & 47 \\
\hline Estimator & 2 & 10 & 25 & 12 & 8.2 & 68 \\
\hline Estimator & 4 & 10 & 25 & 12 & 7.7 & 64 \\
\hline
\end{tabular}

\section{Deposit density table}

\begin{tabular}{|c|c|c|c|c|}
\hline $\begin{array}{c}\text { Mean of consensus estimates } \\
\text { of undiscovered deposits }\end{array}$ & $\begin{array}{c}\text { Number of } \\
\text { discovered } \\
\text { deposits }\end{array}$ & $\begin{array}{c}\text { Total number of } \\
\text { deposits }\end{array}$ & Area, $\mathbf{k m}^{\mathbf{2}}$ & $\begin{array}{c}\text { Deposit density, number } \\
\text { of deposits/100,000 } \mathbf{k m}^{2}\end{array}$ \\
\hline $\mathbf{9 . 6}$ & 2 & 12 & 51,613 & 23 \\
\hline
\end{tabular}




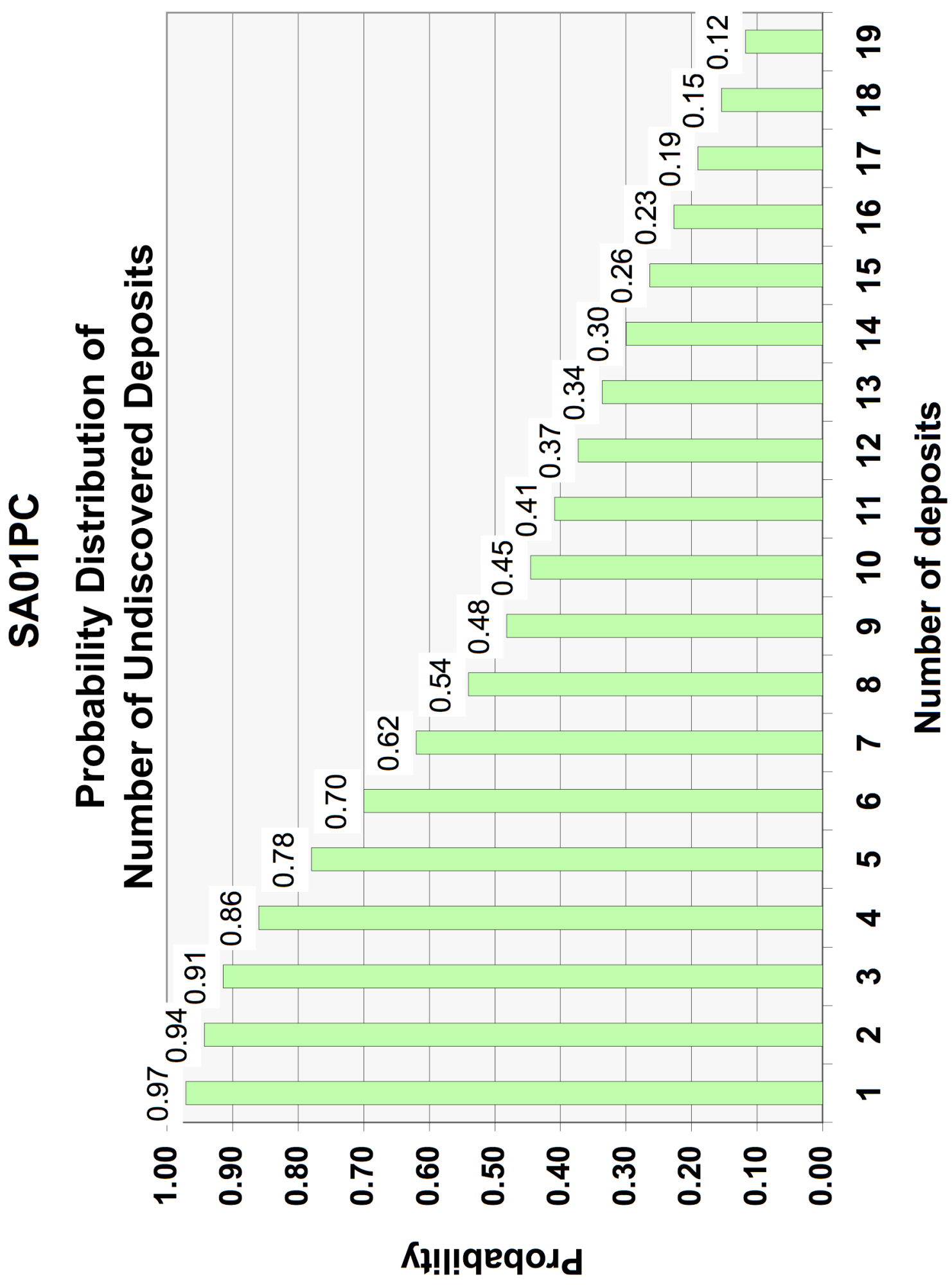




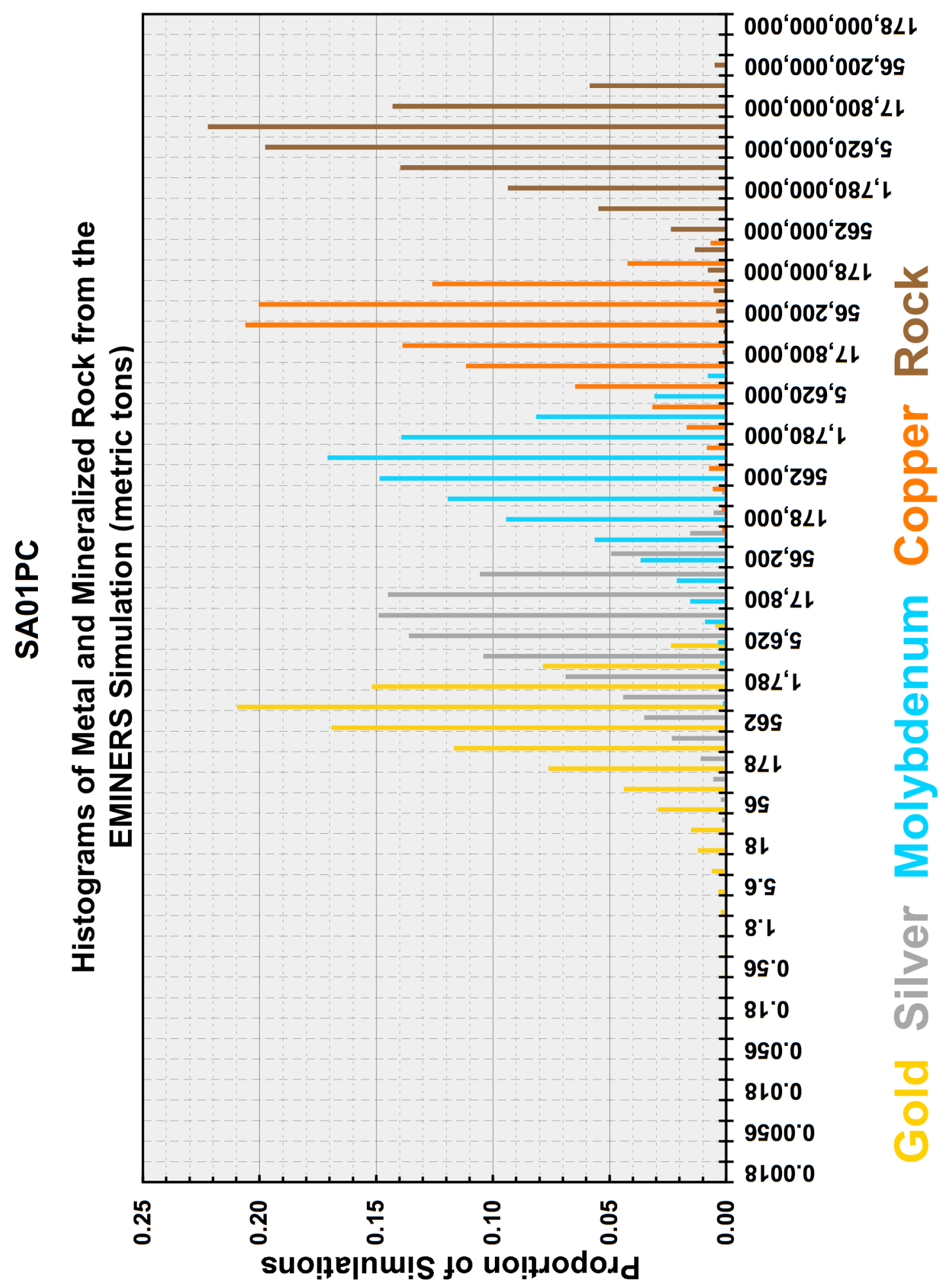




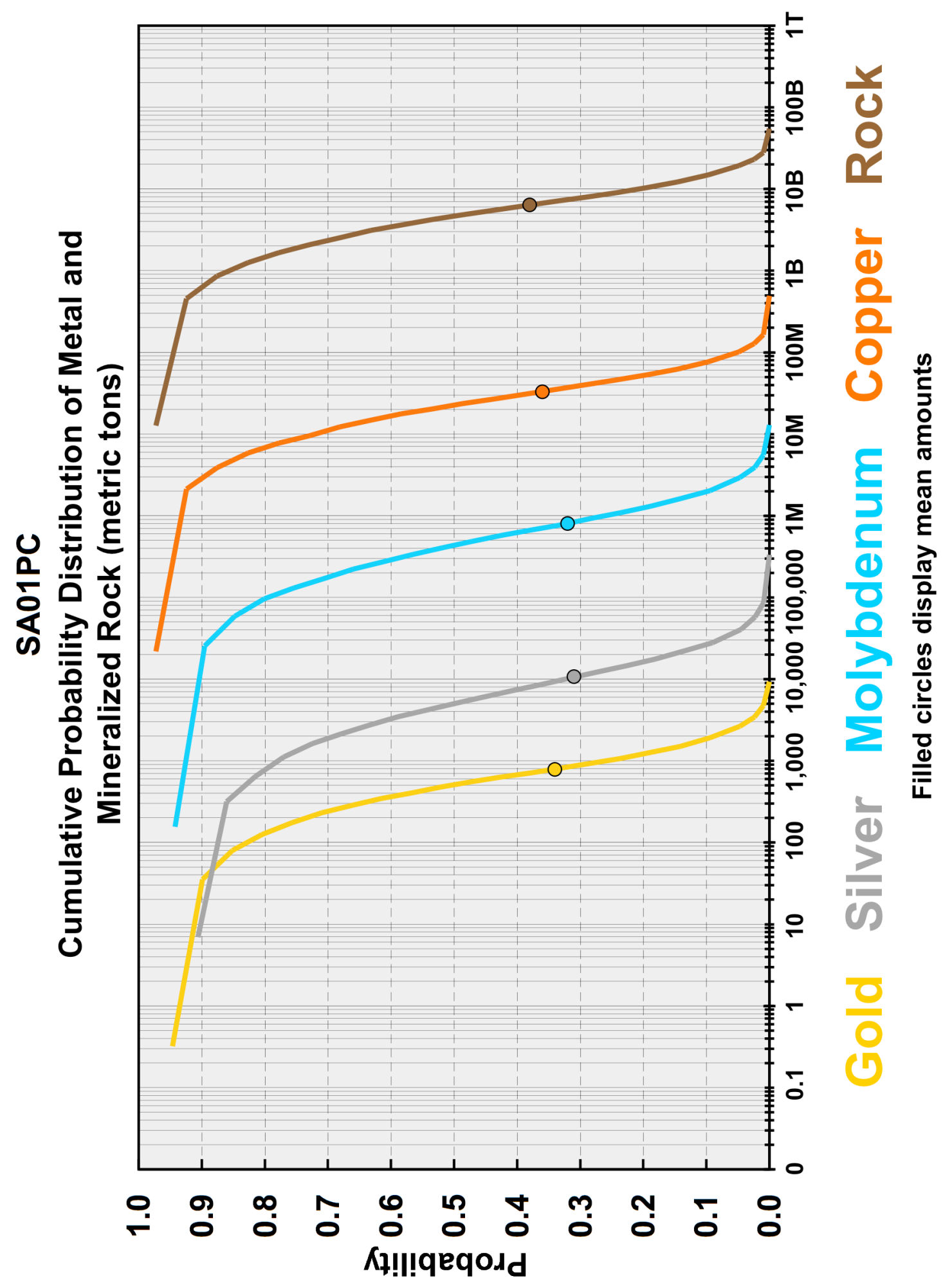




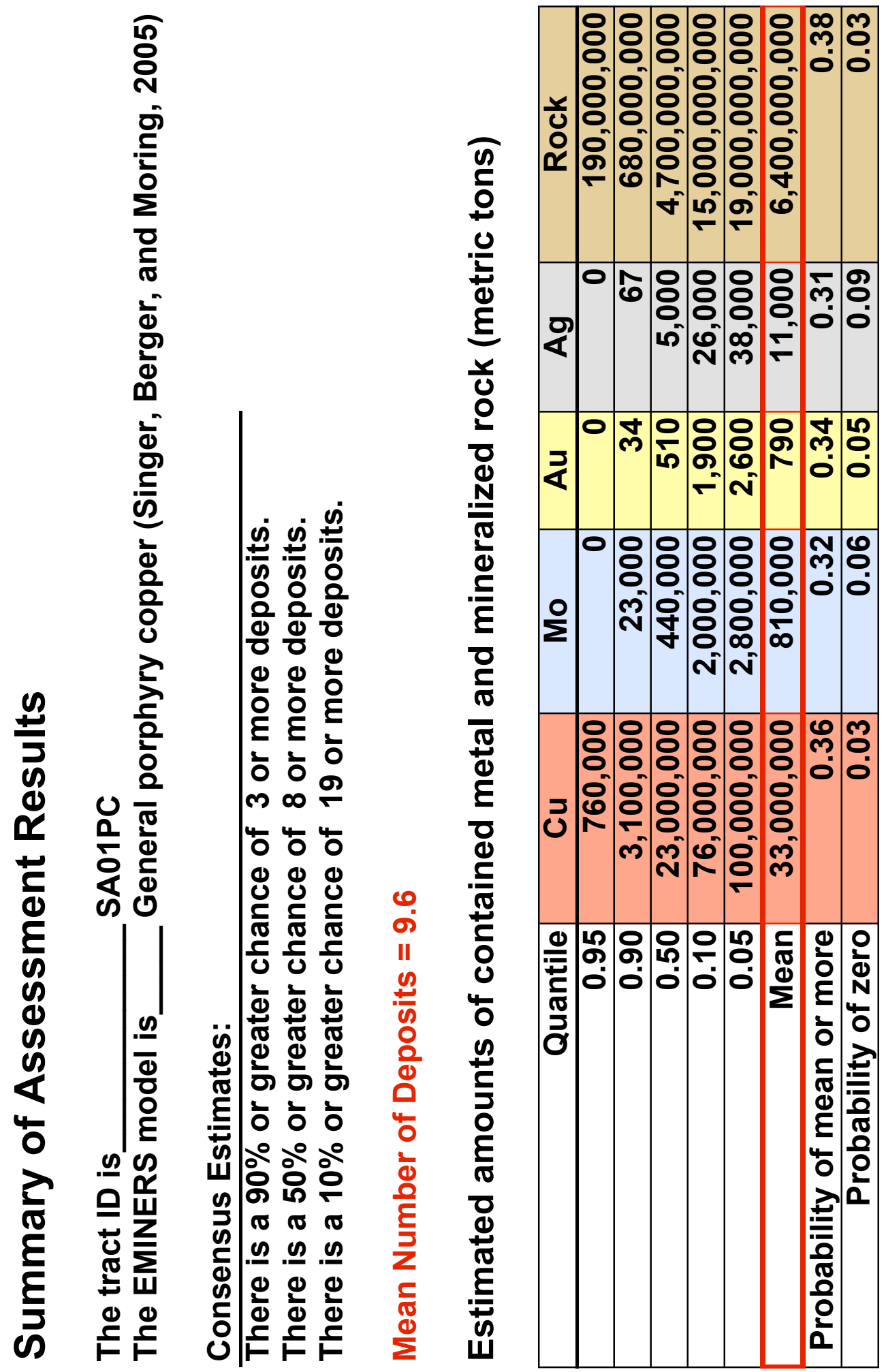




\section{Rationale for tract delineation}

This tract is drawn to encompass Paleocene-Eocene mostly calc-alkaline plutonic host rocks for porphyry copper deposits. It includes plutons of intermediate composition, principally tonalities and granodiorites, of the Mande batholith, together with accompanying basic volcanic rocks with interlayered sedimentary rocks. The tract extends a short distance into Panama to include the northern part of the Acandi batholith, together with several small outliers to the northwest, and the associated Rio Pito prospect. The tract is the westernmost tract in Colombia and coincides with the western cordillera of the country. The tract extends south into Ecuador and ends just northwest of Quito where it includes the Eocene Santiago batholith, which is composed of granodiorites, diorite, and porphyritic plutonic rocks. Also included in the tract are (1) projections of host rocks beneath areas of post-mineralization cover rock where the team believed the thickness of cover is less than $1 \mathrm{~km}$, and (2) some areas of volcanic and other country rocks beneath which unexposed plutonic host rocks are likely to occur within $1 \mathrm{~km}$ of the surface. Approximately 30 percent of the tract is covered by post-mineralization-age shallow-water marine sandstones and conglomerates of Oligocene to Pliocene age. Much of the country rocks are immature Cretaceous-early Tertiary island-arc rocks deposited on oceanic crust (Sillitoe, 1982). The host rocks in the tract were thus emplaced in an oceanic domain and overlie an ophiolitic basement (Sillitoe and others, 1982). The northeast edge of the tract is bordered by a thick section of deltaic sediments.

\section{Rationale for model choice}

The size and grades of the discovered porphyry copper deposits in the tract are not significantly different (table 3) from the general porphyry copper deposit model (Singer, Berger, and Moring, 2005), which therefore was used to represent the undiscovered deposits. The discovered deposits have geologic features typical of porphyry copper deposits. Potassium silicate and sericitic alteration is associated with the porphyry copper prospects and supergene alteration is minor.

\section{Deposits and prospects}

There are two discovered deposits, Acandi (38 Ma) and Pegadorcito-Pantanos (43 Ma). The date for Acandi is a recent one provided by Carlos Mario Celada (oral commun., 2005). Two prospects were considered during the assessment: Murinado (55 Ma) and Rio Pito (49 Ma). The Rio Andagueda and the Piedrancha prospects in Colombia were not considered. Neither were several additional prospects identified later during the review process, including Piedrancha (JICA-INGEOMINAS, 1983), Patascoy (Naciones Unidas, 1981), Pisno (Orrego, 1977), Andágueda River (Chakrabarti and Durango, 1979), and Arboledas, all of which are within or adjacent to defined tracts.

\section{Exploration history}

The tract is moderately explored. A stream sediment geochemical study was conducted across the northern part of the tract. First-order streams were sampled along northeast-trending transects spaced 20 km apart (INGEOMINAS-Naciones Unidas, 1977; Nacioues Unidas, 1981). A moderate amount of the area is composed of exposed plutonic rocks permissive for the formation of porphyry copper deposits and much of the country rocks conceal others. The tract is only about 70 percent explored at the surface and poorly explored at depth. Additional sources of information about deposits and prospects in the tract include Hodges and others, 1984, and Mpodozis and Ramos, 1990.

\section{Rationale for numerical estimate}

Members of the assessment team used their collective knowledge of numbers of discovered deposits in the tract and (or) in similar areas elsewhere in the world to make estimates throughout the tract 
that also were consistent with the deposit density model of Singer and others (2005). A number of features suggested the probable occurrence of a relatively large number of undiscovered deposits. The mineralizing processes that form porphyry copper deposits were active in the host rocks producing both deposits and prospects in this relatively large tract. The level of erosion is sufficient to bring many deposits relatively close to the surface without removing most of them. About 30 percent of the tract is unexplored where covered by younger rocks. Finally, while about 70 percent of the tract has been explored at the surface, this part is poorly explored at depth.

\section{Expected distribution of undiscovered deposits}

The probability of occurrence of an undiscovered deposit is believed to be reasonably uniform throughout the tract except beneath areas of younger cover rocks where the potential is higher because these areas are unexplored. In addition, undiscovered deposits might be somewhat more likely to occur just west of the westernmost indicated edge of the buried Precambrian craton.

\section{References cited}

Chakrabarti, A.K., and Durango, J.R., 1979, Geology and geochemistry of the Rio Andágueda porphyry copper prospect, Choco, western Colombia: INGEOMINAS, Internal report I-1806, 137 p., Bogotá.

Hodges, C.A., Cox, D.P., Singer, D.A., Case, J.E., Berger, B.R., and Albers, J.P., 1984, U.S. Geological Survey-INGEOMINAS mineral resource assessment of Colombia: U.S. Geological Survey Open-File Report 84-345, 348 p.

INGEOMINAS-Naciones Unidas, 1977, Proyecto de metales basicos en las Cordilleras Central y Occidental. Informe Técnico: Prepared for the Government of Colombia: New York, United Nations, $82 \mathrm{p}$.

JICA - INGEOMINAS, 1983, Report on a geological survey of the Piedrancha area: INGEOMINAS, Consolidated report phases I, II and III. Internal Report I-2268. Bogotá.

Mpodozis, Constanino, and Ramos, Victor, 1990, The Andes of Chile and Argentina, in Ericksen, G.E., Cañas Pinochet, Maria Teresa, and Reinemund, J.A., eds., Geology of the Andes and its relation to hydrocarbon and mineral resources: Circum-Pacific Council for Energy and Mineral Resources, Houston, Texas, p. $59-90$.

Naciones Unidas, 1981, Mineralización en la zona del Patascoy, Intendencia del Putumayo, Colombia: Informe Interno D-40, Bogotá.

Orrego, A., 1977, Geología y geoquímica del area mineralazada El Pisno, Cauca - Colombia: INGEOMINAS Internal Report I-1747, Bogotá.

Sillitoe, R.H., 1982, Epochs of intrusion-related copper mineralization in the Andes: Journal of South American Earth Sciences, v. 1, no. 1, p. 89-107.

Sillitoe, R.H., Jaramillo, Luis, Damon, P.E., Shafiquillah, Muhammed, and Escobar, Ricardo, 1982, Setting, characteristics, and age of the Andean porphyry copper belt in Colombia: Economic Geology, v. 77, p. 1837-1850.

Singer, D.A., Berger, V.I., Menzie, W.D., and Berger, B.R., 2005, Porphyry copper density: Economic Geology, v. 100, no. 3, p. 491-514.

Singer, D.A., Berger, V.I., and Moring, B.C., 2005, Porphyry copper deposits of the world-Database, map, and grade and tonnage models: U.S. Geological Survey Open-file Report 2005-1060, http://pubs.usgs.gov/of/2005/1060/) 


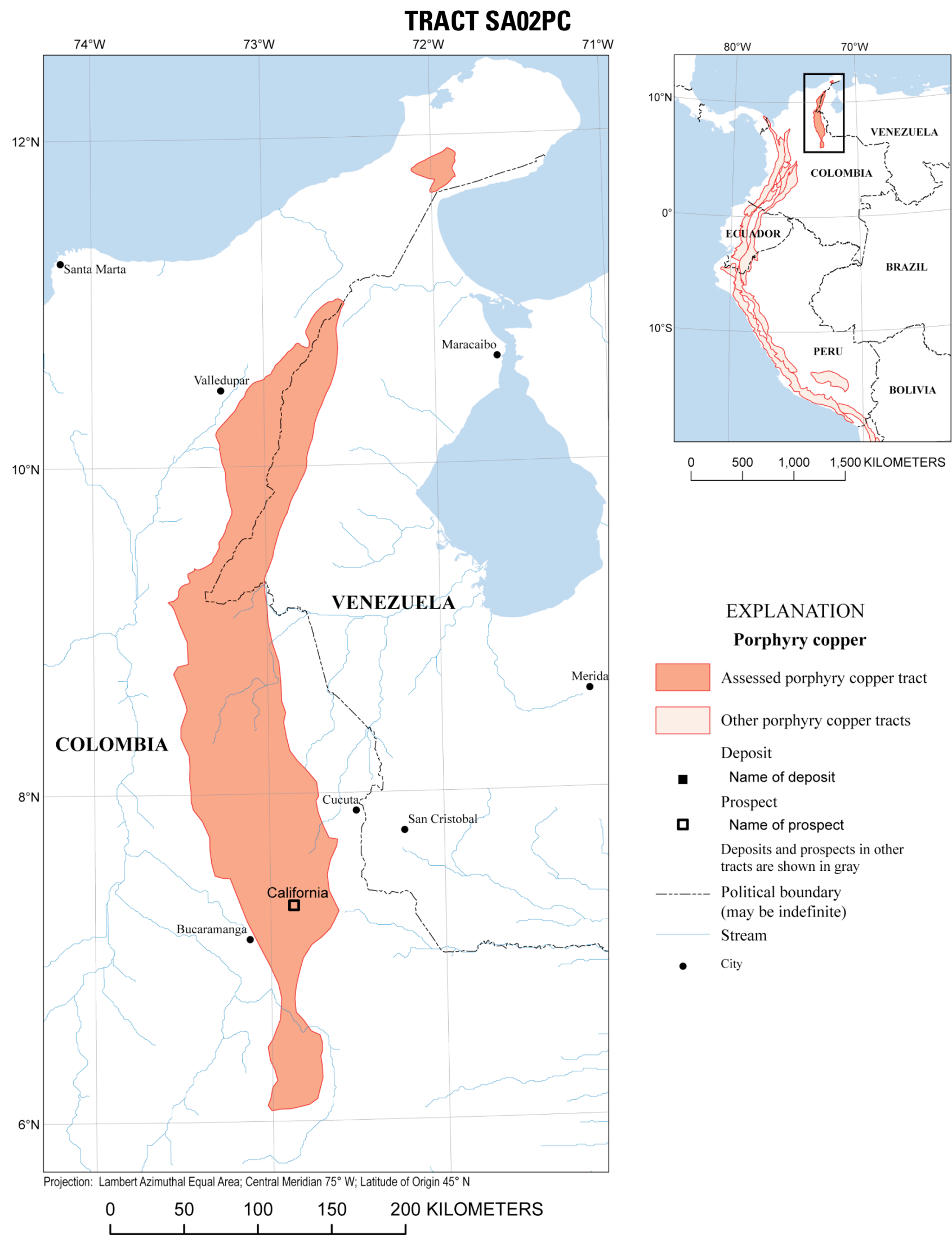




\section{Estimated Undiscovered Porphyry Copper Resources in Tract SA02PC- Colombia and Venezuela}

Charles G. Cunningham, ${ }^{1}$ Eduardo 0. Zappettini, ${ }^{2}$ Waldo Vivallo S., ${ }^{3}$ Carlos Mario Celada, ${ }^{4}$ Jorge Quispe, ${ }^{5}$ Donald A. Singer, ${ }^{1}$ Joseph A Briskey, ${ }^{1}$ David M. Sutphin, ${ }^{1}$ Mariano Gajardo M., ${ }^{3}$ Alejandro Diaz, ${ }^{3}$ Carlos Portigliati, ${ }^{3}$ Vladimir I. Berger, ${ }^{1}$ Rodrigo Carrasco, ${ }^{3}$ and Klaus J. Schulz ${ }^{1}$

'USA-U.S. Geological Survey (USGS)

${ }^{2}$ Argentina-Instituto de Geología y Recursos Minerales (SEGEMAR)

${ }^{3}$ Chile-Servicio Nacional de Geología y Minería (SERNAGEOMIN)
${ }^{4}$ Colombia-Instituto Colombiano de Geología y Minería (INGEOMINAS)

${ }^{5}$ Peru-Instituto Geológico Minero y Metalúrgico (INGEMMET)

\begin{tabular}{|l|l|}
\hline Deposit type assessed: Porphyry Copper & $\begin{array}{l}\text { Model: General porphyry copper deposit model } \\
\text { (Singer, Berger, and Moring, 2005) }\end{array}$ \\
\hline Tract name: Colombia Jurassic California & Countries: Colombia and Venezuela \\
\hline Tract ID: SA02PC & Region: South America \\
\hline Date of assessment: May 16-18, 2005 & Date of last revision: \\
\hline Assessment depth: 1 km & \\
\hline Assessment team leader: Donald A. Singer & Regional coordinator: Charles G. Cunningham \\
\hline $\begin{array}{l}\text { Estimators: Carlos Mario Celada, Vladimir I. Berger, Joseph A Briskey, Charles G. Cunningham, } \\
\text { Donald A. Singer, David M. Sutphin, Waldo Vivallo S., and Eduardo O. Zappettini. }\end{array}$ \\
\hline
\end{tabular}

Table of estimated numbers of undiscovered deposits by quantile. Also showing calculated mean $(\mathrm{m})$, standard deviation $(s)$, and coefficient of variation in percent $(\mathrm{Cv} \%)$. Sorted by mean.

\begin{tabular}{|l|c|c|c|c|c|c|}
\hline \multicolumn{1}{|c|}{ Estimators } & $\mathbf{9 0}$ & $\mathbf{5 0}$ & $\mathbf{1 0}$ & $\boldsymbol{m}$ & $\boldsymbol{s}$ & $\mathbf{C v} \%$ \\
\hline Estimator & 0 & 2 & 3 & 1.7 & 1.1 & 65 \\
\hline Estimator & 1 & 2 & 3 & 1.9 & 0.84 & 44 \\
\hline Estimator & 0 & 2 & 4 & 2.0 & 1.5 & 75 \\
\hline Estimator & 1 & 2 & 4 & 2.2 & 1.2 & 55 \\
\hline Estimator & 1 & 2 & 4 & 2.2 & 1.2 & 55 \\
\hline Estimator & 1 & 3 & 3 & 2.3 & 0.74 & 32 \\
\hline Consensus of estimators & $\mathbf{1}$ & $\mathbf{3}$ & $\mathbf{5}$ & $\mathbf{2 . 9}$ & $\mathbf{1 . 5}$ & $\mathbf{5 2}$ \\
\hline Estimator & 1 & 4 & 7 & 3.9 & 2.2 & 56 \\
\hline Estimator & 1 & 4 & 8 & 4.2 & 2.5 & 60 \\
\hline
\end{tabular}

\section{Deposit density table}

\begin{tabular}{|c|c|c|c|c|}
\hline $\begin{array}{l}\text { Mean of consensus estimates } \\
\text { of undiscovered deposits }\end{array}$ & $\begin{array}{l}\text { Number of } \\
\text { discovered } \\
\text { deposits }\end{array}$ & $\begin{array}{c}\text { Total number of } \\
\text { deposits }\end{array}$ & Area, km² & $\begin{array}{r}\text { Deposit density, number } \\
\text { of deposits } / 100,000 \mathrm{~km}^{2}\end{array}$ \\
\hline 2.9 & 0 & 2.9 & 26,631 & 11 \\
\hline
\end{tabular}




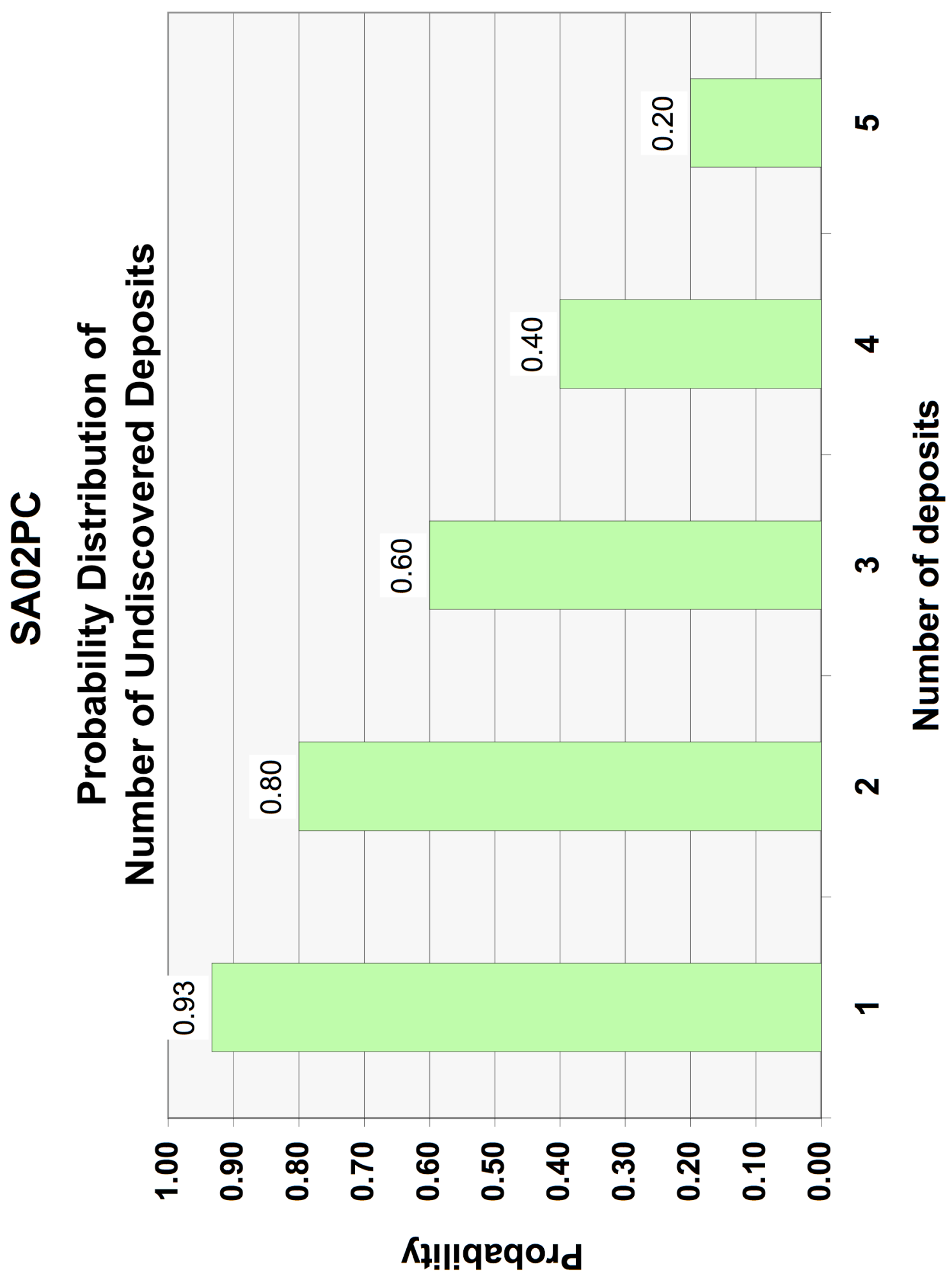




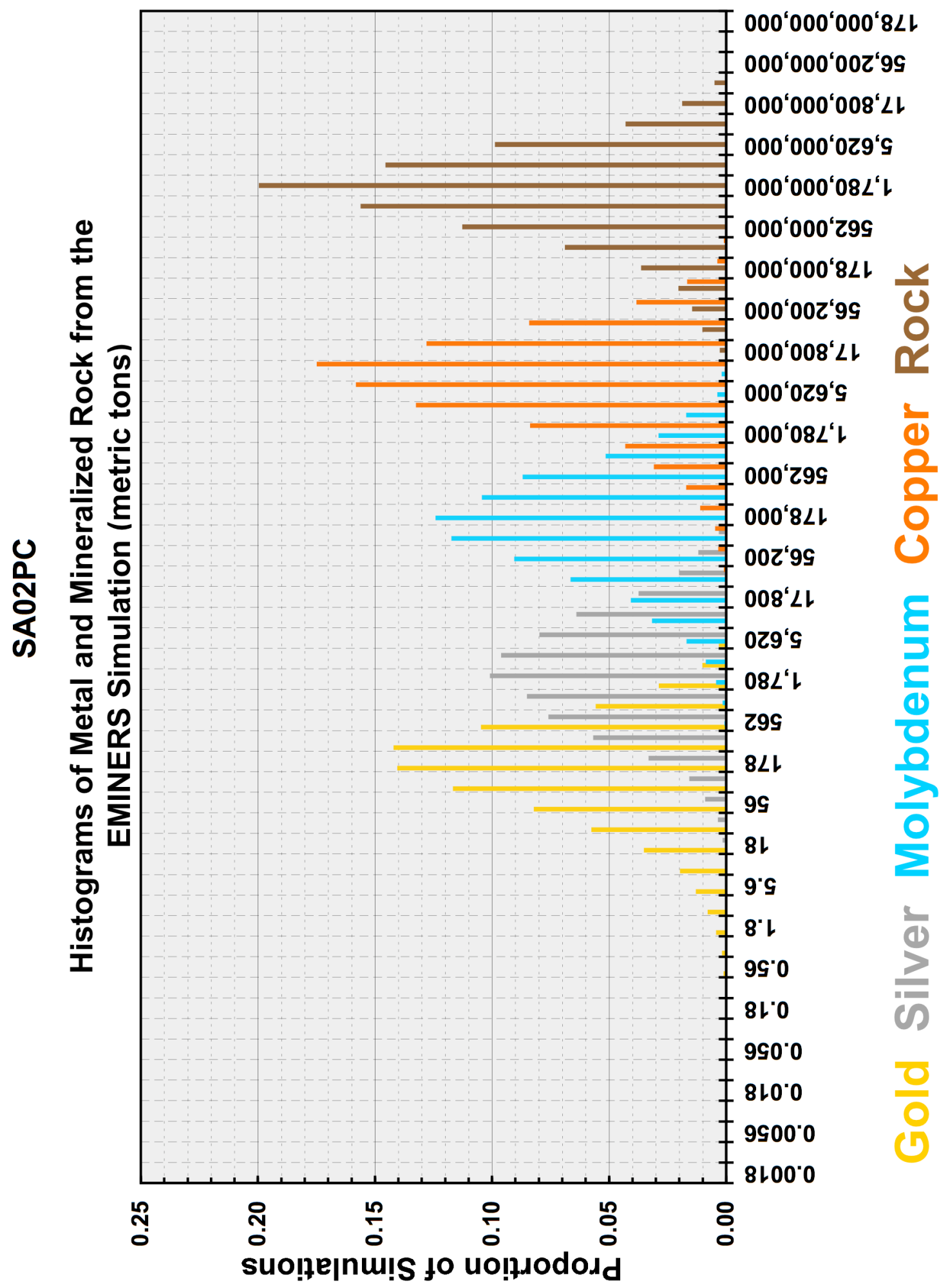




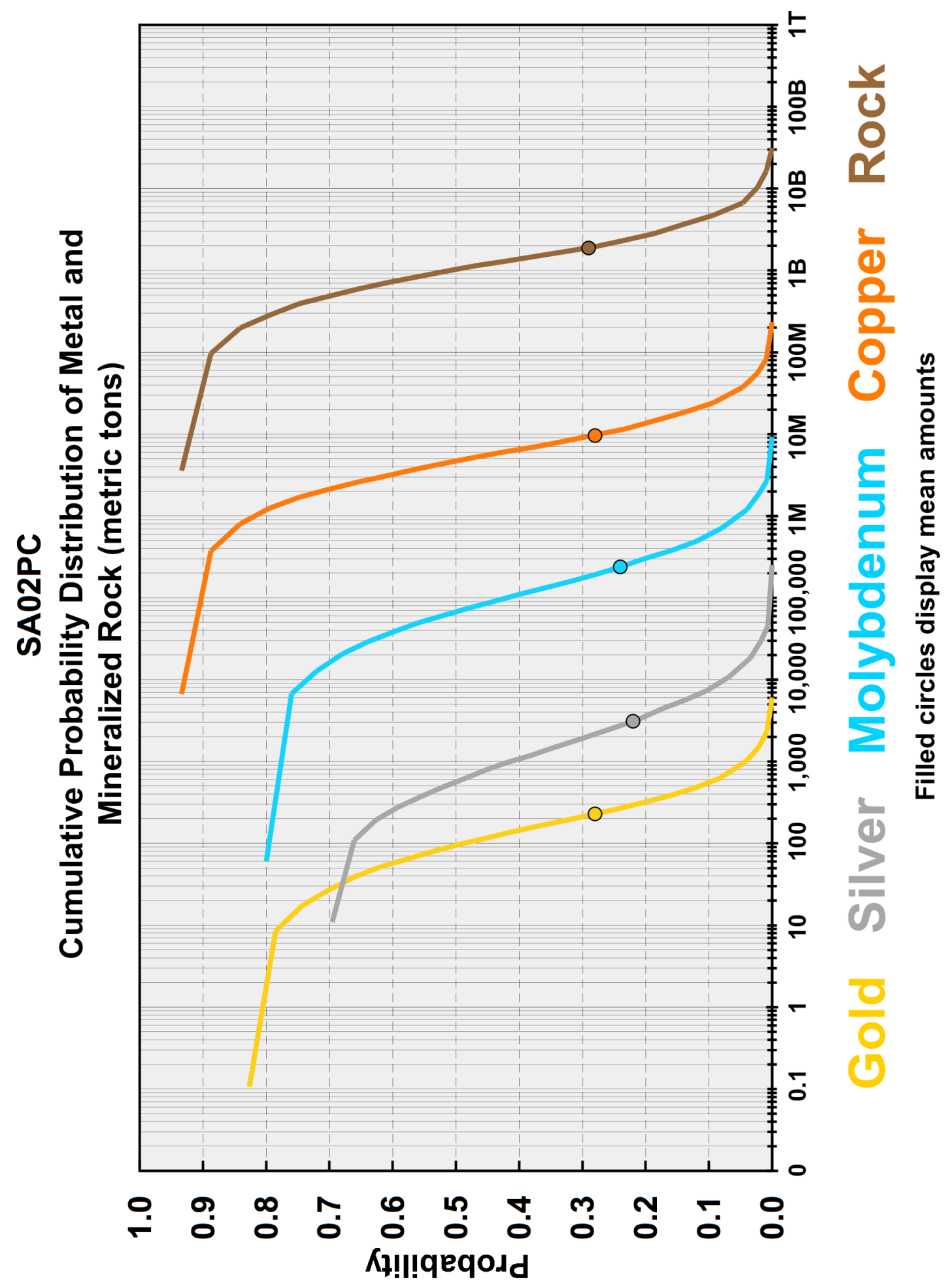




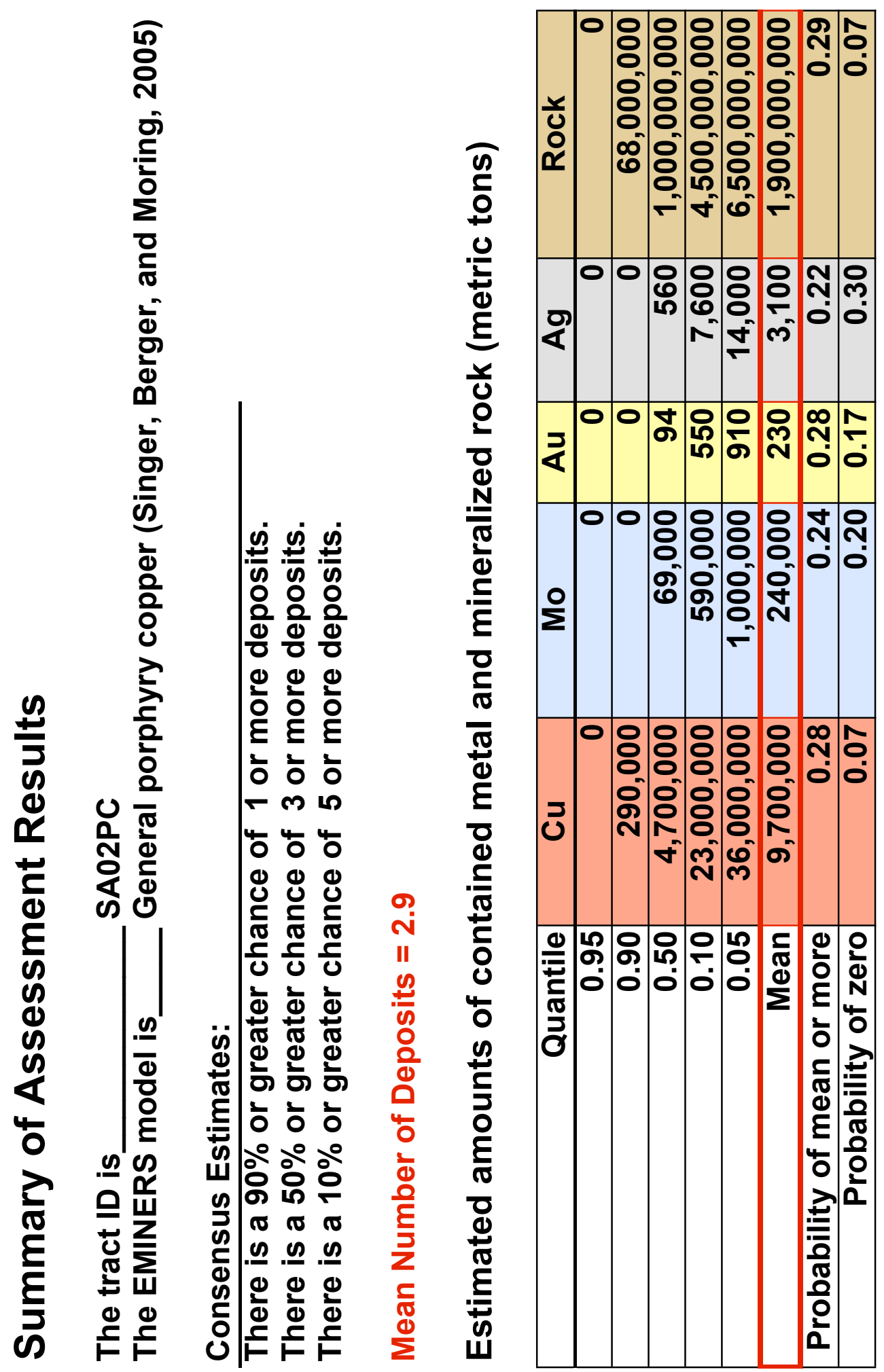




\section{Rationale for tract delineation}

This tract, the northernmost defined in the Andes, has two parts. It includes a small area in northern Colombia that contains rocks similar to those in the larger area to the south but has no known indications of porphyry-copper-style mineralization. The tract is located on continental crust and is defined by the distribution, projected to $1 \mathrm{~km}$ depth, of mainly Late Jurassic rhyolitic to intermediate composition volcanic rocks, principally trachytes, rhyolites, and andesites (Sillitoe and others, 1982), and their subordinate plutonic equivalents. Information on the ages and general chemistry of these rocks, together with the tectonic history of the region, makes the tract permissive for the occurrence of porphyry copper deposits. Country rocks consist mainly of Triassic silicic plutonic rocks and Precambrian and Paleozoic metasedimentary rocks. The Triassic plutonic rocks appear to be extension related and so were judged not permissive. Younger cover rocks, principally Jurassic and Cretaceous epicontinental sedimentary rocks, comprise less than about 10 percent of the tract. Cratonic Precambrian gneisses are present in the Santander Massif. The tract is bounded on the southwest side by a thick sequence of fluvial, lacustrine, and volcaniclastic rocks whereas the west and east sides are bounded by major regional faults. A short section of the eastern boundary of the small northern area extends under water.

\section{Rationale for model choice}

Because the tract contains no discovered deposits, and there was no reason to reject the general porphyry copper deposit model (Singer, Berger, and Moring, 2005), this model was used to represent the undiscovered deposits. The one prospect identified in the tract has geologic features typical of porphyry copper deposits.

\section{Deposits and prospects}

One prospect, California, is dated at $144 \mathrm{Ma}$ and appears to be a high-sulfidation type with alunite, enargite, and hydrothermal breccias (Sillitoe and others, 1982).

\section{Exploration history}

To the best of the team's knowledge, the area is almost completely unexplored and is not extensively prospected.

\section{Rationale for numerical estimate}

Analogies with numbers of deposits known in similar areas that team members have studied elsewhere, together with reference to the deposit density model of Singer and others (2005), helped guide the estimates of undiscovered porphyry copper deposits in the tract. Although the tract is not well explored, access is good and there is relatively little cover by younger rocks and sediments approximately 90 percent of the permissive host rocks, and their country rocks, are exposed. Consequently, estimators were surprised that only one prospect is known and they estimated a relatively small number of undiscovered deposits.

\section{Expected distribution of undiscovered deposits}

Based on available geological, geophysical, and exploration information, the assessment team knows no reason why the probability of occurrence of an undiscovered deposit would not be reasonably uniform throughout the tract. 


\section{References cited}

Sillitoe, R.H., Jaramillo, Luis, Damon, P.E., Shafiquillah, Muhammed, and Escobar, Ricardo, 1982, Setting, characteristics, and age of the Andean porphyry copper belt in Colombia: Economic Geology, v. 77, p. 1837-1850.

Singer, D.A., Berger, V.I., Menzie, W.D., and Berger, B.R., 2005, Porphyry copper density: Economic Geology, v. 100, no. 3, p. 491-514.

Singer, D.A., Berger, V.I., and Moring, B.C., 2005, Porphyry copper deposits of the world-Database, map, and grade and tonnage models: U.S. Geological Survey Open-file Report 2005-1060, http://pubs.usgs.gov/of/2005/1060/) 


\section{TRACT SA03PC}
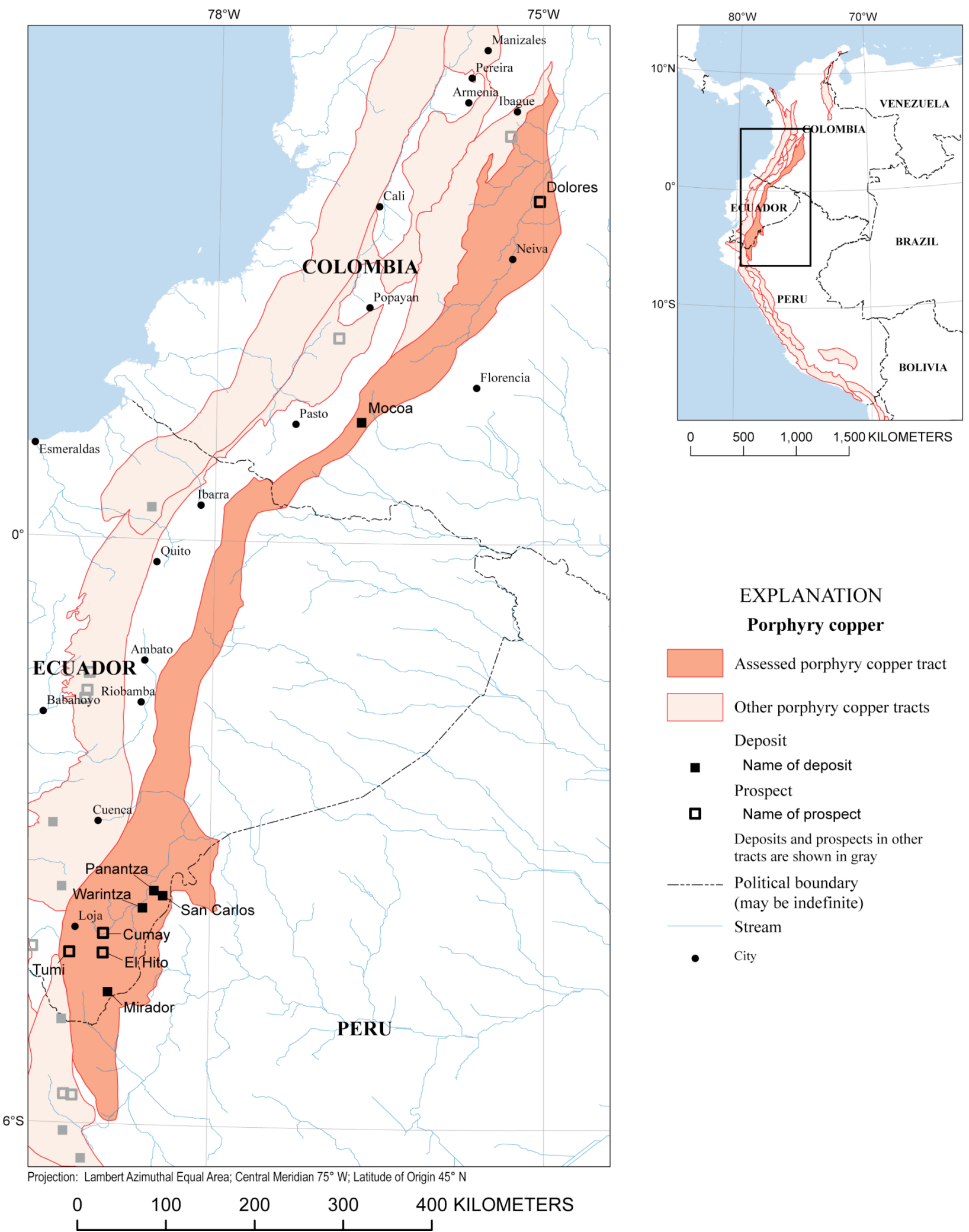

\section{EXPLANATION}

Porphyry copper

Assessed porphyry copper tract

Other porphyry copper tracts

Deposit

- Name of deposit

Prospect

口 Name of prospect

Deposits and prospects in other tracts are shown in gray

Political boundary (may be indefinite) Stream

- $\quad$ City 


\section{Estimated Undiscovered Porphyry Copper Resources in Tract SA03PC- Colombia, Ecuador, and Peru}

Charles G. Cunningham, ${ }^{1}$ Eduardo 0. Zappettini, ${ }^{2}$ Waldo Vivallo S., ${ }^{3}$ Carlos Mario Celada, ${ }^{4}$ Jorge Quispe, ${ }^{5}$ Donald A. Singer, ${ }^{1}$ Joseph A Briskey, ${ }^{1}$ David M. Sutphin, ${ }^{1}$ Mariano Gajardo M., ${ }^{3}$ Alejandro Diaz, ${ }^{3}$ Carlos Portigliati, ${ }^{3}$ Vladimir I. Berger, ${ }^{1}$ Rodrigo Carrasco, ${ }^{3}$ and Klaus J. Schulz ${ }^{1}$

'USA-U.S. Geological Survey (USGS)

${ }^{2}$ Argentina - Instituto de Geología y Recursos Minerales (SEGEMAR)

${ }^{3}$ Chile-Servicio Nacional de Geología y Minería (SERNAGEOMIN)
${ }^{4}$ Colombia-Instituto Colombiano de Geología y Minería (INGEOMINAS)

${ }^{5}$ Peru-Instituto Geológico Minero y Metalúrgico (INGEMMET)

\begin{tabular}{|l|l|}
\hline Deposit type assessed: Porphyry Copper & $\begin{array}{l}\text { Model: General porphyry copper deposit model } \\
\text { (Singer, Berger, and Moring, 2005) }\end{array}$ \\
\hline $\begin{array}{l}\text { Tract name: Colombia-Ecuador-Peru Jurassic } \\
\text { San Carlos }\end{array}$ & Countries: Colombia, Ecuador, and Peru \\
\hline Tract ID: SA03PC & Region: South America \\
\hline Date of assessment: May 16-18, 2005 & Date of last revision: \\
\hline Assessment depth: 1 km & Regional coordinator: Charles G. Cunningham \\
\hline Assessment team leader: Donald A. Singer & $\begin{array}{l}\text { Estimators: Carlos Mario Celada, Vladimir I. Berger, Joseph A Briskey, Charles G. Cunningham, } \\
\text { Mariano Gajardo M., Donald A. Singer, David M. Sutphin, Waldo Vivallo S., and Eduardo O. Zappettini. }\end{array}$ \\
\hline
\end{tabular}

Table of estimated numbers of undiscovered deposits by quantile. Also showing calculated mean $(m)$, standard deviation $(s)$, and coefficient of variation in percent $(C v \%)$. Sorted by mean.

\begin{tabular}{|l|c|c|c|c|c|c|}
\hline \multicolumn{1}{|c|}{ Estimators } & $\mathbf{9 0}$ & $\mathbf{5 0}$ & $\mathbf{1 0}$ & $\boldsymbol{m}$ & $\boldsymbol{s}$ & $\mathbf{C v} \%$ \\
\hline Estimator & 5 & 5 & 11 & 6.5 & 2.6 & 40 \\
\hline Estimator & 5 & 9 & 14 & 9.0 & 3.4 & 38 \\
\hline Estimator & 5 & 9 & 20 & 11 & 5.7 & 52 \\
\hline Estimator & 5 & 10 & 20 & 11 & 5.6 & 51 \\
\hline Estimator & 5 & 10 & 20 & 11 & 5.6 & 51 \\
\hline Consensus of estimators & $\mathbf{6}$ & $\mathbf{1 1}$ & $\mathbf{2 0}$ & $\mathbf{1 2}$ & $\mathbf{5 . 3}$ & $\mathbf{4 4}$ \\
\hline Estimator & 8 & 12 & 20 & 13 & 4.7 & 36 \\
\hline Estimator & 8 & 14 & 20 & 13 & 4.5 & 35 \\
\hline Estimator & 8 & 15 & 25 & 15 & 6.3 & 42 \\
\hline Estimator & 8 & 15 & 30 & 17 & 8.2 & 48 \\
\hline
\end{tabular}

\section{Deposit density table}

\begin{tabular}{|c|c|c|c|c|}
\hline $\begin{array}{c}\text { Mean of consensus estimates } \\
\text { of undiscovered deposits }\end{array}$ & $\begin{array}{c}\text { Number of } \\
\text { discovered } \\
\text { deposits }\end{array}$ & $\begin{array}{c}\text { Total number of } \\
\text { deposits }\end{array}$ & Area, $\mathbf{~ m m}^{\mathbf{2}}$ & $\begin{array}{c}\text { Deposit density, number } \\
\text { of deposits/100,000 } \mathbf{k m}^{2}\end{array}$ \\
\hline $\mathbf{1 2}$ & 5 & 17 & 67,709 & 25 \\
\hline
\end{tabular}




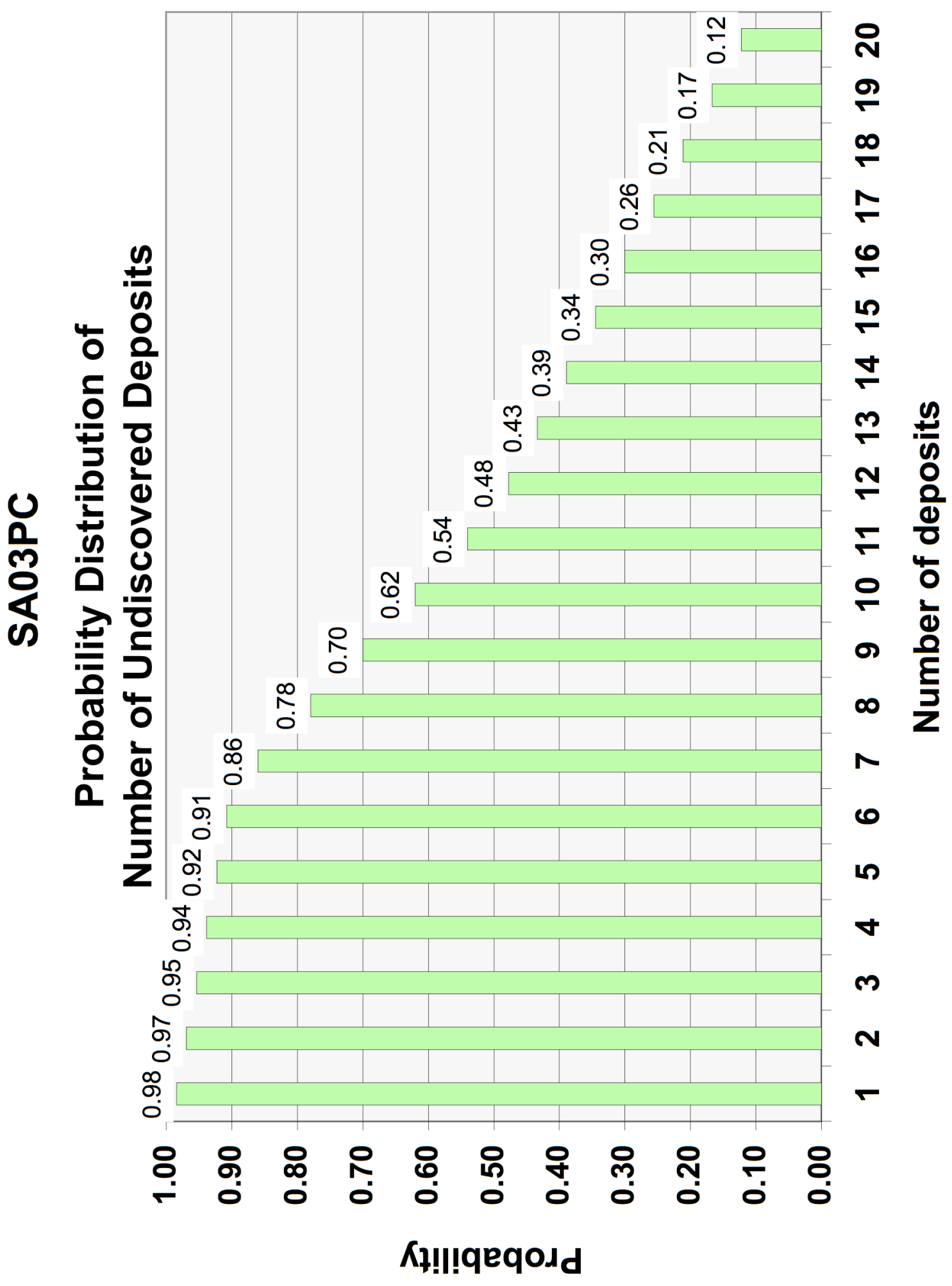




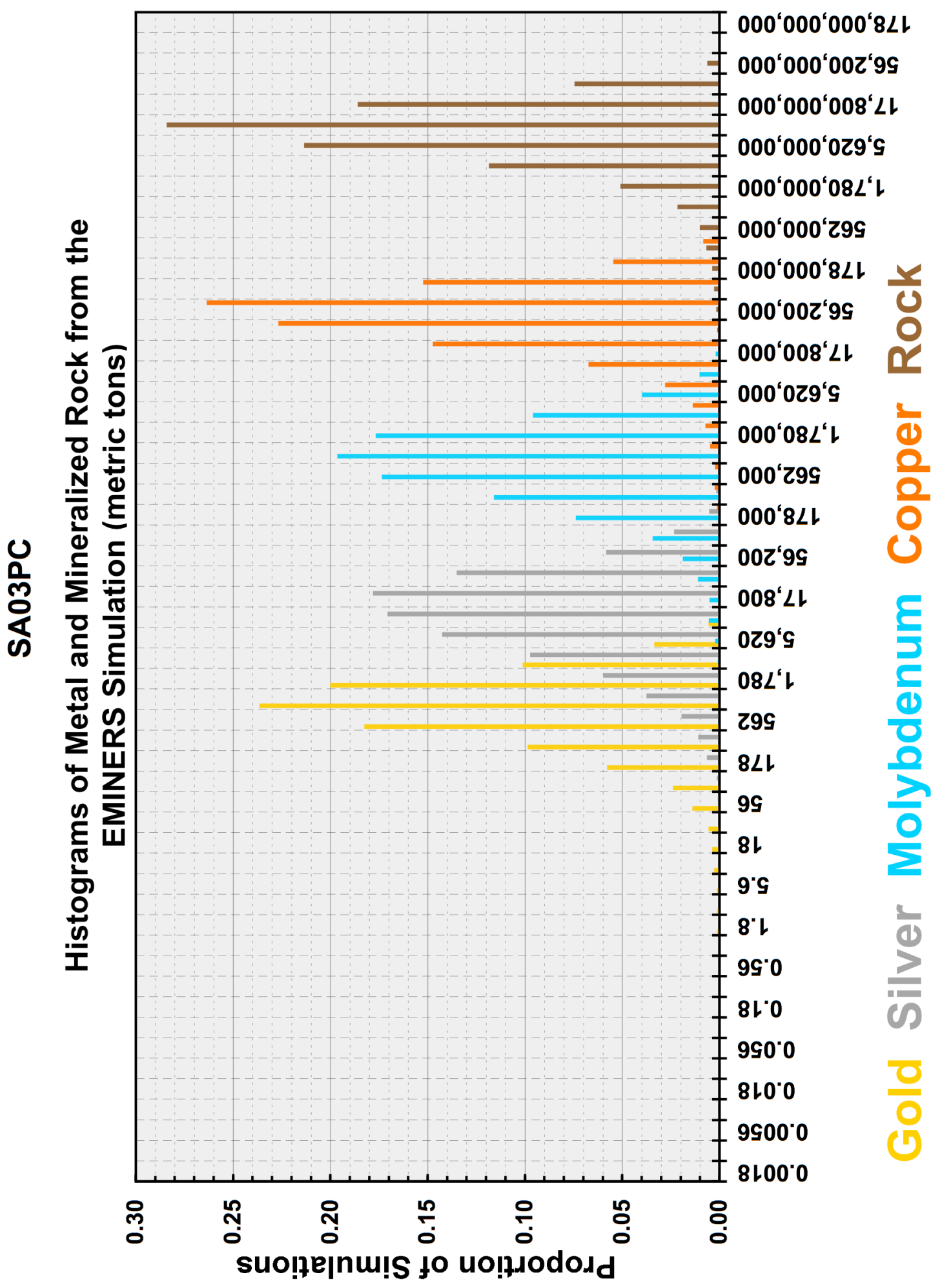




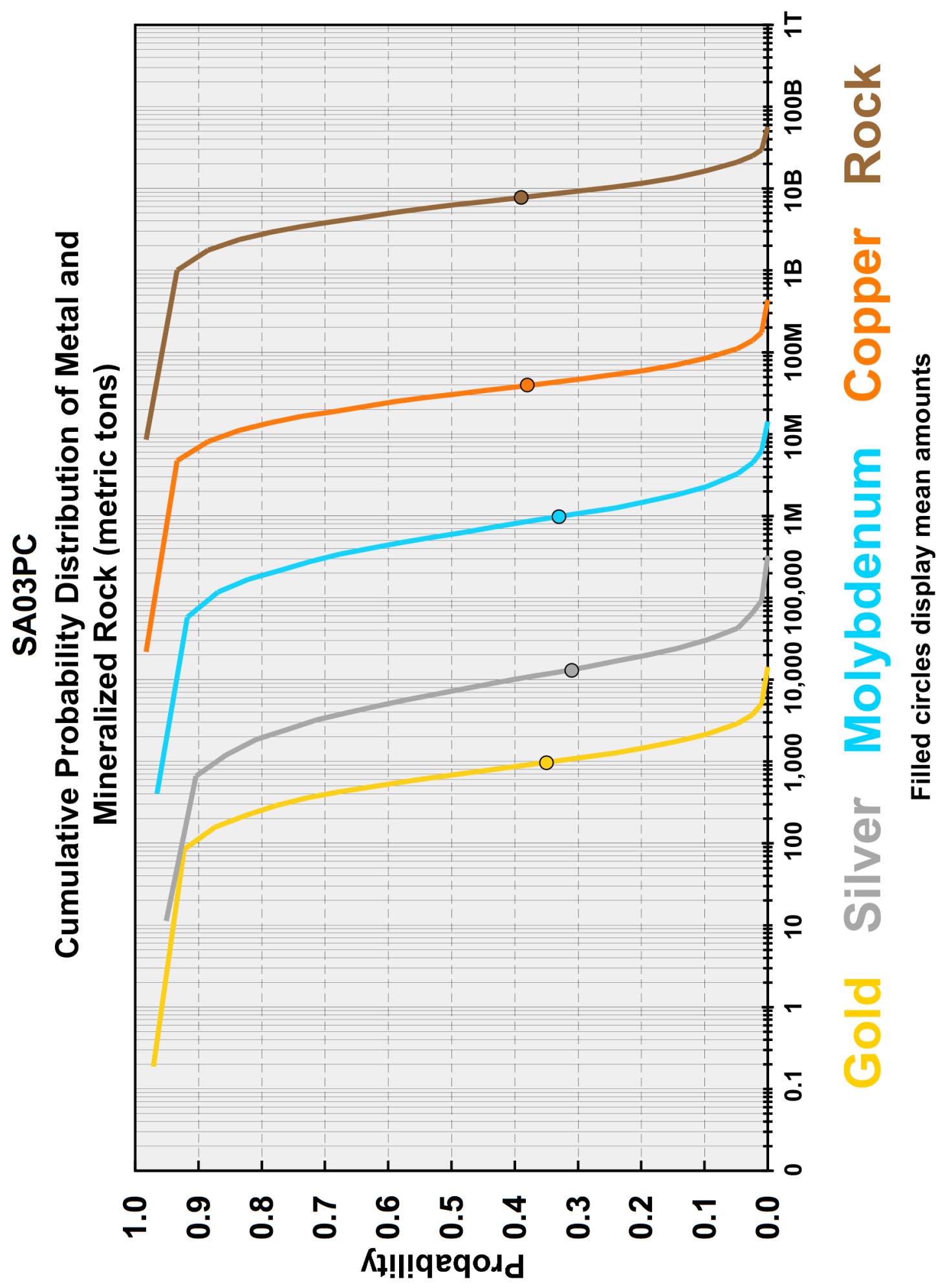




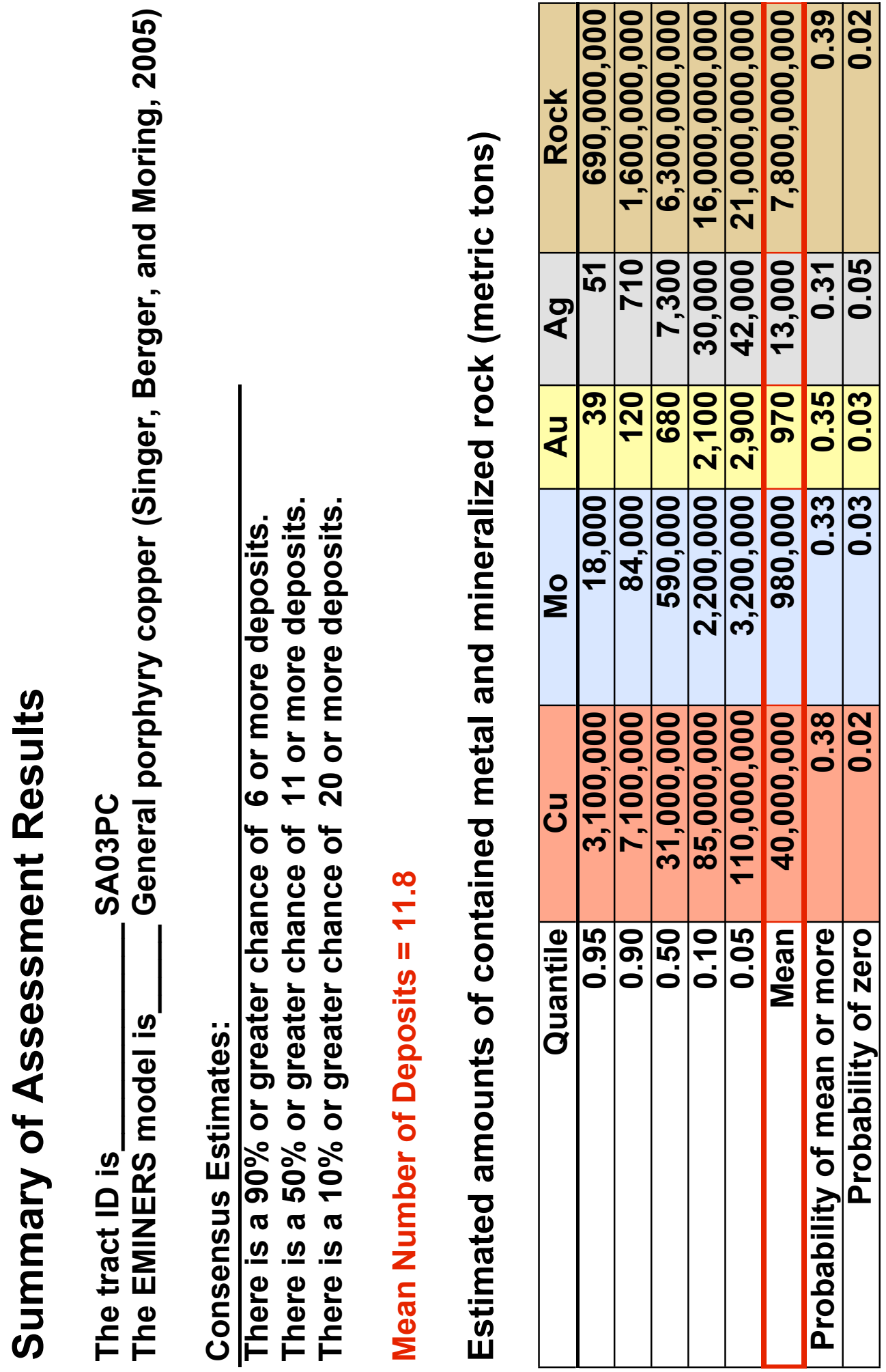




\section{Rationale for tract delineation}

This tract is defined by the distribution of Jurassic mainly calc-alkaline plutons and by the distribution of volcanic and other country rocks and cover rocks within or beneath which such plutons are expected to occur within $1 \mathrm{~km}$ of the surface. The presence of an earliest Cretaceous-age (141 Ma) porphyry copper prospect (Cumay) in these host rocks suggests that: (1) additional dating of the prospect or its host rocks may be needed; (2) larger-scale maps might show one or more small Early Cretaceous plutons hosting the prospect; or (3) the prospect is related to an unidentified, concealed pluton of this age. Basement rocks of the craton are Precambrian gneisses overlain by Paleozoic and Mesozoic epicontinental rocks that contain a prominent Jurassic red-bed sequence and Cretaceous carbonates (Sillitoe and others, 1982). The tract is bordered along its east side by the regional Suaza fault that brings Precambrian metamorphic rocks into juxtaposition with Jurassic silicic to basic volcanic rocks and intercalated sedimentary rocks. Intrusive rocks include intermediate composition granodiorites and tonalities.

Permissive rocks in the tract include the Mocoa batholith in Colombia. Magmatic activity and associated porphyry copper deposits in Colombia began in the Jurassic and migrated episodically westward during the Cretaceous and the Paleocene-Eocene, before reversing and moving eastward forming the Miocene belt.

In Ecuador, the tract consists primarily of Jurassic basaltic and andesitic lava flows intruded by Jurassic calc-alkaline, I-type granodiorites and diorites characterized by relatively low initial Sr values (Litherland and others, 1994). The tract extends approximately north-south through the middle of Ecuador ending near the southern border of the Zamora batholith (Gendall and others, 2000). The southern part of the tract is not thrust-faulted like the northern part and this may be the reason there are more prospects known in the south.

Jurassic rocks similar to mineralized rocks in Ecuador extend the tract a short distance into northern Peru where their distribution is fault controlled. Scattered outcrops of similar host rocks along the south coast of Peru were recognized after the assessment workshop and therefore are not part of this assessment.

\section{Rationale for model choice}

The size and grades of the discovered porphyry copper deposits in the tract are not significantly different (table 3) from the general porphyry copper deposit model (Singer, Berger, and Moring, 2005), which therefore was used to represent the undiscovered deposits.

\section{Deposits and prospects}

The tract has five discovered deposits and four prospects. One deposit (Mocoa) and one prospect (Dolores) have been recognized in Jurassic rocks in Colombia. In the southern part of the tract, in Ecuador, there are four discovered deposits (Mirador, Panantza, San Carlos, and Warintza) and three prospects (Cumay, El Hito, and Tumi). There are no Jurassic deposits or prospects known in Peru.

\section{Exploration history}

United Nations stream-sample exploration in the 1970s found 91 anomalies, of which 7 were porphyry copper type. One porphyry copper anomaly (Macoa) was drilled. The San Carlos, Panantza, and Kutukus prospects in the Zamora River Copper Belt were identified in or about the year 2000 by pannedconcentrate drainage sampling (Lowell and Quevedo, 2002). The northern end of this tract is in the Eastern Cordillera of Colombia and has been relatively less explored in recent years compared to the southern end in Ecuador and Peru. 


\section{Rationale for numerical estimate}

Members of the assessment team used their collective knowledge of numbers of discovered deposits in the tract and (or) in similar areas elsewhere in the world to make estimates throughout the tract that also were consistent with the deposit density model of Singer and others (2005). A number of undiscovered deposits are likely to occur in the tract. The mineralizing processes that form porphyry copper were active in the host rocks and produced both deposits and prospects in this relatively large tract. The level of erosion is sufficient to bring many deposits relatively close to the surface without removing most of them. Roughly a third of the tract is unexplored where covered by younger rocks and much of the remaining area of the tract is not thoroughly explored to a depth of one kilometer.

\section{Expected distribution of undiscovered deposits}

The presence and distribution of prospects and recent discoveries, and the focus of current exploration activity, suggest that the greatest potential for occurrence of undiscovered deposits is concentrated in the southern part of the tract in Peru and especially in Ecuador in the vicinity of the Zamora batholith. However, the team knows of no reason based on available knowledge of the general geology why the northern part of the tract should not be equally endowed with porphyry copper deposits. Moreover, the northern part is relatively less explored. Although deposits have not been discovered in the Peruvian part of the tract, the presence of similar-age Jurassic rocks there is encouraging. The probability of occurrence of an undiscovered deposit is expected to be higher beneath areas of younger cover rocks because these areas are unexplored or relatively less well explored.

\section{References cited}

Gendall, I.R., Quevedo, L.A., Sillitoe, R.H., Spencer, R.M., Puente, C.O., León, J.P., and Romulo, R.P., 2000, Discovery of a Jurassic porphyry copper belt, Pangui area, southern Ecuador: Society of Economic Geologists newsletter, No. 43, p. 1-15.

Litherland, M., Aspden, J.A., and Jemielita, R.A., 1994, The metamorphic belts of Ecuador: Overseas Memoir of the British Geological Survey, No. 11, 147 p.

Lowell, J.D., and Quevedo, L., 2002, Exploring Jurassic porphyry coppers in the Amazon jungle of Ecuador: Preprint 02-116, 2002 SME Annual Meeting, Feb. 25-27, Phoenix, AZ.

Sillitoe, R.H., Jaramillo, Luis, Damon, P.E., Shafiquillah, Muhammed, and Escobar, Ricardo, 1982, Setting, characteristics, and age of the Andean porphyry copper belt in Colombia: Economic Geology, v. 77 , p. 1837-1850.

Singer, D.A., Berger, V.I., Menzie, W.D., and Berger, B.R., 2005, Porphyry copper density: Economic Geology, v. 100, no. 3, p. 491-514.

Singer, D.A., Berger, V.I., and Moring, B.C., 2005, Porphyry copper deposits of the world-Database, map, and grade and tonnage models: U.S. Geological Survey Open-file Report 2005-1060, http://pubs.usgs.gov/of/2005/1060/) 


\section{TRACT SA04PC}
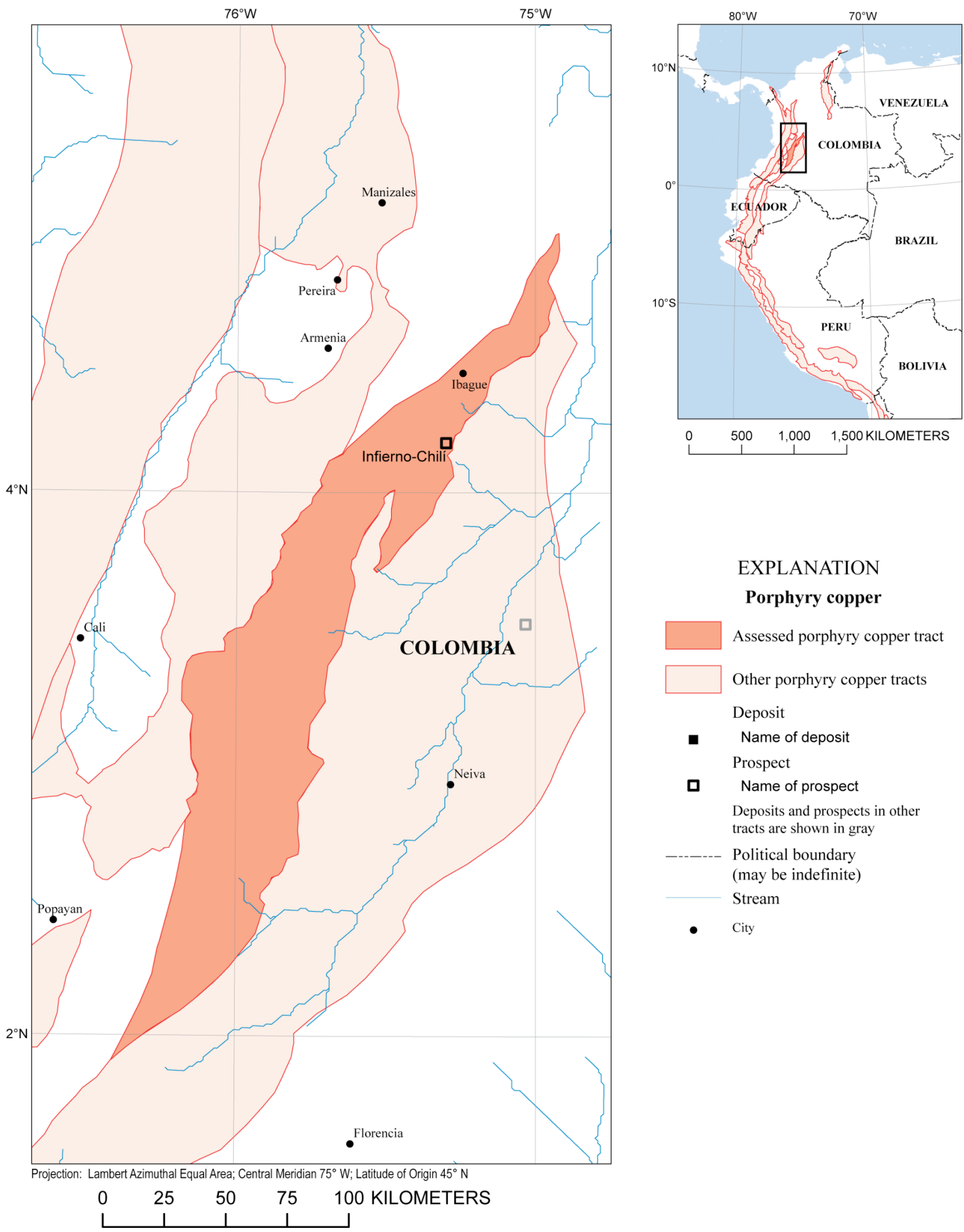

EXPLANATION

Porphyry copper

Assessed porphyry copper tract

Other porphyry copper tracts

Deposit

- Name of deposit Prospect

口 Name of prospect Deposits and prospects in other tracts are shown in gray

Political boundary (may be indefinite) Stream

- $\quad$ City 


\section{Estimated Undiscovered Porphyry Copper Resources in Tract SA04PC- Colombia}

Charles G. Cunningham, ${ }^{1}$ Eduardo 0. Zappettini, ${ }^{2}$ Waldo Vivallo S., ${ }^{3}$ Carlos Mario Celada, ${ }^{4}$ Jorge Quispe, ${ }^{5}$ Donald A. Singer, ${ }^{1}$ Joseph A Briskey, ${ }^{1}$ David M. Sutphin, ${ }^{1}$ Mariano Gajardo M., ${ }^{3}$ Alejandro Diaz, ${ }^{3}$ Carlos Portigliati, ${ }^{3}$ Vladimir I. Berger, ${ }^{1}$ Rodrigo Carrasco, ${ }^{3}$ and Klaus J. Schulz ${ }^{1}$

'USA-U.S. Geological Survey (USGS)

${ }^{2}$ Argentina-Instituto de Geología y Recursos Minerales (SEGEMAR)

${ }^{3}$ Chile-Servicio Nacional de Geología y Minería (SERNAGEOMIN)
${ }^{4}$ Colombia-Instituto Colombiano de Geología y Minería (INGEOMINAS)

${ }^{5}$ Peru-Instituto Geológico Minero y Metalúrgico (INGEMMET)

\begin{tabular}{|l|l|}
\hline Deposit type assessed: Porphyry Copper & $\begin{array}{l}\text { Model: General porphyry copper deposit model } \\
\text { (Singer, Berger, and Moring, 2005) }\end{array}$ \\
\hline Tract name: Colombia Cretaceous Infierno-Chilí & Countries: Colombia \\
\hline Tract ID: SA04PC & Region: South America \\
\hline Date of assessment: May 16-18, 2005 & Date of last revision: \\
\hline Assessment depth: 1 km & Regional coordinator: Charles G. Cunningham \\
\hline Assessment team leader: Donald A. Singer & $\begin{array}{l}\text { Estimators: Carlos Mario Celada, Vladimir I. Berger, Joseph A Briskey, Charles G. Cunningham, } \\
\text { Mariano Gajardo M., Carlos Portigliati, Alvaro Puig Godoy, Donald A. Singer, David M. Sutphin, Waldo } \\
\text { Vivallo S., and Eduardo O. Zappettini. }\end{array}$ \\
\hline
\end{tabular}

Table of estimated numbers of undiscovered deposits by quantile. Also showing calculated mean $(m)$, standard deviation $(s)$, and coefficient of variation in percent $(\mathrm{Cv} \%)$. Sorted by mean.

\begin{tabular}{|l|c|c|c|c|c|c|}
\hline \multicolumn{1}{|c|}{ Estimators } & $\mathbf{9 0}$ & $\mathbf{5 0}$ & $\mathbf{1 0}$ & $\boldsymbol{m}$ & $\boldsymbol{s}$ & $\boldsymbol{C v} \%$ \\
\hline Estimator & 0 & 0 & 1 & 0.30 & 0.50 & 170 \\
\hline Estimator & 0 & 1 & 2 & 1.0 & 0.79 & 79 \\
\hline Estimator & 0 & 1 & 2 & 1.0 & 0.79 & 79 \\
\hline Estimator & 0 & 1 & 2 & 1.0 & 0.79 & 79 \\
\hline Estimator & 0 & 1 & 4 & 1.6 & 1.5 & 94 \\
\hline Estimator & 1 & 2 & 3 & 1.9 & 0.84 & 44 \\
\hline Consensus of estimators & $\mathbf{1}$ & $\mathbf{2}$ & $\mathbf{4}$ & $\mathbf{2 . 2}$ & $\mathbf{1 . 2}$ & $\mathbf{5 5}$ \\
\hline Estimator & 1 & 2 & 5 & 2.5 & 1.6 & 64 \\
\hline Estimator & 2 & 3 & 4 & 2.9 & 0.88 & 30 \\
\hline Estimator & 2 & 3 & 5 & 3.2 & 1.3 & 41 \\
\hline Estimator & 2 & 4 & 6 & 3.9 & 1.5 & 38 \\
\hline Estimator & 3 & 5 & 10 & 5.7 & 2.7 & 47 \\
\hline
\end{tabular}

\section{Deposit density table}

\begin{tabular}{|c|c|c|c|c|}
\hline $\begin{array}{c}\text { Mean of consensus estimates } \\
\text { of undiscovered deposits }\end{array}$ & $\begin{array}{c}\text { Number of } \\
\text { discovered } \\
\text { deposits }\end{array}$ & $\begin{array}{c}\text { Total number of } \\
\text { deposits }\end{array}$ & Area, $\mathbf{~ m m}^{\mathbf{2}}$ & $\begin{array}{c}\text { Deposit density, number } \\
\text { of deposits/100,000 } \mathbf{k m}^{\mathbf{2}}\end{array}$ \\
\hline $\mathbf{2 . 2}$ & 0 & 2.2 & 10,986 & 20 \\
\hline
\end{tabular}




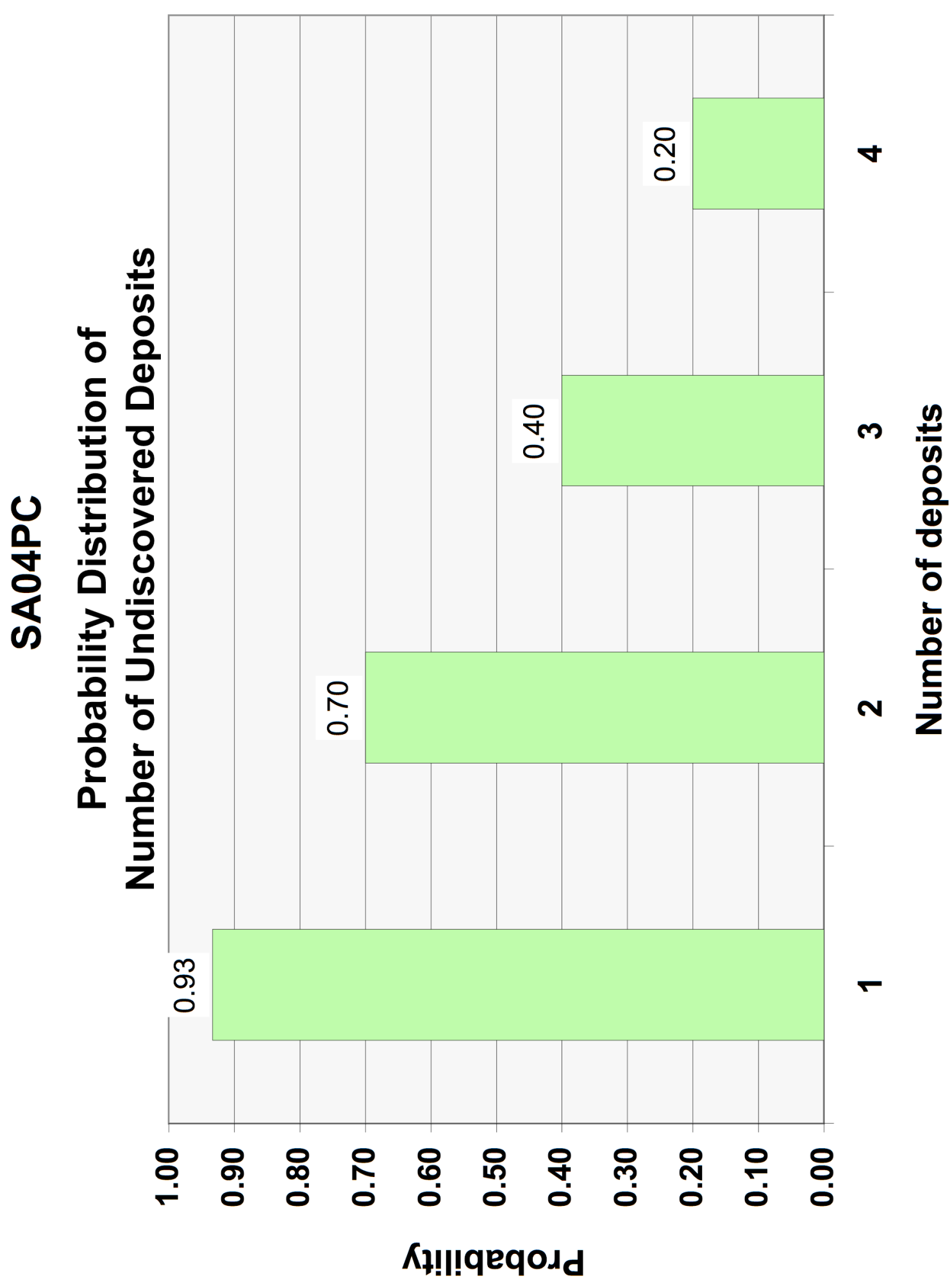




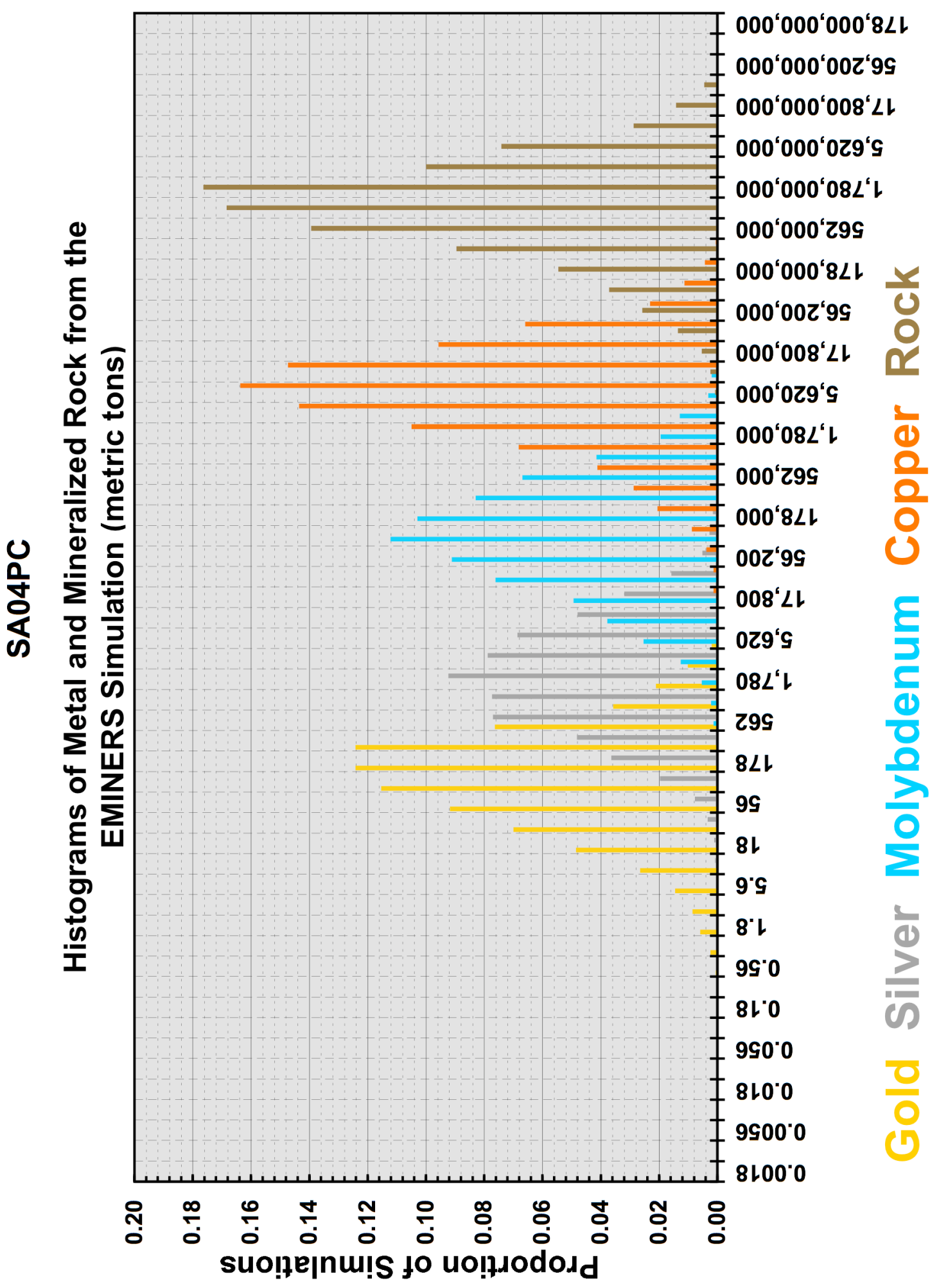




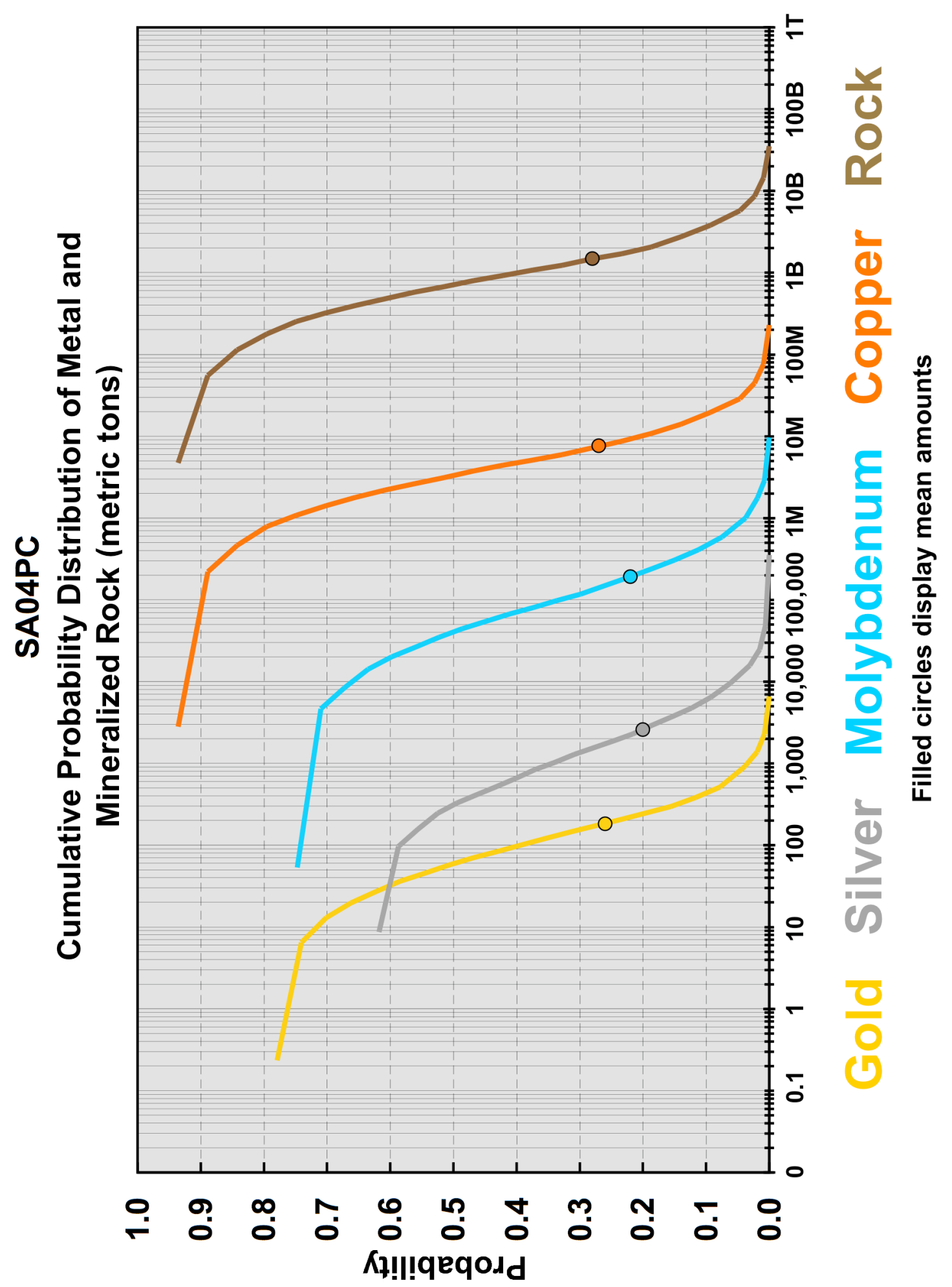









\section{Rationale for tract delineation}

This tract is defined by the distribution of Cretaceous intermediate-composition mostly calcalkaline plutons and by the distribution of volcanic and other country rocks and cover rocks within or beneath which such plutons are expected to occur within $1 \mathrm{~km}$ of the surface. This tract is poorly defined in Colombia and does not appear to continue into Ecuador. The permissive plutons are mostly granodiorites and tonalites. The large batholiths to the north were excluded because they are too deeply eroded. There is a large, regional fault along the southwest side of the tract that is downthrown to the southwest and juxtaposes a thick section of intermediate composition pyroclastic rocks down against the plutonic rocks. Less than about 10 percent of the tract is composed of younger cover rocks, principally Cretaceous epicontinental sedimentary rocks and Tertiary volcanic rocks.

\section{Rational for model choice}

Because the tract contains no discovered deposits, and there was no reason to reject the general porphyry copper deposit model (Singer, Berger, and Moring, 2005), this model was used to represent the undiscovered deposits.

\section{Deposits and prospects}

The tract contains the Infierno-Chilí prospect, which is hosted in the Ibagué batholith that has been dated at $131 \mathrm{Ma}$ (Sillitoe and others, 1982). There are no discovered deposits in the tract.

\section{Exploration history}

This area was included in a United Nation's stream-sample exploration program in the 1970s. One anomaly (Los Andes) had three holes drilled in it yielding values of up to $800 \mathrm{ppm} \mathrm{Cu}$ and $200 \mathrm{ppm} \mathrm{Mo.}$ The tract is located immediately east of Cali and therefore has been readily accessible for exploration.

\section{Rationale for numerical estimate}

Estimates of numbers of undiscovered porphyry copper deposits in the tract were guided by analogies with numbers of deposits known in similar areas elsewhere, and with reference to the deposit density model of Singer and others (2005). The team's small estimate of undiscovered deposits in part reflects the area's relatively small size and a level of erosion that appears sufficient to have removed most of the plutonic-volcanic transition zone in which many porphyry copper deposits form. Moreover, while exposures are excellent with little cover by younger rocks and sediments, exploration has identified only a single significant prospect in addition to the one stream-sediment geochemical anomaly drilled with disappointing results.

\section{Expected distribution of undiscovered deposits}

The probability of occurrence of an undiscovered deposit is believed to be reasonably uniform throughout the tract except beneath areas of younger cover rocks where the potential is higher because these areas are unexplored or relatively less well explored.

\section{References cited}

Sillitoe, R.H., Jaramillo, Luis, Damon, P.E., Shafiquillah, Muhammed, and Escobar, Ricardo, 1982, Setting, characteristics, and age of the Andean porphyry copper belt in Colombia: Economic Geology, v. 77, p. 1837-1850.

Singer, D.A., Berger, V.I., Menzie, W.D., and Berger, B.R., 2005, Porphyry copper density: Economic Geology, v. 100, no. 3, p. 491-514. 
Singer, D.A., Berger, V.I., and Moring, B.C., 2005, Porphyry copper deposits of the world-Database, map, and grade and tonnage models: U.S. Geological Survey Open-file Report 2005-1060, http://pubs.usgs.gov/of/2005/1060/) 
TRACT SA05PC

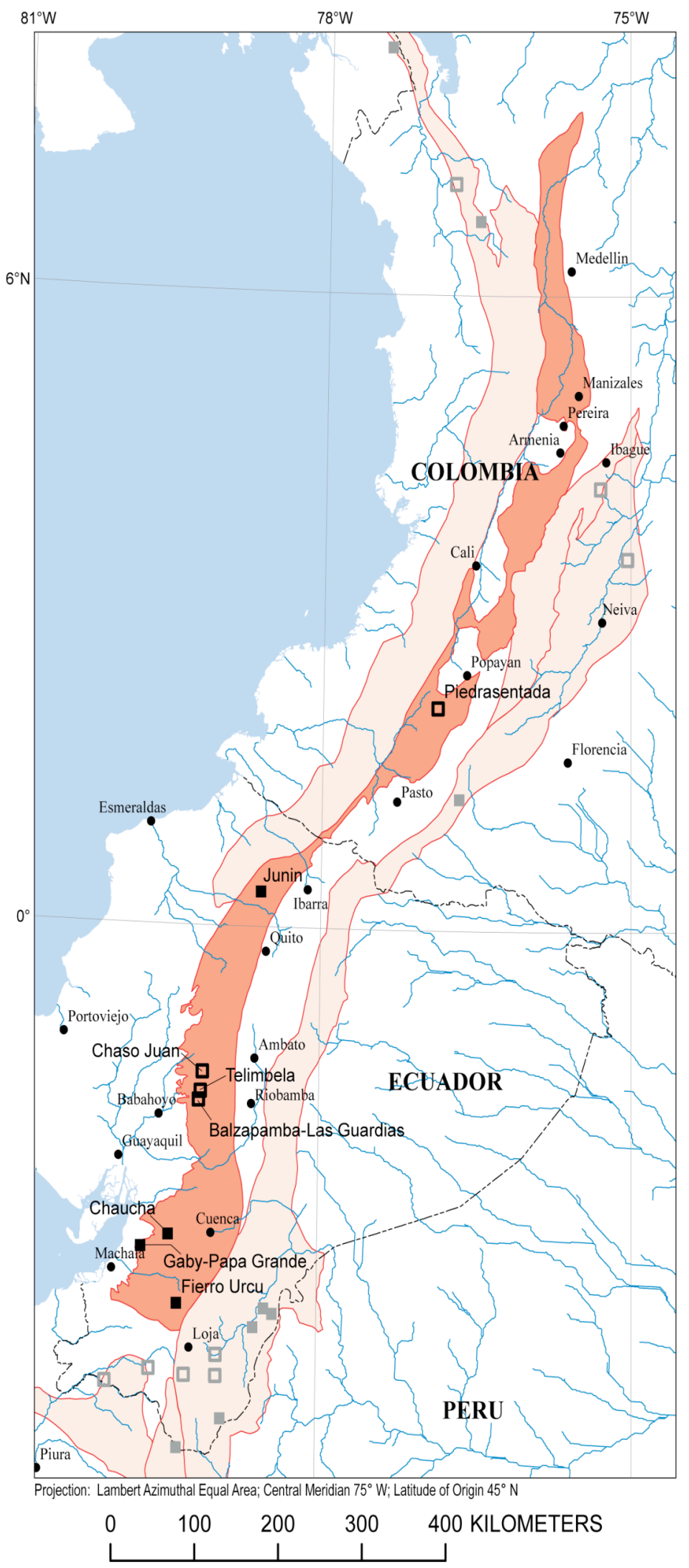

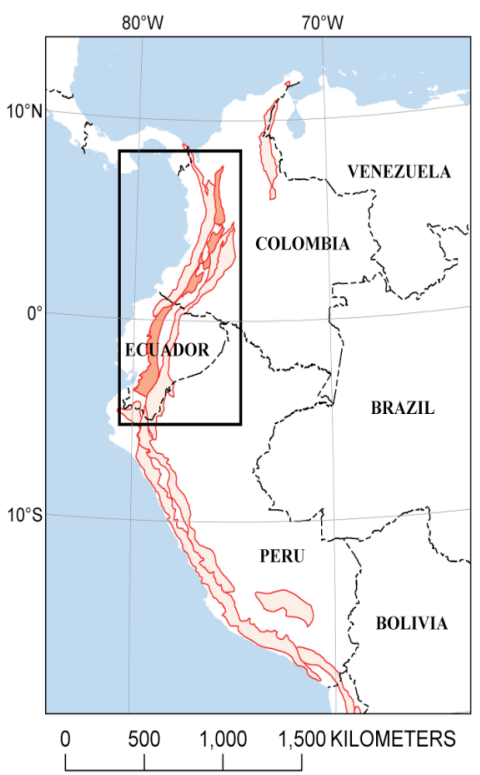

\section{EXPLANATION}

Porphyry copper

Assessed porphyry copper tract

Other porphyry copper tracts

Deposit

- Name of deposit

Prospect

口 Name of prospect

Deposits and prospects in other tracts are shown in gray

Political boundary (may be indefinite) Stream

- City 


\section{Estimated Undiscovered Porphyry Copper Resources in Tract SA05PC- Colombia and Ecuador}

Charles G. Cunningham, ${ }^{1}$ Eduardo 0. Zappettini, ${ }^{2}$ Waldo Vivallo S., ${ }^{3}$ Carlos Mario Celada, ${ }^{4}$ Jorge Quispe ${ }^{5}$ Donald A. Singer, ${ }^{1}$ Joseph A Briskey, ${ }^{1}$ David M. Sutphin, ${ }^{1}$ Mariano Gajardo M., ${ }^{3}$ Alejandro Diaz, ${ }^{3}$ Carlos Portigliati, ${ }^{3}$ Vladimir I. Berger, ${ }^{1}$ Rodrigo Carrasco, ${ }^{3}$ and Klaus J. Schulz ${ }^{1}$

'USA-U.S. Geological Survey (USGS)

${ }^{2}$ Argentina-Instituto de Geología y Recursos Minerales (SEGEMAR)

${ }^{3}$ Chile-Servicio Nacional de Geología y Minería (SERNAGEOMIN)
${ }^{4}$ Colombia-Instituto Colombiano de Geología y Minería (INGEOMINAS)

${ }^{5}$ Peru-Instituto Geológico Minero y Metalúrgico (INGEMMET)

\begin{tabular}{|l|l|}
\hline Deposit type assessed: Porphyry Copper & $\begin{array}{l}\text { Model: General porphyry copper deposit model } \\
\text { (Singer, Berger, and Moring, 2005) }\end{array}$ \\
\hline $\begin{array}{l}\text { Tract name: Colombia-Ecuador Miocene } \\
\text { Chaucha }\end{array}$ & Countries: Colombia and Ecuador \\
\hline Tract ID: SA05PC & Region: South America \\
\hline Date of assessment: May 16-18, 2005 & Date of last revision: \\
\hline Assessment depth: $1 \mathrm{~km}$ & Regional coordinator: Charles G. Cunningham \\
\hline Assessment team leader: Donald A. Singer & $\begin{array}{l}\text { Estimators: Carlos Mario Celada, Vladimir I. Berger, Joseph A Briskey, Charles G. Cunningham, } \\
\text { Mariano Gajardo M., Donald A. Singer, David M. Sutphin, Waldo Vivallo S., and Eduardo O. Zappettini. }\end{array}$ \\
\hline
\end{tabular}

Table of estimated numbers of undiscovered deposits by quantile. Also showing calculated mean $(m)$, standard deviation $(s)$, and coefficient of variation in percent $(C v \%)$. Sorted by mean.

\begin{tabular}{|l|r|r|r|r|c|c|}
\hline \multicolumn{1}{|c|}{ Estimators } & $\mathbf{9 0}$ & $\mathbf{5 0}$ & $\mathbf{1 0}$ & $\mathbf{m}$ & $\boldsymbol{s}$ & Cv\% \\
\hline Estimator & 5 & 8 & 12 & 8.0 & 2.7 & 34 \\
\hline Estimator & 6 & 9 & 12 & 8.6 & 2.4 & 28 \\
\hline Estimator & 7 & 10 & 12 & 9.2 & 2.1 & 23 \\
\hline Estimator & 5 & 8 & 20 & 10 & 5.8 & 58 \\
\hline Estimator & 5 & 12 & 17 & 11 & 4.3 & 39 \\
\hline Consensus of estimators & $\mathbf{6}$ & $\mathbf{1 1}$ & $\mathbf{1 9}$ & $\mathbf{1 2}$ & $\mathbf{4 . 9}$ & $\mathbf{4 1}$ \\
\hline Estimator & 8 & 12 & 22 & 13 & 5.4 & 42 \\
\hline Estimator & 5 & 12 & 25 & 13 & 7.3 & 56 \\
\hline Estimator & 6 & 11 & 28 & 14 & 8.3 & 59 \\
\hline Estimator & 10 & 15 & 20 & 14 & 3.9 & 28 \\
\hline
\end{tabular}

\section{Deposit density table}

\begin{tabular}{|c|c|c|c|c|}
\hline $\begin{array}{c}\text { Mean of consensus estimates } \\
\text { of undiscovered deposits }\end{array}$ & $\begin{array}{c}\text { Number of } \\
\text { discovered } \\
\text { deposits }\end{array}$ & $\begin{array}{c}\text { Total number of } \\
\text { deposits }\end{array}$ & Area, $\mathbf{k m}^{\mathbf{2}}$ & $\begin{array}{c}\text { Deposit density, number of } \\
\text { deposits/100,000 } \mathbf{k m}^{\mathbf{2}}\end{array}$ \\
\hline $\mathbf{1 2}$ & 4 & 16 & 58,797 & 27 \\
\hline
\end{tabular}




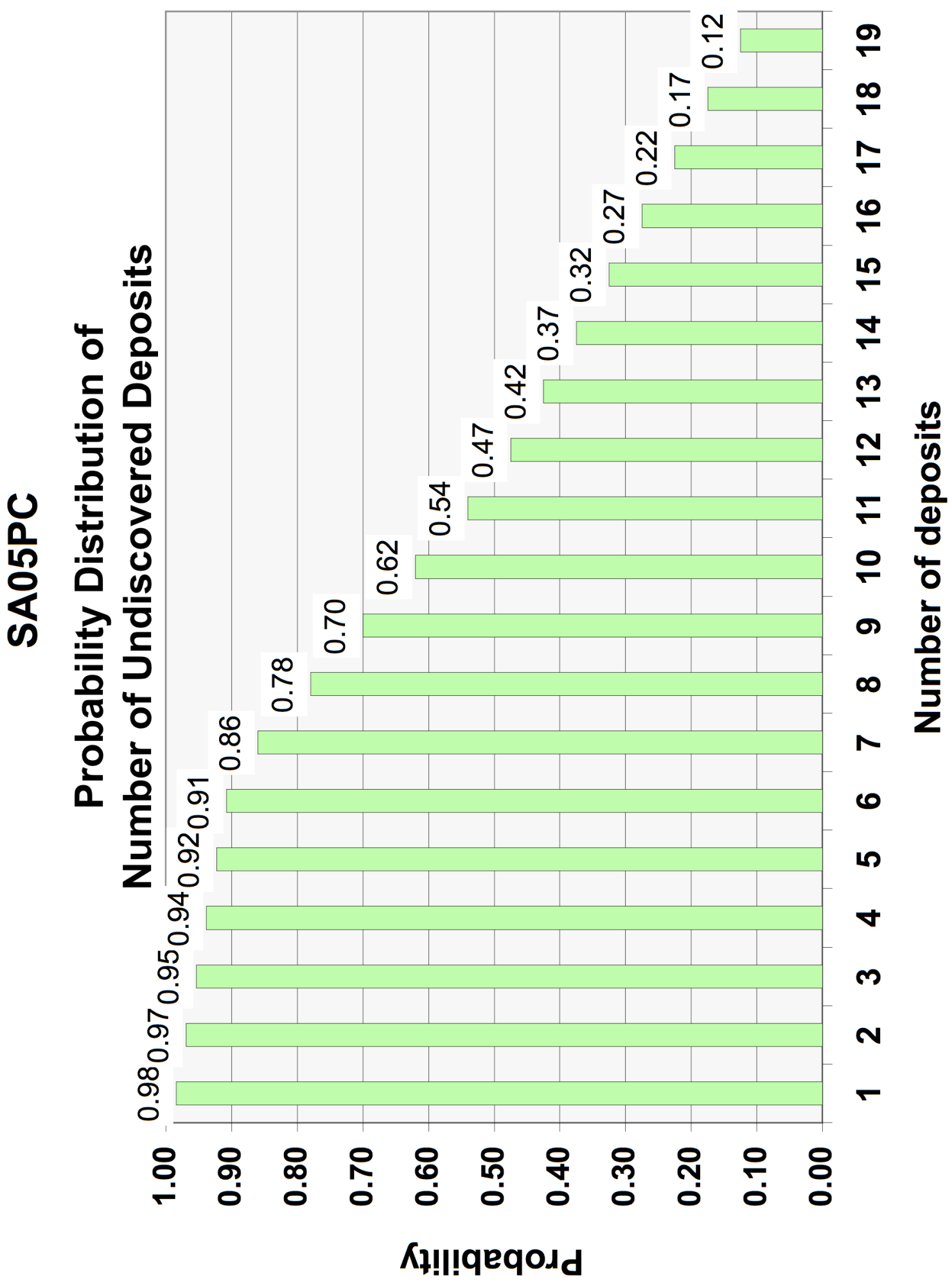




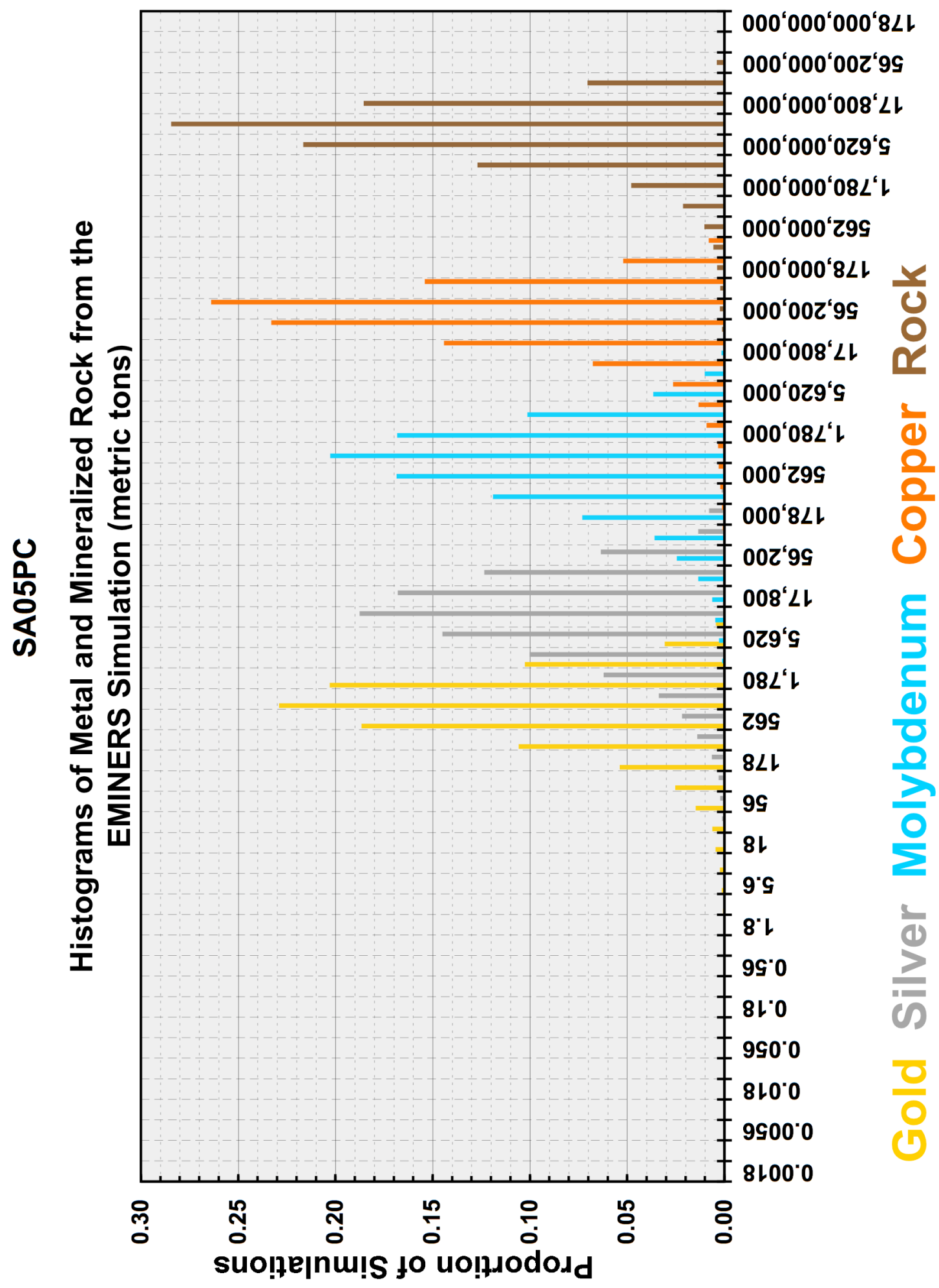




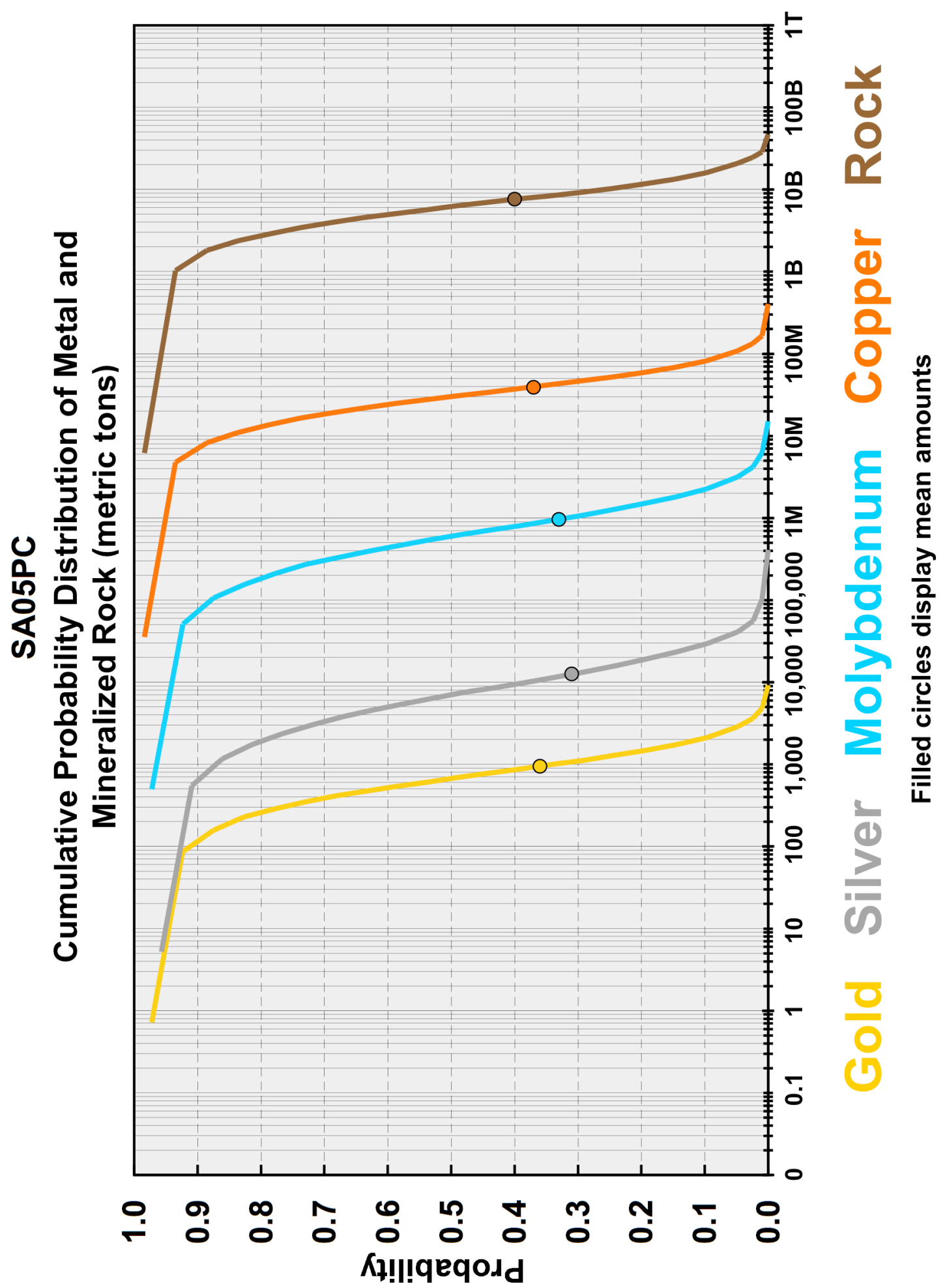




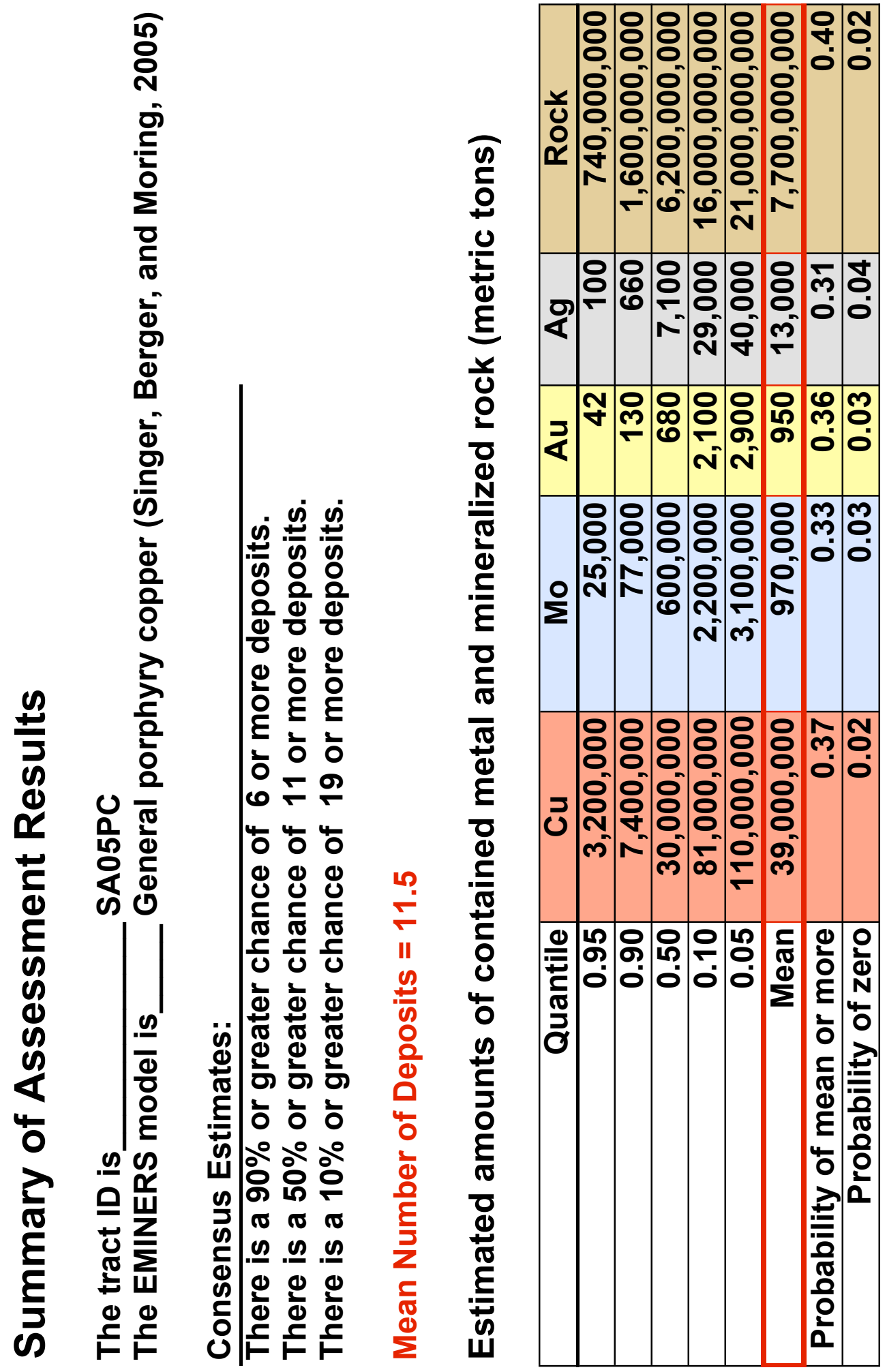




\section{Rationale for tract delineation}

This tract is defined by the distribution of Miocene principally calc-alkaline plutons and by the distribution of volcanic and other country rocks and cover rocks within or beneath which such plutons are expected to occur within $1 \mathrm{~km}$ of the surface. The northern part of the tract outlines the occurrence of Miocene plutons localized near and on either side of a regional fault. The southern boundary is drawn on a structural break at $4^{\circ}$ South. This tract includes most of the Central Cordillera of Colombia and extends south across Ecuador. The Central Cordillera is intruded by a series of calc-alkaline dacite porphyry and tonalite stocks with associated copper mineralization (Sillitoe and others, 1982). In Ecuador, the discovered Miocene porphyry copper deposits are associated with granite plutons, or with intermediate composition plutons, principally tonalites and granodiorites, and their spatially associated volcanic rocks. The tract also marks the juncture of a section of thick $(35-45 \mathrm{~km})$ Precambrian granulite facies rocks of the continental crust to the east with mafic and ultramafic oceanic rocks to the west. The granulites are part of the Guyana Shield (Sillitoe and others, 1982). In Colombia, the western side of the tract is bounded by a thick section of Quaternary pyroclastic rocks and the eastern side is bounded by outcropping Paleozoic and Precambrian metamorphic rocks. The eastern side of the tract also is limited by the presence of a thick section of lava flows and pyroclastic deposits from Pliocene stratovolcanoes. About one-third of the tract is covered by younger rocks and sediments.

\section{Rationale for model choice}

The size and grades of the four discovered porphyry copper deposits in the tract are not significantly different (table 3 ) from the general porphyry copper deposit model (Singer, Berger, and Moring, 2005), which therefore was used to represent the undiscovered deposits. Gemuts and others (1992) also concluded that the mineralogic, grade, and tonnage characteristics of the deposits are consistent with the general model for porphyry copper deposits.

\section{Deposits and prospects}

At the time of the assessment, the tract was known to contain four discovered deposits (Chaucha, Fierro Urcu, Gaby-Papa Grande, and Junin) and four prospects (Balzapamba-Las Guardias, Chaso Juan, Piedrasentada, and Telimbela). All except Piedrasentada are in Ecuador.

\section{Exploration history}

The tract is moderately explored. Twenty-five percent of the tract is covered by a regular streamsediment geochemical survey conducted by the United Nations. A geochemical and geophysical survey was made by a British organization somewhere in the southern part of tract (Anonymous, 2000).

\section{Rationale for numerical estimation}

Members of the assessment team used their collective knowledge of numbers of discovered deposits in the tract and (or) in similar areas elsewhere in the world to make estimates throughout the tract that were consistent with the deposit density model of Singer and others (2005). The estimating team believes the tract to contain a relatively large number of undiscovered deposits. Four discovered deposits and four explored prospects already have been found in this relatively large tract. About two thirds of the tract is only moderately explored and the remaining third is relatively unexplored because of cover by younger rocks and sediments. In Colombia, the moderate level of erosion has been sufficient to bring many deposits relatively close to the surface without removing most of them. Within the Ecuador part of the tract, relatively small host-rock plutons exposed within a large volcanic field suggest that most porphyry copper deposits that might have formed are likely to be preserved from erosion. 


\section{Expected distribution of undiscovered deposits}

The distribution of undiscovered deposits in the tract is believed to be controlled, in part, by the subsurface position of the western edge of the craton. Undiscovered deposits also are more likely to occur under the younger rocks and sediments that cover approximately a third of the tract, especially in Ecuador.

\section{References cited}

Anonymous, 2000, Evaluacion distritos mineros del Ecuador. Depositos porfídicos y epi-mesotermales relacionados con intrusiones de las Cordilleras Occidental y Real: Ministerio de Energía y Minas, Subsecretaría de Minas, Direccíon Nacional de Geologíia, Proyecto de Desarrolo Minero y Control Ambiental, Volumen 4, 316 p.

Gemuts, I., López, G., Jíimenez. F., 1992, Gold deposits of Southern Ecuador: SEG Newsletter, October, no. 11, p. $1,13-15$.

Sillitoe, R.H., Jaramillo, Luis, Damon, P.E., Shafiquillah, Muhammed, and Escobar, Ricardo, 1982, Setting, characteristics, and age of the Andean porphyry copper belt in Colombia: Economic Geology, v. 77, p. 1837-1850.

Singer, D.A., Berger, V.I., Menzie, W.D., and Berger, B.R., 2005, Porphyry copper deposit density: Economic Geology, v. 100, p. 491-514.

Singer, D.A., Berger, V.I., and Moring, B.C., 2005, Porphyry copper deposits of the world-Database, map, and grade and tonnage models: U.S. Geological Survey Open-file Report 2005-1060, http://pubs.usgs.gov/of/2005/1060/). 


\section{TRACT SA06PC}
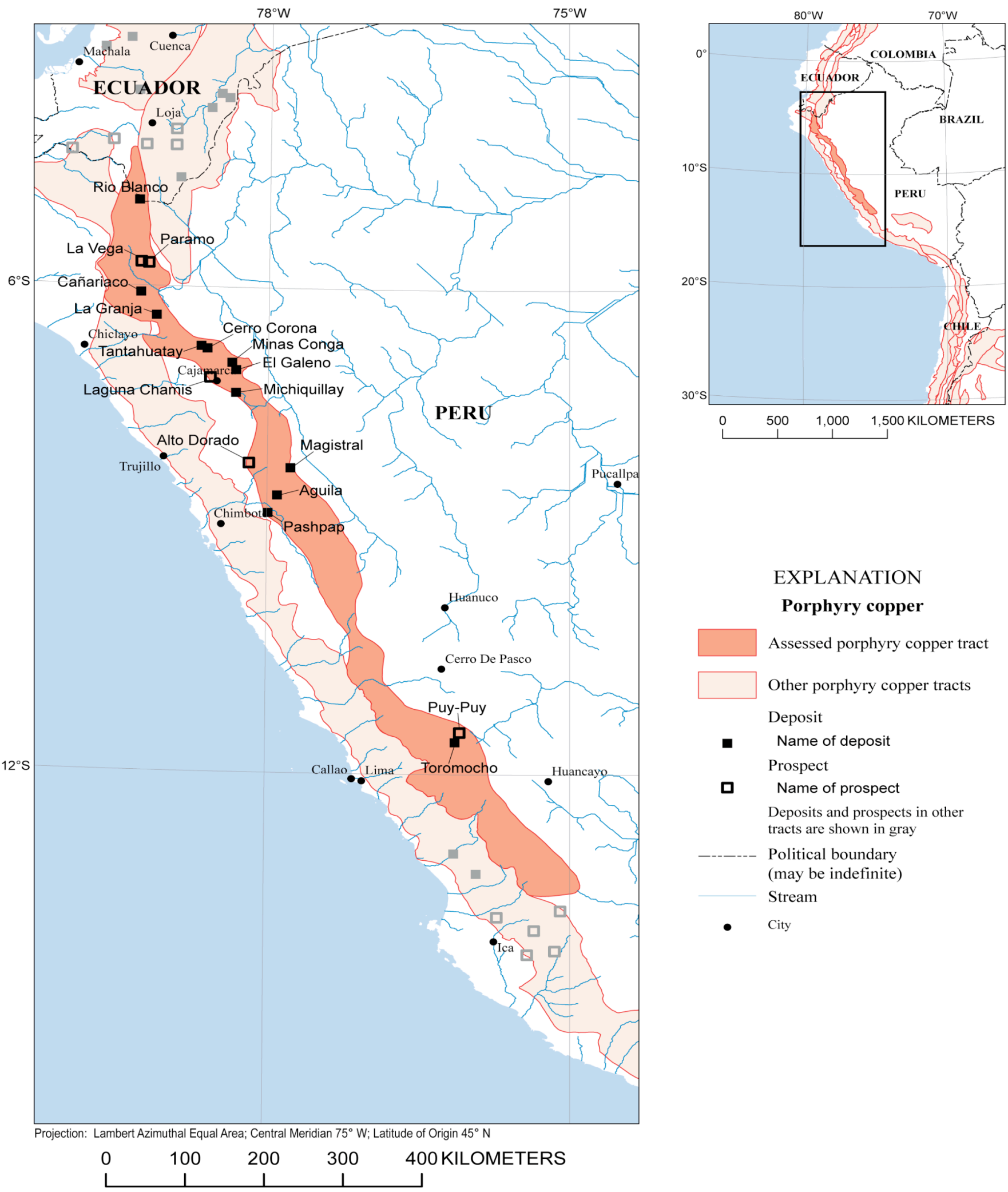

\section{EXPLANATION}

\section{Porphyry copper}

Assessed porphyry copper tract

Other porphyry copper tracts

Deposit

- Name of deposit Prospect

ㅁ Name of prospect

Deposits and prospects in other tracts are shown in gray

Political boundary (may be indefinite) Stream

- $\quad$ City 


\section{Estimated Undiscovered Porphyry Copper Resources in Tract SA06PC- Peru and Ecuador}

Charles G. Cunningham, ${ }^{1}$ Eduardo 0. Zappettini, ${ }^{2}$ Waldo Vivallo S., ${ }^{3}$ Carlos Mario Celada, ${ }^{4}$ Jorge Quispe, ${ }^{5}$ Donald A. Singer, ${ }^{1}$ Joseph A Briskey, ${ }^{1}$ David M. Sutphin, ${ }^{1}$ Mariano Gajardo M., ${ }^{3}$ Alejandro Diaz, ${ }^{3}$ Carlos Portigliati, ${ }^{3}$ Vladimir I. Berger, ${ }^{1}$ Rodrigo Carrasc $0,{ }^{3}$ and Klaus J. Schulz

'USA-U.S. Geological Survey (USGS)

${ }^{2}$ Argentina-Instituto de Geología y Recursos Minerales (SEGEMAR)

${ }^{3}$ Chile-Servicio Nacional de Geología y Minería (SERNAGEOMIN)
${ }^{4}$ Colombia-Instituto Colombiano de Geología y Minería (INGEOMINAS)

${ }^{5}$ Peru-Instituto Geológico Minero y Metalúrgico (INGEMMET)

\section{Deposit type assessed: Porphyry Copper}

Tract name: Peru-Ecuador middle-late Miocene La Granja

Tract ID: SA06PC

Date of assessment: May 16-18, 2005

Assessment depth: $1 \mathrm{~km}$

Assessment team leader: Donald A. Singer

Estimators: Carlos Mario Celada, Vladimir I. Berger, Charles G. Cunningham, Alejandro Diaz, Mariano Gajardo M., Carlos Portigliati, Alvaro Puig Godoy, Donald A. Singer, David M. Sutphin, Waldo Vivallo S., and Eduardo O. Zappettini.

Table of estimated numbers of undiscovered deposits by quantile. Also showing calculated mean $(\mathrm{m})$, standard deviation $(s)$, and coefficient of variation in percent $(\mathrm{Cv} \%)$. Sorted by mean.

\begin{tabular}{|l|c|c|c|c|c|c|}
\hline \multicolumn{1}{|c|}{ Estimators } & $\mathbf{9 0}$ & $\mathbf{5 0}$ & $\mathbf{1 0}$ & $\boldsymbol{m}$ & $\boldsymbol{s}$ & $\boldsymbol{C v} \%$ \\
\hline Estimator & 4 & 6 & 8 & 5.7 & 1.6 & 28 \\
\hline Estimator & 8 & 10 & 15 & 10 & 3.0 & 30 \\
\hline Estimator & 5 & 10 & 18 & 11 & 4.8 & 44 \\
\hline Estimator & 6 & 12 & 20 & 12 & 5.2 & 43 \\
\hline Estimator & 6 & 12 & 25 & 14 & 7.1 & 51 \\
\hline Estimator & 8 & 13 & 25 & 15 & 6.5 & 43 \\
\hline Consensus of estimators & $\mathbf{8}$ & $\mathbf{1 3}$ & $\mathbf{2 5}$ & $\mathbf{1 5}$ & $\mathbf{6 . 5}$ & $\mathbf{4 3}$ \\
\hline Estimator & 6 & 12 & 30 & 15 & 9.0 & 60 \\
\hline Estimator & 6 & 14 & 30 & 16 & 8.8 & 55 \\
\hline Estimator & 12 & 18 & 24 & 17 & 4.7 & 28 \\
\hline Estimator & 10 & 15 & 30 & 17 & 7.7 & 45 \\
\hline Estimator & 15 & 25 & 45 & 27 & 11 & 41 \\
\hline
\end{tabular}

\section{Deposit density table}

\begin{tabular}{|c|c|c|c|c|}
\hline $\begin{array}{c}\text { Mean of consensus estimates of } \\
\text { undiscovered deposits }\end{array}$ & $\begin{array}{c}\text { Number of } \\
\text { discovered } \\
\text { deposits }\end{array}$ & $\begin{array}{c}\text { Total number of } \\
\text { deposits }\end{array}$ & Area, $\mathbf{~ k m}^{2}$ & $\begin{array}{c}\text { Deposit density, number of } \\
\text { deposits/100,000km }\end{array}$ \\
\hline $\mathbf{1 5}$ & 12 & 27 & 53,186 & 51 \\
\hline
\end{tabular}




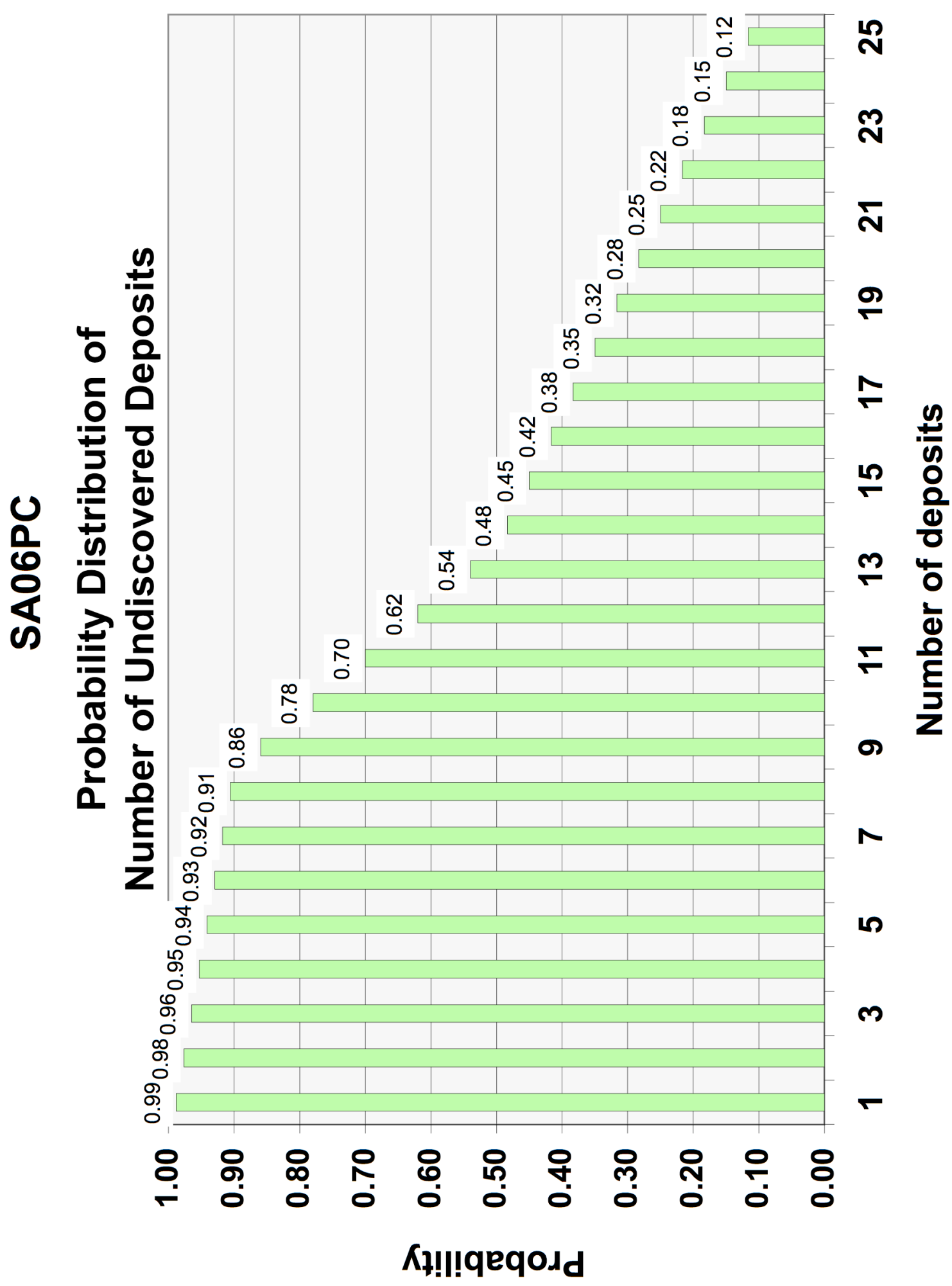




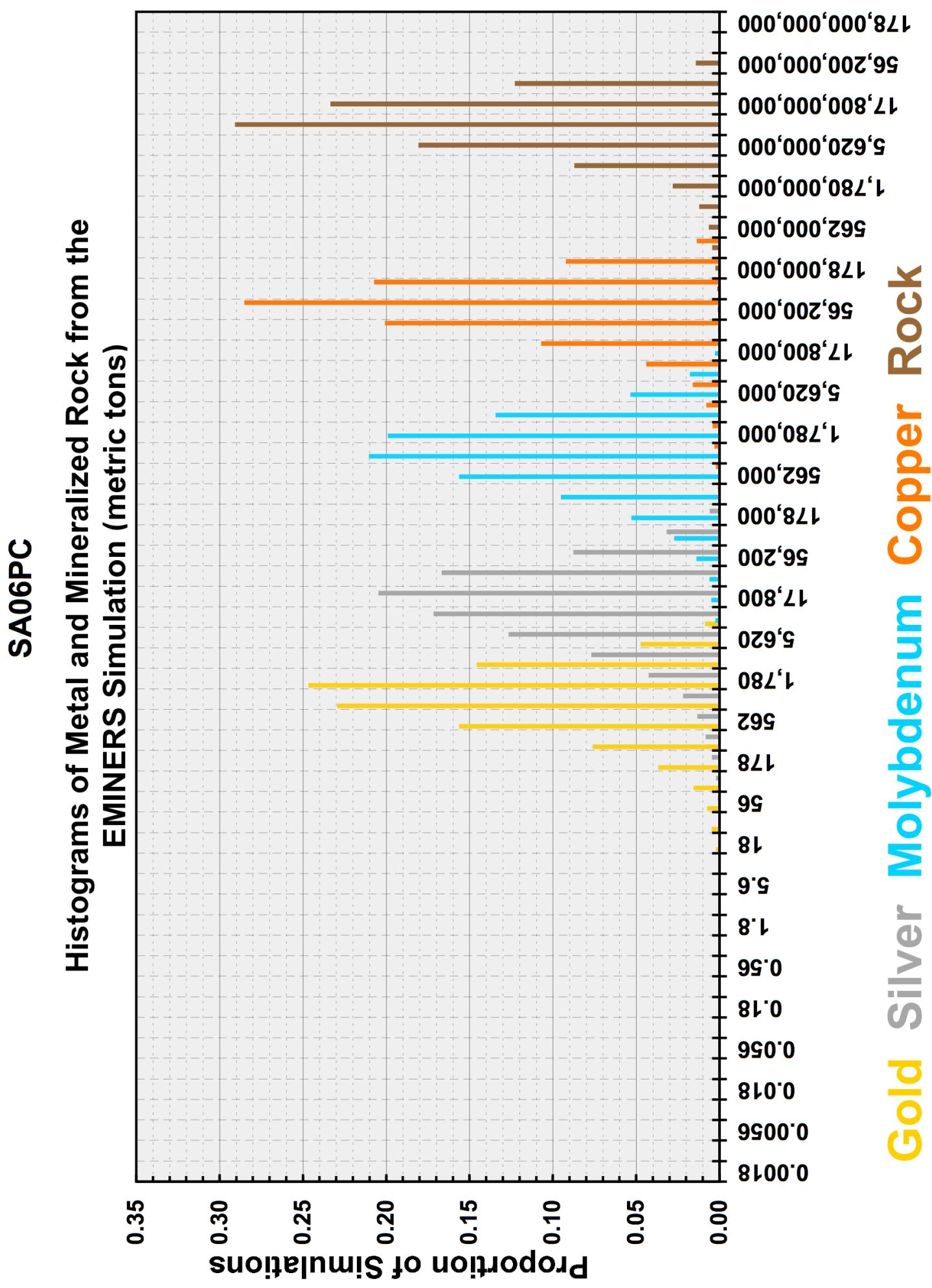




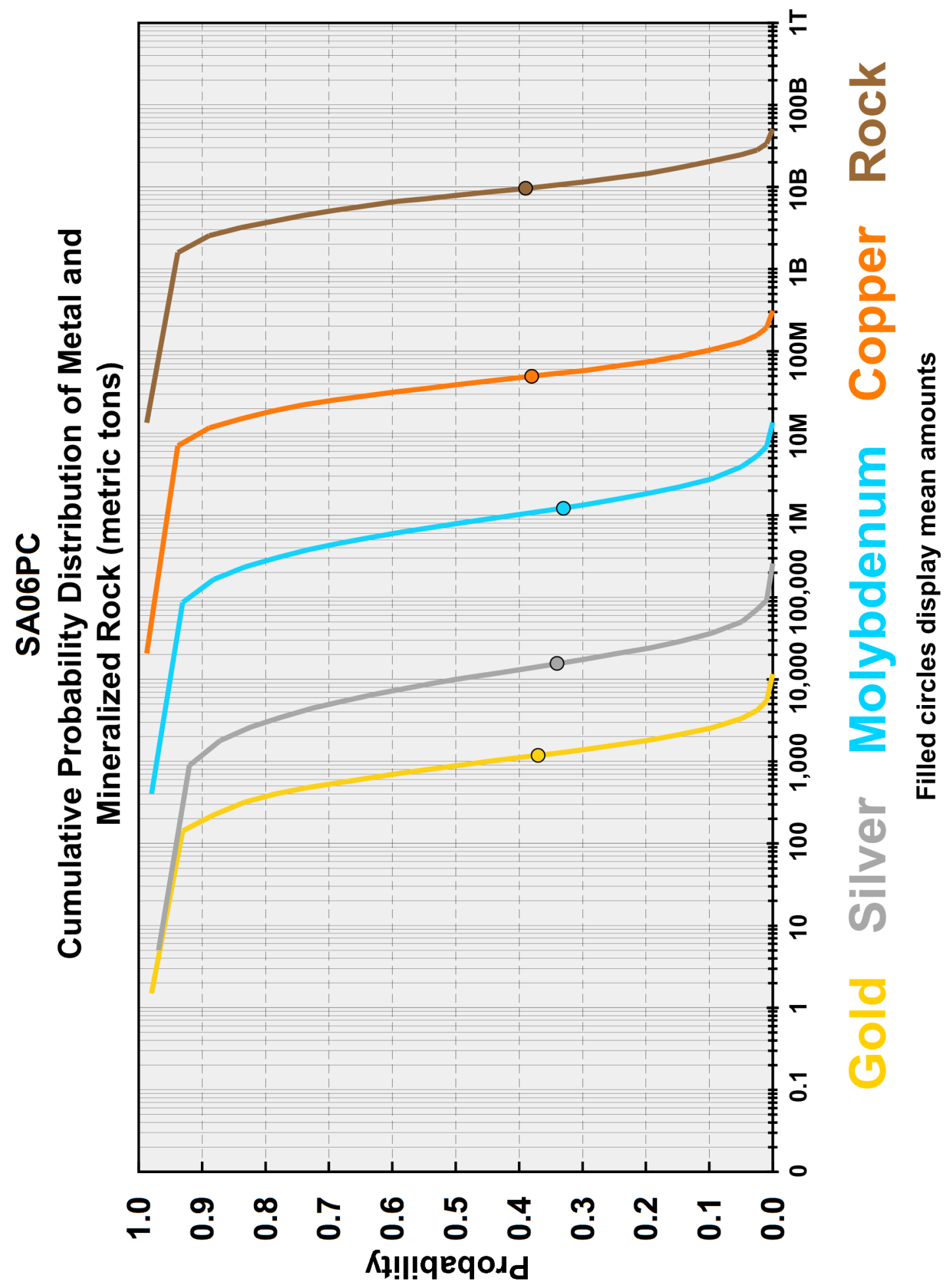




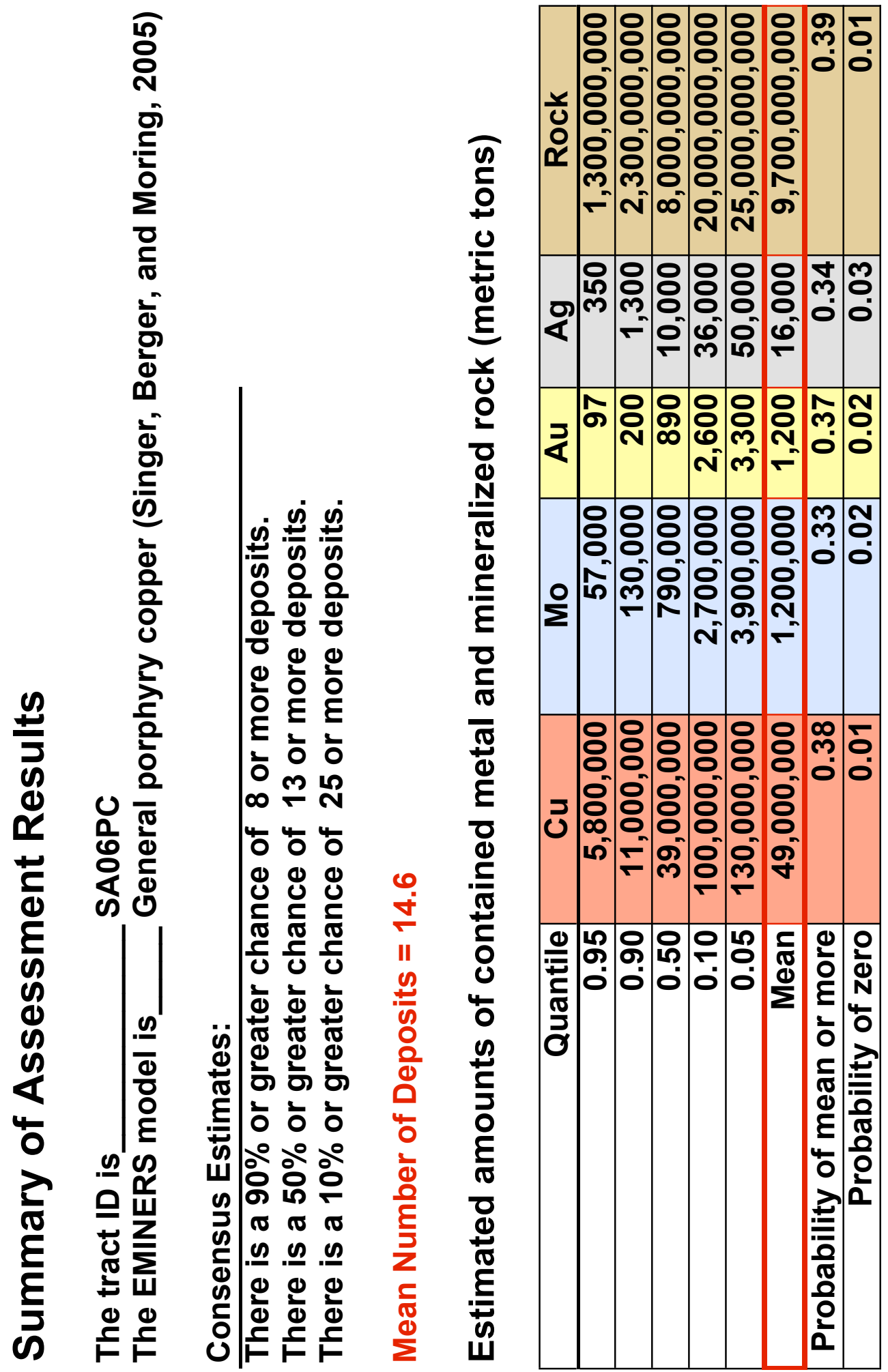




\section{Rationale for tract delineation}

This tract is defined by the distribution of middle to late Miocene mainly calc-alkaline plutons and by the distribution of volcanic and other country rocks and cover rocks within or beneath which such plutons are expected to occur within $1 \mathrm{~km}$ of the surface.

\section{Rationale for model choice}

The size and grades of the discovered porphyry copper deposits in the tract are not significantly different (table 3) from the general porphyry copper deposit model (Singer, Berger, and Moring, 2005), which therefore was used to represent the undiscovered deposits. The composition and zoning of mineralization and alteration in discovered deposits and prospects also support the choice of the general porphyry copper deposit model.

\section{Deposits and prospects}

At the time of the assessment, there were 12 discovered deposits in the tract: Aguila, Cañariaco, Cerro Corona, El Galeno, La Granja, Magistral, Michiquillay, Minas Conga, Pashpap, Rio Blanco, Tantahuatay, and Toromocho. There were five prospects: Alto Dorado, La Vega, Laguna Chamis, Paramo, and Puy-Puy. Recent investigations tentatively have identified additional prospects. The deposits are characterized by stockworks and disseminations of chalcopyrite, molybdenite, and gold in both porphyritic stocks and adjacent country rocks. The deposits commonly are characterized by concentric zones of potassic, phyllic, and propylitic hydrothermally altered rocks (Petersen and Vidal, 1996; Macfarlane, Prol-Ledesma, and Conrad, 1994). Mineral deposits are strongly aligned consistent with control by regional faults.

\section{Exploration history}

Exposed rocks are well explored in the approximately one-quarter of the tract north of $7^{\circ} \mathrm{S}$ latitude. Exploration in this area includes regional geochemistry. The southern three-quarters of the tract is well explored in the vicinity of known mineral deposits. The remaining 70-90 percent of this southern area is covered by younger rocks and sediments (Cabello, 2002; Little, 1995) and is less well explored.

\section{Rationale for numerical estimate}

Members of the assessment team used their collective knowledge of numbers of discovered deposits in the tract and (or) in similar areas elsewhere in the world to make estimates throughout the tract that also were consistent with the deposit density model of Singer and others (2005). The presence of numerous deposits and prospects discovered in exposed rocks led the assessment team to extrapolate relatively large numbers of undiscovered deposits beneath the 70-90 percent of the area covered by younger rocks and sediments, especially south of $7^{\circ} \mathrm{S}$ latitude.

\section{Expected distribution of undiscovered deposits}

The probability of occurrence of an undiscovered deposit is higher beneath the extensive areas of younger cover rocks and sediments, which are unexplored or relatively less well explored than the exposed host rocks and their older country rocks. There are multiple sub-belts of porphyry copper deposits recognized within the Miocene tract (Noble and McKee, 1999) that reflect the generation and dying out of discrete magmatic arcs. The probability of occurrence of an undiscovered deposit is expected to be higher within these sub-belts. 


\section{References cited}

Cabello, J., 2002, Copper exploration in the Central Andes: a review: BHP Billiton, Chile, 7 p., www.metabulletin.com/speakerpaper/copper/presentations/bhpbilliton.pdf

Little, M.L., 1995, Exploration review: South America, Peru: SEG Newsletter, no. 22, p.34-35.

Macfarlane, A.W., Prol-Ledesma, R.-M., and Conrad, M.E., 1994, Isotope and fluid inclusion studies of geological and hydrothermal processes, Northern Peru: Economic Geology, v. 86, p. 645-677.

Noble, D.C., and McKee, E.H., 1999, The Miocene metallogenic belt of central and northern Perú: Skinner, B.J., ed., Geology and ore deposits of the central Andes: Society of Economic Geologists Special Publication No. 7, p.155-193.

Petersen, U., and Vidal, C.E., 1996, Magmatic and tectonic controls on the nature and distribution of copper deposits in Peru, in Camus, F., Sillitoe, R.H., and Petersen, R., eds., Andean copper deposits: new discoveries, mineralization, styles and metallogeny: Society of Economic Geologists Special Publication no. 5, p. 1-18.

Singer, D.A., Berger, Vladimir, Menzie, W.D., and Berger, B.R., 2005, Porphyry copper deposit density: Economic Geology, v. 100, p.491-514.

Singer, D.A., Berger, V.I., and Moring, B.C., 2005, Porphyry copper deposits of the world-Database, map, and grade and tonnage models: U.S. Geological Survey Open-file Report 2005-1060, http://pubs.usgs.gov/of/2005/1060/) 


\section{TRACT SA07PC}
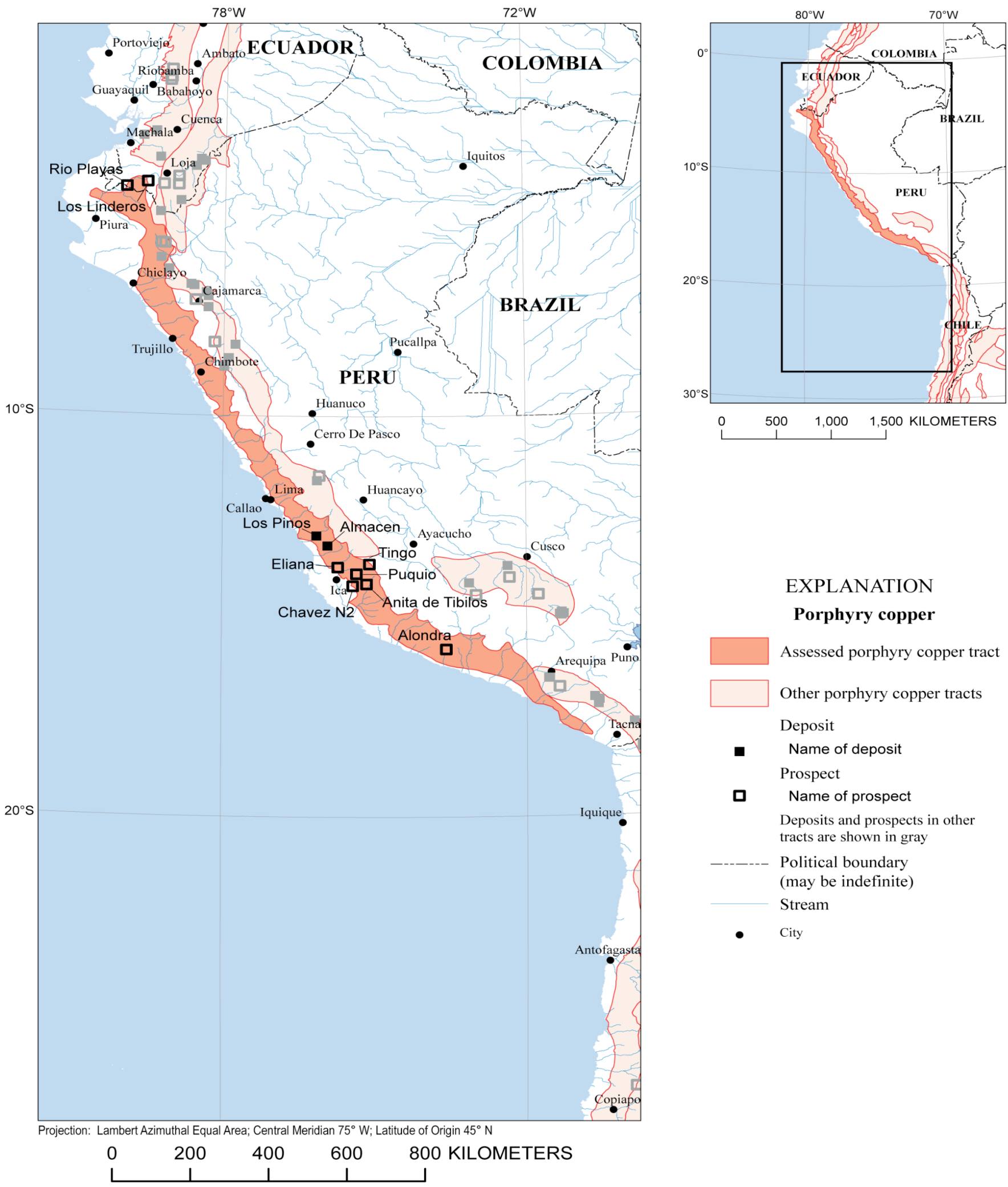

\section{EXPLANATION}

\section{Porphyry copper}

Assessed porphyry copper tract

Other porphyry copper tracts

Deposit

- Name of deposit

Prospect

口 Name of prospect

Deposits and prospects in other tracts are shown in gray

Political boundary (may be indefinite) Stream

- $\quad$ City 


\section{Estimated Undiscovered Porphyry Copper Resources in Tract SA07PC- Peru and Ecuador}

Charles G. Cunningham, ${ }^{1}$ Eduardo 0. Zappettini, ${ }^{2}$ Waldo Vivallo S., ${ }^{3}$ Carlos Mario Celada, ${ }^{4}$ Jorge Quispe, ${ }^{5}$ Donald A. Singer, ${ }^{1}$ Joseph A Briskey, ${ }^{1}$ David M. Sutphin, ${ }^{1}$ Mariano Gajardo M., ${ }^{3}$ Alejandro Diaz, ${ }^{3}$ Carlos Portigliati, ${ }^{3}$ Vladimir I. Berger, ${ }^{1}$ Rodrigo Carrasco, ${ }^{3}$ and Klaus J. Schulz ${ }^{1}$

'USA-U.S. Geological Survey (USGS)

${ }^{2}$ Argentina - Instituto de Geología y Recursos Minerales (SEGEMAR)

${ }^{3}$ Chile-Servicio Nacional de Geología y Minería (SERNAGEOMIN)
${ }^{4}$ Colombia-Instituto Colombiano de Geología y Minería (INGEOMINAS)

${ }^{5}$ Peru-Instituto Geológico Minero y Metalúrgico (INGEMMET)

\begin{tabular}{|l|l|}
\hline Deposit type assessed: Porphyry Copper & $\begin{array}{l}\text { Model: General porphyry copper deposit model } \\
\text { (Singer, Berger, and Moring, 2005) }\end{array}$ \\
\hline Tract name: Peru-Ecuador Cretaceous Almacen & Countries: Peru and Ecuador \\
\hline Tract ID: SA07PC & Region: South America \\
\hline Date of assessment: May 16-18, 2005 & Date of last revision: \\
\hline Assessment depth: $1 \mathrm{~km}$ & Regional coordinator: Charles G. Cunningham \\
\hline Assessment team leader: Donald A. Singer & $\begin{array}{l}\text { Estimators: Carlos Mario Celada, Vladimir I. Berger, Charles G. Cunningham, Alejandro Diaz, Mariano } \\
\text { Gajardo M., Carlos Portigliati, Alvaro Puig Godoy, Donald A. Singer, David M. Sutphin, Waldo Vivallo } \\
\text { S., and Eduardo O. Zappettini }\end{array}$ \\
\hline
\end{tabular}

Table of estimated numbers of undiscovered deposits by quantile. Also showing calculated mean $(m)$, standard deviation $(s)$, and coefficient of variation in percent $(C v \%)$. Sorted by mean.

\begin{tabular}{|l|r|r|r|r|r|c|}
\hline \multicolumn{1}{|c|}{ Estimators } & $\mathbf{9 0}$ & $\mathbf{5 0}$ & $\mathbf{1 0}$ & $\boldsymbol{m}$ & $\boldsymbol{s}$ & $\boldsymbol{C v} \%$ \\
\hline Estimator & 0 & 1 & 3 & 1.3 & 1.2 & 92 \\
\hline Estimator & 1 & 2 & 3 & 1.9 & 0.84 & 44 \\
\hline Estimator & 1 & 2 & 5 & 2.5 & 1.6 & 64 \\
\hline Estimator & 1 & 2 & 5 & 2.5 & 1.6 & 64 \\
\hline Estimator & 1 & 3 & 4 & 2.6 & 1.1 & 42 \\
\hline Consensus of estimators & $\mathbf{1}$ & $\mathbf{3}$ & $\mathbf{8}$ & $\mathbf{3 . 8}$ & $\mathbf{2 . 6}$ & $\mathbf{6 8}$ \\
\hline Estimator & 1 & 4 & 8 & 4.2 & 2.5 & 60 \\
\hline Estimator & 1 & 4 & 10 & 4.8 & 3.3 & 69 \\
\hline Estimator & 2 & 4 & 10 & 5.1 & 3.1 & 61 \\
\hline Estimator & 3 & 5 & 8 & 5.1 & 2.0 & 39 \\
\hline Estimator & 1 & 3 & 15 & 5.9 & 5.3 & 90 \\
\hline Estimator & 2 & 5 & 15 & 7.0 & 4.9 & 70 \\
\hline
\end{tabular}

\section{Deposit density table}

\begin{tabular}{|c|c|c|c|c|}
\hline $\begin{array}{c}\text { Mean of consensus estimates of } \\
\text { undiscovered deposits }\end{array}$ & $\begin{array}{c}\text { Number of } \\
\text { discovered } \\
\text { deposits }\end{array}$ & $\begin{array}{c}\text { Total number of } \\
\text { deposits }\end{array}$ & Area, $\mathbf{k m}^{\mathbf{2}}$ & $\begin{array}{c}\text { Deposit density, number of } \\
\text { deposits/100,000km² }\end{array}$ \\
\hline $\mathbf{3 . 8}$ & 2 & 5.8 & 107,297 & 5 \\
\hline
\end{tabular}




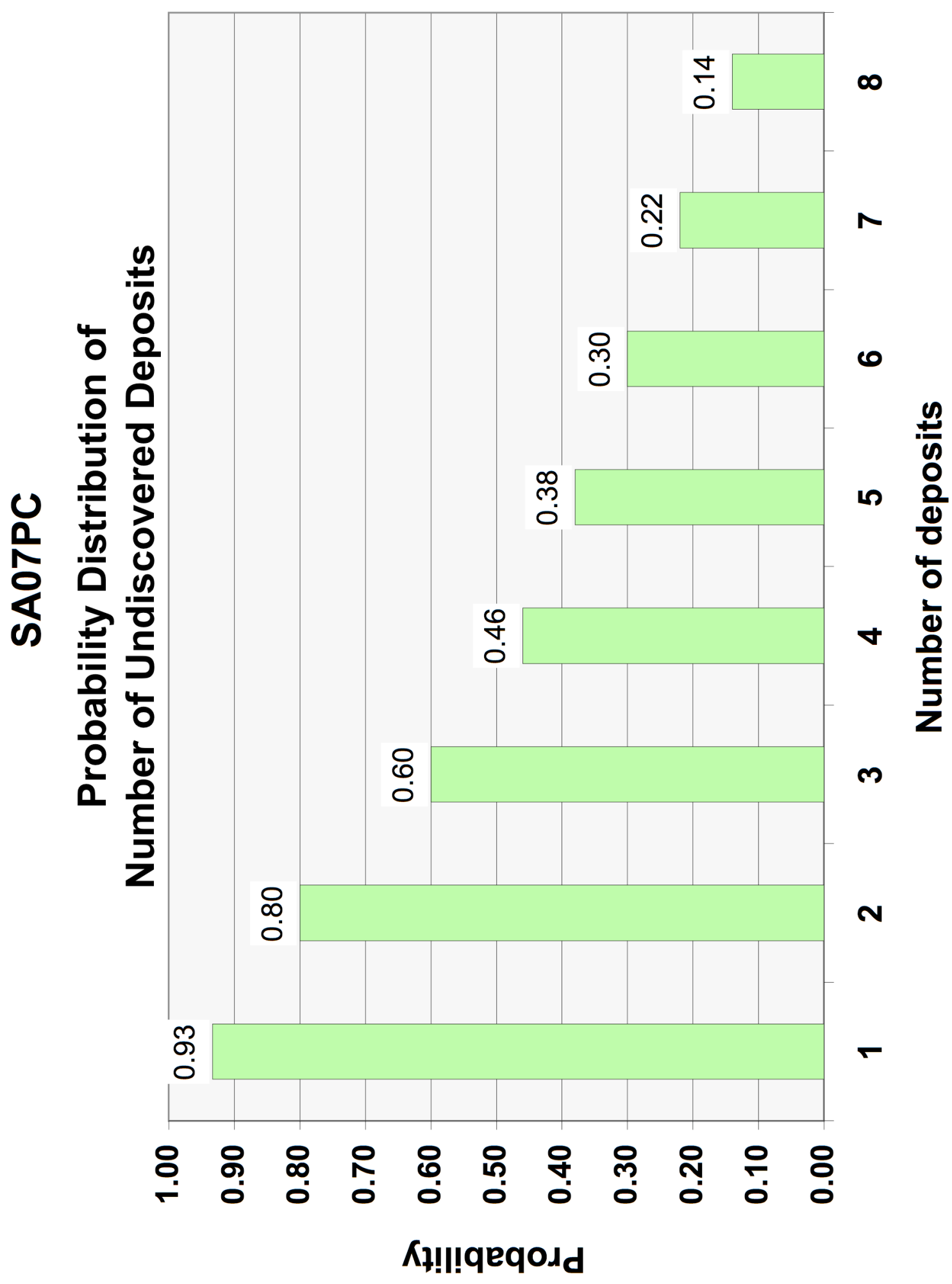




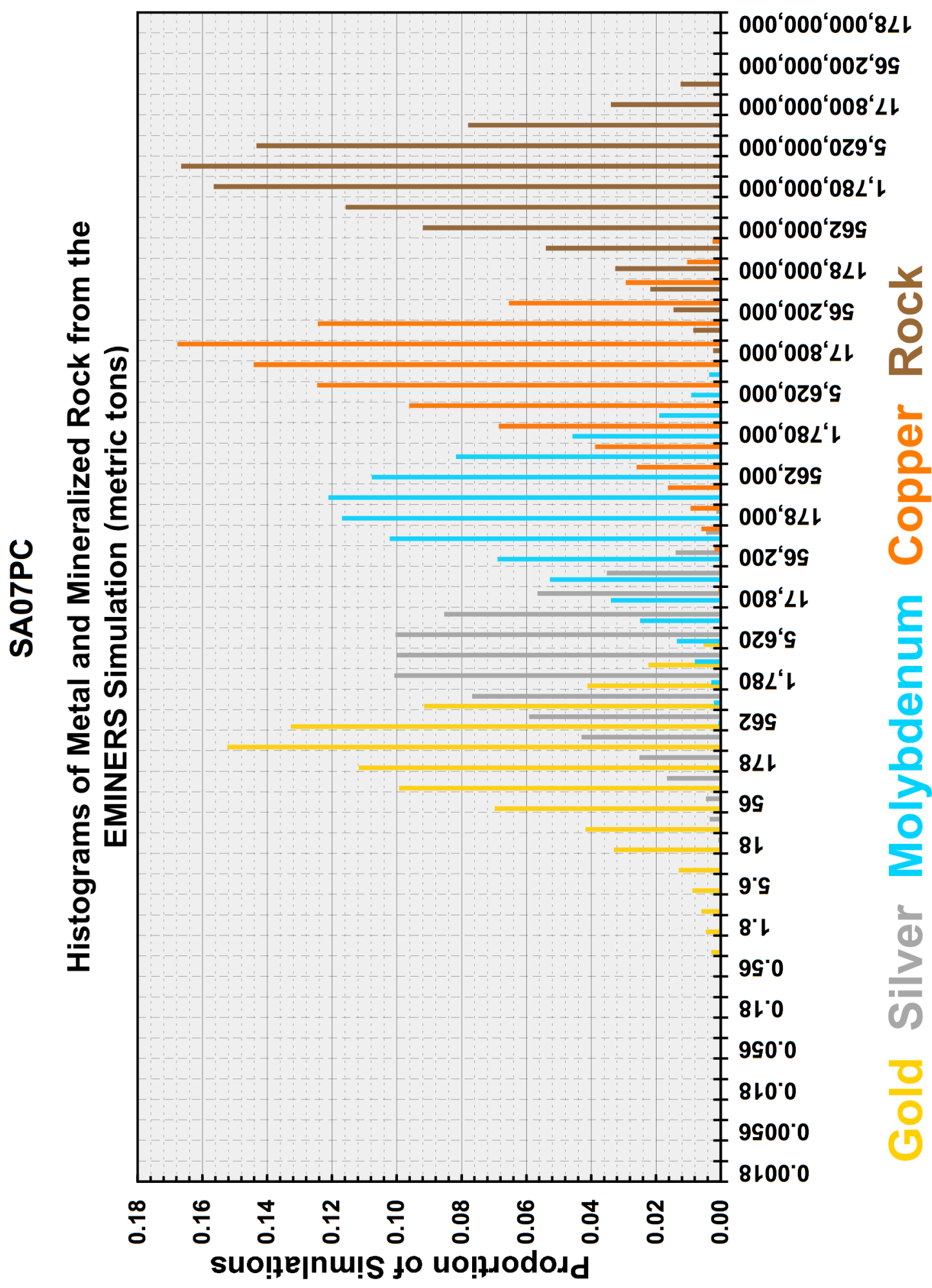




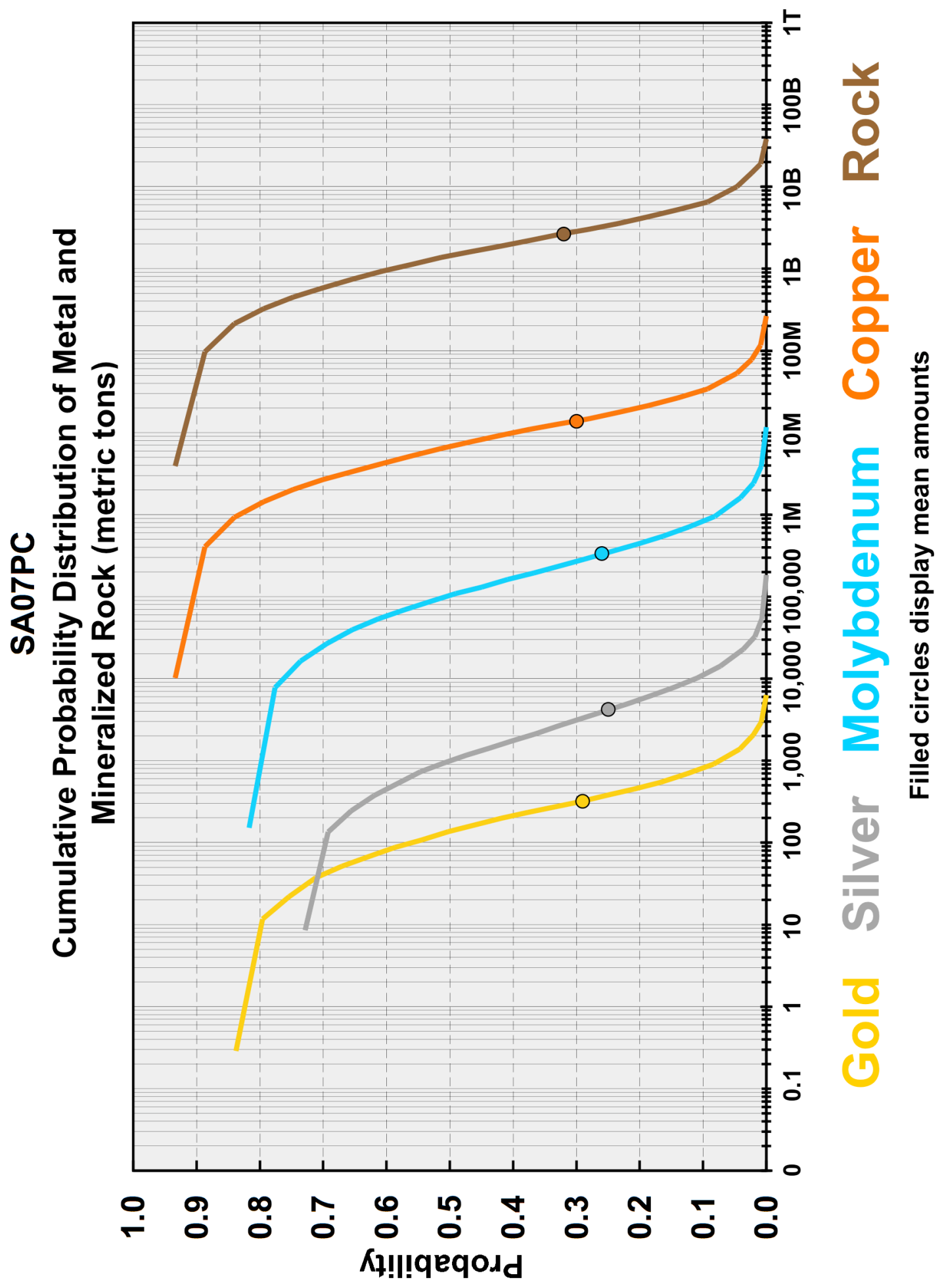




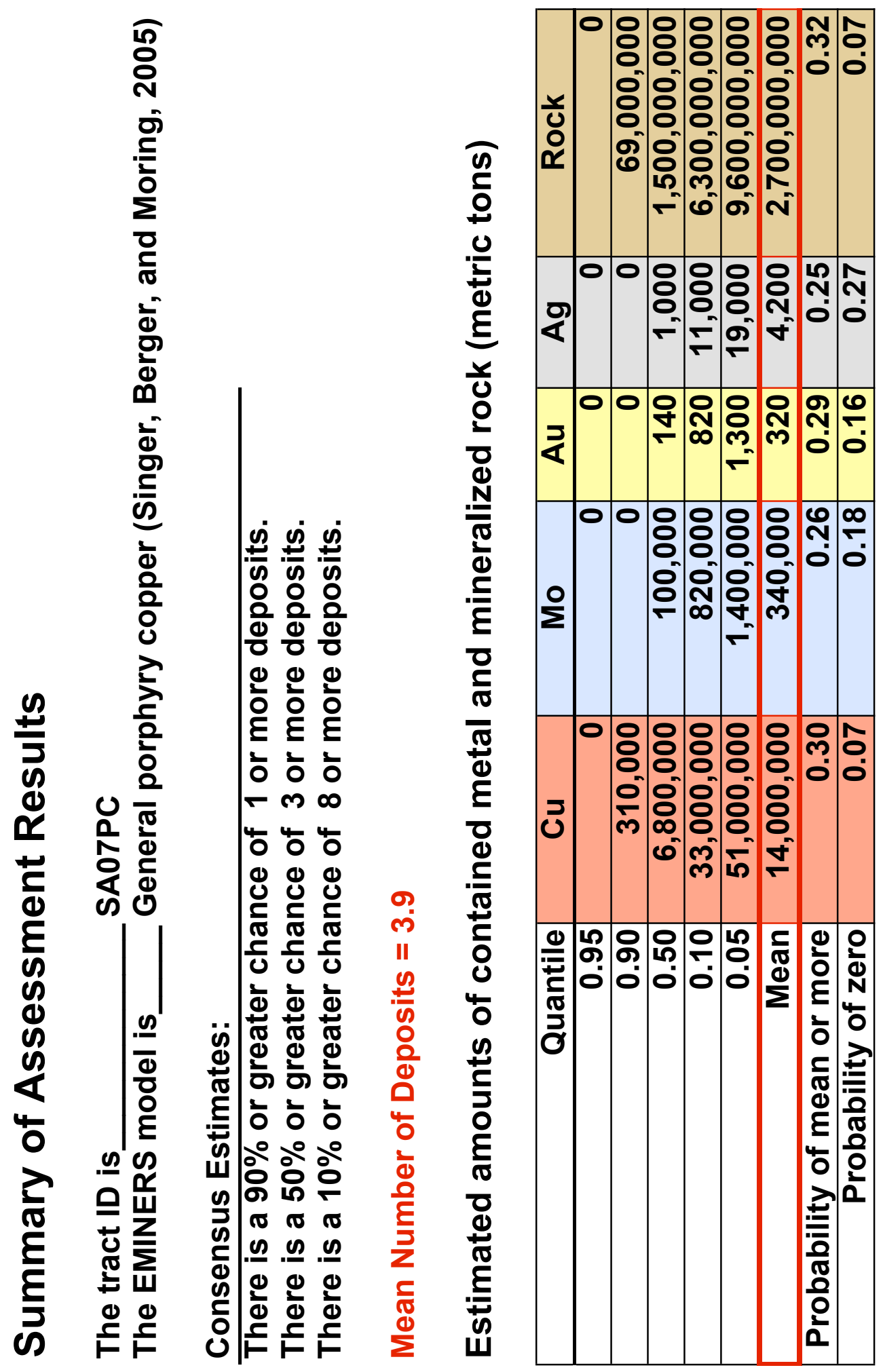




\section{Rationale for tract delineation}

This 1600-km-long tract was delineated using the distribution of Cretaceous plutons and volcanic and other country and cover rocks within or beneath which such plutons are expected to occur within $1 \mathrm{~km}$ of the surface. The plutons are mainly calc-alkaline diorites and tonalites, principally of the Coastal batholith and smaller batholiths. The Coastal batholith has the Perú-Chile oceanic trench on the west and the Brazilian craton on the east, and is the result of subduction of the oceanic Nazca plate beneath the South American plate (Benavides-Cáceres, 1999).

\section{Rationale for model choice}

The size and grades of the discovered porphyry copper deposits in this tract are not significantly different (table 3) from the general porphyry copper deposit model (Singer, Berger, and Moring, 2005), which therefore was used to represent the undiscovered deposits. Discovered mineral deposits and known prospects in the tract are mineralogically and structurally typical of porphyry copper deposits present around the world.

\section{Deposits and prospects}

There are two known discovered deposits, Almacen and Los Pinos, whose ages have not been published. In addition, eight prospects have been located: Alondra, Anita de Tibilos, Chavez N2, Eliana, Los Linderos, Puquio, Rio Playas, and Tingo. Several unlocated Cretaceous-age prospects are present in the southern part of the tract. The copper and molybdenum-rich cores of some of these prospects are host to potassic and phyllic alteration minerals. Descriptions of the geology of deposits and prospects in the tract include those of Anonymous (1994), Gossens and Hollister (1973), Paladines (1980), and Vidal (1985).

\section{Exploration history}

Although the rocks in this tract are poorly explored, they are better explored than similar rocks in tract SA04PC.

\section{Rationale for numerical estimate}

Analogies with numbers of deposits known in similar areas that team members have studied elsewhere, together with reference to the deposit density model of Singer and others (2005), helped guide the estimates of undiscovered porphyry copper deposits in this tract. Estimated numbers of undiscovered deposits are relatively small for such a large tract. Although there are several discovered deposits and known prospects in this poorly explored tract, the porphyry copper host rocks are deeply eroded and the assessment team believes that many, and perhaps most, porphyry copper deposits once present have been eroded away.

\section{Expected distribution of undiscovered deposits}

Discovered deposits and prospects are all in the southern end of the tract suggesting that this area may be the less deeply eroded and thus more likely to contain undiscovered deposits.

\section{References cited}

Anonymous, 1994, Arequipa acquires Peruvian company: Northern Miner, v. 80, no. 41, December 12, p.16. 
Benavides-Cáceres, Víctor, 1999, Orogenic evolution of the Peruvian Andes: the Andean cycle: in Skinner, B.J., ed., Geology and ore deposits of the central Andes, Society of Economic Geologists Special Publication No. 7, p. 61-107.

Goossens, P.J., and Hollister, V.F., 1973, Structural control and hydrothermal alteration pattern of Chaucha porphyry copper, Ecuador: Mineralium Deposita, v. 8, p. 321-331.

Paladines, A.P., 1980, Mapa metalogénico de la Republica del Ecuador, escala 1:1,000,000: Ministerio de Recursos Naturales y Energéticos, Dirección General de Geología y Minas, 1 folio.

Singer, D.A., Berger, V.I., Menzie, W.D., and Berger, B.R., 2005, Porphyry copper density: Economic Geology, v. 100, no. 3, p. 491-514.

Singer, D.A., Berger, V.I., and Moring, B.C., 2005, Porphyry copper deposits of the world-Database, map, and grade and tonnage models: U.S. Geological Survey Open-file Report 2005-1060, http://pubs.usgs.gov/of/2005/1060/)

Vidal, C., 1985, Metallogenesis associated with the Coastal Batholith of Peru: a review: in Pitcher, W.S., Atherton, M.P., Cobbing, E.J., and Beckinsale, R.D., eds., Magmatism at a plate edge, the Peruvian Andes: Blackie, London, p. 243-249. 
TRACT SA08PC
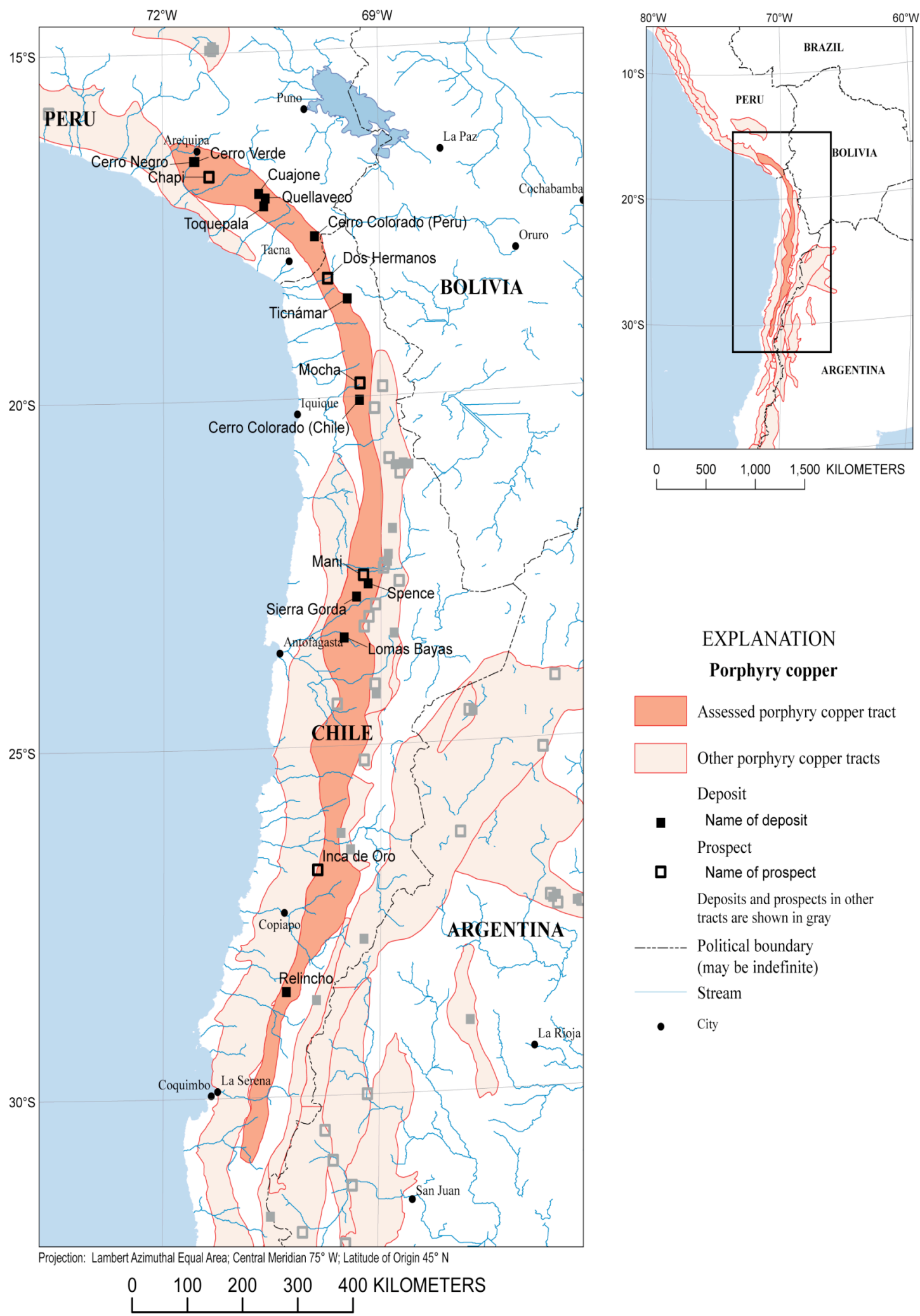

EXPLANATION

Porphyry copper

Assessed porphyry copper tract

Other porphyry copper tracts

Deposit

- Name of deposit

Prospect

口 Name of prospect

Deposits and prospects in other tracts are shown in gray

Political boundary (may be indefinite) Stream

- $\quad$ City 


\section{Estimated Undiscovered Porphyry Copper Resources in Tract SA08PC- Chile and Peru}

Charles G. Cunningham, ${ }^{1}$ Eduardo 0. Zappettini, ${ }^{2}$ Waldo Vivallo S., ${ }^{3}$ Carlos Mario Celada, ${ }^{4}$ Jorge Quispe,${ }^{5}$ Donald A. Singer, ${ }^{1}$ Joseph A Briskey, ${ }^{1}$ David M. Sutphin, ${ }^{1}$ Mariano Gajardo M., ${ }^{3}$ Alejandro Diaz, ${ }^{3}$ Carlos Portigliati, ${ }^{3}$ Vladimir I. Berger, ${ }^{1}$ Rodrigo Carrasco, ${ }^{3}$ and Klaus J. Schulz ${ }^{1}$

'USA-U.S. Geological Survey (USGS)

${ }^{2}$ Argentina-Instituto de Geología y Recursos Minerales (SEGEMAR)

${ }^{3}$ Chile-Servicio Nacional de Geología y Minería (SERNAGEOMIN)
${ }^{4}$ Colombia-Instituto Colombiano de Geología y Minería (INGEOMINAS)

${ }^{5}$ Peru-Instituto Geológico Minero y Metalúrgico (INGEMMET)

\begin{tabular}{|l|l|}
\hline Deposit type assessed: Porphyry Copper & $\begin{array}{l}\text { Model: General porphyry copper deposit model } \\
\text { (Singer, Berger, and Moring, 2005) }\end{array}$ \\
\hline $\begin{array}{l}\text { Tract name: Chile-Peru Paleocene-Eocene } \\
\text { Toquepala }\end{array}$ & Countries: Peru and Chile \\
\hline Tract ID: SA08PC & Region: South America \\
\hline Date of assessment: May 16-18, 2005 & Date of last revision: \\
\hline Assessment depth: $1 \mathrm{~km}$ & Regional coordinator: Charles G. Cunningham \\
\hline Assessment team leader: Donald A. Singer & $\begin{array}{l}\text { Estimators: Carlos Mario Celada, Vladimir I. Berger, Rodrigo Carrasco, Charles G. Cunningham, } \\
\text { Alejandro Diaz, Mariano Gajardo M., Carlos Portigliati, Alvaro Puig Godoy, Donald A. Singer, Waldo } \\
\text { Vivallo S., and Eduardo O. Zappettini. }\end{array}$ \\
\hline
\end{tabular}

Table of estimated numbers of undiscovered deposits by quantile. Also showing calculated mean $(m)$, standard deviation $(s)$, and coefficient of variation in percent $(C v \%)$. Sorted by mean.

\begin{tabular}{|l|c|c|c|c|c|c|}
\hline \multicolumn{1}{|c|}{ Estimators } & $\mathbf{9 0}$ & $\mathbf{5 0}$ & $\mathbf{1 0}$ & $\boldsymbol{m}$ & $\boldsymbol{s}$ & $\mathbf{C v} \%$ \\
\hline Estimator & 5 & 10 & 15 & 9.7 & 3.7 & 38 \\
\hline Estimator & 6 & 10 & 15 & 9.9 & 3.5 & 35 \\
\hline Estimator & 6 & 10 & 18 & 11 & 4.6 & 42 \\
\hline Estimator & 5 & 10 & 20 & 11 & 5.6 & 51 \\
\hline Estimator & 5 & 10 & 20 & 11 & 5.6 & 51 \\
\hline Estimator & 4 & 10 & 24 & 12 & 7.3 & 61 \\
\hline Consensus of estimators & $\mathbf{6}$ & $\mathbf{1 1}$ & $\mathbf{2 2}$ & $\mathbf{1 2}$ & $\mathbf{6 . 0}$ & $\mathbf{5 0}$ \\
\hline Estimator & 8 & 12 & 20 & 13 & 4.7 & 36 \\
\hline Estimator & 10 & 14 & 18 & 13 & 3.3 & 25 \\
\hline Estimator & 5 & 10 & 30 & 14 & 9.4 & 67 \\
\hline Estimator & 8 & 15 & 25 & 15 & 6.3 & 42 \\
\hline Estimator & 8 & 15 & 35 & 18 & 10 & 56 \\
\hline
\end{tabular}

\section{Deposit density table}

\begin{tabular}{|c|c|c|c|c|}
\hline $\begin{array}{c}\text { Mean of consensus estimates of } \\
\text { undiscovered deposits }\end{array}$ & $\begin{array}{c}\text { Number of } \\
\text { discovered } \\
\text { deposits }\end{array}$ & $\begin{array}{c}\text { Total number of } \\
\text { deposits }\end{array}$ & Area, $\mathbf{~ k m}^{2}$ & $\begin{array}{c}\text { Deposit density, number of } \\
\text { deposits/100,000 } \mathbf{k m}^{2}\end{array}$ \\
\hline $\mathbf{1 2}$ & 12 & 24 & 69,087 & 35 \\
\hline
\end{tabular}




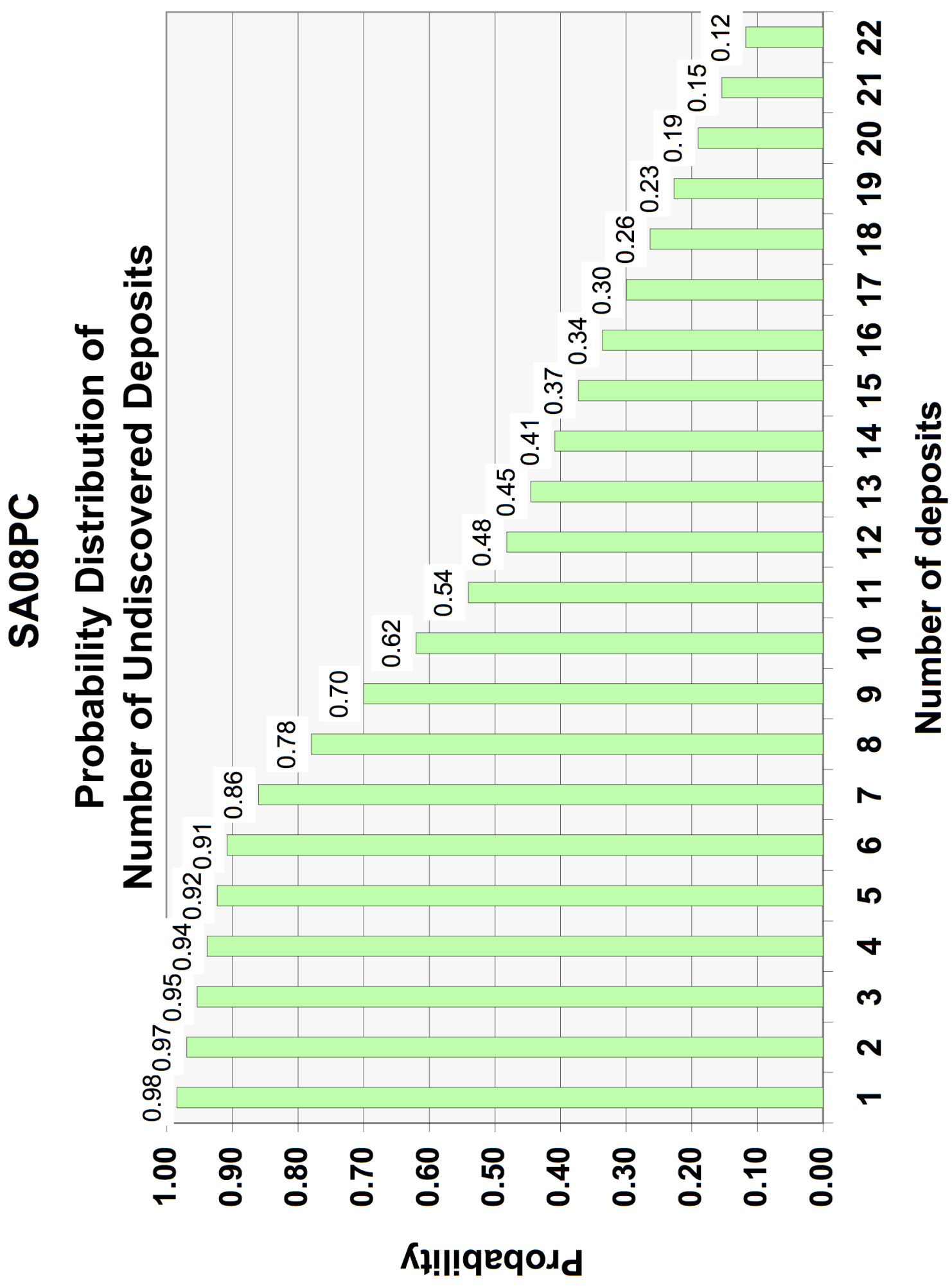




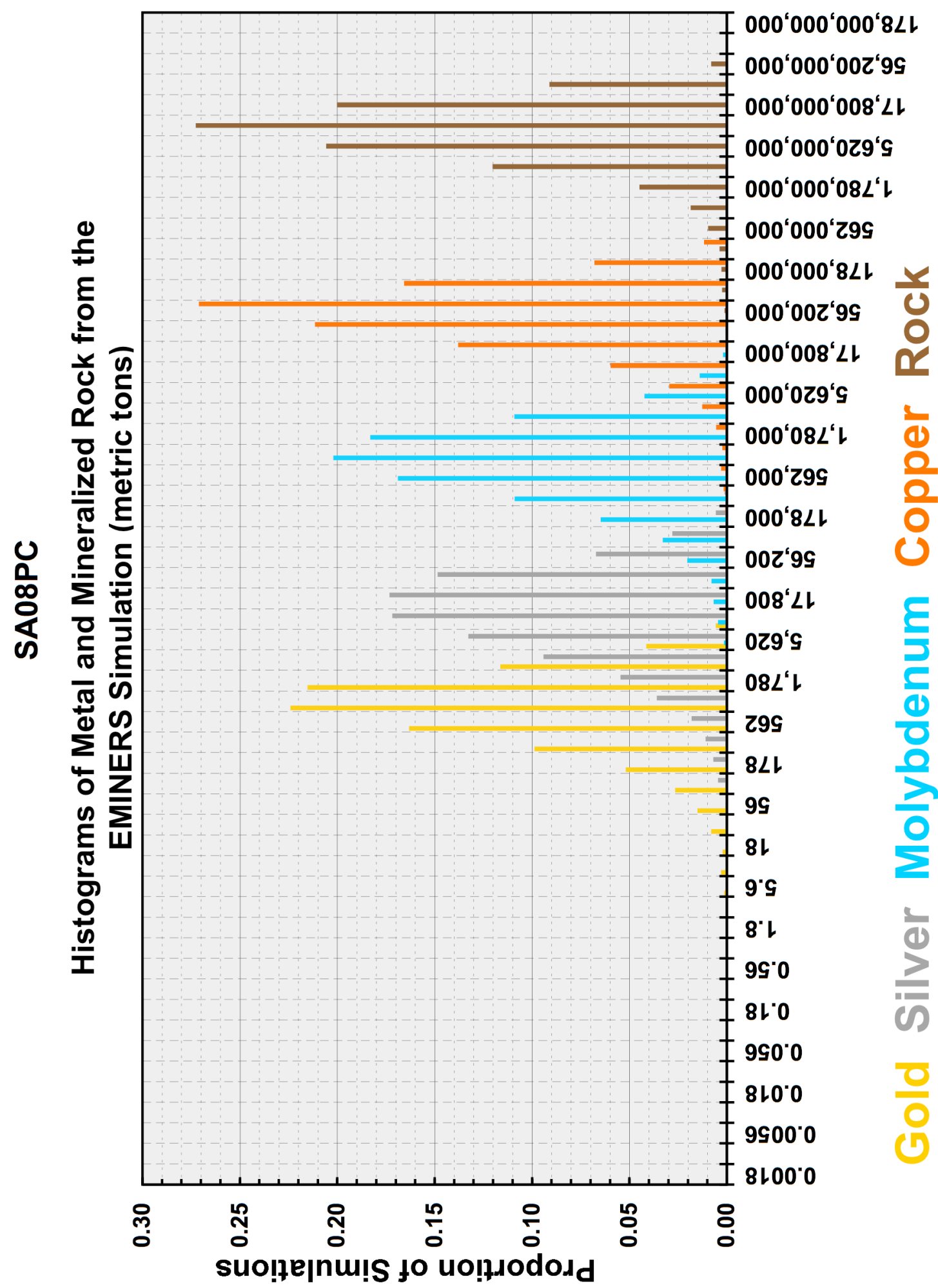




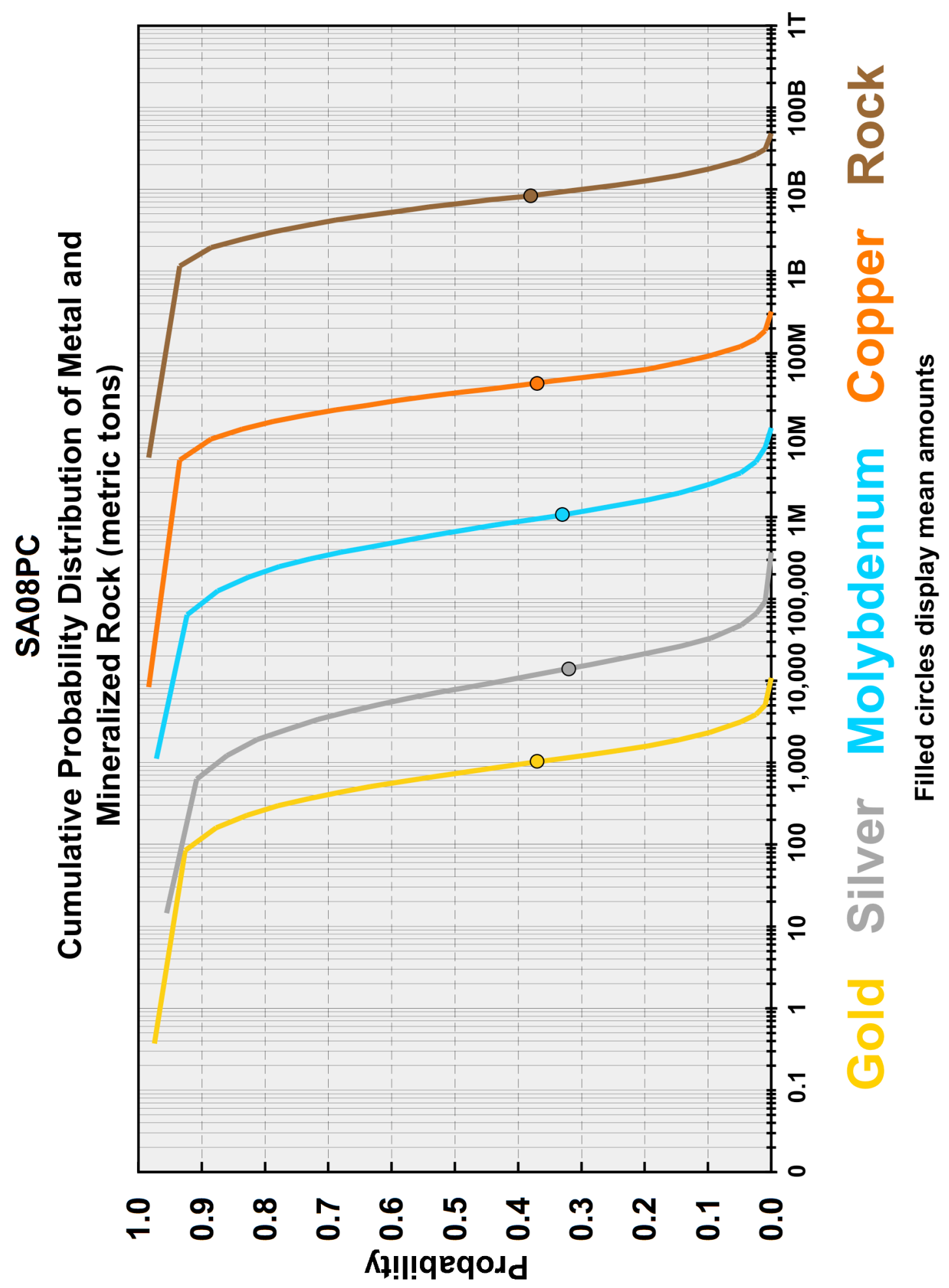




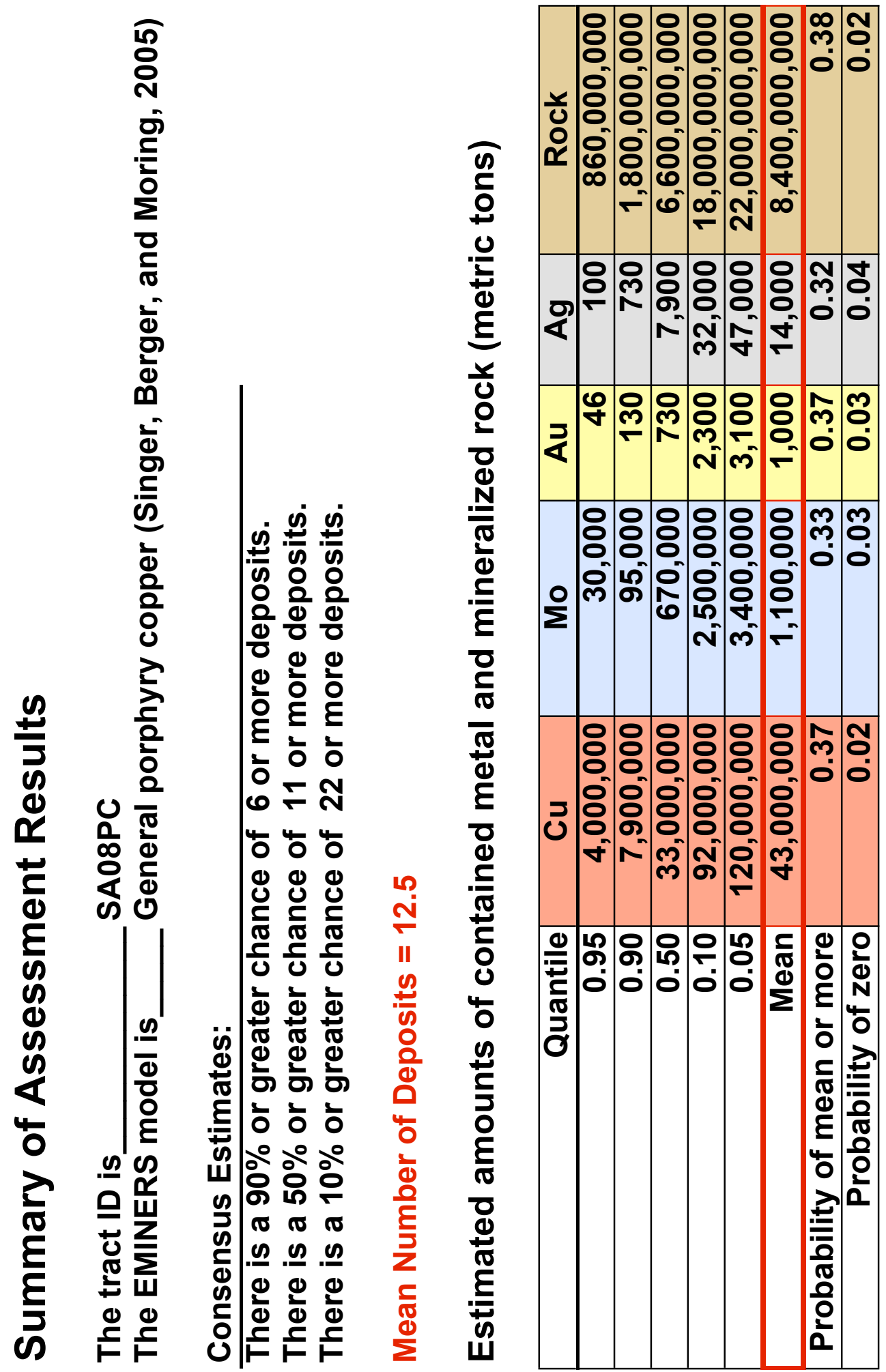




\section{Rationale for tract delineation}

This tract is defined by the distribution of Paleocene and Eocene mostly calc-alkaline plutons and by the distribution of volcanic and other country rocks and cover rocks within or beneath which such plutons are expected to occur within $1 \mathrm{~km}$ of the surface. The tract extends south from southern Peru where mineralization is associated with the Paleocene Toquepala volcanics and coeval porphyry plutons. In Chile, the tract includes Paleocene and Eocene rhyolite volcanic domes, dacite pyroclastic rocks, and associated calderas. Consequently, the southern parts of the tract are more likely to contain porphyry copper deposits buried by consanguineous volcanic rocks. There is approximately 70 percent cover by these and other younger rocks and sediments. Additional information about tract geology and mineral deposits include Sillitoe (1990), Clark (1993), Long (1995), Zweng and Clark (1995), Petersen and Vidal (1996), Mattos and Valle (2000), and Zappettini and others (2001).

\section{Rationale for model choice}

The size and grades of the discovered porphyry copper deposits in the tract are not significantly different (table 3) from the general porphyry copper deposit model (Singer, Berger, and Moring, 2005), which therefore was used to represent the undiscovered deposits. Moreover, a number of classic porphyry-copper-type deposits are known in the tract.

\section{Deposits and prospects}

Twelve discovered porphyry copper deposits were known in the tract at the time of the assessment. Six of these deposits are in southern Peru: Cerro Colorado, Cerro Negro, Cerro Verde, Cuajone, Quellaveco, and Toquepala. The remaining six are in Chile: Cerro Colorado, Lomas Bayas, Relincho, Sierra Gorda, Spence, and Ticnámar. Peru had one porphyry copper prospect, Chapi, and Chile had four: Dos Hermanos, Inca de Oro, Mani, and Mocha.

The largest and richest porphyry copper deposits of Perú (Toquepala, Quellaveco, Cuajone, and Cerro Verde) are included in this tract and are classical porphyry copper deposits as defined by mineralogy, alteration zoning, and grade-tonnage characteristics. These deposits are related to the early Eocene Caldera batholith (Petersen and Vidal, 1996). In contrast to most Chilean porphyry copper deposits, enargite is generally absent and silver is important in deposits in this tract (Petersen and Vidal, 1996).

\section{Exploration history}

Exposed rocks have been prospected but not systematically explored. There is some exploration drilling in covered areas - approximately 70 to 80 exploration holes were drilled in the tract north of Sierra Gorda.

\section{Rationale for numerical estimate}

Members of the assessment team used their collective knowledge of numbers of discovered deposits in the tract and (or) in similar areas elsewhere in the world to make estimates throughout the tract that also were consistent with the deposit density model of Singer and others (2005). The presence of numerous discovered deposits and prospects in this large, poorly explored tract with about 70 percent younger cover rocks contributed to relatively high estimates of numbers of undiscovered deposits. In addition, many parts of the tract are not deeply eroded suggesting that undiscovered deposits are likely to be preserved within $1 \mathrm{~km}$ of the surface, including many of those areas of host rock under cover. 


\section{Expected distribution of undiscovered deposits}

The probability of occurrence of an undiscovered deposit is not uniform throughout this tract. For example, some of the southern parts of the tract in Chile are more likely to contain undiscovered porphyry copper deposits where covered by volcanic rocks consanguineous with known events of porphyry copper mineralization in the tract. Another example is in southern Peru where a number of large porphyry copper deposits occur in small plutons exposed by erosion within the vast area covered by the Toquepala volcanic field, which is cogenetic with the plutons and deposits. The assessment team did not have time or sufficiently detailed data available at the time of assessment to subdivide the tract into multiple areas having relatively uniform internal probabilities of occurrence for an undiscovered deposit.

\section{References cited}

Clark, A.H., 1993, Are outsize porphyry copper deposits either anatomically or environmentally distinctive, in Whiting, B.H., Hodgson, C.J., and Mason, R., eds., Giant ore deposits: Society of Economic Geologists Special Publication 2, p. 213-283.

Long, K.R., 1995, Production and reserves of Cordilleran (Alaska to Chile) porphyry copper deposits, in Pierce, F.W., and Bolm, J.G., eds., Porphyry copper deposits of the American Cordillera: Tucson, Arizona Geological Society Digest 20, p. 35-68.

Mattos, R., and Valle, J., 2000, Exploracion, geología y desarrollo del yacimiento Toquepala,: Primer volumen de monografias de yacimientos minerales Peruanos. Historia, exploration y geología: Lima, Instituto de Ingenieros de Minas del Peru, p. 101-116.

Petersen, Ulrich, and Vidal, C.E., 1996, Magmatic and tectonic controls on the nature and distribution of copper deposits in Peru, in Camus, F., Sillitoe, R.H., and Petersen, R., eds., Andean copper deposits: new discoveries, mineralization, styles and metallogeny: Society of Economic Geologists Special Publication no. 5, p. 1-18.

Sillitoe, R.H., 1990, Copper deposits and Andean evolution, in Ericksen, G.E., Cañas Pinochet, M.T., and Reinemund, J.A., eds., Geology of the Andes and its relation to hydrocarbon and mineral resources: Circum-Pacific Council for Energy and Mineral Resources Earth Science Series, v. 11, Houston, p. 285311.

Singer, D.A., Berger, V.I., and Moring, B.C., 2005, Porphyry copper deposits of the world-Database, map, and grade and tonnage models: U.S. Geological Survey Open-file Report 2005-1060, http://pubs.usgs.gov/of/2005/1060/)

Singer, D.A., Berger, V.I., Menzie, W.D., and Berger, B.R., 2005, Porphyry copper density: Economic Geology, v. 100, no. 3, p. 491-514.

Zappettini, Eduardo, Miranda-Angles, Vitaliano, Rodriguez S., Carolina, Palacios, Oscar, Cocking, Robert, Godeas, Marta, Uribe-Zeballos, Hernán, Vivallo S., Waldo, Paz, Manuel Maidana, Seggiaro, Raúl., Heuschmidt, Bertand, Gardeweg P., Moyra, Boulangger Rondoy, Elmere, Korzeniewski, Lidia I., Mpodozis M., Constantino, Carpio R., Mario, and Rubiolo, Daniel, 2001, Mapa metalogénico de la región fronteriza entre Argentina, Bolivia, Chile y Perú $\left(14^{\circ} \mathrm{S}-28^{\circ} \mathrm{S}\right)$ : Servicio Nacional de Geología y Minería, Publicacion Geológica Multinacional No. 2, Santiago, Chile, escala 1:1,000,000, 222 p., 1 map.

Zweng, P.L., and Clark, A.H., 1995, Hypogene evolution of the Toquepala porphyry copper-molybdenum deposit, Moquegua, southeastern Peru, in Pierce, F.W., and Bolm, J.G., eds., Porphyry copper deposits of the American Cordillera: Tucson, Arizona Geological Society Digest 20, p. 566-612. 
TRACT SA09PC

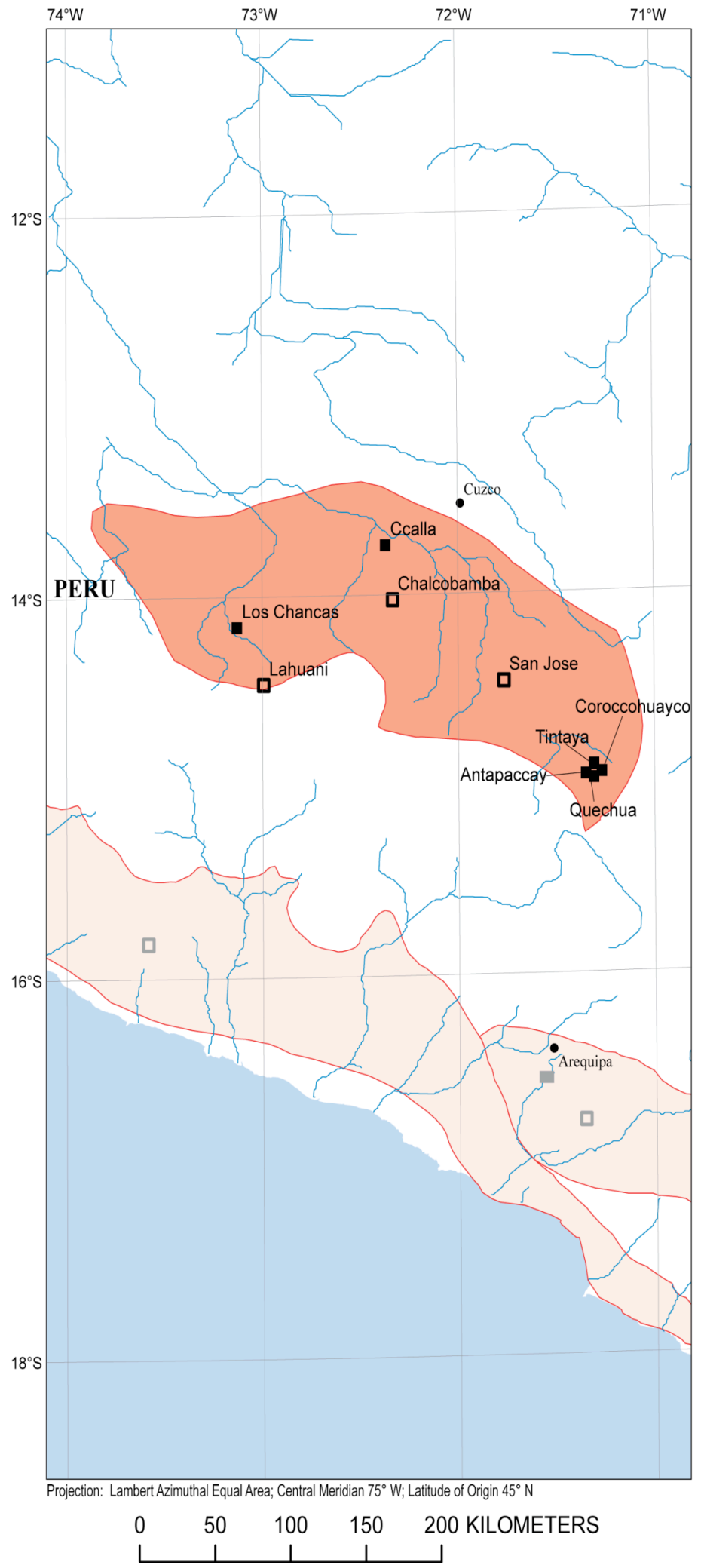

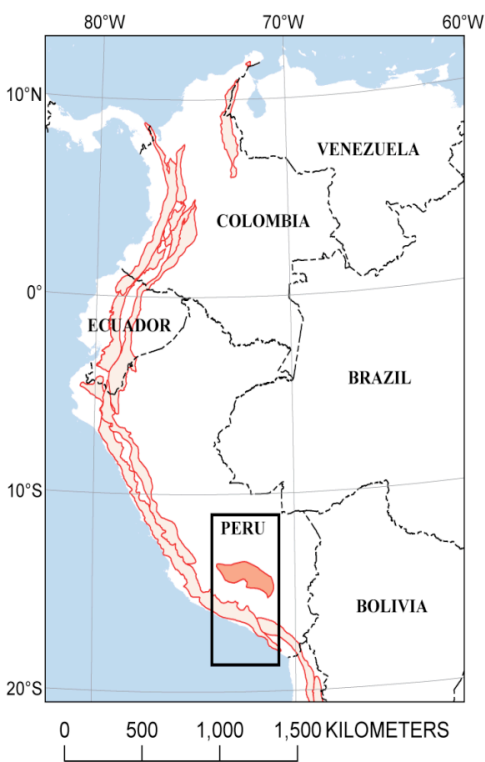

EXPLANATION

Porphyry copper

Assessed porphyry copper tract

Other porphyry copper tracts

Deposit

- Name of deposit

Prospect

口 Name of prospect

Deposits and prospects in other tracts are shown in gray

Political boundary (may be indefinite)

Stream

- $\quad$ City 


\section{Estimated Undiscovered Porphyry Copper Resources in Tract SA09PC- Peru}

Charles G. Cunningham, ${ }^{1}$ Eduardo 0. Zappettini, ${ }^{2}$ Waldo Vivallo S., ${ }^{3}$ Carlos Mario Celada, ${ }^{4}$ Jorge Quispe ${ }^{5}$ Donald A. Singer, ${ }^{1}$ Joseph A Briskey, ${ }^{1}$ David M. Sutphin, ${ }^{1}$ Mariano Gajardo M., ${ }^{3}$ Alejandro Diaz, ${ }^{3}$ Carlos Portigliati, ${ }^{3}$ Vladimir I. Berger, ${ }^{1}$ Rodrigo Carrasc $0,{ }^{3}$ and Klaus J. Schulz ${ }^{1}$

'USA-U.S. Geological Survey (USGS)

${ }^{2}$ Argentina - Instituto de Geología y Recursos Minerales (SEGEMAR)

${ }^{3}$ Chile-Servicio Nacional de Geología y Minería (SERNAGEOMIN)
${ }^{4}$ Colombia - Instituto Colombiano de Geología y Minería (INGEOMINAS)

${ }^{5}$ Peru-Instituto Geológico Minero y Metalúrgico (INGEMMET)

\begin{tabular}{|l|l|}
\hline Deposit type assessed: Porphyry Copper & $\begin{array}{l}\text { Model: General porphyry copper deposit model } \\
\text { (Singer, Berger, and Moring, 2005) }\end{array}$ \\
\hline $\begin{array}{l}\text { Tract name: Peru Eocene-Oligocene } \\
\text { Antapaccay }\end{array}$ & Countries: Peru \\
\hline Tract ID: SA09PC & Region: South America \\
\hline Date of assessment: May 16-18, 2005 & Date of last revision: \\
\hline Assessment depth: $1 \mathrm{~km}$ & Regional coordinator: Charles G. Cunningham \\
\hline Assessment team leader: Donald A. Singer & $\begin{array}{l}\text { Estimators: Carlos Mario Celada, Vladimir I. Berger, Rodrigo Carrasco, Charles G. Cunningham, } \\
\text { Alejandro Diaz, Mariano Gajardo M., Carlos Portigliati, Alvaro Puig Godoy, Donald A. Singer, Waldo } \\
\text { Vivallo S., and Eduardo O. Zappettini. }\end{array}$ \\
\hline
\end{tabular}

Table of estimated numbers of undiscovered deposits by quantile. Also showing calculated mean $(m)$, standard deviation $(s)$, and coefficient of variation in percent $(C v \%)$. Sorted by mean.

\begin{tabular}{|l|r|r|r|r|r|c|}
\hline \multicolumn{1}{|c|}{ Estimators } & $\mathbf{9 0}$ & $\mathbf{5 0}$ & $\mathbf{1 0}$ & $\boldsymbol{m}$ & $\boldsymbol{s}$ & Cv\% \\
\hline Estimator & 1 & 2 & 5 & 2.5 & 1.6 & 64 \\
\hline Estimator & 1 & 3 & 6 & 3.2 & 1.9 & 59 \\
\hline Estimator & 2 & 4 & 8 & 4.5 & 2.3 & 51 \\
\hline Estimator & 2 & 4 & 10 & 5.1 & 3.1 & 61 \\
\hline Estimator & 3 & 5 & 8 & 5.1 & 2.0 & 39 \\
\hline Estimator & 3 & 5 & 9 & 5.4 & 2.4 & 44 \\
\hline Consensus of estimators & $\mathbf{3}$ & $\mathbf{5}$ & $\mathbf{9}$ & $\mathbf{5 . 4}$ & $\mathbf{2 . 4}$ & $\mathbf{4 4}$ \\
\hline Estimator & 2 & 5 & 10 & 5.5 & 3.0 & 55 \\
\hline Estimator & 5 & 7 & 9 & 6.7 & 1.7 & 25 \\
\hline Estimator & 4 & 8 & 12 & 7.7 & 3.0 & 39 \\
\hline Estimator & 4 & 8 & 12 & 7.7 & 3.0 & 39 \\
\hline Estimator & 5 & 8 & 15 & 8.9 & 3.9 & 44 \\
\hline
\end{tabular}

\section{Deposit density table}

\begin{tabular}{|c|c|c|c|c|}
\hline $\begin{array}{c}\text { Mean of consensus estimates of } \\
\text { undiscovered deposits }\end{array}$ & $\begin{array}{c}\text { Number of } \\
\text { discovered } \\
\text { deposits }\end{array}$ & $\begin{array}{c}\text { Total number of } \\
\text { deposits }\end{array}$ & Area, $\mathbf{~ k m}^{2}$ & $\begin{array}{c}\text { Deposit density, number of } \\
\text { deposits/100,000 } \mathbf{k m}^{2}\end{array}$ \\
\hline $\mathbf{5 . 4}$ & 6 & 11 & 30,154 & 36 \\
\hline
\end{tabular}




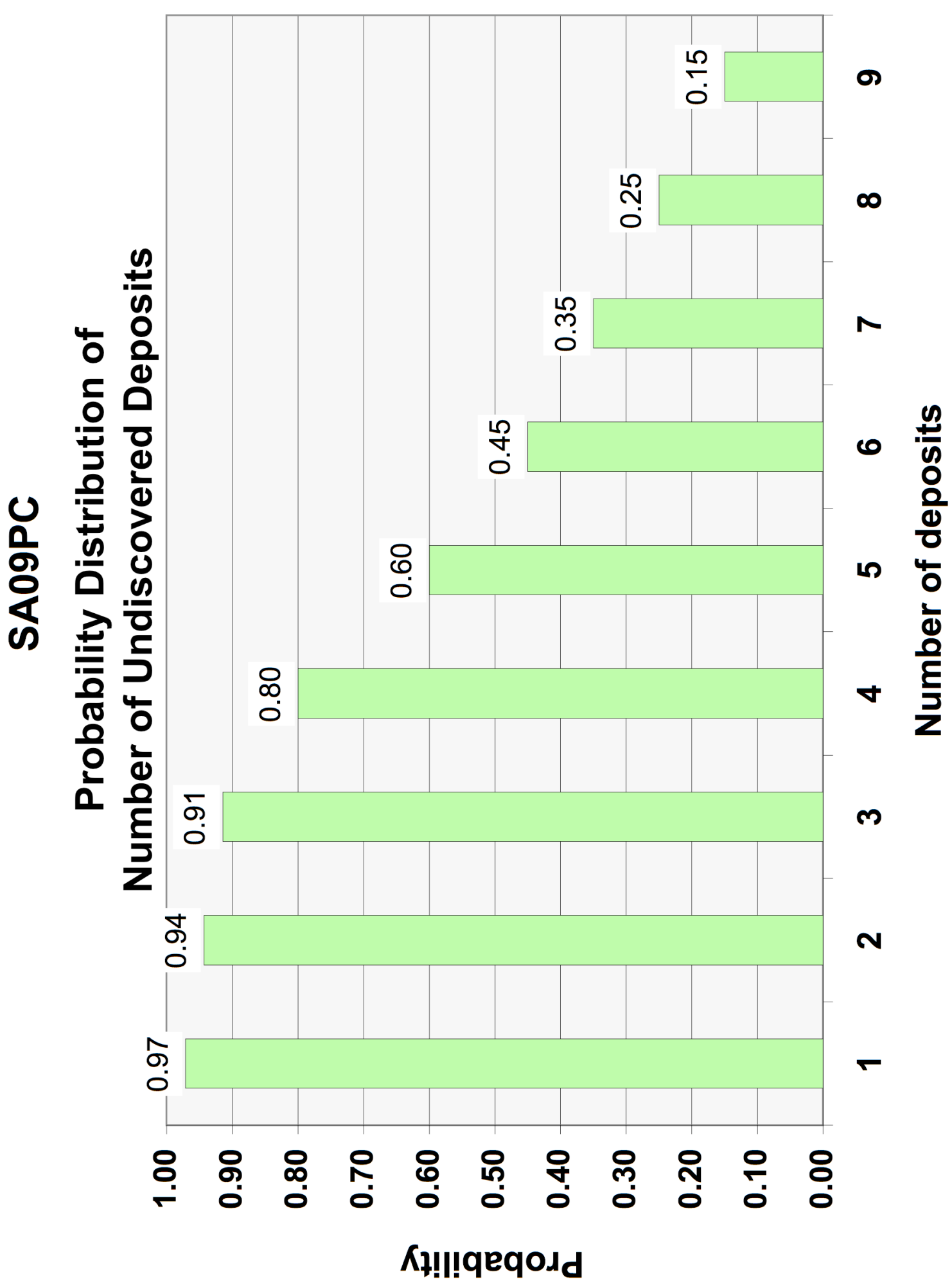




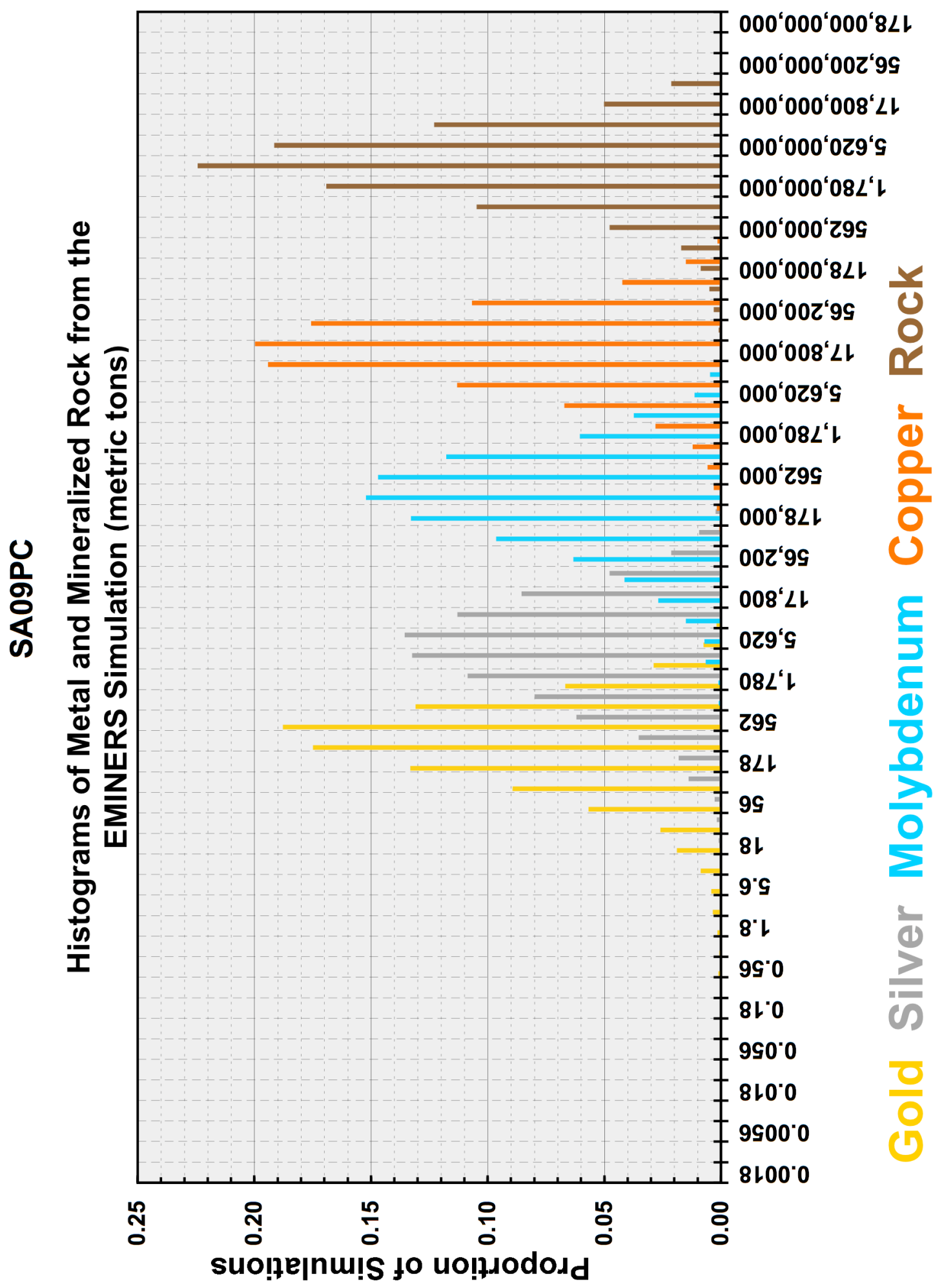




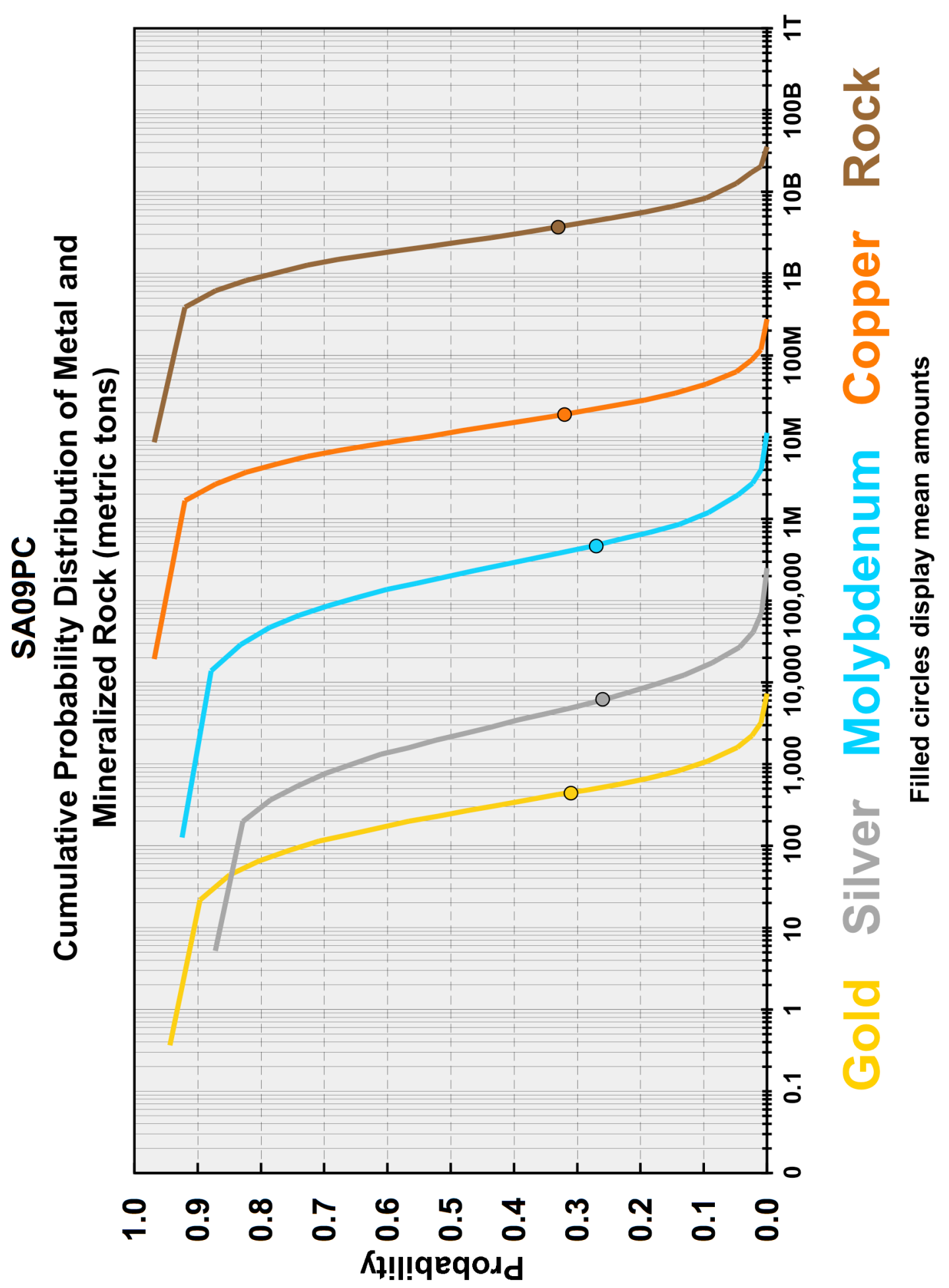




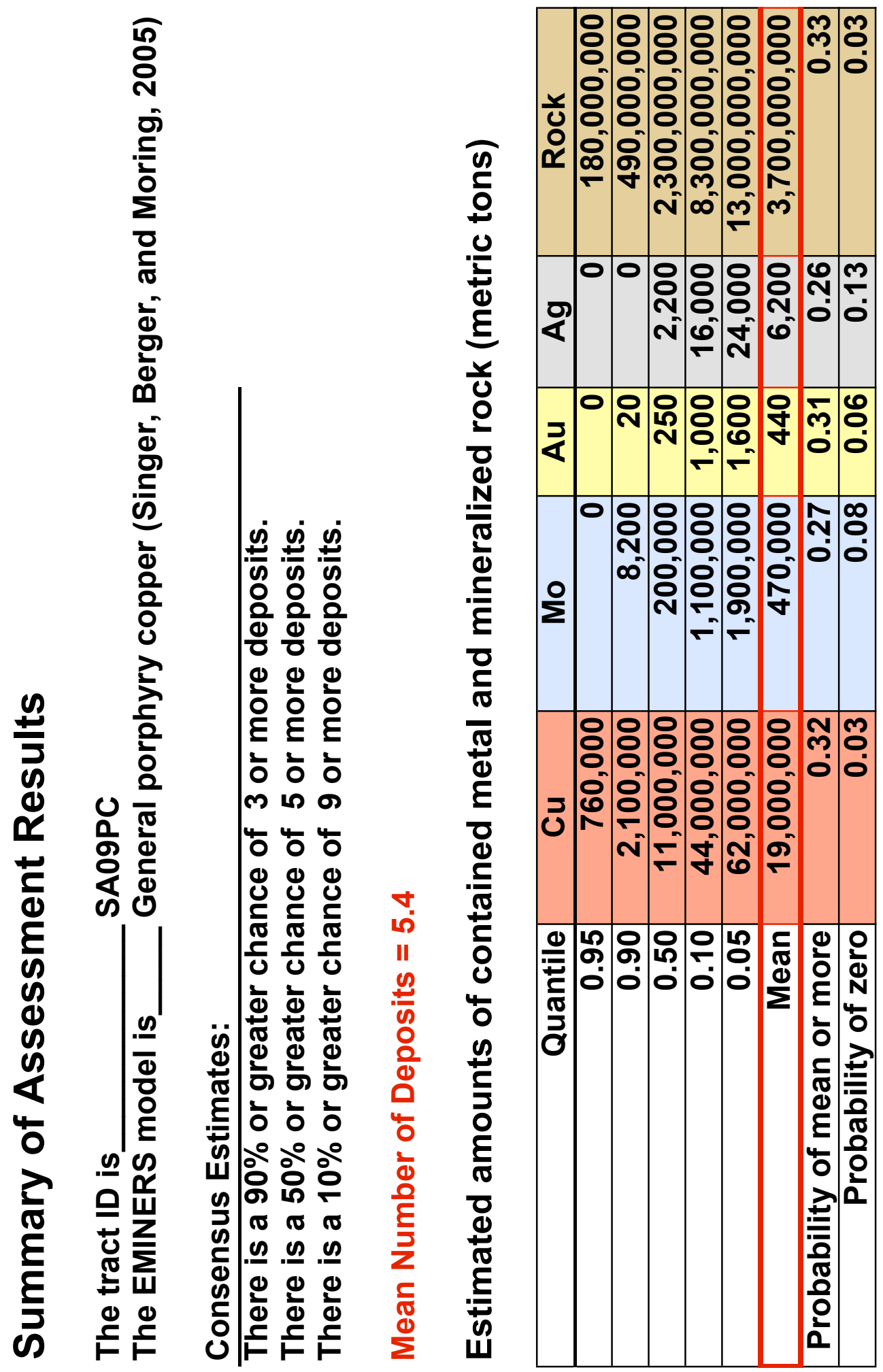




\section{Rationale for tract delineation}

This tract is defined by the distribution of Eocene to Oligocene mostly calc-alkaline plutons and by the distribution of volcanic and other country rocks and cover rocks within or beneath which such plutons are expected to occur within $1 \mathrm{~km}$ of the surface. The tract includes volcanic-arc lava flows, breccias, and epizonal plutons, all of which are discontinuous northern extensions of equivalent rocks in EoceneOligocene subtracts SA10aPC and SA10bPC, and tract SA12PC. The tract is bounded on the southwest side by a thick section of younger Neogene volcanic rocks.

\section{Rationale for model choice}

A statistical $t$-test (table 3 ) of the average tonnage and grades of these deposits compared to the general porphyry copper deposit model (Singer, Berger, and Moring, 2005) shows significantly higher copper grades than the other deposits in the model. The discovered porphyry copper deposits in this tract commonly contain skarn mineralization that increased the copper grades above the average grade of other porphyry copper deposits. The estimating team believes that the undiscovered porphyry copper deposits in this tract will not be associated with the carbonate rocks that help produce the skarns and therefore the general porphyry copper model is selected for this tract despite failing the $t$-test.

\section{Deposits and prospects}

The tract contains six discovered deposits: Antapaccay, Ccalla, Coroccohuayco, Los Chancas, Quechua, and Tintaya. In addition, three porphyry copper prospects were known at the time of the assessment: Chalcobamba, Lahuani, and San Jose. The spatial distribution of known deposits in the tract appears to be relatively uniform.

Discovered deposits in the tract have many of the classical alteration and mineralogical features of porphyry copper deposits and they form skarn deposits where copper-bearing plutons intruded carbonate host rocks. Additional information is in Fierro and others (1997), Noble and others (1984), Perelló and others (2003), Petersen and Vidal (1996), and Zappettini and others (2001).

\section{Exploration history}

Exposed rocks in the tract are well explored at the surface in the northern half, but the southern half is less well explored and has been only sporadically prospected.

\section{Rationale for numerical estimate}

Members of the assessment team used their collective knowledge of numbers of discovered deposits in the tract and (or) in similar areas elsewhere in the world to make estimates throughout the tract that also were consistent with the deposit density model of Singer and others (2005). This medium-sized tract has a relatively large number of discovered deposits for its size. Moreover, the exposed rocks are incompletely explored with little or no exploration beneath cover. Consequently, the estimating team judges that a number of undiscovered deposits are likely to exist both at the surface and especially beneath cover.

\section{Expected distribution of undiscovered deposits}

Based on knowledge and information available at the time of tract delineation, the assessment team members know of no reason why the probability of occurrence of an undiscovered deposit would not be reasonably uniform in most of the tract. Exceptions are those areas of host rock projected under younger cover rocks where the potential is higher because such areas are unexplored or relatively so. 


\section{References cited}

Fierro, J.R., Zweng, P.L., Gamarra, H.R., and Garate, G.L., 1997, Chabuca Este Cu-(Au,Ag) skarn deposit at Tintaya, Peru: IX Congreso Peruano de Geología. Resúmenos Extendidos. Sociedad Geológica del Perú, v. 1, p. 37-39.

Noble, D.C., McKee, E.H., Eyzaguirre, V.P., and Marocco, R., 1984, Age and regional tectonic and metallogenetic implications of igneous activity and mineralization in the Andahuaylas-Yauri belt of southern Peru: Economic Geology, v. 79, p. 172-176.

Perelló, J., Carlotto, V., Zárate, A., Ramos, P. Rosso, H., Neyra, C., Caballero, A., Fuster, N., and Muhr, R., 2003, Porphyry-style alteration and mineralization of the middle Eocene to early Oligocene Andahuaylas-Yauri belt, Cuzco region, Peru: Economic Geology, v 98, p. 1575-1605.

Petersen, U., and Vidal, C.E., 1996, Magmatic and tectonic controls on the nature and distribution of copper deposits in Peru, in Camus, F., Sillitoe, R.H., and Petersen, R., eds., Andean copper deposits: new discoveries, mineralization, styles and metallogeny: Society of Economic Geologists Special Publication no. 5, p. 1-18.

Singer, D.A., Berger, V.I., Menzie, W.D., and Berger, B.R., 2005, Porphyry copper density: Economic Geology, v. 100, no. 3, p. 491-514.

Singer, D.A., Berger, V.I., and Moring, B.C., 2005, Porphyry copper deposits of the world-Database, map, and grade and tonnage models: U.S. Geological Survey Open-file Report 2005-1060, http://pubs.usgs.gov/of/2005/1060/)

Zappettini, Eduardo, Miranda-Angles, Vitaliano, Rodriguez S., Carolina, Palacios, Oscar, Cocking, Robert, Godeas, Marta, Uribe-Zeballos, Hernán, Vivallo S., Waldo, Paz, Manuel Maidana, Seggiaro, Raúl., Heuschmidt, Bertand, Gardeweg P., Moyra, Boulangger Rondoy, Elmere, Korzeniewski, Lidia I., Mpodozis M., Constantino, Carpio R., Mario, and Rubiolo, Daniel, 2001, Mapa metalogénico de la región fronteriza entre Argentina, Bolivia, Chile y Perú $\left(14^{\circ} \mathrm{S}-28^{\circ} \mathrm{S}\right)$ : Servicio Nacional de Geología y Minería, Publicacion Geológica Multinacional No. 2, Santiago, Chile, escala 1:1,000,000, 222 p., 1 map. 
TRACT SA10aPC
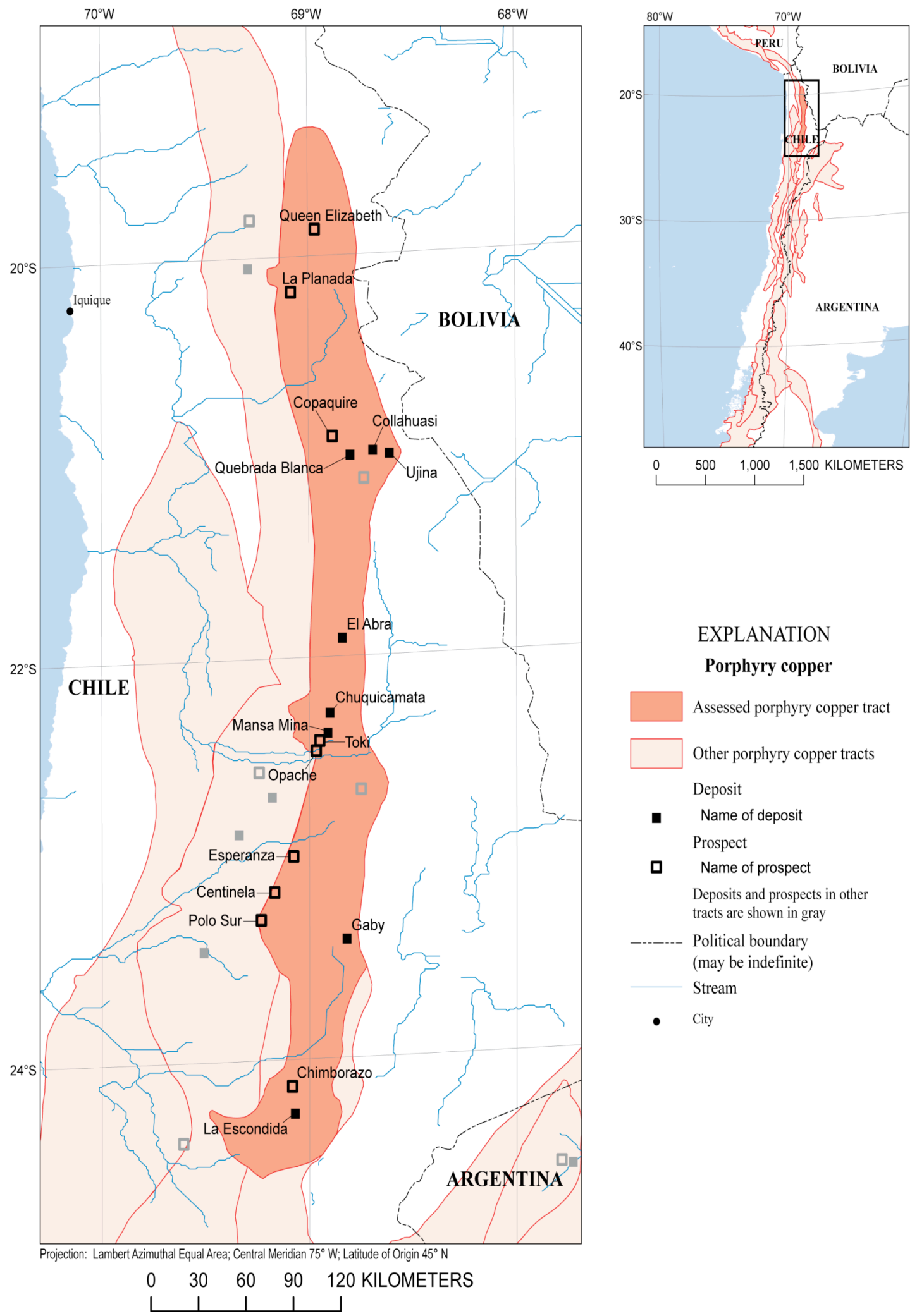

\section{EXPLANATION}

Porphyry copper

Assessed porphyry copper tract

Other porphyry copper tracts

Deposit

- Name of deposit

Prospect

口 Name of prospect

Deposits and prospects in other tracts are shown in gray

Political boundary (may be indefinite)

Stream

- $\quad$ City 


\section{TRACT SA10bPC}
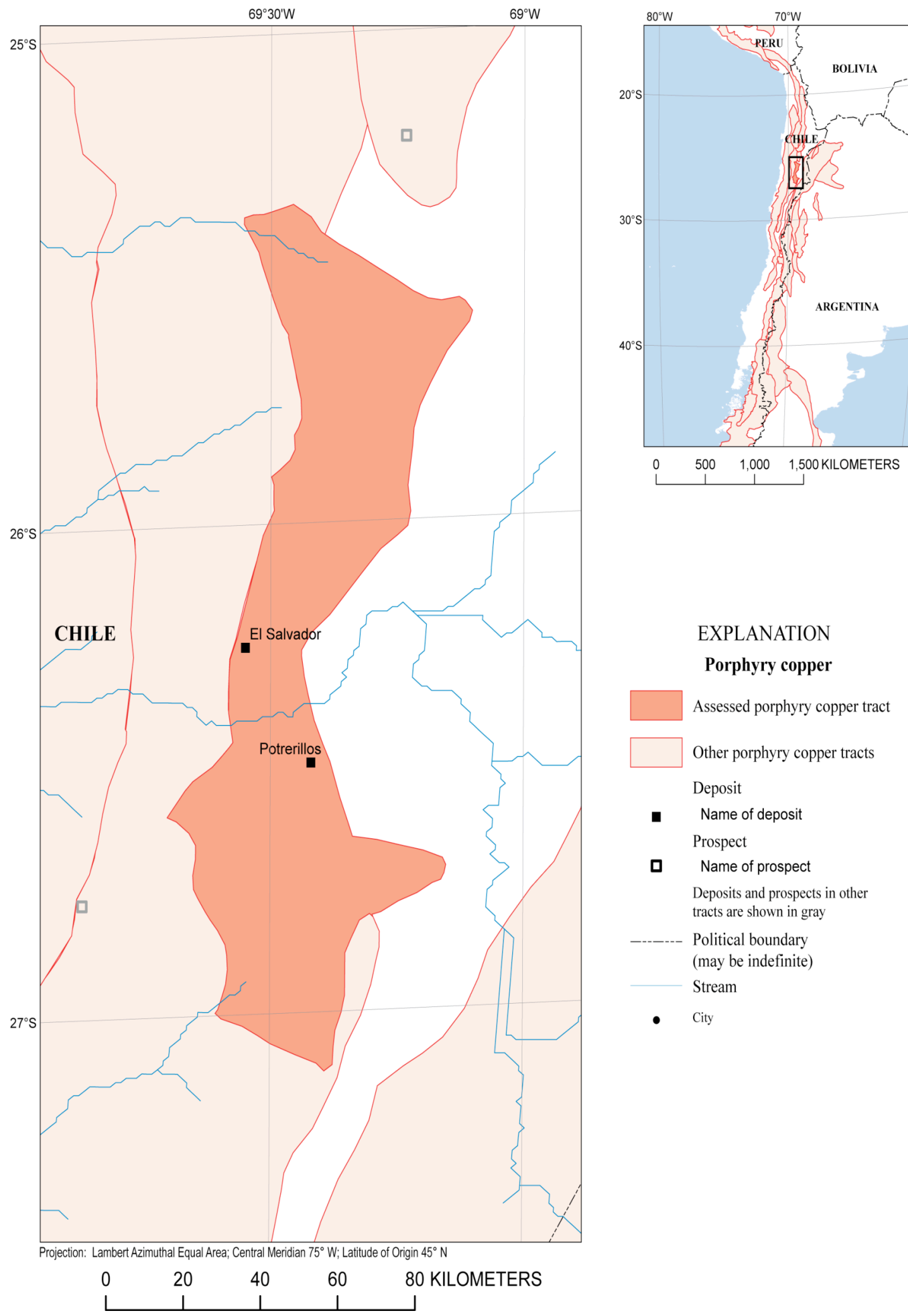

EXPLANATION

Porphyry copper

Assessed porphyry copper tract

Other porphyry copper tracts

Deposit

- Name of deposit

Prospect

口 Name of prospect Deposits and prospects in other tracts are shown in gray

Political boundary (may be indefinite) Stream

- $\quad$ City 


\section{Estimated Undiscovered Porphyry Copper Resources in Tract SA10a,bPC- Chile}

Charles G. Cunningham, ${ }^{1}$ Eduardo 0. Zappettini, ${ }^{2}$ Waldo Vivallo S., ${ }^{3}$ Carlos Mario Celada, ${ }^{4}$ Jorge Quispe ${ }^{5}$ Donald A. Singer, ${ }^{1}$ Joseph A Briskey, ${ }^{1}$ David M. Sutphin, ${ }^{1}$ Mariano Gajardo M., ${ }^{3}$ Alejandro Diaz, ${ }^{3}$ Carlos Portigliati, ${ }^{3}$ Vladimir I. Berger, ${ }^{1}$ Rodrigo Carrasco, ${ }^{3}$ and Klaus J. Schulz ${ }^{1}$

'USA-U.S. Geological Survey (USGS)

${ }^{2}$ Argentina - Instituto de Geología y Recursos Minerales (SEGEMAR)

${ }^{3}$ Chile-Servicio Nacional de Geología y Minería (SERNAGEOMIN)
${ }^{4}$ Colombia-Instituto Colombiano de Geología y Minería (INGEOMINAS)

${ }^{5}$ Peru-Instituto Geológico Minero y Metalúrgico (INGEMMET)

\begin{tabular}{|c|c|}
\hline Deposit type assessed: Porphyry Copper & $\begin{array}{l}\text { Model: Giant porphyry copper deposit model } \\
\text { (Singer, Briskey, and Cunningham, Appendix I) }\end{array}$ \\
\hline $\begin{array}{l}\text { Tract name: Chile Eocene-Oligocene } \\
\text { Chuquicamata }\end{array}$ & Countries: Chile \\
\hline Tract ID: SA10a,bPC & Region: South America \\
\hline Date of assessment: May 16-18, 2005 & Date of last revision: \\
\hline \multicolumn{2}{|l|}{ Assessment depth: $1 \mathrm{~km}$} \\
\hline Assessment team leader: Donald A. Singer & Regional coordinator: Charles G. Cunningham \\
\hline $\begin{array}{l}\text { Estimators: Carlos Mario Celada, Vladimir } \\
\text { Gajardo M., Carlos Portigliati, Alvaro Puig C } \\
\text { Zappettini. }\end{array}$ & $\begin{array}{l}\text { Donald A. Singer, Waldo Vivallo S., and Eduardo O. } \\
\text { Donales G. Cunningham, Alejandro Diaz, Mariano }\end{array}$ \\
\hline
\end{tabular}

Table of estimated numbers of undiscovered deposits by quantile. Also showing calculated mean $(\mathrm{m})$, standard deviation $(s)$, and coefficient of variation in percent $(C v \%)$. Sorted by mean.

\begin{tabular}{|l|c|c|c|c|c|c|}
\hline \multicolumn{1}{|c|}{ Estimators } & $\mathbf{9 0}$ & $\mathbf{5 0}$ & $\mathbf{1 0}$ & $\boldsymbol{m}$ & $\boldsymbol{s}$ & Cv\% \\
\hline Estimator & 1 & 2 & 6 & 2.8 & 2.0 & 71 \\
\hline Estimator & 1 & 3 & 5 & 2.9 & 1.5 & 52 \\
\hline Estimator & 2 & 4 & 9 & 4.8 & 2.7 & 56 \\
\hline Estimator & 2 & 4 & 10 & 5.1 & 3.1 & 61 \\
\hline Estimator & 2 & 4 & 10 & 5.1 & 3.1 & 61 \\
\hline Estimator & 3 & 5 & 10 & 5.7 & 2.7 & 47 \\
\hline Consensus of estimators & $\mathbf{3}$ & $\mathbf{5}$ & $\mathbf{1 1}$ & $\mathbf{6 . 0}$ & $\mathbf{3 . 1}$ & $\mathbf{5 2}$ \\
\hline Estimator & 5 & 7 & 10 & 7.0 & 2.1 & 30 \\
\hline Estimator & 3 & 7 & 15 & 8.0 & 4.4 & 55 \\
\hline Estimator & 3 & 7 & 16 & 8.3 & 4.8 & 58 \\
\hline Estimator & 4 & 8 & 14 & 8.3 & 3.7 & 45 \\
\hline
\end{tabular}

\section{Deposit density table}

\begin{tabular}{|c|c|c|c|c|}
\hline $\begin{array}{c}\text { Mean of consensus estimates of } \\
\text { undiscovered deposits }\end{array}$ & $\begin{array}{c}\text { Number of } \\
\text { discovered } \\
\text { deposits }\end{array}$ & $\begin{array}{c}\text { Total number of } \\
\text { deposits }\end{array}$ & Area, $\mathbf{k m}^{\mathbf{2}}$ & $\begin{array}{c}\text { Deposit density, number of } \\
\text { deposits/100,000km }\end{array}$ \\
\hline $\mathbf{6 . 0}$ & 10 & 16 & 25,690 & 62 \\
\hline
\end{tabular}




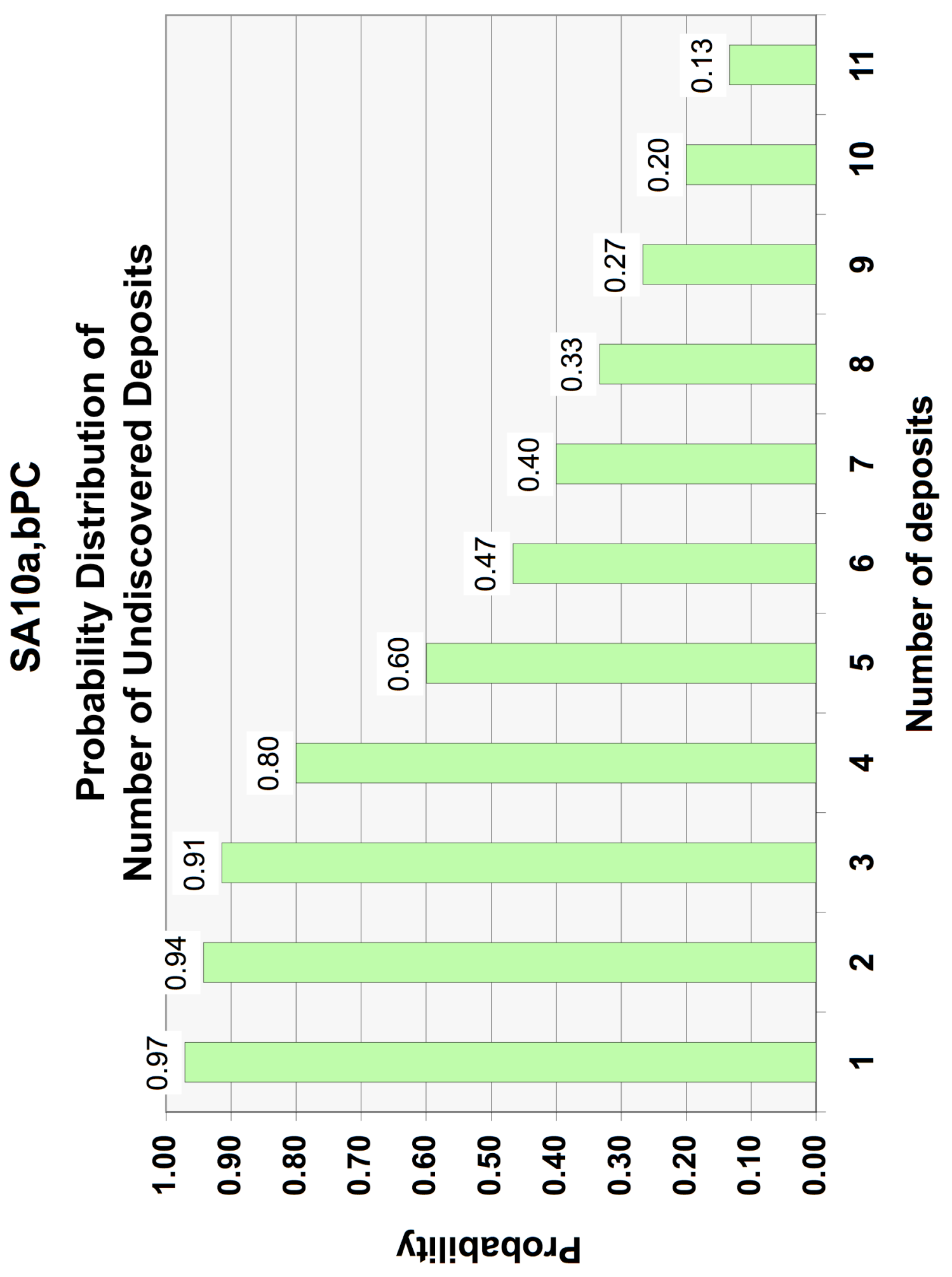




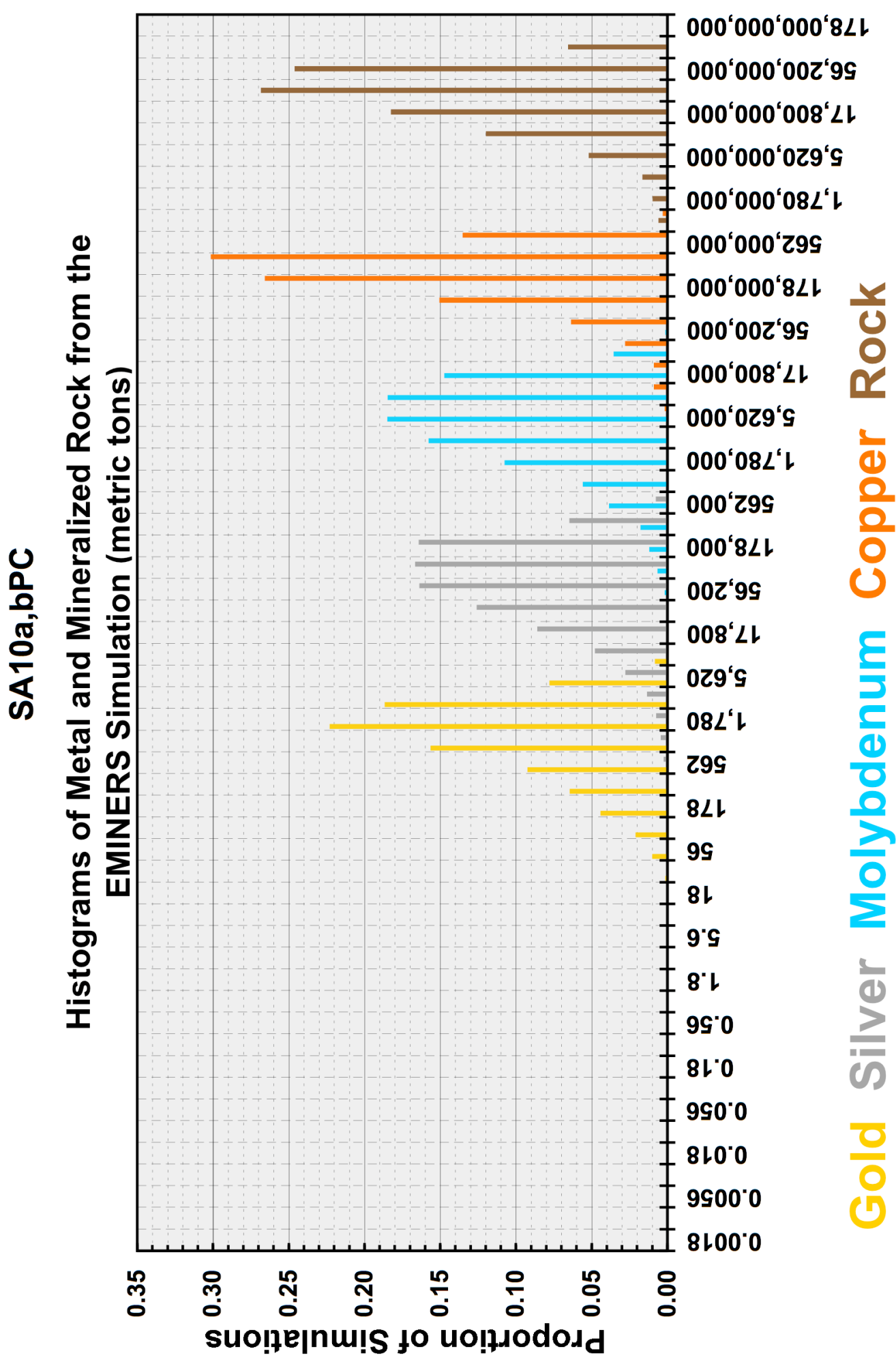




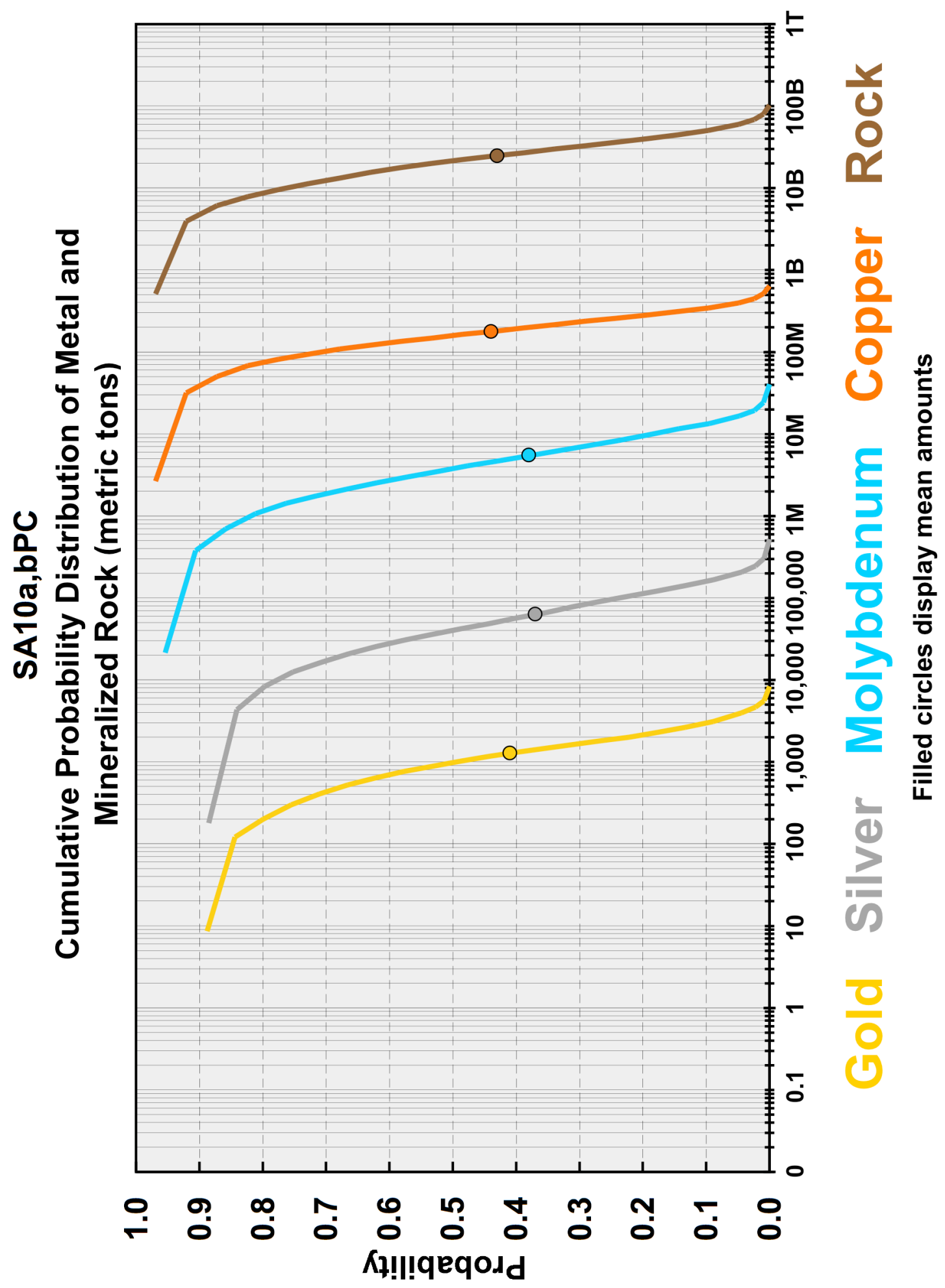




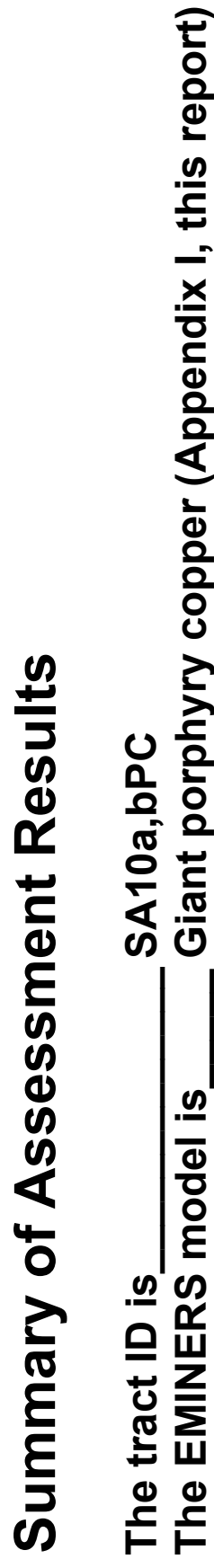

통

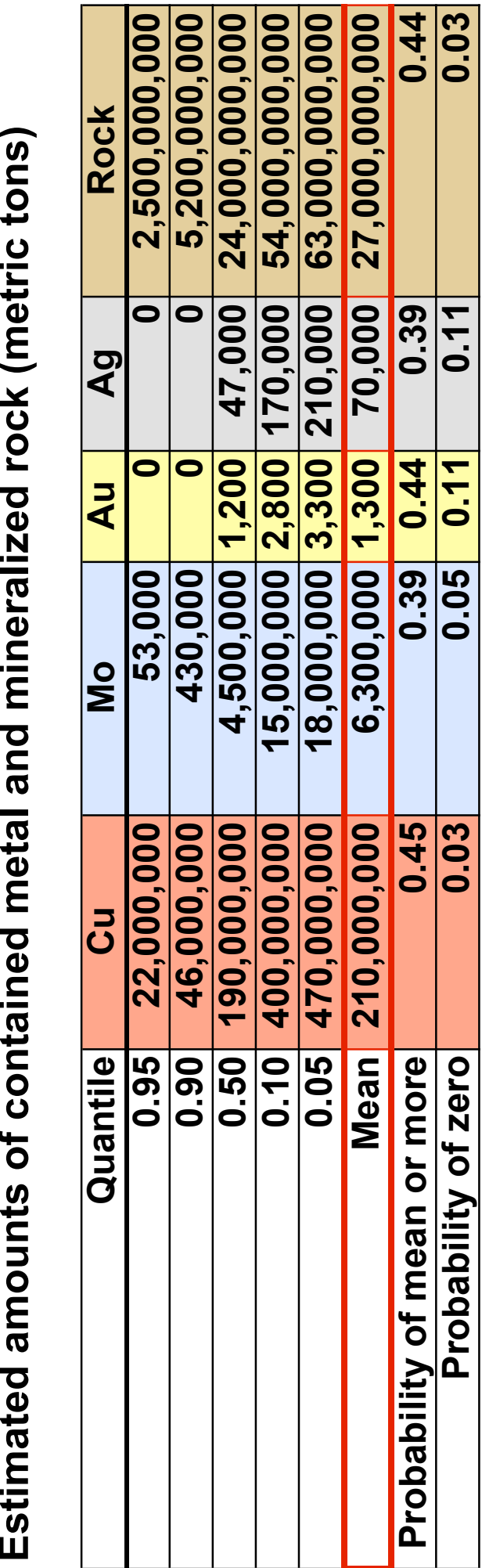




\section{Rationale for tract delineation}

This tract is defined by the distribution of Eocene to Oligocene mainly calc-alkaline plutons and by the distribution of volcanic and other country rocks and cover rocks within or beneath which such plutons are expected to occur within $1 \mathrm{~km}$ of the surface. The tract includes volcanic-arc lava flows, breccias, and epizonal plutons that are discontinuous extensions of equivalent rocks in Eocene-Oligocene tracts SA9PC and SA12PC. The locations of many deposits in the tract are controlled by the regional West Fault system (Camus, 2003). Most of the tract is superimposed upon the older Permian tract SA18PC and upon small parts of the east flank of the older Paleocene-Eocene tract SA08PC. There has been speculation that preexisting rocks permissive for copper mineralization or copper-enriched host rocks (pre-enrichment) in one or both of the older tracts may have contributed to the unusually large average size and grades of the discovered porphyry copper deposits in tract SA10a,bPC. Additional and (or) alternative contributing factors are summarized in Appendix I and elsewhere in this report. Approximately 70 percent of the tract is covered by younger rocks and sediments. Additional information about the geology and mineral deposits in the tract include Fuller (1989), Zentilli and others (1994), Long (1995), Pierce and Bolm (1995), Münchmeyer (1996), Zentilli, Aracena, and Graves (1997), Tarkian and Stribrny (1999), Cuadra and Rojas (2001), and Ossandon and others (2001).

\section{Rationale for model choice}

Tract SA10a,bPC is host to some of the largest and best known porphyry copper deposits in South America. It includes subtracts SA10aPC and SA10bPC, both of which are Eocene-Oligocene in age and are located just east of permissive tracts of Cretaceous and Paleocene-Eocene age. A $t$-test (table 3) of appropriate known deposits in both of these subtracts indicated average tonnages significantly higher than the general porphyry copper deposit model (Singer, Berger, and Moring, 2005). In addition, subtract SA10aPC has average copper grades that are significantly higher than those of the general model. Consequently, a new giant porphyry copper deposit grade and tonnage model (Appendix I) was constructed and used to represent the undiscovered deposits in tracts SA10a,bPC and SA14bPC.

\section{Deposits and prospects}

At the time of the assessment, the tract was known to contain 10 discovered deposits: Chuquicamata, Collahuasi, El Abra, Gaby, La Escondida, Mansa Mina, Quebrada Blanca, Ujina, El Salvador, and Potrerillos. Nine porphyry copper prospects also were considered by the assessment team at the time of the assessment: Centinela, Chimborazo, Copaquire, Esperanza, La Planada, Opache, Polo Sur, Queen Elizabeth, and Toki. At the time of this assessment, Esperanza did not meet the criteria cited herein to be classified as a discovered deposit.

\section{Exploration history}

Exposed host rocks and their older country rocks are very well explored and the team does not believe undiscovered deposits are likely to exist at or near the surface in the tract. However, a few deposits are being found under the extensive areas of post-mineralization-age cover rocks and sediments and much of this covered area remains poorly explored or unexplored.

\section{Rationale for numerical estimate}

Members of the assessment team used their collective knowledge of numbers of discovered deposits in the tract and (or) in similar areas elsewhere in the world to make estimates throughout the tract that also were consistent with the deposit density model of Singer and others (2005). Exposed host rocks in the tract contain many discovered porphyry copper deposits. There is no reason to believe that 
undiscovered deposits would not also be numerous at depth in large areas of the tract where host rocks are projected beneath the cover of younger rocks and sediments. The occurrence of a few additional undiscovered deposits also is possible deep within areas of exposed host rocks and their country rocks.

\section{Expected distribution of undiscovered deposits}

The probability of occurrence of an undiscovered deposit is not uniform throughout this tract. For example, there is considerable small-scale clustering of discovered (and probably undiscovered) deposits and prospects but no practical way to subdivide the tract on that basis. Moreover, undiscovered deposits are much more likely to occur in host rocks where covered by younger cover rocks and sediments than in exposed host-rocks, which are extensively explored.

\section{References cited}

Camus I., Francisco, 2003, Geología de los sistemas porfíricos en los Andes de Chile: Corporacíon Nacional del Cobre de Chile, Servicio Nacional de Geología y Minería, and Sociedad Geológica de Chile, 267 p.

Cuadra, P.C., and Rojas, G.S., 2001, Oxide mineralization at the Radomiro Tomic porphyry copper deposit, Northern Chile: Economic Geology, v. 96, p. 387-400.

Fuller, C.R., 1989, Distribution and characteristics of Chilean copper deposits, in Ericksen, G.E., Cañas Pinochet, M.T., and Reinemund, J.A., eds., Geology of the Andes and its relation to hydrocarbon and mineral resources: Circum Pacific Council for Energy and Mineral Resources Earth Science Series, v. 11, Houston, p. 245-256.

Long, K.R., 1995, Production and reserves of Cordilleran (Alaska to Chile) porphyry copper deposits, in Pierce, F.W., and Bolm, J.G., eds., Porphyry copper deposits of the American Cordillera: Tucson, Arizona Geological Society Digest v. 20, p. 35-68.

Münchmeyer, C., 1996, Exotic deposits - products of lateral migration of supergene solutions from porphyry copper deposits, in Camus, F., Sillitoe, R.H., and Petersen, R., eds., Andean copper deposits: new discoveries, mineralization, style and metallogeny: Society of Economic Geologists Special Publication no. 5, p. 43-58.

Ossandon, G.C., Freraut, R.C., Gustafson, L.B., Lindsay, D.D., and Zentilli, M., 2001, Geology of the Chuquicamata Mine: a progress report: Economic Geology, v. 96, p. 249-270.

Pierce, F.W., and Bolm, J.G., eds., 1995, Porphyry copper deposits of the American Cordillera: Tucson, Arizona Geological Society Digest, v. 20, 656 p.

Singer, D.A., Berger, V.I., Menzie, W.D., and Berger, B.R., 2005, Porphyry copper density: Economic Geology, v. 100, no. 3, p. 491-514.

Singer, D.A., Berger, V.I., and Moring, B.C., 2005, Porphyry copper deposits of the world-Database, map, and grade and tonnage models: U.S. Geological Survey Open-file Report 2005-1060, http://pubs.usgs.gov/of/2005/1060/)

Tarkian, M., and Stribrny, B., 1999, Platinum-group elements in porphyry copper deposits: a reconnaissance study: Mineralogy and Petrology, v. 65, p. 161-183.

Zentilli, M., Leiva G.Q., Rojas de la J.R., and Graves, M.C., 1994, The Chuquicamata porphyry copper system revisited: Congreso Geológico Chileno, 7th, Concepción, 1994, Actas, v. 2, p. 1647-1651.

Zentilli, M., Aracena, I., and Graves, M.C., 1997, Reconnaissance trace element study of Chuquicamata, Mansa Mina, and Radomiro Tomic porphyry copper deposits, Chile: Congreso Geológico Chileno, 8th, Antofagasta, 1997, Actas, v. 3, p. 1913-1917. 


\section{TRACT SA11PC}

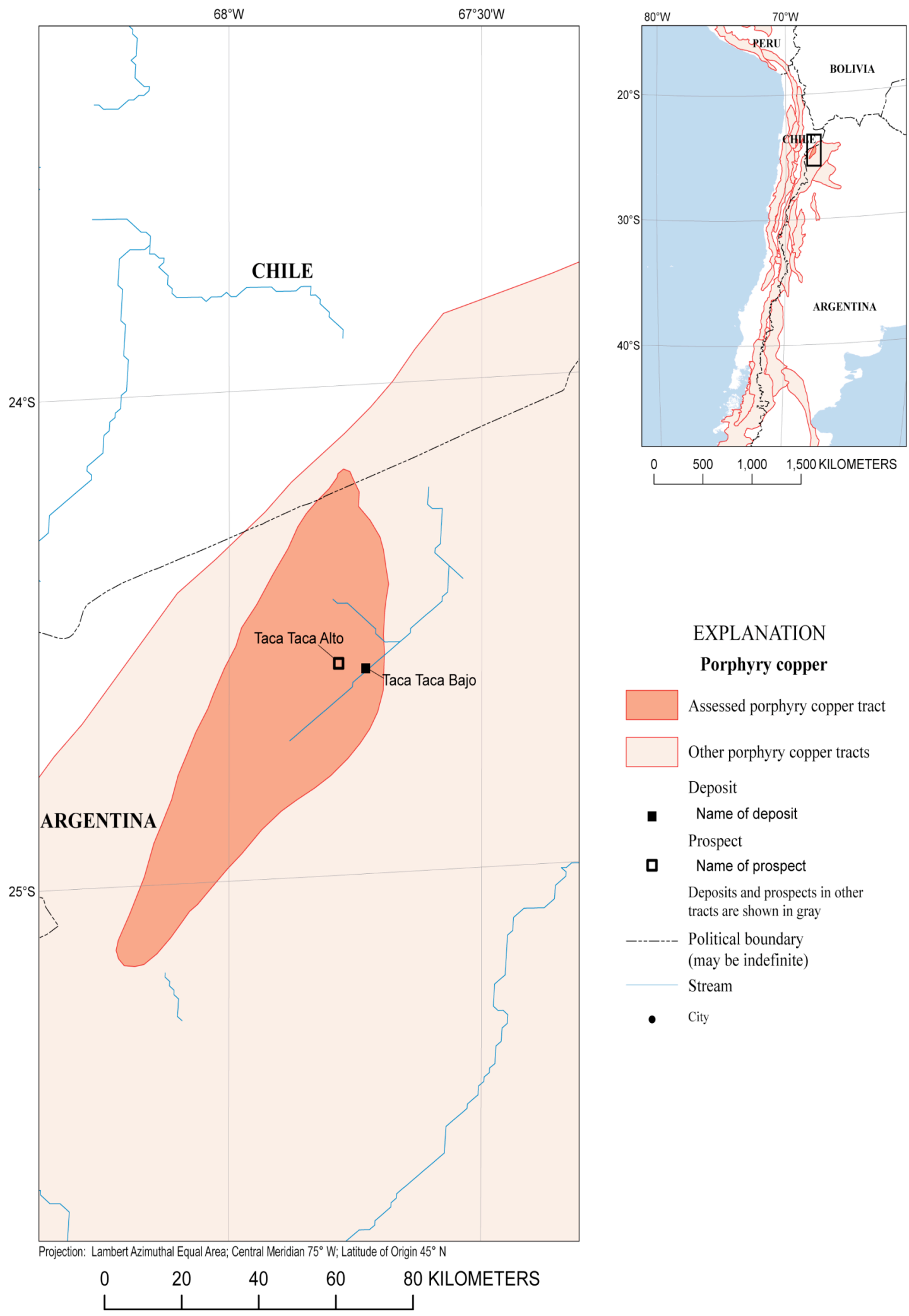




\section{Estimated Undiscovered Porphyry Copper Resources in Tract SA11PC- Argentina}

Charles G. Cunningham, ${ }^{1}$ Eduardo 0. Zappettini, ${ }^{2}$ Waldo Vivallo S., ${ }^{3}$ Carlos Mario Celada, ${ }^{4}$ Jorge Quispe, ${ }^{5}$ Donald A. Singer, ${ }^{1}$ Joseph A Briskey, ${ }^{1}$ David M. Sutphin, ${ }^{1}$ Mariano Gajardo M., ${ }^{3}$ Alejandro Diaz, ${ }^{3}$ Carlos Portigliati, ${ }^{3}$ Vladimir I. Berger, ${ }^{1}$ Rodrigo Carrasco, ${ }^{3}$ and Klaus J. Schulz ${ }^{1}$

'USA-U.S. Geological Survey (USGS)

${ }^{2}$ Argentina - Instituto de Geología y Recursos Minerales (SEGEMAR)

${ }^{3}$ Chile-Servicio Nacional de Geología y Minería (SERNAGEOMIN)
${ }^{4}$ Colombia - Instituto Colombiano de Geología y Minería (INGEOMINAS)

${ }^{5}$ Peru-Instituto Geológico Minero y Metalúrgico (INGEMMET)

\begin{tabular}{|l|l|}
\hline Deposit type assessed: Porphyry Copper & $\begin{array}{l}\text { Model: General porphyry copper deposit model } \\
\text { (Singer, Berger, and Moring, 2005) }\end{array}$ \\
\hline $\begin{array}{l}\text { Tract name: Argentina Eocene-Oligocene } \\
\text { Taca Taca Bajo }\end{array}$ & Countries: Argentina \\
\hline Tract ID: SA11PC & Region: South America \\
\hline Date of assessment: May 16-18, 2005 & Date of last revision: \\
\hline Assessment depth: $1 \mathrm{~km}$ & Regional coordinator: Charles G. Cunningham \\
\hline Assessment team leader: Donald A. Singer & $\begin{array}{l}\text { Estimators: Carlos Mario Celada, Vladimir I. Berger, Rodrigo Carrasco, Charles G. Cunningham, } \\
\text { Alejandro Diaz, Mariano Gajardo M., Carlos Portigliati, Alvaro Puig Godoy, Donald A. Singer, Waldo } \\
\text { Vivallo S., and Eduardo O. Zappettini. }\end{array}$ \\
\hline
\end{tabular}

Table of estimated numbers of undiscovered deposits by quantile. Also showing calculated mean $(m)$, standard deviation $(s)$, and coefficient of variation in percent $(C v \%)$. Sorted by mean.

\begin{tabular}{|l|c|c|c|c|c|c|}
\hline \multicolumn{1}{|c|}{ Estimators } & $\mathbf{9 0}$ & $\mathbf{5 0}$ & $\mathbf{1 0}$ & $\boldsymbol{m}$ & $\boldsymbol{s}$ & $\mathbf{C v} \%$ \\
\hline Estimator & 0 & 0 & 1 & 0.30 & 0.50 & 170 \\
\hline Estimator & 0 & 1 & 2 & 1.0 & 0.79 & 79 \\
\hline Estimator & 0 & 1 & 2 & 1.0 & 0.79 & 79 \\
\hline Estimator & 0 & 1 & 2 & 1.0 & 0.79 & 79 \\
\hline Estimator & 0 & 1 & 2 & 1.0 & 0.79 & 79 \\
\hline Estimator & 0 & 1 & 2 & 1.0 & 0.79 & 79 \\
\hline Estimator & 0 & 1 & 3 & 1.3 & 1.2 & 92 \\
\hline Estimator & 0 & 1 & 3 & 1.3 & 1.2 & 92 \\
\hline Consensus of estimators & $\mathbf{0}$ & $\mathbf{1}$ & $\mathbf{3}$ & $\mathbf{1 . 3}$ & $\mathbf{1 . 2}$ & $\mathbf{9 2}$ \\
\hline Estimator & 1 & 2 & 4 & 2.2 & 1.2 & 55 \\
\hline Estimator & 1 & 2 & 4 & 2.2 & 1.2 & 55 \\
\hline Estimator & 1 & 2 & 5 & 2.5 & 1.6 & 64 \\
\hline
\end{tabular}

\section{Deposit density table}

\begin{tabular}{|c|c|c|c|c|}
\hline $\begin{array}{c}\text { Mean of consensus estimates of } \\
\text { undiscovered deposits }\end{array}$ & $\begin{array}{c}\text { Number of } \\
\text { discovered } \\
\text { deposits }\end{array}$ & $\begin{array}{c}\text { Total number of } \\
\text { deposits }\end{array}$ & Area, $\mathbf{~ k m}^{\mathbf{2}}$ & $\begin{array}{c}\text { Deposit density, number of } \\
\text { deposits/100,000 } \mathbf{k m}^{2}\end{array}$ \\
\hline $\mathbf{1 . 3}$ & 1 & 2.3 & 2,429 & 95 \\
\hline
\end{tabular}




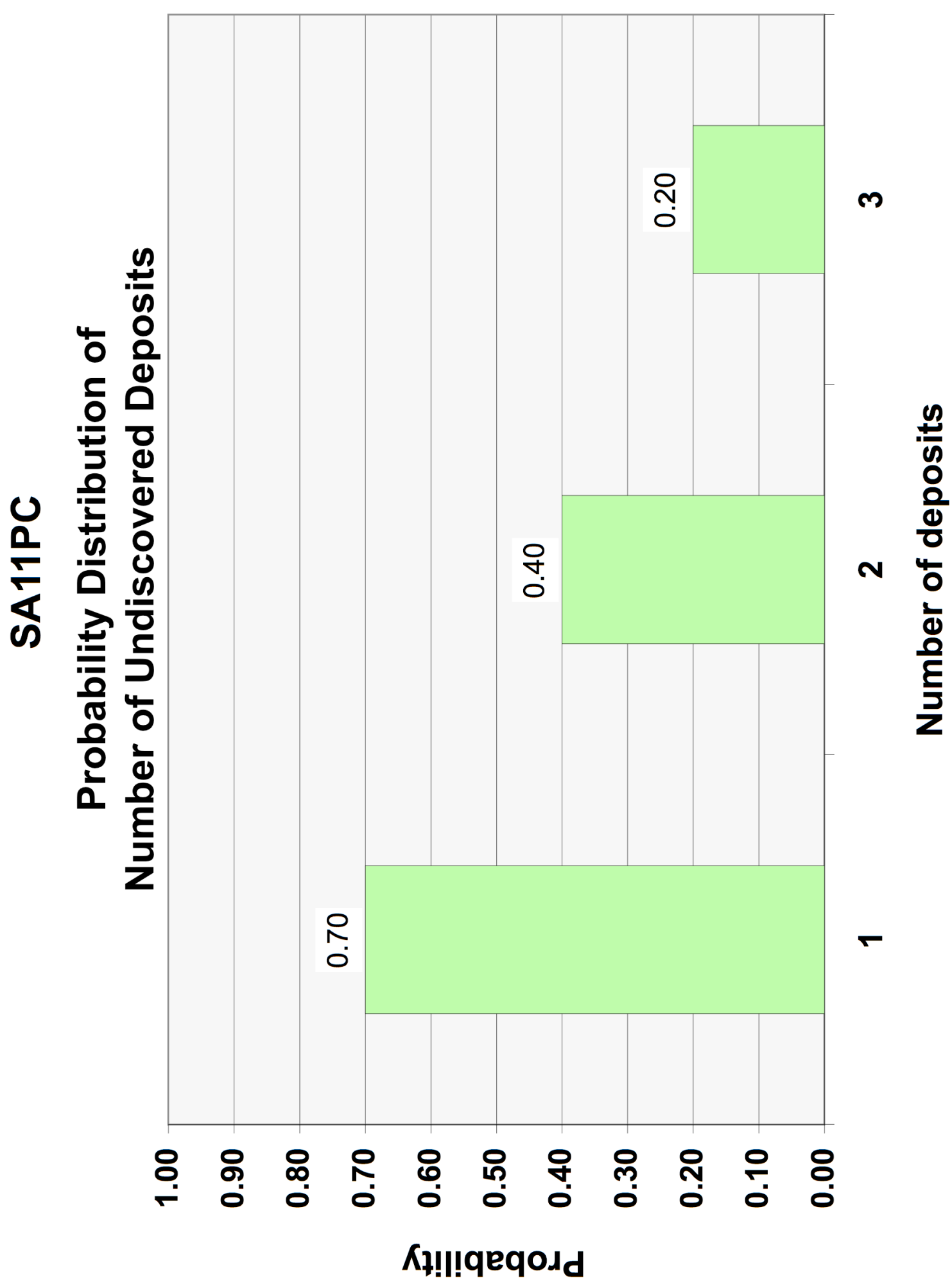




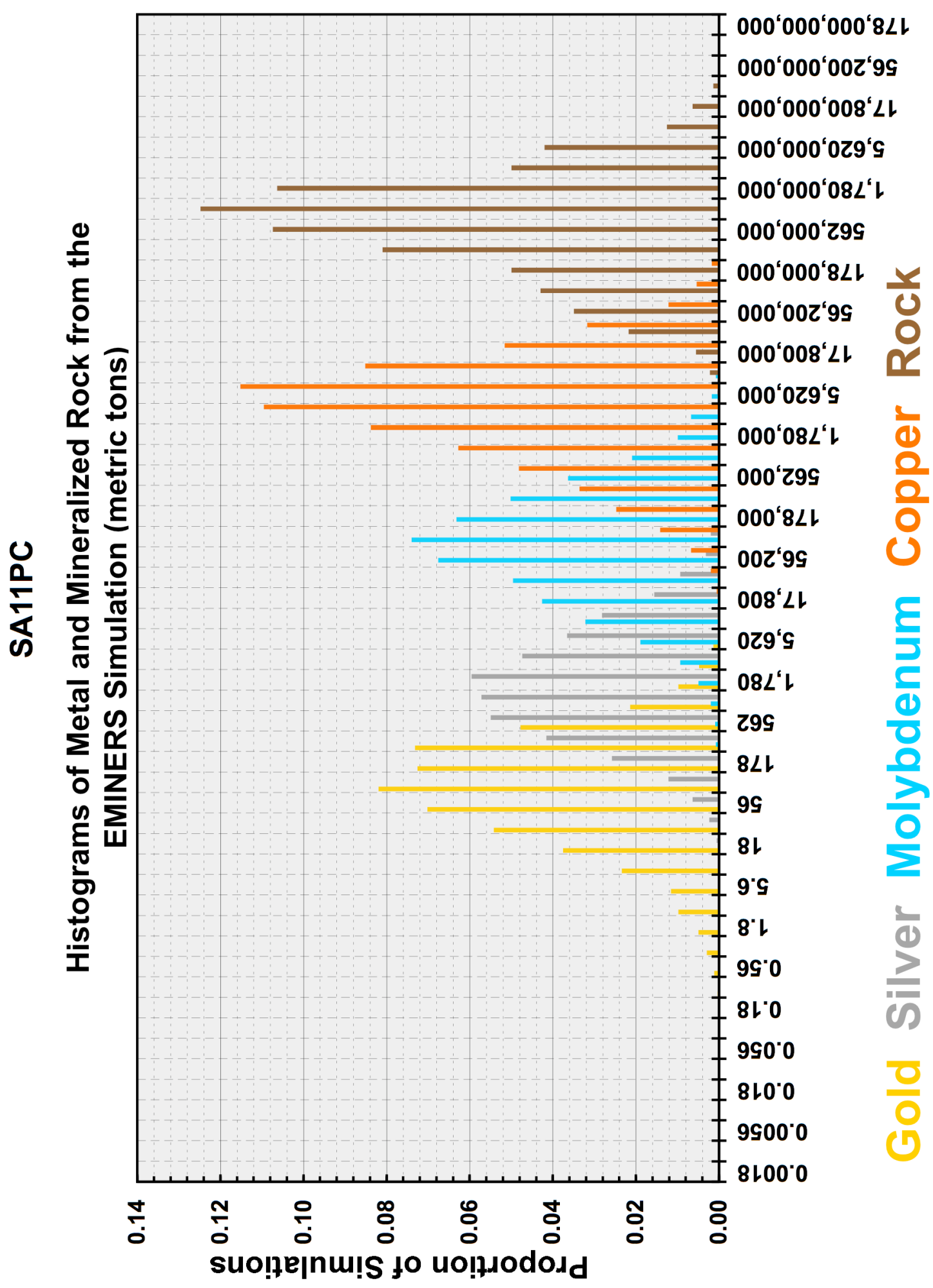




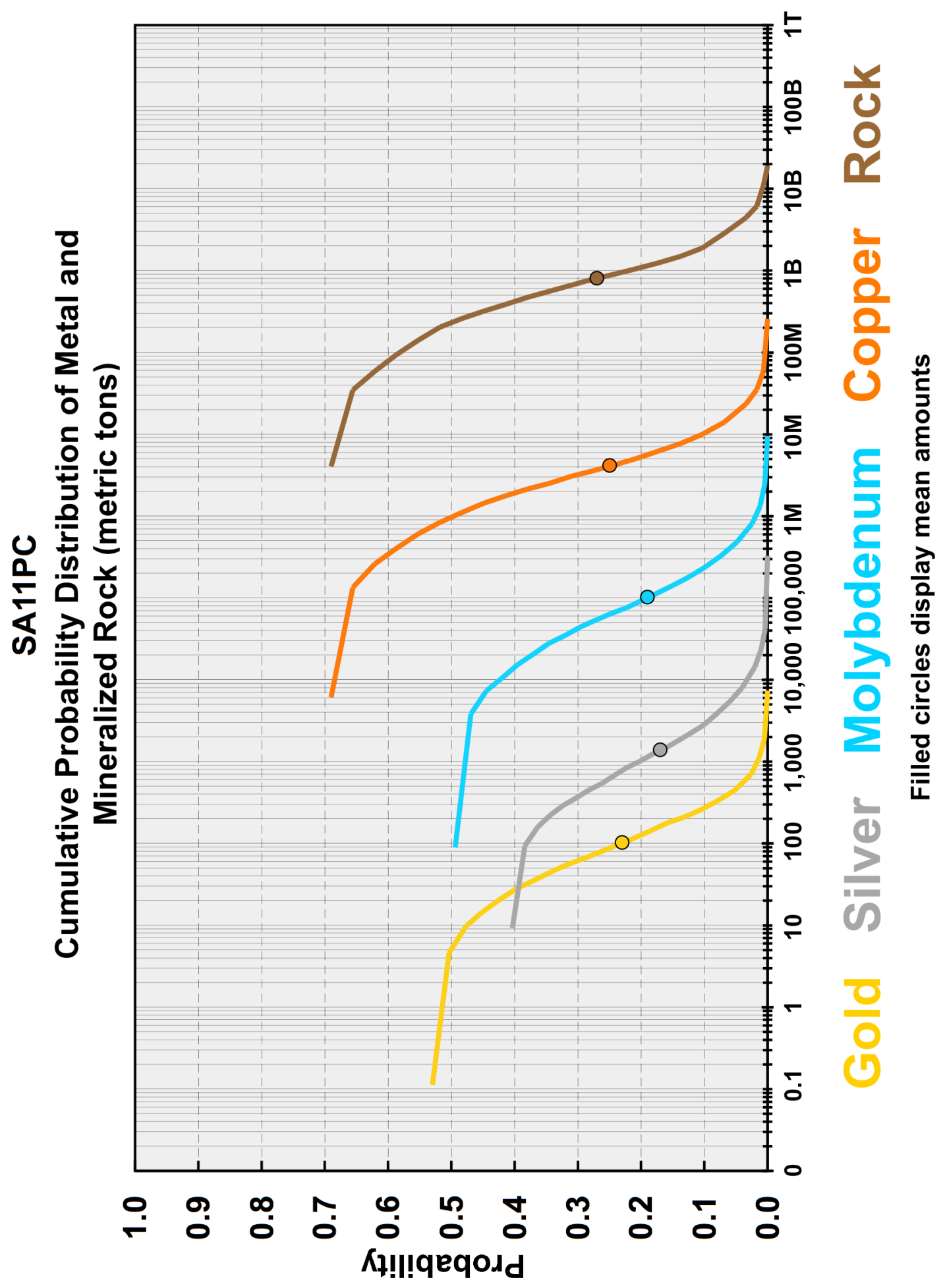




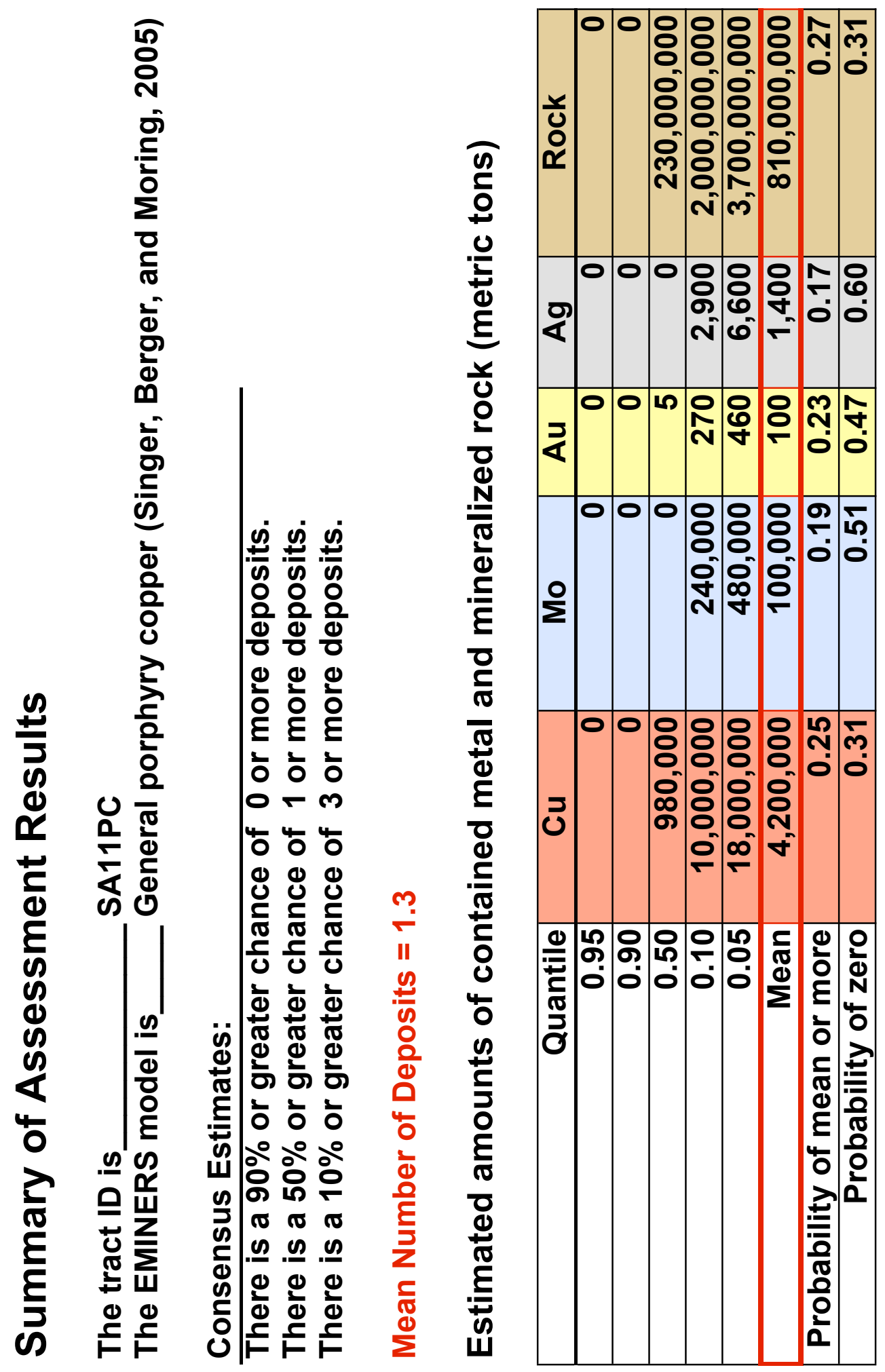




\section{Rationale for tract delineation}

This tract is defined by the distribution of Eocene to Oligocene mostly calc-alkaline plutons and by the distribution of volcanic and other country rocks and cover rocks within or beneath which such plutons are expected to occur within $1 \mathrm{~km}$ of the surface. Recent $\mathrm{K} / \mathrm{Ar}$ age determinations on biotite from these host rocks are $28.7 \pm 0.20 \mathrm{Ma}$ and $29.4 \pm 0.20 \mathrm{Ma}$ (Rojas and others, 1999). Approximately 85 percent of the tract is covered by younger rocks and sediments.

\section{Rationale for model choice}

The size and grades of the discovered porphyry copper deposit in the tract are not significantly different (table 3) from the general porphyry copper deposit model (Singer, Berger, and Moring, 2005), which therefore was used to represent the undiscovered deposits. Mineralogy, structure, and alteration of the known deposit Taca Taca Bajo is typical of the general model of porphyry copper deposits.

\section{Deposits and prospects}

At the time of the assessment, and according to the classification criteria cited herein, the tract contains one discovered deposit, Taca Taca Bajo, and one prospect, Taca Taca Alto. Additional sources of information about these mineralized areas include Sillitoe (1977) and Blower (2003).

\section{Exploration history}

The tract is moderately explored. Initial exploration began in 1967 at the mineral deposit Taca Taca Bajo, which was drilled on 400 meter centers in 1996 (Rojas and others, 1999). The prospect Taca Taca Alto was later described by Rubinstein, Segal, and Zappettini (1999).

\section{Rationale for numerical estimate}

Members of the assessment team used their collective knowledge of numbers of discovered deposits in the tract and (or) in similar areas elsewhere in the world to make estimates throughout the tract that also were consistent with the deposit density model of Singer and others (2005). The team was encouraged by the presence of one discovered deposit and one prospect, which demonstrate that the mineralizing processes that form porphyry copper deposits were active in the tract. Moreover, the tract is poorly explored because most of the plutonic host rocks are covered by younger rocks and sediments. Nonetheless, the team's estimate is low because of, and consistent with, the tract's small size.

\section{Expected distribution of undiscovered deposits}

The tract was drawn to enclose an area of geology where the probability of occurrence of an undiscovered deposit is believed to be reasonably uniform based on knowledge and information available to the team at the time of tract delineation.

\section{References cited}

Blower, S., 2003, Taca Taca property: Lumina Copper Corporation Technical Report, 80 p. http://www.luminacopper.com/s/TacaTacaProperty.asp

Rojas, N., Drobe, J., Lane, R., y Bonafede, D., 1999, El pórfiro cuprifero de Taca Taca Bajo, Salta: en Zappettini, E.O., ed., Recursos minerales de la Republica Argentina: Instituto de Geología y Recursos Minerales SEGEMAR, Anales 35, Buenos Aires, p.1321-1331.

Rubinstein N.A., Segal, SJ., and Zappettini, E.O., 1999, El porfiro cuprifero Taca-Taca Alto, Salta, en Zappettini, E.O., ed., Recursos minerales de la Republica Argentina: Instituto de Geología y Recursos Minerales SEGEMAR, Anales 35, Buenos Aires, p.1333-1336. 
Sillitoe, R.H., 1977, Permo-Carboniferous, upper Cretaceous, and Miocene porphyry copper-type mineralization in the Argentinean Andes: Economic Geology, v. 72, p. 99-109.

Singer, D.A., Berger, V.I., Menzie, W.D., and Berger, B.R., 2005, Porphyry copper density: Economic Geology, v. 100, no. 3, p. 491-514.

Singer, D.A., Berger, V.I., and Moring, B.C., 2005, Porphyry copper deposits of the world-Database, map, and grade and tonnage models: U.S. Geological Survey Open-file Report 2005-1060, http://pubs.usgs.gov/of/2005/1060/) 


\section{TRACT SA12PC}
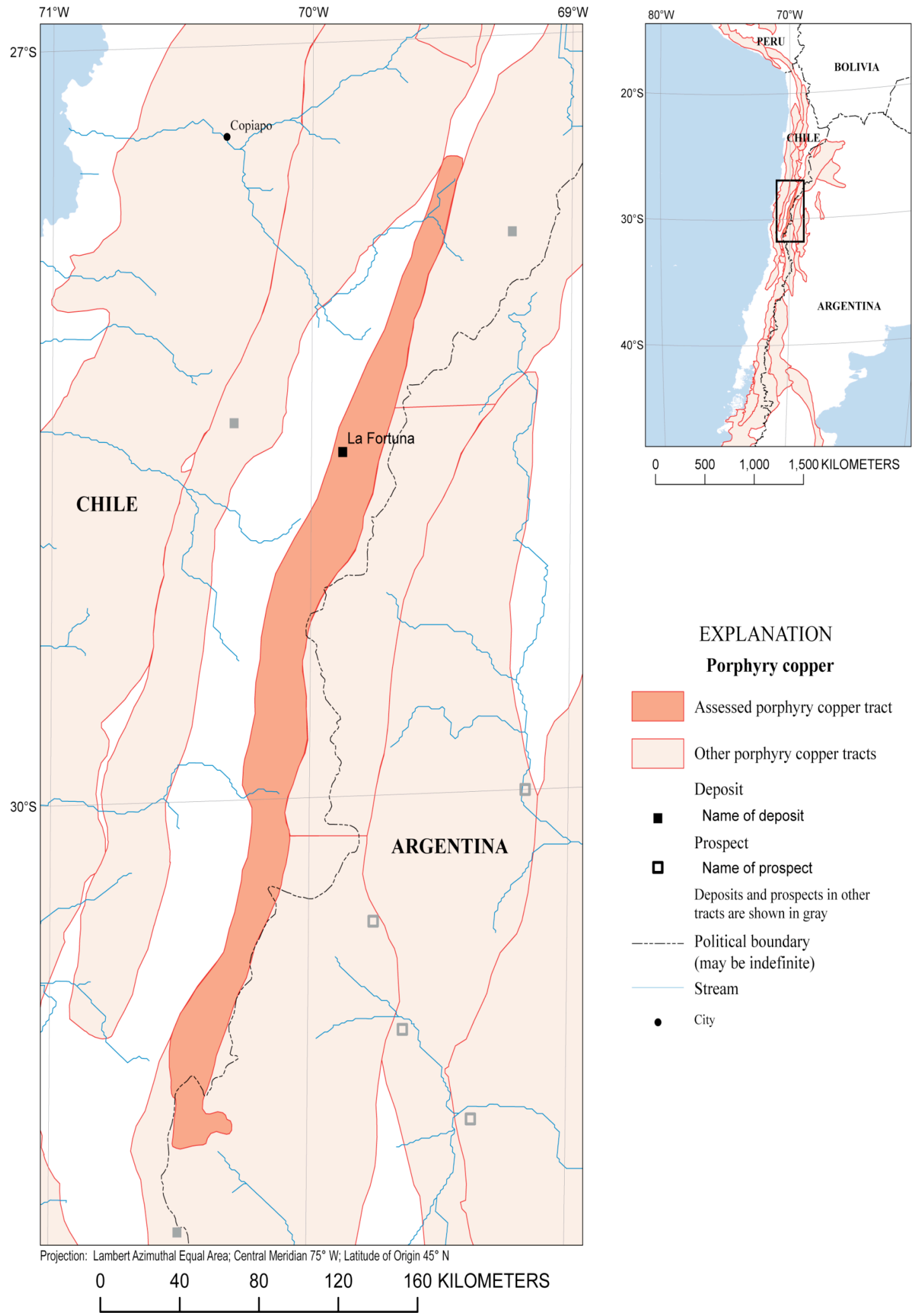

\section{EXPLANATION}

Porphyry copper

Assessed porphyry copper tract

Other porphyry copper tracts

Deposit

- Name of deposit

Prospect

口 Name of prospect

Deposits and prospects in other tracts are shown in gray

Political boundary (may be indefinite) Stream

- $\quad$ City 


\section{Estimated Undiscovered Porphyry Copper Resources in Tract SA12PC- Chile and Argentina}

Charles G. Cunningham, ${ }^{1}$ Eduardo 0. Zappettini, ${ }^{2}$ Waldo Vivallo S., ${ }^{3}$ Carlos Mario Celada, ${ }^{4}$ Jorge Quispe, ${ }^{5}$ Donald A. Singer, ${ }^{1}$ Joseph A Briskey, ${ }^{1}$ David M. Sutphin, ${ }^{1}$ Mariano Gajardo M., ${ }^{3}$ Alejandro Diaz, ${ }^{3}$ Carlos Portigliati, ${ }^{3}$ Vladimir I. Berger, ${ }^{1}$ Rodrigo Carrasco, ${ }^{3}$ and Klaus J. Schulz ${ }^{1}$

'USA-U.S. Geological Survey (USGS)

${ }^{2}$ Argentina - Instituto de Geología y Recursos Minerales (SEGEMAR)

${ }^{3}$ Chile-Servicio Nacional de Geología y Minería (SERNAGEOMIN)
${ }^{4}$ Colombia-Instituto Colombiano de Geología y Minería (INGEOMINAS)

${ }^{5}$ Peru-Instituto Geológico Minero y Metalúrgico (INGEMMET)

\begin{tabular}{|c|c|}
\hline Deposit type assessed: Porphyry Copper & $\begin{array}{l}\text { Model: General porphyry copper deposit model } \\
\text { (Singer, Berger, and Moring, 2005) }\end{array}$ \\
\hline $\begin{array}{l}\text { Tract name: Chile-Argentina Eocene-Oligocene } \\
\text { La Fortuna }\end{array}$ & Countries: Chile and Argentina \\
\hline Tract ID: SA12PC & Region: South America \\
\hline Date of assessment: May 16-18, 2005 & Date of last revision: \\
\hline \multicolumn{2}{|l|}{ Assessment depth: $1 \mathrm{~km}$} \\
\hline Assessment team leader: Donald A. Singer & Regional coordinator: Charles G. Cunningham \\
\hline \multicolumn{2}{|c|}{$\begin{array}{l}\text { Estimators: Carlos Mario Celada, Vladimir I. Berger, Rodrigo Carrasco, Charles G. Cunningham, } \\
\text { Alejandro Diaz, Mariano Gajardo M., Carlos Portigliati, Donald A. Singer, Waldo Vivallo S., and } \\
\text { Eduardo O. Zappettini. }\end{array}$} \\
\hline
\end{tabular}

Table of estimated numbers of undiscovered deposits by quantile. Also showing calculated mean $(m)$, standard deviation $(s)$, and coefficient of variation in percent $(C v \%)$. Sorted by mean.

\begin{tabular}{|l|c|c|c|c|c|c|}
\hline \multicolumn{1}{|c|}{ Estimators } & $\mathbf{9 0}$ & $\mathbf{5 0}$ & $\mathbf{1 0}$ & $\mathbf{m}$ & $\boldsymbol{s}$ & $\mathbf{C v} \%$ \\
\hline Estimator & 0 & 1 & 5 & 1.9 & 1.9 & 100 \\
\hline Estimator & 1 & 2 & 3 & 1.9 & 0.84 & 44 \\
\hline Estimator & 1 & 2 & 4 & 2.2 & 1.2 & 55 \\
\hline Estimator & 1 & 3 & 5 & 2.9 & 1.5 & 52 \\
\hline Estimator & 1 & 3 & 7 & 3.5 & 2.3 & 66 \\
\hline Estimator & 2 & 4 & 6 & 3.9 & 1.5 & 38 \\
\hline Estimator & 2 & 4 & 8 & 4.5 & 2.3 & 51 \\
\hline Consensus of estimators & $\mathbf{2}$ & $\mathbf{4}$ & $\mathbf{8}$ & $\mathbf{4 . 5}$ & $\mathbf{2 . 3}$ & $\mathbf{5 1}$ \\
\hline Estimator & 2 & 4 & 11 & 5.4 & 3.4 & 63 \\
\hline Estimator & 3 & 7 & 15 & 8.0 & 4.4 & 55 \\
\hline Estimator & 6 & 10 & 20 & 11 & 5.3 & 48 \\
\hline
\end{tabular}

\section{Deposit density table}

\begin{tabular}{|c|c|c|c|c|}
\hline $\begin{array}{c}\text { Mean of consensus estimates of } \\
\text { undiscovered deposits }\end{array}$ & $\begin{array}{c}\text { Number of } \\
\text { discovered } \\
\text { deposits }\end{array}$ & $\begin{array}{c}\text { Total number of } \\
\text { deposits }\end{array}$ & Area, $\mathbf{~ m}^{2}$ & $\begin{array}{c}\text { Deposit density, number of } \\
\text { deposits/100,000 } \mathbf{k m}^{2}\end{array}$ \\
\hline $\mathbf{4 . 5}$ & 1 & 5.5 & 6,913 & 80 \\
\hline
\end{tabular}




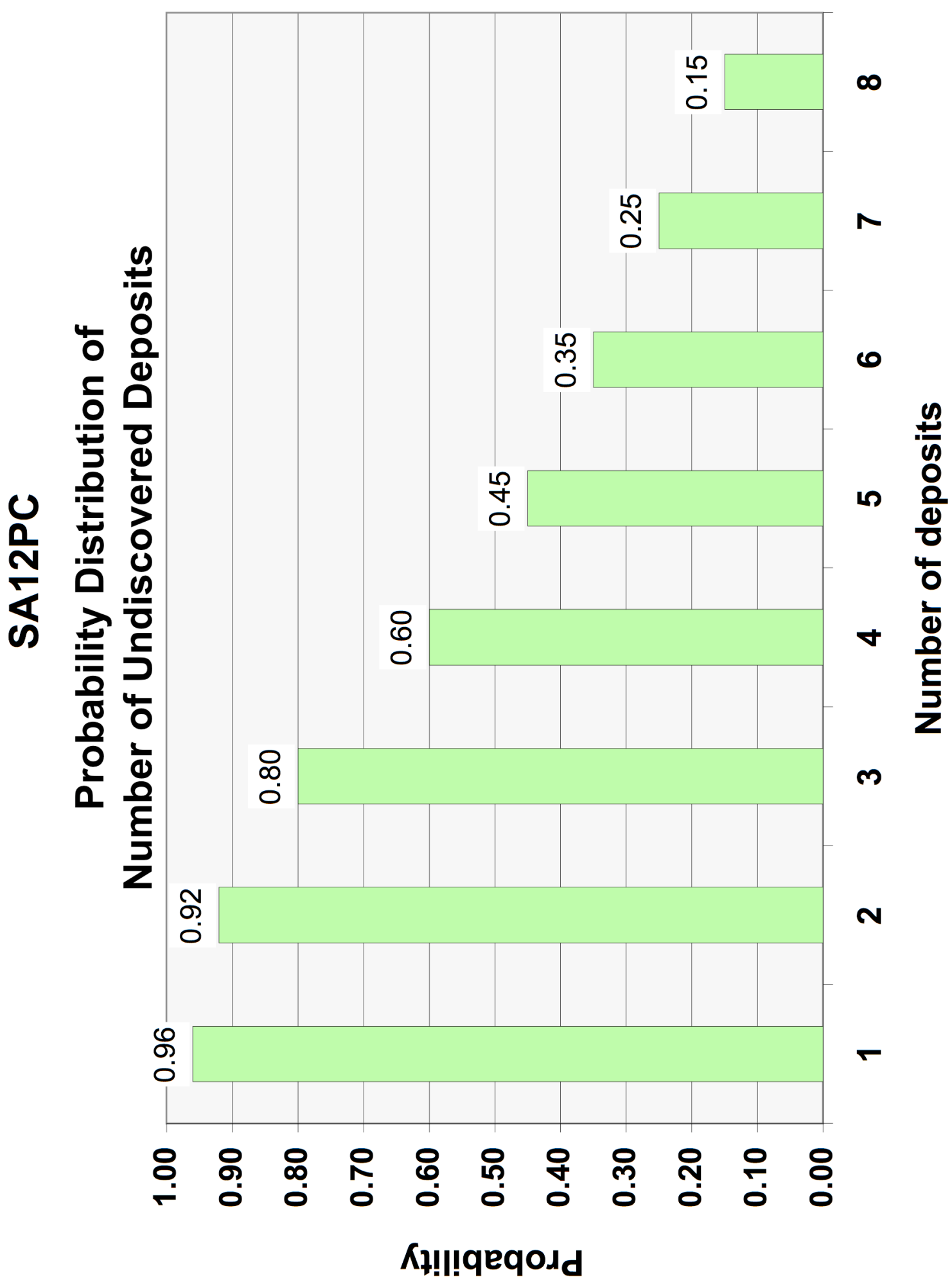




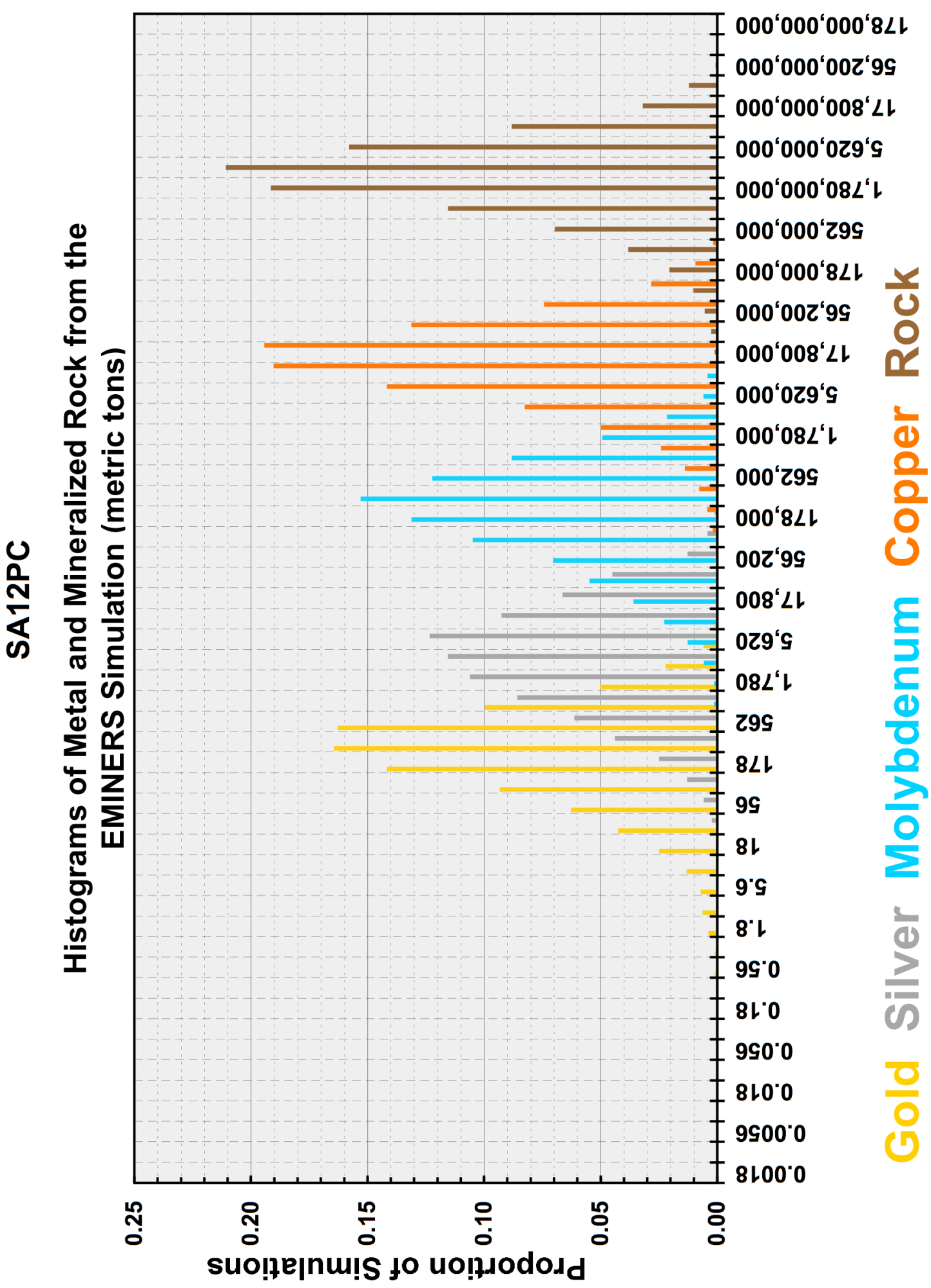




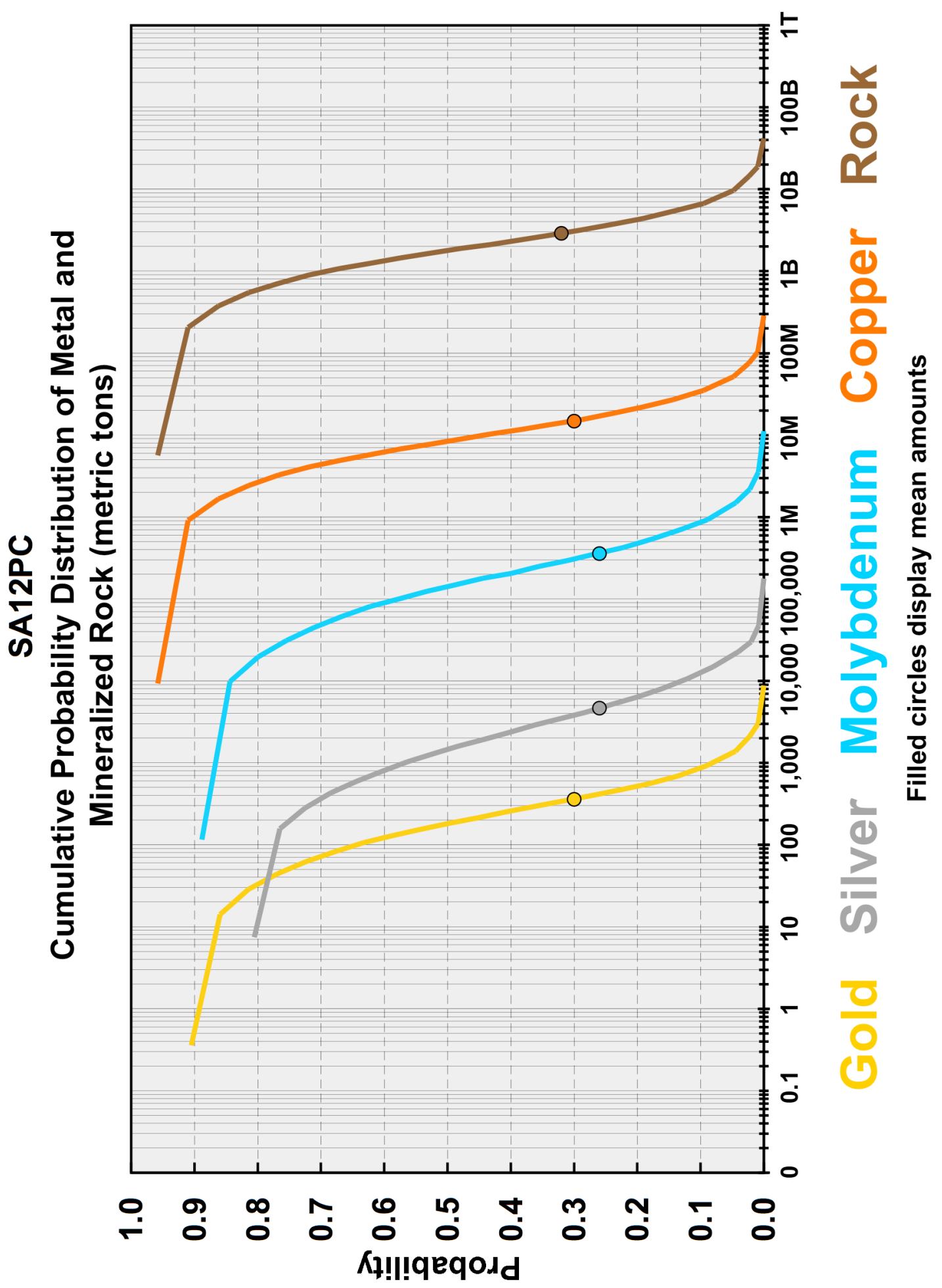




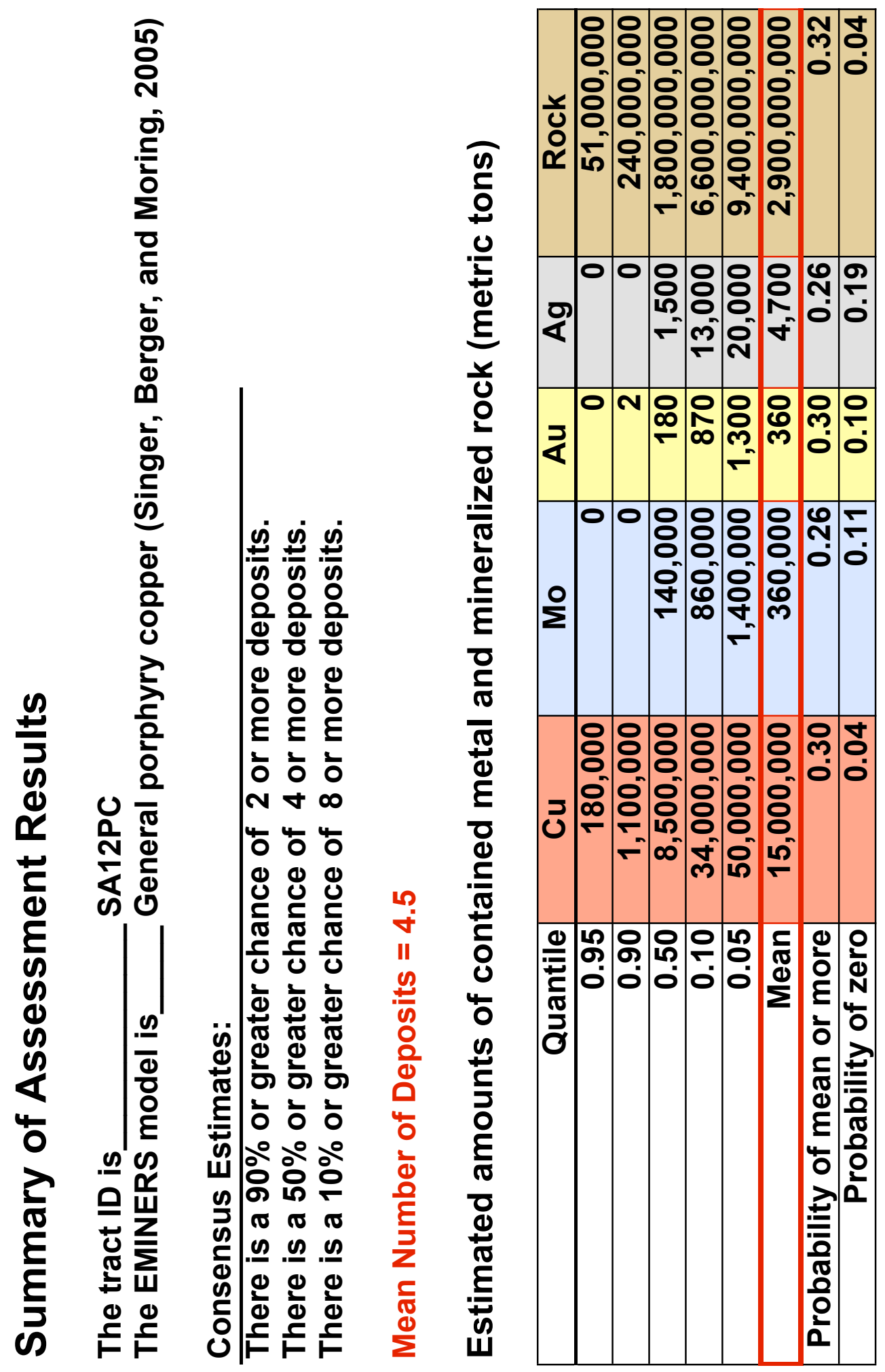




\section{Rationale for tract delineation}

This tract is defined by the distribution of Eocene-Oligocene principally calc-alkaline plutons and by the distribution of volcanic and other country rocks and cover rocks within or beneath which such plutons are expected to occur within $1 \mathrm{~km}$ of the surface. The tract contains volcanic-arc lava flows, breccias, and epizonal plutons that are a discontinuous southern extension of equivalent rocks in EoceneOligocene tracts SA9PC, SA10aPC, and SA10bPC that contain important deposits such as Chuquicamata. Like those three tracts, tract SA12PC is located a short distance east of the Paleocene-Eocene arc. A major difference between tracts SA12PC and SA10aPC is that emplacement of magmas in the latter tract may have incorporated all or part of some older Permian rocks permissive for porphyry copper deposits or copper-enriched host rocks thereby contributing to the unusually large average size of deposits in tract SA10aPC. A tract of older Permian porphyry copper deposits, SA16aPC, also exists at the latitude of tract SA12PC, but is offset a short distance to the east. Consequently, undiscovered deposits in tract SA12PC are unlikely to be enriched, at least not by this same mechanism. Tract SA12PC is partly bounded by faults on the east and west sides. Approximately 70 percent of the likely extent of permissive rocks is covered by younger rocks and sediments.

\section{Rationale for model choice}

The size and grades of the discovered porphyry copper deposit in the tract are not significantly different (table 3) from the general porphyry copper deposit model (Singer, Berger, and Moring, 2005), which therefore was used to represent the undiscovered deposits. The structure and the sulfide and alteration mineralogy of the known deposit in this tract are typical of deposits in the general porphyry copper deposit model.

\section{Deposits and prospects}

The tract contains one discovered deposit, La Fortuna. Sources of additional information about this deposit include Perelló and others (1994, 1996), Anonymous (2001), and Noranda News Release (2001).

\section{Exploration history}

Exploration has focused on known mineralized areas and places where plutonic host rocks occur at or near the surface. A United Nations geochemical survey was conducted in the southern end of the tract and there was some exploration drilling in the central part.

\section{Rationale for numerical estimate}

Members of the assessment team used their collective knowledge of numbers of discovered deposits in the tract and (or) in similar areas elsewhere in the world to make estimates throughout the tract that also were consistent with the deposit density model of Singer and others (2005). Although this is a relatively small tract, there were several reasons why many estimators were optimistic about the probability for occurrence of a number of undiscovered deposits. The host rocks in this tract are equivalent to those in highly mineralized tracts SA10a,bPC and SA09PC. The presence of a discovered deposit is evidence that the mineralizing processes forming porphyry copper deposits also were active in the tract. Finally, much of the tract is unexplored where approximately 70 percent of it is covered by younger rocks and sediments. 


\section{Expected distribution of undiscovered deposits}

Based on knowledge and information available to the team at the time of tract delineation, the tract was drawn to enclose an area of geology where the probability of occurrence of an undiscovered deposit is believed to be reasonably uniform, except for those areas beneath younger cover rocks where this potential is expected to be higher because these areas are unexplored or relatively so.

\section{References cited}

Anonymous, 2001, Impressive El Morro intersections: Mining Journal, March, p. 181.

Noranda News Release, 2001, September 28: www.noranda.com

Perelló, J., Urzúa, F., Cabello, J., and Ortiz, F., 1994, Clustered, gold-bearing Oligocene porphyry copper and associated epithermal mineralization at La Fortuna, Vallenar region, northern Chile: 7th Congresso Geologico Chileno, Actas, v. 2, p. 1607-1612.

Perelló, J., Urzúa, F., Cabello, J., and Ortiz, F., 1996, Clustered, gold-bearing Oligocene porphyry copper and associated epithermal mineralization at La Fortuna, Vallenar region, northern Chile, in Camus, F., Sillitoe, R.H., and Petersen, R., eds., Andean copper deposits: new discoveries, mineralization, styles and metallogeny: Society of Economic Geologists Special Publication no. 5, p. 81-90.

Singer, D.A., Berger, V.I., Menzie, W.D., and Berger, B.R., 2005, Porphyry copper density: Economic Geology, v. 100, no. 3, p. 491-514.

Singer, D.A., Berger, V.I., and Moring, B.C., 2005, Porphyry copper deposits of the world-Database, map, and grade and tonnage models: U.S. Geological Survey Open-file Report 2005-1060, http://pubs.usgs.gov/of/2005/1060/) 


\section{TRACT SA13aPC}
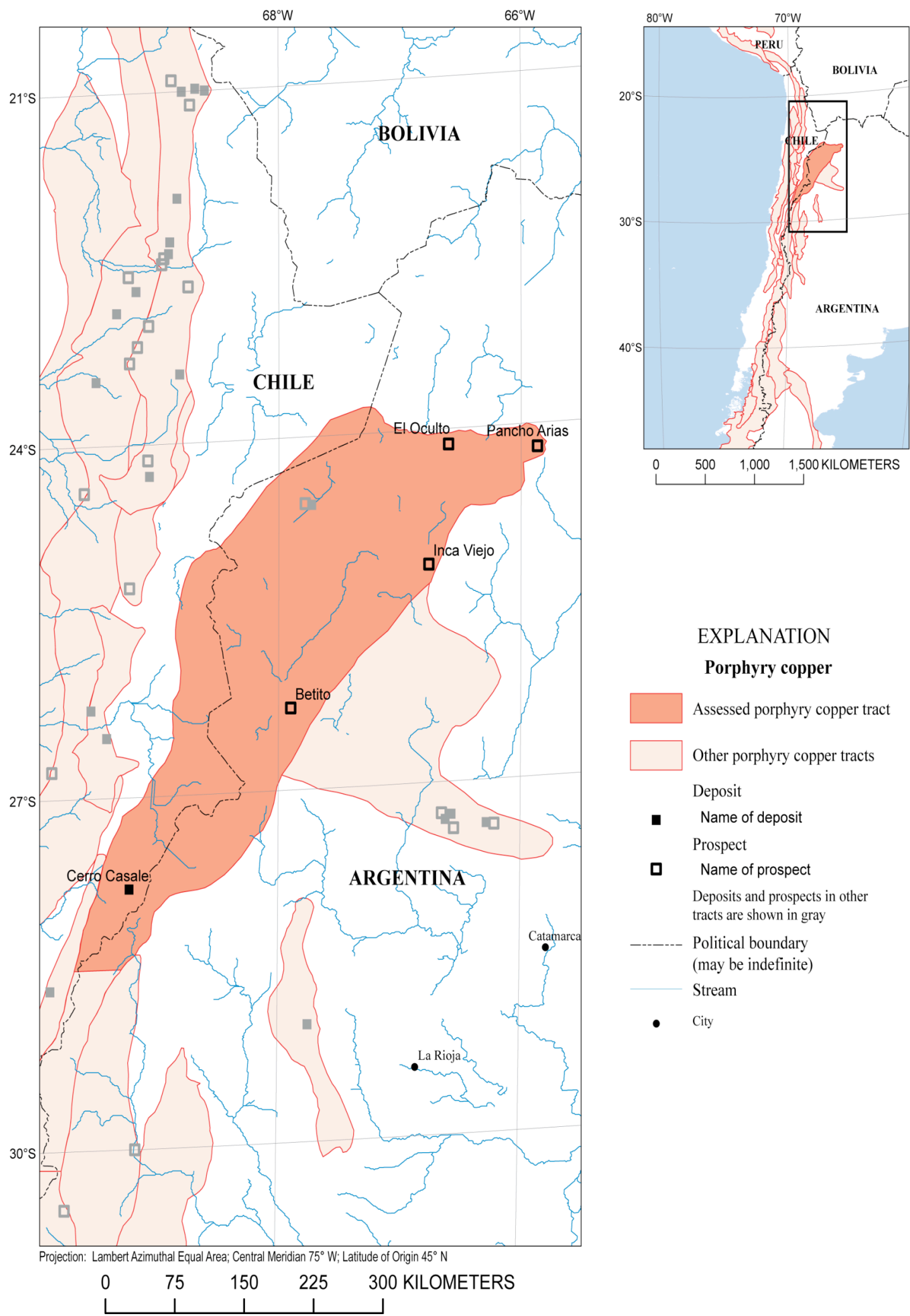

\section{EXPLANATION}

Porphyry copper

Assessed porphyry copper tract

Other porphyry copper tracts

Deposit

- Name of deposit

Prospect

口 Name of prospect

Deposits and prospects in other tracts are shown in gray

Political boundary (may be indefinite) Stream

- $\quad$ City 


\section{Estimated Undiscovered Porphyry Copper Resources in Tract SA13aPC- Argentina and Chile}

Charles G. Cunningham, ${ }^{1}$ Eduardo 0. Zappettini, ${ }^{2}$ Waldo Vivallo S., ${ }^{3}$ Carlos Mario Celada, ${ }^{4}$ Jorge Quispe ${ }^{5}$ Donald A. Singer, ${ }^{1}$ Joseph A Briskey, ${ }^{1}$ David M. Sutphin, ${ }^{1}$ Mariano Gajardo M., ${ }^{3}$ Alejandro Diaz, ${ }^{3}$ Carlos Portigliati, ${ }^{3}$ Vladimir I. Berger, ${ }^{1}$ Rodrigo Carrasco, ${ }^{3}$ and Klaus J. Schulz ${ }^{1}$

'USA-U.S. Geological Survey (USGS)

${ }^{2}$ Argentina - Instituto de Geología y Recursos Minerales (SEGEMAR)

${ }^{3}$ Chile-Servicio Nacional de Geología y Minería (SERNAGEOMIN)
${ }^{4}$ Colombia-Instituto Colombiano de Geología y Minería (INGEOMINAS)

${ }^{5}$ Peru-Instituto Geológico Minero y Metalúrgico (INGEMMET)

\begin{tabular}{|l|l|}
\hline Deposit type assessed: Porphyry Copper & $\begin{array}{l}\text { Model: General porphyry copper deposit model } \\
\text { (Singer, Berger, and Moring, 2005) }\end{array}$ \\
\hline $\begin{array}{l}\text { Tract name: Argentina-Chile Miocene-Pliocene } \\
\text { Cerro Casale }\end{array}$ & Countries: Argentina and Chile \\
\hline Tract ID: SA13aPC & Region: South America \\
\hline Date of assessment: May 16-18, 2005 & Date of last revision: June 15, 2006 \\
\hline Assessment depth: 1 km & \\
\hline Assessment team leader: Joseph A Briskey & Regional coordinator: Charles G. Cunningham \\
\hline Estimators: Joseph A Briskey, Charles G. Cunningham, Klaus J. Schulz, and Eduardo O. Zappettini. \\
\hline
\end{tabular}

Table of estimated numbers of undiscovered deposits by quantile. Also showing calculated mean $(\mathrm{m})$, standard deviation $(s)$, and coefficient of variation in percent $(\mathrm{Cv} \%)$. Sorted by mean.

\begin{tabular}{|c|c|c|c|c|c|c|}
\hline Estimators & 90 & 50 & 10 & $m$ & $s$ & $C v \%$ \\
\hline Consensus of estimators & 4 & 8 & 24 & 11 & 7.5 & 68 \\
\hline
\end{tabular}

\section{Deposit density table}

\begin{tabular}{|c|c|c|c|c|}
\hline $\begin{array}{c}\text { Mean of consensus estimates of } \\
\text { undiscovered deposits }\end{array}$ & $\begin{array}{c}\text { Number of } \\
\text { discovered } \\
\text { deposits }\end{array}$ & $\begin{array}{c}\text { Total number of } \\
\text { deposits }\end{array}$ & Area, $\mathbf{k m}^{\mathbf{2}}$ & $\begin{array}{c}\text { Deposit density, number of } \\
\text { deposits/100,000km }\end{array}$ \\
\hline $\mathbf{1 1}$ & 1 & 12 & 70,587 & 17 \\
\hline
\end{tabular}




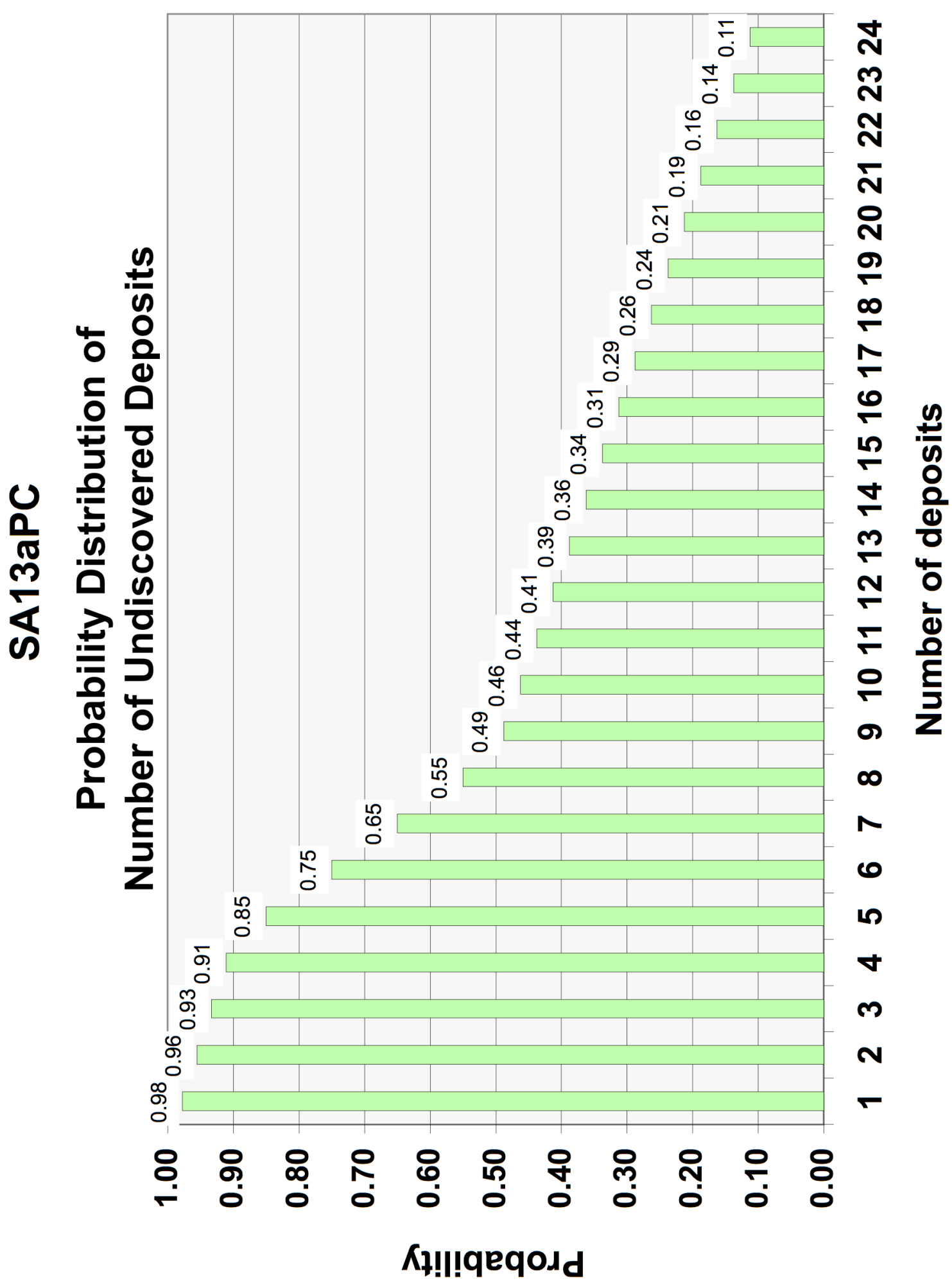




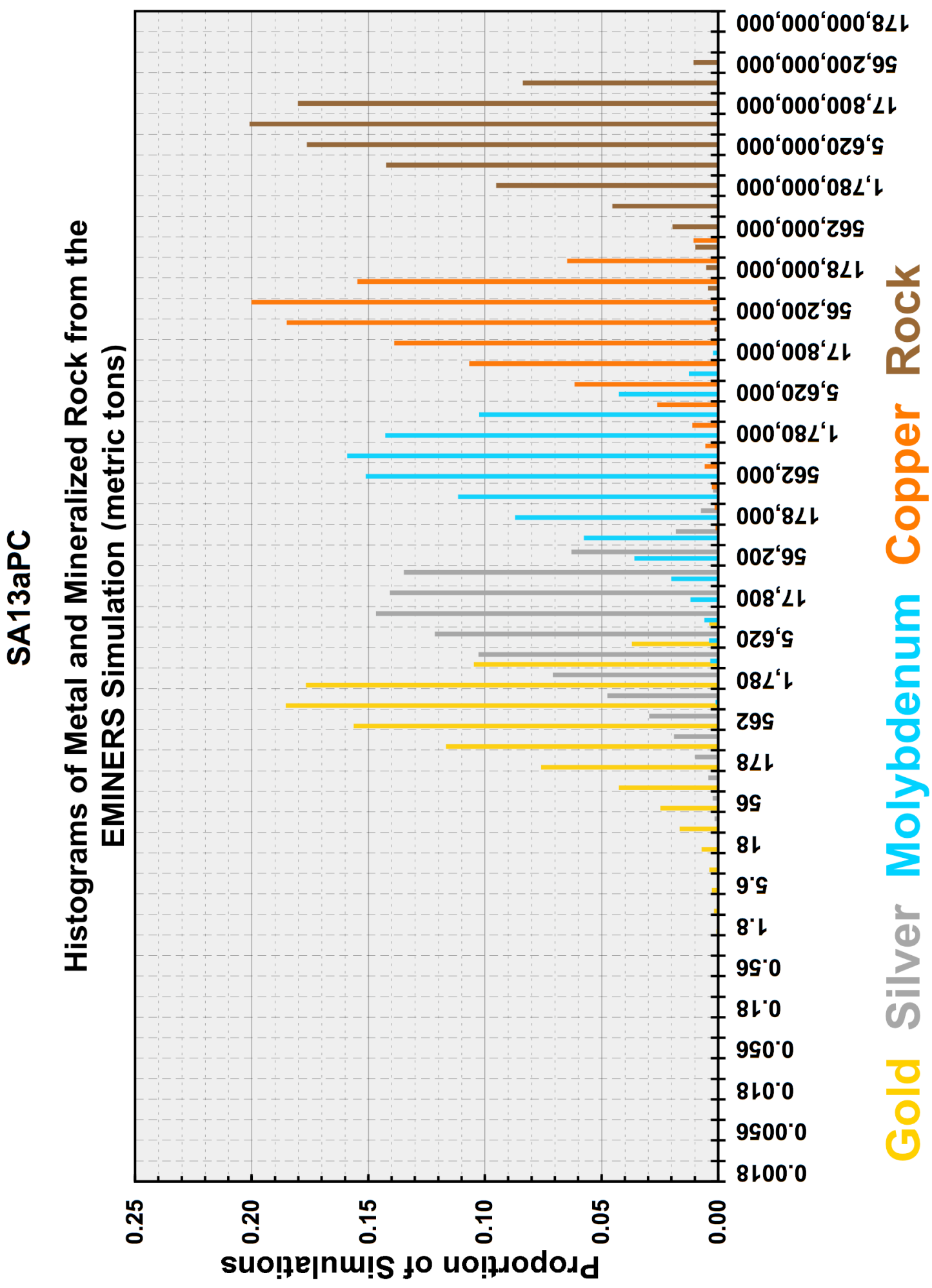




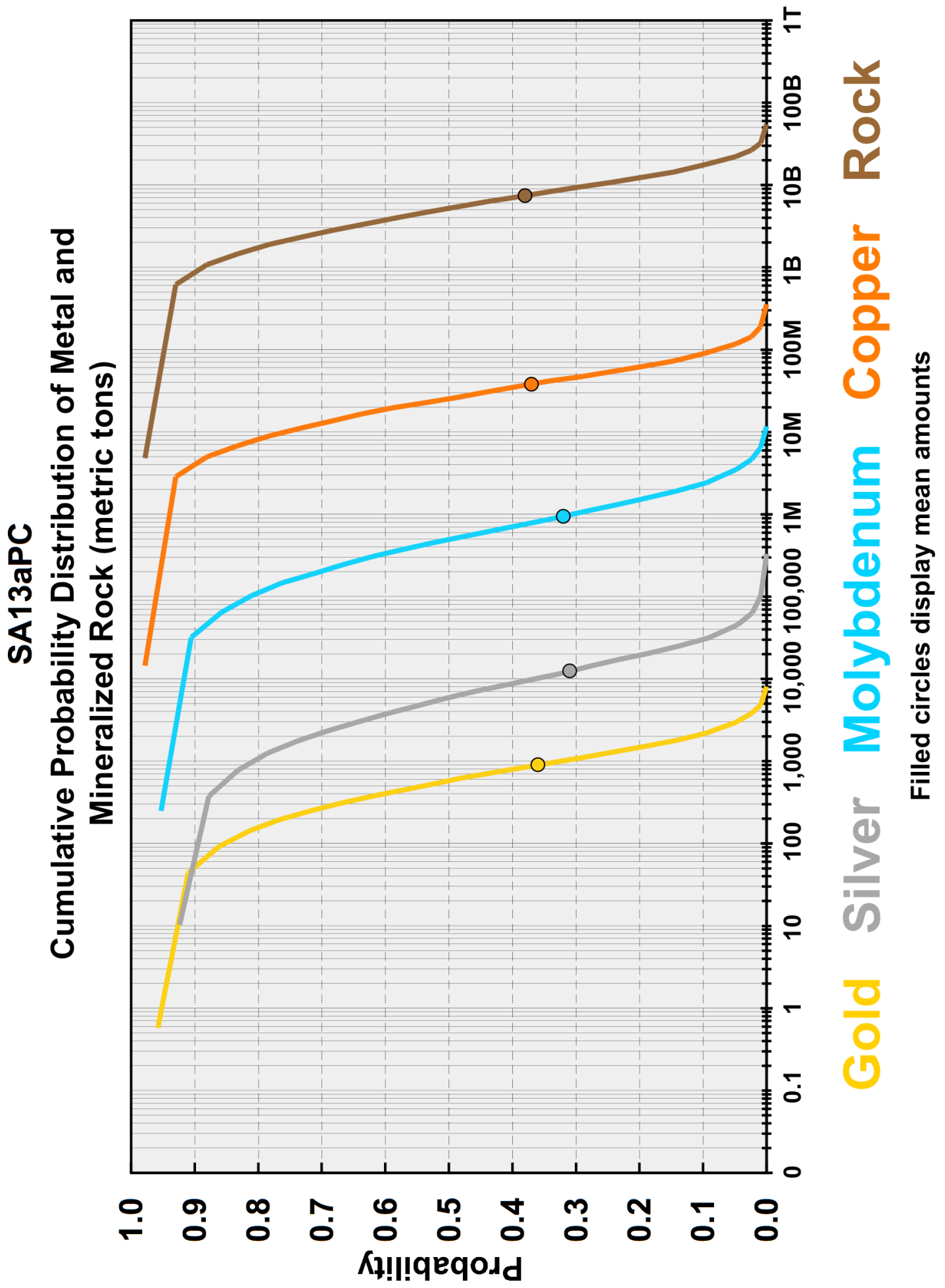




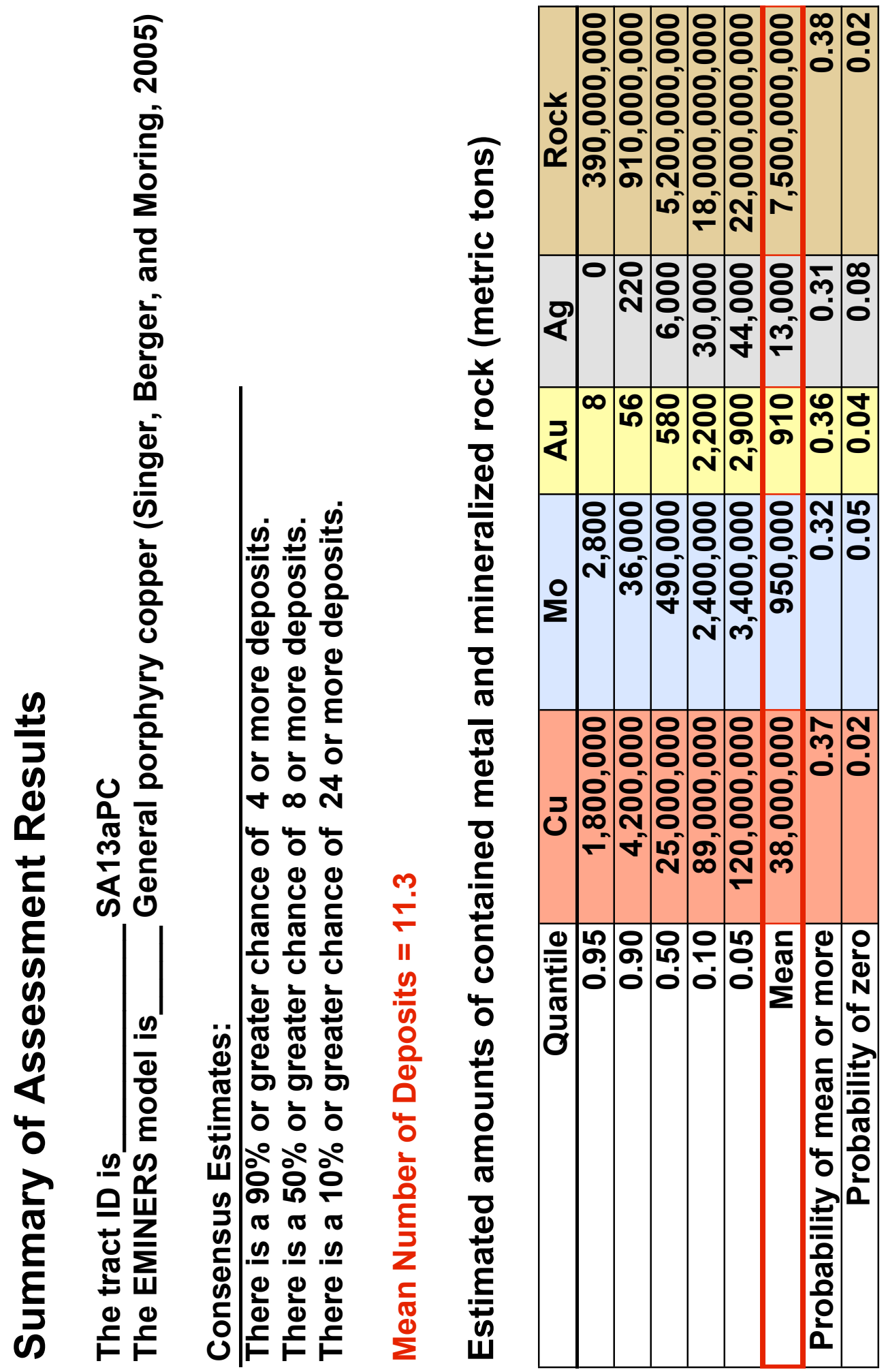




\section{Rationale for tract delineation}

This tract is defined by the distribution of Miocene-Pliocene plutons and by the distribution of volcanic and other country rocks and cover rocks within or beneath which such plutons are expected to occur within $1 \mathrm{~km}$ of the surface. The delineation of the tract depends in part on the distribution of Miocene-Pliocene continental volcanic rocks containing lava flows, volcanic breccias, and ash-flow tuffs. These volcanic rocks are best exposed in, but not restricted to, three discordant bands that trend northwest across this northeast-trending tract. Examination of 1:500,000 scale geologic maps shows that many small, widespread outcrops of plutonic and also volcanic rocks occur between the bands. The northwest trend of the aggregate surface distribution of these volcanic and plutonic rocks, which are spatially associated with the porphyry copper deposits in the tract, also cuts across a north-trending, generally faultcontrolled assortment of older rocks.

Approximately 50 percent of tract SA13aPC is covered by younger rocks and sediments including salars judged to be quite shallow $(<1 \mathrm{~km})$ because they commonly contain outcrops of bedrock. There is less erosion and thicker, more extensive volcanic cover in tract SA13aPC compared to tract SA13cPC to the south where the topography rises up to the Altiplano. Consequently, two separate tracts were created in anticipation that the probability of occurrence of an undiscovered deposit would be higher in tract SA13aPC where permissive host rocks beneath the volcanic cover are poorly explored or unexplored in contrast to tract SA13cPC where there is little to no younger cover. Further sources of information about the geology of the tract and its mineral deposits include Sillitoe, McKee, and Vila (1991); Villa and Sillitoe (1991); and Sillitoe (2000).

\section{Rationale for model choice}

The size and grades of the discovered porphyry copper deposit in the tract are not significantly different (table 3) from the general porphyry copper deposit model (Singer, Berger, and Moring, 2005), which therefore was used to represent the undiscovered deposits. The mineralogy, structure, and alteration of the discovered deposit and prospects in the tract are typical of deposits in the general model.

\section{Deposits and prospects}

At the time of the assessment, the tract was known to contain one discovered deposit, Cerro Casale; and four prospects: Betito, El Oculto, Inca Viejo, and Pancho Arias. This deposit and three of the prospects have dates of 14-15Ma. Deposits and prospects in tract SA13bPC to the south are slightly younger, 10-13 Ma.

Some porphyry copper deposits in the tract are characterized by stockworks and disseminations of chalcopyrite, molybdenite, and gold in porphyritic rocks and nearby country rocks, and commonly contain concentric zones of potassic, phyllic, and propylitic hydrothermally altered rocks.

\section{Exploration history}

The tract is moderately explored and includes a geochemical survey by the United Nations.

\section{Rationale for numerical estimate}

The estimating team decided that the most useful way to begin discussions leading to numerical estimates for this tract was to begin with estimates suggested by the porphyry copper deposit density model of Singer and others (2005). Numbers of undiscovered deposits suggested by the model at the $90^{\text {th }}$, $50^{\text {th }}$, and $10^{\text {th }}$ percentiles were evaluated, discussed, modified, and remodified iteratively by the group in relation to the their collective knowledge of, and available information about, the mineral resource geology and exploration history for the tract. This process continued until consensus estimates were 
achieved for the tract that were satisfactory to all members of the group. The probable occurrence of numerous undiscovered deposits in the tract is consistent with the presence of a number of discovered deposits and prospects in a large tract where the exposed permissive rocks are only moderately explored and half are virtually unexplored because of cover by younger rocks and sediments, and especially by volcanic rocks consanguineous with the permissive host-rock plutons.

\section{Expected distribution of undiscovered deposits}

Based on knowledge and information available to the team at the time of tract delineation, the tract was drawn to enclose an area of geology where the probability of occurrence of an undiscovered deposit is believed to be reasonably uniform, except for those areas beneath younger cover rocks where this potential is expected to be higher because these areas are unexplored or relatively less well explored.

\section{References cited}

Sillitoe, R.H., McKee, E.H., and Vila, T., 1991, Reconnaissance K-Ar geochronology of the Maricunga gold-silver belt, Northern Chile: Economic Geology, v. 86, p. 1261-1270.

Sillitoe, R.H., 2000, Gold-rich porphyry deposits: descriptive and genetic models and their role in exploration and discovery, in Hagemann, S.G., and Brown, P.E., eds., Gold in 2000: Reviews in Economic Geology, v. 13, p. 315-345.

Singer, D.A., Berger, V.I., Menzie, W.D., and Berger, B.R., 2005, Porphyry copper density: Economic Geology, v. 100, no. 3, p. 491-514.

Singer, D.A., Berger, V.I., and Moring, B.C., 2005, Porphyry copper deposits of the world-Database, map, and grade and tonnage models: U.S. Geological Survey Open-file Report 2005-1060, http://pubs.usgs.gov/of/2005/1060/)

Vila, T., and Sillitoe, R.H., 1991, Gold-rich porphyry systems in the Maricunga gold-silver belt, Northern Chile: Economic Geology, v. 86, p. 1238-1260. 


\section{TRACT SA13bPC}

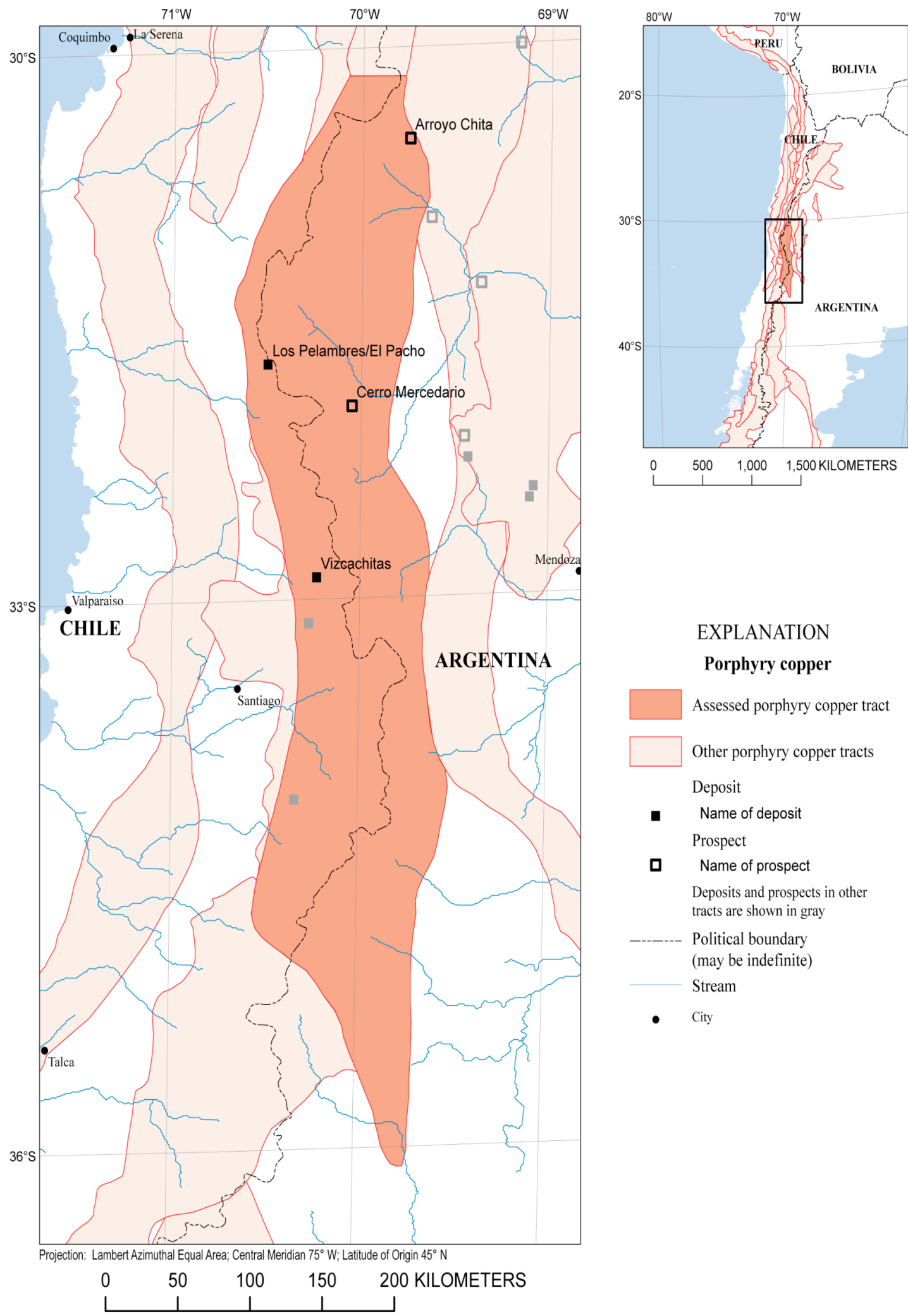




\section{Estimated Undiscovered Porphyry Copper Resources in Tract SA13bPC- Argentina and Chile}

Charles G. Cunningham, ${ }^{1}$ Eduardo 0. Zappettini, ${ }^{2}$ Waldo Vivallo S., ${ }^{3}$ Carlos Mario Celada, ${ }^{4}$ Jorge Quispe ${ }^{5}$ Donald A. Singer, ${ }^{1}$ Joseph A Briskey, ${ }^{1}$ David M. Sutphin, ${ }^{1}$ Mariano Gajardo M., ${ }^{3}$ Alejandro Diaz, ${ }^{3}$ Carlos Portigliati, ${ }^{3}$ Vladimir I. Berger, ${ }^{1}$ Rodrigo Carrasco, ${ }^{3}$ and Klaus J. Schulz ${ }^{1}$

'USA-U.S. Geological Survey (USGS)

${ }^{2}$ Argentina - Instituto de Geología y Recursos Minerales (SEGEMAR)

${ }^{3}$ Chile-Servicio Nacional de Geología y Minería (SERNAGEOMIN)
${ }^{4}$ Colombia-Instituto Colombiano de Geología y Minería (INGEOMINAS)

${ }^{5}$ Peru-Instituto Geológico Minero y Metalúrgico (INGEMMET)

\begin{tabular}{|l|l|}
\hline Deposit type assessed: Porphyry Copper & $\begin{array}{l}\text { Model: General porphyry copper deposit model } \\
\text { (Singer, Berger, and Moring, 2005) }\end{array}$ \\
\hline $\begin{array}{l}\text { Tract name: Argentina-Chile Miocene-Pliocene } \\
\text { Los Pelambres }\end{array}$ & Countries: Argentina and Chile \\
\hline Tract ID: SA13bPC & Region: South America \\
\hline Date of assessment: May 16-18, 2005 & Date of last revision: \\
\hline Assessment depth: $1 \mathrm{~km}$ & Regional coordinator: Charles G. Cunningham \\
\hline Assessment team leader: Donald A. Singer & $\begin{array}{l}\text { Estimators: Carlos Mario Celada, Vladimir I. Berger, Rodrigo Carrasco, Alejandro Diaz, Mariano } \\
\text { Gajardo M., Carlos Portigliati, Donald A. Singer, Waldo Vivallo S., and Eduardo O. Zappettini. }\end{array}$ \\
\hline
\end{tabular}

Table of estimated numbers of undiscovered deposits by quantile. Also showing calculated mean $(m)$, standard deviation $(s)$, and coefficient of variation in percent $(C v \%)$. Sorted by mean.

\begin{tabular}{|l|r|r|r|r|c|c|}
\hline \multicolumn{1}{|c|}{ Estimators } & $\mathbf{9 0}$ & $\mathbf{5 0}$ & $\mathbf{1 0}$ & $\boldsymbol{m}$ & $\boldsymbol{s}$ & Cv\% \\
\hline Estimator & 3 & 4 & 6 & 4.1 & 1.3 & 32 \\
\hline Estimator & 2 & 5 & 10 & 5.5 & 3.0 & 55 \\
\hline Estimator & 2 & 5 & 10 & 5.5 & 3.0 & 55 \\
\hline Estimator & 2 & 5 & 10 & 5.5 & 3.0 & 55 \\
\hline Estimator & 2 & 5 & 10 & 5.5 & 3.0 & 55 \\
\hline Estimator & 4 & 6 & 8 & 5.7 & 1.6 & 28 \\
\hline Consensus of estimators & $\mathbf{3}$ & $\mathbf{6}$ & $\mathbf{1 1}$ & $\mathbf{6 . 4}$ & $\mathbf{3 . 0}$ & $\mathbf{4 7}$ \\
\hline Estimator & 2 & 5 & 14 & 6.7 & 4.5 & 67 \\
\hline Estimator & 4 & 7 & 15 & 8.2 & 4.2 & 51 \\
\hline Estimator & 5 & 10 & 15 & 9.7 & 3.7 & 38 \\
\hline
\end{tabular}

\section{Deposit density table}

\begin{tabular}{|c|c|c|c|c|}
\hline $\begin{array}{c}\text { Mean of consensus estimates of } \\
\text { undiscovered deposits }\end{array}$ & $\begin{array}{c}\text { Number of } \\
\text { discovered } \\
\text { deposits }\end{array}$ & $\begin{array}{c}\text { Total number of } \\
\text { deposits }\end{array}$ & Area, $\mathbf{~ m}^{\mathbf{2}}$ & $\begin{array}{c}\text { Deposit density, number of } \\
\text { deposits/100,000km }\end{array}$ \\
\hline $\mathbf{6 . 4}$ & 2 & 8.4 & 41,799 & 20 \\
\hline
\end{tabular}




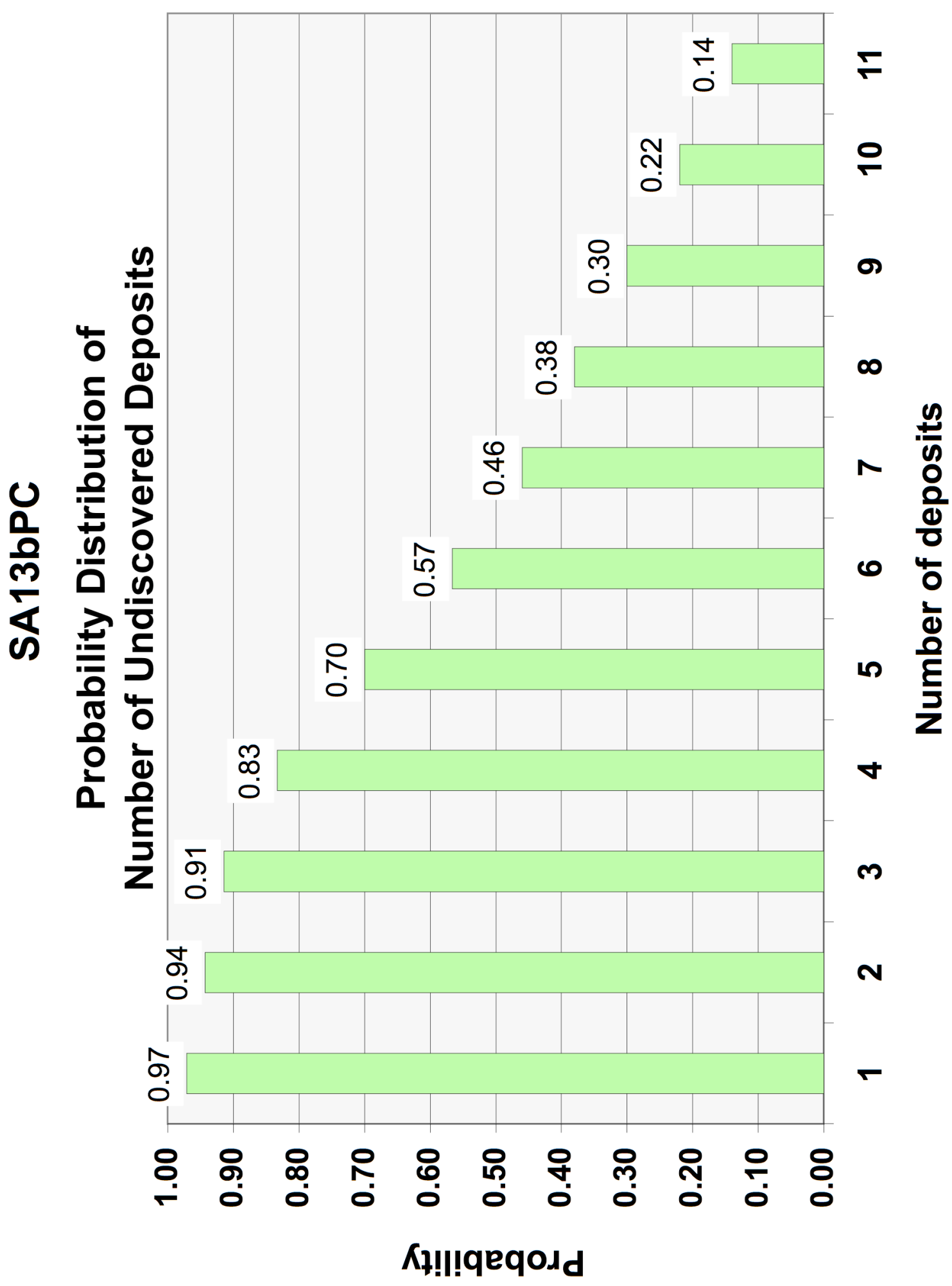




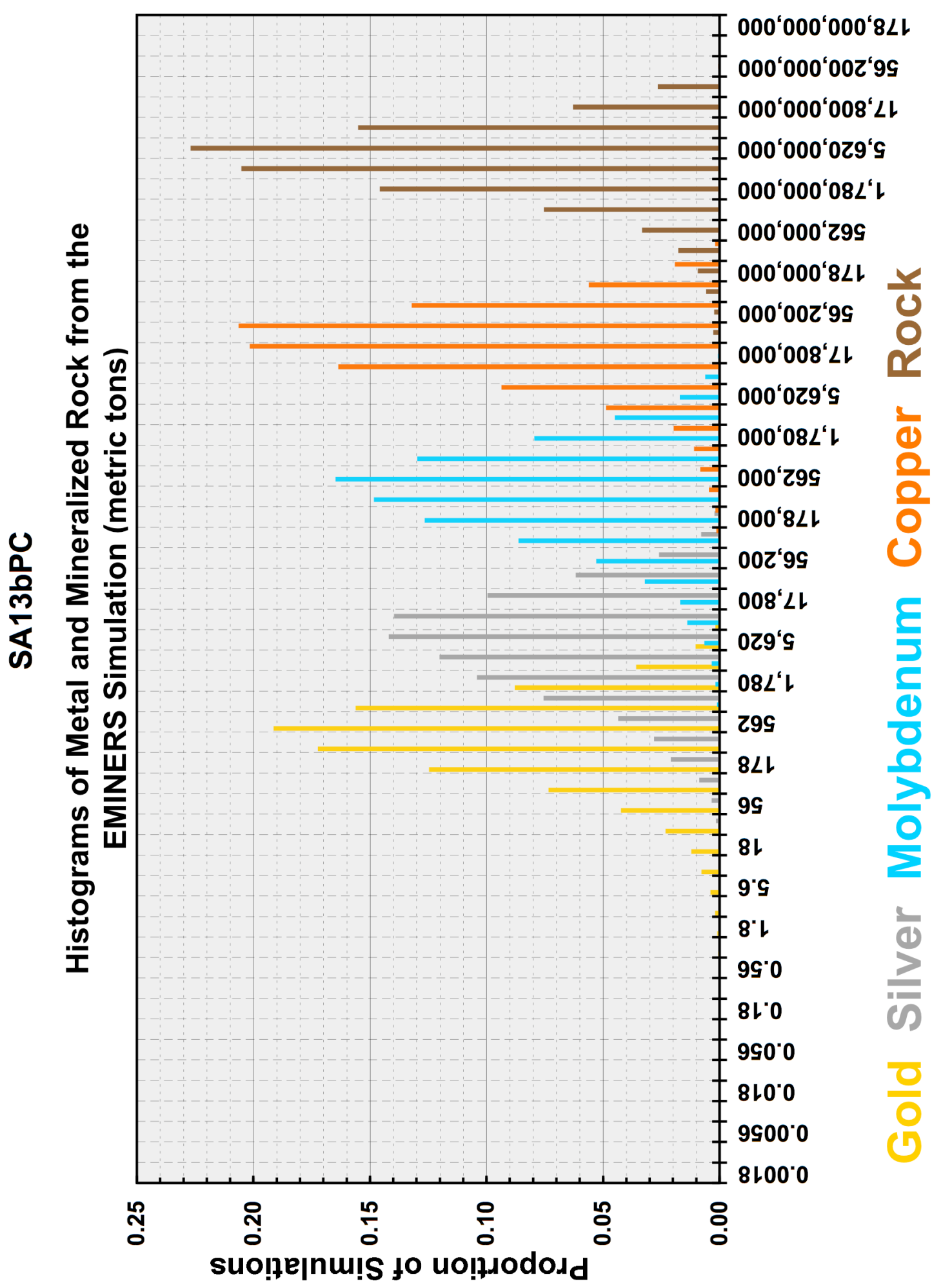









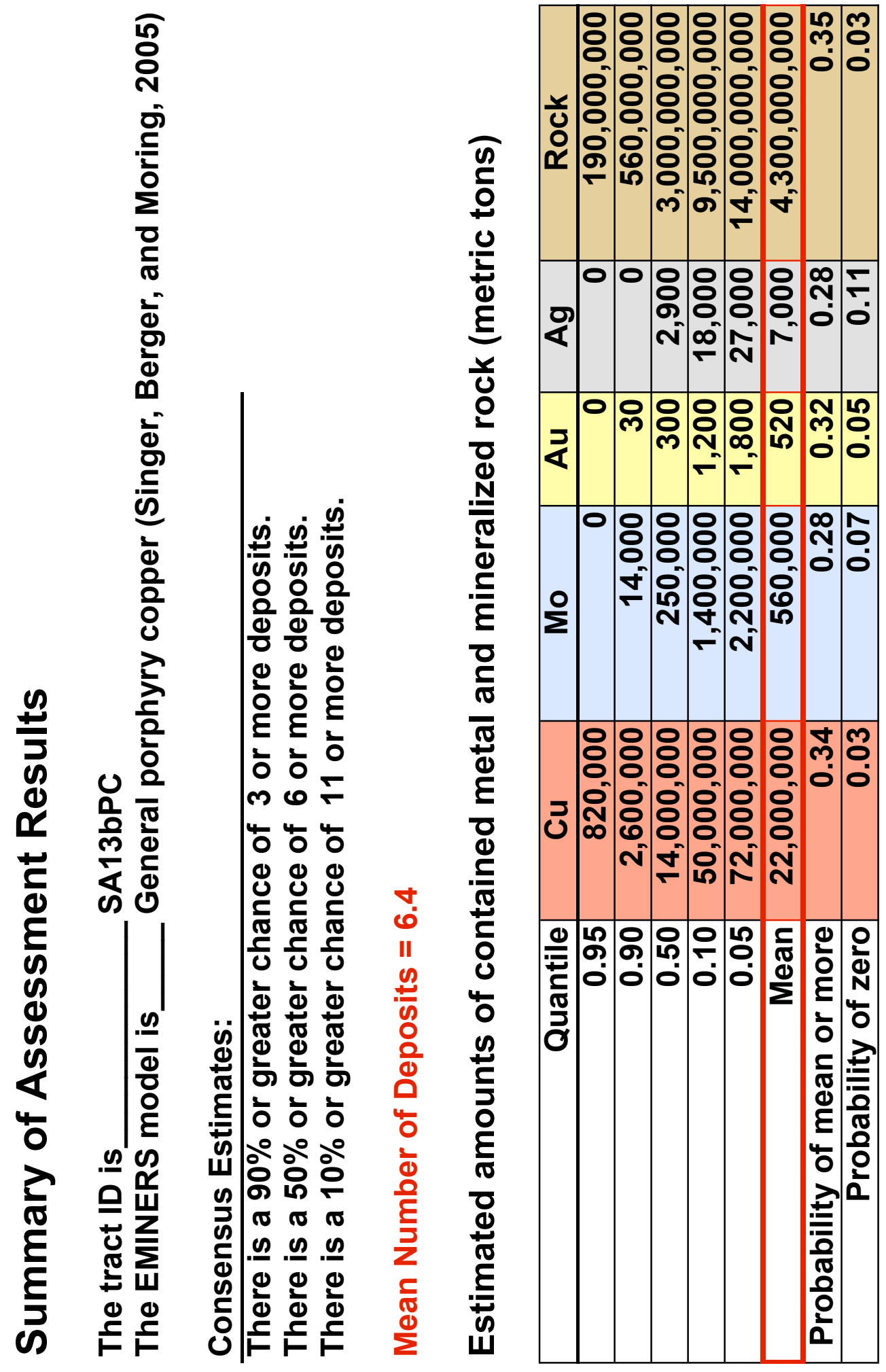




\section{Rationale for tract delineation}

This tract is defined by the distribution of Miocene-Pliocene principally calc-alkaline plutons and by the distribution of volcanic and other country rocks and cover rocks within or beneath which such plutons are expected to occur within $1 \mathrm{~km}$ of the surface. Approximately 70 percent of the tract consists of older country rocks and much of the remainder is covered by andesitic volcanic rocks. There is less erosion in tract SA13bPC compared to tract SA13cPC to the north. Consequently, two separate tracts were created in anticipation that the probability of occurrence of an undiscovered deposit would be higher in tract SA13bPC where permissive host rocks beneath areas of younger cover are poorly explored or unexplored in contrast to tract SA13cPC where there is little to no cover.

\section{Rationale for model choice}

The size and grades of the discovered porphyry copper deposits in the tract are not significantly different (table 3) from the general porphyry copper deposit model (Singer, Berger, and Moring, 2005), which therefore was used to represent the undiscovered deposits. The composition and distribution of mineralogy, structure, and alteration in the discovered deposits also is typical of deposits in the general model.

\section{Deposits and prospects}

Two discovered deposits, Los Pelambres/El Pachon and Vizcachitas, and two prospects, Arroyo Chita and Cerro Mercedario, were known in the tract at the time of the assessment. The Vizcachitas deposit has K/Ar age determinations on secondary biotite from the intrusions of 10.4 and $12 \pm 0.3 \mathrm{Ma}$ (Leo Hathaway, written comm., 2006). Discovered deposits and prospects in tract SA13bPC are slightly younger (10-13 Ma) than those in tract SA13aPC (14-15 Ma).

Tract SA13bPC also contains two other porphyry copper prospects, Vicuña and Josemaria, which were discovered after this assessment was completed. A recent report (Nilsson, 2006) indicates that preliminary inferred resources for Josemaria, at 0.3 percent copper cut off, are 374 million metric tons with 0.4 percent copper and $0.29 \mathrm{~g} / \mathrm{t}$ gold.

\section{Exploration history}

The exposed part of tract SA13bPC is moderately explored. Exploration has been more intense around known deposits and prospects. A United Nations geochemical survey was conducted in the tract.

\section{Rationale for numerical estimate}

Members of the assessment team used their collective knowledge of numbers of discovered deposits in the tract and (or) in similar areas elsewhere in the world to make estimates throughout the tract that also were consistent with the deposit density model of Singer and others (2005). Porphyry copper mineralizing processes active in this medium size tract have produced two discovered deposits. The estimating team believes a number of undiscovered deposits also are likely to occur, particularly at depth within the extensive areas of only moderately explored older country rocks, as well as beneath poorly explored or unexplored younger cover rocks and sediments.

\section{Expected distribution of undiscovered deposits}

Based on knowledge and information available to the team at the time of tract delineation, the tract was drawn to enclose an area of geology where the probability of occurrence of an undiscovered deposit is believed to be reasonably uniform, except for those areas beneath younger cover rocks where this potential is expected to be higher because these areas are unexplored or relatively less well explored. 


\section{References cited}

Nilsson, J.P., 2006, Josemaria project, San Juan Province, Argentina: Unpublished report, Nilsson Mine Services Ltd. \& Mario Rossi M. Sc. - Geosystems International, January 23, 2006.

Singer, D.A., Berger, V.I., Menzie, W.D., and Berger, B.R., 2005, Porphyry copper density: Economic Geology, v. 100, no. 3, p. 491-514.

Singer, D.A., Berger, V.I., and Moring, B.C., 2005, Porphyry copper deposits of the world-Database, map, and grade and tonnage models: U.S. Geological Survey Open-file Report 2005-1060, http://pubs.usgs.gov/of/2005/1060/) 


\section{TRACT SA13cPC}
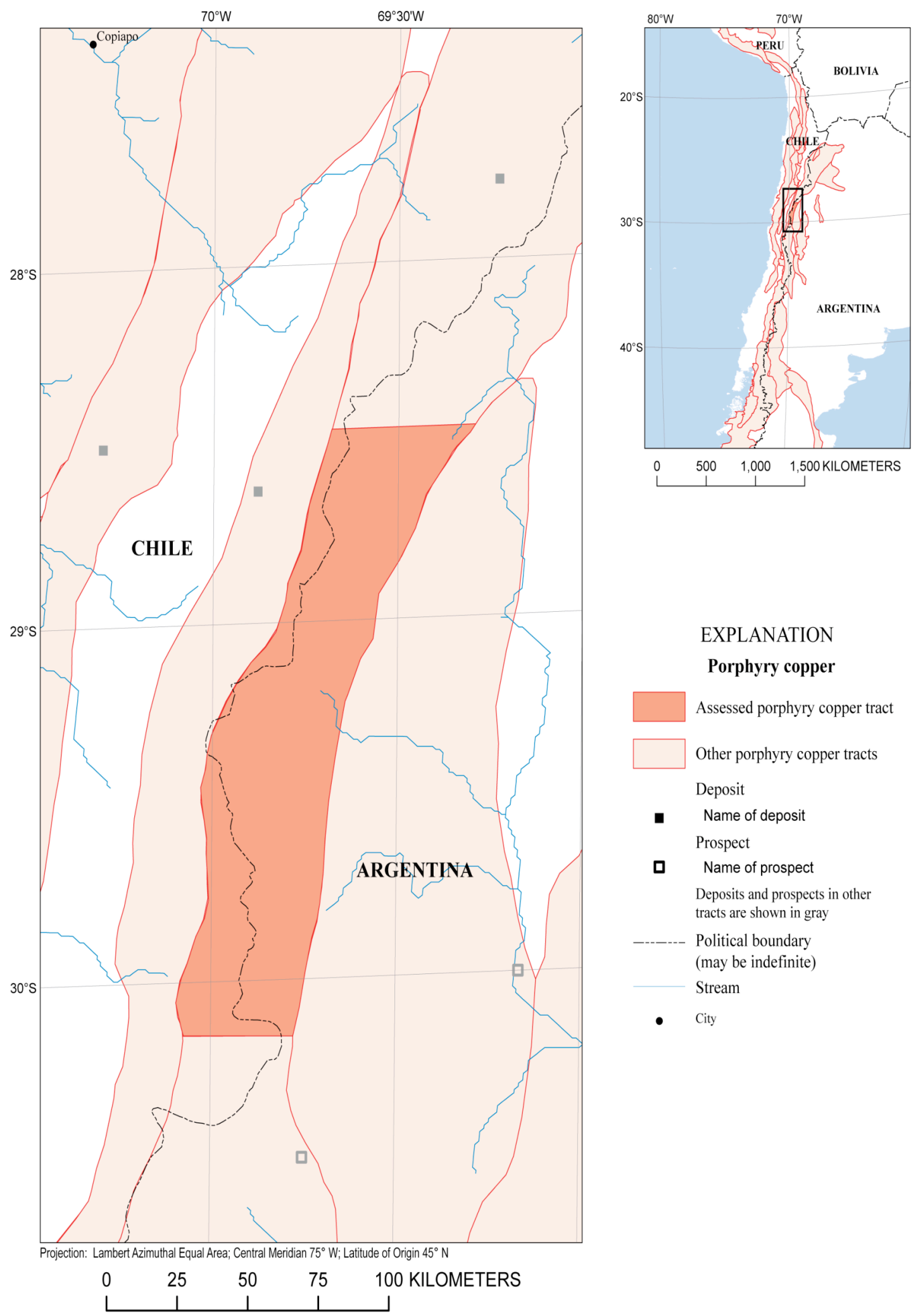

EXPLANATION

Porphyry copper

Assessed porphyry copper tract

Other porphyry copper tracts

Deposit

- Name of deposit

Prospect

口 Name of prospect

Deposits and prospects in other tracts are shown in gray

Political boundary

(may be indefinite)

Stream

- $\quad$ City 


\section{Estimated Undiscovered Porphyry Copper Resources in Tract SA13cPC- Argentina and Chile}

Charles G. Cunningham, ${ }^{1}$ Eduardo 0. Zappettini, ${ }^{2}$ Waldo Vivallo S., ${ }^{3}$ Carlos Mario Celada, ${ }^{4}$ Jorge Quispe ${ }^{5}$ Donald A. Singer, ${ }^{1}$ Joseph A Briskey, ${ }^{1}$ David M. Sutphin, ${ }^{1}$ Mariano Gajardo M., ${ }^{3}$ Alejandro Diaz, ${ }^{3}$ Carlos Portigliati, ${ }^{3}$ Vladimir I. Berger, ${ }^{1}$ Rodrigo Carrasco, ${ }^{3}$ and Klaus J. Schulz ${ }^{1}$

'USA-U.S. Geological Survey (USGS)

${ }^{2}$ Argentina - Instituto de Geología y Recursos Minerales (SEGEMAR)

${ }^{3}$ Chile-Servicio Nacional de Geología y Minería (SERNAGEOMIN)
${ }^{4}$ Colombia-Instituto Colombiano de Geología y Minería (INGEOMINAS)

${ }^{5}$ Peru-Instituto Geológico Minero y Metalúrgico (INGEMMET)

\begin{tabular}{|l|l|}
\hline Deposit type assessed: Porphyry Copper & $\begin{array}{l}\text { Model: General porphyry copper deposit model } \\
\text { (Singer, Berger, and Moring, 2005) }\end{array}$ \\
\hline Tract name: Argentina-Chile Miocene-Pliocene & Countries: Argentina and Chile \\
\hline Tract ID: SA13cPC & Region: South America \\
\hline Date of assessment: June 16, 2006 & Date of last revision: \\
\hline Assessment depth: $1 \mathrm{~km}$ & \\
\hline Assessment team leader: Joseph A Briskey & Regional coordinator: Charles G. Cunningham \\
\hline Estimators: Joseph A Briskey, Charles G. Cunningham, Klaus J. Schulz, and Eduardo O. Zappettini. \\
\hline
\end{tabular}

Table of estimated numbers of undiscovered deposits by quantile. Also showing calculated mean $(m)$, standard deviation $(s)$, and coefficient of variation in percent $(\mathrm{Cv} \%)$. Sorted by mean.

\begin{tabular}{|c|c|c|c|c|c|c|}
\hline Estimators & 90 & 50 & 10 & $m$ & $s$ & $C v \%$ \\
\hline Consensus of estimators & 1 & 2 & 4 & 2.2 & 1.2 & 55 \\
\hline
\end{tabular}

\section{Deposit density table}

\begin{tabular}{|c|c|c|c|c|}
\hline $\begin{array}{c}\text { Mean of consensus estimates of } \\
\text { undiscovered deposits }\end{array}$ & $\begin{array}{c}\text { Number of } \\
\text { discovered } \\
\text { deposits }\end{array}$ & $\begin{array}{c}\text { Total number of } \\
\text { deposits }\end{array}$ & Area, $\mathbf{~ k m}^{\mathbf{2}}$ & $\begin{array}{c}\text { Deposit density, number of } \\
\text { deposits/100,000 }\end{array}$ \\
\hline $\mathbf{2 . 2}$ & 0 & 2.2 & 5,767 & \\
\hline
\end{tabular}




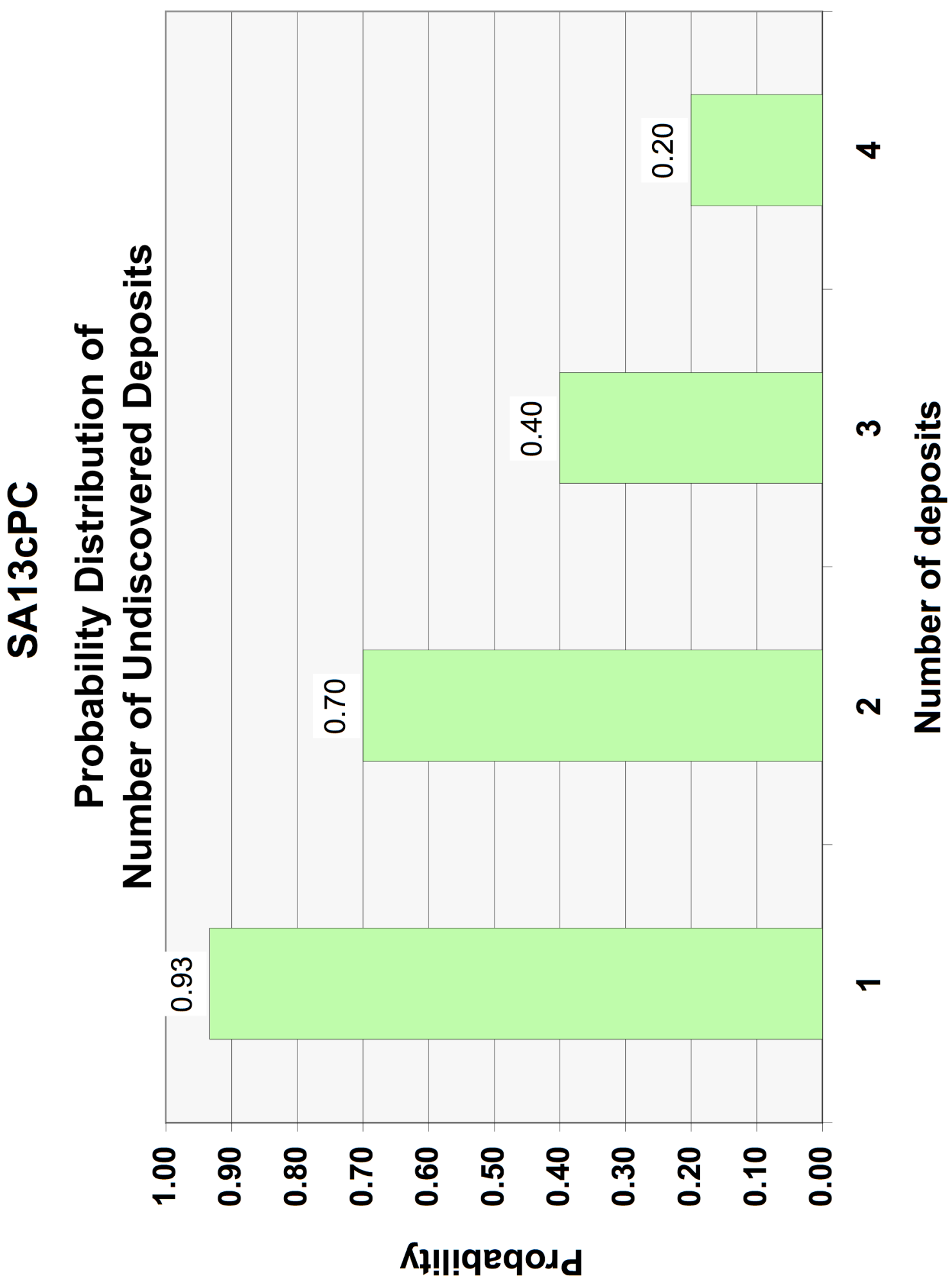




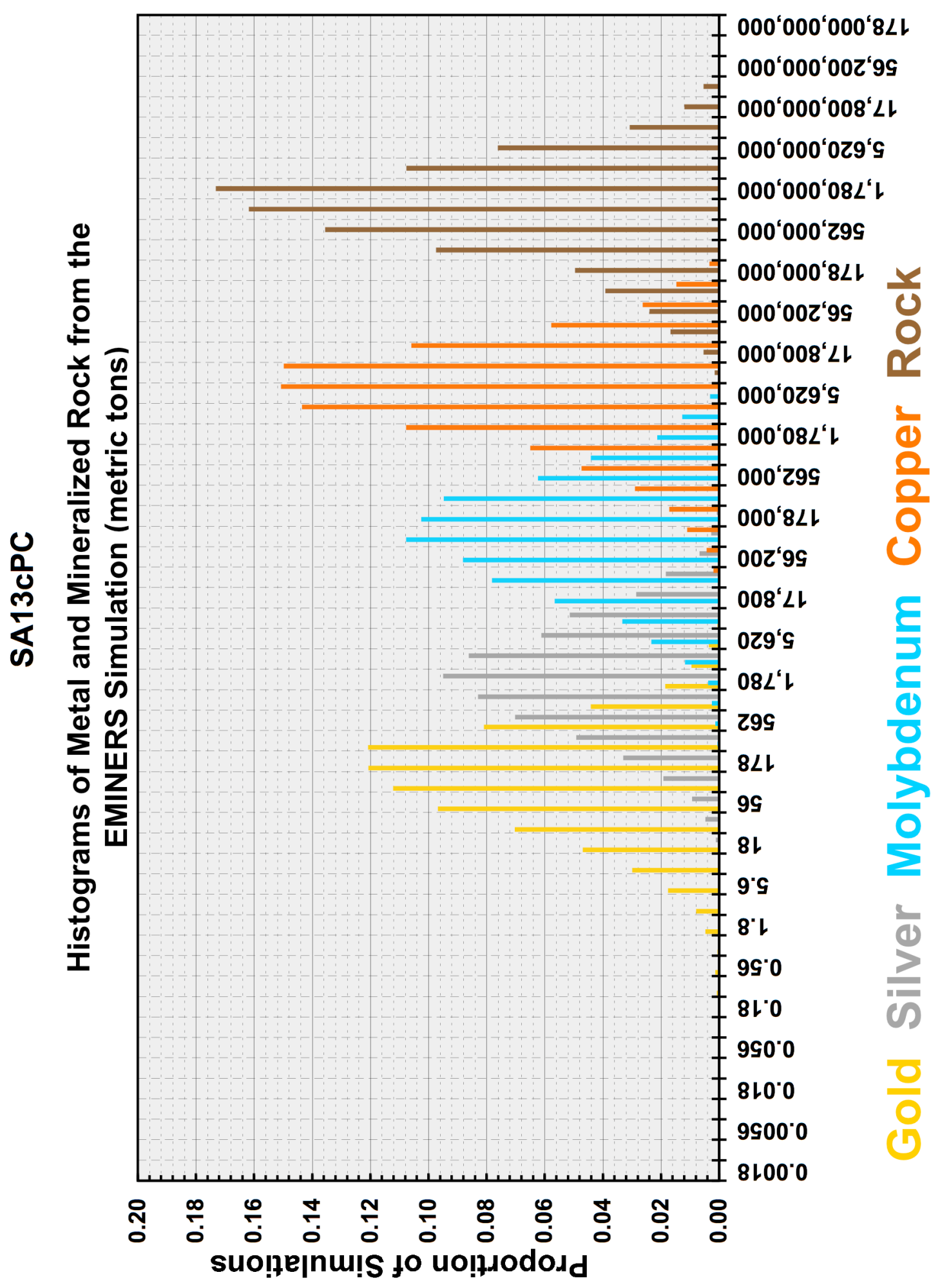




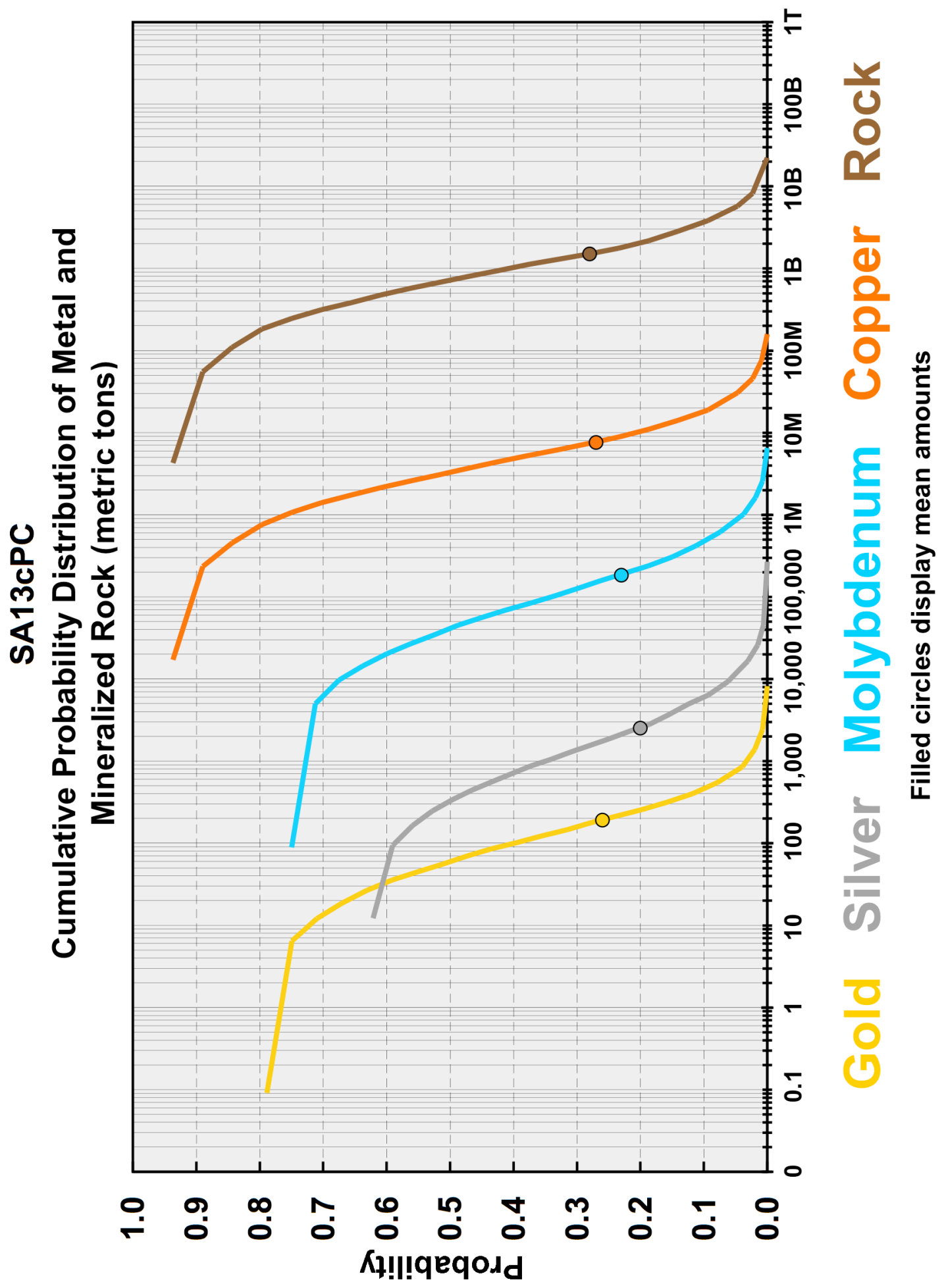




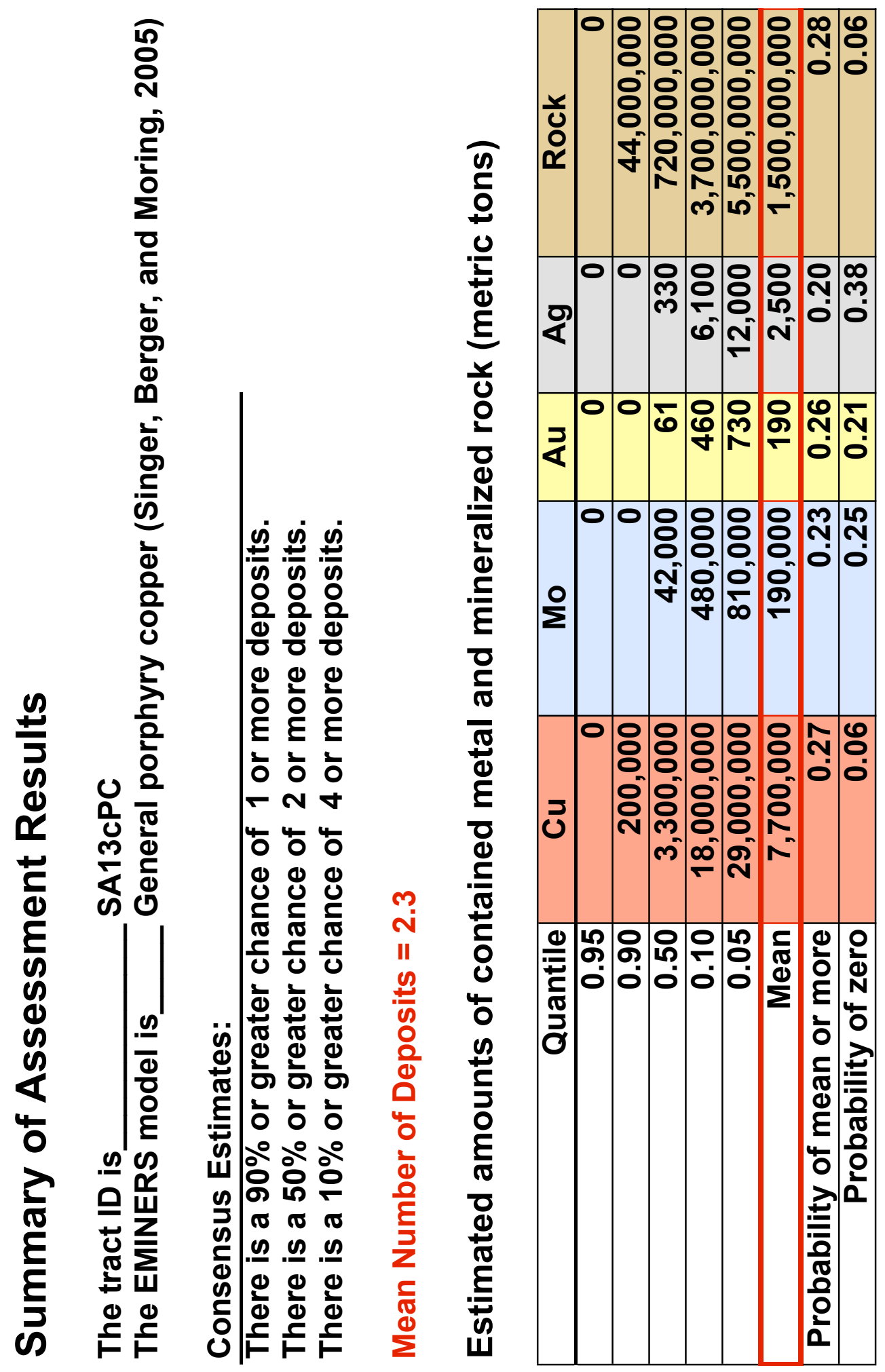




\section{Rationale for tract delineation}

This tract is defined by the distribution of Miocene-Pliocene calc-alkaline plutons and by the distribution of volcanic and other country rocks and cover rocks within or beneath which such plutons are expected to occur within $1 \mathrm{~km}$ of the surface. Erosion has stripped nearly all of the younger cover rocks from the tract in contrast to tracts SA13aPC and SA13bPC to the north and south, respectively, which still retain extensive areas of younger cover. Consequently, tract SA13cPC was created as a separate tract in anticipation that the probability of occurrence of an undiscovered deposit would be lower than in the other two tracts where permissive host rocks beneath large areas of younger cover are poorly explored or unexplored.

\section{Rationale for model choice}

Because the tract contains no discovered deposits, and there was no reason to reject the general porphyry copper deposit model (Singer, Berger, and Moring, 2005), this model was used to represent the undiscovered deposits. This assumption is supported by $t$-tests (table 3 ) showing that the size and grades of discovered deposits in geologically equivalent host rocks in tracts SA13aPC and SA13bPC are not significantly different from the general porphyry copper deposit model (Singer, Berger, and Moring, 2005).

\section{Deposits and prospects}

Permissive rocks in tract SA13cPC have no discovered porphyry copper deposits or prospects. However, equivalent rocks in tract SA13aPC to the north contain deposits and prospects with ages 14-15 $\mathrm{Ma}$, and equivalent rocks in tract SA13bPC to the south contain deposits and prospects with ages 10-13 Ma.

\section{Exploration history}

Tract SA13cPC is moderately explored. Because erosion has removed essentially all of its younger cover rocks, this tract is better explored than tract SA13aPC, which is approximately 50 percent covered, and tract SA13bPC, which is approximately 20-30 percent covered.

\section{Rationale for numerical estimate}

The estimating team decided that the most useful way to begin discussions leading to numerical estimates for this tract was with estimates suggested by the porphyry copper deposit density model of Singer and others (2005). Numbers of undiscovered deposits suggested by the model at the $90^{\text {th }}, 50^{\text {th }}$, and $10^{\text {th }}$ percentiles were evaluated, discussed, modified, and remodified iteratively by the group in relation to the their collective knowledge of, and available information about, the mineral resource geology and exploration history for the tract. This process continued until consensus estimates were achieved for the tract that were satisfactory to all members of the group.

The estimating team concluded that the tract probably contains fewer deposits than suggested by the density model because moderate exploration to date has not found a single deposit or prospect in this small tract with essentially no younger cover.

\section{Expected distribution of undiscovered deposits}

The tract was drawn to enclose an area of geology where the probability of occurrence of an undiscovered deposit was expected to be reasonably uniform based on knowledge and information available to the team at the time of tract delineation. 


\section{References cited}

Singer, D.A., Berger, V.I., Menzie, W.D., and Berger, B.R., 2005, Porphyry copper density: Economic Geology, v. 100, no. 3, p. 491-514.

Singer, D.A., Berger, V.I., and Moring, B.C., 2005, Porphyry copper deposits of the world-Database, map, and grade and tonnage models: U.S. Geological Survey Open-file Report 2005-1060, http://pubs.usgs.gov/of/2005/1060/) 
TRACT SA13dPC
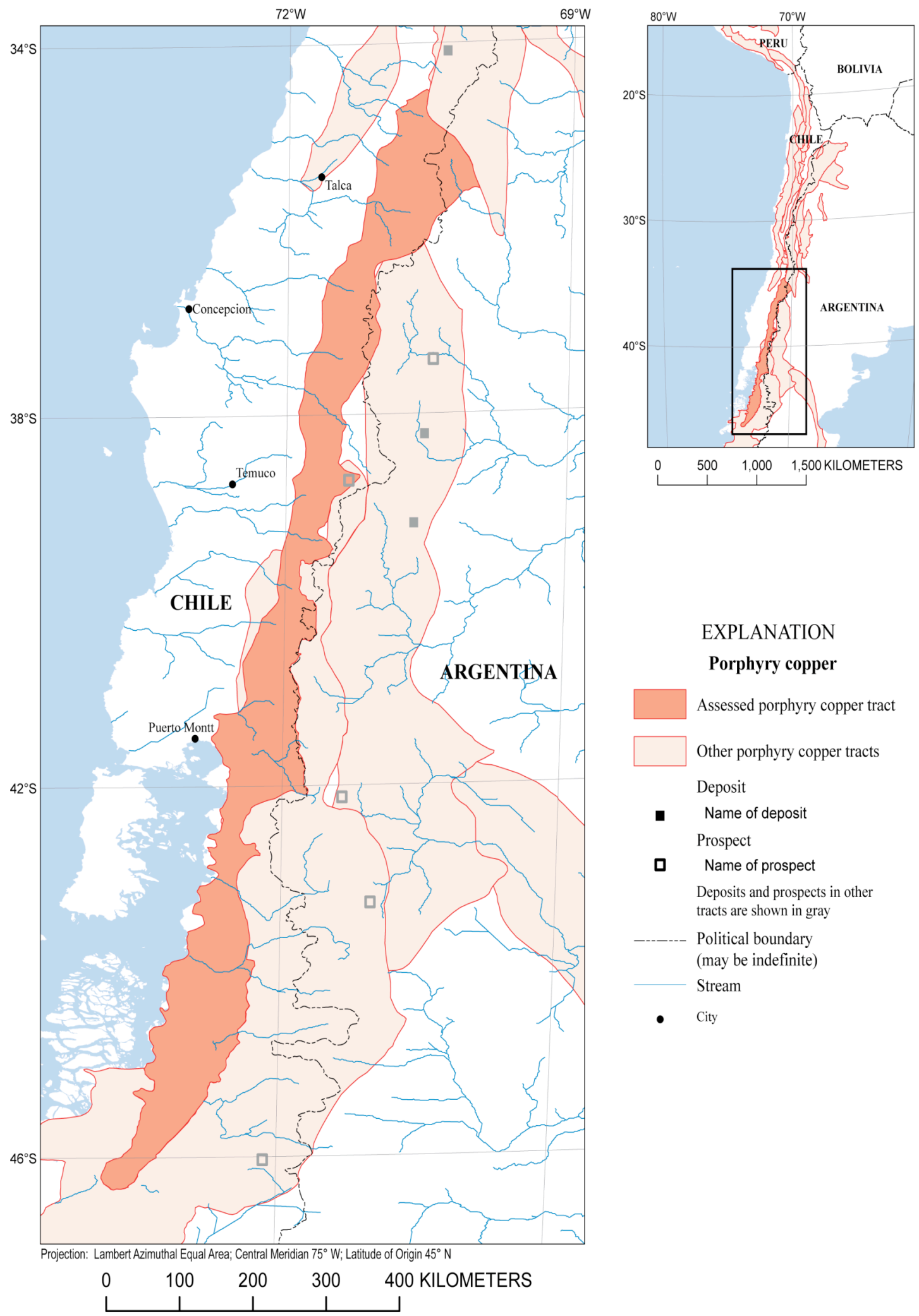

EXPLANATION

Porphyry copper

Assessed porphyry copper tract

Other porphyry copper tracts

Deposit

- Name of deposit

Prospect

口 Name of prospect

Deposits and prospects in other tracts are shown in gray

Political boundary (may be indefinite) Stream

- $\quad$ City 


\section{Estimated Undiscovered Porphyry Copper Resources in Tract SA13dPC- Chile and Argentina}

Charles G. Cunningham, ${ }^{1}$ Eduardo 0. Zappettini, ${ }^{2}$ Waldo Vivallo S., ${ }^{3}$ Carlos Mario Celada, ${ }^{4}$ Jorge Quispe ${ }^{5}$ Donald A. Singer, ${ }^{1}$ Joseph A Briskey, ${ }^{1}$ David M. Sutphin, ${ }^{1}$ Mariano Gajardo M., ${ }^{3}$ Alejandro Diaz, ${ }^{3}$ Carlos Portigliati, ${ }^{3}$ Vladimir I. Berger, ${ }^{1}$ Rodrigo Carrasco, ${ }^{3}$ and Klaus J. Schulz ${ }^{1}$

'USA-U.S. Geological Survey (USGS)

${ }^{2}$ Argentina - Instituto de Geología y Recursos Minerales (SEGEMAR)

${ }^{3}$ Chile-Servicio Nacional de Geología y Minería (SERNAGEOMIN)
${ }^{4}$ Colombia-Instituto Colombiano de Geología y Minería (INGEOMINAS)

${ }^{5}$ Peru-Instituto Geológico Minero y Metalúrgico (INGEMMET)

\begin{tabular}{|l|l|}
\hline Deposit type assessed: Porphyry Copper & $\begin{array}{l}\text { Model: General porphyry copper deposit model } \\
\text { (Singer, Berger, and Moring, 2005) }\end{array}$ \\
\hline Tract name: Chile-Argentina Miocene coastal & Countries: Chile and Argentina \\
\hline Tract ID: SA13dPC & Region: South America \\
\hline Date of assessment: May 6, 2006 & Date of last revision: \\
\hline Assessment depth: $1 \mathrm{~km}$ & \\
\hline Assessment team leader: Joseph A Briskey & Regional coordinator: Charles G. Cunningham \\
\hline Estimators: Waldo Vivallo S., Eduardo O. Zappettini, Charles G. Cunningham \\
\hline
\end{tabular}

Table of estimated numbers of undiscovered deposits by quantile. Also showing calculated mean $(m)$, standard deviation $(s)$, and coefficient of variation in percent $(C v \%)$. Sorted by mean.

\begin{tabular}{|l|c|c|c|c|c|c|}
\hline \multicolumn{1}{|c|}{ Estimators } & $\mathbf{9 0}$ & $\mathbf{5 0}$ & $\mathbf{1 0}$ & $\mathbf{m}$ & $\boldsymbol{s}$ & $\mathbf{C v} \%$ \\
\hline Estimator & 0 & 1 & 3 & 1.3 & 1.2 & 92 \\
\hline Estimator & 0 & 1 & 3 & 1.3 & 1.2 & 92 \\
\hline Estimator & 0 & 1 & 3 & 1.3 & 1.2 & 92 \\
\hline Consensus of estimators & $\mathbf{0}$ & $\mathbf{1}$ & $\mathbf{3}$ & $\mathbf{1 . 3}$ & $\mathbf{1 . 2}$ & $\mathbf{9 2}$ \\
\hline
\end{tabular}

\section{Deposit density table}

\begin{tabular}{|c|c|c|c|c|}
\hline $\begin{array}{c}\text { Mean of consensus estimates of } \\
\text { undiscovered deposits }\end{array}$ & $\begin{array}{c}\text { Number of } \\
\text { discovered } \\
\text { deposits }\end{array}$ & $\begin{array}{c}\text { Total number of } \\
\text { deposits }\end{array}$ & ${\text { Area, } \mathbf{~ k m}^{2}}^{\mathbf{2}}$ & $\begin{array}{c}\text { Deposit density, number of } \\
\text { deposits/100,000km }\end{array}$ \\
\hline $\mathbf{1 . 3}$ & 0 & 1.3 & 63,233 & \\
\hline
\end{tabular}




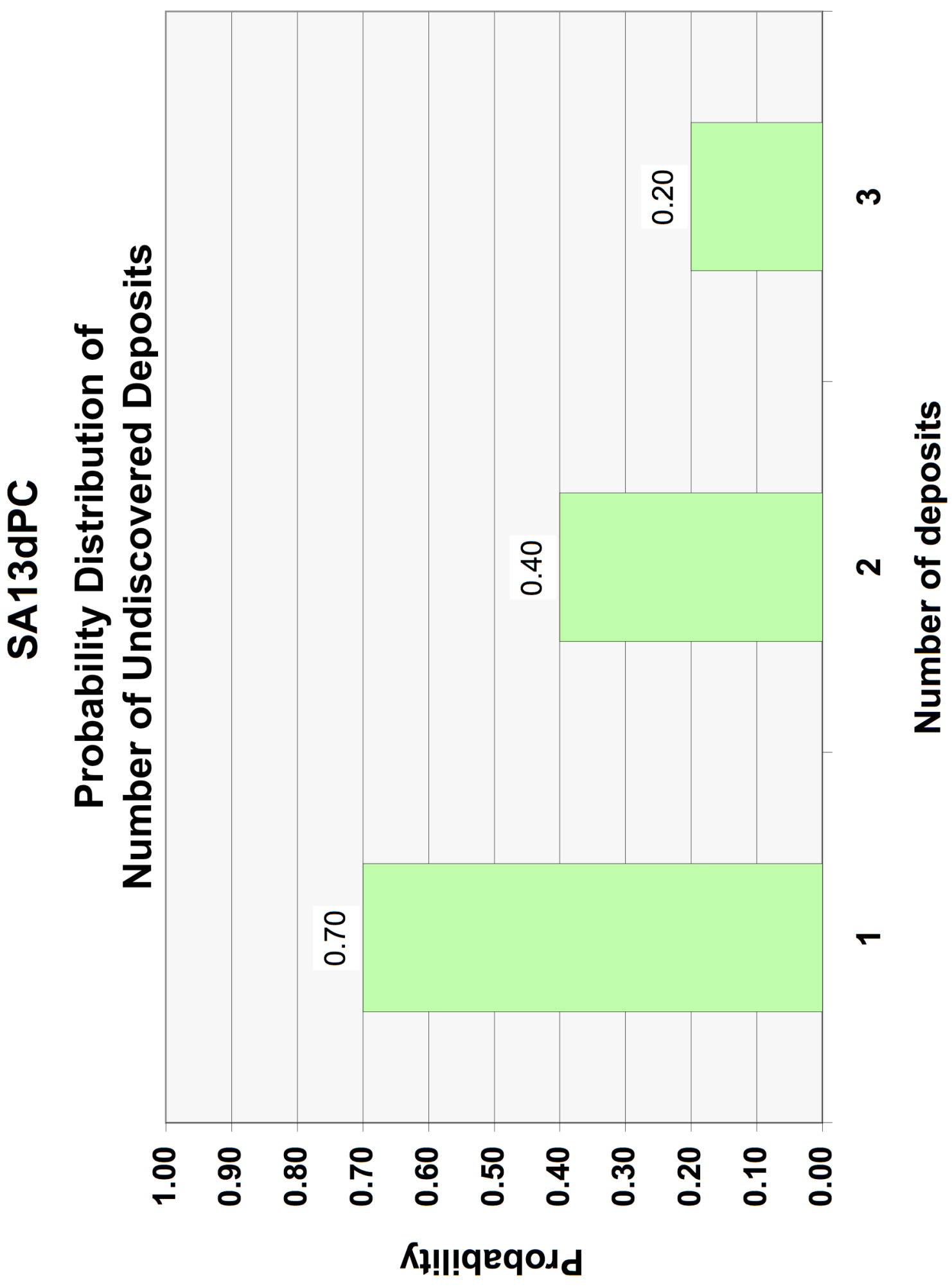




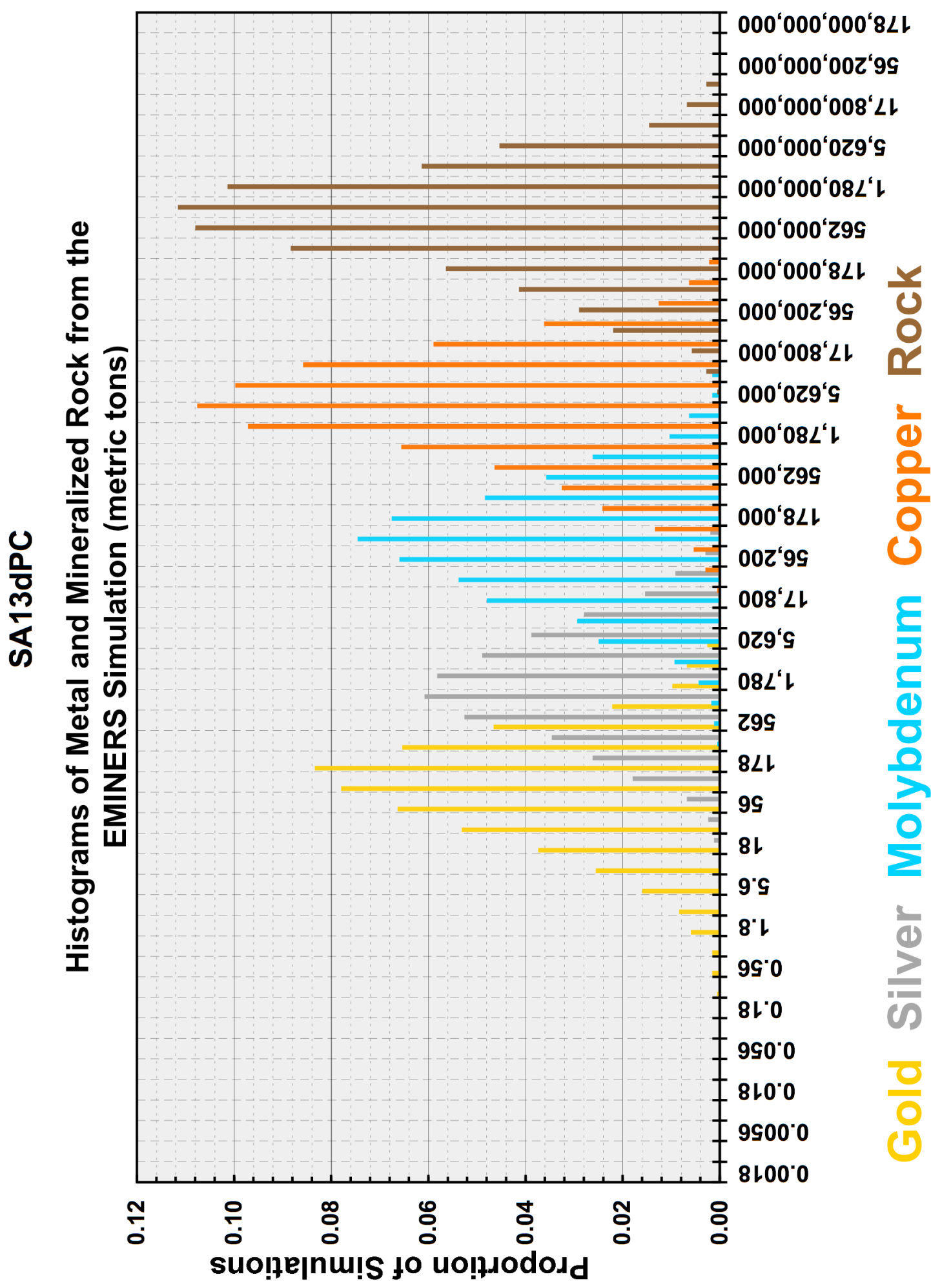









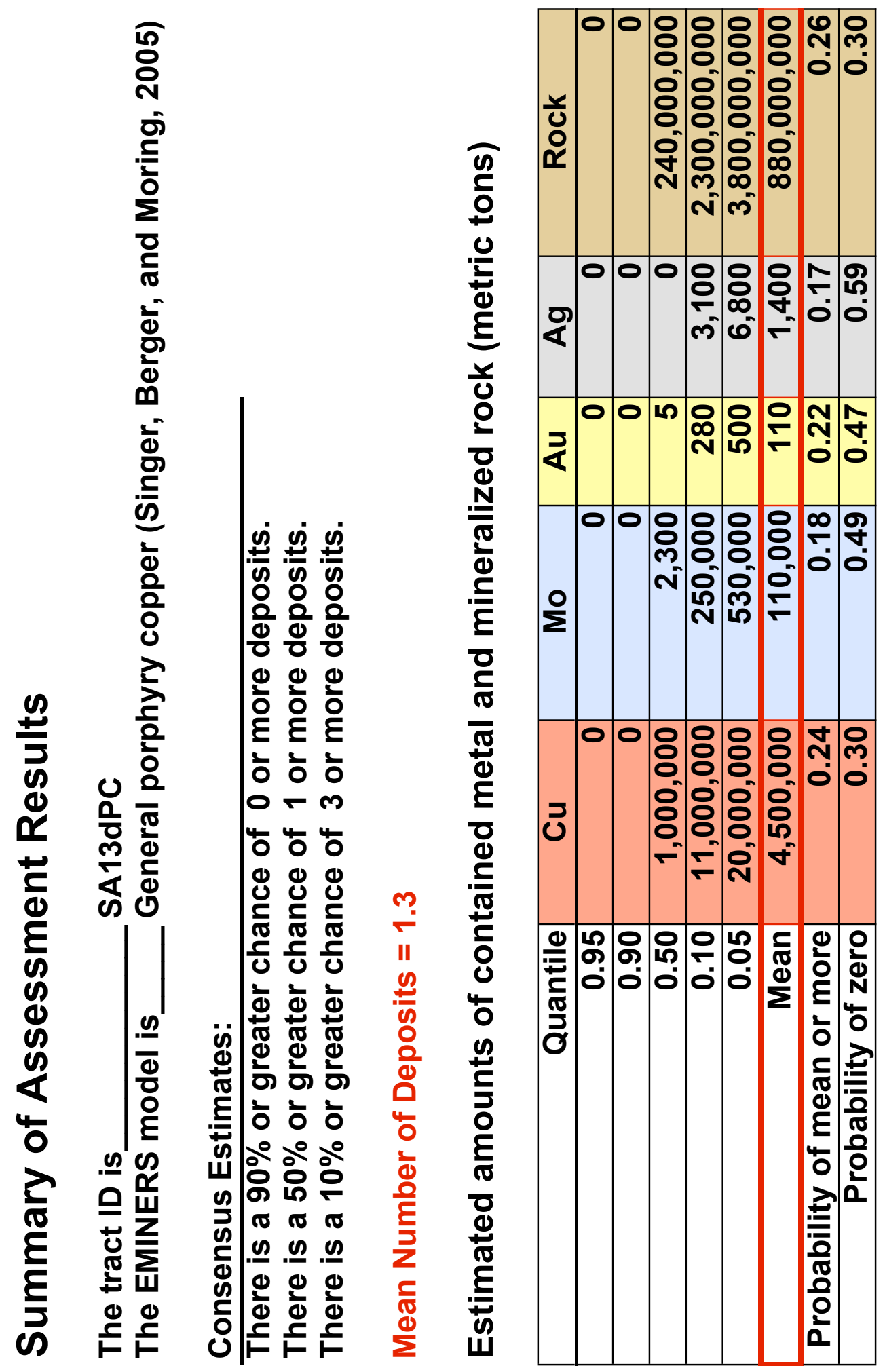




\section{Rationale for tract delineation}

This tract is defined by the distribution of Miocene (6-18 Ma) calc-alkalic granodiorite, diorite, and tonalite plutons and by the distribution of volcanic and other country rocks and cover rocks within or beneath which such plutons are expected to occur within $1 \mathrm{~km}$ of the surface. These permissive plutons include a number of batholiths and formed at about the same time and apparently as a part of the subduction event that also formed the permissive Miocene-Pliocene plutons in the three contiguous tracts SA13aPC, SA13bPC, and SA13cPC to the north. Tract SA13dPC is more deeply eroded than the three northern tracts and erosion appears to be deepest south of Latitude $38-39^{\circ} \mathrm{S}$ where the tract is associated with the Liquiñe-Ofqui fault system, which is an important regional fault system, especially in the region $39-46^{\circ} \mathrm{S}$. The batholiths are reasonably well exposed, especially south of Latitude $38-39^{\circ} \mathrm{S}$, but are not highly fractured. Approximately 40 percent of the tract is covered by younger volcanic rocks and glacial sediments.

The tract boundaries were drawn generally to follow the outcrop pattern of the permissive Miocene plutons, including any intrusions into the wall rock and any evidence of hydrothermal alteration that might indicate the presence of unexposed plutons. The tract boundaries should include vent facies rocks but exclude solely volcaniclastic or alluvial facies equivalents. The tract includes the unit $\mathrm{Mg}$ on the geological map of Chile (Servicio Nacional de Geología y Minería, 2002) and T2ap on the Metallogenic map of South America (Zappettini, 2005). Recent detailed geologic mapping and geochemistry indicates the Miocene tectonics between $35^{\circ}$ and $39^{\circ}$ evolved from a steep subduction zone to a transient shallow zone (Kay and Ramos, 2006).

\section{Rationale for model choice}

Because the tract contains no discovered deposits, and there was no reason to reject the general porphyry copper deposit model (Singer, Berger, and Moring, 2005), this model was used to represent the undiscovered deposits. In addition, the geology, geochemistry, ages, and general geotectonic setting of deposits and prospects in the contiguous northern tracts are typical of deposits in the general model.

\section{Deposits and prospects}

Tract SA13dPC does not contain any discovered porphyry copper deposits or prospects. However, there are scattered copper occurrences that might be the result of porphyry-copper-forming processes that once operated in the tract.

\section{Exploration history}

Exposed permissive rocks in tract SA13dPC are moderately explored and are better explored than those in tracts SA13aPC-SA13cPC. Many companies have explored these rocks in the tract but no large alteration systems have been found. Regional aeromagnetic and geochemical surveys have been conducted in the area bounded by latitudes $41-44^{\circ} \mathrm{S}$.

\section{Rationale for numerical estimate}

Analogies with numbers of deposits known in similar areas that team members have studied elsewhere were used as a basis for estimating the number of undiscovered porphyry copper deposits in the tract. Evidence considered by the estimating team suggests that the tract is unlikely to contain many undiscovered deposits. Although the tract is large and approximately 60 percent of its area consists of exposed permissive host-rock plutons and their older country rocks, moderate exploration by many companies has not discovered a single deposit or prospect. The team believes that although more extensive and intensive exploration might yet discover a deposit in exposed permissive rocks, such 
discoveries are more likely beneath the approximately 40 percent of the tract covered by younger rocks and sediments. Conversely, the level of erosion of permissive rocks is relatively deep, and while probably not deep enough to remove all of the porphyry copper deposits that may have formed in the tract, it probably is deep enough to have removed most of them. The paucity of fracturing in the batholiths suggests that at this level these rocks were relatively closed to the generation of the kinds of hydrothermal systems necessary to form porphyry copper deposits.

\section{Expected distribution of undiscovered deposits}

Based on knowledge and information available to the team at the time of tract delineation, the probability of occurrence of an undiscovered deposit is believed to be reasonably uniform throughout the tract, except: (1) beneath areas of younger cover rocks where the probability may be slightly higher because little or no exploration is known there, and (2) south of latitude $38-39^{\circ} \mathrm{S}$ where erosion is deeper and the probability is likely to be lower.

\section{References cited}

Kay, S.M., and Ramos, V.A., eds., 2006, Evolution of an Andean margin: A tectonic and magmatic view from the Andes to the Nequén Basin $\left(35^{\circ}-39^{\circ} \mathrm{S}\right.$ lat): The Geological Society of America, Special Paper 407, Boulder, Colorado, 359 p.

Servicio Nacional de Geología y Minería, 2002, Mapa geologico de Chile, Escala 1:1,000,000.

Singer, D.A., Berger, V.I., and Moring, B.C., 2005, Porphyry copper deposits of the world-Database, map, and grade and tonnage models: U.S. Geological Survey Open-file Report 2005-1060, http://pubs.usgs.gov/of/2005/1060/)

Zappettini, E.O., 2005, Metallogenic map of South America: Anales 44, Instituto de Geología y Recursos Minerales, Servicio Geológico Minero Argentino, Scale 1:5,000,000 and explanatory text. Buenos Aires. 
TRACT SA14aPC

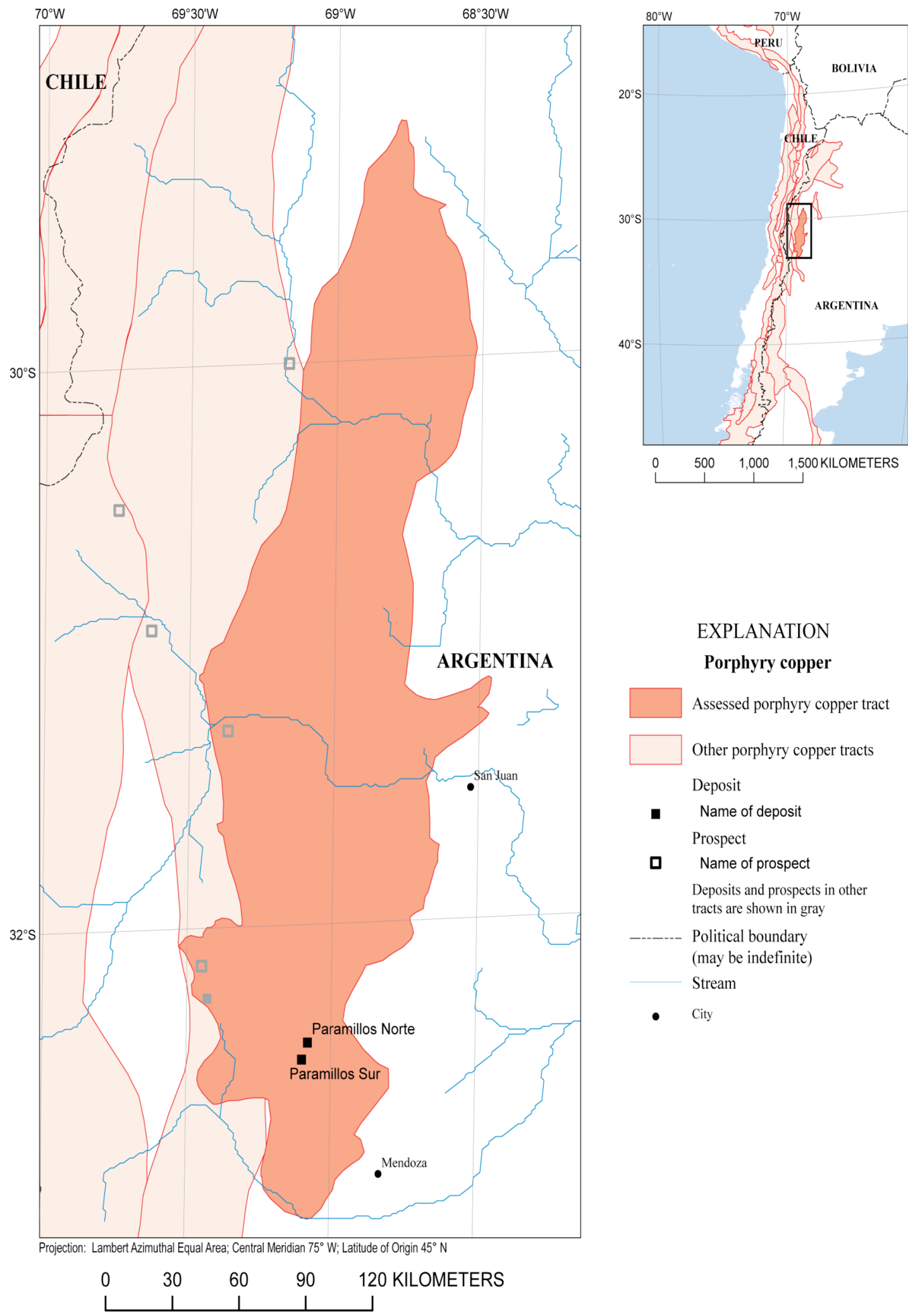




\section{Estimated Undiscovered Porphyry Copper Resources in Tract SA14aPC- Argentina}

Charles G. Cunningham, ${ }^{1}$ Eduardo 0. Zappettini, ${ }^{2}$ Waldo Vivallo S., ${ }^{3}$ Carlos Mario Celada, ${ }^{4}$ Jorge Quispe ${ }^{5}$ Donald A. Singer, ${ }^{1}$ Joseph A Briskey, ${ }^{1}$ David M. Sutphin, ${ }^{1}$ Mariano Gajardo M., ${ }^{3}$ Alejandro Diaz, ${ }^{3}$ Carlos Portigliati, ${ }^{3}$ Vladimir I. Berger, ${ }^{1}$ Rodrigo Carrasco, ${ }^{3}$ and Klaus J. Schulz ${ }^{1}$

'USA-U.S. Geological Survey (USGS)

${ }^{2}$ Argentina - Instituto de Geología y Recursos Minerales (SEGEMAR)

${ }^{3}$ Chile-Servicio Nacional de Geología y Minería (SERNAGEOMIN)
${ }^{4}$ Colombia - Instituto Colombiano de Geología y Minería (INGEOMINAS)

${ }^{5}$ Peru-Instituto Geológico Minero y Metalúrgico (INGEMMET)

\begin{tabular}{|l|l|}
\hline Deposit type assessed: Porphyry Copper & $\begin{array}{l}\text { Model: General porphyry copper deposit model } \\
\text { (Singer, Berger, and Moring, 2005) }\end{array}$ \\
\hline Tract name: Argentina Miocene Paramillos & Countries: Argentina \\
\hline Tract ID: SA14aPC & Region: South America \\
\hline Date of assessment: May 16-18, 2005 & Date of last revision: June 16, 2006 \\
\hline Assessment depth: 1 km & Regional coordinator: Charles G. Cunningham \\
\hline Assessment team leader: Joseph A Briskey & Estimators: Charles G. Cunningham, Klaus J. Schulz, Joseph A Briskey, and Eduardo O. Zappettini. \\
\hline
\end{tabular}

Table of estimated numbers of undiscovered deposits by quantile. Also showing calculated mean $(m)$, standard deviation $(s)$, and coefficient of variation in percent $(C v \%)$. Sorted by mean.

\begin{tabular}{|c|c|c|c|c|c|c|}
\hline Estimators & 90 & 50 & 10 & $m$ & $s$ & Cv\% \\
\hline Consensus of estimators & 2 & 4 & 13 & 6.0 & 4.2 & 70 \\
\hline
\end{tabular}

\section{Deposit density table}

\begin{tabular}{|c|c|c|c|c|}
\hline $\begin{array}{c}\text { Mean of consensus estimates of } \\
\text { undiscovered deposits }\end{array}$ & $\begin{array}{c}\text { Number of } \\
\text { discovered } \\
\text { deposits }\end{array}$ & $\begin{array}{c}\text { Total number of } \\
\text { deposits }\end{array}$ & Area, $\mathbf{~ k m}^{\mathbf{2}}$ & $\begin{array}{c}\text { Deposit density, number of } \\
\text { deposits/100,000 }\end{array}$ \\
\hline $\mathbf{6 . 0}$ & 2 & 8 & 21,721 & \\
\hline
\end{tabular}




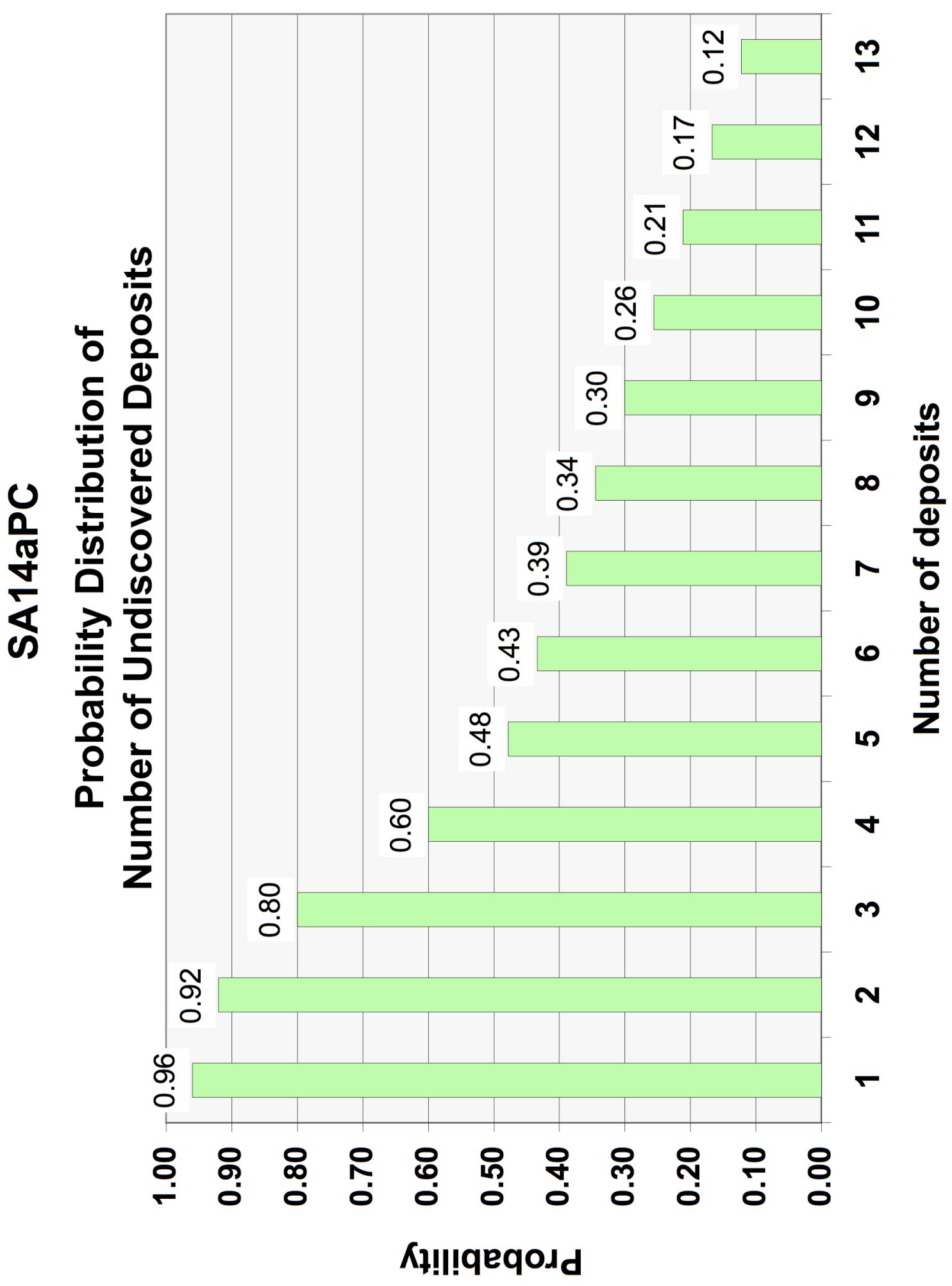




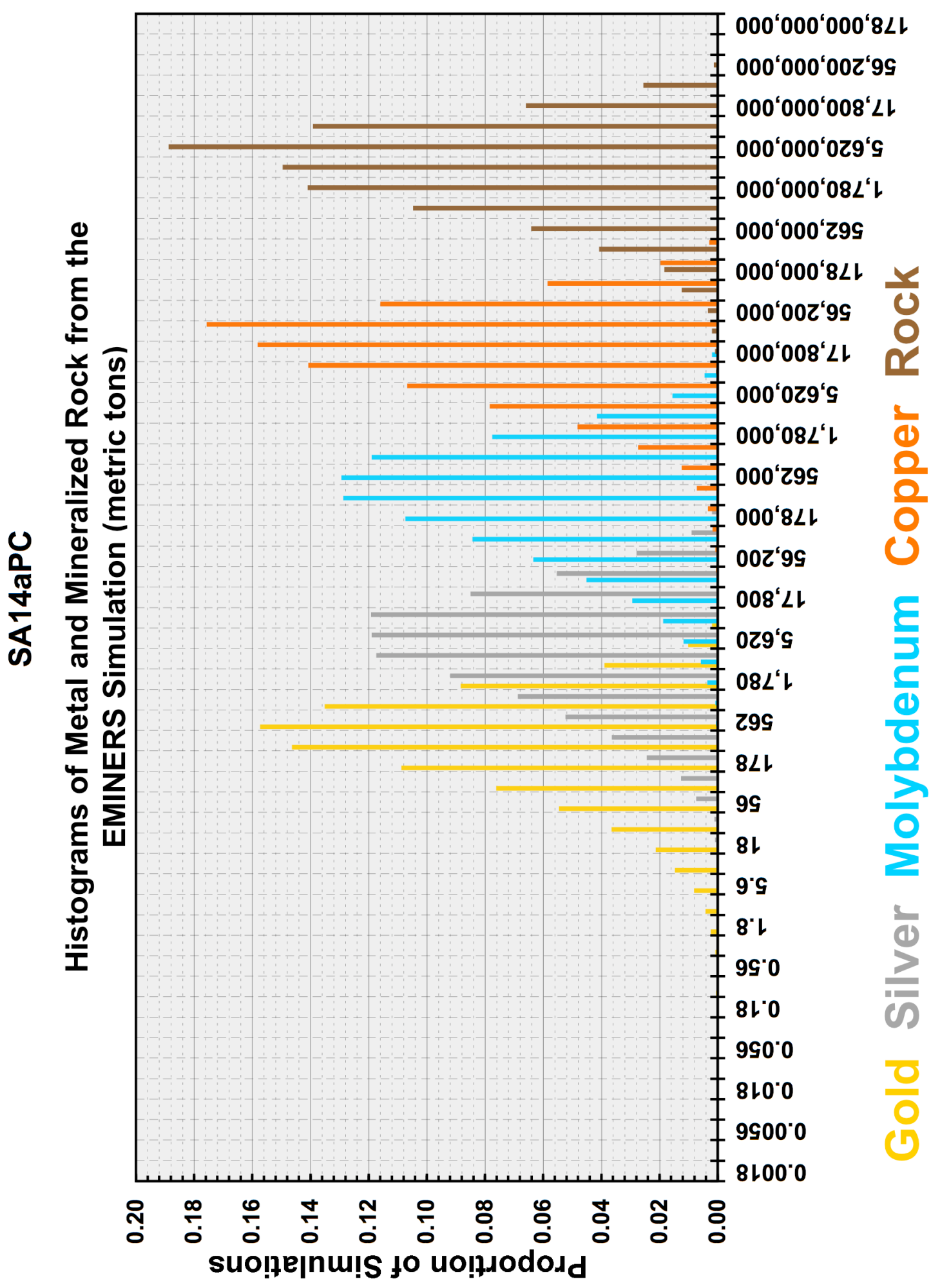




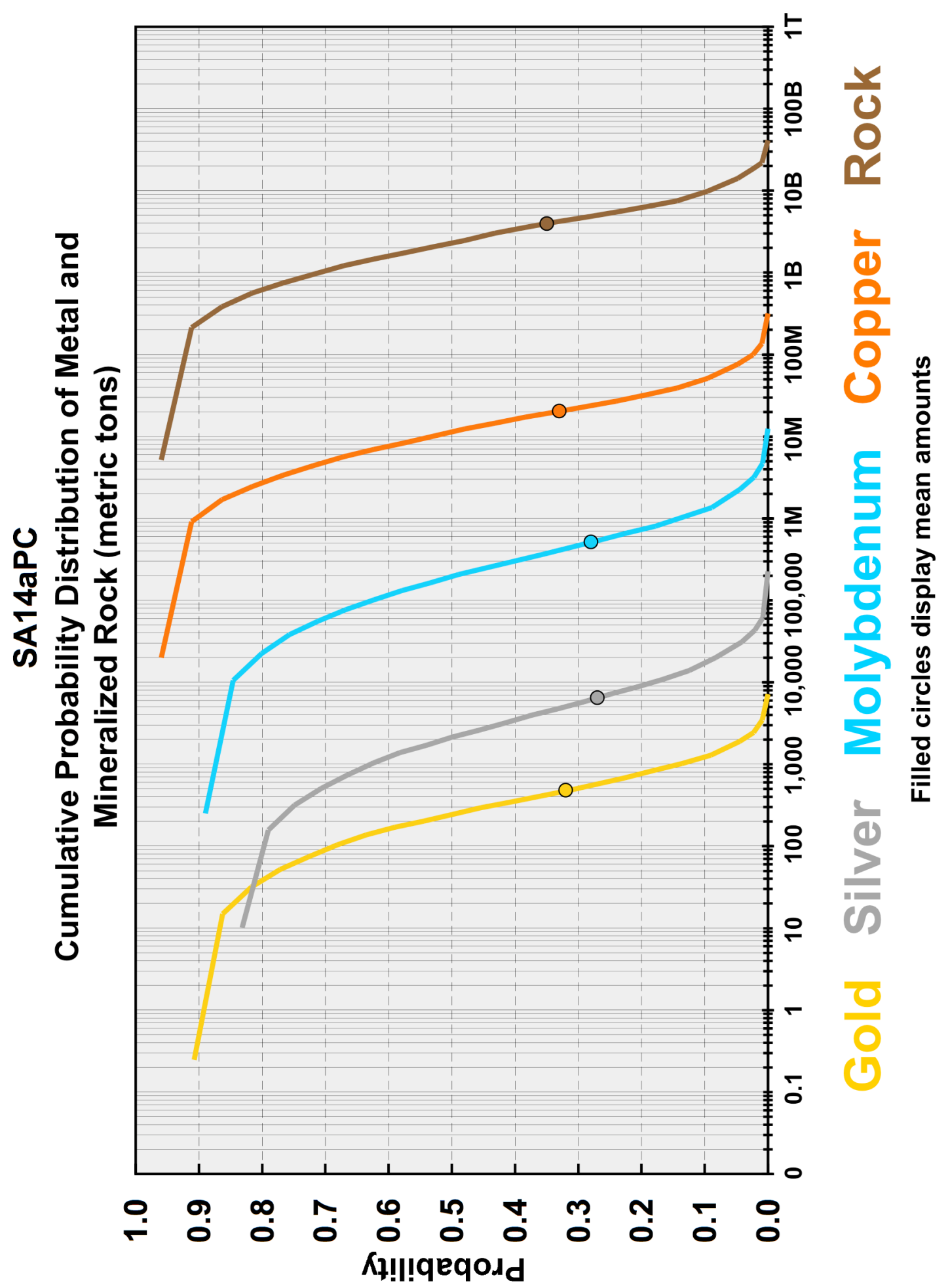




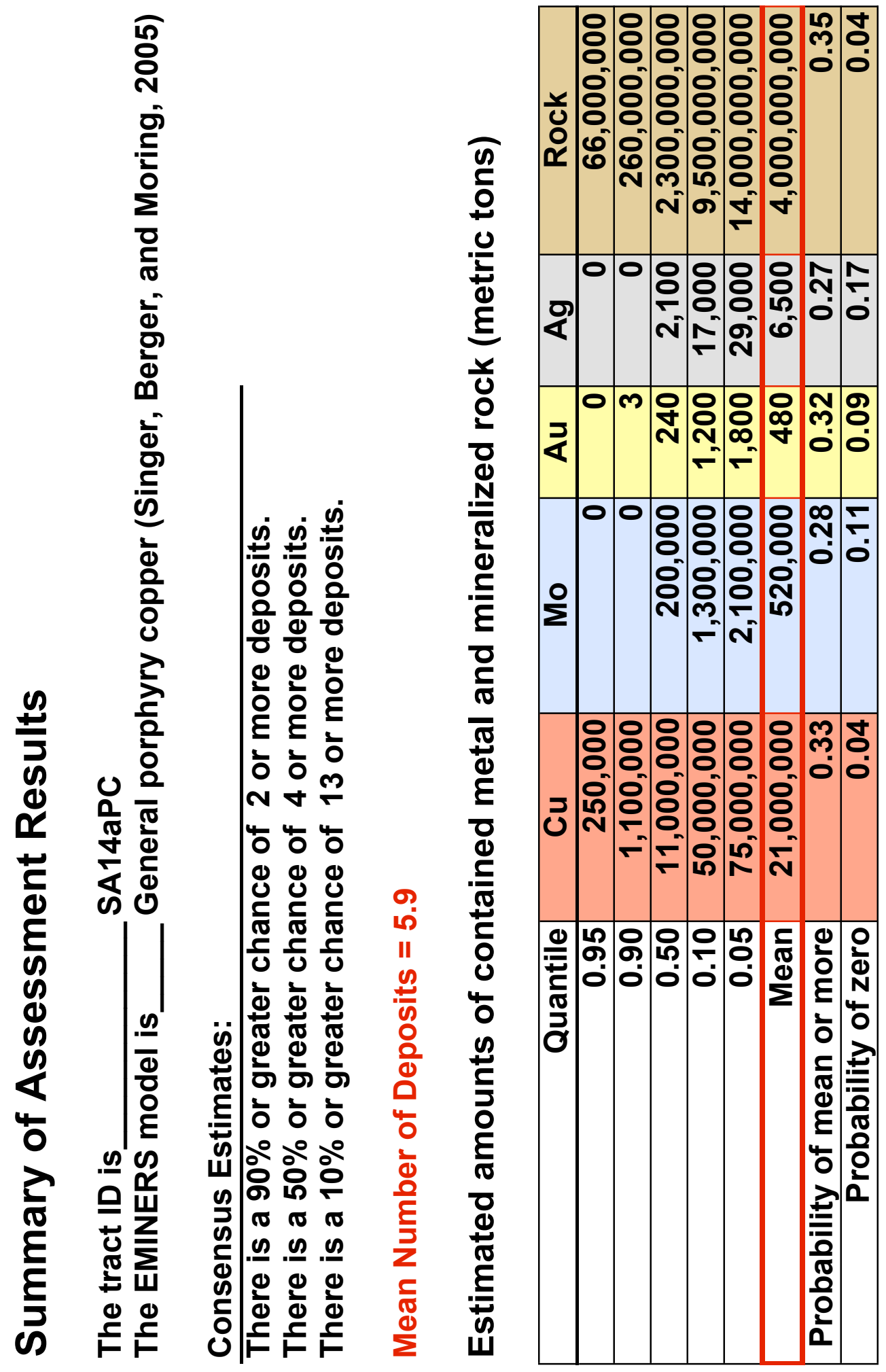




\section{Rationale for tract delineation}

This tract is defined by the distribution of mainly late Miocene to early Pliocene, mostly calcalkalic plutons and by the distribution of volcanic and other country rocks and cover rocks within or beneath which such plutons are expected to occur within $1 \mathrm{~km}$ of the surface. The plutons are mostly too small to differentiate at million scale and intrude folded and intensely thrust faulted Paleozoic country rocks. The tract is one of a group of four tracts (SA14a,b,c,dPC) of the same age that as a group trend northeasterly at an angle to the north-south trend of other Andean tracts. Basement country rocks are mostly thick Ordovician limestone. About 30 percent of the tract is covered by younger rocks and sediments.

\section{Rationale for model choice}

The size and grades of the two discovered porphyry copper deposits in the tract are not significantly different (table 3 ) from the general porphyry copper deposit model (Singer, Berger, and Moring, 2005), which therefore was used to represent the undiscovered deposits. Moreover, the mineralogy, structure, and alteration of these deposits is typical of deposits in the general model.

\section{Deposits and prospects}

The tract contains two discovered porphyry copper deposits, Paramillos Norte and Paramillos Sur, both with dates of $14 \mathrm{Ma}$. Sources of information about the geology of the tract and its mineral deposits include in Long (1995), Carrasquero (1999), Lavandaio and Fusari (1999), and Romani (1999).

\section{Exploration history}

Although a geochemical survey was conducted in the tract by the United Nations, the tract is not well explored overall.

\section{Rationale for numerical estimate}

The estimating team decided that the most useful way to begin discussions leading to numerical estimates for this tract was with estimates suggested by the porphyry copper deposit density model of Singer and others (2005). Numbers of undiscovered deposits suggested by the model at the $90^{\text {th }}, 50^{\text {th }}$, and $10^{\text {th }}$ percentiles were evaluated, discussed, modified, and remodified iteratively by the group in relation to their collective knowledge of, and available information about, the mineral resource geology and exploration history for the tract. This process continued until consensus estimates were achieved for the tract that were satisfactory to all members of the group. Although the tract is relatively small, it is poorly explored. Hence, the discovery of two porphyry copper deposits at this early stage of exploration suggests that a number of undiscovered deposits are likely to exist. In addition, the tract is not deeply eroded and any undiscovered deposits are likely to be preserved.

\section{Expected distribution of undiscovered deposits}

The tract encloses an area of geology where the probability of occurrence of undiscovered deposits was expected to be reasonably uniform based on knowledge and information available to the team at the time of tract delineation. Because the tract is not well explored, the estimating team judged that both exposed and covered permissive rocks have similar probabilities. 


\section{References cited}

Carrasquero, S.I., 1999, Porphyry-type and epithermal ore deposits in the Paramillos de Uspallata district, Mendoza, Argentina, in Stanley, C.J., et al., eds., Mineral deposits: processes to processing, v. 2: Proceedings of the Fifth Biennial SGA Meeting, Balkema, Rotterdam, p. 487-490.

Lavandaio, E., and Fusari, C., 1999, Distrito polimetalico Mendoza Norte, Mendoza, in Zappettini, E.O., ed., Recursos minerales de la Republica Argentina: Instituto de Geología y Recursos Minerales SEGEMAR, Anales 35, Buenos Aires, p. 1705-1716.

Long, K.R., 1995, Production and reserves of Cordilleran (Alaska to Chile) porphyry copper deposits, in Pierce, F.W., and Bolm, J.G., eds., Porphyry copper deposits of the American Cordillera: Tucson, Arizona Geological Society Digest 20, p. 35-68.

Romani, R.R., 1999, El porfiro cuprifero Paramillos Sur, Mendoza, in Zappettini, E.O., ed., Recursos minerales de la Republica Argentina: Instituto de Geología y Recursos Minerales SEGEMAR, Anales 35, Buenos Aires, p. 1513-1523.

Singer, D.A., Berger, V.I., Menzie, W.D., and Berger, B.R., 2005, Porphyry copper density: Economic Geology, v. 100, no. 3, p. 491-514.

Singer, D.A., Berger, V.I., and Moring, B.C., 2005, Porphyry copper deposits of the world-Database, map, and grade and tonnage models: U.S. Geological Survey Open-file Report 2005-1060, http://pubs.usgs.gov/of/2005/1060/) 


\section{TRACT SA14bPC}
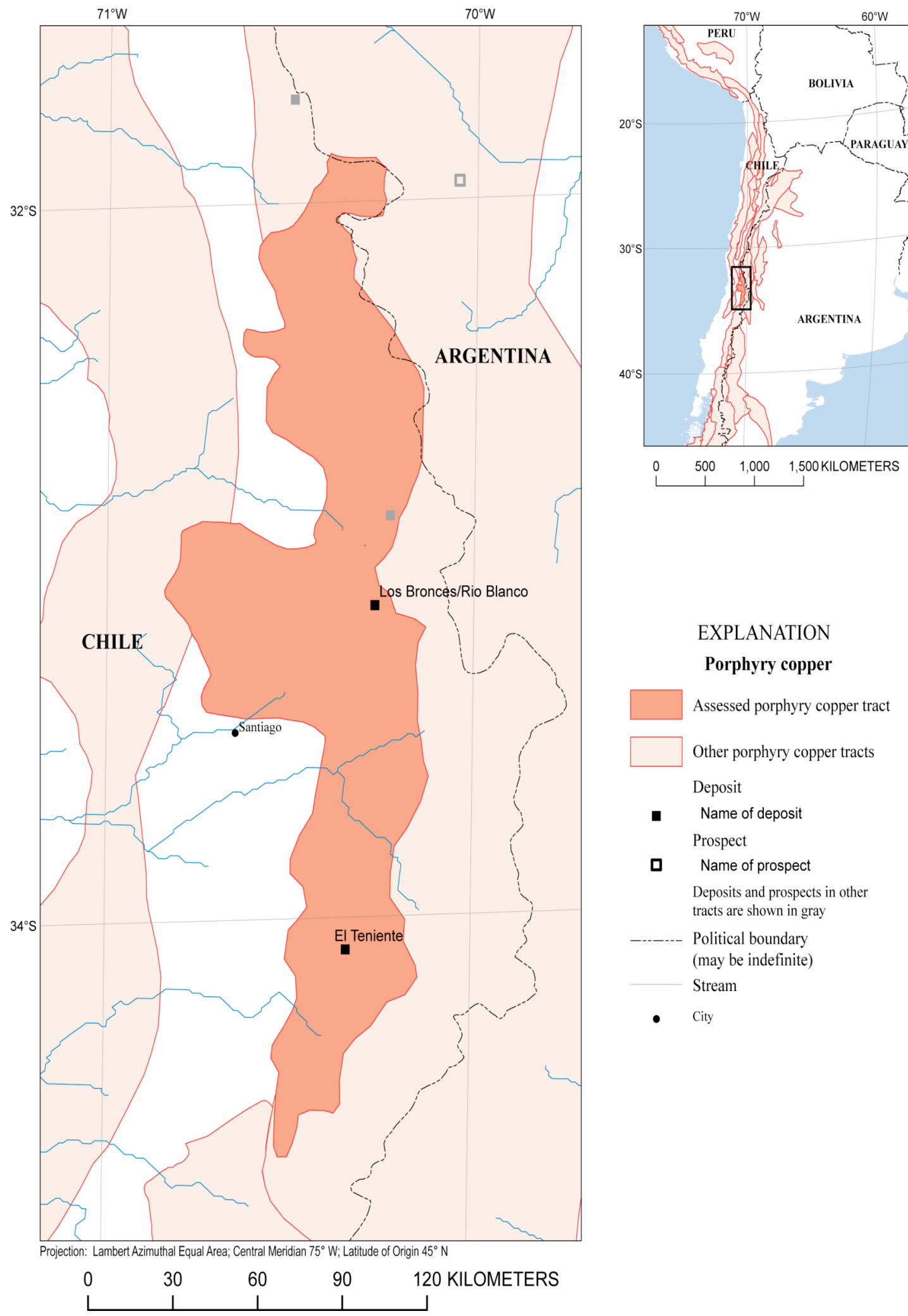

\section{EXPLANATION}

Porphyry copper

Assessed porphyry copper tract

Other porphyry copper tracts

Deposit

- Name of deposit

Prospect

口 Name of prospect

Deposits and prospects in other tracts are shown in gray

Political boundary

(may be indefinite)

Stream

- $\quad$ City 


\section{Estimated Undiscovered Porphyry Copper Resources in Tract SA14bPC- Chile}

Charles G. Cunningham, ${ }^{1}$ Eduardo 0. Zappettini, ${ }^{2}$ Waldo Vivallo S., ${ }^{3}$ Carlos Mario Celada ${ }^{4}$ Jorge Quispe ${ }^{5}$ Donald A. Singer, ${ }^{1}$ Joseph A Briskey, ${ }^{1}$ David M. Sutphin, ${ }^{1}$ Mariano Gajardo M., ${ }^{3}$ Alejandro Diaz, ${ }^{3}$ Carlos Portigliati, ${ }^{3}$ Vladimir I. Berger, ${ }^{1}$ Rodrigo Carrasco $0,{ }^{3}$ and Klaus J. Schulz ${ }^{1}$

'USA-U.S. Geological Survey (USGS)

${ }^{2}$ Argentina - Instituto de Geología y Recursos Minerales (SEGEMAR)

${ }^{3}$ Chile-Servicio Nacional de Geología y Minería (SERNAGEOMIN)
${ }^{4}$ Colombia-Instituto Colombiano de Geología y Minería (INGEOMINAS)

${ }^{5}$ Peru-Instituto Geológico Minero y Metalúrgico (INGEMMET)

\begin{tabular}{|l|l|}
\hline Deposit type assessed: Porphyry Copper & $\begin{array}{l}\text { Model: Giant porphyry copper deposit model } \\
\text { (Singer, Briskey, and Cunningham, Appendix I) }\end{array}$ \\
\hline Tract name: Chile Miocene-Pliocene El Teniente & Countries: Chile \\
\hline Tract ID: SA14bPC & Region: South America \\
\hline Date of assessment: May 16-18, 2005 & Date of last revision: \\
\hline Assessment depth: 1 km & Regional coordinator: Charles G. Cunningham \\
\hline Assessment team leader: Joseph A Briskey & $\begin{array}{l}\text { Estimators: Alvaro Puig Godoy, Waldo Vivallo S., Charles G. Cunningham, Joseph A Briskey, Klaus J. } \\
\text { Schulz, Alejandro Diaz, and Juan Pablo Lacassie. }\end{array}$ \\
\hline
\end{tabular}

Table of estimated numbers of undiscovered deposits by quantile. Also showing calculated mean $(m)$, standard deviation $(s)$, and coefficient of variation in percent $(C v \%)$. Sorted by mean.

\begin{tabular}{|c|c|c|c|c|c|c|}
\hline Estimators & 90 & 50 & 10 & $m$ & $s$ & Cv\% \\
\hline Consensus of estimators & 1 & 2 & 3 & 1.9 & 0.84 & 44 \\
\hline
\end{tabular}

\section{Deposit density table}

\begin{tabular}{|c|c|c|c|c|}
\hline $\begin{array}{c}\text { Mean of consensus estimates of } \\
\text { undiscovered deposits }\end{array}$ & $\begin{array}{c}\text { Number of } \\
\text { discovered } \\
\text { deposits }\end{array}$ & $\begin{array}{c}\text { Total number of } \\
\text { deposits }\end{array}$ & Area, $\mathbf{~ k m}^{\mathbf{2}}$ & $\begin{array}{c}\text { Deposit density, number of } \\
\text { deposits/100,000km }\end{array}$ \\
\hline $\mathbf{1 . 9}$ & 2 & 3.9 & 9,284 & 42 \\
\hline
\end{tabular}




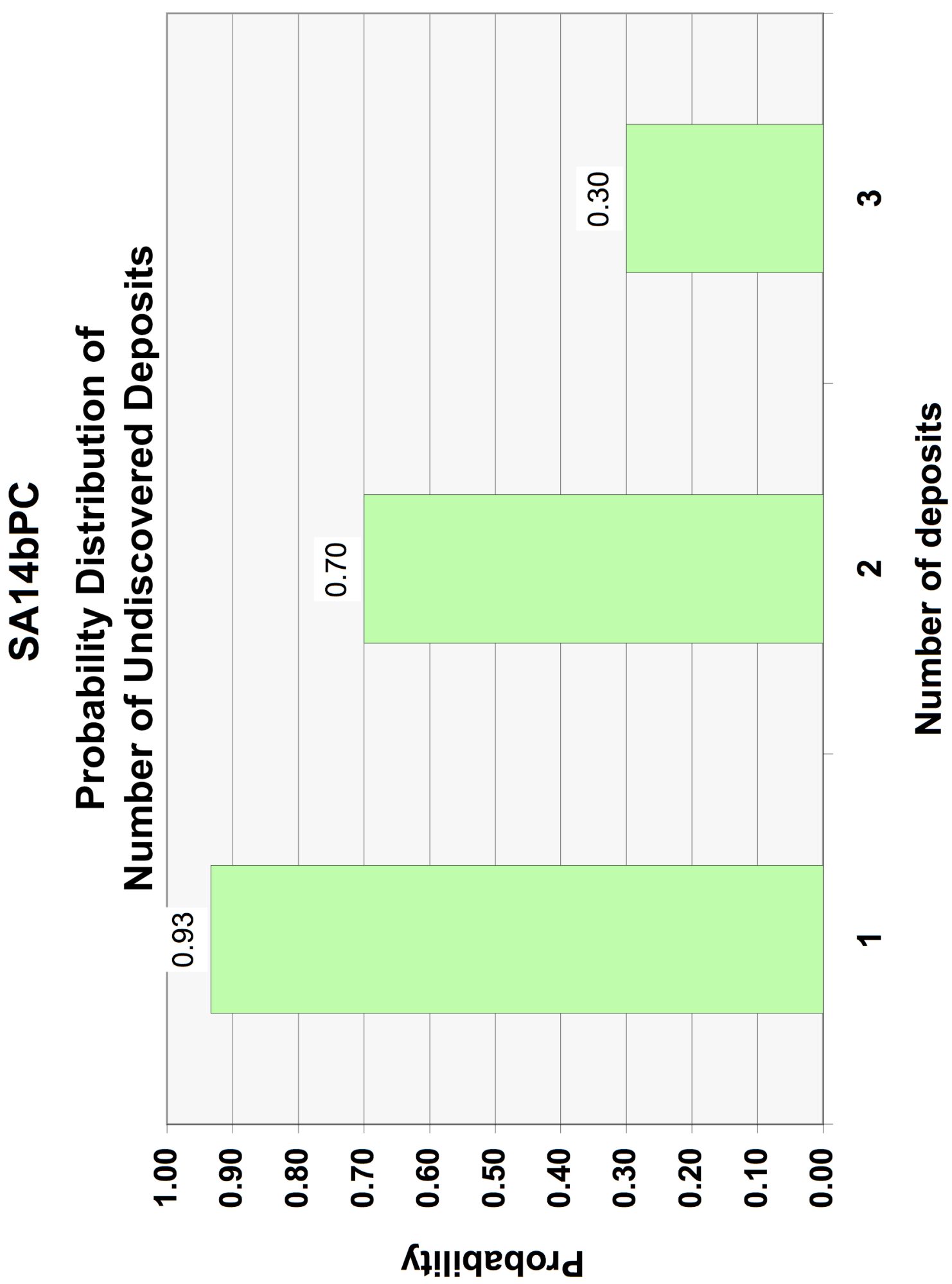




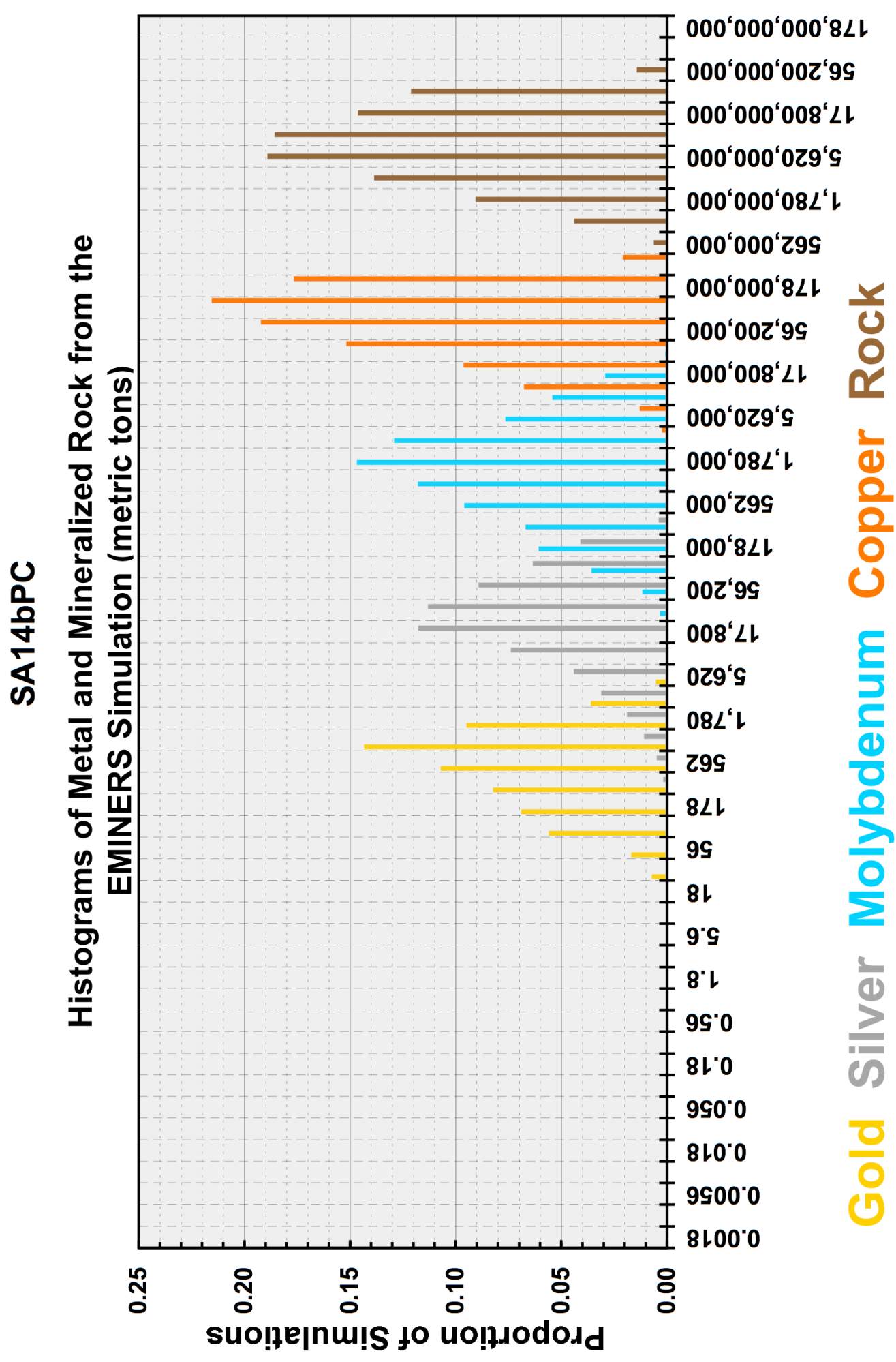




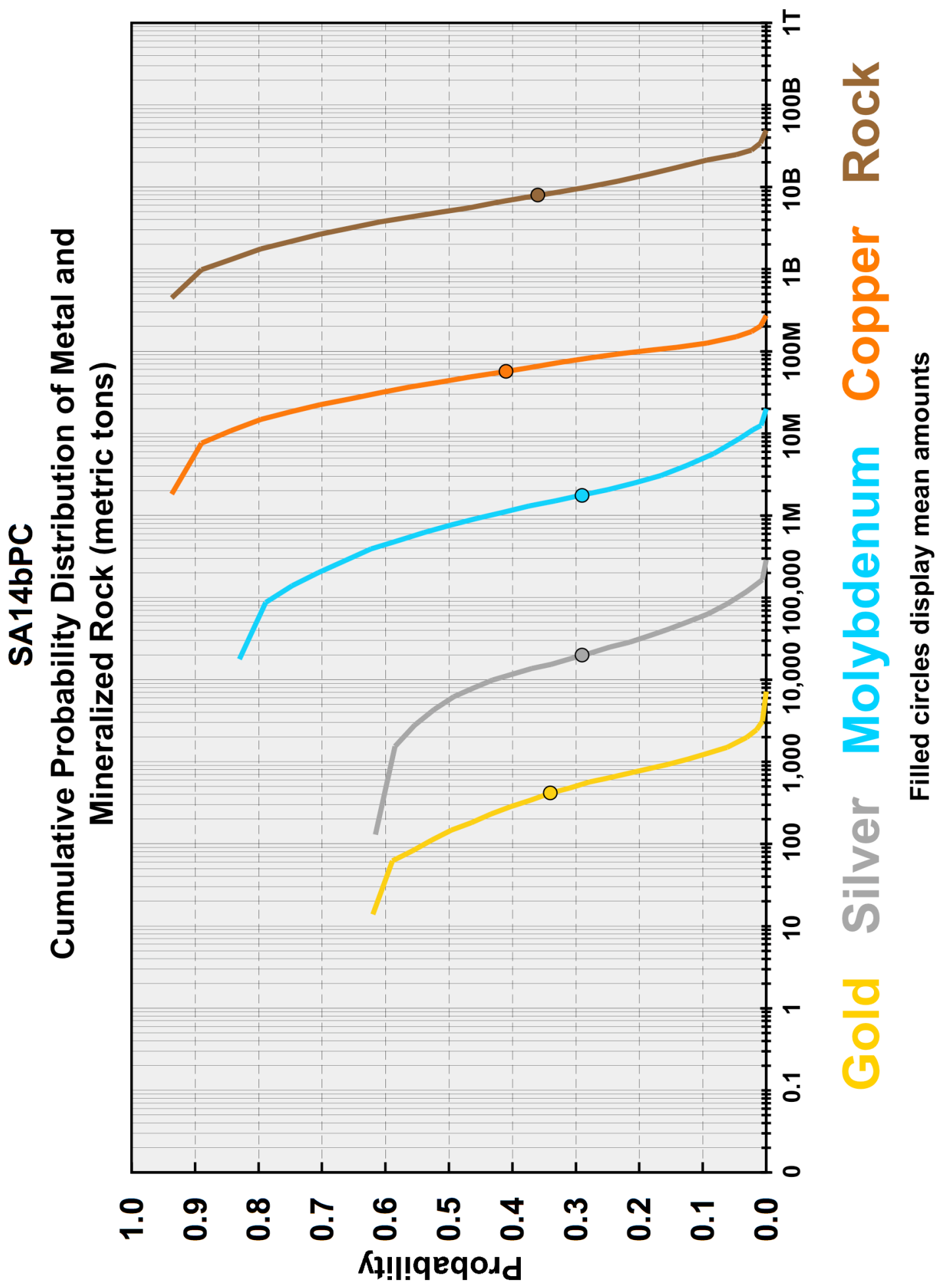




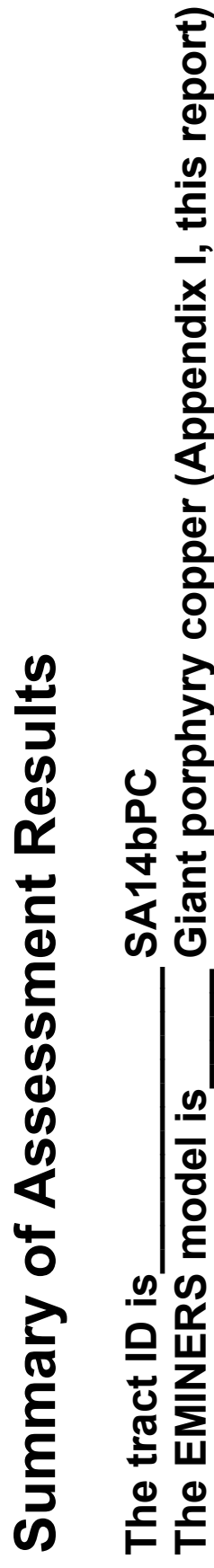

눙
$\frac{0}{\Phi}$
$\frac{0}{2}$

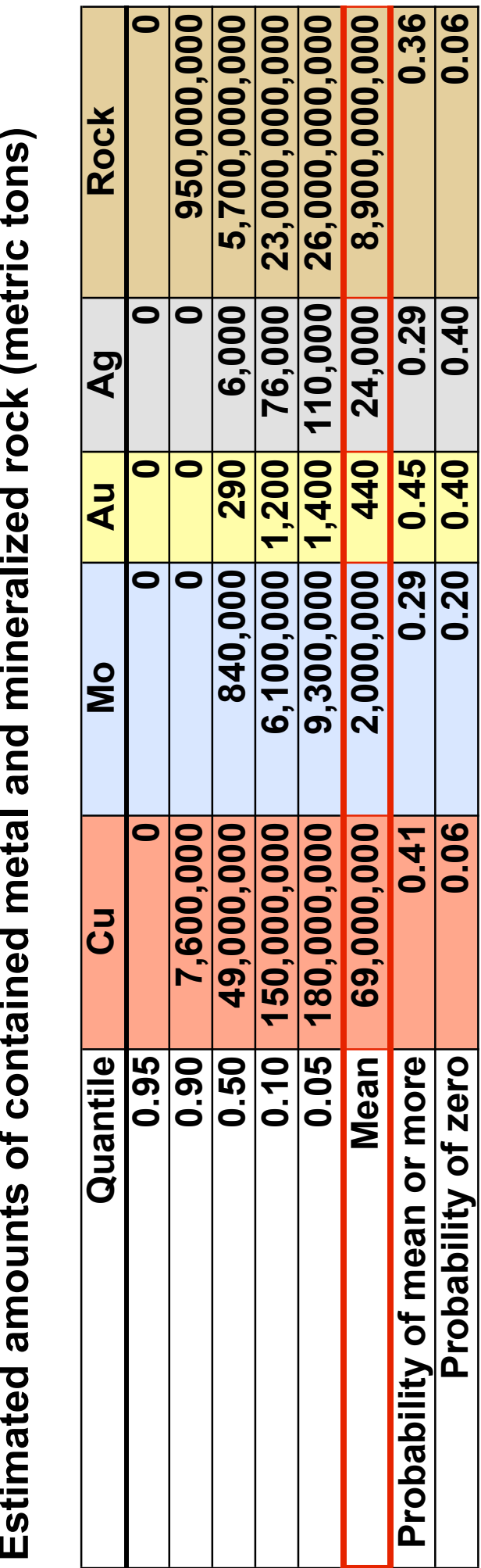




\section{Rationale for tract delineation}

This tract is defined by the distribution of mainly late Miocene to early Pliocene, mostly calcalkalic plutons and by the distribution of volcanic and other country rocks and cover rocks within or beneath which such plutons are expected to occur within $1 \mathrm{~km}$ of the surface. The tract is one of a group of four tracts (SA14a,b,c,dPC) of the same age that as a group trend northeasterly at an angle to the northsouth trend of other Andean tracts. Most surface rocks consist of volcanic-arc lavas, breccias, pyroclastic rocks, and volcanic domes that are coeval to slightly older than the discovered porphyry copper deposits in the tract. The tract is bounded by thrust faults along part of the western margin. The rocks in the tract are well mapped in the vicinity of known deposits but are less well mapped as a whole because of difficult access in this steep terrain. Additional sources of information about the known deposits and their geology include Cannell and others (2005), Deckhart and others (2005), and Skewes and others (2002).

\section{Rationale for model choice}

A $t$-test (table 3 ) of discovered deposits in the tract indicated tonnages are significantly higher than the general model of Singer, Berger, and Moring (2005). A new giant porphyry copper deposit grade and tonnage model (Appendix I) was constructed using deposits in this tract and tract SA10a,bPC and was used to represent the grades and tonnages of undiscovered deposits in this tract.

\section{Deposits and prospects}

The tract hosts two discovered deposits, El Teniente and Los Bronces/Rio Blanco. El Teniente is one of the youngest and largest porphyry copper deposits of the Andes and the world (Maksaev and others, 2004). Both deposits are characterized by the presence of hydrothermal explosion breccias and locally abundant tourmalinization. Because this tract is spatially coincident with tract SA13bPC, there was speculation among some assessment team members that the unusually large average tonnage of these deposits may have resulted during their formation by the incorporation of parts of older deposits like those discovered in tract SA13bPC. Mineralogy, structure, and alteration of the two deposits are typical of porphyry copper deposits in general.

\section{Exploration history}

The mountain range that hosts the El Teniente deposit has been mapped in moderate detail, especially around known mineralized centers. A United Nations geochemical survey covered $80-85 \%$ of the tract.

\section{Rationale for numerical estimate}

The estimating team decided that the most useful way to begin discussions leading to numerical estimates for this tract was with estimates suggested by the porphyry copper deposit density model of Singer and others (2005). Numbers of undiscovered deposits suggested by the model at the $90^{\text {th }}, 50^{\text {th }}$, and $10^{\text {th }}$ percentiles were evaluated, discussed, modified, and remodified iteratively by the group in relation to the their collective knowledge of, and available information about, the mineral resource geology and exploration history for the tract. This process continued until consensus estimates were achieved for the tract that were satisfactory to all members of the group.

The mean of the team's estimate is 1.9 undiscovered deposits. This number is about one third smaller than the mean given by the density model. For a tract this size, the density model gives a mean of about 4.8 undiscovered deposits. Subtracting the 2 discovered deposits would leave a mean of about 2.8 undiscovered deposits. The main reason that the team's estimate is lower is that exploration appears to have been sufficient to have found all exposed deposits. Consequently, and because there are no large 
areas of younger cover, undiscovered deposits are likely to be fewer and to occur deep within older country rocks.

\section{Expected distribution of undiscovered deposits}

Based on knowledge and information available to the team at the time of tract delineation, the probability of occurrence of an undiscovered deposit deep below the surface is believed to be reasonably uniform throughout the tract.

\section{References cited}

Cannell, J.C., Cooke, D.R., Hollings, P., and Stein, H., 2005, Geology, mineralization, alteration, and structural evolution of the El Teniente porphyry $\mathrm{Cu}-\mathrm{Mo}$ deposit: Economic Geology, v. 100, p. 9791003.

Deckhart, K., Clark, A.H., Aguilar A., C., Vargas R., R., Bertens N., A., Mortensen, J.K., and Fanning, M, 2005, Magmatic and hydrothermal chronology of the giant Río Blanco porphyry copper deposit, Central Chile: Implications of an integrated U-Pb and ${ }^{40} \mathrm{Ar} /{ }^{39}$ database, Economic Geology, v. 100, p. 905-934.

Maksaev, Victor, Munizaga, Francisco, McWilliams, Michael, Fanning, Mark, Mathur, Ryan, Ruiz, Joaquin, and Zentilli, Marcos, 2004, New geochronology for El Teniente, Chilean Andes, from U-Pb, ${ }^{40} \mathrm{Ar} /{ }^{39} \mathrm{Ar}$, Re-Os, and fission-track dating: Implications for the evolution of a supergiant porphyry $\mathrm{Cu}-$ Mo deposit: in Sillitoe, R.H., Perelló, Jose, and Vidal, C.E., eds., Andean metallogeny: New discoveries, concepts, and updates: Society of Economic Geologists, Special Publication No. 11, p. 15-54.

Singer, D.A., Berger, V.I., Menzie, W.D., and Berger, B.R., 2005, Porphyry copper density: Economic Geology, v. 100, no. 3, p. 491-514.

Singer, D.A., Berger, V.I., and Moring, B.C., 2005, Porphyry copper deposits of the world-Database, map, and grade and tonnage models: U.S. Geological Survey Open-file Report 2005-1060, http://pubs.usgs.gov/of/2005/1060/)

Skewes, M.A., Arévalo, A.G., Floody, R., Zúniga, P., and Stern, C.R., 2002, The giant El Teniente deposit: Hypogene copper distribution and emplacement: Society of Economic Geologists Special Publication 9, p. 299-332. 
TRACT SA14cPC
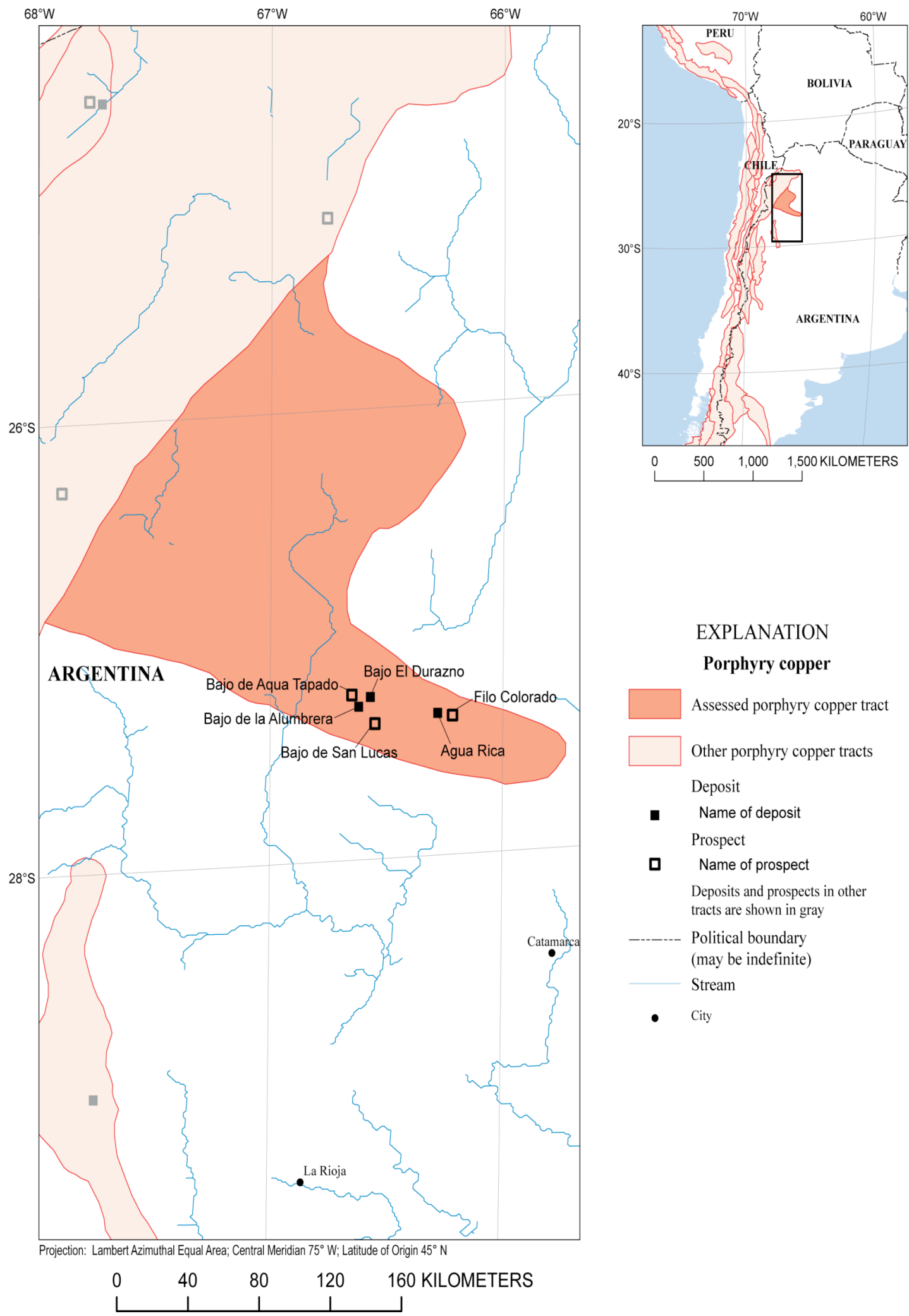

EXPLANATION

Porphyry copper

Assessed porphyry copper tract

Other porphyry copper tracts

Deposit

- Name of deposit

Prospect

口 Name of prospect

Deposits and prospects in other tracts are shown in gray

Political boundary

(may be indefinite)

Stream

- $\quad$ City 


\section{Estimated Undiscovered Porphyry Copper Resources in Tract SA14cPC- Argentina}

Charles G. Cunningham, ${ }^{1}$ Eduardo 0. Zappettini, ${ }^{2}$ Waldo Vivallo S., ${ }^{3}$ Carlos Mario Celada, ${ }^{4}$ Jorge Quispe ${ }^{5}$ Donald A. Singer, ${ }^{1}$ Joseph A Briskey, ${ }^{1}$ David M. Sutphin, ${ }^{1}$ Mariano Gajardo M., ${ }^{3}$ Alejandro Diaz, ${ }^{3}$ Carlos Portigliati, ${ }^{3}$ Vladimir I. Berger, ${ }^{1}$ Rodrigo Carrasco, ${ }^{3}$ and Klaus J. Schulz ${ }^{1}$

'USA-U.S. Geological Survey (USGS)

${ }^{2}$ Argentina - Instituto de Geología y Recursos Minerales (SEGEMAR)

${ }^{3}$ Chile-Servicio Nacional de Geología y Minería (SERNAGEOMIN)
${ }^{4}$ Colombia-Instituto Colombiano de Geología y Minería (INGEOMINAS)

${ }^{5}$ Peru-Instituto Geológico Minero y Metalúrgico (INGEMMET)

\begin{tabular}{|c|c|}
\hline Deposit type assessed: Porphyry Copper & $\begin{array}{l}\text { Model: General porphyry copper deposit model } \\
\text { (Singer, Berger, and Moring, 2005) }\end{array}$ \\
\hline $\begin{array}{l}\text { Tract name: Argentina Miocene-Pliocene } \\
\text { Bajo de la Alumbrera }\end{array}$ & Countries: Argentina \\
\hline Tract ID: SA14cPC & Region: South America \\
\hline Date of assessment: May 16-18, 2005 & Date of last revision: \\
\hline \multicolumn{2}{|l|}{ Assessment depth: $1 \mathrm{~km}$} \\
\hline Assessment team leader: Donald A. Singer & Regional coordinator: Charles G. Cunningham \\
\hline $\begin{array}{l}\text { Estimators: Carlos Mario Celada, Vladimir } \\
\text { Gajardo M., Carlos Portigliati, Alvaro Puig C } \\
\text { Zappettini. }\end{array}$ & $\begin{array}{l}\text { Rodrigo Carrasco, Alejandro Diaz, Mariano } \\
\text { onald A. Singer, Waldo Vivallo S., and Eduardo O }\end{array}$ \\
\hline
\end{tabular}

Table of estimated numbers of undiscovered deposits by quantile. Also showing calculated mean $(m)$, standard deviation $(s)$, and coefficient of variation in percent $(C v \%)$. Sorted by mean.

\begin{tabular}{|l|c|c|c|c|c|c|}
\hline \multicolumn{1}{|c|}{ Estimators } & $\mathbf{9 0}$ & $\mathbf{5 0}$ & $\mathbf{1 0}$ & $\mathbf{m}$ & $\boldsymbol{s}$ & $\mathbf{C v} \%$ \\
\hline Estimator & 1 & 3 & 5 & 2.9 & 1.5 & 52 \\
\hline Estimator & 1 & 3 & 7 & 3.5 & 2.3 & 66 \\
\hline Estimator & 2 & 4 & 6 & 3.9 & 1.5 & 38 \\
\hline Estimator & 2 & 4 & 6 & 3.9 & 1.5 & 38 \\
\hline Estimator & 3 & 4 & 6 & 4.1 & 1.3 & 32 \\
\hline Estimator & 3 & 4 & 8 & 4.7 & 2.1 & 45 \\
\hline Estimator & 3 & 5 & 7 & 4.8 & 1.6 & 33 \\
\hline Consensus of estimators & $\mathbf{3}$ & $\mathbf{5}$ & $\mathbf{8}$ & $\mathbf{5 . 1}$ & $\mathbf{2 . 0}$ & $\mathbf{3 9}$ \\
\hline Estimator & 2 & 5 & 10 & 5.5 & 3.0 & 55 \\
\hline Estimator & 4 & 8 & 12 & 7.7 & 3.0 & 39 \\
\hline Estimator & 5 & 8 & 15 & 8.9 & 3.9 & 44 \\
\hline
\end{tabular}

\section{Deposit density table}

\begin{tabular}{|c|c|c|c|c|}
\hline $\begin{array}{c}\text { Mean of consensus estimates of } \\
\text { undiscovered deposits }\end{array}$ & $\begin{array}{c}\text { Number of } \\
\text { discovered } \\
\text { deposits }\end{array}$ & $\begin{array}{c}\text { Total number of } \\
\text { deposits }\end{array}$ & Area, $\mathbf{~ k m}^{\mathbf{2}}$ & $\begin{array}{c}\text { Deposit density, number of } \\
\text { deposits/100,000 } \mathbf{k m}^{\mathbf{2}}\end{array}$ \\
\hline $\mathbf{5 . 1}$ & 3 & 8.1 & 24,048 & 34 \\
\hline
\end{tabular}




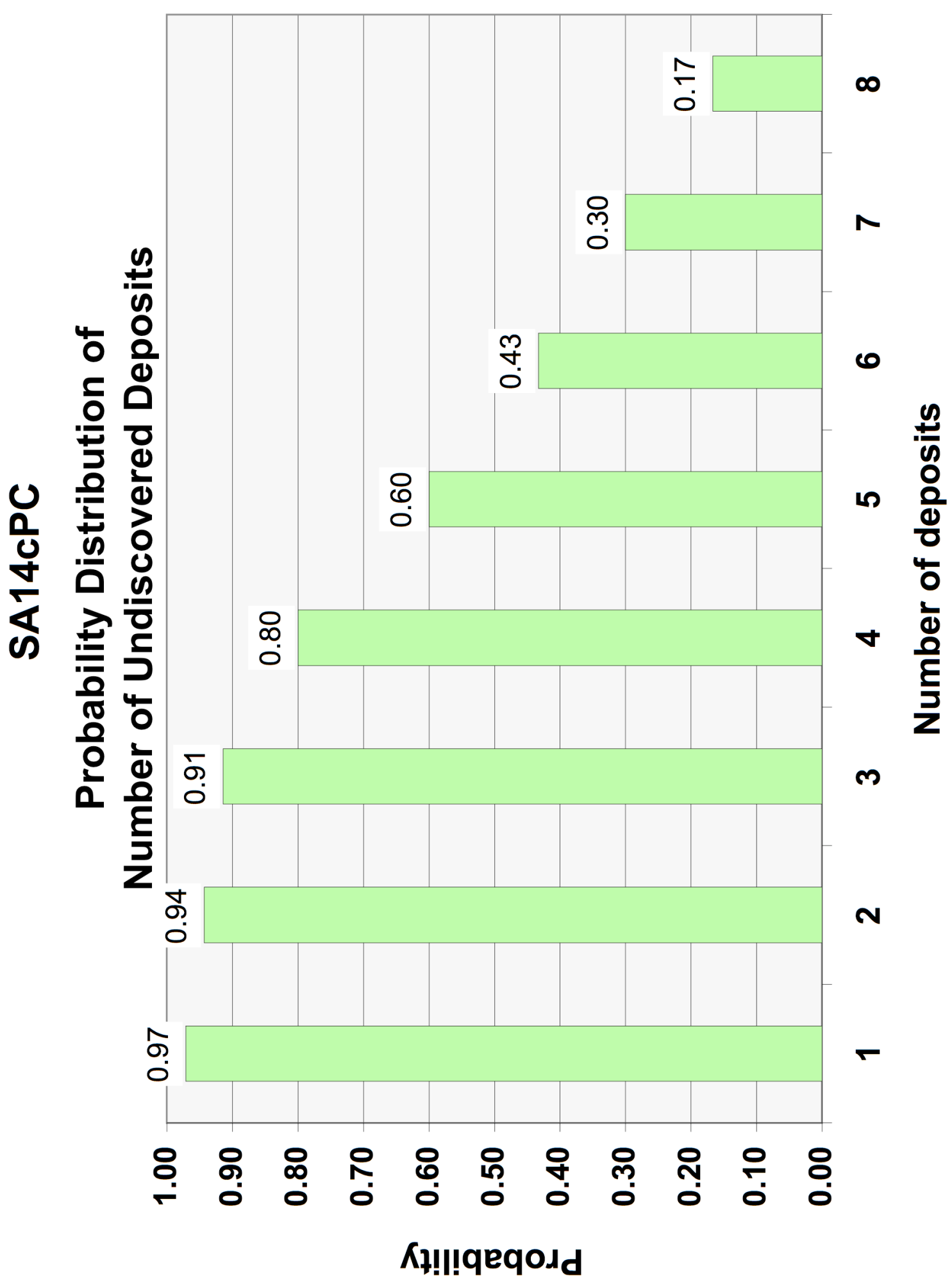




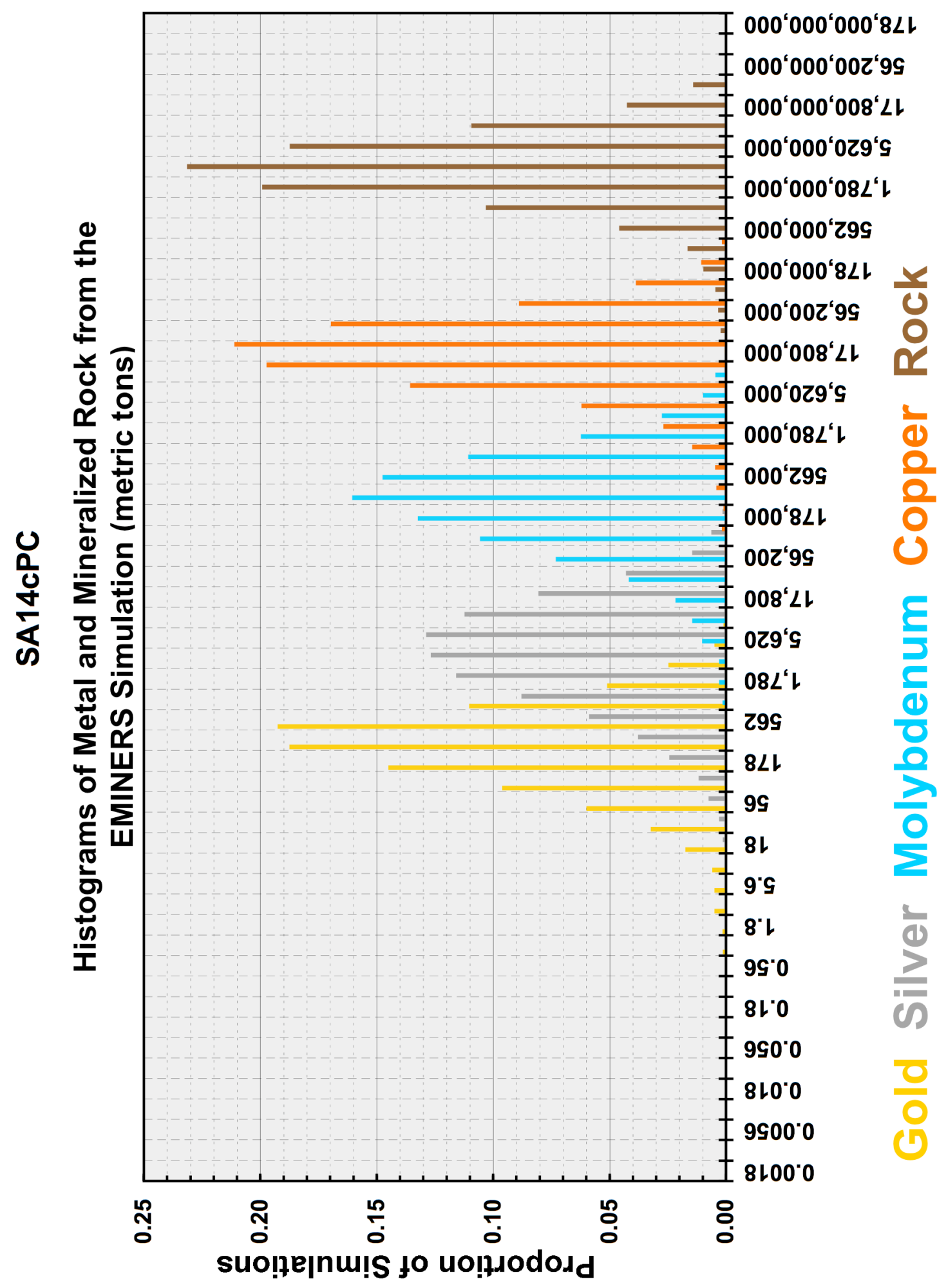




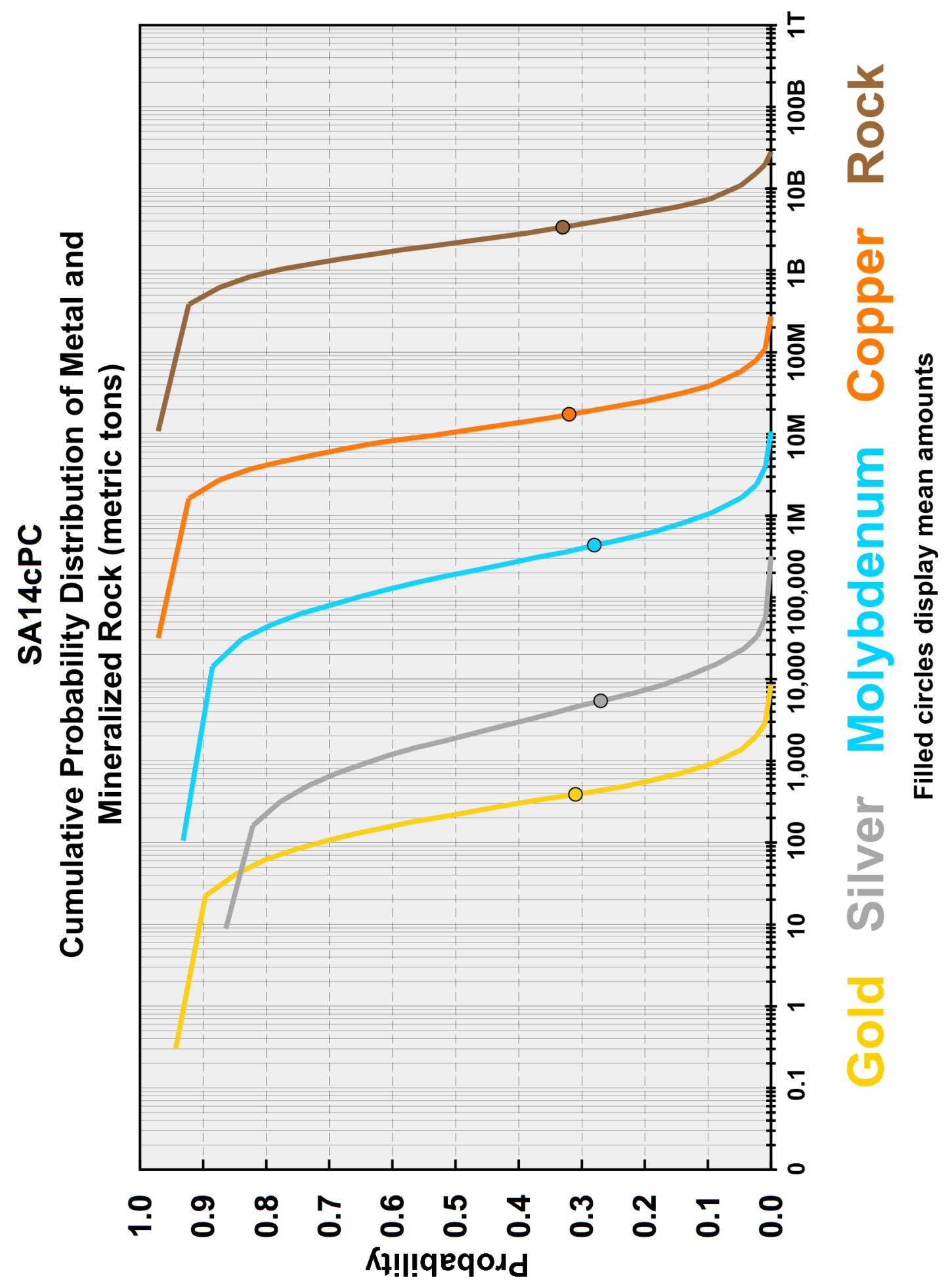




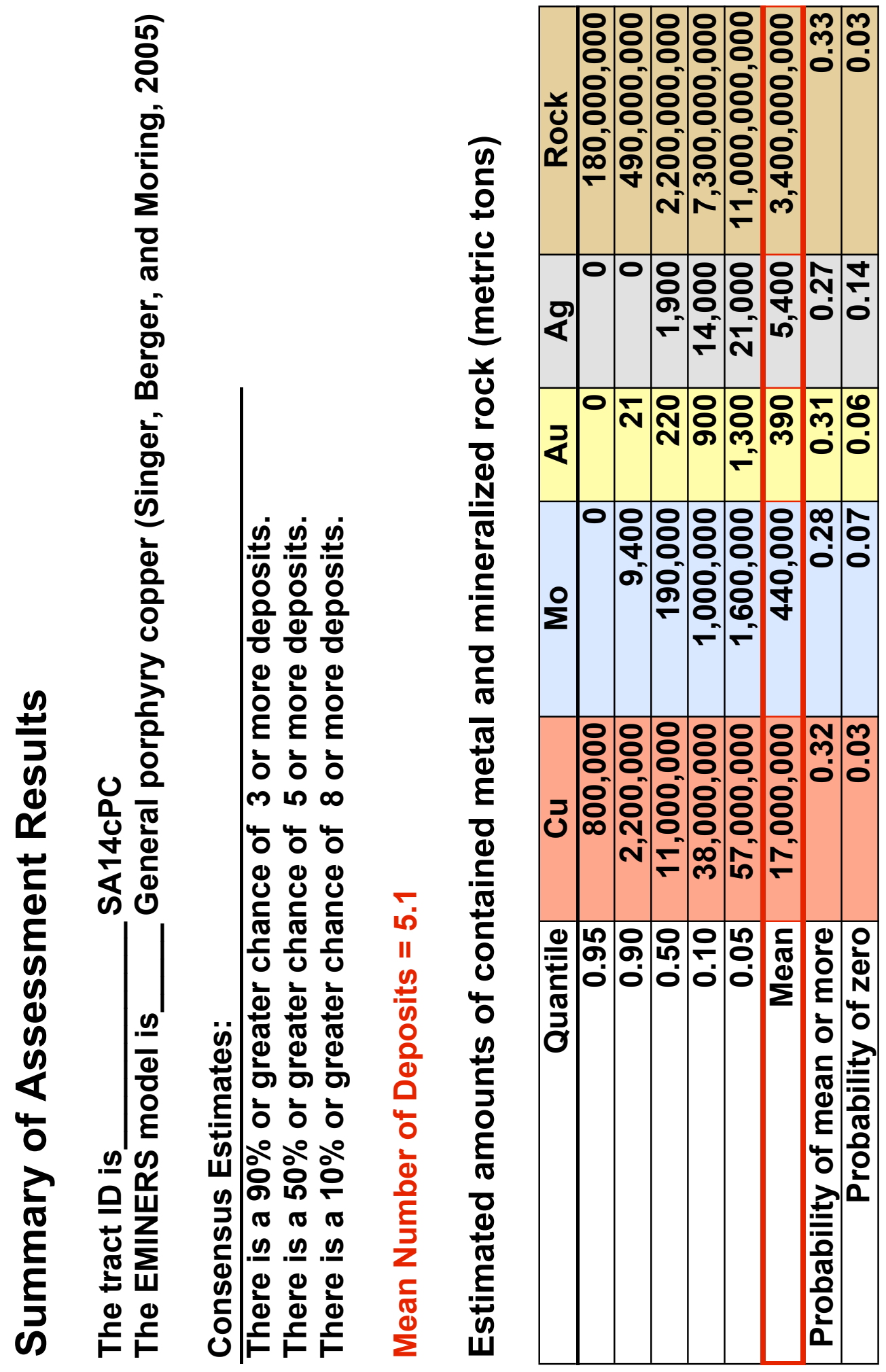




\section{Rationale for tract delineation}

This tract is defined by the distribution of mainly late Miocene to early Pliocene, mostly calcalkalic plutons and by the distribution of volcanic and other country rocks and cover rocks within or beneath which such plutons are expected to occur within $1 \mathrm{~km}$ of the surface. The tract is one of a group of four tracts (SA14a,b,c,dPC) of the same age that as a group trend northeasterly at an angle to the generally north-south trend of other Andean tracts. Exposed volcanic rocks associated with plutons having the appropriate petrochemistry to host porphyry copper deposits include lavas, breccias, pyroclastic rocks, and volcanic domes that are coeval to slightly older than the plutons. Where some of these volcanic rocks are excluded or crosscut by the tract boundary, they usually consist of outflow rather than vent facies. The tract is about 40 percent covered by younger rocks and sediments. Depth of erosion increases progressively toward the southeastern part of the tract and, as a result, the geology beneath the cover rocks and sediments is better known in this area.

The tract includes a southeast-trending alignment of Tertiary volcanic rocks that are spatially associated with the distribution of known porphyry copper deposits and prospects. This trend extends to the northwest into tract SA13aPC. The trend generally is parallel to the direction of Miocene-Pliocene subduction and may reflect leakage along a tear fault perpendicular to the subduction trench of the subducting plate. Examination of 1:500,000 scale geologic maps shows the presence within this trend of small plutonic bodies too small to be identified on a 1:1 million scale geologic map.

Additional sources of information about the geology of the tract and it mineral deposits and prospects include Sillitoe (1995); Sasso and Clark (1998); Angera (1999); Ulrich, Günther, and Heinrich (2001); Ulrich and Helmrich (2001); and Proffett (2003).

\section{Rationale for model choice}

The size and grades of the discovered porphyry copper deposits in the tract are not significantly different (table 3) from the general porphyry copper deposit model (Singer, Berger, and Moring, 2005), which therefore was used to represent the undiscovered deposits. In addition, the silicate and sulfide mineralogy, structure, and alteration and mineral zoning in the discovered deposits and prospects are typical of deposits in the general model.

\section{Deposits and prospects}

The tract contains three discovered deposits: Agua Rica, Bajo de la Alumbrera, and Bajo El Durazno. There also are three prospects: Bajo de Agua Tapado, Bajo de San Lucas, and Filo Colorado.

\section{Exploration history}

The tract is moderately explored around known mineralized centers and in the southeast where more host rocks have been exposed by deeper erosion. The tract is poorly explored elsewhere. There has been a United Nations geochemical survey in the tract.

\section{Rationale for numerical estimate}

Members of the assessment team used their collective knowledge of numbers of discovered deposits in the tract and in similar areas elsewhere in the world to make estimates throughout the tract that also were consistent with the deposit density model of Singer and others (2005). For several reasons, the team believes that a substantial number of undiscovered deposits are present in the tract. Although the tract is relatively small, it contains several discovered deposits and prospects even though exposed permissive rocks are not well explored away from known centers of mineralization and 40 percent are covered by younger rocks and sediments. 


\section{Expected distribution of undiscovered deposits}

Based on knowledge and information available to the team at the time of tract delineation, the tract was drawn to enclose an area of geology where the probability of occurrence of an undiscovered deposit was expected to be greater along the southeast trend of host-rock plutons and of known mineral deposits and prospects. Away from this trend, this potential, while lower, may be reasonably uniform because both exposed and covered permissive rocks are poorly explored or unexplored, respectively.

\section{References cited}

Angera, J.A., 1999, Mina Bajo de la Alumbrera, Catamarca, in Zappettini, E.O., ed., Recursos minerales de la Republica Argentina: Instituto de Geología y Recursos Minerales SEGEMAR, Anales 35, Buenos Aires, p. 1451-1461.

Proffett, J.M., 2003, Geology of the Bajo de la Alumbrera porphyry Cu-(Mo-Au) deposit, Argentina: Economic Geology, v. 98 p. 1535-1574.

Sasso, A.M., and Clark, A.H., 1998, The Farallón Negro Group, northwest Argentina: magmatic, hydrothermal and tectonic evolution and implications for $\mathrm{Cu}$-Au metallogeny in the Andean back-arc: Society of Economic Geologists Newsletter, no. 34, p. 1, 8-18.

Sillitoe, R.H., 1995, Exploration and discovery of base- and precious-metal deposits in the Circum-Pacific region during the last 25 years; Bajo de La Alumbrera: Resource Geology Special Issue No. 19, Published by the Society of Resource Geology, Tokyo, 119 p.

Singer, D.A., Berger, V.I., Menzie, W.D., and Berger, B.R., 2005, Porphyry copper density: Economic Geology, v. 100, no. 3, p. 491-514.

Singer, D.A., Berger, V.I., and Moring, B.C., 2005, Porphyry copper deposits of the world-Database, map, and grade and tonnage models: U.S. Geological Survey Open-file Report 2005-1060, http://pubs.usgs.gov/of/2005/1060/)

Ulrich, T., Günther, D., and Heinrich, C.A., 2001, The evolution of a porphyry Cu-Au deposit, based on LA-ICP-MS analysis of fluid inclusions: Bajo de la Alumbrera, Argentina: Economic Geology, v. 96, no. 8, p. 1743-1774.

Ulrich, T., and Heinrich, C.A., 2001, Geology and alteration geochemistry of the porphyry Cu-Au deposit at Bajo de la Alumbrera, Argentina: Economic Geology, v. 96, no. 8, p. 1719-1742. 
TRACT SA14dPC

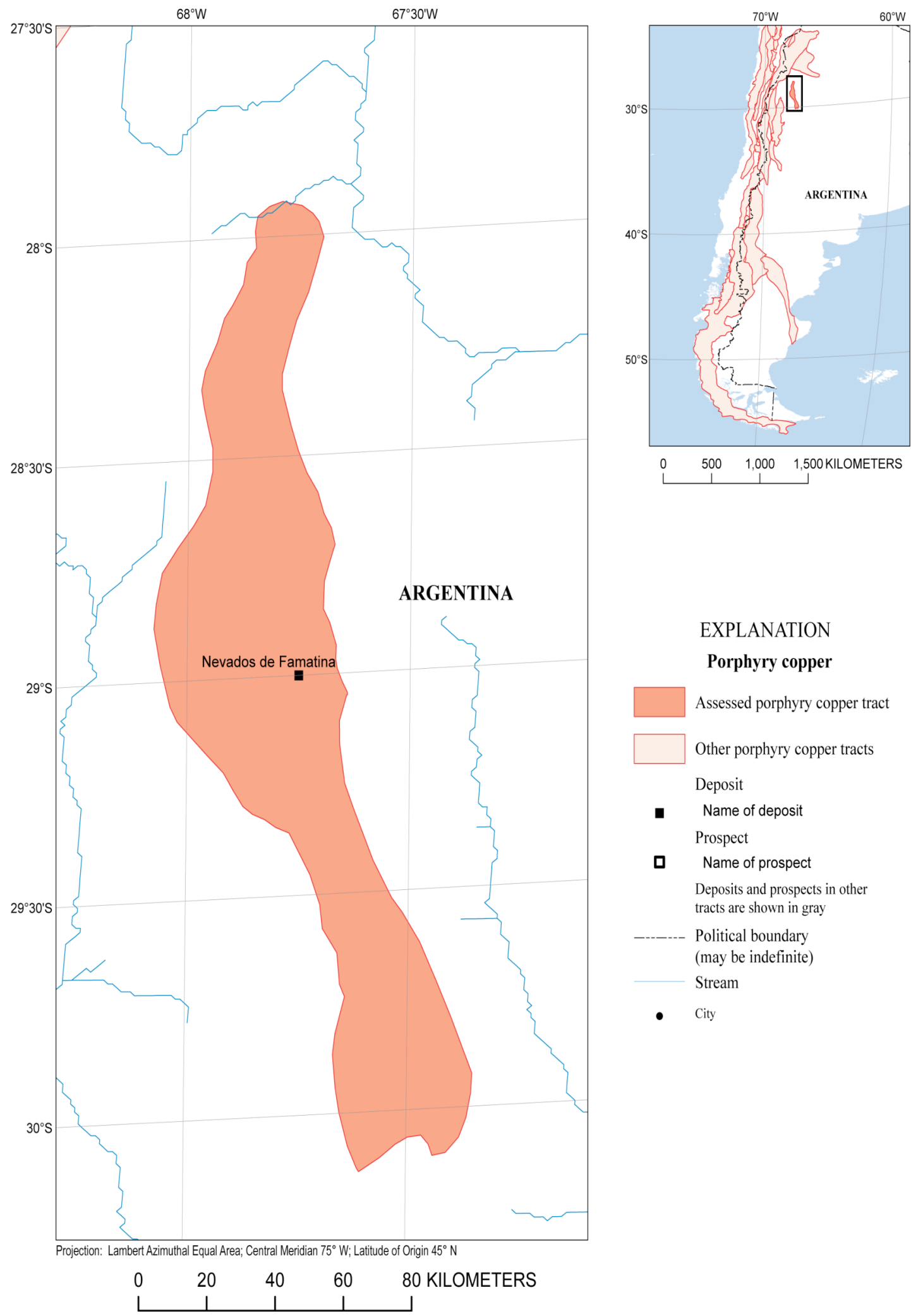




\section{Estimated Undiscovered Porphyry Copper Resources in Tract SA14dPC- Argentina}

Charles G. Cunningham, ${ }^{1}$ Eduardo 0. Zappettini, ${ }^{2}$ Waldo Vivallo S., ${ }^{3}$ Carlos Mario Celada, ${ }^{4}$ Jorge Quispe, ${ }^{5}$ Donald A. Singer, ${ }^{1}$ Joseph A Briskey, ${ }^{1}$ David M. Sutphin, ${ }^{1}$ Mariano Gajardo M., ${ }^{3}$ Alejandro Diaz, ${ }^{3}$ Carlos Portigliati, ${ }^{3}$ Vladimir I. Berger, ${ }^{1}$ Rodrigo Carrasco, ${ }^{3}$ and Klaus J. Schulz ${ }^{1}$

'USA-U.S. Geological Survey (USGS)

${ }^{2}$ Argentina - Instituto de Geología y Recursos Minerales (SEGEMAR)

${ }^{3}$ Chile-Servicio Nacional de Geología y Minería (SERNAGEOMIN)
${ }^{4}$ Colombia-Instituto Colombiano de Geología y Minería (INGEOMINAS)

${ }^{5}$ Peru-Instituto Geológico Minero y Metalúrgico (INGEMMET)

\begin{tabular}{|l|l|}
\hline Deposit type assessed: Porphyry Copper & $\begin{array}{l}\text { Model: General porphyry copper deposit model } \\
\text { (Singer, Berger, and Moring, 2005) }\end{array}$ \\
\hline $\begin{array}{l}\text { Tract name: Argentina Miocene-Pliocene } \\
\text { Nevados de Famatina }\end{array}$ & Countries: Argentina \\
\hline Tract ID: SA14dPC & Region: South America \\
\hline Date of assessment: May 16-18, 2005 & Date of last revision: June 16, 2006 \\
\hline Assessment depth: 1 km & Regional coordinator: Charles G. Cunningham \\
\hline Assessment team leader: Joe Briskey & Estimators: Charles G. Cunningham, Klaus J. Schulz, Joseph A Briskey, and Eduardo O. Zappettini. \\
\hline
\end{tabular}

Table of estimated numbers of undiscovered deposits by quantile. Also showing calculated mean $(m)$, standard deviation $(s)$, and coefficient of variation in percent $(C v \%)$. Sorted by mean.

\begin{tabular}{|c|c|c|c|c|c|c|}
\hline Estimators & 90 & 50 & 10 & $m$ & $s$ & $C v \%$ \\
\hline Consensus of estimators & 1 & 3 & 7 & 3.5 & 2.3 & 66 \\
\hline
\end{tabular}

\section{Deposit density table}

\begin{tabular}{|c|c|c|c|c|}
\hline $\begin{array}{c}\text { Mean of consensus estimates of } \\
\text { undiscovered deposits }\end{array}$ & $\begin{array}{c}\text { Number of } \\
\text { discovered } \\
\text { deposits }\end{array}$ & $\begin{array}{c}\text { Total number of } \\
\text { deposits }\end{array}$ & Area, $\mathbf{~ k m}^{2}$ & $\begin{array}{c}\text { Deposit density, number of } \\
\text { deposits/100,000km }\end{array}$ \\
\hline $\mathbf{3 . 5}$ & 1 & 4.5 & 5,770 & \\
\hline
\end{tabular}




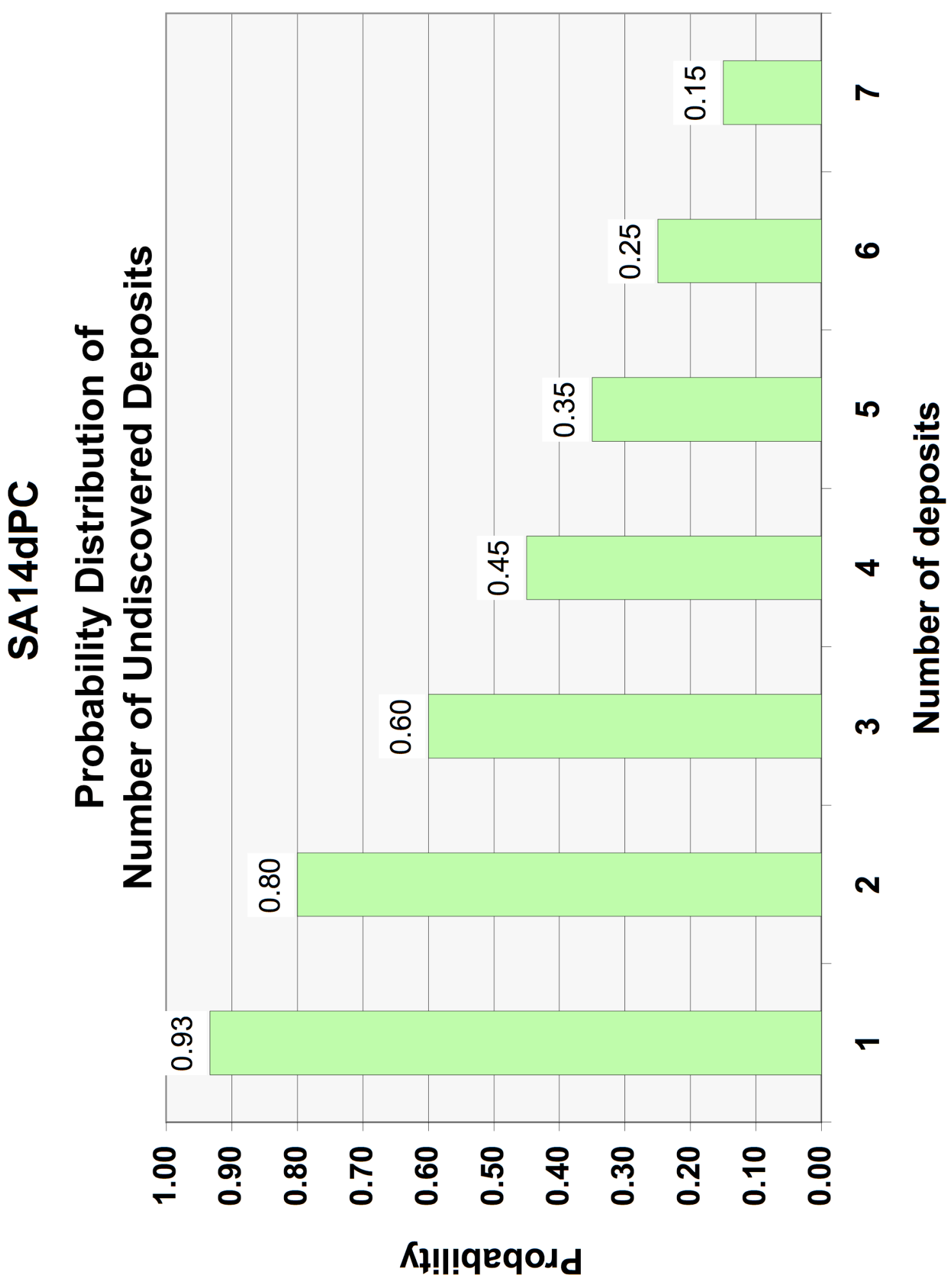




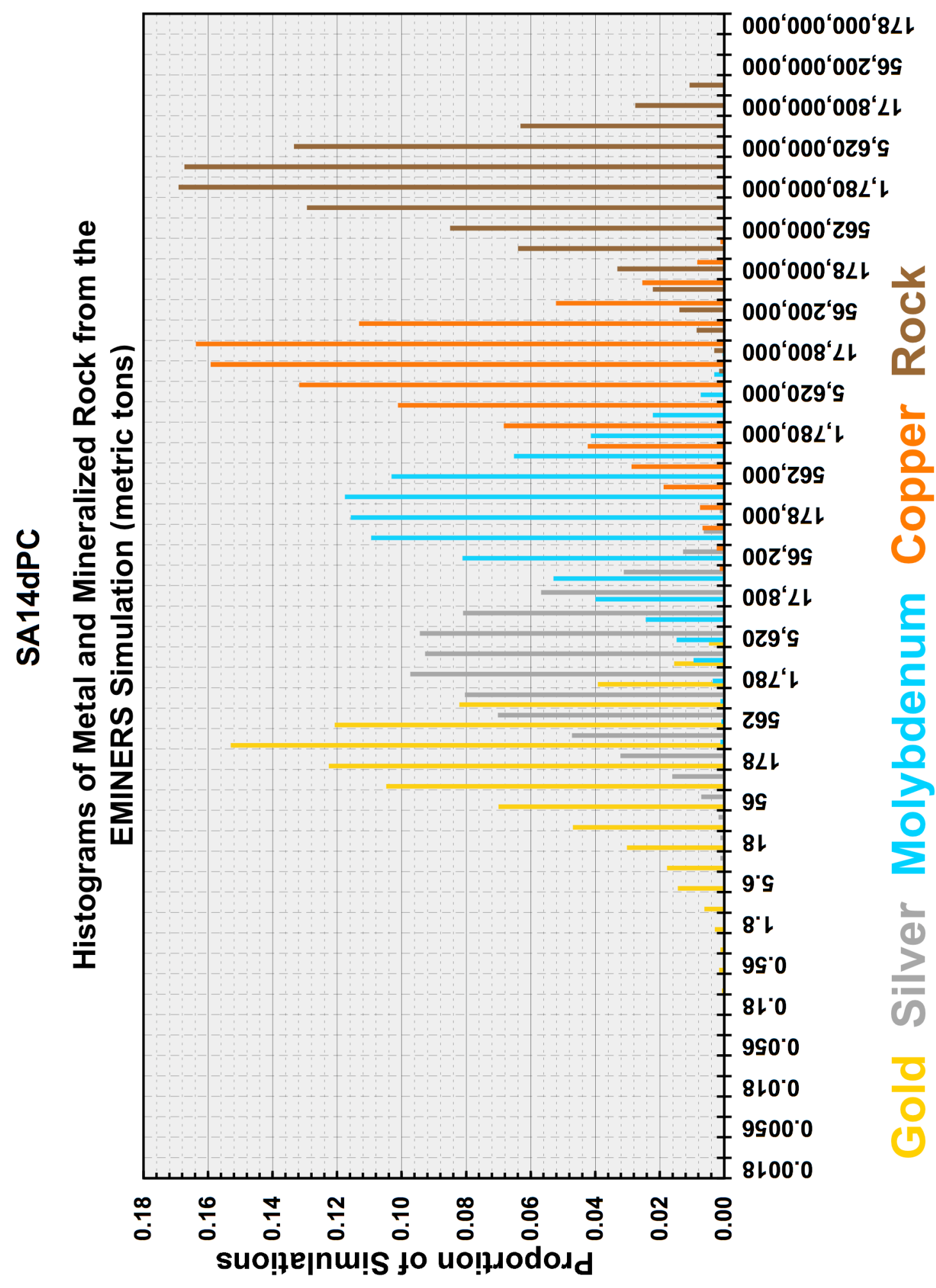




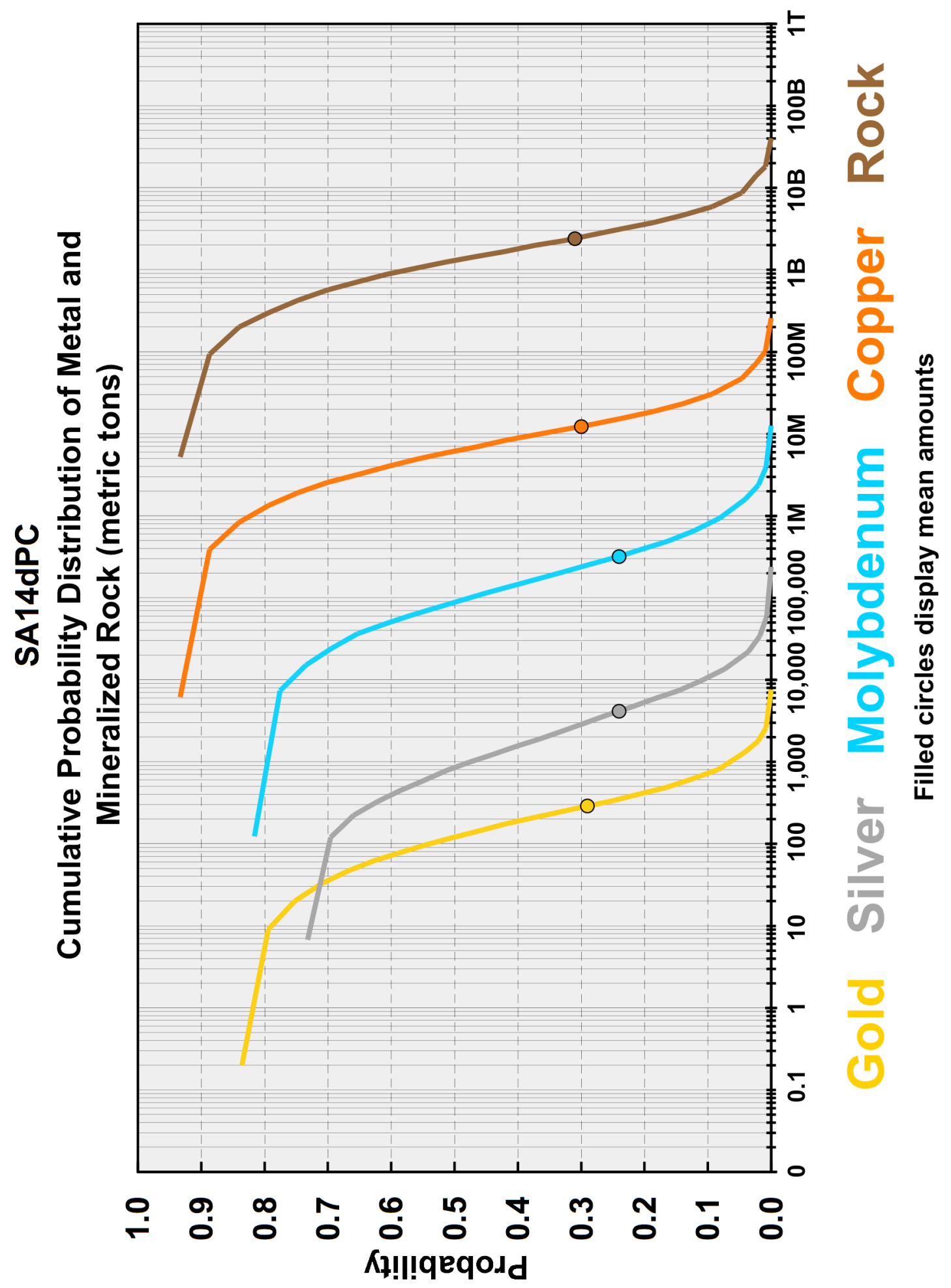




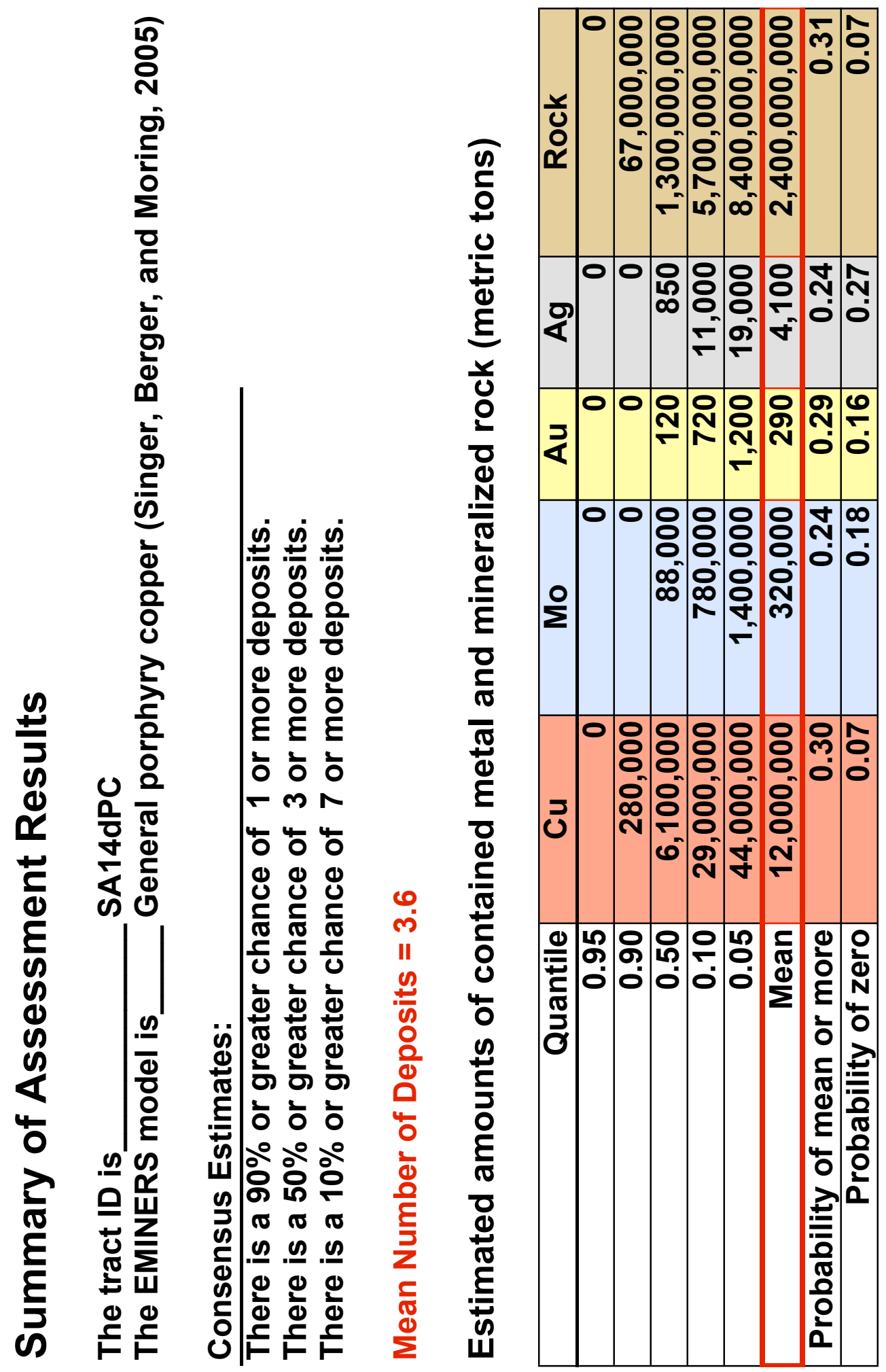




\section{Rationale for tract delineation}

This tract is defined by the distribution of mainly late Miocene to early Pliocene, mostly calcalkalic plutons and by the distribution of volcanic and other country rocks and cover rocks within or beneath which such plutons are expected to occur within $1 \mathrm{~km}$ of the surface. The tract is one of a group of four tracts (SA14a,b,c,dPC) of the same age that as a group trend northeasterly at an angle to the northsouth trend of other Andean tracts. Most of the rocks exposed at the surface include lavas, breccias, and volcanic domes that are coeval to slightly older than the plutons. About 70 percent of the tract is covered by younger rocks and sediments.

\section{Rationale for model choice}

The size and grades of the discovered porphyry copper deposit in the tract are not significantly different (table 3) from the general porphyry copper deposit model (Singer, Berger, and Moring, 2005), which therefore was used to represent the undiscovered deposits. The mineralogy, structure, and alteration of the discovered deposit are typical of deposits in the general model.

\section{Deposits and prospects}

The tract contains one discovered deposit, Nevados de Famatina. Descriptions of the geology and mineral deposits in the Nevados de Famatina mining district include that of Losada-Calderón and McPhail (1996).

\section{Exploration history}

Although difficult access has limited exploration, the tract is moderately explored around known mineralized centers. A United Nations geochemical survey was conducted in the tract.

\section{Rationale for numerical estimate}

The estimating team decided that the most useful way to begin discussions leading to numerical estimates for this tract was with estimates suggested by the porphyry copper deposit density model of Singer and others (2005). Numbers of undiscovered deposits suggested by the model at the $90^{\text {th }}, 50^{\text {th }}$, and $10^{\text {th }}$ percentiles were evaluated, discussed, modified, and remodified iteratively by the group in relation to the their collective knowledge of, and available information about, the mineral resource geology and exploration history for the tract. This process continued until consensus estimates were achieved for the tract that were satisfactory to all members of the group. The presence of a discovered deposit demonstrates that mineralizing processes forming porphyry copper deposits were active in the tract. The team's estimates are consistent with the density model and with limited exploration in the tract, especially beneath the 70 percent of the tract that is covered.

\section{Expected distribution of undiscovered deposits}

Based on knowledge and information available to the team at the time of tract delineation, the tract was drawn to enclose an area of geology where the probability of occurrence of an undiscovered deposit is believed to be reasonably uniform

\section{References cited}

Losada-Calderón, A.J., and McPhail, D.C., 1996, Porphyry and high-sulfidation epithermal mineralization in the Nevados del Famatina mining district, Argentina: in Camus, Francisco, Sillitoe, R.M., and Petersen, Richard, eds., Andean copper deposits: New discoveries, mineralization, styles and metallogeny: Society of Economic Geologists, Special Publication No. 5, p.91-117. 
Singer, D.A., Berger, V.I., Menzie, W.D., and Berger, B.R., 2005, Porphyry copper density: Economic Geology, v. 100, no. 3, p. 491-514.

Singer, D.A., Berger, V.I., and Moring, B.C., 2005, Porphyry copper deposits of the world-Database, map, and grade and tonnage models: U.S. Geological Survey Open-file Report 2005-1060, http://pubs.usgs.gov/of/2005/1060/) 


\section{TRACT SA15PC}

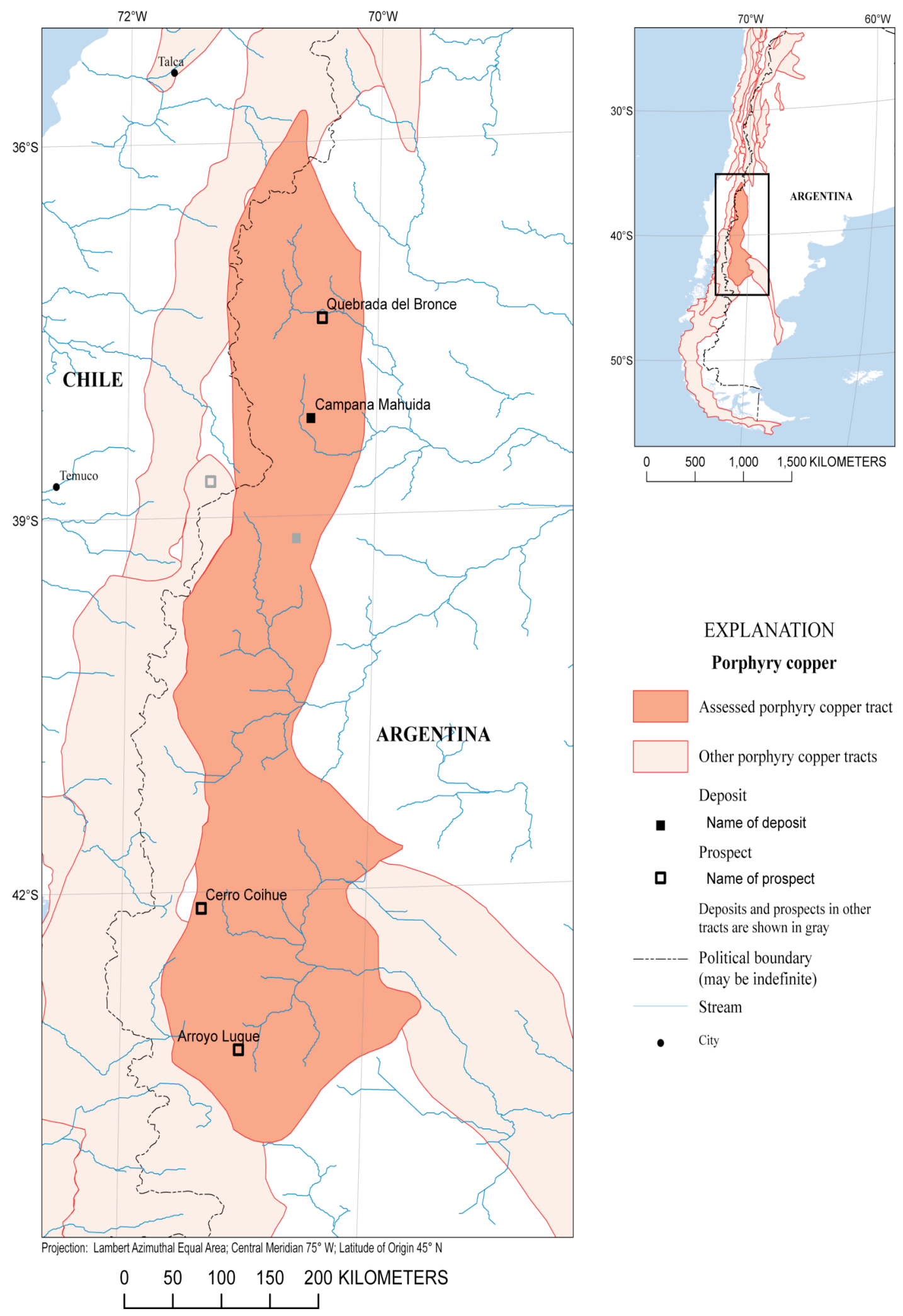




\section{Estimated Undiscovered Porphyry Copper Resources in Tract SA15PC- Argentina and Chile}

Charles G. Cunningham, ${ }^{1}$ Eduardo 0. Zappettini, ${ }^{2}$ Waldo Vivallo S., ${ }^{3}$ Carlos Mario Celada, ${ }^{4}$ Jorge Quispe, ${ }^{5}$ Donald A. Singer, ${ }^{1}$ Joseph A Briskey, ${ }^{1}$ David M. Sutphin, ${ }^{1}$ Mariano Gajardo M., ${ }^{3}$ Alejandro Diaz, ${ }^{3}$ Carlos Portigliati, ${ }^{3}$ Vladimir I. Berger, ${ }^{1}$ Rodrigo Carrasco, ${ }^{3}$ and Klaus J. Schulz ${ }^{1}$

'USA-U.S. Geological Survey (USGS)

${ }^{2}$ Argentina - Instituto de Geología y Recursos Minerales (SEGEMAR)

${ }^{3}$ Chile-Servicio Nacional de Geología y Minería (SERNAGEOMIN)
${ }^{4}$ Colombia-Instituto Colombiano de Geología y Minería (INGEOMINAS)

${ }^{5}$ Peru-Instituto Geológico Minero y Metalúrgico (INGEMMET)

\begin{tabular}{|c|c|}
\hline Deposit type assessed: Porphyry Copper & $\begin{array}{l}\text { Model: General porphyry copper deposit model } \\
\text { (Singer, Berger, and Moring, 2005) }\end{array}$ \\
\hline $\begin{array}{l}\text { Tract name: Argentina-Chile } \\
\text { Late Cretaceous-middle Eocene Campana Mahuida }\end{array}$ & Countries: Argentina and Chile \\
\hline Tract ID: SA15PC & Region: South America \\
\hline Date of assessment: May 16-18, 2005 & Date of last revision: \\
\hline \multicolumn{2}{|l|}{ Assessment depth: $1 \mathrm{~km}$} \\
\hline Assessment team leader: Donald A. Singer & Regional coordinator: Charles G. Cunningham \\
\hline $\begin{array}{l}\text { Estimators: Carlos Mario Celada, Vladimir I. Berg } \\
\text { Gajardo M., Carlos Portigliati, Donald A. Singer, W } \\
\text { Briskey. }\end{array}$ & $\begin{array}{l}\text {, Rodrigo Carrasco, Alejandro Diaz, Mariano } \\
\text { ldo Vivallo S., Eduardo O. Zappettini, and Joseph A }\end{array}$ \\
\hline
\end{tabular}

Table of estimated numbers of undiscovered deposits by quantile. Also showing calculated mean $(m)$, standard deviation $(s)$, and coefficient of variation in percent $(C v \%)$. Sorted by mean.

\begin{tabular}{|c|r|r|r|r|r|r|r|}
\hline Estimators & 90 & 50 & 10 & $m$ & $s$ & $C v \%$ \\
\hline Consensus of estimators & 1 & 2 & 11 & 4.3 & 3.9 & 91 \\
\hline
\end{tabular}

\section{Deposit density table}

\begin{tabular}{|c|c|c|c|c|}
\hline $\begin{array}{c}\text { Mean of consensus estimates of } \\
\text { undiscovered deposits }\end{array}$ & $\begin{array}{c}\text { Number of } \\
\text { discovered } \\
\text { deposits }\end{array}$ & $\begin{array}{c}\text { Total number of } \\
\text { deposits }\end{array}$ & Area, $\mathbf{~ k m}^{2}$ & $\begin{array}{c}\text { Deposit density, number of } \\
\text { deposits/100,000km }\end{array}$ \\
\hline $\mathbf{4 . 3}$ & 1 & 5.3 & 83,204 & 6 \\
\hline
\end{tabular}




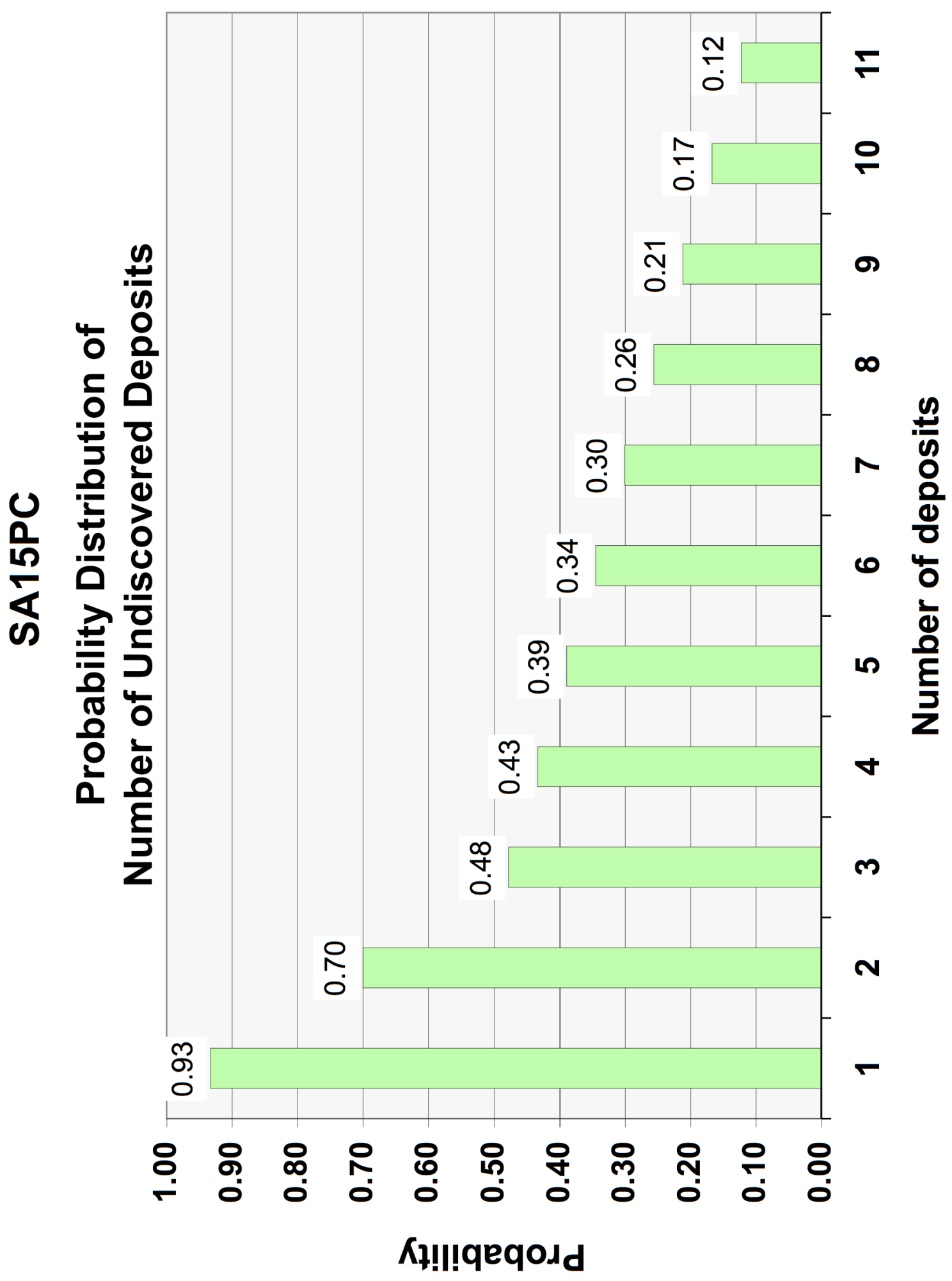




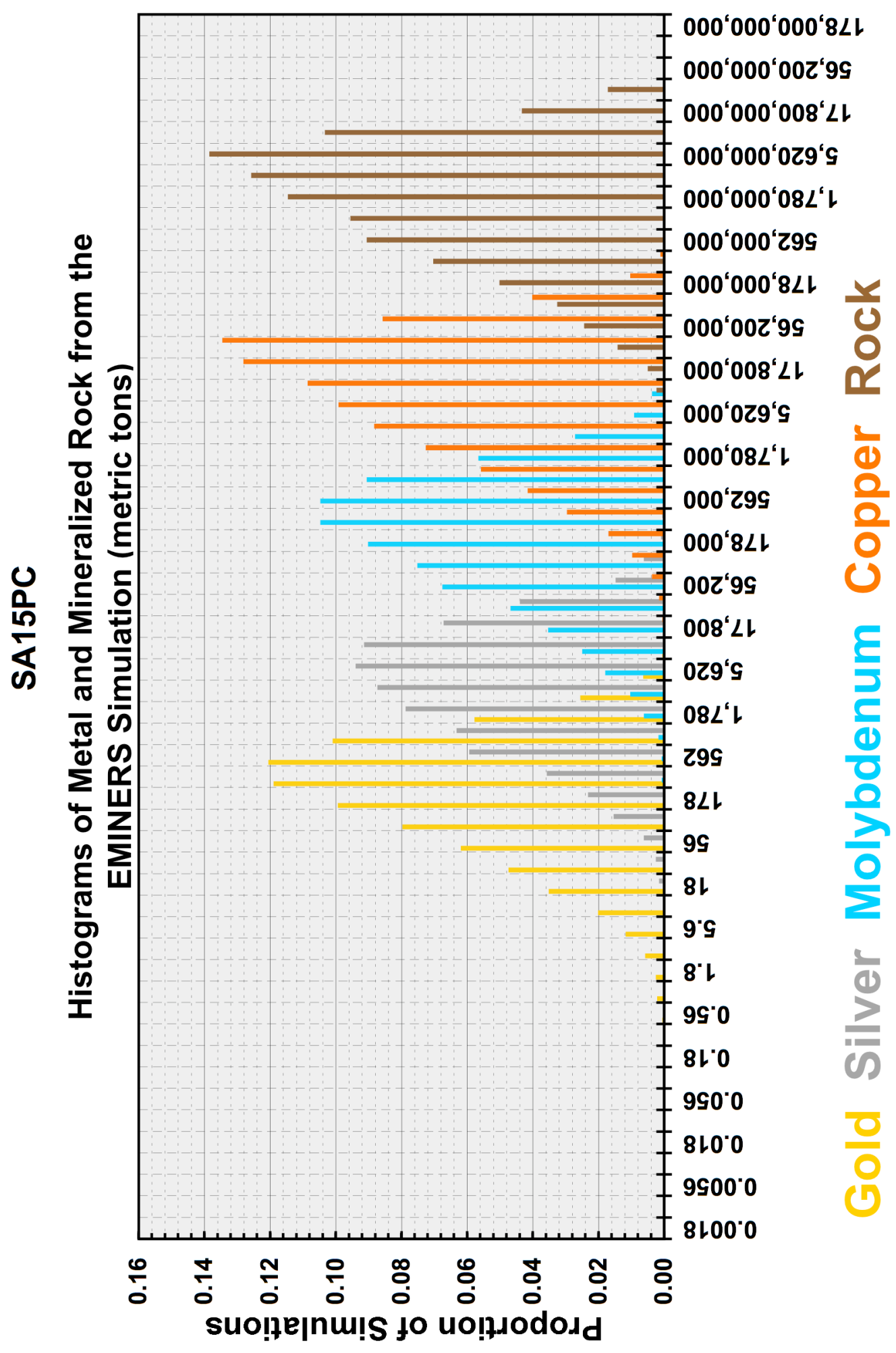




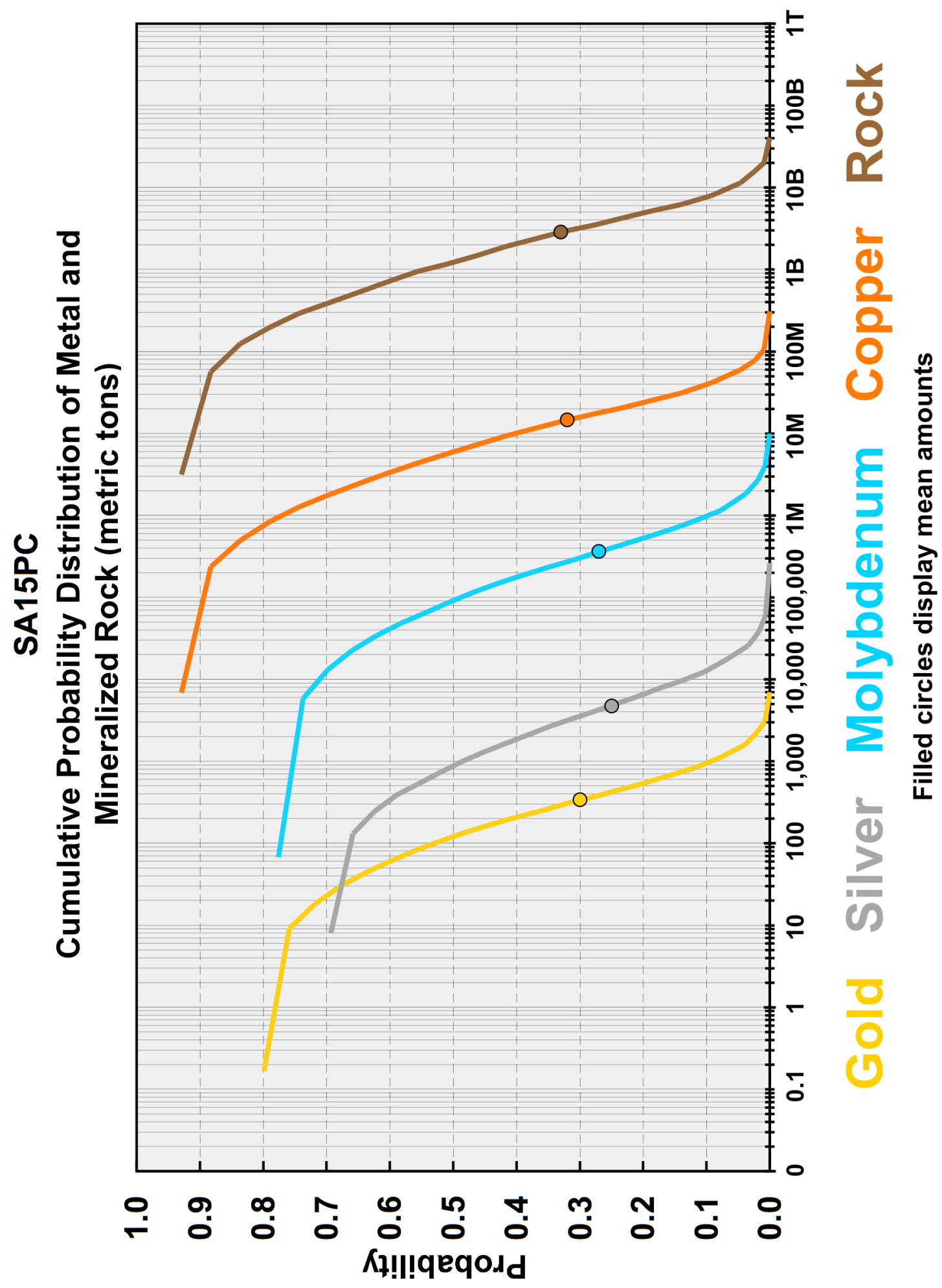



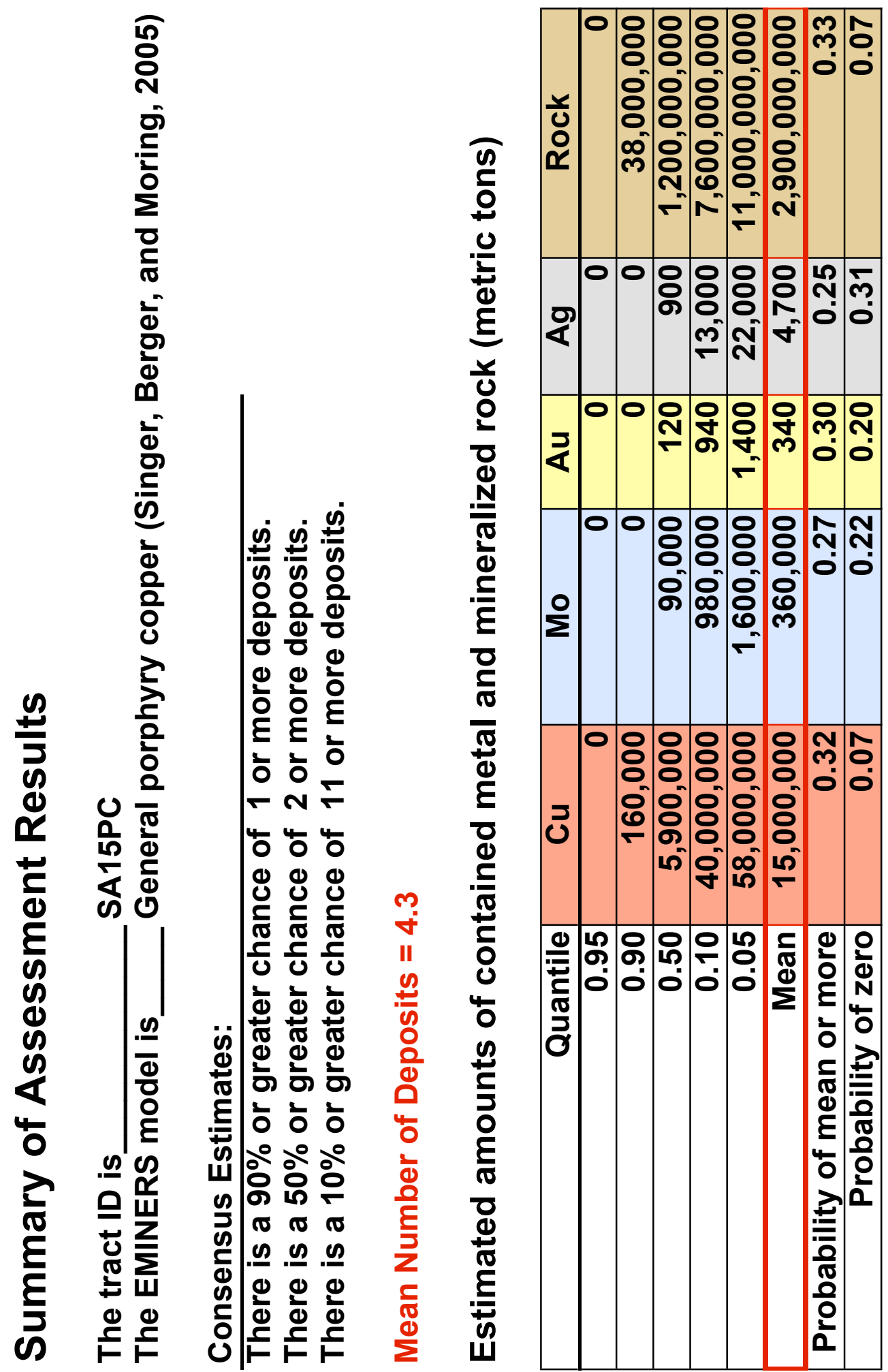


\section{Rationale for tract delineation}

This tract is defined by the distribution of a heterogeneous assemblage of Late Cretaceous to middle Eocene (Franchini and others, 2003) mainly calc-alkalic plutons and volcanic and other country rocks and cover rocks within or beneath which such plutons are expected to occur within $1 \mathrm{~km}$ of the surface. Compositions of the plutons include granite, granodiorite, andesite, diorite, and dacite. Although most of these plutons are too small to be portrayed on a million-scale map, examples can be seen on the 1:500,000-scale map by Delpino and Deza (1995). Many of these permissive rocks are related to the north-south trending axis of a back-arc basin filled with early Cretaceous carbonate rocks and laminated, friable shales. In the northern part of the tract, Franchini and others (2003) used available dates to group igneous rocks into three different magmatic cycles: Late Cretaceous, Paleocene, and middle Eocene. The tract is about 80 percent covered by rocks and sediments that are consanguineous with, or younger than, most of the permissive plutons.

\section{Rationale for model choice}

The size and grades of the discovered porphyry copper deposit in the tract are not significantly different (table 3) from the general porphyry copper deposit model (Singer, Berger, and Moring, 2005), which therefore was used to represent the undiscovered deposits. Moreover, the mineralogy, structure, and alteration of the discovered deposit and prospects in the tract are typical of deposits in the general model.

\section{Deposits and prospects}

The tract contains one discovered deposit, Campana Mahuida, together with three prospects, Cerro Coihue, Arroyo Luque, and Quebrada del Bronce. Skarn occurrences and high-sulfidation polymetallic veins also are present in the tract.

The Campana Mahuida deposit in the Campana Mahuida district is the most important porphyry copper deposit known in the tract. Amphibole from this deposit has been dated at $60.7 \pm 1.9 \mathrm{Ma}$ (Franchini and others, 2003). Most of the analyzed igneous rocks from Campana Mahuida are metaluminous with $\mathrm{A} / \mathrm{CNK}$ ratios greater than 1.1 and they are anomalously high in the incompatible elements thorium, niobium, and cerium (Franchini and others, 2003).

The Cerro Coihue prospect, no. 82 on the Metallogenic Map of Argentina (Servicio Geólogica Minero Argentino, 1999), is a porphyry copper-gold prospect with an age geologically constrained between the Jurassic and Eocene.

The Arroyo Luque prospect, no. 52 on the Metallogenic Map of Argentina (Servicio Geólogica Minero Argentino, 1999), has an age geologically constrained to the Late Cretaceous and occurs in an area where tracts SA15PC and SA20PC overlap. Consequently, the prospect could belong to either tract spatially and geochronologically.

The Quebrada del Bronce prospect is in the Caicayen district where host plutons are characterized as being I-type, magnetite series, calc-alkaline, porphyritic sills of intermediate composition with porphyry style potassic and phyllic alteration (Franchini, Meinert, and Montenegro, 2000). An uncertain middle Eocene age for the prospect is implied by whole-rock K-Ar dates of $44.7 \pm 2 \mathrm{Ma}$ on two fine to medium crystalline stocks in the district (Llambías and Rapela, 1989; Franchini, Meinert, and Montenegro, 2000).

Additional sources of information about the geology and mineralization in the tract include Sillitoe (1977), Long (1995), Secretaria de Minería (1995), Case and Malvicini (1999), Chabert and Zanettini (1999), and Franchini and others (2007). 


\section{Exploration history}

The tract is moderately explored around known mineralized centers. A United Nations geochemical survey was conducted in the tract.

\section{Rationale for numerical estimate}

The assessment team initially made individual estimates in the northern part of the tract where host plutons and areas of porphyry-copper-type mineralization are relatively well exposed and studied (e.g., Llambías and Rapela, 1989; Delpino and Deza, 1995; Secretaría de Minería, 1995; Case and Malvicini, 1999; Chabert and Zanettini, 1999; Franchini, Meinert, and Montenegro, 2000; Franchini and others, 2003 and 2007). Subsequently, the team compared the results of these estimates to the porphyry copper density model of Singer and others (2005) and used the model to proportionately expand the results of the initial estimates throughout the remainder of the tract, most of which is covered by younger rocks and sediments.

Although the tract is approximately 80 covered, it is large and geologically diverse, and the team was surprised that prospecting, and moderate exploration around known mineralized areas, have found only one small deposit and three prospects. Moreover, there was much uncertainty about what lay beneath the extensive areas of cover. Consequently, the team's estimates are relatively small for such a large tract.

\section{Expected distribution of undiscovered deposits}

Considering that the tract is mostly covered, and systematic exploration has focused on known mineralized areas, the team expects the probability of occurrence of undiscovered deposits to be reasonably uniform based on knowledge and information available to them at the time of tract delineation.

\section{References cited}

Case, A.M., and Malvicini, L., 1999, El porfiro cuprifero con oro de la Quebrada del Bronce, Neuquen, in Zappettini, E.O., ed., Recursos minerales de la Republica Argentina: Instituto de Geología y Recursos Minerales SEGEMAR, Anales 35, Buenos Aires, p. 1337-1341.

Chabert, M.R., and Zanettini, J.C.M., 1999, Porfiro cuprifero Campana Mahuida, Neuquen, in Zappettini, E.O., ed., Recursos minerales de la Republica Argentina: Instituto de Geología y Recursos Minerales SEGEMAR, Anales 35, Buenos Aires, p. 1279-1288.

Delpino, Daniel, and Deza, Mario, 1995, Mapa Geológico y de Recursos Minerales de la Provincia del Neuquén, Argentina: Buenos Aires, Republica Argentina Secretaria de Minería, one map, scale 1:500,000.

Franchini, Marta, Impiceini, Agnes, Meinert, Lawrence, Grathoff, Georg, and Schalamuk, Isidoro B.A., 2007, Clay mineralogy and zonation in the Campana Mahuida porphyry Cu deposit, Neuquén, Argentina: Implications for porphyry $\mathrm{Cu}$ exploration: Economic Geology, v. 102, p. 27-54.

Franchini, Marta, López-Escobar, Leopoldo, Schalamuk, I.B.A., and Meinert, Lawrence, 2003, Magmatic characteristics of the Paleocene Cerro Nevazón region and other Late Cretaceous to Early Tertiary calcalkaline subvolcanic to plutonic units in the Neuquén Andes, Argentina: Journal of South American Earth Sciences, v. 16, Issue 5, p. 399-421.

Franchini, M.B., Meinert, L.D., and Montenegro, T.F., 2000, Skarns related to porphyry-style mineralization at Caicayén Hill, Neuquén, Argentina: composition and evolution of hydrothermal fluids: Economic Geology, v. 95, p. 1197-1213.

Llambías, E., and Rapela, C., 1989, Las volcanitas de Collipilli, Neuquén y su relación con otras unidades Paleógenas de la Cordillera: Revista de la Asociación Geológica [Argentina], v. 44, p. 224-236. 
Long, K.R., 1995, Production and reserves of Cordilleran (Alaska to Chile) porphyry copper deposits, in Pierce, F.W., and Bolm, J.G., eds., Porphyry copper deposits of the American Cordillera: Tucson, Arizona Geological Society Digest 20, p. 35-68.

Secretaría de Minería, 1995, Mapa Geológica y de Recursos Minerales de la Provincia del Neuquén, República Argentina: Dirección Nacional del Servicio Nacional, Escala 1:500,000.

Servicio Geólogica Minero Argentino, 1999, Mapa Metalogenético de la Repúbica Argentina: Servicio Geólogica Minero Argentino, Zappettini, Eduardo, Coordinator, Escala 1:2,500,000, v. 2.0.

Sillitoe, R.H., 1977, Permo-Carboniferous, upper Cretaceous, and Miocene porphyry copper-type mineralization in the Argentinean Andes: Economic Geology, v. 72, p. 99-109.

Singer, D.A., Berger, V.I., Menzie, W.D., and Berger, B.R., 2005, Porphyry copper density: Economic Geology, v. 100, no. 3, p. 491-514.

Singer, D.A., Berger, V.I., and Moring, B.C., 2005, Porphyry copper deposits of the world-Database, map, and grade and tonnage models: U.S. Geological Survey Open-file Report 2005-1060, http://pubs.usgs.gov/of/2005/1060/) 
TRACT SA16aPC

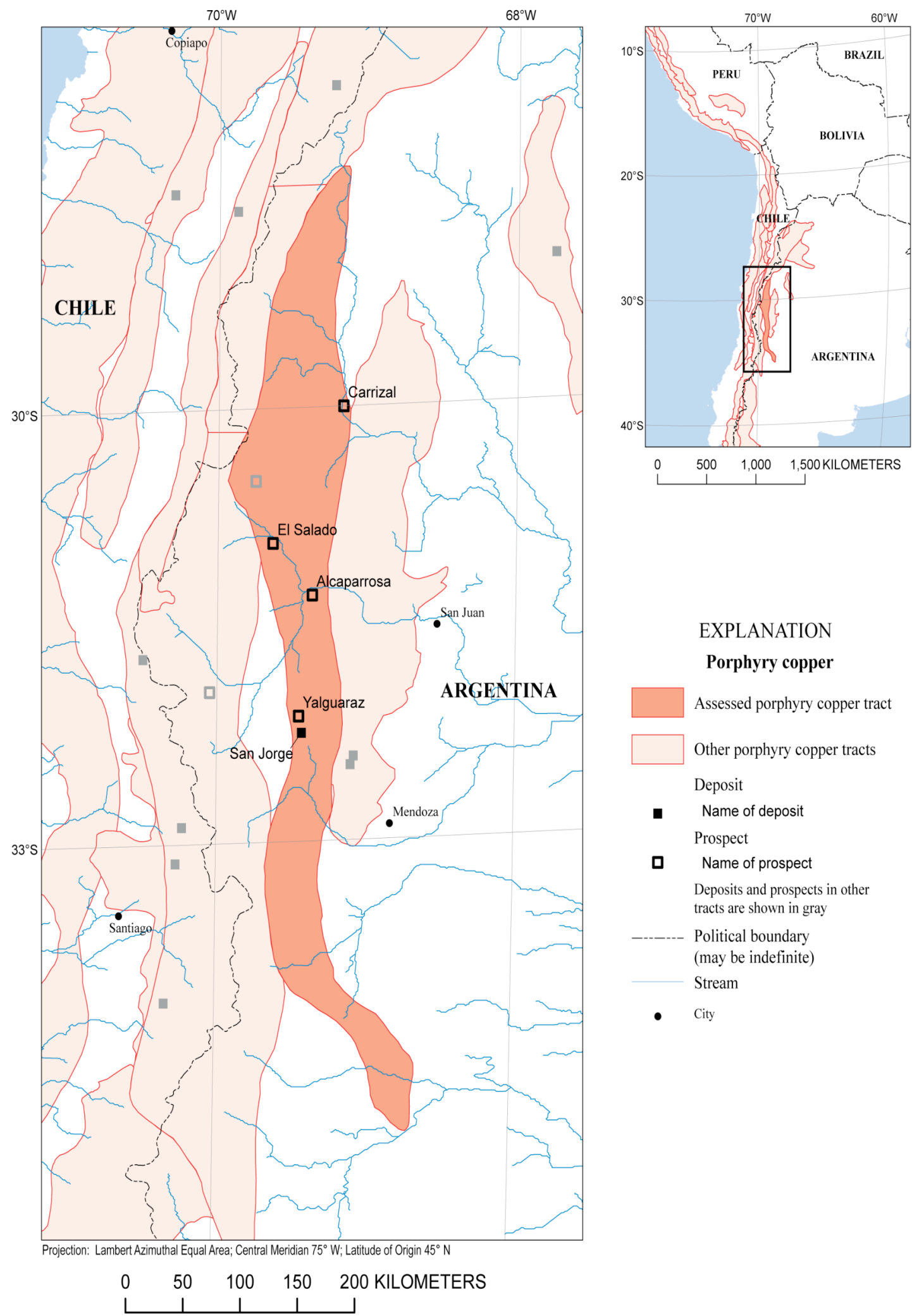




\section{TRACT SA16bPC}

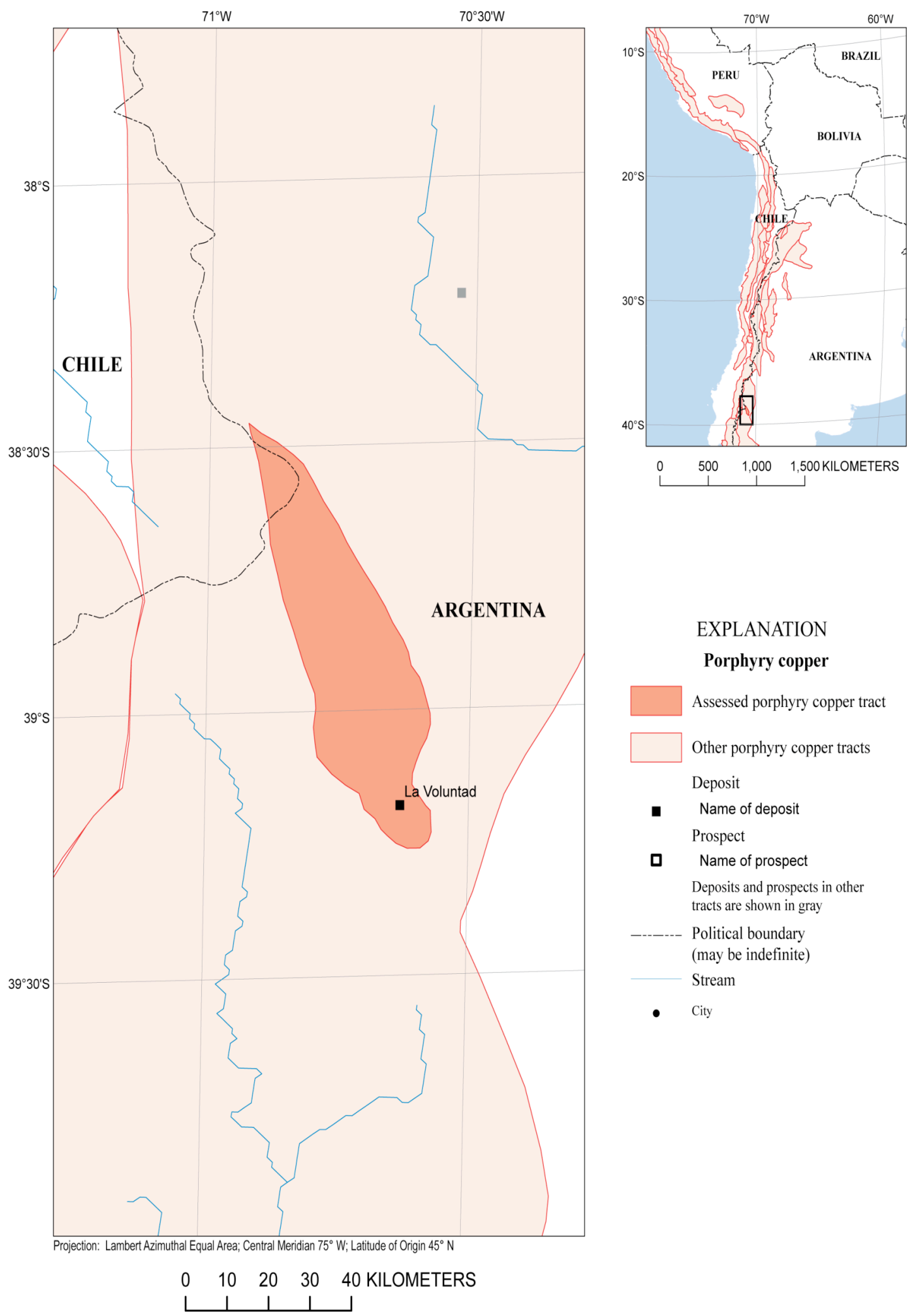




\section{Estimated Undiscovered Porphyry Copper Resources in Tract SA16a,bPC- Argentina and Chile}

Charles G. Cunningham, ${ }^{1}$ Eduardo 0. Zappettini, ${ }^{2}$ Waldo Vivallo S., ${ }^{3}$ Carlos Mario Celada, ${ }^{4}$ Jorge Quispe ${ }^{5}$ Donald A. Singer, ${ }^{1}$ Joseph A Briskey, ${ }^{1}$ David M. Sutphin, ${ }^{1}$ Mariano Gajardo M., ${ }^{3}$ Alejandro Diaz, ${ }^{3}$ Carlos Portigliati, ${ }^{3}$ Vladimir I. Berger, ${ }^{1}$ Rodrigo Carrasco, ${ }^{3}$ and Klaus J. Schulz ${ }^{1}$

'USA-U.S. Geological Survey (USGS)

${ }^{2}$ Argentina - Instituto de Geología y Recursos Minerales (SEGEMAR)

${ }^{3}$ Chile-Servicio Nacional de Geología y Minería (SERNAGEOMIN)
${ }^{4}$ Colombia-Instituto Colombiano de Geología y Minería (INGEOMINAS)

${ }^{5}$ Peru-Instituto Geológico Minero y Metalúrgico (INGEMMET)

\begin{tabular}{|l|l|}
\hline Deposit type assessed: Porphyry Copper & $\begin{array}{l}\text { Model: General porphyry copper deposit model } \\
\text { (Singer, Berger, and Moring, 2005) }\end{array}$ \\
\hline Tract name: Argentina Permian San Jorge & Countries: Argentina and Chile \\
\hline Tract ID: SA16a,bPC & Region: South America \\
\hline Date of assessment: May 16-18, 2005 & Date of last revision: \\
\hline Assessment depth: $1 \mathrm{~km}$ & \\
\hline Assessment team leader: Donald A. Singer & Regional coordinator: Charles G. Cunningham \\
\hline $\begin{array}{l}\text { Estimators: Carlos Mario Celada, Vladimir I. Berger, Rodrigo Carrasco, Alejandro Diaz, Mariano } \\
\text { Gajardo M., Carlos Portigliati, Donald A. Singer, Waldo Vivallo S., and Eduardo O. Zappettini. }\end{array}$ \\
\hline
\end{tabular}

Table of estimated numbers of undiscovered deposits by quantile. Also showing calculated mean $(\mathrm{m})$, standard deviation $(s)$, and coefficient of variation in percent $(C v \%)$. Sorted by mean.

\begin{tabular}{|l|c|c|c|c|c|c|}
\hline \multicolumn{1}{|c|}{ Estimators } & $\mathbf{9 0}$ & $\mathbf{5 0}$ & $\mathbf{1 0}$ & $\boldsymbol{m}$ & $\boldsymbol{s}$ & $\boldsymbol{C v} \boldsymbol{0}$ \\
\hline Estimator & 0 & 1 & 1 & 0.70 & 0.41 & 59 \\
\hline Estimator & 1 & 2 & 4 & 2.2 & 1.2 & 55 \\
\hline Estimator & 1 & 2 & 4 & 2.2 & 1.2 & 55 \\
\hline Estimator & 1 & 2 & 6 & 2.8 & 2.0 & 71 \\
\hline Estimator & 1 & 3 & 6 & 3.2 & 1.9 & 59 \\
\hline Consensus of estimators & $\mathbf{2}$ & $\mathbf{3}$ & $\mathbf{6}$ & $\mathbf{3 . 5}$ & $\mathbf{1 . 6}$ & $\mathbf{4 6}$ \\
\hline Estimator & 2 & 3 & 7 & 3.8 & 2.0 & 53 \\
\hline Estimator & 2 & 3 & 7 & 3.8 & 2.0 & 53 \\
\hline Estimator & 3 & 5 & 7 & 4.8 & 1.6 & 33 \\
\hline Estimator & 3 & 6 & 10 & 6.1 & 2.6 & 43 \\
\hline
\end{tabular}

\section{Deposit density table}

\begin{tabular}{|c|c|c|c|c|}
\hline $\begin{array}{c}\text { Mean of consensus estimates of } \\
\text { undiscovered deposits }\end{array}$ & $\begin{array}{c}\text { Number of } \\
\text { discovered } \\
\text { deposits }\end{array}$ & $\begin{array}{c}\text { Total number of } \\
\text { deposits }\end{array}$ & Area, $\mathbf{~ k m}^{\mathbf{2}}$ & $\begin{array}{c}\text { Deposit density, number of } \\
\text { deposits/100,000km }\end{array}$ \\
\hline $\mathbf{3 . 5}$ & 2 & 5.5 & 29,080 & 19 \\
\hline
\end{tabular}




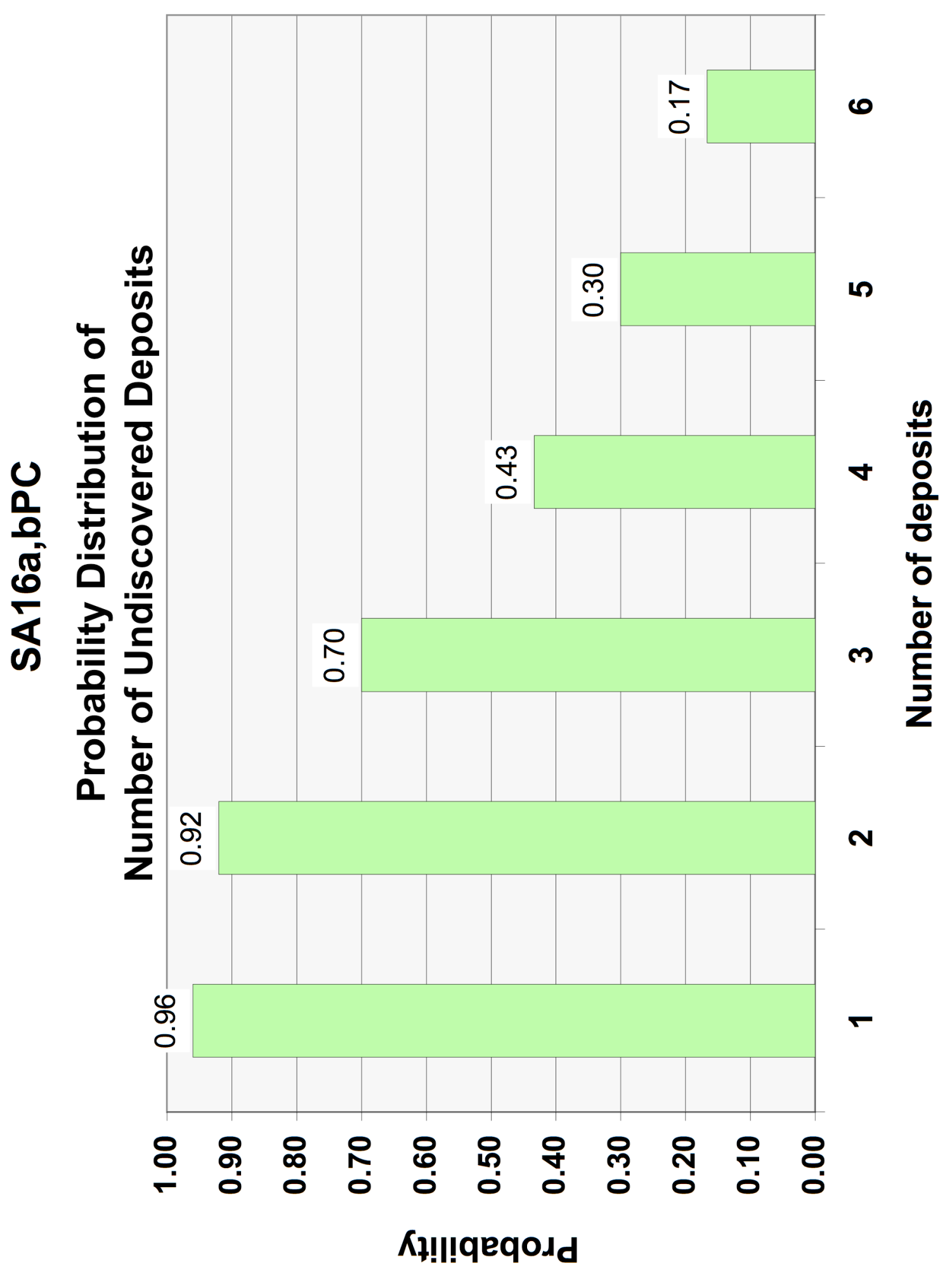




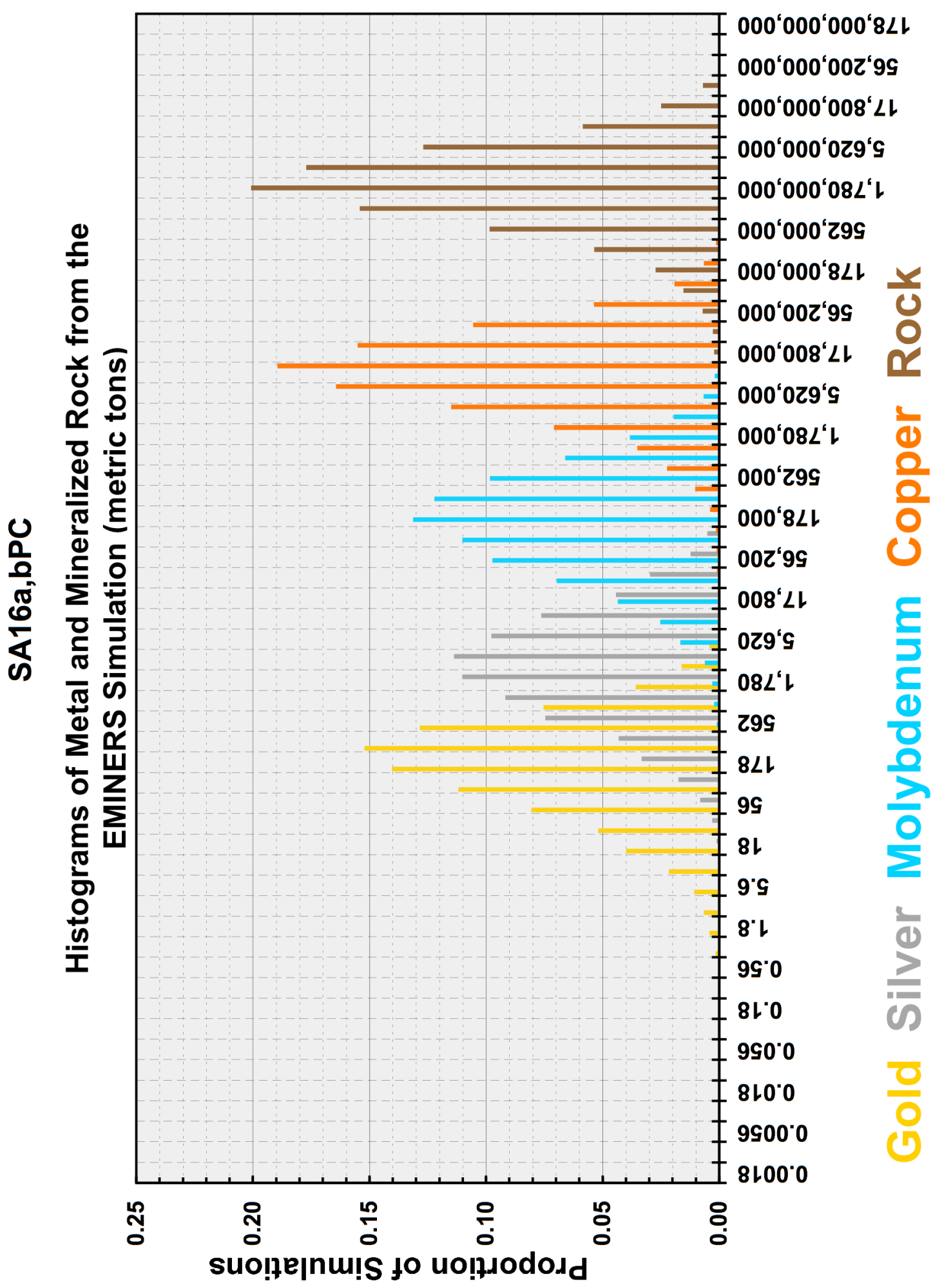




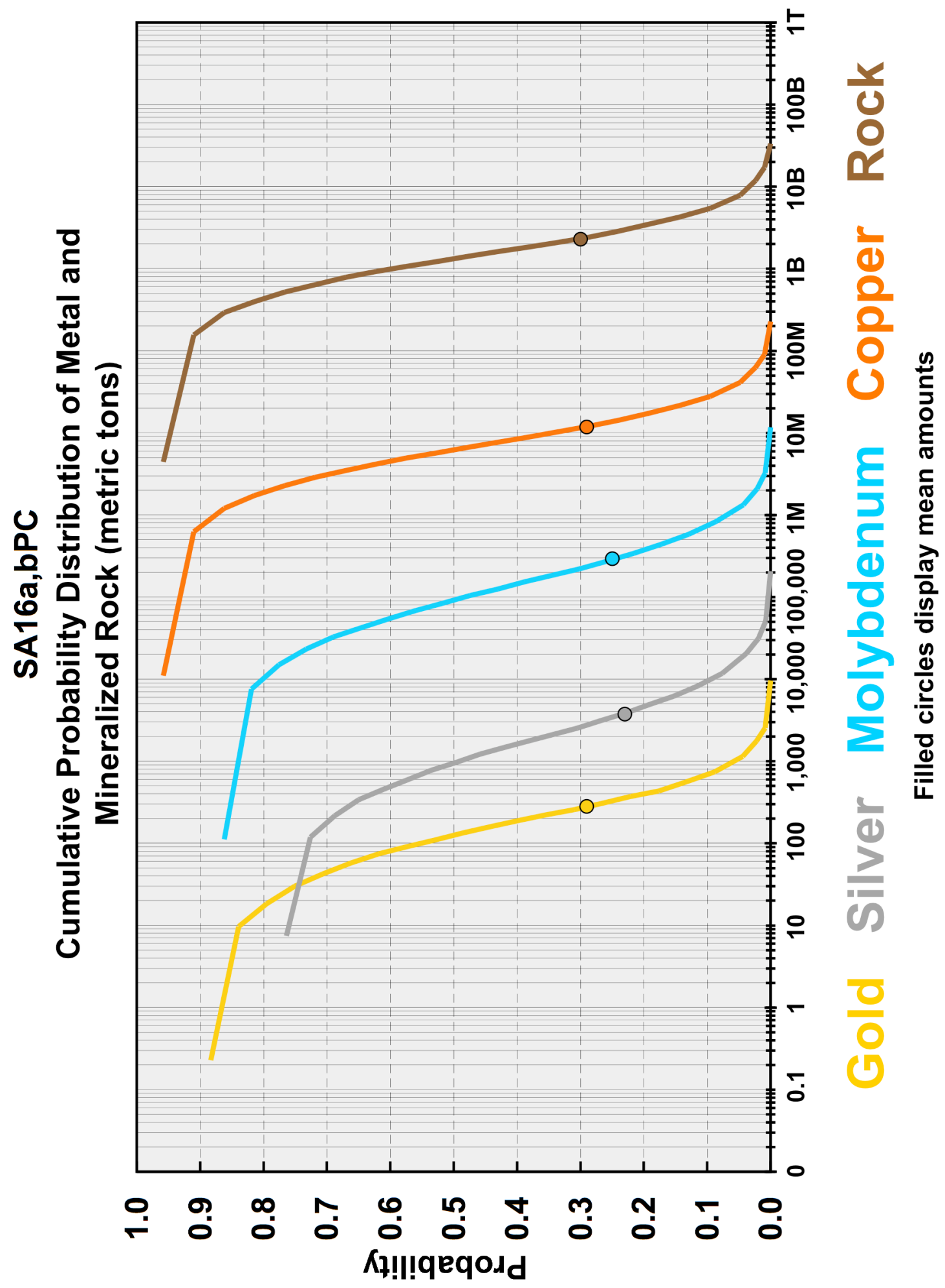




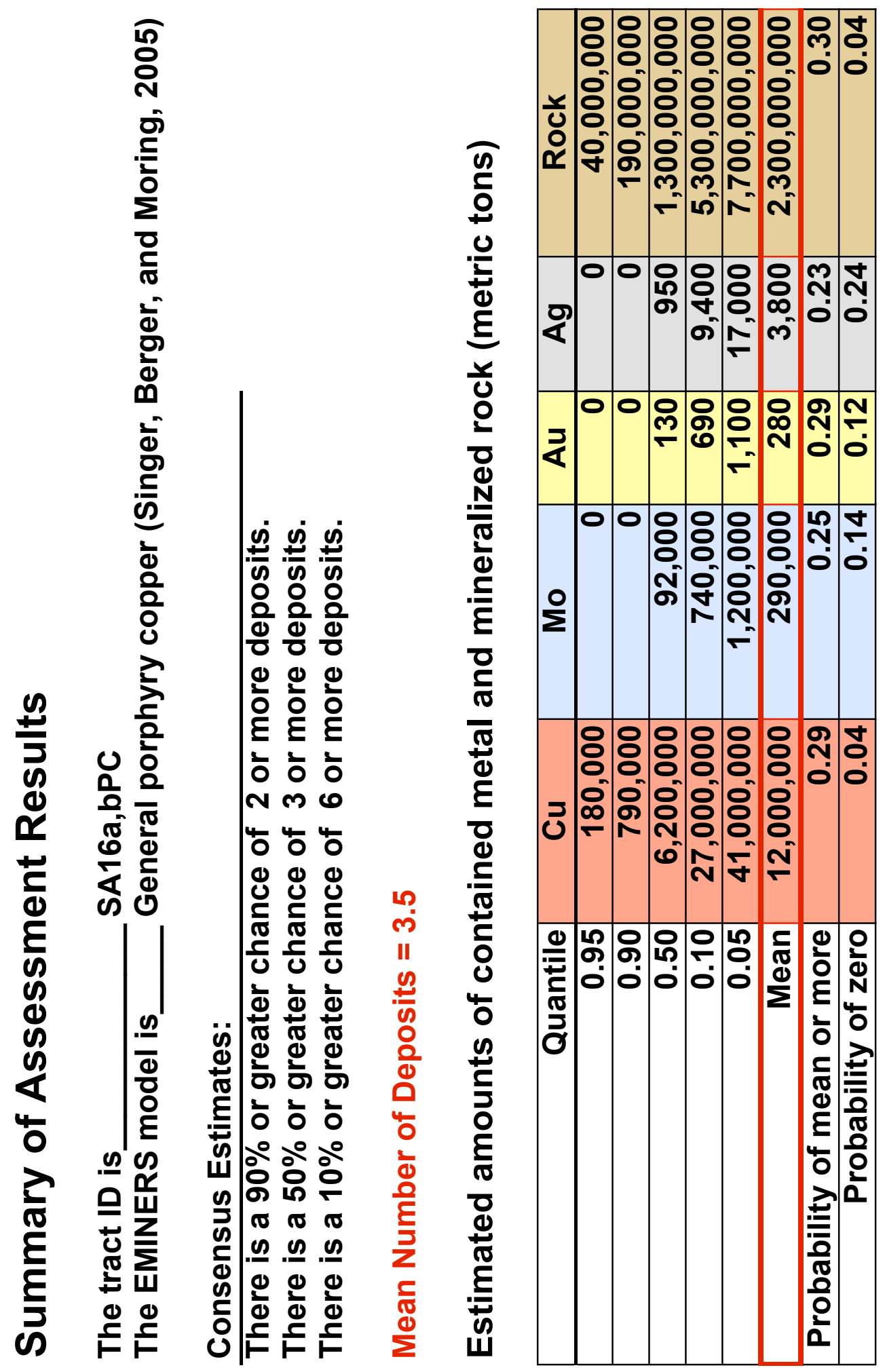




\section{Rationale for tract delineation}

Tract SA16a,bPC consists of the two geographically separate sub-tracts SA16aPC and SA16bPC, which are southern continuations of Permian tract SA18PC. Tract SA16a,bPC is defined by the distribution of Permian calc-alkaline intrusive rocks, generally of dioritic to dacitic composition, and by the distribution of volcanic and other country rocks and cover rocks within or beneath which these intrusive rocks are expected to occur within $1 \mathrm{~km}$ of the surface. Approximately 80 percent of the tract is covered by younger rocks and sediments. The Permian tracts in the Andes generally are the oldest hypogene copper-bearing tracts related to the current architecture of the subduction zone. Additional information about the geology and mineralization in the tract include Little (1995), Cardó (1999), Madrid and Williams (1999), Williams and Madrid (1999), and Williams and others (1999).

\section{Rationale for model choice}

The size and grades of the discovered porphyry copper deposits in the tract are not significantly different (table 3) from the general porphyry copper deposit model (Singer, Berger, and Moring, 2005), which therefore was used to represent the undiscovered deposits. Mineralogy, structure, and alteration in discovered deposits and prospects are typical of deposits in the general model.

\section{Deposits and prospects}

The tract contains two discovered deposits, San Jorge and La Voluntad. In addition, there are four known prospects: Alcaparrosa, Carrizal, El Salado, and Yalguaraz. Several ages have been published for San Jorge: $257 \pm 5 \mathrm{Ma}$ and $263 \pm 5 \mathrm{Ma}$ (Williams and others, 1999), and $270 \pm 4 \mathrm{Ma}$ (Sillitoe, 1977).

Hydrothermally altered rocks in the tract commonly are centered around zones of potassic alteration and extend outward through phyllic and propylitic alteration. Fine-grained tourmaline is a common component of breccia matrixes. In some deposits such as San Jorge, the influence of faulting on the emplacement of intrusions and alteration can be observed in their spatial alignment.

The tract contains Permian-Triassic tuffs and breccias spatially associated with coeval epizonal plutons providing evidence that the known porphyry copper deposits were formed near the Earth's surface and that this environment is exposed locally. The La Voluntad deposit in tract SA16bPC is hydrothermally altered and mineralized and centered around a tonalite stock.

\section{Exploration history}

Tract SA16a,bPC is moderately explored around known mineralized centers. A regional United Nations geochemical survey included the tract. Arsenic is anomalous locally and the Carrizal prospect originally was mined for this element (Rubinstein, 1999). Local geochemical surveys such as at La Voluntad defined anomalous zones of copper, gold, silver, and molybdenum (Garrido and Domínguez, 1999). Electromagnetic techniques were used at some prospects, such as Yalguaraz and San Jorge, to define and extend targets in concert with locally extensive drilling.

\section{Rationale for numerical estimate}

Members of the assessment team used their collective knowledge of numbers of discovered deposits in the tract and (or) in similar areas elsewhere in the world to make estimates throughout the tract that also were consistent with the deposit density model of Singer and others (2005). Two discovered deposits and four prospects have been found by exploration restricted mainly to known mineralized centers in exposed permissive host rocks. This suggested to the team that a number of undiscovered deposit are likely to exist in these areas as well as in relatively unexplored parts of the tract, both at depth 
in areas of exposed permissive rocks away from centers of known mineralization, and especially beneath younger rocks and sediments that cover approximately 80 percent of the tract.

\section{Expected distribution of undiscovered deposits}

Based on knowledge and information available to the team at the time of tract delineation, the probability of occurrence of an undiscovered deposit is believed to be reasonably uniform throughout most of the tract. Arguably, the focus of exploration around areas of known mineralization in exposed permissive rocks might have reduced this probability thereby discovering some or many of the deposits in such places.

\section{References cited}

Cardó, R., 1999, Distrito polimetálico Castaño Viejo, San Juan, in Zappettini, E.O., ed., Recursos minerales de la Republica Argentina: Instituto de Geología y Recursos Minerales SEGEMAR, Anales 35, Buenos Aires, p. 857-863.

Garrido, M., and Dominguez, E., 1999, El yacimiento de porfiro cuprifero La Voluntad, Neuquen, in Zappettini, E.O., ed., Recursos minerales de la Republica Argentina: Instituto de Geología y Recursos Minerales SEGEMAR, Anales 35, Buenos Aires, p. 809-818.

Little, M.L., 1995, South America, Argentina, exploration review: SEG Newsletter, no. 23, p. 29-30.

Madrid, Javier, and Williams, W.C., 1999, Pórfiro cuprifero Yalguaraz, Mendoza in Recursos Minerales de la República Argentina, Zappettini, E.,O., ed., Instituto de Geología y Resources Minerales (SEGEMAR), Anales 35, p. 789-796, Buenos Aires, Argentina.

Rubinstein, N.A., 1999, Manifestación de pórfiro cuprifero Carrizal, San Juan, in Recursos Minerales de la República Argentina, Zappettini, E,O., ed., Instituto de Geología y Resources Minerales (SEGEMAR), Anales 35, p. 785-787, Buenos Aires, Argentina.

Sillitoe, R.H., 1977, Permo-Carboniferous, Upper Cretaceous, and Miocene porphyry copper-type mineralization in the Argentine Andes: Economic Geology, v. 72, p. 99-109.

Singer, D.A., Berger, V.I., Menzie, W.D., and Berger, B.R., 2005, Porphyry copper density: Economic Geology, v. 100, no. 3, p. 491-514.

Singer, D.A., Berger, V.I., and Moring, B.C., 2005, Porphyry copper deposits of the world-Database, map, and grade and tonnage models: U.S. Geological Survey Open-file Report 2005-1060, http://pubs.usgs.gov/of/2005/1060/)

Williams, W.C., and Madrid, J., 1999, El porfiro cuprifero San Jorge, Mendoza, in Zappettini, E.O., ed., Recursos minerales de la Republica Argentina: Instituto de Geología y Recursos Minerales SEGEMAR, Anales 35, Buenos Aires, p. 797-808.

Williams, W.C., Meissl, E., Madrid, J., and de Machuca, B.C., 1999, The San Jorge porphyry copper deposit, Mendoza, Argentina: a combination of orthomagmatic and hydrothermal mineralization: Ore Geology Reviews, v. 14, p. 185-201. 


\section{TRACT SA17PC}
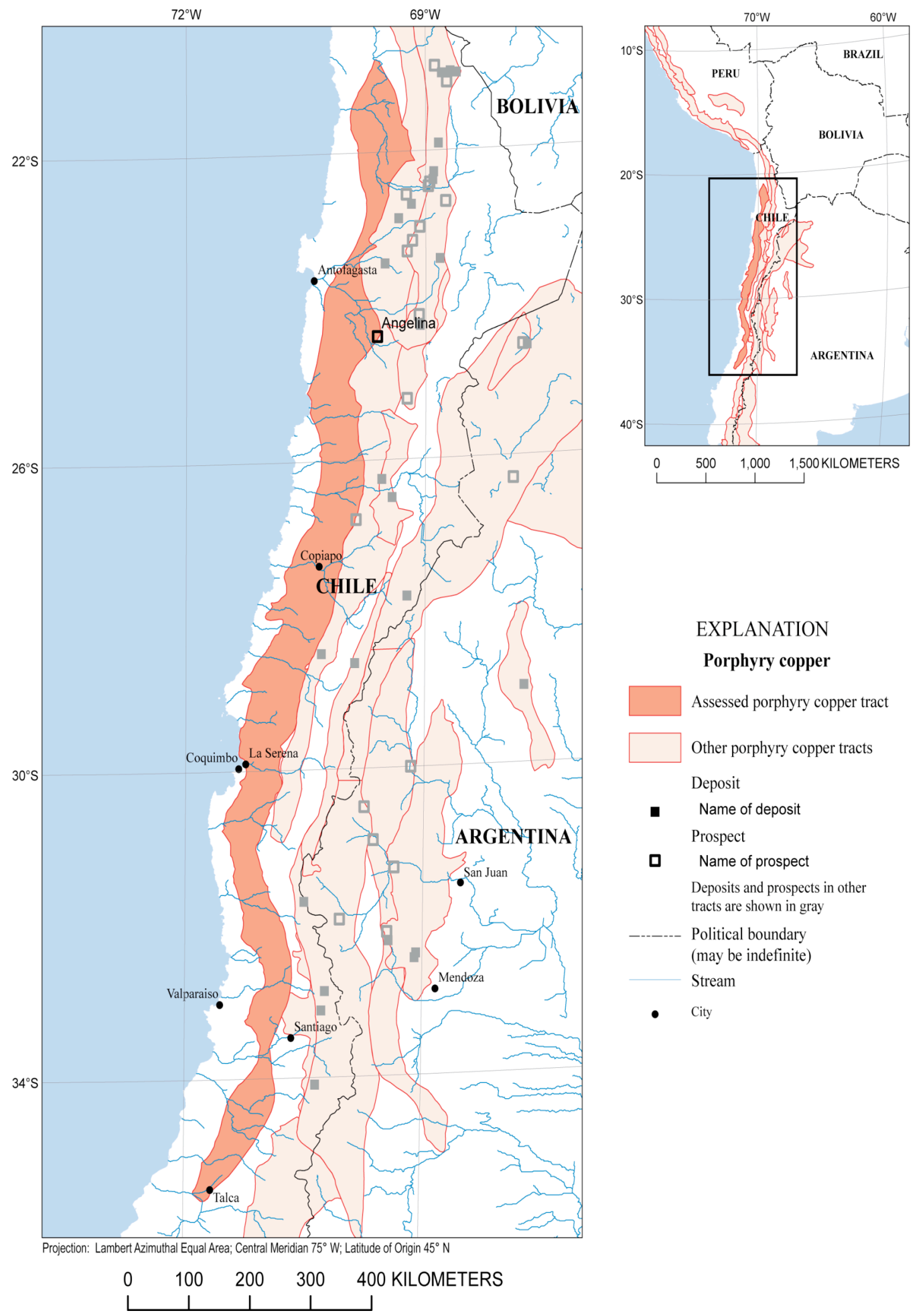

\section{EXPLANATION}

Porphyry copper

Assessed porphyry copper tract Other porphyry copper tracts Deposit

- Name of deposit Prospect

口 Name of prospect

Deposits and prospects in other tracts are shown in gray Political boundary (may be indefinite) Stream 


\section{Estimated Undiscovered Porphyry Copper Resources in Tract SA17PC- Chile}

Charles G. Cunningham, ${ }^{1}$ Eduardo 0. Zappettini, ${ }^{2}$ Waldo Vivallo S., ${ }^{3}$ Carlos Mario Celada ${ }^{4}$ Jorge Quispe ${ }^{5}$ Donald A. Singer, ${ }^{1}$ Joseph A Briskey, ${ }^{1}$ David M. Sutphin, ${ }^{1}$ Mariano Gajardo M., ${ }^{3}$ Alejandro Diaz, ${ }^{3}$ Carlos Portigliati, ${ }^{3}$ Vladimir I. Berger, ${ }^{1}$ Rodrigo Carrasco $0,{ }^{3}$ and Klaus J. Schulz ${ }^{1}$

'USA-U.S. Geological Survey (USGS)

${ }^{2}$ Argentina - Instituto de Geología y Recursos Minerales (SEGEMAR)

${ }^{3}$ Chile-Servicio Nacional de Geología y Minería (SERNAGEOMIN)
${ }^{4}$ Colombia-Instituto Colombiano de Geología y Minería (INGEOMINAS)

${ }^{5}$ Peru-Instituto Geológico Minero y Metalúrgico (INGEMMET)

\begin{tabular}{|l|l|}
\hline Deposit type assessed: Porphyry Copper & $\begin{array}{l}\text { Model: General porphyry copper deposit model } \\
\text { (Singer, Berger, and Moring, 2005) }\end{array}$ \\
\hline Tract name: Chile Cretaceous Antucoya & Countries: Chile \\
\hline Tract ID: SA17PC & Region: South America \\
\hline Date of assessment: May 16-18, 2005 & Date of last revision: \\
\hline Assessment depth: $1 \mathrm{~km}$ & \\
\hline Assessment team leader: Donald A. Singer & Regional coordinator: Charles G. Cunningham \\
\hline $\begin{array}{l}\text { Estimators: Carlos Mario Celada, Vladimir I. Berger, Rodrigo Carrasco, Alejandro Diaz, Mariano } \\
\text { Gajardo M., Carlos Portigliati, Donald A. Singer, Waldo Vivallo S., and Eduardo O. Zappettini. }\end{array}$ \\
\hline
\end{tabular}

Table of estimated numbers of undiscovered deposits by quantile. Also showing calculated mean $(m)$, standard deviation $(s)$, and coefficient of variation in percent $(C v \%)$. Sorted by mean.

\begin{tabular}{|l|r|r|r|r|r|c|}
\hline \multicolumn{1}{|c|}{ Estimators } & $\mathbf{9 0}$ & $\mathbf{5 0}$ & $\mathbf{1 0}$ & $\boldsymbol{m}$ & $\boldsymbol{s}$ & $\mathbf{C v} \%$ \\
\hline Estimator & 2 & 4 & 8 & 4.5 & 2.3 & 51 \\
\hline Estimator & 1 & 3 & 12 & 5.0 & 4.2 & 84 \\
\hline Estimator & 2 & 5 & 10 & 5.5 & 3.0 & 55 \\
\hline Estimator & 3 & 6 & 8 & 5.5 & 1.9 & 35 \\
\hline Estimator & 3 & 6 & 9 & 5.8 & 2.3 & 40 \\
\hline Estimator & 2 & 5 & 13 & 6.4 & 4.1 & 64 \\
\hline Consensus of estimators & $\mathbf{3}$ & $\mathbf{6}$ & $\mathbf{1 2}$ & $\mathbf{6 . 7}$ & $\mathbf{3 . 4}$ & $\mathbf{5 1}$ \\
\hline Estimator & 4 & 7 & 12 & 7.3 & 3.1 & 42 \\
\hline Estimator & 2 & 7 & 20 & 9.3 & 6.6 & 71 \\
\hline Estimator & 5 & 10 & 18 & 11 & 4.8 & 44 \\
\hline
\end{tabular}

\section{Deposit density table}

\begin{tabular}{|c|c|c|c|c|}
\hline $\begin{array}{c}\text { Mean of consensus estimates of } \\
\text { undiscovered deposits }\end{array}$ & $\begin{array}{c}\text { Number of } \\
\text { discovered } \\
\text { deposits }\end{array}$ & $\begin{array}{c}\text { Total number of } \\
\text { deposits }\end{array}$ & Area, $\mathbf{k m}^{\mathbf{2}}$ & $\begin{array}{c}\text { Deposit density, number of } \\
\text { deposits/100,000 } \mathbf{k m}^{2}\end{array}$ \\
\hline $\mathbf{6 . 7}$ & 0 & 6.7 & 77,511 & 9 \\
\hline
\end{tabular}




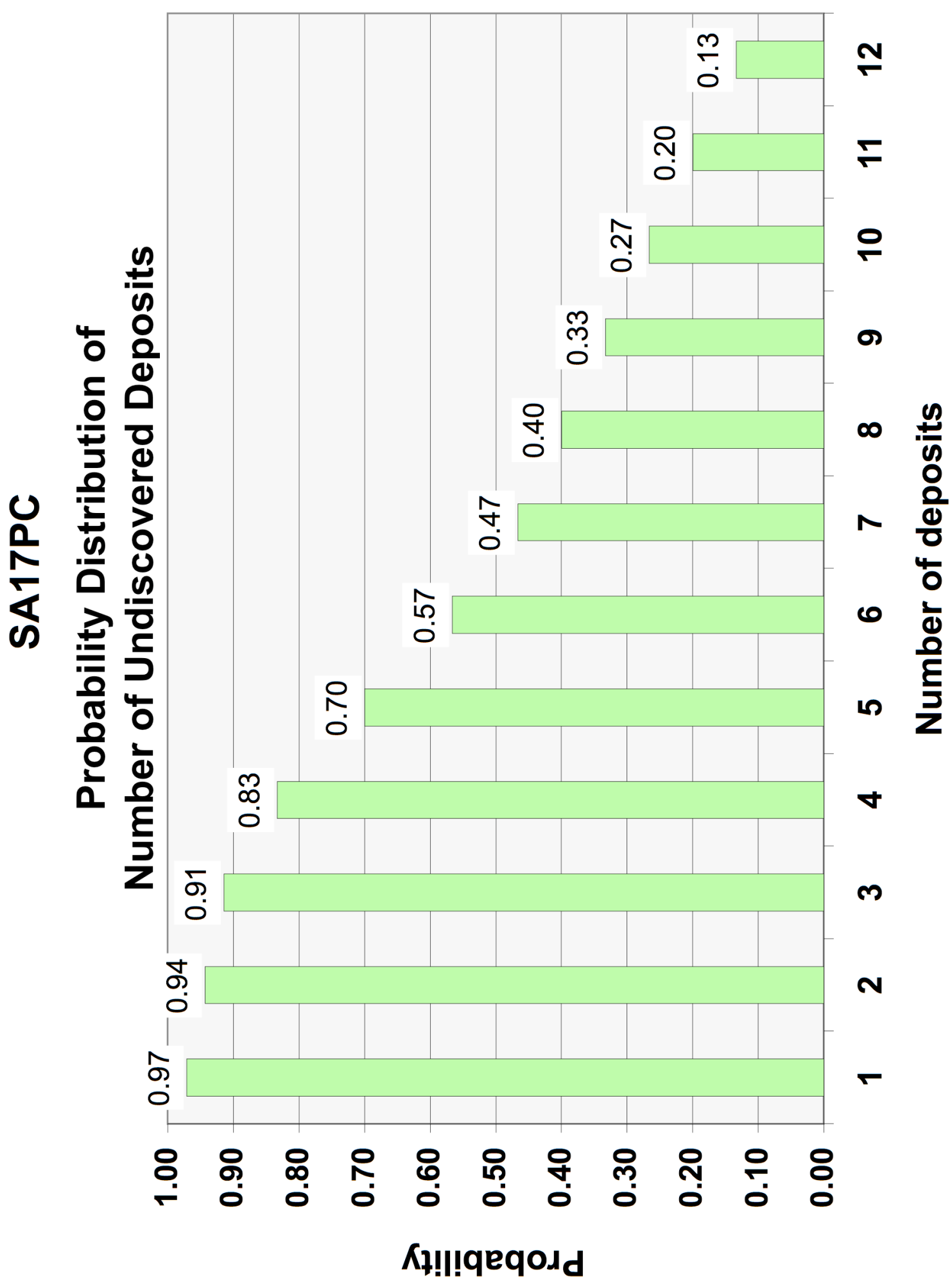




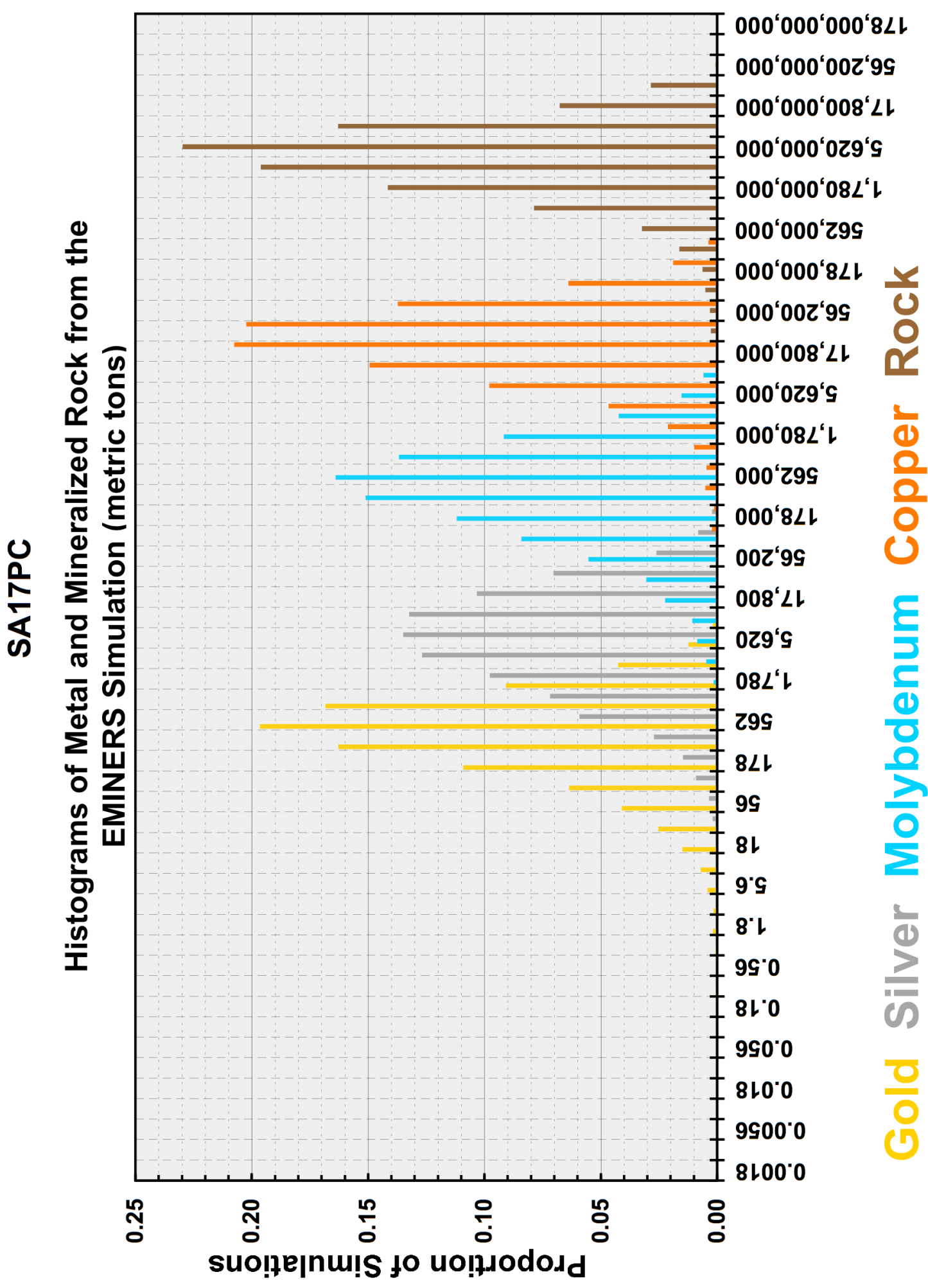




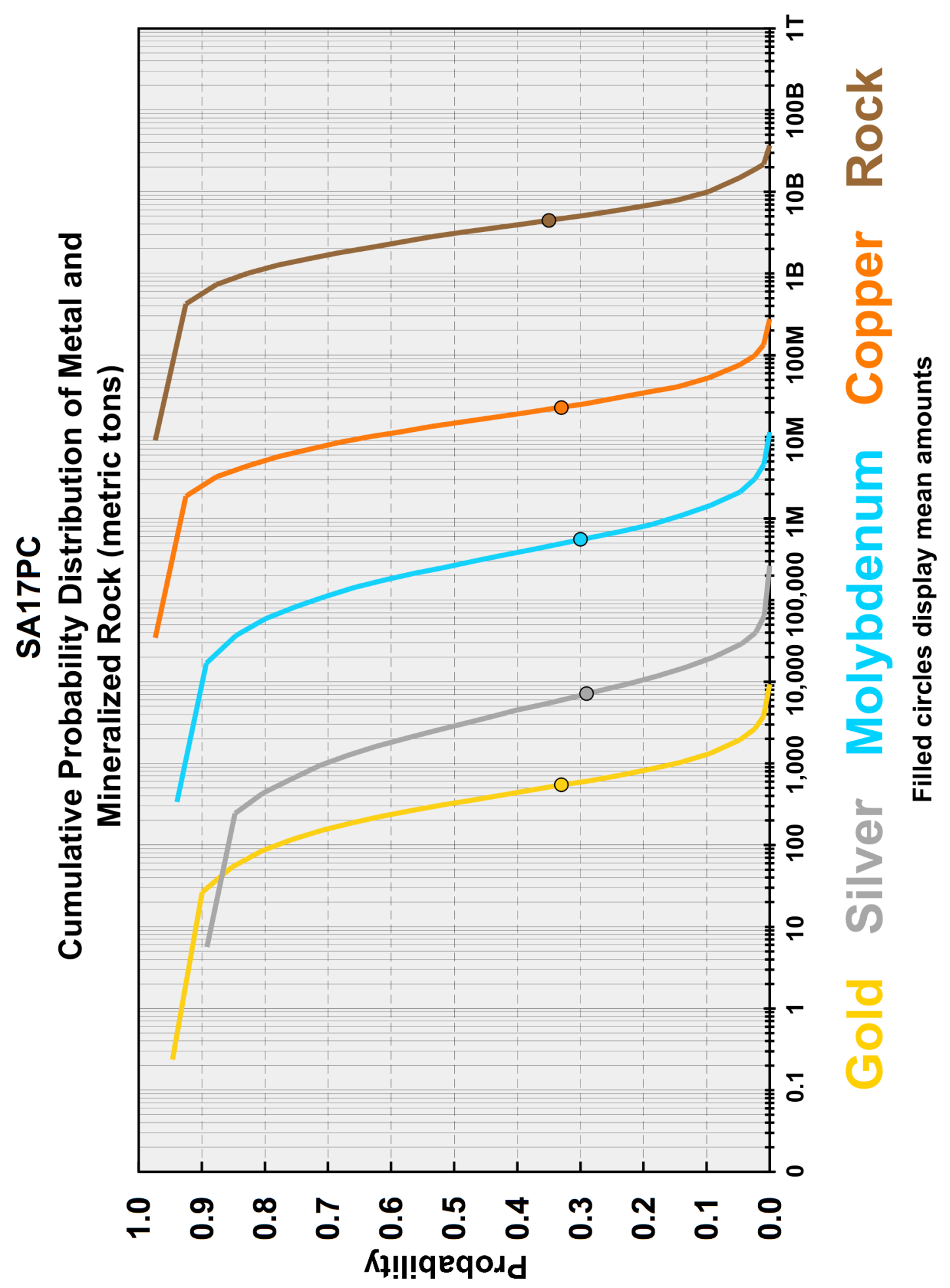




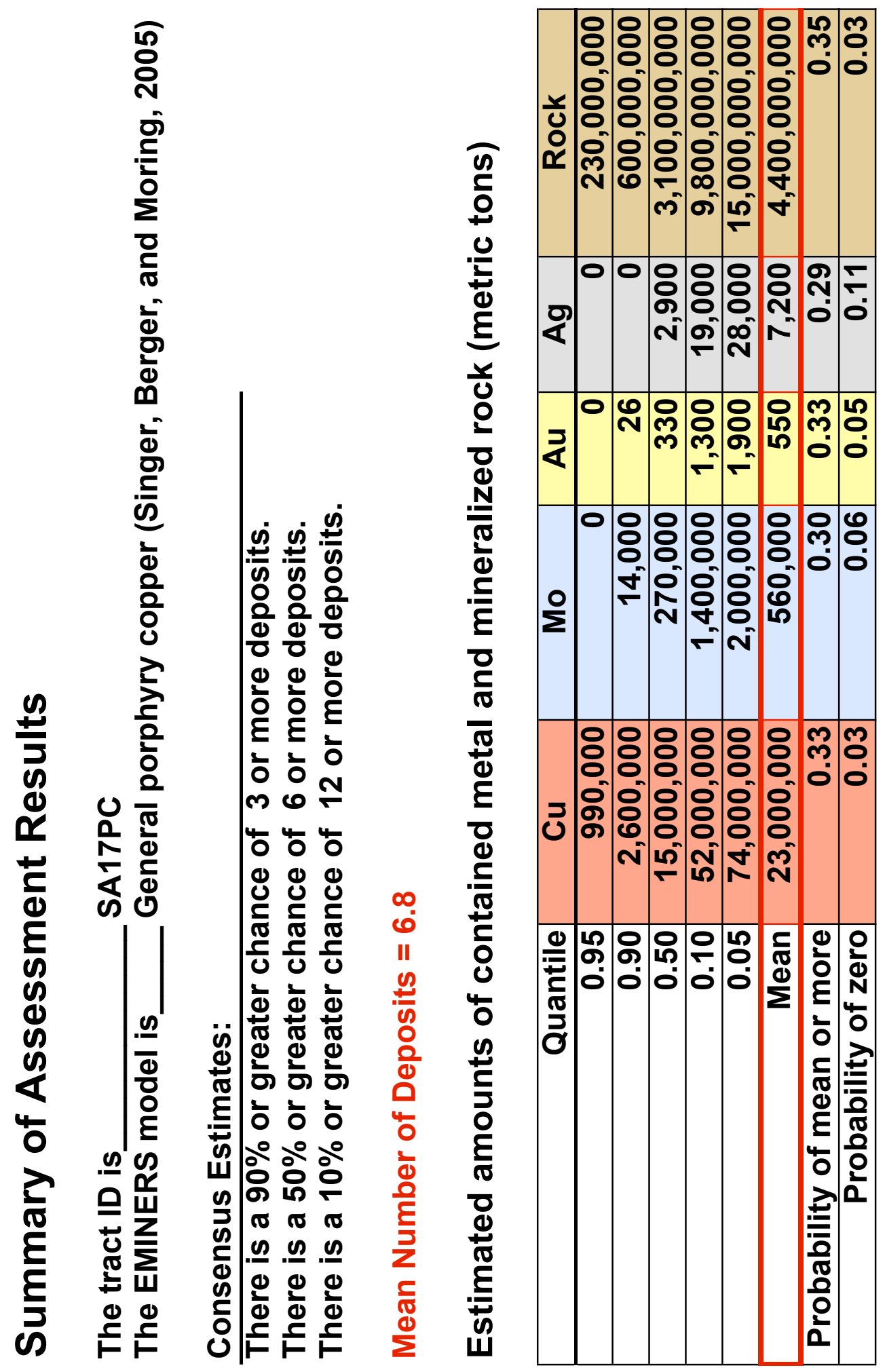




\section{Rationale for tract delineation}

This tract is defined by the distribution of Cretaceous calc-alkalic plutons, including batholiths, and by the distribution of volcanic and other country rocks and cover rocks, within or beneath which such plutons are expected to occur within $1 \mathrm{~km}$ of the surface. About 25 percent of the tract is covered by younger rocks and sediments. Many of the Jurassic volcanic and plutonic rocks that are widespread in western Chile occur among the country rocks in the tract. It is possible that future studies of these older rocks could someday identify additional igneous arcs permissive for the occurrence of undiscovered porphyry copper deposits.

\section{Rationale for model choice}

Because the tract contains no discovered deposits, and there was no reason to reject the general porphyry copper deposit model (Singer, Berger, and Moring, 2005), this model was used to represent the undiscovered deposits.

\section{Deposits and prospects}

At the time of the assessment, the tract was known to contain only one prospect, Angelina, which has not been dated. Subsequently, two additional porphyry copper prospects were recognized. Both of these new prospects are fairly well explored and have been dated: Antucoya-Buey Muerto (132-137 Ma), and Puntiallas-Galenosa (118-132 Ma) (Perelló, Martini, and Muhr, 2003).

\section{Exploration history}

The tract is moderately explored around known mineralized areas. A United Nations geochemical survey was conducted in the tract.

\section{Rationale for numerical estimate}

Analogies with numbers of deposits known in similar areas that team members have studied elsewhere, together with reference to the deposit density model of Singer and others (2005), helped guide the estimates of undiscovered porphyry copper deposits in the tract. For several reasons, the estimating team expects that a number of undiscovered deposits are likely to occur in the tract. At the time of assessment, a porphyry copper prospect had been found in the tract, thus demonstrating that the mineralizing processes that form porphyry copper deposits were active in the tract's host rocks.

Moreover, exploration in this large tract has been restricted mainly to known mineralized areas in exposed permissive host rocks. The tract is relatively unexplored elsewhere, including at depth around areas of known mineralization and especially beneath the approximately 25 percent of the tract that is covered by younger rocks and sediments. The estimated number of undiscovered deposits in the tract is somewhat small for a tract this large, which mainly reflects the team's evaluation that relatively deep erosion of the plutons and batholiths probably has removed a number of deposits.

\section{Expected distribution of undiscovered deposits}

Based on knowledge and information available to the team at the time of tract delineation, the probability of occurrence of an undiscovered deposit is believed to be reasonably uniform throughout most of the tract. 


\section{References cited}

Perelló, J., Martini, R., and Muhr, R., 2003, Buey Muerto: Porphyry copper mineralization in the early Cretaceous arc of northern Chile [abs.]: 10th Congresso Geológico Chileno, Concepción, 2003, CDROM, 1 p.

Singer, D.A., Berger, V.I., Menzie, W.D., and Berger, B.R., 2005, Porphyry copper density: Economic Geology, v. 100, no. 3, p. 491-514.

Singer, D.A., Berger, V.I., and Moring, B.C., 2005, Porphyry copper deposits of the world-Database, map, and grade and tonnage models: U.S. Geological Survey Open-file Report 2005-1060, http://pubs.usgs.gov/of/2005/1060/) 


\section{TRACT SA18PC}

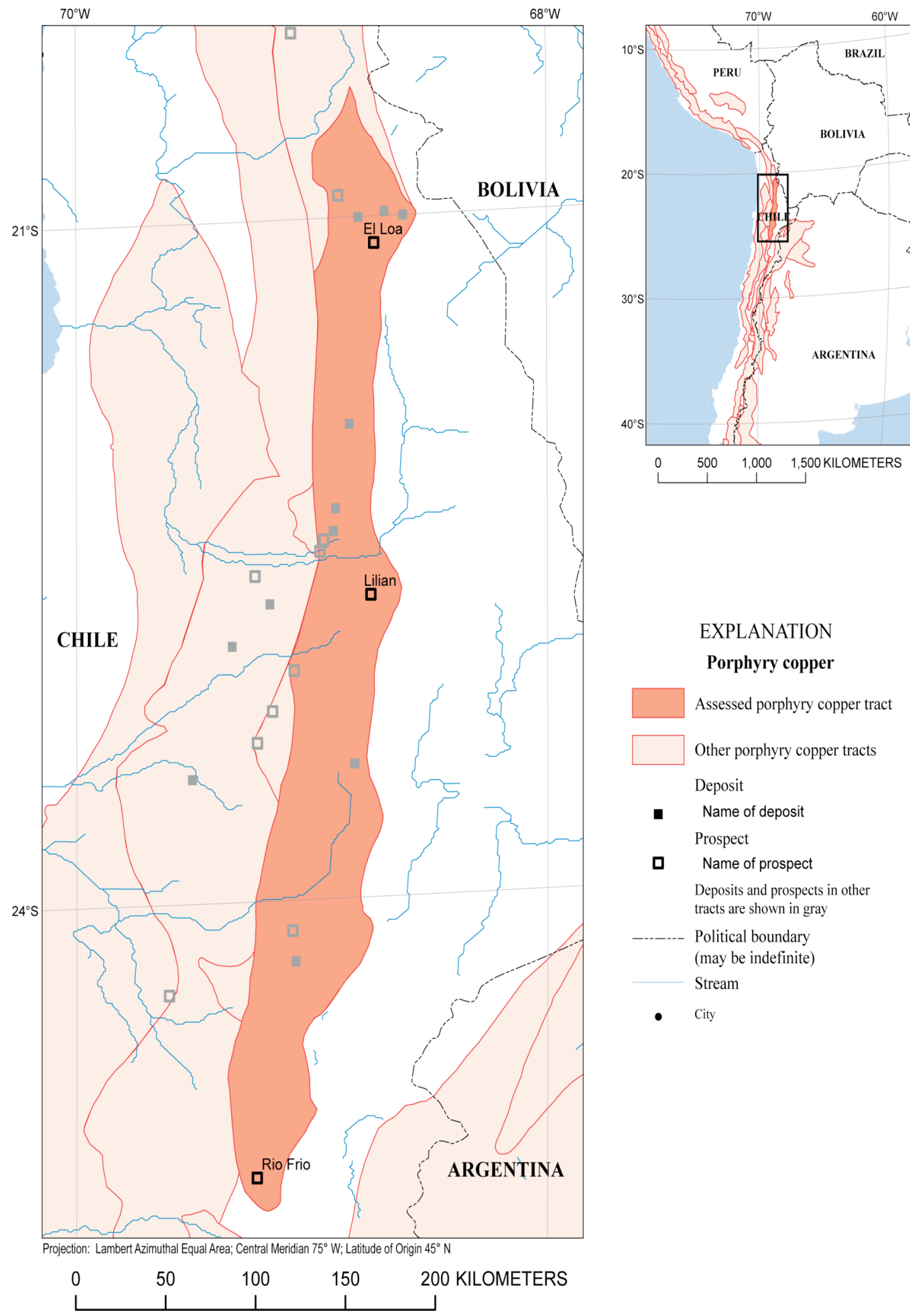




\section{Estimated Undiscovered Porphyry Copper Resources in Tract SA18PC- Chile}

Charles G. Cunningham, ${ }^{1}$ Eduardo 0. Zappettini, ${ }^{2}$ Waldo Vivallo S., ${ }^{3}$ Carlos Mario Celada ${ }^{4}$ Jorge Quispe ${ }^{5}$ Donald A. Singer, ${ }^{1}$ Joseph A Briskey, ${ }^{1}$ David M. Sutphin, ${ }^{1}$ Mariano Gajardo M., ${ }^{3}$ Alejandro Diaz, ${ }^{3}$ Carlos Portigliati, ${ }^{3}$ Vladimir I. Berger, ${ }^{1}$ Rodrigo Carrasc $0,{ }^{3}$ and Klaus J. Schulz

'USA-U.S. Geological Survey (USGS)

${ }^{2}$ Argentina - Instituto de Geología y Recursos Minerales (SEGEMAR)

${ }^{3}$ Chile-Servicio Nacional de Geología y Minería (SERNAGEOMIN)
${ }^{4}$ Colombia-Instituto Colombiano de Geología y Minería (INGEOMINAS)

${ }^{5}$ Peru-Instituto Geológico Minero y Metalúrgico (INGEMMET)

\begin{tabular}{|l|l|}
\hline Deposit type assessed: Porphyry Copper & $\begin{array}{l}\text { Model: General porphyry copper deposit model } \\
\text { (Singer, Berger, and Moring, 2005) }\end{array}$ \\
\hline Tract name: Chile Permian El Loa & Countries: Chile \\
\hline Tract ID: SA18PC & Region: South America \\
\hline Date of assessment: May 16-18, 2005 & Date of last revision: \\
\hline Assessment depth: $1 \mathrm{~km}$ & \\
\hline Assessment team leader: Donald A. Singer & Regional coordinator: Charles G. Cunningham \\
\hline $\begin{array}{l}\text { Estimators: Carlos Mario Celada, Vladimir I. Berger, Rodrigo Carrasco, Alejandro Diaz, Mariano } \\
\text { Gajardo M., Carlos Portigliati, Donald A. Singer, Waldo Vivallo S., and Eduardo O. Zappettini. }\end{array}$ \\
\hline
\end{tabular}

Table of estimated numbers of undiscovered deposits by quantile. Also showing calculated mean $(\mathrm{m})$, standard deviation $(s)$, and coefficient of variation in percent $(C v \%)$. Sorted by mean.

\begin{tabular}{|l|c|c|c|c|c|c|}
\hline \multicolumn{1}{|c|}{ Estimators } & $\mathbf{9 0}$ & $\mathbf{5 0}$ & $\mathbf{1 0}$ & $\boldsymbol{m}$ & $\boldsymbol{s}$ & $\boldsymbol{C} \boldsymbol{c}$ \\
\hline Estimator & 0 & 0 & 1 & 0.30 & 0.50 & 170 \\
\hline Estimator & 0 & 1 & 2 & 1.0 & 0.79 & 79 \\
\hline Estimator & 0 & 1 & 3 & 1.3 & 1.2 & 92 \\
\hline Estimator & 0 & 1 & 3 & 1.3 & 1.2 & 92 \\
\hline Estimator & 1 & 2 & 3 & 1.9 & 0.84 & 44 \\
\hline Estimator & 1 & 2 & 4 & 2.2 & 1.2 & 55 \\
\hline Consensus of estimators & $\mathbf{1}$ & $\mathbf{2}$ & $\mathbf{4}$ & $\mathbf{2 . 2}$ & $\mathbf{1 . 2}$ & $\mathbf{5 5}$ \\
\hline Estimator & 1 & 3 & 5 & 2.9 & 1.5 & 52 \\
\hline Estimator & 2 & 4 & 5 & 3.6 & 1.2 & 33 \\
\hline Estimator & 1 & 3 & 8 & 3.8 & 2.6 & 68 \\
\hline
\end{tabular}

\section{Deposit density table}

\begin{tabular}{|c|c|c|c|c|}
\hline $\begin{array}{c}\text { Mean of consensus estimates of } \\
\text { undiscovered deposits }\end{array}$ & $\begin{array}{c}\text { Number of } \\
\text { discovered } \\
\text { deposits }\end{array}$ & $\begin{array}{c}\text { Total number of } \\
\text { deposits }\end{array}$ & Area, $\mathbf{~ k m}^{\mathbf{2}}$ & $\begin{array}{c}\text { Deposit density, number of } \\
\text { deposits/100,000km }\end{array}$ \\
\hline $\mathbf{2 . 2}$ & 0 & 2.2 & 17,765 & 12 \\
\hline
\end{tabular}




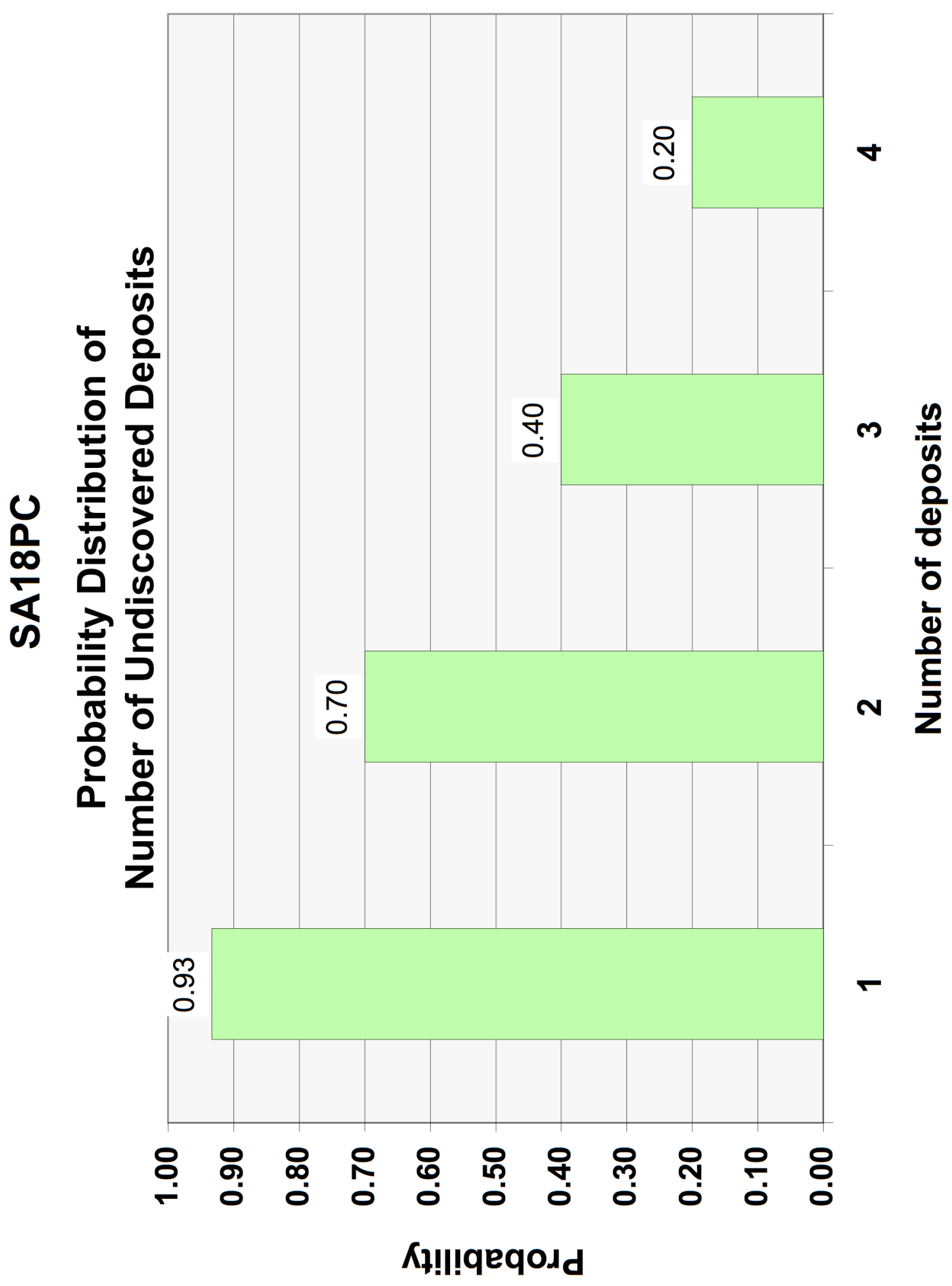




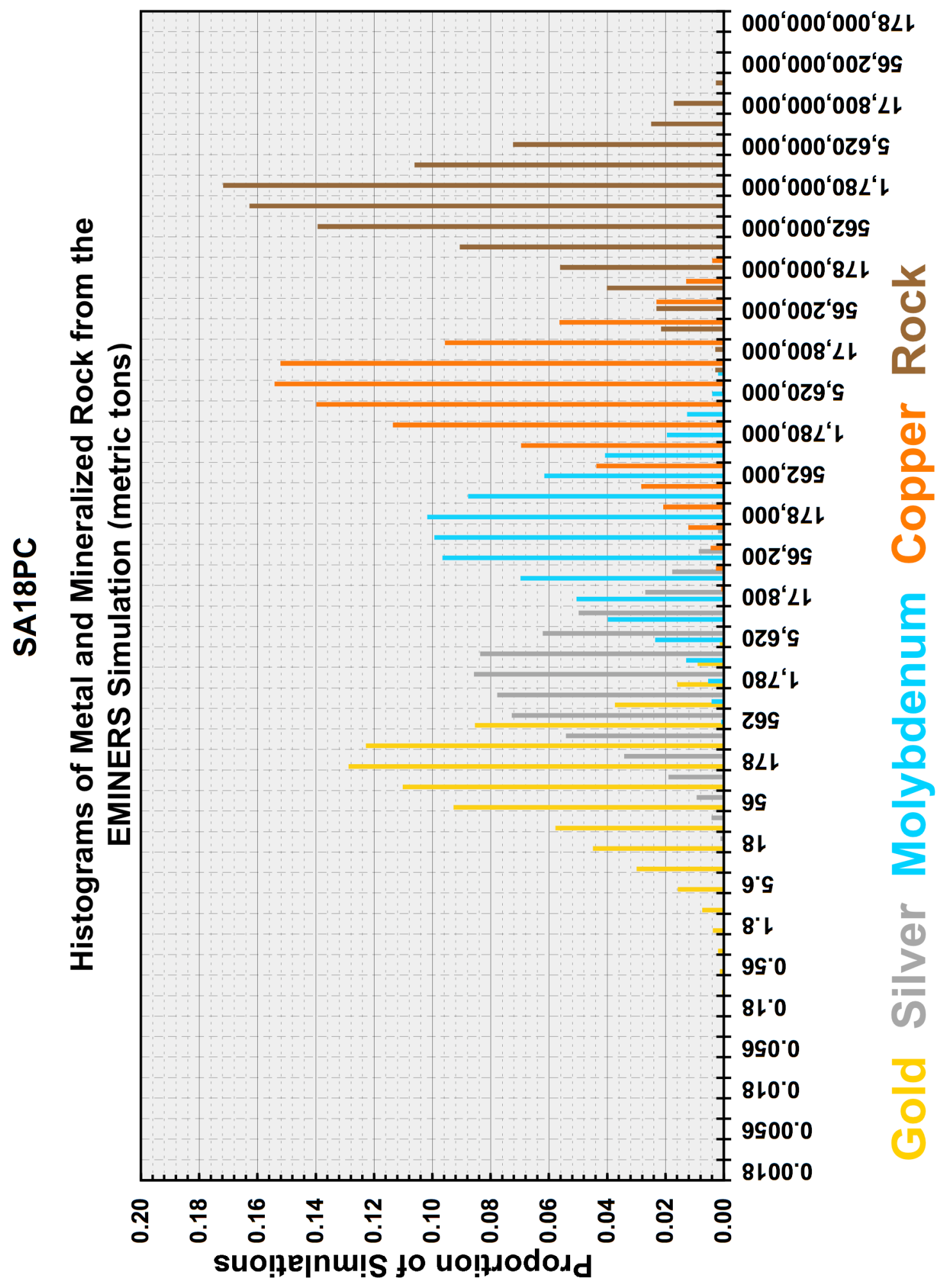




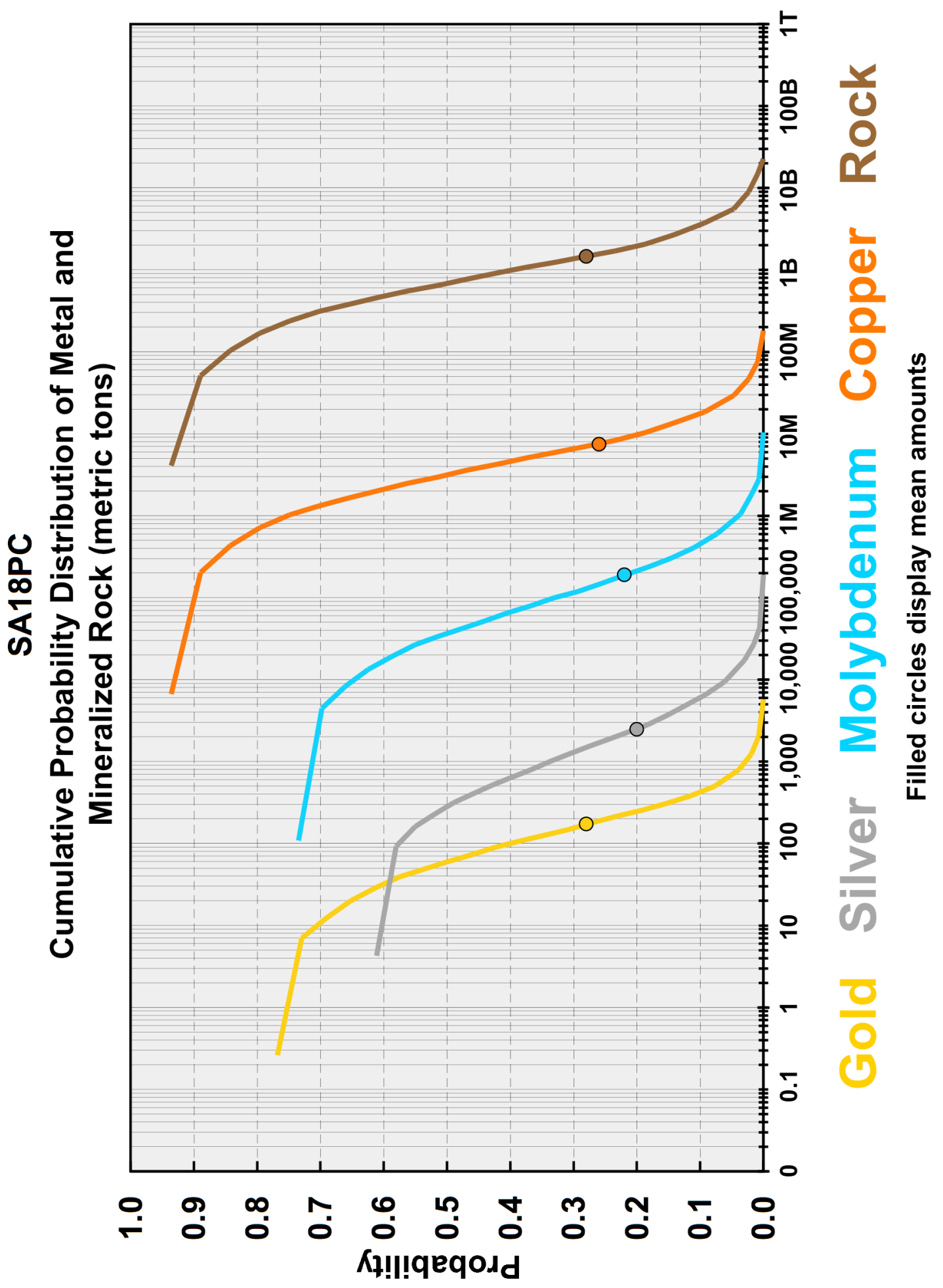




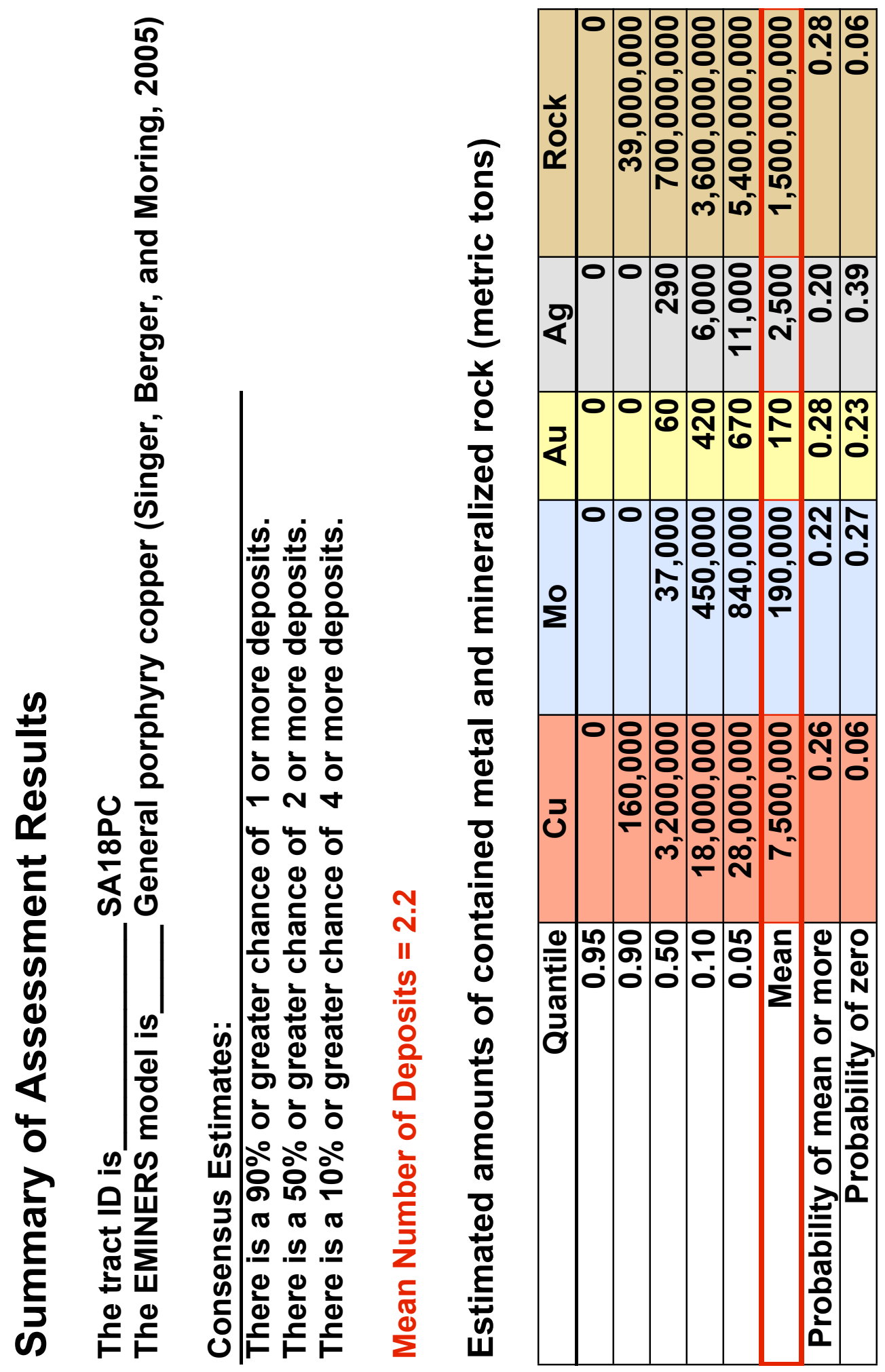




\section{Rationale for tract delineation}

This tract is defined by the distribution of Permian calc-alkaline plutons and by the distribution of volcanic and other country rocks and cover rocks within or beneath which such plutons are expected to occur within $1 \mathrm{~km}$ of the surface. The location of the tract coincides largely with that of tract SA10a,bPC, which contains the largest amount of porphyry copper of any tract in the Andes. There has been speculation that pre-existing copper mineralization or copper-enriched host rocks in tract SA18PC may have contributed to the unusually large average size and grades of the discovered porphyry copper deposits in tract SA10a,bPC. About 50 percent of the tract is covered by younger rocks and sediments.

\section{Rationale for model choice}

Because the tract contains no discovered deposits, and there was no reason to reject the general porphyry copper deposit model (Singer, Berger, and Moring, 2005), this model was used to represent the undiscovered deposits. Porphyry copper prospects in the tract have geological characteristics like those of deposits in the general model (Camus, 2002).

\section{Deposits and prospects}

The tract has three porphyry copper prospects: El Loa, Lilian, and Rio Frio.

\section{Exploration history}

There has been moderate exploration specific to exposed Permian host rocks and their country rocks only around known mineralized centers of this age. However, the tract is spatially coincident with tract SA10a,bPC, which is intensely explored. The tract also has been covered by a regional geochemical survey conducted by the United Nations.

\section{Rationale for numerical estimate}

Analogies with numbers of deposits known in similar areas that team members have studied elsewhere, together with reference to the deposit density model of Singer and others (2005), helped guide the estimates of undiscovered porphyry copper deposits in the tract.

The estimating team expects the tract to contain relatively few undiscovered deposits for its size. Although the tract contains three porphyry copper prospects, there are no discovered deposits. Moreover, while the exposed Permian host and country rocks are not well explored outside of known mineralized centers, the tract is spatially coincident with most of tract SA10aPC, which is intensely explored to the point that the team believes undiscovered porphyry copper deposits of any age are unlikely to exist at or near the surface.

\section{Expected distribution of undiscovered deposits}

The probability of occurrence of an undiscovered deposit is not uniform throughout the tract. Because of the intense exploration in spatially coincident tract SA10a,bPC, there is a high probability that undiscovered deposits estimated for tract SA18PC will occur in the 50 percent of the tract covered by younger rocks.

\section{References cited}

Camus F., 2002, The Andean porphyry systems, in Cooke, David., and Pongratz, J., eds., Giant ore deposits: characteristics, genesis and exploration: Centre for Ore Deposit Research Special Publication 4, University of Tasmania, Hobart. 
Singer, D.A., Berger, V.I., Menzie, W.D., and Berger, B.R., 2005, Porphyry copper density: Economic Geology, v. 100, no. 3, p. 491-514.

Singer, D.A., Berger, V.I., and Moring, B.C., 2005, Porphyry copper deposits of the world-Database, map, and grade and tonnage models: U.S. Geological Survey Open-file Report 2005-1060, http://pubs.usgs.gov/of/2005/1060/) 


\section{TRACT SA19PC}
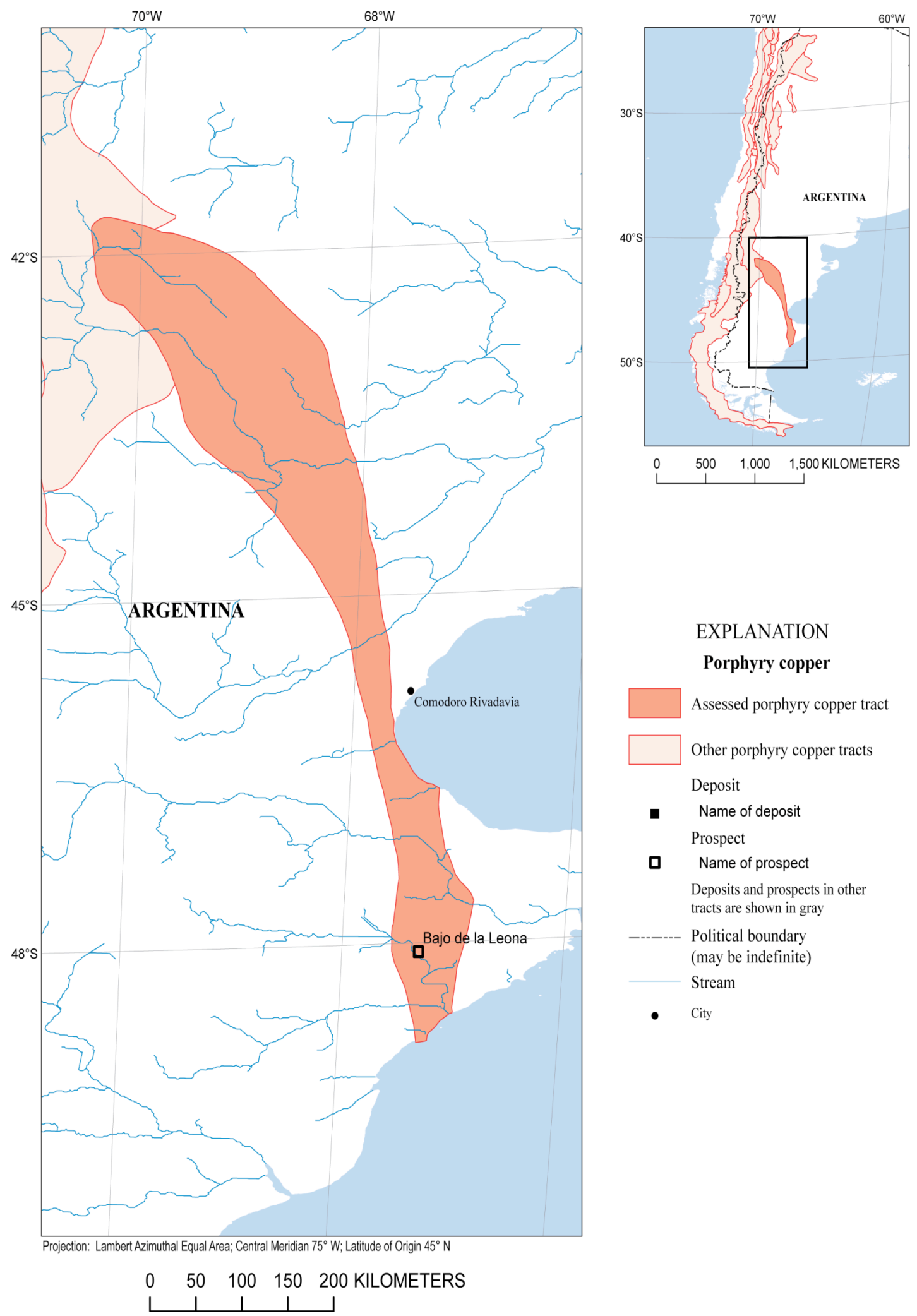

\section{EXPLANATION}

Porphyry copper

Assessed porphyry copper tract Other porphyry copper tracts Deposit

- Name of deposit Prospect

- Name of prospect Deposits and prospects in other tracts are shown in gray Political boundary (may be indefinite) Stream

- $\quad$ City 


\section{Estimated Undiscovered Porphyry Copper Resources in Tract SA19PC— Argentina}

Charles G. Cunningham, ${ }^{1}$ Eduardo 0. Zappettini, ${ }^{2}$ Waldo Vivallo S., ${ }^{3}$ Carlos Mario Celada, ${ }^{4}$ Jorge Quispe ${ }^{5}$ Donald A. Singer, ${ }^{1}$ Joseph A Briskey, ${ }^{1}$ David M. Sutphin, ${ }^{1}$ Mariano Gajardo M., ${ }^{3}$ Alejandro Diaz, ${ }^{3}$ Carlos Portigliati, ${ }^{3}$ Vladimir I. Berger, ${ }^{1}$ Rodrigo Carrasco, ${ }^{3}$ and Klaus J. Schulz ${ }^{1}$

'USA-U.S. Geological Survey (USGS)

${ }^{2}$ Argentina - Instituto de Geología y Recursos Minerales (SEGEMAR)

${ }^{3}$ Chile-Servicio Nacional de Geología y Minería (SERNAGEOMIN)
${ }^{4}$ Colombia-Instituto Colombiano de Geología y Minería (INGEOMINAS)

${ }^{5}$ Peru-Instituto Geológico Minero y Metalúrgico (INGEMMET)

\begin{tabular}{|l|l|}
\hline Deposit type assessed: Porphyry Copper & $\begin{array}{l}\text { Model: General porphyry copper deposit model } \\
\text { (Singer, Berger, and Moring, 2005) }\end{array}$ \\
\hline $\begin{array}{l}\text { Tract name: Argentina, Late Triassic to Middle } \\
\text { Jurassic, Bajo de la Leona }\end{array}$ & Countries: Argentina \\
\hline Tract ID: SA19PC & Region: South America \\
\hline Date of assessment: July 11, 2006 & Date of last revision: \\
\hline Assessment depth: 1 km & \\
\hline Assessment team leader: Donald A. Singer & Regional coordinator: Charles G. Cunningham \\
\hline Estimators: Eduardo O. Zappettini, Charles G. Cunningham, Carlos Mario Celada, and Donald A. Singer \\
\hline
\end{tabular}

Table of estimated numbers of undiscovered deposits by quantile. Also showing calculated mean $(m)$, standard deviation $(s)$, and coefficient of variation in percent $(C v \%)$. Sorted by mean.

\begin{tabular}{|l|c|c|c|c|c|c|}
\hline \multicolumn{1}{|c|}{ Estimators } & $\mathbf{9 0}$ & $\mathbf{5 0}$ & $\mathbf{1 0}$ & $\boldsymbol{m}$ & $\boldsymbol{s}$ & $\boldsymbol{C v} \%$ \\
\hline Estimator & 0 & 1 & 2 & 1.0 & 0.79 & 79 \\
\hline Estimator & 0 & 1 & 3 & 1.3 & 1.2 & 92 \\
\hline Estimator & 0 & 1 & 3 & 1.3 & 1.2 & 92 \\
\hline Consensus of estimators & $\mathbf{0}$ & $\mathbf{1}$ & $\mathbf{4}$ & $\mathbf{1 . 6}$ & $\mathbf{1 . 5}$ & $\mathbf{9 4}$ \\
\hline Estimator & 0 & 2 & 6 & 2.6 & 2.2 & 85 \\
\hline
\end{tabular}

\section{Deposit density table}

\begin{tabular}{|c|c|c|c|c|}
\hline $\begin{array}{c}\text { Mean of consensus estimates of } \\
\text { undiscovered deposits }\end{array}$ & $\begin{array}{c}\text { Number of } \\
\text { discovered } \\
\text { deposits }\end{array}$ & $\begin{array}{c}\text { Total number of } \\
\text { deposits }\end{array}$ & Area, $\mathbf{~ k m}^{2}$ & $\begin{array}{c}\text { Deposit density, number of } \\
\text { deposits/100,000km }\end{array}$ \\
\hline $\mathbf{1 . 6}$ & 0 & 1.6 & 45,642 & 4 \\
\hline
\end{tabular}




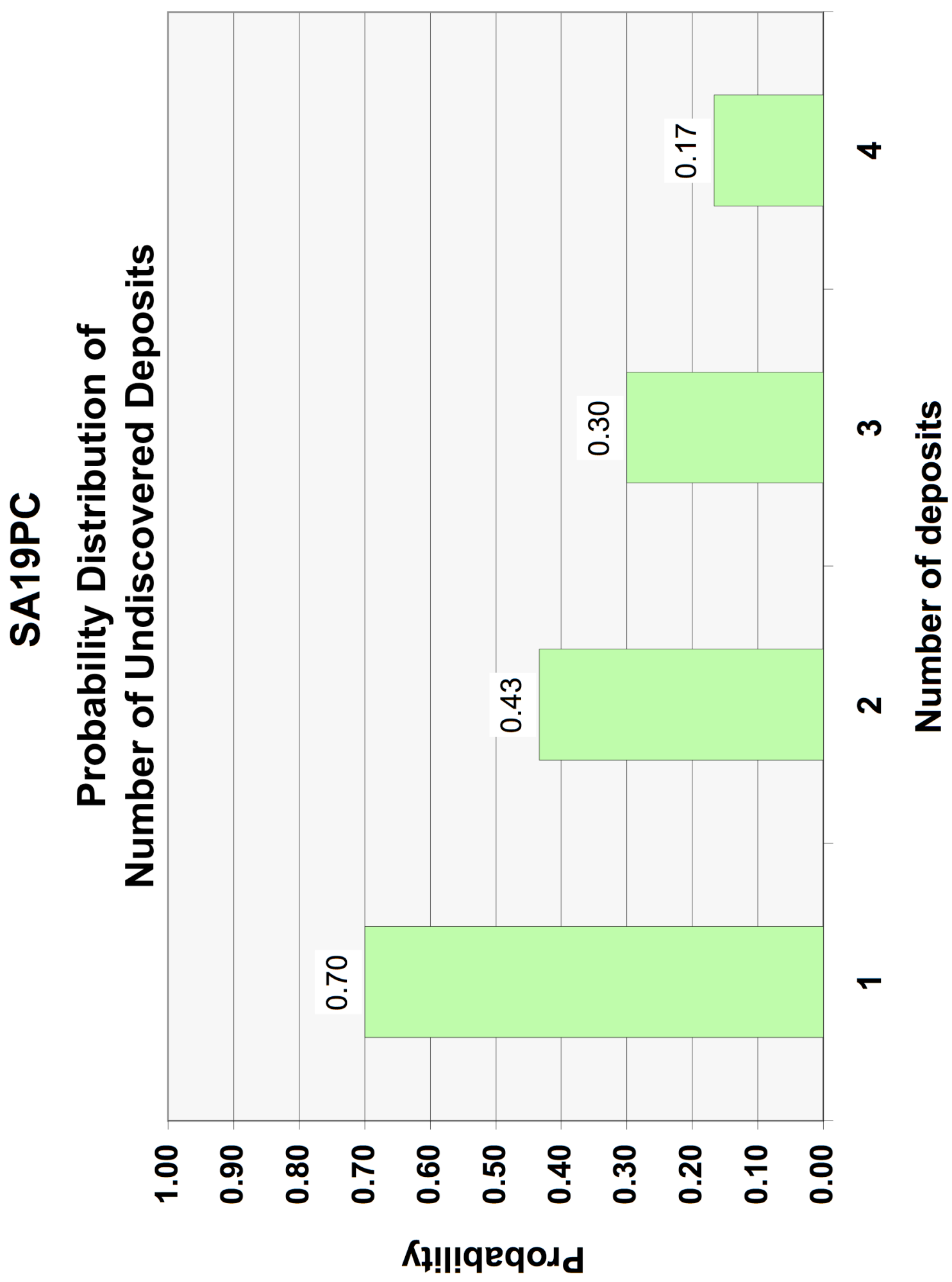




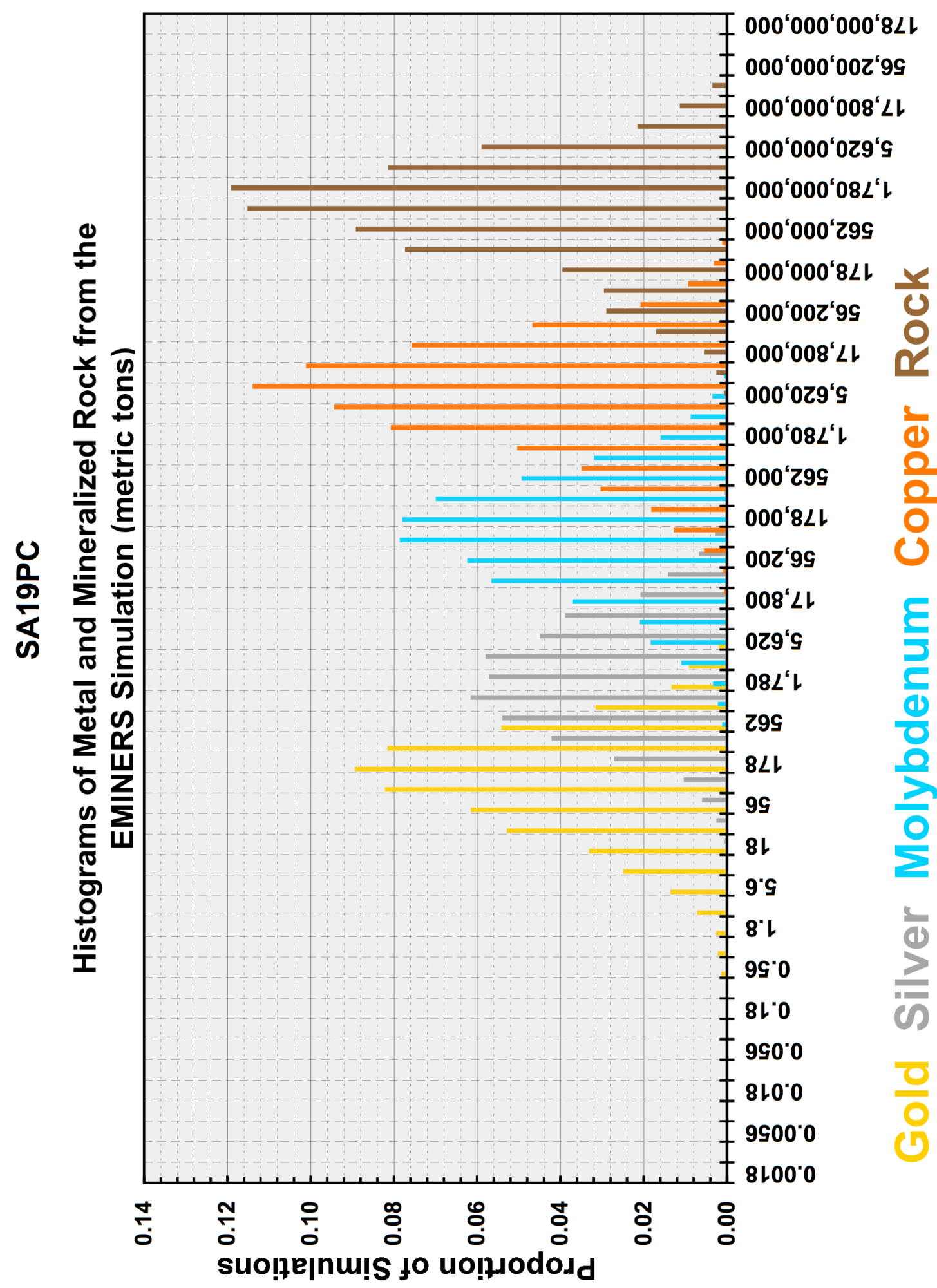




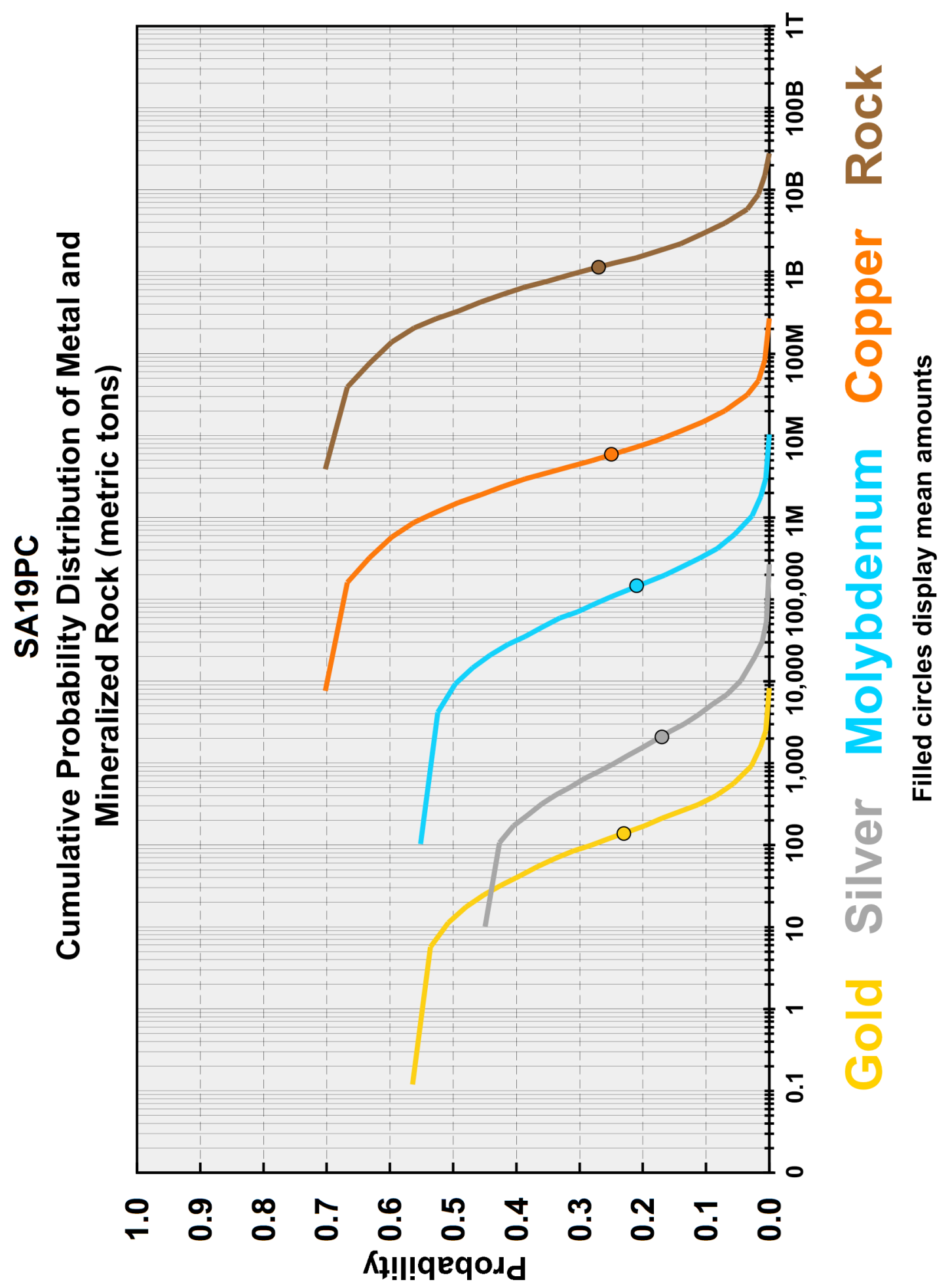




\section{Summary of Assessment Results}

The tract ID is SA19PC

The EMINERS model is General porphyry copper (Singer, Berger, and Moring, 2005)

Consensus Estimates:

There is a $90 \%$ or greater chance of 0 or more deposits.

There is a $\mathbf{5 0 \%}$ or greater chance of 1 or more deposits.

There is a $10 \%$ or greater chance of 4 or more deposits.

Mean Number of Deposits $=1.6$

Estimated amounts of contained metal and mineralized rock (metric tons)

\begin{tabular}{|r|r|r|r|r|r|}
\hline Quantile & \multicolumn{1}{|c|}{ Cu } & \multicolumn{1}{c|}{ Mo } & \multicolumn{1}{c|}{ Au } & \multicolumn{1}{c|}{ Ag } & \multicolumn{1}{c|}{ Rock } \\
\hline 0.95 & 0 & 0 & 0 & 0 & 0 \\
\hline 0.90 & 0 & 0 & 0 & 0 & 0 \\
\hline 0.50 & $1,400,000$ & 8,600 & 13 & 0 & $320,000,000$ \\
\hline 0.10 & $15,000,000$ & 350,000 & 340 & 4,600 & $3,100,000,000$ \\
\hline 0.05 & $25,000,000$ & 670,000 & 630 & 9,100 & $4,900,000,000$ \\
\hline Mean & $5,900,000$ & 150,000 & 140 & 2,100 & $1,100,000,000$ \\
\hline Probability of mean or more & 0.25 & 0.21 & 0.23 & 0.17 & 0.27 \\
\hline Probability of zero & 0.30 & 0.45 & 0.44 & 0.55 & 0.30 \\
\hline
\end{tabular}




\section{Rationale for tract delineation}

This tract is defined by the distribution of Late Triassic to Middle Jurassic calc-alkaline plutons and by the distribution of volcanic and other country rocks and cover rocks within or beneath which such plutons are expected to occur within $1 \mathrm{~km}$ of the surface. The northwest trend of the tract reflects the trends of the Subcordilleran batholith and of the Central Patagonian Batholith (Rapela and others, 1991; Zappettini, 2005) in the eastern part of the Macizo del Deseado, Argentina. The Central Patagonian batholith, which contains the one known porphyry copper prospect in the tract, consists mostly of hornblende-biotite granodiorite and granite intruded by leucocratic granite. $\mathrm{Rb}-\mathrm{Sr}$ ages on the batholith range from 202 to $225 \mathrm{Ma}$ (Constantino Mpodozis, unpublished data; Munizaga and others, 1988; Rapela and Kay, 1988). The country rocks consist of lower Paleozoic metasedimentary rocks that were accreted to South America along a east-west trending late Paleozoic suture during the Permian (Zappettini, 2005, after Mpodozis, unpublished data; and Mosquera and Ramos, 2007). About 70 percent of the tract is covered, mainly by extensive 168-170 Ma rhyolitic ash-flow tuffs of the Chon Aike Formation (Kay and others, 1989; Pankhurst and Rapela, 1993; Márquez and Godeas, 1999) related to the opening of the southern Atlantic ocean.

\section{Rationale for model choice}

Because the tract contains no discovered deposits, and there was no reason to reject the general porphyry copper deposit model (Singer, Berger, and Moring, 2005), this model was used to represent the undiscovered deposits. This tract has only one known prospect but its copper-molybdenum mineralogy and hydrothermal alteration are consistent with the characteristics of deposits in the general model.

\section{Deposits and prospects}

The tract has no known discovered porphyry copper deposits, but has one prospect, Bajo de la Leona, which has been dated at about $200 \mathrm{Ma}$ (Marquez and Godeas, 1999).

\section{Exploration history}

Tract SA19PC is moderately explored around known mineralized centers. There are some geophysical surveys and drilling in the vicinity of mineralized and hydrothermally altered rocks.

\section{Rationale for numerical estimate}

Analogies with numbers of deposits known in similar areas that team members have studied elsewhere, together with reference to the deposit density model of Singer and others (2005), helped guide the estimates of undiscovered porphyry copper deposits in the tract. The presence of the Bajo de la Leona prospect demonstrates that the mineralizing processes forming porphyry copper deposits were active at least locally in the host rocks. Moreover, the tract is poorly explored, especially beneath the extensive areas of younger cover. However, the level of erosion is relatively deep. All of the exposed permissive rocks are batholithic suggesting that most porphyry copper deposits that may have formed in subvolcanic environments above the batholiths, and in the apical parts of the batholiths, probably have been removed.

\section{Expected distribution of undiscovered deposits}

The tract was drawn to enclose an area of geology where the probability of occurrence of an undiscovered deposit was expected to be reasonably uniform based on knowledge and information available to the team at the time of tract delineation. 


\section{References cited}

Kay, S.M., Ramos, V.A., Mpodozis, Constantino, and Sruoga, Patricia, 1989, Late Paleozoic to Jurassic silicic magmatism at the Gondwana margin: Analogy to the Middle Proterozoic in North America?: Geology, v. 17, no. 4, p. 324-328.

Márquez, Marcelo, and Godeas, M. C., 1999, Las mineralizaciones cupro-molibdeníferas del Bajo de la Leona, Santa Cruz: in: Recursos Minerales de la Republica Argentina, Zappettini, E.O., Ed., Instituto de Geología y Recursos Minerales SEGEMAR, Anales 35, p. 845-850, Buenos Aires, Argentina.

Mosquera, Alfonso, and Ramos, V.A., 2007, Intraplate deformation in the Neuquen Embaymént, in Kay, S.M., and Ramos, V.A., eds., Evolution of the Andean Margin-A tectonic and magmatic view from the

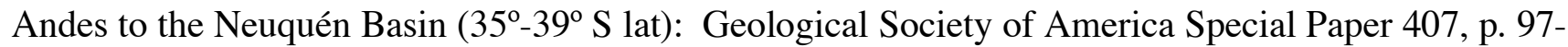
123.

Munizaga, F., Herve, F., Drake, R., Pankhurst, R., Brook, R., and Snelling, N., 1988, Geochronology of the lake region of south-central Chile $\left(39^{\circ}-42^{\circ} \mathrm{S}\right)$; preliminary results. Journal of South American Earth Sciences, v. 1, no. 3, p. 309-316.

Pankhurst, R.J., and Rapela, C.W.,1993, The Jurassic acidic volcanism of northeast Patagonia: a short lived event of deep origin: II International Symposium on Andean Geodynamics, Oxford, Proceedings, p. 423-425.

Rapela, C.W., Dias, C.F., Francese, J.R., Alonso, G., and Benvenuto, A.R., 1991, El batolito de la Patagonia central: evidencias de un magmatismo triásico-jurásico asociado a fallas transcurrentes: Revista Geológica de Chile, v. 18, no. 2, p. 121-138.

Rapela, C.W., and Kay, S.M., 1988, Late Paleozoic to Recent magmatic evolution of northern Patagonia: Episodes, v. 2, No. 3, P. 175-182.

Singer, D.A., Berger, V.I., Menzie, W.D., and Berger, B.R., 2005, Porphyry copper density: Economic Geology, v. 100, no. 3, p. 491-514.

Singer, D.A., Berger, V.I., and Moring, B.C., 2005, Porphyry copper deposits of the world-Database, map, and grade and tonnage models: U.S. Geological Survey Open-file Report 2005-1060, http://pubs.usgs.gov/of/2005/1060/)

Zappettini, E.O., 2005, Mapa metalogenético de América del Sur: 1:5,000,000, Servicio Geológico Minero Argentino, Anales no. 44, Buenos Aires, Argentina 275 p. 


\section{TRACT SA20PC}

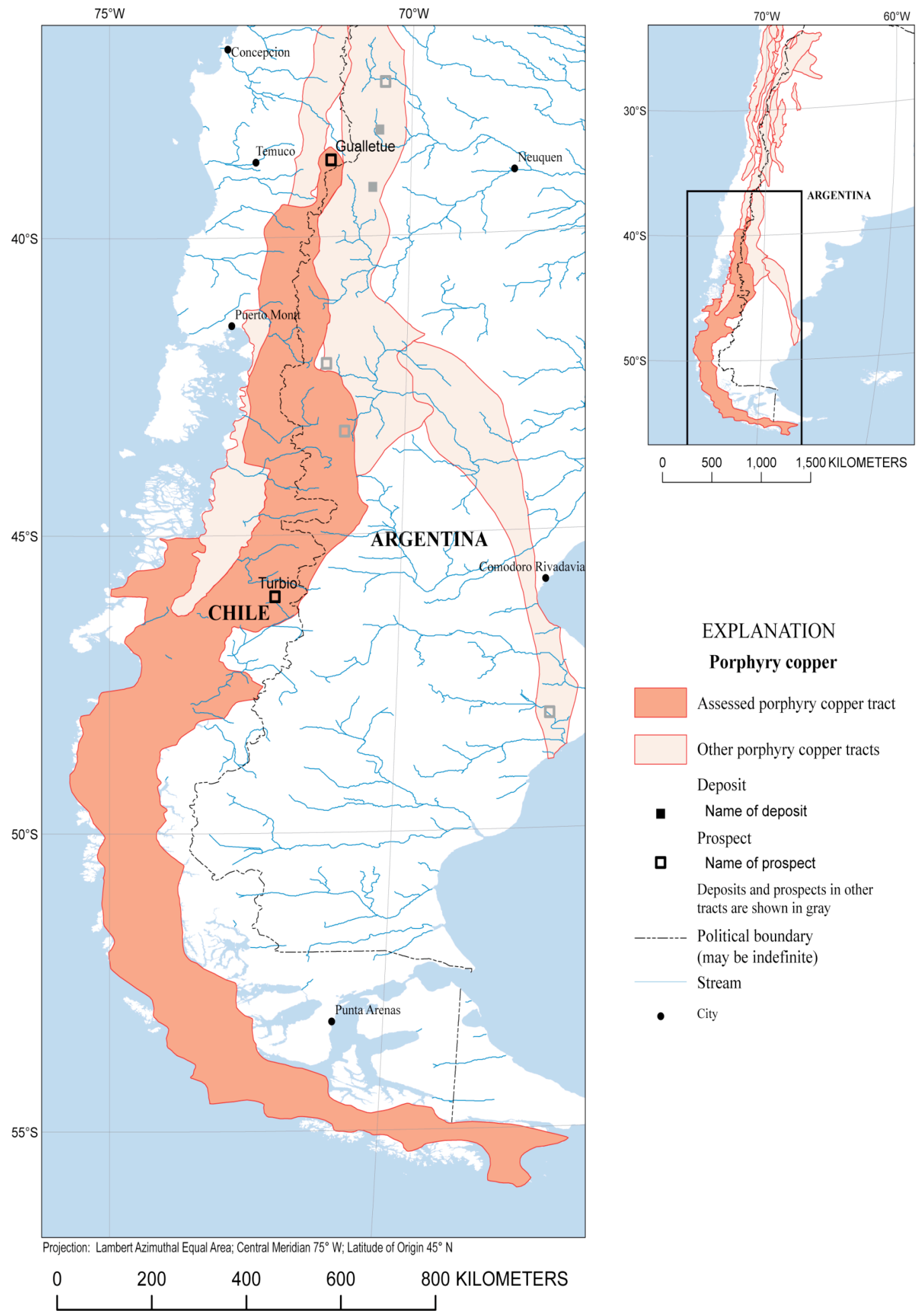




\section{Estimated Undiscovered Porphyry Copper Resources in Tract SA20PC- Chile and Argentina}

Charles G. Cunningham, ${ }^{1}$ Eduardo 0. Zappettini, ${ }^{2}$ Waldo Vivallo S., ${ }^{3}$ Carlos Mario Celada, ${ }^{4}$ Jorge Quispe ${ }^{5}$ Donald A. Singer, ${ }^{1}$ Joseph A Briskey, ${ }^{1}$ David M. Sutphin, ${ }^{1}$ Mariano Gajardo M., ${ }^{3}$ Alejandro Diaz, ${ }^{3}$ Carlos Portigliati, ${ }^{3}$ Vladimir I. Berger, ${ }^{1}$ Rodrigo Carrasco, ${ }^{3}$ and Klaus J. Schulz ${ }^{1}$

'USA-U.S. Geological Survey (USGS)

${ }^{4}$ Colombia-Instituto Colombiano de Geología y Minería (INGEOMINAS)

${ }^{2}$ Argentina - Instituto de Geología y Recursos Minerales (SEGEMAR)

${ }^{5}$ Peru-Instituto Geológico Minero y Metalúrgico (INGEMMET)

${ }^{3}$ Chile-Servicio Nacional de Geología y Minería (SERNAGEOMIN)

\begin{tabular}{|l|l|}
\hline Deposit type assessed: Porphyry Copper & $\begin{array}{l}\text { Model: General porphyry copper deposit model } \\
\text { (Singer, Berger, and Moring, 2005) }\end{array}$ \\
\hline Tract name: Chile-Argentina Cretaceous Turbio & Countries: Chile and Argentina \\
\hline Tract ID: SA20PC & Region: South America \\
\hline Date of assessment: March 2007 & Date of last revision: \\
\hline Assessment depth: $1 \mathrm{~km}$ & \\
\hline Assessment team leader: Donald A. Singer & Regional coordinator: Charles G. Cunningham \\
\hline $\begin{array}{l}\text { Estimators: Carlos Mario Celada, Waldo Vivallo S., Donald A. Singer, Charles G. Cunningham, and } \\
\text { Eduardo O. Zappettini. }\end{array}$
\end{tabular}

Table of estimated numbers of undiscovered deposits by quantile. Also showing calculated mean $(m)$, standard deviation $(s)$, and coefficient of variation in percent $(\mathrm{Cv} \%)$. Sorted by mean.

\begin{tabular}{|l|c|c|c|c|c|c|}
\hline \multicolumn{1}{|c|}{ Estimators } & $\mathbf{9 0}$ & $\mathbf{5 0}$ & $\mathbf{1 0}$ & $\boldsymbol{m}$ & $\boldsymbol{s}$ & $\mathbf{C v} \%$ \\
\hline Estimator & 0 & 1 & 3 & 1.3 & 1.2 & 92 \\
\hline Estimator & 0 & 1 & 4 & 1.6 & 1.5 & 94 \\
\hline Consensus of estimators & $\mathbf{0}$ & $\mathbf{2}$ & $\mathbf{5}$ & $\mathbf{2 . 3}$ & $\mathbf{1 . 8}$ & $\mathbf{7 8}$ \\
\hline Estimator & 1 & 2 & 5 & 2.5 & 1.6 & 64 \\
\hline Estimator & 0 & 2 & 6 & 2.6 & 2.2 & 85 \\
\hline Estimator & 0 & 2 & 7 & 2.9 & 2.6 & 90 \\
\hline
\end{tabular}

\section{Deposit density table}

\begin{tabular}{|c|c|c|c|c|}
\hline $\begin{array}{c}\text { Mean of consensus estimates of } \\
\text { undiscovered deposits }\end{array}$ & $\begin{array}{c}\text { Number of } \\
\text { discovered } \\
\text { deposits }\end{array}$ & $\begin{array}{c}\text { Total number of } \\
\text { deposits }\end{array}$ & ${\text { Area, } \mathbf{~ k m}^{2}}^{2}$ & $\begin{array}{c}\text { Deposit density, number of } \\
\text { deposits/100,000km }\end{array}$ \\
\hline $\mathbf{2 . 3}$ & 0 & 2.3 & 223,011 & 1 \\
\hline
\end{tabular}




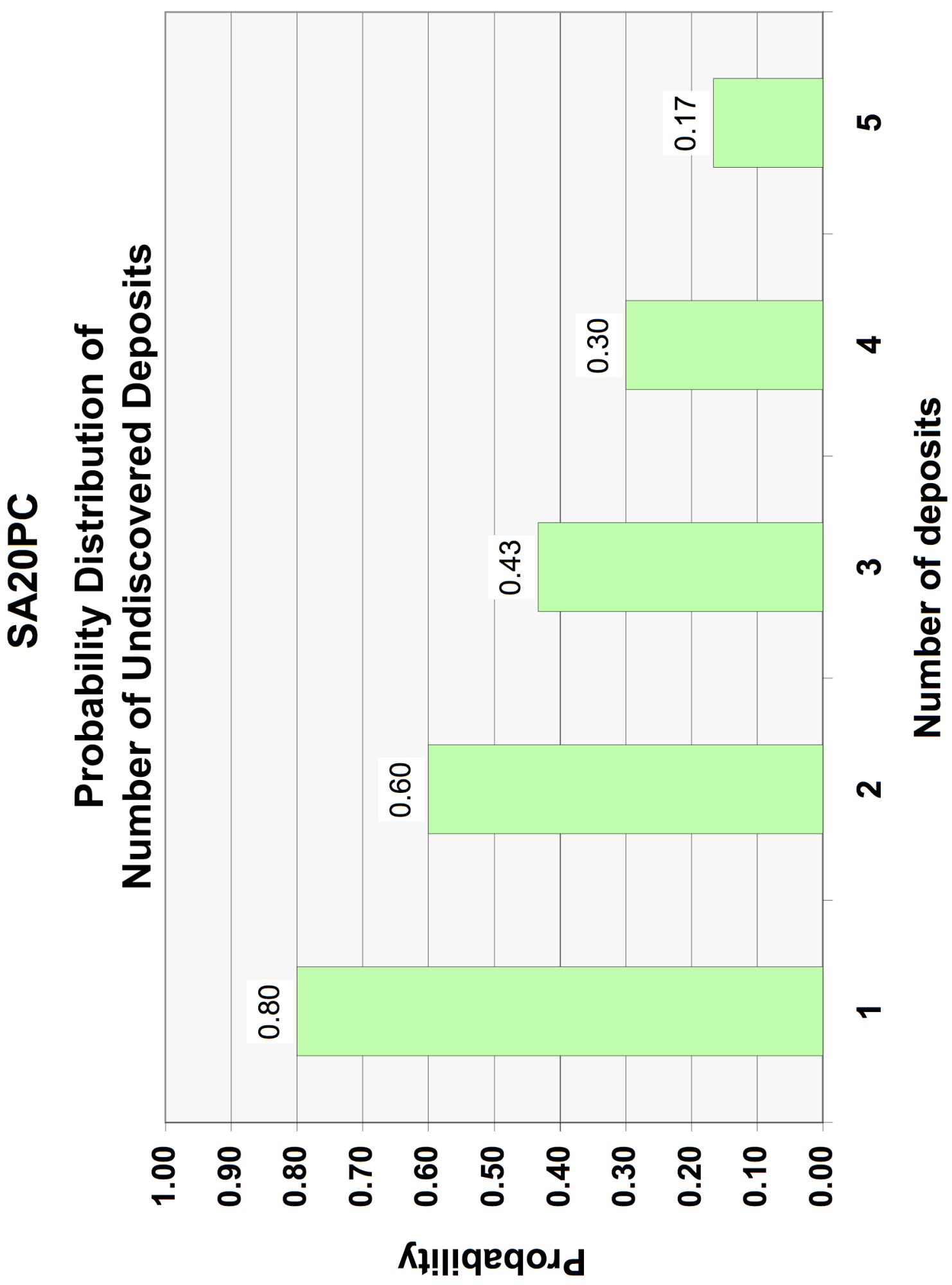




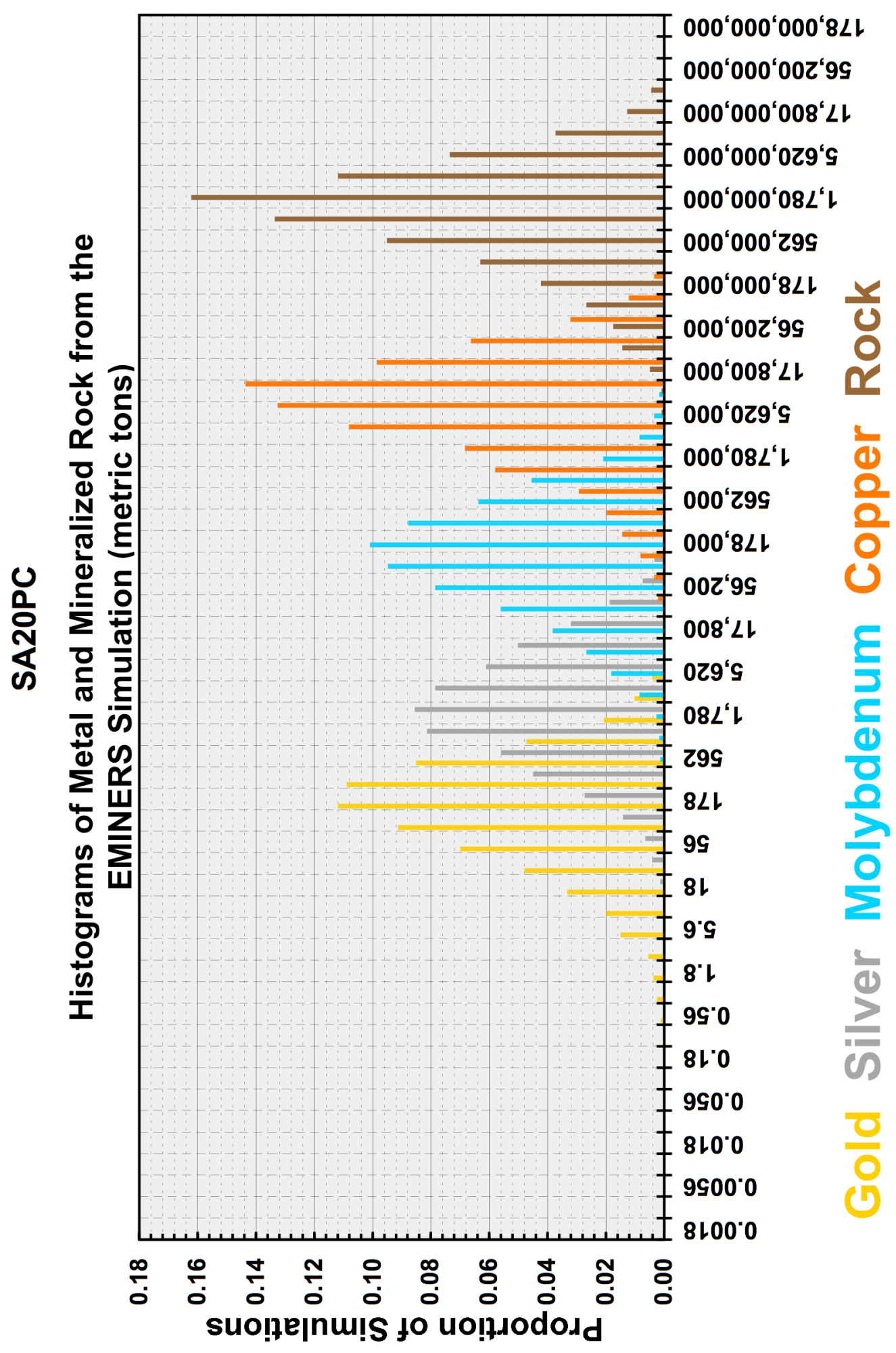




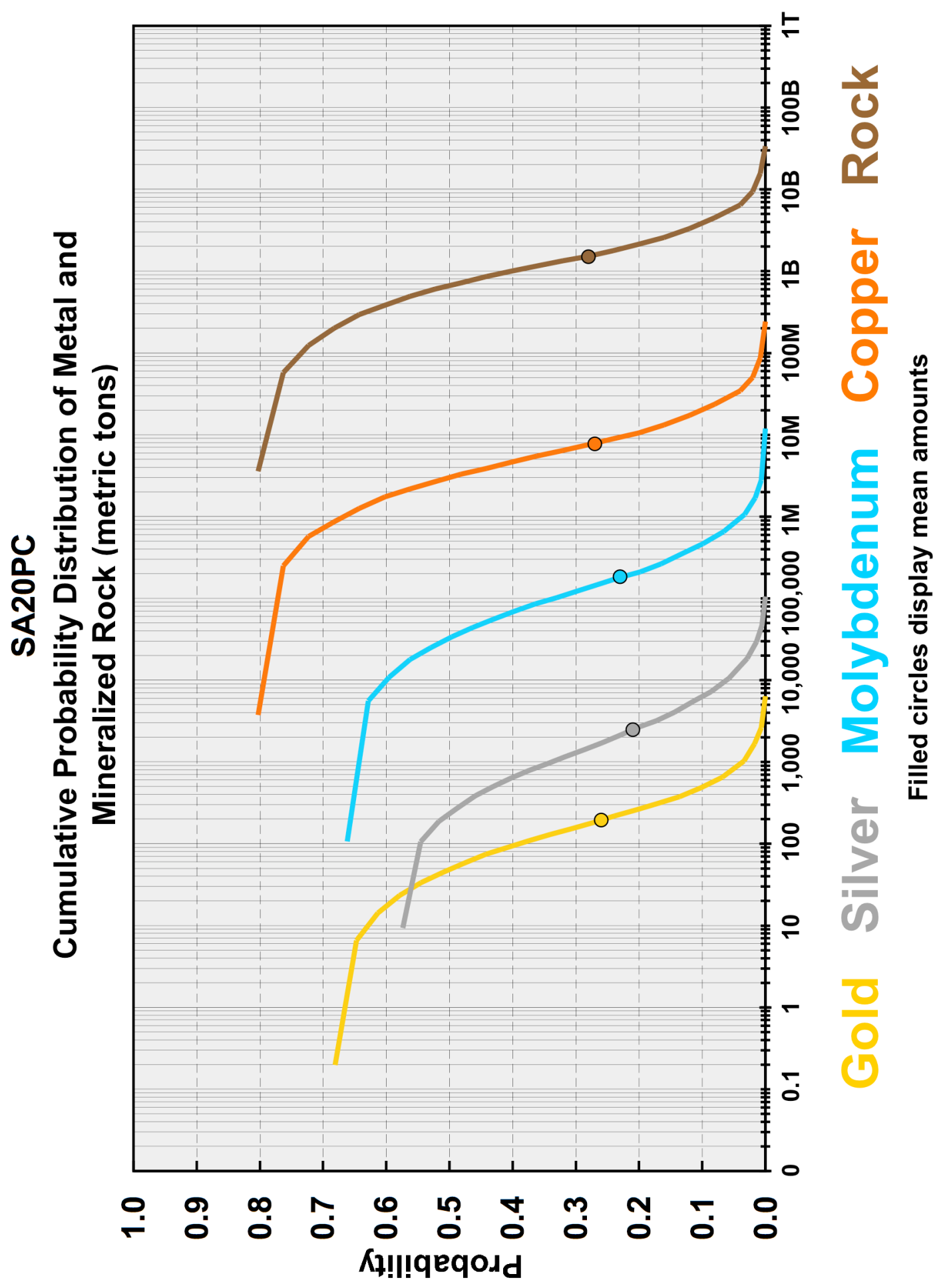




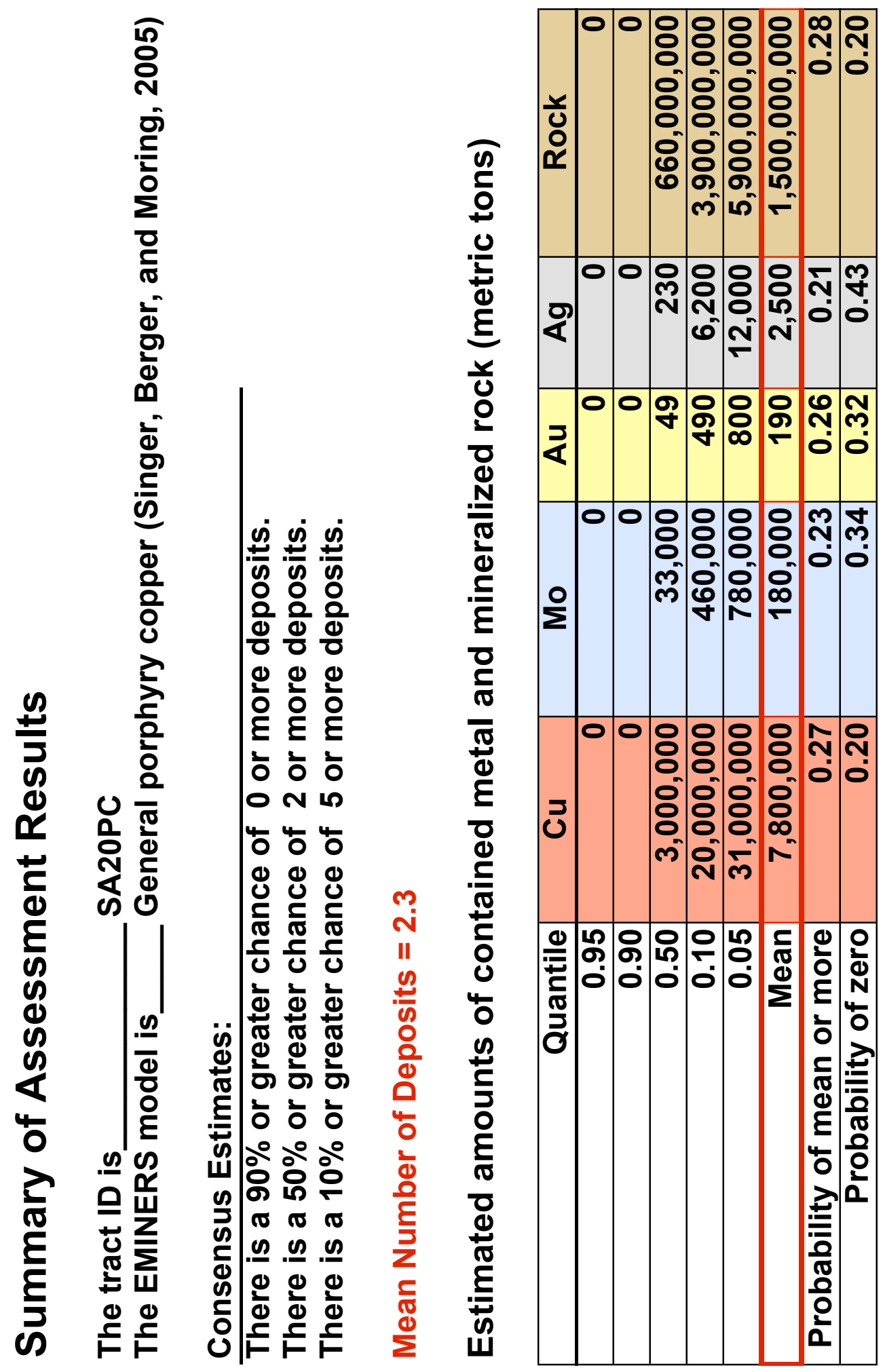




\section{Rationale for tract delineation}

This tract is defined by the distribution of Cretaceous calc-alkaline batholiths and plutons and by the distribution of volcanic and other country rocks and cover rocks within or beneath which these bodies are expected to occur within $1 \mathrm{~km}$ of the surface. Most of the batholiths and plutons consist principally of biotite and hornblende-bearing granite, granodiorite, and tonalite collectively shown as map unit Kig on the geological map of Chile (Servicio Nacional de Geología y Minería, 2003).

\section{Rationale for model choice}

Because the tract contains no discovered deposits, and there was no reason to reject the general porphyry copper deposit model (Singer, Berger, and Moring, 2005), this model was used to represent the undiscovered deposits. The metallic and alteration mineralogy of known porphyry copper prospects in the tract are typical of deposits in the general model.

\section{Deposits and prospects}

Although the tract is very large, only two prospects have been located, Gualletué, near the northern tip of the tract, and Turbio, near the middle. Turbio has not been dated but Gualletué has a Late Cretaceous date. The Arroyo Luque prospect, presently assigned to tract 15, could be in either tract SA15PC or tract SA20PC because it occurs where the tracts overlap spatially as well as in age. Arroyo Luque is No. 52 on the Metallogenic Map of Argentina (Servicio Geológico Minero Argentino, 1999).

\section{Exploration history}

Although parts of the tract have high relief, are remote, and (or) are covered with ice, most of the tract is generally well exposed and has been moderately explored.

\section{Rationale for numerical estimate}

Analogies with numbers of deposits known in similar areas that team members have studied elsewhere, together with reference to the deposit density model of Singer and others (2005), helped guide the estimates of undiscovered porphyry copper deposits in the tract. The presence of two known prospects demonstrate that porphyry-copper-forming process were active at least locally in this very large, well exposed, but only moderately explored tract. Nonetheless, the team's estimate is low principally because it appears that most of the rocks in the tract are batholithic and have been eroded too deeply for most porphyry copper deposits to have been preserved, especially in the southern part of the tract (Nelson, 1996).

\section{Expected distribution of undiscovered deposits}

Based on knowledge and information available to the team at the time of tract delineation, the probability of occurrence of an undiscovered deposit is believed to be reasonably uniform throughout the tract.

\section{References cited}

Nelson, E.P., 1996, Suprasubduction mineralization-Metallo-tectonic terranes of the southernmost Andes, in Scholl, D.W., Kirby, S.H., and Platt, J.P., eds., Subduction-Top to bottom: American Geophysical Union Geophysical Monograph 96, p. 315-330.

Servicio Nacional de Geología y Minería, 2003, Mapa geologico de Chile: version digital: Servicio Nacional de Geología y Minería, Publicacion geologica digital No. 4, CD-ROM, version 1.0. 
Servicio Geológico Minero Argentino, 1999, Mapa Metalogenético de la Repúbica Argentina: Servicio Geológico Minero Argentino, Zappettini, Eduardo, Coordinator, Escala 1:2,500,000, v. 2.0.

Singer, D.A., Berger, V.I., Menzie, W.D., and Berger, B.R., 2005, Porphyry copper density: Economic Geology, v. 100, no. 3, p. 491-514.

Singer, D.A., Berger, V.I., and Moring, B.C., 2005, Porphyry copper deposits of the world-Database, map, and grade and tonnage models: U.S. Geological Survey Open-file Report 2005-1060, http://pubs.usgs.gov/of/2005/1060/) 